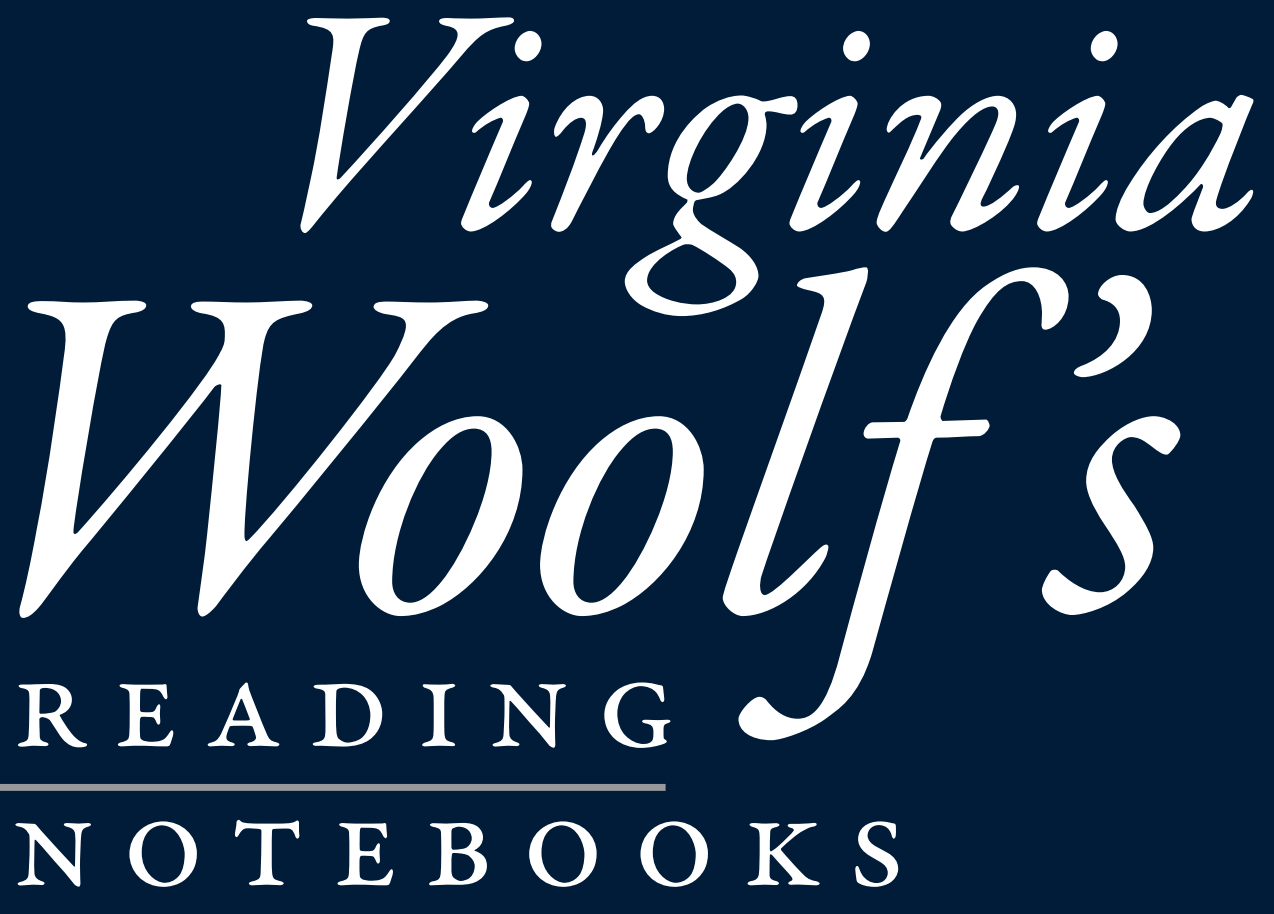

Brenda R. Silver 



\section{Virginia Woolf's \\ READING \\ NOTEBOOKS}




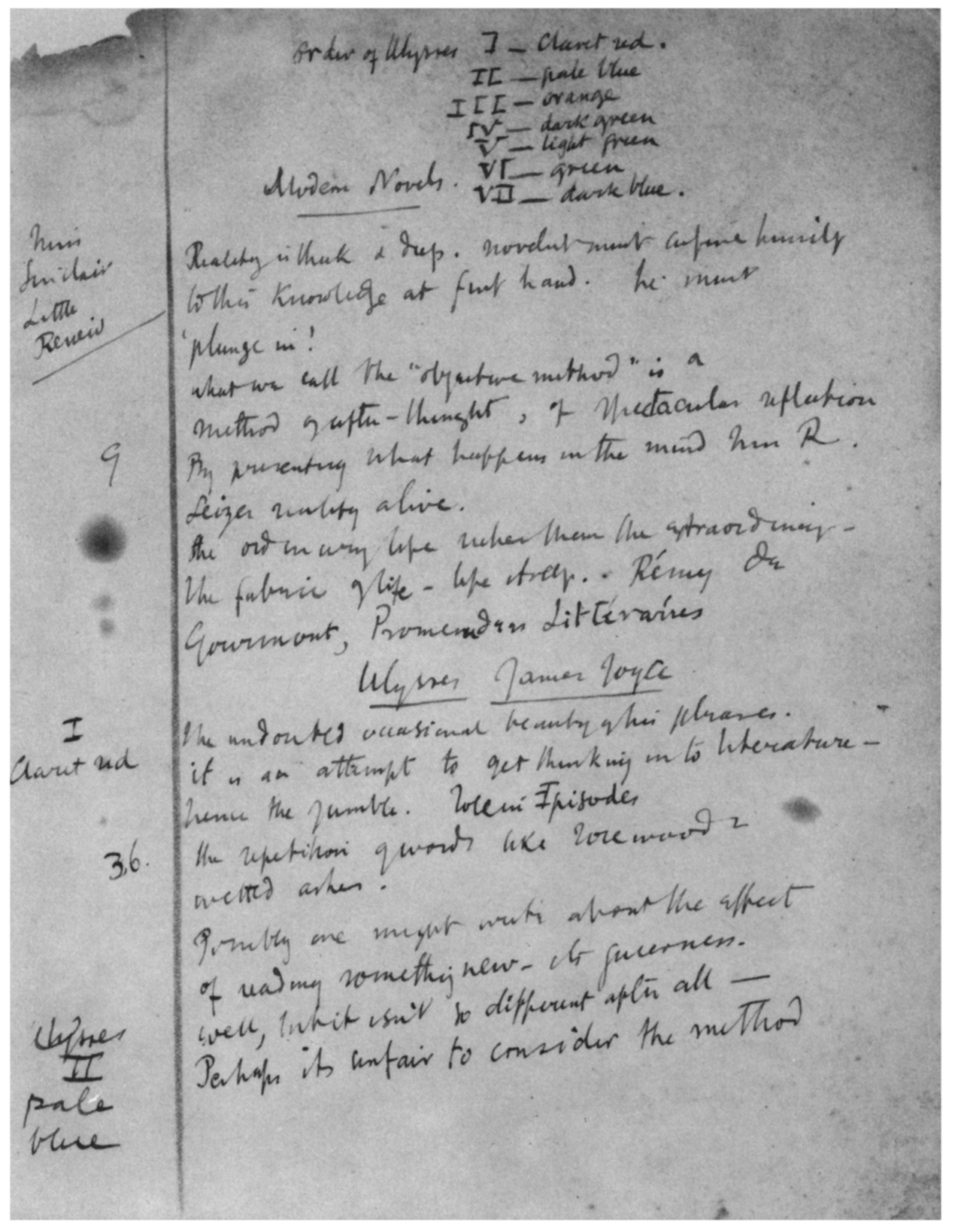

First page of Virginia Woolf's reading notes for "Modern Novels," Volume XXXI. 


\title{
Virginia Woolf's
}

\author{
R E A D I N G
}

N O T E B O O K S

Brenda R. Silver

PRINCETON UNIVERSITY PRESS

PRINCETON, NEW JERSEY 
Copyright $\odot 1983$ by Princeton University Press

Published by Princeton University Press,

41 William Street, Princeton, New Jersey

In the United Kingdom: Princeton University Press, Guildford, Surrey

All Rights Reserved

Library of Congress Cataloging in Publication Data will be found at the end of this book 
FOR MY PARENTS 



\section{CONTENTS}

PREFACE

xi

ACKNOWLEDGMENTS

xiii

INTRODUCTION: THE UNCOMMON READER

NOTES ON THE TEXT

Virginia Woolf's READING NOTEBOOKS

I. Holograph Reading Notes. Vol. 1

II. Holograph Reading Notes. Vol. 2

III. Holograph Reading Notes. Vol. 3

IV. Holograph Reading Notes. Vol. 4

V. Holograph Reading Notes. Vol. 5

VI. Holograph Reading Notes. Vol. 6

VII. Holograph Reading Notes. Vol. 7

VIII. Holograph Reading Notes. Vol. 8

IX. Holograph Reading Notes. Vol. 9

X. Holograph Reading Notes. Vol. 10

XI. Holograph Reading Notes. Vol. 11

XII. Holograph Reading Notes. Vol. 12

XIII. Holograph Reading Notes. Vol. 13

XIV. Holograph Reading Notes. Vol. 14

XV. Holograph Reading Notes. Vol. 15

XVI. Holograph Reading Notes. Vol. 16

XVII. Holograph Reading Notes. Vol. $17 \quad 96$

XVIII. Holograph Reading Notes. Vol. 18

XIX. Holograph Reading Notes. Vol. 19

XX. Holograph Reading Notes. Vol. 20

XXI. Holograph Reading Notes. Vol. 21

XXII. Holograph Reading Notes. Vol. 22

XXIII. Holograph Reading Notes. Vol. 23

XXIV. Holograph Reading Notes. Vol. 24

XXVI. Holograph Reading Notes. Vol. 26 
XXVII. [Diary] Holograph Notebook, Unsigned. Christmas 1904-May 31, 1905. No. 3

XXVIII. Choephori of Aeschylus. Edited by A. W. Verrall. Holograph Reading Notes, Dated January 1907

XXIX. Holograph Reading Notes, January 1909-March 1911

XXX. [A Writer's Diary] Holograph Notebook.

November 16, 1918-January 24, 1919

XXXI. Modern Novels (Joyce). Holograph Notebook, Unsigned and Undated

XXXII. [Flush] Holograph and Typewritten Reading Notes, Unsigned and Undated

XXXIII. [Three Guineas] Holograph Reading Notes, Unsigned and Undated

XXXIV. Monk's House Papers/A.21

XXXV. Monk's House Papers/B.1a

XXXVI. Monk's House Papers/B.2a

XXXVII. Monk's House Papers/B.2c

XXXVIII. Monk's House Papers/B.2d

XXXIX. Monk's House Papers/B.2f

XL. Monk's House Papers/B.2h

XLI. Monk's House Papers/B.2i

XLII. Monk's House Papers/B.2j

XLIII. Monk's House Papers/B.2k

XLIV. Monk's House Papers/B.2.1

XLV. Monk's House Papers/B.2m

XLVI. Monk's House Papers/B.2n

XLVII. Monk's House Papers/B.2o

XLVIII. Monk's House Papers/B.2p

XLIX. Monk's House Papers/B.2q

L. Monk's House Papers/B.3a

LI. Monk's House Papers/B.3b

LII. Monk's House Papers/B.3c

LIII. Monk's House Papers/B.3d

LIV. Monk's House Papers/B.3e

LV. Monk's House Papers/B.16a

LVI. Monk's House Papers/B.16b 
LVII. Monk's House Papers/B.16e 254

LVIII. Monk's House Papers/B.16f. Vol. 1

LIX. Monk's House Papers/B.16f. Vol. $2 \quad 273$

LX. Monk's House Papers/B.16f. Vol. $3 \quad 295$

LXI. Monk's House Papers/B.17a 314

LXII. Monk's House Papers/B.17b 317

LXIII. Monk's House Papers/B.17c 329

LXIV. Monk's House Papers/B.17d 333

LXV. Monk's House Papers/B.17e 337

LXVI. Monk's House Papers/B.17f 339

LXVII. Notes on Oliver Goldsmith $\quad 340$

APPENDIX A: LIST OF NOTEBOOKS 345

APPENDIX B: CHRONOLOGICAL CHART 350

GENERAL INDEX $\quad 352$

TITLE INDEX TO VIRGINIA WOOLF'S PUBLISHED WORKS 381 



\section{PREFACE}

On May 27, 1938, Virginia Woolf recorded in her diary the end of her thirty-year association with Bruce Richmond and the Times Literary Supplement: "I learnt a lot of my craft writing for him: how to compress; how to enliven; and also was made to read with a pen and notebook, seriously." A few months later she was planning "to collect, even bind together, my innumerable T.L.S. notes: to consider them as material for some kind of critical book: quotations? comments? ranging all through English literature as I've read and noted it during the past 20 years." 1 Although Woolf never wrote this book, a large number of her reading notes, both bound and unbound, ranging from her translations of the classics (1905) to her preparations for her last, unfinished essays, "Anon" and "The Reader" (1940-1941), are preserved in the Yale University Library and the two major repositories of Woolf papers - the New York Public Library (Berg Collection) and the University of Sussex Library. Virginia Woolf's Reading Notebooks describes, dates, and identifies the sources of sixty-seven volumes of these notes.

The majority of the entries in these volumes are those Woolf made when reading for reviews, for critical or biographical essays, for her own information about a subject, or for background for a book. Two notebooks contain early translations and comments on Greek and Latin literature; one, notes for Flush; eleven, notes for Three Guineas; eight, notes for Roger Fry: A Biography; and two, notes for the history of English literature that was to open with "Anon" and "The Reader." Other notebooks trace the development of single essays, of the ideas about novels that resulted in "Phases of Fiction," of the eighty or so starts she claimed to have made on the first Common Reader and the three years she spent on The Common Reader: Second Series.

Even the briefest glance at the reading notes is enough to show their crucial role in Woolf's growth as critic, biographer, historian, and feminist, and the seriousness she brought to her tasks. No matter what the subject, no matter how long or short the piece, she sought out the relevant letters and diaries, biographies and autobiographies, histories and criticism-both contemporary and modernthat would place the work and its author in their literary and cultural 


\section{[ PREFACE ]}

contexts. This thoroughness is as evident in the notes for her earliest reviews in the first decade of the century as it is in her reading for her "Common History book" thirty-five years later. She used the notes to record facts, to speculate on why authors in different periods thought and wrote the way they did, to ask questions about style and technique, and to record her own impressions-the impact of the book on a twentieth-century woman and novelist.

\section{NOTES}

1. A Writer's Diary, ed. Leonard Woolf (London: Hogarth Press, 1953), May 27 and October 14, 1938; hereafter cited as $A W D$. 


\section{ACKNOWLEDGMENTS}

One summer day at Monk's House, Virginia Woolf "went in and found the table laden with [unread] books": "I looked in and sniffed them all. I could not resist carrying . . . one off and broaching it" ( $A W D$, August 24, 1933). Woolf's excitement anticipates my own response on discovering the numerous volumes of her reading notes, first at the Berg Collection and then at the University of Sussex Library: I, too, could not resist immediately taking a volume off and deciphering it. Soon I was hooked. Virginia Woolf's Reading Notebooks, to borrow her words again, re-creates the "vast fertility of pleasure [the notebooks] hold for me." In making the contents of these volumes available to others, in bringing this project to fruition, I am indebted to the many librarians, colleagues, assistants, and friends who shared my fascination with the reading notes and my belief in their value. I am pleased, at last, to acknowledge them here.

First, I wish to thank Quentin Bell and Angelica Garnett, Administrators of the Author's Literary Estate, for their permission to reproduce the passages from the manuscript reading notes that comprise the heart of this book. Both Quentin Bell and Anne Olivier Bell generously shared their time and their knowledge with me throughout the project, and I am deeply grateful for their continuous and active support.

In addition, I wish to acknowledge the Henry W. and Albert A. Berg Collection of English and American Literature, The New York Public Library, Astor, Lenox and Tilden Foundations; the University of Sussex Library; and the Beinecke Library, Yale University, for allowing me to publish extracts from the manuscripts in their possession. At all three libraries, I have met with unfailing courtesy and help. I wish particularly to express my gratitude to Dr. Lola L. Szladits, Curator of the Berg Collection, who shared the excitement of my original discovery of the notebooks and has supported me throughout. John Burt, Elizabeth Inglis, and Adrian Peasgood at the University of Sussex Library were exemplary in making the various materials in the Monk's House Papers accessible and consistently made my long hours in their sunny library cheerful and productive.

I am also indebted to Mrs. Pamela Diamand, the librarians at King's College Library, Cambridge, and Donald A. Laing for their 
help with the Roger Fry materials. My special appreciation goes to Professor Laing, who allowed me to use sections of his bibliography of Fry's writings before it was published and made my search for sources his own.

Numerous colleagues and friends have contributed to this work by helping me identify references, by reading drafts of the introductory sections, by sharing their knowledge of Woolf's reading, writing, and manuscripts with me, and by feeding and housing me while in New York City and England. In particular, I wish to thank Ellen Hawkes, who first urged me to translate my rough indexes of the reading notes into a book, and the other Woolf scholars who aided and encouraged me over the years: Margaret Comstock, Louise A. DeSalvo, Alice Fox, John W. Graham, Joanna Lipking, William McBrien, Jane Marcus, Sara Ruddick, Lucio P. Ruotolo, and Elizabeth Steele. Helene P. Foley and Christian Wolff provided information about the Greek materials; Lynn Anthony Higgins translated passages in French for inclusion in the text; Mary Kelley, Paula Mayhew, Annette Niemtzow, and Charles T. Wood offered excellent editorial comments and intellectual sustenance. Peter A. Bien, Alan T. Gaylord, and Peter Saccio, my departmental colleagues, were always ready to answer questions and read sections of the book. To Stephen Orgel, who gave me substantial help in the initial exploratory stages and throughout the writing of the book, I owe a very special debt. Finally, Kay Andrews and Melissa Llewelyn-Davies, whose friendship, hospitality, and insights sustained me during my many months in Sussex and London, contributed more to the book than I can ever thank them for.

Other people helped me as well, and these too I wish to acknowledge: Karen Swann and Anne Tierney, my research assistants in the early stages, whose detective abilities were often truly astounding; Donald Fowley, Victoria Grossack, Elizabeth Stevens, and, with special thanks, Noel Ricker, all of whom spent hours at the computer entering and editing the text; and Dorothy A. Beck, who skillfully prepared the index. I am also indebted to Dartmouth College, which generously provided me with a Faculty Fellowship to begin my research in England and with additional research support to complete the work.

The editors and designers at Princeton University Press have played an invaluable role in making this book possible. I am extremely grateful to Catherine Dammeyer Thatcher, for her careful copy editing and wise decisions, and to Laury Egan, for her suggestions about format. I reserve special thanks for Jerry Sherwood, whose faith in 
this book and expertise encouraged me from the beginning and paved the way for the completion of the work.

My final thank you belongs to my family, for their inexhaustible enthusiasm and cheer: my sisters, Lois Keates and Carol Starrels, and my parents, Milton and Frances Silver, to whom the book is dedicated with love. To my husband, Paul M. H. Tobias, I owe more than I can say-and more than he would want to hear. Let it suffice that his unending care and support, his critical eye, and his general good sense created an environment that sustained both me and the book.

Excerpts from The Letters of Virginia Woolf (vols. 1-6), The Diary of Virginia Woolf (vols. 1-3), A Writer's Diary, Collected Essays (vols. 1-2), and Three Guineas are reprinted by permission of the Author's Literary Estate and The Hogarth Press Ltd.; and also by permission of Harcourt Brace Jovanovich Inc.: copyright $\odot$ 1975, 1976, 1977, 1978, 1979, 1980 by Quentin Bell and Angelica Garnett; ๑ 1953, 1954 by Leonard Woolf. The facsimile of the page from Woolf's notebook that appears as the frontispiece is reproduced by courtesy of Quentin Bell and Angelica Garnett, Administrators of the Author's Literary Estate, and the Henry W. and Albert A. Berg Collection of English and American Literature, Astor, Lenox and Tilden Foundations. 

Virginia Woolf's

READING NOTEBOOKS 



\section{INTRODUCTION: THE UNCOMMON READER}

Sometimes I think heaven must be one continuous unexhausted reading.

By her own account and by the testimony of her writing, Virginia Woolf was from her childhood far more than the "common reader" she later named herself. Born into a long line of professionals and writers, she expressed early in life a passion for reading and ideas that stimulated in turn her own creative energy. She read for pleasure, and she read for work. She read to ease her mind, and to fertilize it. "It was the Elizabethan prose writers I loved first \& most wildly," she recalled in 1929, "stirred by Hakluyt, which father lugged home for me . . \& \& why I dont know, but I became enraptured. . . . I used to read it $\&$ dream of those obscure adventurers, $\&$ no doubt practised their style in my copy books." 1 Later, a recurring refrain in her letters and diaries became, I'm "replenishing my cistern at night with Swift," or whoever it was at the time $(D$, III, June 27,1925$)$. "Yet after all," she insisted, "thats the way to write [an essay on the Burneys]; ... the truth of one's sensations is not in the fact, but in the reverberation. When I have read three lines, I remake them entirely, if they're prose, and not poetry; and it is this which is the truth."2 But there is another side to Woolf's reading as well-what she called her "serious" reading for her critical essays and reviews: "reading with pen and notebook" and "with an end in view" ( $D$, II, July 28, 1923). Both aspects are amply illustrated in the thousands of entries jumbled together in the sixty-seven volumes of her reading notes. As windows into Woolf's mind, these notes illuminate the responses of the woman and artist-a modernist with an abiding sense of the past and a belief that literature is "one brain, after all" ( $L, I V, 1980)$ - to the world around her, and trace the growth of the dreamy young reader into a major figure in the intellectual history of the twentieth century.

Today, more than the critical books she polished and published, the reading notes are a "rough, but vigorous statue testifying to the great fun $\&$ pleasure [the] habit of reading" gave Woolf ( $D$, II, July 28,1923 ). For one thing, their bulk is impressive (and the notes she left represent only a fraction of what she actually read). As a repository of facts and ideas for her articles and reviews, these volumes provide proof (if it is still needed) of her commitment as both literary 


\section{[ INTRODUCTION ]}

and social critic. Equally impressive is her breadth: Woolf ranged freely through genres, periods, and countries, glancing at some only once or twice and returning, fascinated, to others. Notes on fiction, poetry, and drama jostle each other on her pages, intermingling with notes on history, biography, journals, criticism, science, anthropology, and newspaper reports of contemporary events. Some of the earliest entries translate and comment on Greek and Latin literature, and she continued to read Greek, both in the original and in English and French translations, throughout her life. She read French literature and criticism in the original, Dante in a bilingual edition, Russian fiction in translation. English literature and history she read from beginning to end, constantly reaching for familiar works and excitedly discovering new ones.

At the end of her life, Woolf decided to translate her wide reading into her own history of English literature. Provisionally called Reading at Random or Turning the Page, her "Common History book" was going to capture those aspects of the creative act and its continuity ignored by traditional texts. " "Did I tell you I'm reading the whole of English literature through?" she wrote to Ethel Smyth on February 1, 1941, during the war and only two months before her death. "Thank God, as you would say, one's fathers left one a taste for reading! Instead of thinking, by May we shall be-whatever it may be: I think, only 3 months to read Ben Jonson, Milton, Donne, \& all the rest!" $(L, \mathrm{VI}, 3685){ }^{4}$

In order to understand Woolf's complex response to her legacy, it is necessary to look first at the environment that nourished it. Unlike Kitty Malone, daughter of an Oxford don in The Pargiters, whose bookcase in 1880 contained only works read in childhood, a prayer book and a Bible, two copies of Sesame and Lilies, and three bound volumes on law and duty - and to whom most of English literature was forbidden because it was not "fit reading for a girl"-Woolf was allowed the freedom of her father's library, a freedom rare in those days, and she took advantage of it. ${ }^{5}$ Both her early experiences of literature and her later critical writing attest to her strong sense of a literary tradition that, she felt, she made her own through the act of reading. In the essay called "Reading" (1919), she describes how a young reader sitting in the library of an English country house brings to life a long line of poets stretching from Keats back to "some uncouth poet scarcely able to syllable his words" (CE, II, 13). Later, in her essay on The Countess of Pembroke's Arcadia (1932), Woolf, speaking now as a mature reader/critic, confidently adds her name and her perceptions of the book to "the long succession of readers" dating back to 1655 be- 
fore sending the book, and her essay, into the future: "let us in our turn bring the insight and blindness of our generation to bear upon [the Arcadia], and so pass it on to our successors" $(C E, \mathrm{I}, 19)$.

Woolf's vision of herself as reader and inheritor, however, was from the beginning a dual one. If, on the one hand, she felt herself part of the long line of writers and readers whose minds had joined through the centuries to produce her cultural heritage, she recognized, on the other, the peripheral role women have played in the creation and transmission of that heritage. As she herself was well aware, she read her books not in the schoolrooms of Eton or Oxford or Cambridge, the training ground of the true inheritor, but in the library or the bedroom/study of a private house. Even while preparing her essay on the Arcadia, a work Sidney ostensibly wrote for his sister, a great patron of the arts, Woolf recorded in her reading notes how "The Css of Rutland [was] nothing inferior to her father Sir P.S. in poetry" (XI, B.7); how Lady Anne Clifford's mother, patron to the poet Daniel, "had no language but her own, but read all books of worth that were translated," while it was her "fathers will that [Anne] shd only know English," since a "'young lady [was] not . . to learn any language" (XLVIII, B.2); and how Donne, when his family-life threatened his writing, "left his wife and the steadily growing army of babies at Mitcham" and "had a 'lodging' or apartment in the Strand" (LVIII, B.6). ${ }^{6}$ For Donne, the male, his art took precedence over his family duties; women, denied this option, became patrons.

The dual awareness of inheritance and exclusion is vividly portrayed by the twenty-one-year-old Woolf in a diary entry called "The Country in London" and subtitled "Getting ready for Salisbury, by which I mean laying in books." In the country, she writes:

I read some history: it is suddenly all alive, branching forwards \& backwards \& connected with every kind of thing that seemed entirely remote before. I seem to feel Napoleons influence on our quiet evening in the garden for instance-I think I see for a moment how our minds are all threaded together-how any live mind today is eonne of the very same stuff as Plato's \& Euripides. It is only a continuation \& development of the same thing-It is this common mind that binds the whole world together; \& all the world is mind. ... I feel as though I had grasped the central meaning of the world, $\&$ all these poets $\&$ historians $\&$ philosophers were only following out paths branching from that centre in which I stand. 
When she reads in London, however, the "atmosphere is too hottoo fretful. I read-then I lay down the book-\& say-what right have I, a woman to read all these things that men have done? They would laugh if they saw me."?

In spite of her divided consciousness and the sense of being an intruder, Woolf profited greatly both from her father's library and from Leslie Stephen himself. For one thing, she learned to place literature in its historical, biographical, and cultural contexts, and to recognize the crucial role that social as well as literary conventions play in determining what gets written and how it is received. ${ }^{8}$ Stephen was clear on how one should read English literature-namely, "in conjunction with English history" and with some knowledge "of the philosophy and, still more, ... of the social conditions of the time."9 In a lecture to schoolboys on "The Study of English Literature," he insists that we can understand writers only by forming a picture of the society that shaped them and, by extension, their art: "You should, I say, understand the spirit of the age, and by that I do not mean that you should study what is called the philosophy of history. ... What you require is not a clever analysis, but a vivid representation of the period. You should see it, not be full of formula about it." ${ }^{10}$ The way to acquire this vision, he continues, is to read the documents of the period itself. In the case of Pope, his example, this means "reading some of the most delightful books in the language. ... reading Addison and Swift, and Pope's own correspondence, and Lady Mary's letters, and 'Robinson Crusoe,' and 'Gulliver's Travels,' and Gay and Parnell, and a crowd of smaller writers." 11 Woolf, as if taking her father's words literally, fulfills them in her own reading. Her notes for her essay on "Addison" (1919), for example, begin with the list:

Dict. Nat. Biog

Johnson's Life

Cato

Tatler

Macaulays Essay

Spence's Anecdotes.

Sir Roger de Coverley

Spectator.

Addison. by Courthope. (II, A.1)

The presence at the top of her list of the Dictionary of National Biography, which Stephen edited, as well as her habitual recourse to letters, memoirs, diaries, biographies, and histories in her own pur- 
suit of a writer or a work, indicates the tremendous influence her father's teaching had on Woolf, even as she grew to recognize its limitations. In Three Guineas, for example, she "[regrets] that no lives of maids [servants] ... are to be found in the Dictionary of National Biography"12-a comment on the tendency of biography, and history, to ignore those individuals and classes whose efforts lay outside the centers of intellectual and political power. In 1929, she recalled tapping at her father's study to ask for "the 6th or 7th volume of Gibbons complete works, or Speddings Bacon, or Cowpers letters" ( $L$, IV, 2005), an image that conveys her access to those works which stimulated her own explorations of history even while anticipating her adoption in the thirties of the role of cultural outsider. This image reappears in The Waves (1931) in Louis's perception of himself as an outsider (here by virtue of his middle-class colonial background) knocking on the "grained oak door" of his tutor's study, determined to enter the world of poetry and culture within; ${ }^{13}$ and, in 1931 and 1932, it provided Woolf with the original titles for her newly conceived history of women's exclusion: The Open Door, Opening the Door, A Tap on the Door, A Knock on the Door. ${ }^{14}$

Nevertheless, Woolf's forays into the library afforded her an understanding of social history, both recorded and unrecorded, that determined the bias of her reading and her work. In 1905, she began to teach literature and history at Morley College, and in August 1906, when she wrote a story about a woman historian's research into the land tenure system of medieval England, she included a fictional journal of a young woman in the fifteenth century. As the editors of "The Journal of Mistress Joan Martyn" point out: "Roughly half of the manuscript is devoted to [the narrator's] views on history and her search for old documents." 15 Within the story itself, the narrator defends her method of exploring the legal system of the time by creating scenes that depict the details of daily life: "I have not scrupled to devote several pages of large print to an attempt to show, vividly as in a picture, some scene from the life of the time; here I knock at the serfs door, \& find him roasting rabbits he has poached; I show you the Lord of the Manor setting out on some journey, ... In another room I show you Dame Elinor, at work with her needle."16

During this same period, 1905 to 1906 , when Woolf was often reviewing several books a week, her reading notes include entries from The Cambridge Modern History and A History of Modern Europe, which provided her with the background she needed for her articles (XXXV). At the end of her life, when she began to write her own history of English literature, she repeatedly emphasized the need to 


\section{[ INTRODUCTION ]}

write as well the history of the society that produced and responded to the art. If the origin of literature could be traced to the singing of the birds in the forests of prehistoric Britain, "the tree had to be felled; and a hut made from its branches before the human voice sang too." "Keep a running commentary upon the External," she noted in an outline for the book; "I shd. therefore take a poem \& build up round it the society wh. helps it" ( $A \& R, 382,376)$.

Nowhere, perhaps, does Woolf illustrate the interaction of art and society more clearly than in her reading of works by and about women-her reading of women as creators, subjects, and participants within an essentially male literary tradition and within what she came to call a patriarchal society. Even in her earliest notes she comments on the presentation of feminine psychology, records the details of women's lives and their attitudes toward their work, and analyzes the ways in which women writers have confronted the technical problems of their craft and what might constitute a woman's language. An entry from 1905 describes the legal status of women in the eighteenth century and the rise of women's education in the nineteenth (XXVII, B.2). In 1906, she appreciates that Edith Wharton's House of Mirth presents "American society: as exclusive as English: except that money apparently is the only necessity. A sketch of a girl brought up in such surroundings" (XXXV, B.24); she criticizes Mrs. Henry Graham's House of Siloam as "weak stuff-conventional girl, all the rest of it. becomes a woman after wedding service ... hysterical melodramatic, unpleasant. 'dont flirt and dont slum'" (XXXV, B.23); and she emphasizes Elizabeth Barrett Browning's own recognition in her letters that her life before her meeting with Browning was "bad for her art: didnt know people," as well as noting that "her faults were apparently conscious \& she didnt mind them" and that she was "good upon her artistic theories." "Not merely the early Victorian poetess," she adds; "sternness" (XXXV, B.51).

Later, Woolf began to explore as creative works in their own right what were for Stephen part of the social documents of an agewomen's diaries and letters-recognizing that they filled the gaps left by women's absence from the bookshelves and from the standard literary and historical texts. The three sets of notes on Lady Anne Clifford's Diary are a good example of Woolf's developing sense not only of women's exclusion from culture but of their contributions and their history. In the early 1920s, Woolf read the Diary as background for an essay on the Elizabethans. "Nothing much here except a chronicle," she sums up at the end of her notes, "fine clothes, journeys, details" (XIX, B.3). Although neither the Diary nor Lady Anne ap- 
peared in the finished essay, phrases from Vita Sackville-West's introduction to the work, including lists of goods brought home by Anne's father, George Clifford, Earl of Cumberland, contributed to her evocation of the richness of the age in "The Elizabethan Lumber Room." Ten years later, she turned again to the Diary and to a biography of Lady Anne, this time with the intention of making her an "Elizabethan character"; instead, these works provided Woolf with illustrations of the education given to noblewomen in the sixteenth century - an education that encouraged them to become patrons of poets such as Daniel and Donne but prevented them from writing poetry themselves. Her notes on Williamson's biography emphasize Lady Anne's lifelong love of reading and the fact that although she was not allowed to learn languages, her father permitted her "all other knowledge fit for her sex, since [she] was bred up to greater perfection than himself" (XLVIII, B.2). The glimpses into the life of the Elizabethan woman and patron offered by the Diary then became part of her picture of "Donne After Three Centuries" (XLVIII, Introduction). Not until 1941, however, did Lady Anne emerge as a figure in her own right - the prototype of the early reader-rather than as an accessory to another writer ("The Reader," $A \& R$; see XVI and XXXVII).

Meanwhile, during the late twenties Dorothy Osborne's letters, the correspondence between Jane Carlyle and Geraldine Jewsbury, the diary of Fanny Burney, Dorothy Wordsworth's journals, Mary Wollstonecraft's letters, as well as her educational and political tracts, all became the subjects of individual essays, while simultaneously providing Woolf with the details of women's lives that she then wove together in A Room of One's Own.17 Published in 1929, this work has not only introduced two generations of women readers to a literary heritage they might otherwise never have known existed but it also illustrates the importance of rereading literature with an awareness of the social and cultural constraints that have led to women's silences, as well as to their speech.

One key to Woolf's analysis of these silences lies in her perception, as both novelist and feminist, of the interconnection between social and literary conventions. An entry headed "Novels. Form. (Vicar of Wakefield) Goldsmith" (1921-1922) begins:

The social machinery seems to have imposed a pretty sharp mould upon $18^{\text {th }}$ Cent. fiction: Witness Vicar of Wakefield. ... Here are the makeshifts of a middle class family: to who have lost their money. Goldsmith will break his "form" to bring in an argument about tyrants \& democracy. How viv- 
idly they tell the stories of their loves!-adventures. How arch \& sly \& pointed the psychology is! The conventions for women's behaviour is very marked: love of dress: mothers' desire that their daughters shd. marry. A style low in tone \& very formal. (XXVI, B.1)

Thackeray also provided Woolf with examples of both types of convention. Her notes for her essay "Modern Novels" (1919) include an entry that reads, "Pendennis. Its a very queer convention that makes us believe that people talked or felt or lived as J.A. [Jane Austen] \& Thack. \& Dickens make them." This generalization is illustrated by a single example from the novel: " ${ }^{\text {rs }}$ Shandon cares for nothing but tea when her husband is away. $325 \mathrm{Oh}$ what varieties of pain do we not make our women suffer! \& that leads to a charming apostrophe to the teapot - a kind of jolly abandonment of humour and life" (XXXI, B.5).18 In the mid-thirties, while preparing Three Guineas, Woolf turned to Pendennis for her metaphor of the social conventions that denied women education and prevented them from full participation in the literary or the public world: Arthur's Education Fund, or A.E.F. By this time, however, she had moved beyond the sociological analysis of literature inherited from Stephen to a serious critique of the social and political institutions that threatened not only the survival of literature and criticism but life itself. "[I]n times of public crisis," she wrote in 1941, "the writer exclaims: "I cannot write any more. I have no audience'."19

"I have no audience." Embedded in a draft of her last essay, "The Reader," these words speak eloquently to another aspect of Woolf's own reading: her lifelong insistence on the role of the audience in the creation and re-creation of a work of art. For Woolf, literature resides not just in the written word but in the presence of the living men and women who hear or see or read a work when it first appears, and who later keep it alive through the act of reading. Here again we discern the legacy of Leslie Stephen, who not only emphasized the interaction of audience and writer at every period in history but wrote of Pope: "His best poetry is the incarnation" of the conversation between the poet, his enemies, his patrons, and "the critical circles, who revered him." 20 Even more, however, Woolf's stance may be the result of one of her earliest experiences of literature-hearing her father read aloud; because of this, "many of the great English poems" seemed to her inseparable from his voice..$^{21}$ In fact, literature for Woolf was almost always "spoken," even when read by a lone reader sitting silently with her 
book. The reader, she declared in 1941, "acts the play in the theatre of his own brain." 22 The importance of the speaking voice is apparent in a reading note on The Bacchae in which she laments: "The difficulty of reading Greek is not the words, but getting the fling of the sentence entire-as it leaves the mouth. I am always being knotted up" (XIX, B.47). Commenting on Volpone, she writes: "The prose is so good because it is spoken. not at all Elizabethan" (XIX, B.32).

Books in general, not just plays, were "alive" for Woolf; they had a voice and a body of their own that in turn gave voice and body to the people who wrote and read them. In the 1903 diary entry on reading in the country, "Napoleons influence on our quiet evening in the garden" brought the past to life and made the reader part of it. In "Reading," the young girl sitting by the library window experiences literature as a drama acted before her eyes. Twenty years later, in Between the Acts, literature has become a pageant enacted by the villagers for an audience composed of the entire community, although the words are often blown away.

Woolf's insistence on the active, participatory nature of reading manifests itself in every aspect of her own practice. The same passion for information and ideas that enabled the child in her father's library to acquire a nearly encyclopedic knowledge of English history, biography, and literature, the same instinct for individual styles that prompted her to imitate authors in her copybook, prevented her, finally, from remaining "a dreamy amateur" when she read. "I am surprised \& a little disquieted," she commented in 1928, "by the remorseless severity of my mind: that it never stops reading \& writing" ( $D$, III, November 28). The act of reading, the pleasure and work of conversing with a book and identifying its distinctive voice, became as necessary to Woolf as her daily walks - or her own writing. In 1933, she described having "read, with close and powerful attention, some 12 or 15 books since I came here. What a joy-what a sense as of a Rolls Royce engine once more purring its 70 miles an hour in my brain." "That's the real point of my little brown book," she added in 1938, "that it makes me read-with a pen-following the scent" ( $A W D$, January 5, 1933, and April 11, 1939).

Although the scent Woolf followed varied from book to book and from author to author, she consistently read as both critic and creator, like her father searching out the backgrounds of a work and as an artist, examining its texture. She was, moreover, a self-conscious reader, fascinated with the emotional and intellectual process of reading itself. "One of the amusing things," she writes in an entry headed "How to Read," 


\section{[ INTRODUCTION ]}

is to track your author

down-To see what he goes for. description, or

dialogue. or what. To catch him out.

Directions-about liking the characters-

one shd. try to be independent of this-concentrate

on other characteristics. The excitement of a

story does not last-cannot be read again.

Really it is true I think that all criticism is

done when the book is read: one is too busy

disposing of impressions at the time

You can see people leaving out things on purpose.

The use of certain words.

117. "aboyaient" expressive.

You watch whether people tell things in detail or not

Then there comes a moment when "the author"

begins to split off from the story-but why? (XVIII, B.4)

Despite her disclaimer, this entry is in fact an example of how Woolf did "criticize"-or make discriminations-even as she read. The idea for "How to Read" can be traced to the notes on Le Rouge et le noir that immediately precede it in this volume: " 82 the curious flatness of the character-plain, architectural, disillusioned. a cautious \& prudent hypocrisy. 'It is not a bad thing at his age'. Like a picture in greys \& browns. (One of the amusing things is to track your author down - to see where he lingers)" (XVIII, B.3).

The importance of discovering an author's individual perspective reappears in the beginning of "How Should One Read a Book?" the essay in which she outlines what is essentially her own method of reading. Unlike Stephen, who adopted a sociological stance in his lecture to schoolboys, Woolf speaks in her lecture/essay (presented originally to schoolgirls) primarily as a writer. Drawing upon her awareness of the tools and difficulties of the trade, she advises her audience to pursue a work's distinctive qualities and to ask how successfully it achieves its ends. How, she wants to know, does an author arrange his or her material to produce certain effects and evoke certain responses, and what is the emotion that remains when the reader has finished the book. To answer these questions, she tells her listeners to suspend their critical faculty while actually reading and to open themselves to the twists and turns of the writer's sentences. "Do not dictate to your author," she warns; "try to become him" (CE, II, 2). When we read a novel, for example, this means discovering the angle of vision that determines what stands in the forefront and the back- 
ground of the created world. Each genre, she continues, makes its own demands on readers, but all ask them to exercise their creative powers in learning to share the novelist's perspective, to recognize what characterizes the subject of a biography, or to experience the emotional impact of a poem. Only when the reader has brought the individual work to life can he or she complete the process by comparing it to other works-preferably the best of its kind-thereby judging it. Having accomplished this, the reader is ready to move beyond judgments on particular books to an exploration of the qualities shared by various works of the same genre and to establish the topography and boundaries of his or her own literary world.

At the heart of Woolf's prescription, as well as her practice, is careful attention to those details of a text that reveal, whether consciously or unconsciously, an author's intention and skill. "To begin reading with a pen in my hand," she stated in 1929, "discovering, pouncing, thinking of theories, when the ground is new, remains one of my great excitements" ( $D$, III, December 8$)$. She pounced on individual words, such as "aboyaient" in Le Rouge et le noir, on patterns of imagery, on the qualities that differentiate, for example, Greek drama from Elizabethan, French, and modern, or distinguish novels from plays. A series of notes made around 1935, while she was writing The Years, illustrates her interest in color imagery and its effects on the reader. ${ }^{23}$ "The difference between rare gold coins \& flecked with gold," she comments in an entry on Antigone: "'flecked' gives the horses ear shape" (XLV, B.2). In the same volume, general notes made while reading The Faerie Queene begin: "Perhaps all our first impressions of poetry are visual" (XLV, B.5); and an entry on the "Different layers of the mind in reading poetry" states: "I think it is true that in man the Colour Sense is first touched: roused. Thus in Murder in the Cathedral I am stirred-my senses quickened-first by the purple bullfinch ... by the white sail on the grey sea" (XLV, B.14). In a separate notebook from a slightly earlier period, an entry headed "Colour in Poetry" analyzes images from Shakespeare and Herrick: "Herrick. The [?tinselled] stream-using [?tinselled] to express moonlight on water" (XXIII, B.4).

When Woolf turns to what characterizes an author's work as a whole, she bases her perceptions on an accumulation of individual phrases, descriptions, and scenes. Her notes for "The Novels of George Meredith" consist of fifteen pages of both specific and general observations on The Ordeal of Richard Feveral, Beauchamp's Career ("Given up at Vol 1 . because of the intolerable long windedness"), The Adventures of Harry Richmond, The Egoist, and Mere- 
dith's Letters; they include entries such as, "This is the real Meredith - the girl on her pony ....," or, "The extraordinary formality \& distance of it all. Scene at Richmond with the whores. Here \& there a lady wd. seize a buttonhole." On the sixteenth page of notes, she steps outside the texts to sum up: "That his optimism is wrong. That his optimism comes from his bristly egotism. He wdn't be so optimistic if he could listen instead of talking. The hammer of his phrases scaring all sorts of small things away. Did not let [ . . ] filter in" (XLVI, B.5-10).

If close attention to the details of a text is the first step in her reading process, the second is comparison-of work to work, author to author, genre to genre. "We have only to compare," she blithely tells her audience in "How Should One Read a Book?" In her own reading, she continually hears echoes of other works and lifts her eyes from the page to examine similarities and differences.

Thus, her comment on Meredith's formality and distance continues: "This is contemporary with Turgenev. . . . These are Jonsonian humours rather than moderns. Yet they think-or M thinksabout sex for instance: nature: comedy."

Woolf's distinctive combination of textual analysis and comparison highlights the numerous entries on the novels she read over a threeyear period for "Phases of Fiction," her deliberate exploration of different styles and perspectives in novels and the various needs they satisfy in the reader. "The relief of reading a book which is really composed," an entry on Tristram Shandy begins, "words have stuck to the magnet instead of lying strewn. . . . But why did T.S. blossom among the Richardsons \& the Fieldings?" (XIV, B.16). Reading The Master of Ballantrae after The Bride of Lammermoor leads her to comment: "The feeling that where Scotts words have come pouring out, Stevenson's are picked out of note books" (XXV, B.28). Defoe's Roxana evokes an analysis of the "adventure" novel: "It is a fact that she has apparently no maternal feelings-no feelings of any sort indeed: either for her first master or her children. But this is in keeping. ... Adventure must carry a slight burden of psychology. . . . You must keep moving if you are to have adventures. . . Adventurers have to travel rather light as to feelings" (XXV, B.31). Defoe's mastery of the form is immediately contrasted to W. E. Norris's shallow interpretation in The Triumphs of Sara: "Sara is an adventuress. . . These are ladies \& gentlemen not adventurers. There is no background. . . The question of N's approach. What Defoe [thought]: about truth \& morality No body to Norris. They travel considerably lighter than Defoe. ... There isn't eno' to believe in. . . . In Defoe the people are deep 
eno' to imply their beliefs on other subjects-hence the roundness of the world" (XXV, B.32).

Notes from the same period on What Maisie Knew pinpoint what for Woolf characterizes Henry James's style: "All these minds are reflecting each other indirectly-not H.J. reflections. What people thinkwhat they suspect-of something which we do not clearly see. HJ. doesnt give himself away-doesnt put the pressure on; so that we hesitate too. Even the fun, wh. is very good, is held at arms length. We never get a shock direct." She then contrasts this style to George Eliot's: "Extreme sophistication compared with GE. Curious sexual insinuations - 'suggestiveness'-impropriety-hints-poor Eli GE's women abandoned in ditches astonishingly innocent compared with this" (XIV, B.12). In other notes from the "Phases of Fiction" series, Woolf theorizes about why reading one kind of novel leads to a desire for another: "The whole character [in Jane Austen's Northanger Abbey] is given in dialogue. It shrinks up the vapours amazingly. This however does make one wish for more psychology: therefore the ps: chapter should come next: then the stylists. Then the poets" (XIV, B.4).

An earlier use of comparison underlies her recommendation in "How Should One Read a Book?" that we read King Lear and Agamemnon side by side in order to "bring out [their] common quality" $\left(C E\right.$, II, 10). ${ }^{24} \mathrm{Her}$ advice, as well as her choice of models, grows directly from her own experience while preparing essays on Greek and Elizabethan literature for The Common Reader. In fact, the numerous notes made during this period (1922 to 1925 ) clearly illustrate how the close reading of texts gave rise to comparisons, generalizations, and theories-about plays, playwrights, the two periods-until she found her themes. A diary entry from 1922, for example, records her desire to "read a little Ibsen to compare with Euripides-Racine with Sophocles-perhaps Marlowe with Aeschylus" (D, II, August 28); and reading notes on Ibsen's Hedda Gabler, Racine's Phèdre, and Molière's Misanthrope occur side by side with her notes on Greek and Elizabethan plays, including Marlowe's. The entry on Molière begins, "Reading Misanthrope after Webster, the extreme simplicity of the plot impresses me. All the large emotions hang on very slight movements: In Webster there are too many trees" (XIX, B.21). Her reading of Ben Jonson's plays leads her to speculate: "It strikes me that this English humour is the difference between us-the Elizs. \& the Greeks. At once, there is a roar of laughter: a clapping, stamping horseplay. ... Anyhow, I'm sure humour is the distinction to make, in reading $16^{\text {th }}$ Cent. English after $4^{\text {th }}$ Cent. Greek" (XIX, B.34). She immediately tests her hypothesis by reading Aristophanes' Birds: "It 
seems to me that this is the thing thats missing to make Greek literature complete-laughter. But its very sharp, delicate laughter, after the English. At least in this play" (XIX, B.35).

Woolf's explanation in her essay "On Not Knowing Greek" of why the two forms of laughter differ - "To laugh instantly, it is almost necessary (though Aristophanes may supply us with an exception) to laugh in English. Humour, after all, is closely bound up with a sense of the body" ( $C E, \mathrm{I}, 12)$-returns us to the audience of flesh-andblood human beings who, she believed, inevitably invest a work with their own selves when they read. ${ }^{25}$ For Woolf, the self who continually introduced observations with "it strikes me" was simultaneously reader and writer (in particular, novelist), as the notes make clear. An entry on Dryden's All for Love, after exploring the difference between Elizabethan and eighteenth-century drama, asks, "Is this French, or fiction beginning, or what?" (XLVII, B.2). Coming from a novelist who saw the novel of the future as a reincarnation of the Elizabethan play, such questions give us pause. Previously, while reading The White Devil, Woolf had speculated: "The possibility is that the mind is always becoming more \& more subtle; \& this business of making people speak becomes too crude" (XXV, B.2). Even in her notes on works such as J. A. Symonds's Shakspere's Predecessors and George Saintsbury's History of Elizabethan Literature, read at this time to provide the factual background she needed for her evocation of the plays, her own bias surfaces. She telescopes Symonds's long description of Euphues and its importance to Elizabethan literature into the note, "Euphues, Lyly appeared 1579 a collection of Essays \& Tales. a kind of novel," the last phrase being her own addition (XXV, B.15). The most significant aspect of her entry on Saintsbury's history is the seemingly unrelated comment: "strikes me that the influence of the public would be worth going into. What effects [ . . ] has upon Wells \& Bennett" (XIX, B.9). Here, the fusion of artist and reader/critic/ historian is complete: an awareness of the relationship of writer and public in the past leads directly to a concern for its present manifestations, particularly as it affects the writer of novels.

At some point during her exploration of Elizabethan drama in the early twenties, Woolf perceived that she could organize her critical book, The Common Reader, "with a view to answering certain questions about ourselves" ( $D$, II, September 5,1923$)$. In the completed essays, every work and every period receive the life that only an audience or reader can give them. In "The Elizabethan Lumber Room," modern readers find themselves "untying this packet here, sampling that heap over there" in the process of discovering the 
riches buried in works such as Hakluyt's Voyages and the Verney Memoirs. "The Pastons and Chaucer" introduces us to a contemporary reader, John Paston, who withdraws from family life "to sit in his chair and learn the end of [Chaucer's] story." In 1923, while still trying to find a format for her critical work, originally called Reading, she had the idea of embodying her essays in "Otway conversation"that is, having characters talk about the books as she had had them talk about Conrad in "Mr. Conrad: A Conversation" ( $D$, II, August $17,1923)$. The reading notes inform us that Woolf had also planned other ways in which to give a human voice to her essays and their subjects. An entry headed "Reading. Misc." declares: "Readers do determine the fate of books by going about talking, advising, recommending. They want [to] formulate their opinions in speech" (XLIX, B.26). And a draft of an introductory essay for Reading, called "Byron and Mr. Briggs," introduces us to Mr. Briggs (1775-1859), a spectacle-maker from Cornhill with a taste for literature, who becomes the prototype of the common reader. Old Mr. Briggs, we are told, drove up from Kensington to hear Coleridge, but Coleridge had forgotten the engagement; he heard Coleridge on Measure for Measure but preferred the play itself; and he asked questions such as, "What do you think of the Byron-Leigh controversy?"26 An enigmatic entry in another of the reading notebooks from this period records: "Donne. This article should be . . . put into the mouth of Mary Bickley, an obscure woman 1845. her diary" (XLVII, B.31).

The emphasis on the voice speaking in and about books remained with Woolf throughout her life, offering her at the end a way to defeat the silence brought about by the crisis of World War II. In 1934, her notes for a projected critical work appear under the headings "Four Voices" and "A Discourse for 4 voices Realism Romance Psychology Poetry" (XLV, A.1, A.2). In 1940, she began her history of English literature with an evocation of the anonymous voices of the singer, the preacher, and the playwright, all of whom, in the early years of our civilization, were able to express the common fears and beliefs of their listeners: those "emotions always in being: felt by people always" ( $A \& R, 374)$. "Even the King \& Queen," she noted in an early draft of "Anon," "must have their song makers attached to them," "someone who could express, embody, give voice to the hidden instincts." 27 For Woolf, the universality of "the song making instinct" ( $A \& R, 373)$ - the desire to sing as well as the desire to listen and respond- "must be the most deep rooted, the toughest of the human instincts comparable for persistency with the instinct of self preservation. It is indeed the instinct of self preservation. Only 
when we put two and two together-two pencil strokes, two written words, two bricks do we overcome dissolution and set up some stake against oblivion." No matter how threatened "the song" may be in the modern world, she concludes, it "has the same power over the reader in the 20th century as over the hearer in the 11th" ( $A \& R$, 403), and will survive.

Reader and writer, audience and singer-Woolf was all of these, and if she used her notes to communicate privately with her sources, she used them in addition as a workshop in which to practice her art. Here the critic, the biographer, the feminist, and the novelist gathered together the details that allowed her to "look up from the page \& arrange them ... into one of those makings up which seem so much truer done thus" ( $D$, III, August 8, 1928). Comments, quotations, and ideas recorded in the notes continually reappear, transformed, in her published work. Her notes on Dante's Purgatorio contain the quotation, both in Italian and English, that appears at the end of the 1911 section of The Years. ${ }^{28}$ Her notes on G. M. Trevelyan's History of England open with the quotation about birdsong that not only introduces "Anon" and suggests to Woolf the origin of "the song" but occurs twice in Between the Acts: in the morning when Mrs. Swithin wakes to hear the birds singing and in the evening when she reads her history amid the encroaching darkness of the war. ${ }^{29}$ An entry that begins "The brushed up Sunday appearance even of polar bears" reveals Woolf's "reading" of pictures at the Royal Academy exhibition (XLIV, B.13). "I get an immense deal of pleasure from working out the pictures," she wrote her sister, Vanessa Bell ( $L$, II, 1068); and the details recorded in the reading notes are "interpreted" and brought to life in "The Royal Academy" (CE, IV, 206-211).

Although the list of such discoveries could be greatly extended, a few particularly striking examples stand out. One is the notebook headed "Modern Novels (Joyce)," which contains Woolf's original notes on Ulysses, entered while she was reading the first seven episodes in The Little Review; a sketch for her article on "Modern Novels" (1919); and an entry on May Sinclair's review of Dorothy Richardson's novels that illuminates one source of her well-known statements about "reality" and "life itself."

Woolf's notes on Sinclair's essay read:

Reality is thick \& deep. Novelist must confine himself to this knowledge at first hand. he must 'plunge in'. 


\section{[ INTRODUCTION ]}

What we call the 'objective method' is a method of after-thought, of spectacular reflection By presenting what happens in the mind Miss R. seizes reality alive.

The ordinary life richer than the extraordinarythe fabric of life-life itself. Rémy de

Gourmont, Promenades Littéraires. (XXXI, B.2)

May Sinclair had written: "Reality is thick and deep, too thick and deep and at the same time too fluid to be cut with any convenient carving knife." 30 The two passages from Rémy de Gourmont quoted by Sinclair as a gloss on Richardson's art are even more to the point:

Si la vie en soi est un bienfait, [et] il faut l'accepter comme telle [ou] la nier, le fait même de vivre le contient tout entier, et les grands mouvements de la sensibilité, loin de l'enrichir, l'appauvrissent au contraire, en concentrant sur quelques parties de nous-mêmes, envahies au hasard par la destinée [,] l'effort d'attention qui serait plus uniformement reparti sur l'ensemble de notre conscience vitale. De ce point de vue une vie ou il semblerait ne rien se passer que d'élémentaire et [de] quotidien serait mieux remplie qu'une autre vie riche en apparence d'incidents et d'aventures...

Il y a peut-être un sentiment nouveau a créer, celui de l'amour de la vie pour la vie elle-même, abstraction faite des grandes joies qu'elle ne donne pas à tous, et qu'elle ne donne peut-être à personne ... Notre paradis, c'est la journé qui passe, la minute qui s'envole, le moment qui n'est déjà plus. $^{31}$

In the original version of "Modern Novels," Woolf describes the responsibility of the novelist to capture "life or spirit, truth or reality ... the essential thing": "The mind, exposed to the ordinary course of life, receives upon its surface a myriad impressions, ... composing in their sum what we might venture to call life itself." "Let us record 
the atoms as they fall upon the mind in the order in which they fall, let us trace the pattern, however disconnected and incoherent in appearance, which each sight or incident scores upon the consciousness. Let us not take for granted that life exists more in what is commonly thought big than what is commonly thought small." 32

If the reading notes housed the details that gave texture to Woolf's essays, they also provided a place for her to outline or sketch the "Frame of Article" that would order and focus her impressions and facts. As blueprints for works that often emerged as something quite new, these outlines record her original ideas and begin the complex process of compression and enrichment that accompanied every historical or biographical re-creation, every critical act. Her "Sketches of Article" for "Modern Novels," for example (XXXI, B.4), begins, "Nobody has any wish to abuse the ancients," and includes the recurring comparison of the novel and the Elizabethan play - "Its possible that the novel is to us ... what the drama was to the E's" that receives its fullest expression not in that essay but in "Poetry, Fiction and the Future" ("The Narrow Bridge of Art"). "Some Elizabethans," an outline for an essay on Elizabethan prose, begins, "That we cant attempt the $E^{\text {than }}$ grandiloquence because we haven't their scurrility \& plain speech to match it" (XI, B.10); the outline stands as an intermediate step between her reading notes on Gabriel Harvey, Dekker, Webbe, Puttenham, Fulke Greville, Jonson, Sidney, and The Life and Letters of Sir Henry Wotton, and the two Elizabethan essays finally written for The Common Reader: Second Series. ${ }^{33}$ This outline, moreover, already differs from her original idea for a new set of Elizabethan essays recorded in a reading note on Puttenham's Arte of English Poesie: "Might be two articles, one Webbe \& Harvey Puttenham \&c. The second, Sidney \& Penelope" (XII, B.4). An earlier outline, headed "Notes for Some Elizabethans and Montaigne" (XIX, B.22), illustrates Woolf's original unified conception of what later became "The Elizabethan Lumber Room" and "Notes on an Elizabethan Play" in the first Common Reader.

In fact, the evolution of The Common Reader into its final form is easily traced in these notebooks. At least six volumes contain entries, made over a period of seven years, for her first critical book. The earliest two contain notes and "Sayings and Quotations" about criticism, poetry, and the "Art of Writing" that range from Plato's Symposium through Dryden's Essays, Blake's marginalia, Coleridge's Table Talk, and Keats's Letters, to T. S. Eliot's Sacred Wood (XXX and XXXVIII). Included in this series is Dr. Johnson's dictum from "The Life of Gray," "I rejoice to concur with the common reader," which later 
offered her the title and focus for the emerging book. A second set of quotations, this time from book reviews in the journals of 1923, is gathered in a later notebook (XIX) and provides a footnote to her vision of the lack of critical authority or standards in "How it Strikes a Contemporary." 34 The note on Donne and Mary Bickley - "an obscure woman 1845. her diary" (XLVII, B.31)-suggests Woolf's desire to emphasize the intimate connection between literature and its readers. (The essay on Donne, however, in spite of pages of reading notes, was not written at this time.) ${ }^{35}$ Lists of essays for possible inclusion in her collection and a series of entries headed "Reading. Misc. Ideas" (XLIX) illustrate another stage of the work. When read in conjunction with her diary, the notes in these six volumes chart the eighty or so attempts Woolf claims to have made to fashion a work that would adequately convey her conception of criticism as direct communication between reader and work.

Similar glimpses into her creative process recur throughout the notebooks. A reading note on E. M. Forster's A Passage to India headed "Novels" begins: "Question of perspective: Morgan uses two: his people become mystic. The old lady in P. to I. 266. This is somehow wrong. Question of reality-which reality? But can you mix them? If not, why not? Symbolism. I believe there is something in this" (XVIII, B.12). An entry in her diary, dated December 7, 1925, records: "I am reading the Passage to India. . . . I think I will find some theory about fiction. I shall read six novels, \& start some hares. The one I have in view, is about perspective" (D, III, December 7, 1925). Her reading notes on Robinson Crusoe, made shortly after this, show her working out this theory: "Also the question of perspective. ... [p.] 53 After the wreck 'I never saw them afterwards .... . except 3 of their hats, one cap, \& two shoes that were not fellows' his particularity. That one believes this entirely: Every thing fitted in no looseness. This is one kind of reality" (IV, B.1). Her ideas about perspective were first voiced in the essay on Robinson Crusoe (February 1926), then expanded in "How Should One Read a Book?" (October 1926), and finally given full expression, after many modifications that are recorded in the reading notebooks, in "Phases of Fiction" (1929).

Perhaps the most significant contribution to our understanding of Woolf at work emerges from the vast amount of material she drew upon during the thirties as a background for what began as The Pargiters (1932) and later became The Years (1937) and Three Guineas (1938). In the "First Essay" of The Pargiters, Woolf introduces her fictional history of "a family called Pargiter" by asserting: "This ... is not 


\section{[ INTRODUCTION ]}

a novel of vision, but a novel of fact. It is based upon some scores-I might boldly say thousands - of old memoirs. There is scarcely a statement in it that cannot be [traced to some biography, or] verified" (p. 9; bracketed phrase deleted by Woolf in the original). This assertion, as Woolf truthfully declares, is no "empty boast": twelve volumes of reading notes support her claim. In them we can follow her path as she planned her novel-essay in 1931 and 1932, watch her collecting material and sketching scenes for the book on women, war, and fascism that began to dominate her thoughts in 1935, and observe her, two years later, compiling the footnotes for Three Guineas ${ }^{36}$

Described as a sequel to A Room of One's Own, The Pargiters originated in the talk known today as "Professions for Women," during which Woolf had told the story of her struggle as a young reviewer to kill the "Angel in the House" and had outlined the sexual conventions that still restricted her when she wrote. ${ }^{37}$ In the new work, she planned to attach an historical preface to the talk - "to provide that perspective which is so important for the understanding of the present" (Pargiters, p. 9). In order to do this, she had to become a systematic reader of her culture. Sometime after January 1931, then, Woolf began to gather quotations and facts about women, men, law, sexuality, sports, religion, the Church, science, education, economics, politics, and social mores, taken from a wide variety of newspapers and periodicals, biographies, autobiographies, social and intellectual histories. By February 1932, she "had collected enough powder to blow up St. Paul's" $(A W D)$, and in December 1932, having written over sixty thousand words, she found that the book released "such a torrent of fact as I did not know I had in me. I must have been observing and collecting these 20 years" $(A W D)$. If her original idea had been to explore "the sexual life of women," by November 1932, while writing the first chapter of the book, she planned "to take in everything, sex, education, life etc: . . f from 1880 to here and now" ( $A W D)$.

Later, as the novel split off from the essay and the thirties moved steadily toward war, Woolf's notes began to include more and more facts about war, politics, and fascism and their influence on private lives. "It is to be hoped," she comments in Three Guineas, "that some methodical person has made a collection of the various manifestos and questionnaires issued broadcast during the years 1936-37" (p. 304), and Woolf herself did just that. These manifestoes, along with a selection of letters asking for her support in some cause, newspaper cuttings, a description of a service at St. Paul's, and a great number of quotations and notes from her reading during these years, are now preserved in three large notebooks described in the 


\section{[ INTRODUCTION ]}

Monk's House Papers Catalogue as " 3 bound volumes containing Press Cuttings \& extracts collected or copied by VW relative to $3 \mathrm{Gs"}$ (LVIII, LIX, LX) ${ }^{38}$

Although the full power of the " 3 bound volumes" resides in the accumulation of facts to support her arguments, what strikes me most about the individual entries is Woolf's eye for the details that reveal the conscious and unconscious attitudes governing behavior: her reading of the messages encoded in diverse modes of public and private discourse. Both her training as a sociological critic and her ambiguous relationship to a cultural heritage that simultaneously supported and excluded her contributed in the thirties to her critical analysis of the institutions and attitudes that dominate the public sphere and control private lives. By this time, Woolf no longer cared if the men were laughing. Spurred by the events of the decade and her own growing certainty, she confronted head-on the destructiveness she had long ago attributed to English social structures and values and set out to document its pervasiveness and source. Every book, every newspaper article, became part of her larger vision, even if they were read for completely unrelated ends. A passage from Gosse's biography of Donne read for the second Common Reader, a quotation from Elizabeth Barrett Browning's Letters read for Flush, a verse from her old friend G. Lowes Dickinson's translation of Goethe-all these found their way into the notebooks and into her works.

The same insight that influenced her choice of entries also led to their careful arrangement within the " 3 bound volumes." The effect she achieves is that of a collage, the two or three cuttings on a single page often serving as an ironic commentary on each other, as well as setting up reverberations that extend throughout the whole..$^{39} \mathrm{~A}$ cutting in the first notebook, for example, records Judge MacCardie's comments on women's dress instinct, quoted later in Three Guineas: "Dress, after all, is one of the chief methods of women's self-expression. ... In matters of dress women often remain children to the end" (Ch. II, n.16; the paragraph in the cutting is headed "Sex Allurement"). Other cuttings scattered throughout the notebooks report: "19LB CLOTHES AT CORONATION / WHAT SOME PEERS MUST WEAR / NEW COIFFURE FOR PEERESSES"; "POSTMEN WANT TO BE SMARTER / UNION'S DEMAND TO POSTMASTER-GENERAL / IMPROVEMENTS IN CUT SUGGESTED"; "NEW UNIFORMS FOR ARMY / SMARTER 'WALKING OUT' DRESS / EQUIPMENT TO BE LIGHTER." Photographs show "Count Ciano in flying kit," the dress of "The POPE on his throne in St. Peter's, Rome, during the service held in celebration of his 
79th birthday," women dressed for the races, and the dress of "The Heralds proclaiming the date of the Coronation" of King Edward VIII in 1936. (The last two are from the same edition of the Daily Telegraph.) A further comment on the nature of male attire is provided by an entry referred to in the index of Volume LIX as "Huxley and the Mandrill. The advertising sex." The reference is to a cutting of an article by Julian Huxley on "The Colours of Animals" that includes two photographs. One shows how "The male mandrill advertises his fighting qualities by his face-décor, and so warns off rivals"; the other captures "The male Argus pheasant advertising his attractions to his mate" (LIX, B.29).

When read in their entirety, the " 3 bound volumes" illustrate more than the care that Woolf took in preparing her books or the wealth of facts she amassed; they are an important contribution to the social history of the thirties. The newspaper cuttings and manifestoes document the changing attitudes-in Parliament, in the Church, and among ordinary women and men-toward domestic and foreign politics and toward the possibility of war. They present as well the economic and "scientific" arguments used for and against women's participation in the work force during an economic recession, arguments that are still heard today. Finally, they raise fundamental questions about the often contradictory relationship between our public and private lives. Woolf's recognition of the interaction of these two spheres is recorded explicitly in an entry headed "Dictators" (LIX, B.87). The quotations included in this entry are copied from two articles that appeared in the Daily Herald, August 1, 1936. The first reports how "Sir E.F. Fletcher urged the House of Commons to 'stand up to dictators" "; the second reports a woman's statement when applying for a maintenance order: "My husband insists that I call him 'Sir'.... I also have to clean his boots, fetch his razor when he shaves, and speak up promptly when he asks me questions." These two articles are cited in Three Guineas as "Evidence of the complex nature of satisfactions of dominance" that controls so much of our lives, a craving for power, Woolf implies, that we must understand in both its private and its public manifestations if we are to prevent war $(\mathrm{Ch}$. II, n.32).

At the end of her essay on "How Should One Read a Book?" Woolf returns to her earlier insistence that we suspend our identity while reading; now, however, she qualifies it. We cannot, she admits, totally silence the internal demon who whispers "I hate, I love" when we read, nor would we want to: "We cannot suppress our idiosyn- 
cracy without impoverishing it" ( $C E$, II, 9-10). What emerges from Woolf's notes is a vivid portrait of an artist who read, with the eye of the novelist/biographer for the techniques of her craft and with the eye of the socially aware woman for the details that shape and explain our experience, the books that fed her own rich creative life. Ultimately, her movement in the thirties into the public sphere is inseparable from her needs and values as an individual and an artist, for the forces that cause wars not only destroy lives but foster attitudes inimical to the human instinct for self-expression necessary for the survival of singer and audience alike.

In a letter to Ethel Smyth written at Rodmell in July 1934, Woolf provides a vision of the role of the reader in undermining the forces of dominance and power, a vision that recalls her ability as a young girl to subvert, through the act of reading, the cultural restrictions imposed upon her because of her sex. "... today," she writes,

like a butterfly whose wings have been crinkled up to a frazzle, ... I begin to shake them out, and plane through the air. I've not read so many hours for how many months. Sometimes I think heaven must be one continuous unexhausted reading. Its a disembodied trance-like intense rapture that used to seize me as a girl, and comes back now and again down here, with a violence that lays me low. Did I say I was flying? How then can I be low? Because, my dear Ethel, the state of reading consists in the complete elimination of the ego; and its the ego that erects itself like another part of the body I dont dare to name. ( $L, \mathrm{~V}, 2915)$.

More than an issue of gender, this passage speaks as well to the creation of a community of minds in which individuals, reading "with great sympathy and yet with great severity" ( $C E, \mathrm{II}, 11)$, unite their perceptions and their dreams in an act of mutuality that breaks through false boundaries and opens the way to true communion. As Woolf knew, however, the dream of "a unity that rubs out distinctions," a belief in "the capacity of the human spirit" to achieve freedom and peace, will remain a dream voiced by the poets as long as the sound of guns fills our ears (Three Guineas, 259-260).

In the years following the publication of Three Guineas, Woolf told an audience of working-class readers: "Literature is no one's private ground; literature is common ground" ("The Leaning Tower," $C E$, II, 181). She finished Between the Acts, in which an older woman reads literature and history while a younger woman reads in the newspaper of a girl raped by the horse guards, and both play the role of the 
audience at the village play. Finally, she began "Anon," her portrait of the artist as an outsider capable of cutting through the layers of social convention in order to tap the reservoir of shared emotions hidden beneath. Although Woolf's history breaks off with the birth of the reader at the end of the Elizabethan period, from that moment, she tells us, "We are in a world where nothing is concluded" $(A \& R$, 429). Today we have inherited the legacy of Woolf's love of reading, which the notes help us to make our own. Interspersed as they are with names, addresses, shopping lists, passages from her novels, even drawings, jotted on the backs of pages or interjected into other entries, they fulfill one of the expectations that Woolf brought to her own reading: they re-create the intellectual landscape that nourished one of the major artists of this century and "bring [us] into the presence of a human being unlike any other" $(C E, \mathrm{II}, 2)$.

\section{NOTES}

1. The Diary of Virginia Woolf, ed. Anne Olivier Bell, 3 vols. (New York: Harcourt Brace Jovanovich, Inc., 1977-1980), III, December 29,1929 . Hereafter, references to the three published volumes of the Diary are cited as $D, \mathrm{I}, \mathrm{II}$, or III, followed by the date of the entry.

2. The Letters of Virginia Woolf, ed. Nigel Nicolson and Joanne Trautmann, 6 vols. (New York: Harcourt Brace Jovanovich, Inc., 1975-1980), IV, letter numbered 1981, January 9, 1929. Hereafter, the six volumes of the Letters are cited as $L$, I, II, III, IV, V, or VI, followed by the letter number and, where applicable, the date.

3 . For the history of this work and texts of the first two chapters, see “'Anon' and 'The Reader': Virginia Woolf's Last Essays," edited with an introduction by Brenda R. Silver, Twentieth Century Literature 25, no. 3/4 (Fall/Winter 1979): 356-441. Hereafter cited as $A \& R$.

4. Part of what Woolf's father, Leslie Stephen, left her was his library, which is described and listed in the Catalogue of Books from the Library of Leonard and Virginia Woolf (Brighton: Holleyman \& Treacher, 1975). "Here," the editors write, "we find in rows of dustbegrimed volumes the literary ancestry of Virginia Woolf-for these books she inherited from her father and among them are books which Leslie Stephen inherited from his father and grandfather, and one which probably belonged to his great-grandfather" (p. 5).

5. Virginia Woolf, The Pargiters: The Novel-Essay Portion of "The Years," ed. Mitchell A. Leaska (New York: The New York Public 
Library \& Readex Books, 1977), p. 99. Hereafter cited as Pargiters. In her essay "Leslie Stephen" (1932), Woolf described both her father's encouragement to "Read what you like" and the only lesson he gave her in the art of reading: "To read what one liked because one liked it, never to pretend to admire what one did not" (Collected Essays [New York: Harcourt, Brace \& World, 1967], IV, 79-80; hereafter cited as $C E$ ). Both of these dictums are clearly illustrated in the reading notes. Twenty-six years earlier, however, Woolf had recalled that Stephen stopped reading Vanity Fair to his daughters as it was "too terrible." See Frederick William Maitland, The Life and Letters of Leslie Stephen (London: Duckworth, 1906), p. 475. At the end of her life, while soliciting contributions to the library founded by the London National Society for Women's Service, she declared: "I owe all the education I ever had to my father's library, and so perhaps endow libraries with more divinity than I should" ( $L$, VI, 3394).

6. References to Woolf's reading notes are to the volume and entry number that identify them in my text: for example, Volume XI, entry B.7. As explained in the Notes on the Text (p. 39), I have reproduced Woolf's punctuation and spelling exactly as they appear in the original notebooks. Illegible words are indicated by $[\ldots]$; editorial insertions as [word]; and uncertain readings as [?word].

7. [Diary] Holograph notebook. Unsigned. June 30-October 1, 1903. No. 2. Berg Collection. For an excellent study of Woolf's complicated feelings about her cultural inheritance and those "inheritors" who were also her brothers, see Sara Ruddick, "Private Brother, Public World," in Jane Marcus, ed., New Feminist Essays on Virginia Woolf (Lincoln: Univ. of Nebraska Press, 1981). In her essay, Ruddick discusses the threefold recurrence of a universal mind in Jacob's Room, most notably in Woolf's statement that "There is in the British Museum an enormous mind" that fosters Jacob's sense of inheritance and mastery but discourages and excludes Julia Hedge. "Why," Julia cries, looking at the ring of male names circling the dome, "didn't they leave room for an Eliot or a Brontë?" (Uniform Edition [London: Hogarth Press, 1971], pp. 107, 105). Later, she imagines Jacob and his friends, the young men, laughing in the hall. In an essay entitled "Thinking Back through Our Mothers," Jane Marcus analyzes Woolf's vision of literature as a common mind in terms of Woolf's feminist attack on the individual ego and the "egotistical sublime." Instead, she writes, Woolf developed a "collective sublime" (New Feminist Essays on Virginia Woolf, pp. 9-10).

8. As Louise A. DeSalvo illustrates in her essay, "1897: Virginia Woolf at 15," Stephen actively encouraged and helped his daughter to 
become a historian and a biographer (in Jane Marcus, ed., New Feminist Essays on Virginia Woolf, Vol. II; forthcoming). In 1893, for example, he wrote to Julia Stephen: "Yesterday I discussed George II with 'Ginia'.... She takes in a great deal and will really be an author in time, though I cannot make up my mind in what line. History will be a good thing for her to take up as I can give her some hints" (Sir Leslie Stephen's Mausoleum Book, with an introduction by Alan Bell [Oxford: Clarendon, 1977], p. xxviii). In her essay, DeSalvo provides a detailed analysis of the ways in which the fifteen-year-old Woolf used her extensive reading not only to educate herself but to relieve her anxiety when formal lessons were forbidden her (they were believed to contribute to her "nervousness"): "Reading, in effect, became Woolf's refuge, her solace in grief, her substitute for the friendships that she did not have, the way she carved out an identity for herself as a human being, the way she secured her privacy, the way she began to determine the life that she would choose for herself as a woman." See also Katherine C. Hill, "Virginia Woolf and Leslie Stephen: History and Literary Revolution," PMLA 96, no. 3 (May 1981): 351-362.

9. Leslie Stephen, "The Study of English Literature," Cornhill Magazine, n.s., vol. 8, no. 47 (May 1887): 494-495.

10. Ibid., p. 493. In this essay, Stephen also indicates other auxiliary studies to literature-philosophy, the technicalities of meter and form, the classics-only to dismiss them all. "If I were asked," he continues, "whether a young man would best fit himself for a literary career or for the study of literature by reading books about authors or by reading mathematics, ... I should unhesitatingly advise mathematics" (p. 502). Katherine Hilbery, in Woolf's Night and Day, may well have heard him.

11. Ibid., p. 498.

12. Three Guineas, Uniform Edition (London: Hogarth Press, 1938), p. 296.

13. See Ruddick, "Private Brother, Public World," for an analysis of the significance of this image in The Waves.

14. A Writer's Diary, ed. Leonard Woolf (London: Hogarth Press, 1953), January 23 and 26, 1931; January 1 and February 11, 1932. Hereafter cited as $A W D$.

15. "The Journal of Mistress Joan Martyn," edited with an introduction by Susan M. Squier and Louise A. DeSalvo, Twentieth Century Literature 25, no. 3/4 (Fall/Winter 1979): 238.

16. Ibid., p. 241.

17. The reading notes on these works served Woolf well when she began to write her lectures on women and fiction in 1928, even if the 
details found in A Room of One's Own did not contribute to the original essays. See Volumes IX, XIII, XX, XLVI, XLVIII, and LII.

18. Examples that focus on attitudes toward women are frequent in Woolf's exploration of style. A note on Tristram Shandy (1926), for example, reads: "The thing to analyze is the character of ' $I$ ' who does the talking - the very nicely shaded \& calculated voice which is halfsneering at women, \&c . . has all shades in it" (XIV, B.16).

19. [The Reader]. Folder 4, first sequence, p. 36. Berg Collection.

20. Stephen, "The Study of English Literature," p. 498.

21. In Maitland, The Life and Letters of Leslie Stephen, p. 476.

22. [The Reader]. Folder 3, second sequence, p. 29. Berg Collection.

23. For a study of Woolf's use of color in The Years, see Jane Marcus, "Pargeting 'The Pargiters'," Bulletin of the New York Public Library (Spring 1977): 417-419.

24. In this passage, as well as others in the essay, Woolf may be echoing Sainte-Beuve, who had written: "To know how to read a book and meanwhile to judge it without ceasing to enjoy it is almost the whole art of the critic. But the art consists also in comparing and in noting well the points of comparison: thus, besides Atala read Paul et Virginie and Manon Lescaut; besides René read Oberman and Le Lépreux; besides Les Martyrs read the Odyssey, Télémaque and Milton. Do this and let yourself go. The judgment will result quite naturally; it will form itself from your impression." See Chateaubriand et son group littéraire, in René Wellek, A History of Modern Criticism: 1750-1950. Vol. III: The Age of Transition (New Haven: Yale Univ. Press, 1965), p. 48. Stephen thought Sainte-Beuve one of the two or three critics worth reading (Maitland, The Life and Letters of Leslie Stephen, p. 290); his annotated collection of Sainte-Beuve's works was inherited by Woolf (see Catalogue of Books from the Library of Leonard and Virginia Woolf, Monk's House Catalogue, sec. 1, p. 5).

25. One vivid example of this infusion occurs in a 1923 entry on D. H. Lawrence's The Fox:

The possibility may be, it strikes me in reading Lawrence, that some people may get much further on these suggestions than others. To me they lead nowhere. But all writing is only a way of starting suggestions. Conrad's works for me-L's does not. I see though that it may have this power of suggestion for other people. L concentrates people back again in the body-thats why he's so monotonous-fixes them in with great energy. on theory. But its the triumph of the body. Also with a sex theory, wh. is the most restricting 
of all-the most savage \& binding. Very vivid-very physical-very unhumourless \& stark-but not to me interesting. (XXV, B.11)

26. "Byron and Mr. Briggs," ed. Edward A. Hungerford, Yale Review 58, no. 3 (March 1979): 321-349. The typescript is in the Monk's House Papers, List B, 11d, the University of Sussex Library. The title "Introductory. Briggs \& Byron" appears in a list of projected essays for Reading (XLIX, B.25).

27. [Articles, Essays, Fiction and Reviews] Vol. 8 [1938-1939], p. 64. Berg Collection.

28. "Che per quanti si dice piu li nostro,/tanto possiede piu di ben ciascuno": "For by so many more there are who say 'ours',/So much the more of good doth each possess" (LI, B.1). The phrase is from Canto XV of The Purgatorio, ed. Hermann Oelsner, trans. Thomas Okey, Temple Classics (London: Dent, nd). The quotation appears in The Years, Uniform Edition (London: Hogarth Press, 1937), p. 228. Earlier, in an entry on Book VII of Wordsworth's Prelude, made while she was writing The Hours (Mrs. Dalloway), Woolf copied the following lines:

The matter that detains us now may seem,

To many, neither dignified enough

Nor arduous, yet will not be scorned by them,

Who, looking inward, have observed the ties

That bind the perishable hours of life

Each to the other, \& the curious props

By which the world of memory \& thought

Exists \& is sustained.

This is followed by the comment, "Good quotation for one of my books" (XLVII, B.33).

29. "For many centuries after B[ritain] became an island the untamed forest was king. Its moist \& mossy floor was hidden fr. heavens eye by a close drawn curtain woven of innumerable tree tops, wh. shivered in the breezes of summer dawn \& broke into wild music of millions upon millions of wakening birds" (XXXVII, B.6). The passage occurs in Trevelyan's History of England (London: Longman's, Green, 1926), p. 3, and is alluded to in Between the Acts, Uniform Edition (London: Hogarth Press, 1941), pp. 13-14, 254.

30. "The Novels of Dorothy Richardson," The Little Review 5, no. 12 (April 1918): 4.

31. Ibid., p. 11. "If life itself is a boon, and we must accept or reject it as it is, the very fact of living contains it in its entirety, and the grand movements of sensibility, far from enriching it, on the 


\section{[ INTRODUCTION ]}

contrary impoverish it, by concentrating on certain aspects of ourselves - haphazardly overwhelmed by destiny - the effort of attention which would otherwise be more uniformly distributed over the whole of our vital consciousness. From this point of view, a life where only the ordinary and daily happens would be better filled than another life apparently rich with events and adventures. ..." "There is perhaps a new sentiment to be created, that of love of life for life itself, setting aside the great joys that it [life] does not give to all-and that it gives perhaps to no one. . . Our paradise is the day that passes, the minute that takes flight, the moment that already is no more." (Translated by Lynn Anthony Higgins.) The passages are from "L'Originalité de Maeterlinck" and "La Leçon de Saint-Antoine," in Promenades Littéraires, series 5 and 3, respectively.

32. "Modern Novels," TLS, April 10, 1919, p. 189.

33. "The Strange Elizabethans" and "The Countess of Pembroke's Arcadia." "

34. The original version, without the footnote, appeared in $T L S$, April 5, 1923, pp. 221-222; the revised version, including the quotations from October and November 1923, is in The Common Reader (1925).

35. A projected essay on Shakespeare was also abandoned: "The way to do the $\mathrm{Sh}^{\text {re }}$ chapter is this: say that one walks up to $\mathrm{Sh}^{\mathrm{re}}$ quite openly. The $\mathrm{Sh}^{\text {re }}$ critics seem to have gone away \& written at a distance" (XLIX, B.35).

36. Volumes VII, X, XXIII, XXVI, XXXIII, and LV-LX. Volumes $\mathrm{X}, \mathrm{XXIII}$, and LVIII contain notes made in conjunction with The Pargiters; Volume VII consists of footnotes and lists of sources for Three Guineas.

37. "Professions for Women" appears in CE, II, 284-289; a transcription of the original "[Speech before the London/National Society for Women's Service, January 21, 1931]" appears in The Pargiters, pp. xxvii-xxxxiv.

38. The three volumes are listed in the Sussex catalogue as Monk's House Papers, List B, 16f. Monk's House Papers Catalogue is a typed reproduction of the catalogue entries.

39. In creating her collage, Virginia Woolf anticipated (in a way that I find uncanny) Doris Lessing's Anna Wulf, who, in The Golden Notebook filled her notebooks and lined her walls with similar contradictory newspaper cuttings. 


\section{NOTES ON THE TEXT}

\section{The Notebooks}

Of the sixty-seven notebooks included in Virginia Woolf's Reading Notebooks, thirty-three are in the New York Public Library (Berg Collection), thirty-three are in the University of Sussex Library, and one is in the Beinecke Rare Book and Manuscript Library at Yale University. Each set of notes treated in this guide is referred to as a "notebook," even if it consists of unbound pages, or if, as in five cases, the reading notes are part of a notebook that Woolf also used for a diary or for drafts of a novel or essay. A complete list of the notebooks included appears as Appendix A.

Each notebook included, however short, has been listed as a separate volume, designated by a roman numeral followed by the title or number that identifies it in the Berg Collection, in the Monk's House Papers Catalogue (July 1972), University of Sussex Library, or in the Beinecke Library. The notebooks in the three libraries have been grouped separately. The guide begins with the twenty-six volumes of reading notes catalogued as "Holograph reading notes. Vols. 1-26" by the Berg Collection, followed by the other Berg notebooks arranged in chronological order. The order of the Sussex notebooks is that of their appearance and numbering in the Monk's House Papers Catalogue. In my citations of the Sussex notebooks, I have abbreviated the titles as "MH/A" and "MH/B": Monk's House Papers, List A-Biographical; and Monk's House Papers, List B-Literary. When referring to material included in the guide, I have used the volume and entry number that identifies it in my text.

\section{Editorial Decisions}

The determination of what constituted a "reading notebook" for the purpose of this guide rested on whether the entries consisted of notes that Woolf made while actually "reading with a pen and notebook" in hand. Notebooks, such as her early diaries, where she mentions having read or bought books, and notebooks that include outlines or drafts for essays that are based on her reading have not been included. For example, the notes Woolf made at the back of her diary for 1905 on E. A. Freeman's History of the Norman Conquest are included in the guide; but the main part of the diary, where she 
mentions the books she was reading or reviewing, or had read or reviewed, is not. ${ }^{1}$ Although the entries in this diary are a major source of information about what Woolf read and reviewed-in the same way that her later diaries are-they are not reading notes. In this particular case, the reading notes on several of the books mentioned in the 1905 diary are found in "MH/B.1a" (Sussex), which is Volume XXXV of the guide. Similarly, a manuscript catalogued as "[Holograph reading notes] Notes for Reading at Random" (Berg) has been omitted because it consists of ideas and outlines for what became "Anon" and "The Reader," but not reading notes. Instead, the books Woolf read as a background for her essays are found in "Holograph reading notes. Vol. 16" (Berg) and "MH/B.2c" (Sussex), included in the guide as Volumes XVI and XXXVII, respectively. Other material that is helpful in identifying or commenting on the reading notes is referred to in the introductions to the individual notebooks. No attempt has been made in this guide to record the occasional reading note scattered among Woolf's other manuscripts.

Although a chronological ordering of the notebooks would have been desirable, their history and the nature of their contents made this impossible. According to Quentin Bell, Woolf did not systematically collect or bind her reading notes; instead, she bound them whenever she had time, often combining notes from different periods and different essays. Later, she might remove notes from one volume, only to bind them again elsewhere. Moreover, when she sat down to read, she often took up whatever paper or notebook was at hand; as a result, reading notes from the same period, and often on the same book, may be divided among several different notebooks. Where such overlappings occur, and they are frequent, references to the other relevant volumes or entries appear either in the introduction to the notebook or in the description of the individual entry. For example, the introduction to Volume XVI (Berg), which includes reading notes for "Anon" and "The Reader," directs the user to Volume XXXVII (Sussex), which contains more notes from the same period. Similarly, the user interested in Woolf's reading of Greek literature for The Common Reader will find cross-references in Volumes XIX, XXV, XLVII, and XLIX. Multiple entries on a single work such as The Antigone that were made at different times in Woolf's career are not cross-referenced in the text of the guide; they are, however, listed in the Index. Finally, a chronological chart of the notebooks, which indicates both where notes from a particular year are found and the years covered by a single notebook, appears as Appendix B. 
The notebooks themselves vary greatly in the amount of material they include and in their format: the numbers of authors or books included, how thoroughly Woolf has documented the notes, whether the pages have been numbered. For this reason, each volume has its own introduction, in which its particular interests and problems, as well as any variations in the way it has been described, are explained.

\section{Organization}

\section{Dating}

The major issue addressed in the introduction to each volume is the process of dating the notebooks, which usually consists of dating the individual entries. In turn, the dates of the entries can often be only approximate, based on when Woolf's reviews of the books noted were published or on the mention of the books in her letters or diaries. ${ }^{2}$ Woolf's ink colors, moreover, often indicate different dates for entries. While most of the notebooks contain material dating from the same period, occasionally notes from different periods are bound together. Where such anomalies occur, probable dates are supplied. Where the books noted have been the basis of reviews or essays, I have indicated, either in the introduction to the notebook or within brackets in the individual entry, where and when these were originally published, giving, where available, B. J. Kirkpatrick's reference number in the Bibliography of Virginia Woolf (identified by "Kp."). ${ }^{3}$

\section{Table of Contents}

After the introduction, the treatment of each volume is divided into two sections: "A. TABLE OF CONTENTS," where one or more exists; and "B. ENTRIEs." Section A consists of Woolf's lists of the works or authors included in the notebook; these usually appear on the cover or the first page. They have been reproduced exactly as they appear in the original. Some of the lists record Woolf's projected reading for a particular essay or period, some were made as she read the books, and others were made at the time that she bound the notes and refer to what is (or was) included in the notebook. Often, however, titles listed in the tables of contents fail to appear among the entries themselves; occasionally they turn up in another notebook, but more often they are not available. 


\section{Entries}

Section B records the notes that actually appear in the rotebook, listed in their original order. The separation of what is often a confused mass of notes into "entries" was done to facilitate locating the notes on a particular book or subject in the original notebook, as well as to facilitate identification of the sources. Woolf's haphazard method of collecting her notes, as well as the fact that she often read several books at the same time, make it impossible to assume that the order of the entries is the order in which she read the works. What can be seen, however, are the associations she made while reading. When one book or idea seems to have led her to another, the interconnected notes are either described as a single entry or the reader is referred in one entry to the other related entries. When Woolf was reading Gibbon's autobiography, for example, the phrase "bare footed fryars singing vespers" reminded her of Marlowe's line in The Jew of Malta: "and ducke as low as any bare-foot fryar." The two phrases appear one under the other on a page of assorted notes on Gibbon, and are listed as one entry (VI, B.3). In another place, where a line reading "Henry James. Pacific too beautiful to be beautiful when reproduced" appears between the two pages of notes on South Sea Bubbles, By the Earl and the Doctor, it is listed separately and the user is referred to the preceding entry (XLIV, B.4 and B.5; both entries follow notes on Melville's Typee and Omoo).

What constitutes an "entry" varies from volume to volume, and even within volumes, depending on the nature of the notes and the shape of the notebook as a whole. In notebooks essentially devoted to one or two authors, the notes on each work are listed as a separate entry. In notebooks that contain notes on a large number of works by different authors, books by the same author are often listed as subdivisions of a single entry. Subdivisions are also used when Woolf read two editions of a work simultaneously (as in the case of The Paston Letters), or when the two works that appear under a single heading are so intertwined as to be considered one entry.

Although Woolf's notes almost always jump from the text she is reading to her reactions to it, some entries include a larger proportion of general or speculative comments about the work, its author, or its implications than do others; when this is the case, information about the extent and nature of her comments is provided. In other places, Woolf completely steps outside of her text to draw her ideas together, to devise a theory, or to design a format for an essay. These notes usually appear as separate entries that include, where appli- 
cable, references to the work or works that triggered them. "How to Read," for example, which follows her notes on Stendhal's Le Rouge et le noir and includes an unidentified page reference to that novel, has its own entry but refers the user back to the preceding notes on the novel (XVIII, B.3-4).

Woolf's notes often include references to works that can be traced to a footnote or textual reference in the book she is reading at the time. These references are recorded and identified in the description of the entry in which they appear, but they are not listed separately unless she has noted the work itself. Her entry on Edith Cuthell's Wilhelmina, Morgravine of Baireuth, for example, includes references to the Memoires de la Morgravine de Baireuth, to SainteBeuve's Causeries de lundi, and to Carlyle's History of Freidrich II of Prussia, called Frederick the Great. All three of these works are mentioned in Cuthell's introduction, and all three appear in the first paragraph of Woolf's review of the book. Only Carlyle's History, however, has its own set of notes, and therefore its own entry (XXXV, B.2930 ). Notes that are not connected to her reading, on the other hand, such as addresses, passages from her novels, or random ideas, do have their own entries. When these entries appear, as they often do, on the reverse side of a page containing notes on a different subject, they are listed after the original entry, with instructions designating where they can be found in the notebook.

ENTRY HEADINGS. Each entry is introduced by a heading, enclosed in quotation marks. This heading is either the heading that Woolf herself placed at the beginning of her notes ("The Letters of L. Sterne," for example, or "How to Read"), or the first phrase or sentence of the notes themselves. Either way, the heading is transcribed exactly as it appears in the original text. In this way, the user can find specific notes in the actual notebook where page numbers are not available or where several entries appear on a single page.

NUMBER OF PAGES. The heading is followed by a brief description of the number of pages that comprise that entry and by other information relevant to the location of the notes in the original, to the identification of the source of the notes, or to the content of the notes themselves. In calculating the number of pages for an entry, every page that contains notes related to the entry has been included in the total, even if it is only one line. When a page contains only a line or two of an entry, or an entry itself is only a few lines, this information is also recorded. Occasionally, the description of an entry will read 
"Heading only," indicating that no notes exist beyond the heading itself.

PAGINATION. The pagination within the notebooks varies greatly, ranging from pages with no numbers to pages with two or three sets of numbers. Woolf sometimes numbered the pages as she made her notes, using the same ink that she used for her notetaking; more often, she numbered the pages of a notebook when she bound it, using a blue pencil and numbering the pages more or less consecutively. Where two or more sets of Woolf's numbers exist, the consecutive numbers appear first. Woolf's numbering is identified by "VW." In several of the Berg notebooks, the pages have been numbered in pencil in the upper right corner by the librarians at the New York Public Library. This set of numbers is identified by "NYPL." In the notebooks where page numbers exist, the location of an entry is indicated by page number only. In the unpaginated notebooks, the location of those entries that do not begin on a separate page is given relative to the preceding entry.

OTHER INFORMATION. Almost all of the entries consist of handwritten notes; where the notes are typed, or the entry consists of a newspaper cutting (as in Volumes LVIII-LX), this information is indicated in the description of the entry. Where Woolf has provided documentation for an entry other than that found in the headingsuch as dates, authors or titles for quotations, or marginal notesthese also appear in the description of the entry: "Entry dated 'June 1921'"; "Quotation, annotated 'Keats Letters. 77' "; "Marginal notation, 'Lowell./Chaucer./267/My Study Windows.'”

\section{Sources}

The specification of the book or poem or article that is the source of Woolf's notes has been indented beneath the descriptive matter that introduces the entry. Each source has been identified as fully as possible, including the edition of the work that corresponds to Woolf's notation of page references in her notes. The majority of identifications were made from books found in the British Library or in the London Library. When the specific edition has not been found, either because of insufficient information in Woolf's notes, or, as in the case of several of the novels, because of a profusion of editions, the date of the first edition appears in brackets. In these cases, the user is occasionally referred to those editions of the work listed in the 
Catalogue of Books from the Library of Leonard and Virginia Woolf that Woolf might have read. This catalogue, published by Holleyman \& Treacher (Brighton, 1975), records a large number of the books found in Monk's House and at 24 Victoria Square, Leonard Woolf's two residences at the time of his death. ${ }^{4}$ When Woolf's page references correspond to several editions of the same work (for example, Jebb's edition of Sophocles' plays), or when a work was published in a series such as Bohn's "Standard Library" as well as in other Bohn series with the same page numbers, the first edition is given.

Only those works that can with certainty be identified as part of Woolf's reading have been cited as sources. Where there is some hesitation or speculation about the source of the notes or about whether Woolf actually read a work, the possibilities are included in the description of the entry. This is the case with several titles that Woolf noted, possibly with the intention of reading them, but that are not followed by notes. Moreover, when Woolf read a work that has more than one volume, I have indicated only those volumes that are noted in the particular entry: "Vol. I [of II]"; "Vol. III [of IV]." If both or all of the volumes are noted, the source reads, " 2 vols." or "4 vols." Similarly, when Woolf read a work that appears in a collection, I have given only the volume number that includes her text: "Journal to Stella... .In The Prose Works. Vol. II." Finally, when Woolf's text is part of a larger work, I have included that information as well, since it is often necessary to have the full title in order to find the specific edition in the library. Thus, the source for Dickens's Bleak House includes the information, "Vol. XI of The Works of Charles Dickens. Authentic Edition."

Where the source of a reading note has not been traced, the subject matter and any other relevant information appears after the heading. Unless otherwise noted, the place of publication for all works is London.

\section{Symbols and Abbreviations}

In transcribing from the notebooks I have used the following conventions:

/: line endings

[?word]: an uncertain reading

[word/word]: possible alternative readings

[word]: a word supplied by the editor

$[\ldots]$ : an illegible word or words. 
Where Woolf's punctuation is ambiguous, I have used what made the most sense in context; I have also altered her occasional bracket to a parenthesis in order to avoid confusing it with editorial insertions. Otherwise, Woolf's punctuation, abbreviations and contractions, spelling, and typing errors have been reproduced exactly as they appear in the text, explained where necessary by the use of brackets. One of her habits, for example, was to abbreviate a word by omitting the middle letters and raising the final letter or letters: $\mathrm{Sh}^{\text {re }}$ for Shakespeare; auto ${ }^{y}$ for autobiography. The use of ellipses within the headings and the other quotations from the notes indicates that Woolf's sentence or the passage that she was copying continues beyond my transcription of it.

The following abbreviations have been used throughout the guide:

$A \& R$ : “'Anon' and 'The Reader': Virginia Woolf's Last Essays." Ed. Brenda R. Silver. Twentieth Century Literature 25, no. 3/4 (Fall/Winter 1979): 356-441.

$A W D$ : Virginia Woolf. $A$ Writer's Diary. Ed. Leonard Woolf. London: Hogarth Press, 1953.

CE: Virginia Woolf. Collected Essays. 4 vols. New York: Harcourt, Brace \& World, 1967.

$C R$ : Virginia Woolf. The Common Reader. London: Hogarth Press, 1925.

D, I, II, and III: The Diary of Virginia Woolf. Ed. Anne Olivier Bell. Vol. I: 1915-1920; Vol. II: 1921-1924; Vol. III: 1925-1930. London: Hogarth Press; New York: Harcourt Brace Jovanovich, Inc., 1977-1980. (References are to the dates of the entries.)

[Diary] No. 3: [Diary] Holograph notebook. Unsigned. Christmas 1904-May 31, 1905. No. 3. Berg Collection.

DNB: The Dictionary of National Biography.

Holleyman \& Treacher, M/H or V/s: Catalogue of the Books from the Library of Leonard and Virginia Woolf. Brighton: Holleyman \& Treacher, 1975. M/H indicates the Monk's House catalogue; V/s the Victoria Square catalogue.

Kp.: B. J. Kirkpatrick. A Bibliography of Virginia Woolf. 2nd rev. ed. London: Hart-Davis, 1967.

L, I, II, III, IV, V, and VI: The Letters of Virginia Woolf. Ed. Nigel Nicolson and Joanne Trautmann. Vol. I: 18881912; Vol. II: 1912-1922; Vol. III: 1923-1928; Vol. IV: 1929-1931; Vol. V: 1932-1935; Vol. VI: 1936-1941. Lon- 


\section{[ NOTES ON THE TEXT ]}

don: Hogarth Press; New York: Harcourt Brace Jovanovich, Inc., 1975-1980. (The numbers given in references to this work are letter numbers.)

MH/A or MH/B: Monk's House Papers, List A or List B. University of Sussex Library.

MHP Catalogue: Monk's House Papers Catalogue (1972). University of Sussex Library.

NYPL: New York Public Library.

Pargiters: Virginia Woolf. The Pargiters. The Novel-Essay Portion of "The Years." Ed. Mitchell A. Leaska. New York: The New York Public Library \& Readex Books, 1977.

Roo: A Room of One's Own. New York: Harcourt Brace Jovanovich, Inc., 1929; 1957.

3G: Virginia Woolf. Three Guineas. Uniform Edition. London: Hogarth Press, 1938.

TLS: The Times Literary Supplement.

VW: Virginia Woolf.

\section{NOTES}

1. [Diary] Holograph notebook. Unsigned. Christmas 1904-May 31, 1905. No. 3. Berg Collection. See Volume XXVII.

2. I have used for this purpose the six-volume edition of The Letters of Virginia Woolf, ed. Nigel Nicolson and Joanne Trautmann (New York: Harcourt Brace Jovanovich, Inc.; London: Hogarth Press, 19751980); The Diary of Virginia Woolf, ed. Anne Olivier Bell (New York: Harcourt Brace Jovanovich, Inc.; London: Hogarth Press, 1975-1980), Vol. I-III: 1915-1930; and A Writer's Diary, ed. Leonard Woolf (London: Hogarth Press, 1953). As the remaining volumes of the Diary appear, it will be possible to date the later reading notes more precisely.

3. B. J. Kirkpatrick, A Bibliography of Virginia Woolf, 2nd rev. ed. (London: Hart-Davis, 1967). Unfortunately, the third edition of Kirkpatrick's Bibliography (London: Oxford Univ. Press, 1981) appeared too late for inclusion in this guide.

4. These books as well as others from the Woolfs' library not listed in the Catalogue are housed in the Woolf Collection at Washington State University, Pullman. Another set of the Woolfs' books are at the University of Texas. I am grateful to Elizabeth Steele for sharing with me her unpublished list of the literary works at Pullman not found in the Holleyman \& Treacher Catalogue. 
THE NOTEBOOKS 



\section{Holograph Reading Notes. Vol. 1. (Berg)}

On August 16, 1933, Woolf wrote in her diary, "I want to discuss Form, having been reading Turgenev"-the subject of all the entries in this notebook $(A W D)$. Both the August 16 diary entry and the reading notes themselves contain numerous speculations about "form" and the novelist's art that reappear in her essay, "The Novels of Turgenev," first published in the TLS, December 14, 1933 (Kp. C341). Although Woolf has listed " $12^{\text {th }}$ Night" as well as "Turgenev" on the cover of this notebook, the notes themselves-presumably for her review of the Old Vic production of the play, published September 30, 1933 (New Statesman \& Nation; Kp. C339)have been removed. A diary entry for September 26, 1933, however, establishes a connection between the two essays: "Now I begin the morning by telephoning corrections of Twelfth Night, to the N.S. : put in a comma, take out semi-colon; and so on. Then I come out here, having seen the carp, and write Turgenev" $(A W D)$. On October 12, she was rushing to finish the article $(L, \mathrm{~V}, 2803)$.

All the notes in this volume are in black ink.

\section{A. Table of Contents}

1. Turgenev

Rudin

On the Eve

$12^{\text {th }}$ Night.

1 p., on cover.

B. ENTRIES

1. "Turgenev. Pavlovsky": 2 pp., not numbered.

Pavlovsky, Isaac. Souvenirs sur Tourguéneff. Paris: Nouvelle Libraire Parisienne, Albert Savine, 1887.

2. "Turgenev. Letters": 1 p., not numbered.

[Turgenev, Ivan.] Ivan Tourguéneff d'apres sa correspondance avec ses amis français. Ed. E. Halpérine-Kaminsky. Paris: Bibliotheque-Charpentier, Eugene Fasquelle, 1901.

3. "Life. Maurois Turgenev. Rudin": 1 p., not numbered. (2 lines only.) This entry consists of a single reference, an- 
notated " 76 ," to Maurois' biography: "Wrote Roudine in 1855. His first novel."

Maurois, André. Tourgueniev. Paris: Bernard Grasset, 1931.

4. "The long conversations of the Russians; . . .": 2 pp., not numbered. The entry begins on the same page as B.3, under the general heading, "Life. Maurois Turgenev. Rudin." The second page of the entry consists of general notes on the novel, beginning, "The queer way in wh. the figure is turned round and round until you like him."

Turgenev, Ivan. Rudin. Trans. Constance Garnett. Heinemann, 1894.

5. "1859 On the Eve": 2 pp., not numbered.

Turgenev, Ivan. On the Eve. Trans. Constance Garnett. Heinemann, 1895.

6. "A Hut of Gentlefolk.": 3 pp., not numbered.

Turgenev, Ivan. A House of Gentlefolk. Trans. Constance Garnett. Heinemann, 1894.

7. "Fathers \& Children": 2 pp., not numbered. A note at the end of the entry - "Preface/9 realising instead of idealising"-refers to a statement by Turgenev quoted in Edward Garnett's "Introduction" to the novel: "It was a new method as well as a new type I introduced-that of Realising instead of Idealising" (p. ix).

Turgenev, Ivan. Fathers and Children. Trans. Constance Garnett. Heinemann, 1910.

8. "Smoke": 1 p., not numbered.

Turgenev, Ivan. Smoke. Trans. Constance Garnett. Heinemann, 1896.

9. "Sportsmans Sketches.": 1 p., not numbered.

Turgenev, Ivan. A Sportsman's Sketches. Trans. Constance Garnett. Vol. I [of II]. Heinemann, 1895.

10. "Turgenev.": 1 p., not numbered. (7 lines only.) General notes on Turgenev, reading, "The different 'I's in novel writing. [...] was I the lover of Madame Viardot; the man who was bullied by his mother \&c: but the other I essential-The one who is the revelation of the laws of life." 
11. "Virgin Soil": $3 \mathrm{pp}$., not numbered. The first page is cut off at the bottom; the second page includes the note, " 159 The [half/long] suspected secret that is strongest in us-Freud."

Turgenev, Ivan. Virgin Soil. Trans. Constance Garnett. Heinemann, 1896.

12. "Torrents of Spring": 1 p., not numbered. (5 lines only.) General notes on Turgenev: "Being an artist: seeing what belongs in a [?confusion] of things. bringing the related together. But what is the force that makes one thing seem a whole?" The reference in the heading is to Turgenev's Torrents of Spring and Other Stories, trans. Constance Garnett (Heinemann, 1897).

13. "The poetic quality that gives his books/their peculiar emotion:": 1 p., not numbered. (6 lines only.) General notes on Turgenev, continuing, "That he stands outside. The view of art: that one must be impartial in one sense-use the right I-not the hot one."

14. "Lear of the Steppes.": 1 p., not numbered. (4 lines only.) General notes on Turgenev: "Ts sympathy with the peasant is always clear. to free the serf. That Harlov is a dominating character. Given in size. roughness."

Turgenev, Ivan. "A Lear of the Steppes." In A Lear of the Steppes and Other Stories. Trans. Constance Garnett. Heinemann, 1898.

\section{Holograph Reading Notes. Vol. 2. (Berg)}

Woolf's article on "Joseph Addison," the subject of this notebook, appeared in the $T L S$, June 19, 1919 (Kp. C155). On May 25, 1919, she was reading Addison and discussing him and "Johnson's lives" (B.2) with Lytton Strachey ( $D$, I; see also $L$, II, 1051). On May 30, 1919, Addison's writings were "The problem of [her] life": "But owing to my lethargy, I can't endure to open the Spectator; in a sort of coma I've glided through Roger de Coverley, who seems a very pleasant old gentleman, but not the sort who much interests me" ( $L$, II, 1052).

A label in black ink on the cover of the notebook reads "Addison." The table of contents, dated May 1919, was apparently made 
after the first seven entries and added to as she read more works. The table of contents and notes are written in a variety of inks: the majority are in a blue-gray ink; the others are blue-purple, turquoise, or black. The page numbers are in blue ink; p. 16 is blank.

\section{A. Table of Contents}

1. Addison.

May 1919.

Dict. Nat. Biog

Johnson's Life

Cato

Page

Tatler

Macaulays Essay

Spence's Anecdotes.

6

Sir Roger de Coverley 11

Spectator. 12

Addison. by Courthope. 17

1 p., not numbered.

B. ENTRIES

1. "D.N.B. (L.S.)": 3 pp., numbered 1-3 by VW.

Stephen, Leslie. "Addison, Joseph, D.D." DNB (1885).

2. "Johnson's Lives. Ed. 1806. vol 10": 1 p., numbered 4 by VW.

Johnson, Samuel. "Addison." In The Lives of the English Poets. Johnson, etc., 1806. Vol. X of The Works of Samuel Johnson, D.D.

3. "Cato": 1 p., numbered 5 by VW.

Addison, Joseph. Cato. A Tragedy. In The Works of the Right Honorable Joseph Addison. New ed. Ed. Richard Hurd. Vol.

I. Cadell \& Davies, 1811.

4. "Macaulay. Essay.": 1 p., numbered $6 \mathrm{~A}$ by VW. The entry appears on the reverse of p. 5 and includes some pencil notes at the bottom of the page. More notes on this work appear below, B.5 and B.7.

Macaulay, Thomas Babington. "The Life and Writings of Addison." In Critical and Historical Essays. Ed. A. J.

Grieve. Vol. II. Dent, 1907. 
5. "Tatler": 2 pp., numbered 6-7 by VW. Notes on Macaulay's essay on Addison are inserted on the bottom of p. 6. See above, B.4, and below, B.7.

a) Addison, Joseph. The Tatler. In The Works of the Right Honourable Joseph Addison. New ed. Ed. Richard Hurd. Vol. II. Cadell \& Davies, 1811.

b) Macaulay, Thomas Babington. "The Life and Writings of Addison." In Critical and Historical Essays. Ed. A. J. Grieve. Vol. II. Dent, 1907.

6. "Spences. anecdotes.": 2 pp., numbered 8-9 by VW. The entry begins with a list of page numbers for references to Addison in Spence's work and ends with the note, "stark, stiff, sad, \& severe, is yet so terribly sanguine."

Spence, Joseph. Anecdotes, Observations, and Characters, of Books and Men. Ed. Samuel W. Singer. Carpenter, 1820.

7. "Macaulays Essay Cont": 1 p., numbered 10 by VW. ( 3 lines only.) More notes on this work appear above, B.4 and B.5.

Macaulay, Thomas Babington. "The Life and Writings of Addison." In Critical and Historical Essays. Ed. A. J.

Grieve. Vol. II. Dent, 1907.

8. "Popes Life \& Works.": 1 p., numbered 10 by VW. (3 lines only.) The entry consists of page numbers for references to Addison in The Works of Alexander Pope, ed. Whitwell Elwin, Vol. I (Murray, 1889). The page numbers correspond to those in the index, found in Vol. V of the Works.

9. "Sir Roger de Coverley": 1 p., numbered 11 by VW.

Addison, Joseph. Sir Roger de Coverley. By The Spectator.

Longman, Brown, Green, \& Longmans, 1850.

10. "The Spectator": 4 pp., numbered $12-15$ by VW. The entry includes notes from two different editions of The Spectator. The second set, on pp. 14-15, is headed "returns to 5 tot edition/1811/vol. 4."

a) Addison, Joseph. The Spectator. In The Works of the Right Honourable Joseph Addison. New ed. Ed. Richard Hurd. Vols. II and III. Bohn, 1856. Bohn's British Classics.

b) Addison, Joseph. The Spectator. In The Works of the Right Honourable Joseph Addison. New ed. Ed. Richard Hurd. Vols. IV and V. Cadell \& Davies, 1811.

11. "Addison/by Courthope": 2 pp., numbered $17-18$ by VW.

Courthope, William J. Addison. Macmillan, 1884. 


\section{Holograph Reading Notes. Vol. 3. (Berg)}

"The Novels of Defoe," published in the TLS, April 24, 1919 (Kp. C148), and the subject of this notebook, is only one of the almost weekly reviews and essays that Woolf wrote during 1919. Because of a very tight schedule at this time, Woolf appears to have done all the reading for her article in the weeks immediately preceding its publication. On April 10, 1919, she was "submerged in Defoe; \& [can] only steal 10 minutes from Roxana to write this. I have to read one book a day in order to start on Saturday" $(D, \mathrm{I})$. On April 12, she was reading Moll Flanders and seeing London through Defoe's eyes ( $D$, I). Her absorption with Defoe extended into other aspects of her life; on April 16, she wrote to Vanessa Bell, "Angelica is a lovely name [for Vanessa's daughter]; I wish it had been possible to include Moll Flanders though; or Roxana" ( $L$, II, 1038). She finished the article on April 19, 1919 (D, I, April 20, 1919).

Included among the notes is a "Frame of Article" (B.10) -an outline of the essay-written in black ink with corrections in bluegray ink. The title on the cover sheet, "Defoe:/b: 1659," is in black ink; the rest of the notes are blue-gray.

\section{A. Table of Contents}

1. Defoe: b: 1659.

1 p., on cover.

B. ENTRIES

1. "Wright/Life": 1 p., not numbered. The heading appears in the margin. Pencil notes, some of them inked over. More notes on this work appear below, B.5 and B.9.

Wright, Thomas. The Life of Daniel Defoe. Cassell, 1894.

2. "Captain Singleton": 3 pp., not numbered.

Defoe, Daniel. The Life, Adventures, and Piracies of Captain Singleton. Bohn, 1854. Vol. I of The Novels and Miscellaneous Works.

3. "Preface to Colonel Jack": 1 p., not numbered. The entry appears on the last page of B.2. 4 lines only, reading, "D's own view that his work shd. be useful \& instructive. Public schools \& charities improved. 'Every vicious reader will be encouraged to change.'” 
Defoe, Daniel. "The Preface." In The Life of Colonel Jack. Bohn, 1854. Vol. I of The Novels and Miscellaneous Works.

4. "Life in D.N.B.": 1 p., not numbered.

Stephen, Leslie. "Defoe, Daniel." DNB (1888).

5. "Wright Life.": 2 pp., not numbered. More notes on this work appear above, B.1, and below, B.9.

Wright, Thomas. The Life of Daniel Defoe. Cassell, 1894.

6. "Roxanna.": 3 pp., not numbered. A series of numbers appears on the reverse of the second page, a shopping list on the reverse of the third page.

Defoe, Daniel. Roxana; or, The Fortunate Mistress. Bohn, 1854. Vol. IV of The Novels and Miscellaneous Works.

7. "Moll: Flanders.": 5 pp., not numbered. The entry includes, on the bottom of the fifth page, notes on Defoe's "Preface."

Defoe, Daniel. The Fortunes and Misfortunes of the Famous Moll Flanders. Bohn, 1854. Vol. III of The Novels and Miscellaneous Works.

8. "Later Stuart Tracts": 1 p., not numbered. The entry consists of notes on two of Defoe's essays, following notes on Aitken's "Introduction."

Defoe, Daniel. "The Education of Women" and "Preface to the Eighth Volume of the Review." In Later Stuart Tracts.

Ed. George A. Aitken. Constable, 1903. Vol. XII of An English Garner. Ed. Edward Arber.

9. "Life by Wright.": 5 pp., not numbered. The entry consists of notes and extracts by and about Defoe, arranged under the following headings: "Description of Appearance"; "M. Alphonse Daudet"; "Language"; "Style"; "Walkley on lack of form"; "Aims in Writing" [from "Colonel Jack-Preface"]; "The Education of Women"; "Women"; "Himself." Other notes on this work appear above, B.1 and B.5.

Wright, Thomas. The Life of Daniel Defoe. Cassell, 1894.

10. "Frame of Article": 2 pp., not numbered. General notes for her essay "The Novels of Defoe," beginning, "Defoe almost entirely author of R.C. How he has is scarcely an individual. More like Homer." 


\section{Holograph Reading Notes. Vol. 4. (Berg)}

The notes on Robinson Crusoe that comprise the entire contents of this notebook were made in conjunction with Woolf's essay, "Robinson Crusoe," published in the Nation \& Athenaeum, February 6, 1926 (Kp. C271). Woolf's only known reference to reading the novel at this time occurs in a letter to Vita Sackville-West on January 7, 1926, in which she notes that she has read "some of the Tempest, to compare with Defoe" ( $L$, III, 1608). Another set of notes on this novel, made when she revised the essay for inclusion in The Common Reader: Second Series, appears in XLVIII, B.4.

A label reading "Robinson CRUSOE" in purple ink is pasted on the cover of the notebook; the notes are purple as well.

\section{B. ENTRIES}

1. "Robinson Crusoe": $6 \mathrm{pp}$., not numbered. The entry begins and ends with notes on Charles Whibley's "Introduction" to this edition of the novel.

Defoe, Daniel. The Life and Strange Surprising Adventures of Robinson Crusoe ... Written by Himself. With an Introduction by Charles Whibley. 3 vols. Constable, 1925.

\section{Holograph Reading Notes. Vol. 5. (Berg)}

Woolf's essay, "Swift's Journal to Stella," appeared in the TLS, September 24, 1925 (Kp. C268). On June 27, 1925, while she was making up To the Lighthouse, she was "replenishing [her] cistern at night with Swift": "I am going to write about Stella \& Swift for Richmond" ( $D$, III; the reference is to Bruce Richmond, editor of the $T L S)$. The article was finished on July 20. Although she appears to speak lightly of her criticism in the diary entry ("It is a great standbythis power to make large sums by formulating views on Stendhal \& Swift"), her reading for the Swift article recorded in this volume belies her tone and indicates her seriousness. Another set of notes on Swift's Journal to Stella, made when Woolf revised her essay for publication in The Common Reader: Second Series, appears in XLVIII, B.7.

The cancelled note on David Copperfield (B.7) can also be dated in or around June 1925. On June 12 and 16, 1925, Woolf mentioned 
that she was reading this novel ( $L$, III, $1560 ; D$, III); her article, "David Copperfield," appeared in Nation \& Athenaeum on August 22, 1925 (Kp. C266).

The ink throughout is purple.

B. ENTRIES

1. "Swift. L.S.": 6 pp., not numbered.

Stephen, Leslie. Swift. Macmillan, 1882.

2. "Anecdotes from Scott. Swift": 2 pp., not numbered.

Scott, Walter. Memoirs of Jonathan Swift. In The Works of Jonathan Swift. Ed. Walter Scott. Vol. I. Edinburgh: Constable, 1814.

3. "J. to Stella": 8 pp., not numbered. For later notes on this work, see XLVIII, B.7.

Swift, Jonathan. Journal to Stella. A.D. 1710-1713. Ed. Frederick Ryland. Bell, 1923. Bohn's Popular Library.

Or: Journal to Stella. A.D. 1710-1713. In The Prose Works. Vol. II. Bell, 1897. Bohn's Standard Library.

4. "Swift's Poems to Stella": 2 pp., not numbered. The entry includes the subheading "Stella to Swift," a reference to the poem "Verses by Stella." The notes are all on poems found in the section of Swift's Works titled "Poems Addressed to Vanessa and Stella."

Swift, Jonathan. "Poems Addressed to Vanessa and Stella." In Works. Ed. Walter Scott. Vol. XIV. Edinburgh: Constable, 1814.

5. "Swift to Vanessa": 2 pp., not numbered. The entry consists of notes on letters to and by Vanessa, or "Miss Vanhomrigh." Woolf has misnumbered two of the references, writing "XVI" for volume XIV, and "19" for volume IX.

a) Swift, Jonathan. "Epistolary Correspendence." In Works.

Ed. Walter Scott. Vol. XIV. Edinburgh: Constable, 1814.

b) Swift, Jonathan. "Correspondence Between Swift and Miss Vanhomrigh." In Works. Ed. Walter Scott. Vol.

IX. Edinburgh: Constable, 1814.

6. "Cadenus- Swift to Vanessa": 1 p., not numbered.

Swift, Jonathan. "Cadenus and Vanessa." In Works. Ed. Walter Scott. Vol. XIV. Edinburgh: Constable, 1814. 
7. "Copperfietd/411. I looked at nothing, but I saw everything.":

1 p., not numbered. (Heading only.)

Dickens, Charles. The Personal History of David Copperfield. Vol. I [of II]. Chapman \& Hall,. 1859. Volume XV of The Works of Charles Dickens. Library Edition.

8. "Swift.": 1 p., not numbered. The entry appears on the same page as B.7 and consists of notes on Swift, Stella, and Mrs. Dingley from various sources in Swift's Works: "The Blunders, Deficiencies, Distresses and Misfortunes of Quilca"; letters to "The Rev. Dr. Tisdall," "Mr. Worrall," and "Mr. Tickell." The last two both date from July 1726.

Swift, Jonathan. Works. Ed. Walter Scott. Vols. VII, XV, XVII, and XIX. Edinburgh: Constable, 1814.

\section{Holograph Reading Notes. Vol. 6. (Berg)}

On December 31, 1936, Woolf recorded in her diary that she had "plunged into Gibbon and read and read" $(A W D)$. She had at that time just finished correcting the galleys for The Years, and was planning the work that would tide her over the novel's publication. The diary entry ends, "And in proof of this [her resolve to 'rush into unconsciousness and work'] will go in, get my Gibbon notes and begin a careful sketch of the article." In fact, her "article" turned out to be two: "The Historian and 'The Gibbon'," published in the TLS, April 24, 1937 (Kp. C348), and "Reflections at Sheffield Place," published in the New Statesman \& Nation, June 19, 1937 (Kp. C350). Woolf worked on the first article for about five months. On November 29, 1936, she was "teading all Gibbon to see if I'll do his centenary for the Times" ( $L$, VI, 3194); on March 27, 1937, she was condensing the essay by a thousand words $(A W D)$; and on April 7 , she was still at work $(L, V I, 3232)$. It is possible that she divided the article in two when she condensed it in March.

The reading notes in this volume contributed to both essays. Entries B.2-4 are passages for use in "The Historian and 'The Gibbon'," while the last four entries, B.16-19, are reading notes that pertain to Maria Josepha Holroyd and Hester Gibbon, both of whom figure prominently in "Reflections at Sheffield Place." The note on The Amberley Papers (B.17) resulted from Woolf's delighted reading of that "amazingly interesting memoir" in August/September 1936 
( $L, \mathrm{VI}, 3162,3166$ ). The list that appears as A.2 seems to be a list of references for her essay, rather than an index to the contents of the notebook; most of the items, however, are related to the notes that follow.

The cover sheet for the notebook has "Gibbon" written on it in black ink. The ink throughout is black.

\section{A. Table of Contents}

1. Gibbon

1 p., not numbered.

2. The Gibbon.

Girlhood of Maria Josepha Stanley

Life of Hayley

Historic Papers Studies Meredith Read.

William Law. (for Aunt Hester)

$M^{\text {rs. Gibbon in Bath. }}$

Sheffield Park.

Lord Sheffield.

$1 \mathrm{p}$. , not numbered.

B. ENTRIES

1. "Autoy (Bury)": 2 pp., not numbered. More notes on this work appear below, B.3 and B.9.

[Gibbon, Edward.] Autobiography of Edward Gibbon. As originally edited by Lord Sheffield. Ed. J. B. Bury. Oxford Univ. Press, 1907.

2. "Suddenly turns his light on a particular fact, ...": 1 p., not numbered. General notes for Woolf's essay, "The Historian and 'The Gibbon'."

3. "bare footed fryars singing vespars ../And ducke as low as any bare-foot/Fryar.": 1 p., not numbered. (3 lines only.) The entry appears on the same page as B.2. The first line is a quotation from Gibbon's description of "musing amidst the ruins of the capital" in his Autobiography, also recorded by Woolf in B.9. The second line, "And ducke as low as any bare-foot Fryar," is annotated by Woolf, "Jew of Malta. $2^{\text {nd }}$ act. 1. 786," "262." Both of these quotations appear in her essay, "The Historian and 'The Gibbon'." 
a) [Gibbon, Edward.] Autobiography of Edward Gibbon. As originally edited by Lord Sheffield. Ed. J. B. Bury. Oxford Univ. Press, 1907.

b) Marlowe, Christopher. The Jew of Malta. In Works. Ed. C. F. Tucker Brooke. Oxford: Clarendon Press, 1910.

4. "Johnson certainly was vain of the society/of ladies ...": 1 p., not numbered. The entry appears on the same page as B.2 and B.3; it consists of a quotation, annotated "B. Life of J: iv. 73," which includes a reference to Gibbon: "Mr. Gibbon, with his usual queer, controverted it."

Boswell, James. The Life of Samuel Johnson, L.L.D. Ed. George Birkbeck Hill. Vol. IV. Oxford: Clarendon Press, 1887.

5. "Gibbon Letters": $8 \mathrm{pp}$., not numbered. The entry includes the note, " 327 'The Gib' Sometimes The Gibbon. $\mathrm{M}^{\mathrm{me}} \mathrm{du}$ D. calls him Le Gibbon. This might be the turn of the article." More notes on this work appear below, B.18.

Gibbon, Edward. The Private Letters... 1753-1794. With an Introduction by the Earl of Sheffield. Ed. Rowland E. Prothero. 2 vols. Murray, 1896.

6. "Autobiography": 5 pp., not numbered, and 1 p., on the reverse of the second page. The entry is annotated, on the first page, "First Edition."

Gibbon, Edward. Memoirs of My Life and Writings. In The Miscellaneous Works of Edward Gibbon, Esq., ... illustrated from his Letters, with occasional notes and narrative by John Lord Sheffield. Vol. I. Strahan, Cadell, \& Davies, 1796.

7. "Vindication": 2 pp., not numbered.

Gibbon, Edward. A Vindication of Some Passages in the Fifteenth and Sixteenth Chapters of the History of the Decline and Fall of the Roman Empire. In The Miscellaneous Works of Edward Gibbon, Esq., ... illustrated from his Letters, with occasional notes and narrative by John Lord Sheffield. New ed. Vol. IV. Murray, 1814.

8. "Gibbon.": 16 pp., not numbered. More notes on this work appear below, B.12 and B.14.

Gibbon, Edward. The History of the Decline and Fall of the Roman Empire. Vol. I-III [of XII]. Cadell \& Davies, 1807. 
9. "G. Memoir (Bury": 1 p., not numbered. The entry appears on the reverse of the second page of B.8. More notes on this work appear above, B.1 and B.3.

[Gibbon, Edward.] Autobiography of Edward Gibbon. As originally edited by Lord Sheffield. Ed. J. B. Bury. Oxford Univ. Press, 1907.

10. "Birkbeck Hill. Gibbon. Auy. Notes": 2 pp., not numbered. The entry includes the note, "General Meredith Read. Historical Studies. 2. 479," which is a reference to a footnote on p. 265 of the Birkbeck Hill edition of the Memoirs. This footnote quotes a passage about the Madeira wine in Gibbon's chateau at Lausanne, taken from John Meredith Read's Historical Studies in Vaud, Berne, and Savoy (Chatto \& Windus, 1897), II, 475.

[Gibbon, Edward.] The Memoirs of the Life of Edward Gibbon. Ed. George Birkbeck Hill. Methuen, 1900.

11. "Gibbon. Mowatt.": 1 p., not numbered. (3 lines only.) The entry, which appears on the second page of B.10, reads, "87 G. ... enshrined her picture ( $M^{\text {lle }}$ Chuschod) in his description of the $5^{\text {th }}$ Century Empress Athenais Eudoria."

Mowatt, R. B. Gibbon. Arthur Barker, 1936.

12. "Gibbon.": 2 pp., not numbered. More notes on this work appear above, B.8, and below, B.14.

Gibbon, Edward. The History of the Decline and Fall of the Roman Empire. Vol. IV [of XII]. Cadell \& Davies, 1807.

13. "Notes. B. Hill Gibbon:": 1 p., not numbered. The entry consists of notes for "The Historian and 'The Gibbon'," including 1) a reference to a passage in Rowland E. Prothero's "Preface" to The Private Letters of Edward Gibbon, p. xii (see B.5 above) - "There was only one phrase so indecent in his letters that it had to be left out"; 2) a line reading, "The Walpole quotation coarse Letter VII. 505," which is a reference to a quotation about Gibbon from Horace Walpole's letters, quoted by George Birkbeck Hill in his notes to The Memoirs of the Life of Edward Gibbon ( $\mathrm{p}$. 331; see B.10 above); and 3) a statement about Gibbon attributed to $M^{\text {me }}$ du Deffand, also quoted by Hill (p. 316). The remainder of the notes appear to be Woolf's. 
14. "Gibbon": 2 pp., not numbered, and pencilled notes on the reverse of second page. More notes on this work appear above, B.8 and B.12.

Gibbon, Edward. The History of the Decline and Fall of the Roman Empire. Vol. IV [of XII]. Cadell \& Davies, 1807.

15. "The te Six As": 3 pp., not numbered.

[Gibbon, Edward.] The Autobiographies of Edward Gibbon. Printed verbatim from hitherto unpublished MSS, with an introduction by the Earl of Sheffield. Ed. John Murray. Murray, 1896.

16. "Girlhood of M.J Holroyd.": 10 pp., not numbered. The entry is also headed "M.J. Stanley."

Adeane, J. H. The Girlhood of Maria Josepha Holroyd, Lady Stanley of Alderley. Longmans, 1896.

17. "Am.P./1. 121": 1 p., not numbered. (7 lines only.) The entry appears as an insert on the first page of B.16, and begins, "The end of M.J. in the Amberley Papers. Unwilling to die."

[Amberley.] The Amberley Papers. The Letters and Diaries of Lord and Lady Amberley. Ed. Bertrand and Patricia Russell. Vol. I [of II]. Hogarth Press, 1937.

18. "MJ. Holroyd": 5 pp., not numbered. Marginal notation first page, "Gibbon/Letters." The entry includes notes about Maria Josepha Holroyd and Hester Gibbon, Gibbon's aunt. More notes on this work appear above, B.5.

Gibbon, Edward. The Private Letters ... 1753-1794. With an Introduction by the Earl of Sheffield. Ed. Rowland E. Prothero. 2 vols. Murray, 1896.

19. "Overton. Life of Law": 2 pp., not numbered. The entry is also headed, "Law. Overton. Hester Gibbon."

Overton, J. H. William Law, Nonjuror and Mystic... A sketch of his life, character, and opinions. Longmans, Green, 1881.

\section{Holograph Reading Notes. Vol. 7. (Berg)}

On October 12, 1937, Woolf wrote in her diary, "This is the first morning I write, because at 12 , ten minutes ago, I wrote what I think is the last page of Three Guineas. ... I must now add the bibliography 
and notes" $(A W D)$. In the rest of this diary entry she looks back on how long the book had been "sizzling" in her and at how she had forced herself to put it aside, "save for some frantic notes," until she had finished The Years: "So I have deserved this gallop. And taken time and thought too." This "time and thought" is reflected in the eleven sets of reading notes for Three Guineas (Volumes VII, X, XXVI, XXXIII, XXXIX, and LV-LX), as well as in the difficulty of pinpointing the chronology of the notebooks and the entries. For more information about the chronology, see the introduction to Volume LVIII.

This volume-a collection of loose pages, some lined, some not, some typed, some handwritten-includes notes that were probably made at different times during Woolf's seven-year preparation of Three Guineas and then brought together when she began to compile the bibliography and notes. This supposition is suggested by the fact that all of the entries appear in some form in Three Guineas, most of them as footnotes; moreover, it is supported by what may be the most interesting entry in the volume-B.12-a list of authors, titles, and subjects that all, with one exception, appear in the completed book, as well as in one or more of the reading notebooks. (The exception is "Cahteaubraind [Chateaubriand] on Fame": Woolf was reading Chateaubriand's Memoirs during January and February 1938 [ $L$, VI, 3348, 3368].) Woolf seems to have culled her notebooks to compile this list, gathering the references she had used or would use. The last items on the list, starting with "St. Paul" and concluding with "Gisborne," refer to entries in this notebook; the others correspond to entries in Volumes XXVI, XXXIII, LIX, and LX. Finally, the notes on the Duke of Portland's autobiography (B.8) could not have been made until January or February 1938, when Woolf was completing her notes ( $L$, VI, 3349, 3368).

Despite the difficulty of dating the actual entries, there is some information to suggest when Woolf may originally have read the works noted in this volume. We know, for example, that she read Macaulay (B.2) during June and July 1936 (L, VI, 3141, 3155) and that she was discussing Mary Butt's autobiography, The Crystal Cabinet (B.6), in September 1937 ( $L, \mathrm{VI}, 3311)$. In the beginning of January 1935, Woolf had bought and was reading Renan-perhaps the biography of St. Paul noted in B.1 ( $L, \mathrm{~V}, 2973 ; A W D$, January 1, 19, 1935). On February 11, 1932, Woolf noted that she was reading "Wells on Woman-how she must be ancillary and decorative in the world of the future, because she has been tried, in 10 years, and has not proved anything" ( $A W D$ ). Wells's comments in 1932, which may 
have been an early version of those that Woolf has copied from his Experiment in Autobiography (B.3, 11), set her mind "running upon $A$ Knock on the Door," an early name for the new book on women that became first The Pargiters, then The Years, and, finally, Three Guineas. Wells's book, published in 1934, is possibly the "Wells" that Woolf had out from the library on October 2, 1934 ( $A W D$ ). Even earlier, on January 26, 1930, a year before she began to think of her new book on women, she was reading "Lord Chaplin's life" $(D$, III) - Lady Londonderry's Henry Chaplin: A Memoir (1926), noted in B.7. These notes, however, could have been made up to seven years later.

The variety of paper in this volume and the mixture of typed and handwritten entries emphasize the diversity of the notes collected here. B.4, 5, and 6, for example, are each typed on separate pieces of paper and pasted onto the page that is now numbered 4. B.4 and 5 are typed on white paper, B.6 on blue. When the notes are handwritten, the ink is black. References to Three Guineas in the following entries are to footnotes and indicate the chapter and note: $3 G, I$, n.15.

\section{B. ENTRIES}

1. "St Paul. Renan.": 1 p., numbered 1 by NYPL.

Renan, Ernest. Saint Paul. Paris: Calmann-Levy, 1905.

2. "Macaulay, describing the country gentleman of the/17th Century says:": 1 p., numbered 2 by NYPL. Quotation, annotated "Chap. 3 336" and "Hist of Eng." This quotation appears in $3 G, I, n .15$. Another quotation from Macaulay's History appears as LV, B.6, and LIX, B.88.

Macaulay, Thomas Babington. History of England. Vol. I. Longmans, Green, 1898. Vol. I of The Works of Lord Macaulay. Albany Edition.

3. "Clever ladies in Time \& Tide remain to remind us of it.": 1 p., numbered 3 by NYPL. Quotation, annotated "Experiment in Autobiography by HG Wells. 1934" and "p. 486." The "it" in the heading is the woman's movement. The rest of the entry reads, "Over most of the world it has died down altogether." Another quotation from this work appears below, B.11.

Wells, H. G. Experiment in Autobiography. Vol. II [of II]. Gollancz, 1934. 
4. "As for the word 'Mrs' we need not soonsider it, since it/ does not occur in the Civil Service lists.": 1 p., numbered 4 by NYPL. Typed passage, annotated in black ink, "(87)." Source unidentified. It is possible that the passage is Woolf's, a rejected footnote about women in the Civil Service, which would belong to the beginning of Chapter II of Three Guineas. The marriage bar in the Civil Service is discussed in Ray Strachey's Careers and Openings for Women and in The British Civil Service, ed. William A. Robson, both of which are cited by Woolf in the footnotes. The rest of the passage reads, "What effect this rule has upon the morality of the Service, whether it does not set a premium upon immorality, we need not enquire, for the atmosphere of Whitehall is no doubt proof against the evasions which might occur elsewhere. If a writer, for instance, had to give up writing on marriage, can we feel sure that she would not sometimes conceal the fact of marriage?"

5. "I have also a feeling that girls schools ...": 1 p., numbered 4 by NYPL. Typed quotation followed by Woolf's comments - the basis of footnote 29, Chapter I, Three Guineas. Other notes on this work appear in XXXIII, B.6, and LIX, B.68.

Alington, C. A. Things Ancient and Modern. Longmans, Green, 1936.

6. "See 'The Crystal Cabinet' by Mary Butts (1893-1937/p. 138. The quotation is so interesting that it deserv/to be quoted in full.": $1 \mathrm{p}$., numbered 4 by NYPL. The entry continues with the quotation by Butts - "'For just as I was told that desire for learning in women was against the will of God, so were many innocent freedoms, innocent delights, denied in the same Name" "-and Woolf's comments - "a remark which makes it more than ever desirable that we should have a full biography preferably from the pen of an educated mans daughter of the Gentleman in whose Name such atrocities have been committed." This passage, slightly altered, appears in Three Guineas, I, n.20, along with a quotation from Gisborne that is part of B.14 below.

Butts, Mary. The Crystal Cabinet. My Childhood at Salterns. Methuen, 1937. 
7. "Here are two examples at on ;": 1 p., numbered 5 by NYPL. The remainder of the entry consists of two typed quotations about women's influence, annotated " 86 ," " 57 ," and "Henry Chalin. a memoir Lady L ndonedeerr 1926." The first quotation reads, "had his wife lived it is probable that her influence would have prevailed to save at least some portion of his inheritance.' " The second quotation appears in $3 G, \mathrm{I}$, n.3.

Londonderry, Marchioness of [Edith H.V.T. Stewart]. Henry Chaplin: A Memoir. Macmillan, 1926.

8. "Average days sport at Chatsworth in 1909/1,212 head/men Women and Things by the D. of Portland, page 251": 1 p., numbered 6 by NYPL. (Heading only.) This information appears in $3 G, I$, n. 3 .

Portland, Duke of [William J.A.C.J.C. Bentinck]. Men, Women, and Things: Memories. Faber and Faber, 1937.

9. "That this letter is an ed m's d!": 1 p., numbered 7 by NYPL. The entry appears on the reverse of B.8. The reference in the heading is to "an educated man's daughter," the persona Woolf adopts in Three Guineas. The rest of the notes read, "because there is nothing to give working mens d's. no colleges, playing fields: cannot share their experiences. This letter obviously written by someone who can refer to books, whose dinner is cooked."

10. "I have been Young/HM Swanwick./1935": 1 p., numbered 8 by NYPL. Quotation, annotated "189," beginning, "But I wd. claim for $\mathrm{M}^{\mathrm{rs}}$ Fawcetts great Union ..."

Swanwick, H. M. I Have Been Young. Gollancz, 1935.

11. "Wells/485": 1 p., numbered 8 by NYPL. Quotation beginning, "There has been no perceptible woman's movement ...." This quotation appears in $3 G, \mathrm{II}, \mathrm{n} .3$. Another quotation from this work appears above, B.3.

Wells, H. G. Experiment in Autobiography. Vol. II [of II]. Gollancz, 1934.

12. "Jex Blake/Newitt, W. Must Choose, Hitler quote": 1 p., numbered 9 by NYPL. Typed and handwritten. The entry consists of a list of authors, titles, and subjects that, with the exception of "Cahteaubraind [Chateaubriand] on Fame," reappear in Three Guineas. All of these-except for "Leaves of 
Grass" and "The Bazaar Pippa" - are drawn from entries in other notebooks: "Jex Blake" to "Butler, Josephine" are in Volume XXVI; "Anthony Hope. Gino Watkins." to "Alington girls schools Lord R" are in Volumes XXXIII and LIX; "Sir W. Broadbent" to "Antony" are in Volumes XXXIII and LX; and "St. Paul. Renan" to "Gisborne" are in this volume. The list reads:

Jex Blake

Newitt, W. Must Choose, Hitler quote

Ministry of Women

Leaves of Grass

Astell

Ray 7o, quote on earnings

(74 cannot afford to eat)

Miss Haldane

Cahteaubraind on Fame

Nichols. BM. reading room

Earhart Last flight

Conquest of past. Loewenstein

Geore Sand

Spectator on child birth

Butler, Josephine

Antony Hope. Gino Watkins.

Monica Salmon. 20

Gore

Squire

Life of artist Collyer

Lord F. Hamilton

Antony

Wild as barrister

Laura Knight

Alington

Yeats

Paxton. Bertie on cruelty.

Miss Weeton

Lord Desart. Lady M's allowance

Pendennis

Joad dining a one

Alington girls schools Lord R.

Sir W. Broadbent.

Wright. 
Antony

St Paul Renan

Macaulay

Swanwick

Wells

Mary Butts.

Chaplin 1xxx Londonderry

The Bazaar. Pippa.

Duke of Portland.

Gisborne.

13. "Jex Blake": 3 pp., numbered $10-12$ by NYPL; numbered $5-7$ by VW. Another entry on this work, numbered 8 by VW, appears as XXVI, B.4, and is most likely part of what was a single set of notes. Another set of notes appears in LX, B.57.

Todd, Margaret. The Life of Sophia Jex-Blake. Macmillan, 1918.

14. "Gisborne": 2 pp., numbered 13-14 by NYPL. Three quotations, two of them annotated "63" and " 336 ." The quotation on p. 14, which begins "If the uses of music are explained," appears in $3 G$, I, n. 20 .

Gisborne, Thomas. An Enquiry into the Duties of the Female Sex. 3rd ed. Cadell \& Davies, 1798.

\section{Holograph Reading Notes. Vol. 8. (Berg)}

On November 16, 1931, Woolf was "working very hard-in my way, to furbish up two long Elizabethan articles to front a new Common Reader" $(A W D)$; two of the three entries in this volume are part of that effort. The notes on Sidney's Arcadia (B.2) belong to her reading for " 'The Countess of Pembroke's Arcadia'" and should be used in conjunction with the more complete set of notes on this work in XLVIII, B.3. The notes on Donne's poems, the major entry in this notebook (B.3), are the basis of her essay, "Donne After Three Centuries." Both entries were made after her comment on August 10, 1931 , that she should be reading all of Donne and Sidney ( $L, I V$, 2419). Other notes on Donne's poems and notes on Edmund Gosse's biography of Donne made at this time appear in Volumes XI and XX. 
" "The Countess of Pembroke's Arcadia'" appears to have been written after December 29, 1931 ( $L$, IV, 2497); "Donne After Three Centuries" was written in the first part of February 1932. "Ive been toiling over Donnes poetry all the morning," she commented on February 5, 1932 ( $L, \mathrm{~V}, 2522$ ), a task she finished on February 16: "And I have just 'finished'-I use inverted commas ironically-my Donne, a great but I think well intentioned grind" ( $A W D$; see also, February 8,$1932 ; L, \mathrm{~V}, 2523)$. The idea of writing on Donne had in fact been in Woolf's mind since the preparation of her first critical book; her original notes on the poems, made around 1923, appear in Volume XIX.

The notes on William Cole (B.1) were made in preparation for her review of The Blecheley Diary of the Rev. William Cole, "The Rev. William Cole: A Letter," published in the New Statesman \& Nation, February 6, 1932 (Kp. C333).

"Donne's Poetry" appears on the cover of the notebook in black ink. The entries are in purple ink (B.1) and black and purple ink (B.2-3), with some pencilled notes on Donne.

\section{A. Table of Contents}

1. Donne's Poetry

$1 \mathrm{p}$. , on cover.

B. ENTRIES

1. "A Letter to the Rev./William Cole": 4 pp., numbered 3-6 by NYPL.

[Cole, William.] The Blecheley Diary of the Rev. William Cole. Ed. F. G. Stokes. Constable, 1931.

2. "Sidneys Arcadia": 1 p., numbered 7 by NYPL. Twelve pages of notes on this work appear in XLVIII, B.3.

Sidney, Sir Philip. The Countess of Pembroke's Arcadia. 10th ed., with his Life and Death... and som other new Additions. Calvert \& Pierrepont, 1655.

3. "Donne": 11 pp., numbered 8-18 by NYPL. Another set of notes on the poems made at this time appears in XI, B.4.

Donne, John. The Poems. Ed. Herbert J. C. Grierson. 2 vols. Oxford: Clarendon Press, 1912. 


\section{Holograph Reading Notes. Vol. 9. (Berg)}

Almost all of the entries in this volume are related to three articles published by Woolf, first in the Nation \& Athenaeum and then in the New York Herald Tribune, during September and October 1929: "Cowper and Lady Austen," Nation \& Athenaeum, September 21, 1929 (Kp. C314); "Beau Brummell," Nation \& Athenaeum, September 28, 1929 (Kp. C315); and "Mary Wollstonecraft," Nation \& Athenaeum, October 5, 1929 (Kp. C316). Woolf had "just agreed to do another 4 articles for Mrs Van Doren" of the Herald Tribune on April 13, 1929; the first entry in the notebook, her notes on Cowper's Correspondence, is headed at the top of the page, "Possible article for Herald." She "wrote a little article on Cowper" in the heat of Cassis during June 1929 ( $D$, III, June 15); was "tackling Mary Wollstonecraft" while "in the thick of [her] four Herald articles" on August 5 ( $D$, III); and had more or less finished the four articles by August 19 ( $D$, III; L, IV, 2056, 2057). More notes on Brummell, as well as notes on Dorothy Wordsworth, the fourth "figure" who featured in this particular series of articles, are found in Volume XX.

There is, however, some question about the date of the actual entries on Cowper. Woolf had begun reading Cowper in 1927: on February 21, 1927, she was reading and recommending The Task ( $L$, III, 1718); on February 28, she wrote, "Cowper is a good poet. I'd like to write about him" ( $D$, III); on March 24, she was "finding great consolation for innumerable typhoid germs in the poetry of Cowper" ( $L$, III, 1736); and on February 21, 1928, she wrote to Vanessa Bell, "The Singer [their automobile] I know for a fact to be hermaphrodite like the poet Cowper" ( $L$, III, 1864). This last is probably a reference to a passage in Wright's Life of Cowper which explains that Cowper was persecuted in school because of his defect-hermaphroditism. Woolf notes this passage in her entry on Wright's book, B.4, below. Nevertheless, on December 29, 1928, Woolf is again talking of her desire to read Cowper ( $L$, III, 1796), and there are indications that the notes were made in conjunction with the preparation of her article in 1929. One such indication is the list of her earnings for articles published between March and July 1929 that appears among her notes on Wright's Life of Cowper (B.4-5).

The cancelled notes on women's lack of privacy (B.8) are connected to the writing of $A$ Room of One's Own, which was completed in August 1929 ( $D$, III, March 28, May 12, August 19, 1929); they reappear, including the references to Miss Davies' tale and Florence 
Nightingale's complaint, in Chapter 4 of the book. Woolf's sources for this passage were probably Barbara Stephen's Life of Miss Emily Davies and Florence Nightingale's Cassandra, reprinted in Ray Strachey's The Cause; both of these works are cited in A Room of One's Own.

The majority of the notes, including the table of contents, are in purple ink. The others, part of B.1, are in gray-black ink.

\section{A. Table of Contents}

\section{Cowper}

Letters

Task

Life of Cowper by Wright

Mary Wollstonecraft

1 p., numbered 1 by NYPL.

B. ENTRIES

1. "Possible article for Herald./Cowper.": 17 pp., numbered 2$11,13-19$ by NYPL. The entry is also headed "Cowper's Letters."

Cowper, William. Correspondence. Ed. Thomas Wright. Vols. I-II [of IV]. Hodder \& Stoughton, 1904.

2. "Charlotte/Brontës Life:/Edited by/Clement/Shorter.": 1 p., numbered 12 by NYPL. (Heading only.) This may be a reference to the seven-volume Haworth Edition of The Life and Works of Charlotte Brontë and her Sisters (1899, 1900), with an introduction and notes by Clement K. Shorter. Volume 7 of this edition is Mrs. Gaskell's Life of Charlotte Brontë.

3. "The Task.": 3 pp., numbered $20-22$ by NYPL. The notes are on Books 3-6 of the poem.

Cowper, William. The Task. [1785].

4. "Life of Cowper. Wright. .": 6 pp., numbered 23-26, 28-29 by NYPL.

Wright, Thomas. The Life of William Cowper. 2nd ed. Farncombe, 1921.

5. "W \& F. 100/Books 230": 1 p., numbered 27 by NYPL. The entry consists of a list of Woolf's earnings from the first part of 1929. The list in full reads: "W \& F 100/Books 230/reprint 50/Burney 50/430/P of Fiction 72/502." Three of the 
entries correspond to articles published between March and July 1929: "Women and Fiction" (Kp. C310), "Dr. Burney's Evening Party" (Kp. C313), and "Phases of Fiction" (Kp. C312).

6. "That great figures have a ghostlike quality": 1 p., numbered 30 by NYPL. The entry consists of notes for Woolf's essay, "Beau Brummell." The notes begin with a reference to "The Dss of D" [Duchess of Devonshire], who "appeared" to both Cowper and Brummell and reappears in the opening of the essay.

7. "Godwin. Kegan Paul.": 6 pp., numbered 31-33, 35-37 by NYPL.

Paul, C. Kegan. William Godwin: His Friends, and Contemporaries. Vol. I [of II]. King, 1876.

8. "The house contained but one sitting/room as Miss Davies tale was/to demonstrate; ...": 1 p., numbered 34 by NYPL. The entry consists of cancelled notes on women's lack of privacy that continue, " $\&$ the woman there was seldom uninterrupted as Florence Nightingale was to complain." This passage appears in a more extended form in Chapter 4 of $A$ Room of One's Own.

9. "France standing on the top of golden hours,/And human nature seeming born again./Prelude. Book 6. p. 149": 1 p., numbered 38 by NYPL. (Heading only.) This quotation appears in Woolf's essay, "Mary Wollstonecraft."

Wordsworth, William. The Prelude, or, Growth of a Poet's

Mind. An Autobiographical Poem. Moxon, 1850.

10. "Memoirs of M. Wollstonecraft": 8 pp., numbered 39-46 by NYPL.

Godwin, William. Memoirs of Mary Wollstonecraft. Ed.

W. Clark Durant. Constable, 1927.

11. "Supt to M Woll "': 4 pp., numbered $47-50$ by NYPL; the heading appears on p. 48 . P. 47 consists of two titles, both of which appear in the Supplement: "Post. Works. Vol. 4" [The Posthumous Works of Mary Wollstonecraft, Vol. IV, 1798], and "Fuseli, Life of by Knowles. 1831" [The Life and Writings of Henry Fuseli, ed. J. Knowles, 1831]. P. 49 also consists of titles of works found in the Supplement: "Autobiog. of A.H. Rowan. 1840" [Archibald Hamilton 
Rowan, Autobiography, 1840], and "Letters From Norway Denmark \& Sweden" by Wollstonecraft. For notes on the last work, see below, B.15.

Durant, W. Clark. A Supplement ... Containing hitherto Unpublished or Uncollected Material. In William Godwin. Memoirs of Mary Wollstonecraft. Constable, 1927.

12. "Letters to Imlay": 5 pp., numbered $51-55$ by NYPL; the heading appears on p. 52 .

Wollstonecraft, Mary. Letters to Imlay. Ed. C. Kegan Paul. Kegan Paul, 1879.

13. "She was really in favour.": 1 p., numbered 56 by NYPL. The entry consists of notes for the conclusion of Woolf's essay, "Mary Wollstonecraft," continuing, "One remembers her passionate cry, surely 'I cannot die' \& it's true. Dead though she has been, more than most people she still walks."

14. "Rights of Women./45 She attacks the sacred majesty of Kings.": 1 p., numbered 57 by NYPL. (Heading only.)

Wollstonecraft, Mary. A Vindication of the Rights of Women, with Strictures on Political and Moral Subjects. New ed., with introduction by Mrs. Henry Fawcett. Unwin, 1891.

15. "Letters from Norway 1796": 1 p., numbered 57 by NYPL.

Wollstonecraft, Mary. Letters Written during a Short Residence in Sweden, Norway, and Denmark. Johnson, 1796.

16. "Percy \& Lily Bartholomew./Percy \& Lily Batholomew.": 1 p., numbered 57 by NYPL. (Heading only.) Percy Bartholomew was the Woolfs' gardener at Rodmell.

\section{Holograph Reading Notes. Vol. 10. (Berg)}

The notes collected in this volume appear to range from 1931 to 1939 , and illustrate clearly some of the problems that occur in dating the notebooks. The first part of the volume, with the exception of the entry on Crabbe (B.3), consists of notes about women and men in the nineteenth century that were probably made in 1931 and 1932 when Woolf first began reading the "Scores-I might boldly say thousands-of old memoirs," biographies, and autobiographies that served as a background for her novel-essay, The Pargiters (Pargiters, 9; see also Volume XXIII). The most significant notes in this sec- 
tion are those on The Life of Joseph Wright (B.1), the work that provided Woolf with her portraits of Mr. Gabbit, Sam Hughes, and Mr. Brooke in The Pargiters (see Mitchell A. Leaska's "Introduction" to The Pargiters, xi-xiv). A long passage about Joseph and Lizzie Wright, based on Volume I of this work, appears in Woolf's diary on July 13, 1932, and two sets of notes and quotations, possibly extracted from the notes in this volume, appear in the first of the " 3 bound volumes containing Press Cuttings \& extracts ... relative to 3 Gs" (LVIII), the volume devoted to material Woolf had collected by the beginning of 1933. Similarly, notes on Miss Clough (B.5) and on Bott and Clephane's look at Our Mothers in the late Victorian period (B.4) occur both in this volume and in Volume LVIII.

The notes on Crabbe (B.3) and the notes on The Antigone (B.8) are harder to pinpoint. On February 3, 1932, Woolf sent her nephew, Julian Bell, a birthday gift of Crabbe, a writer, she said, whom she worshipped "illegitimately but with passion"; the note ends with the postscript: "John seems to think you have Crabbe-if so, let me have him, as I want one" ( $L, \mathrm{~V}, 2520)$. Later, on September 26, 1933, Woolf commented, "Why not, one of these days, write a fantasy on the theme of Crabbe? - a biographical fantasy-an experiment in biography" $(A W D)$; it is unclear, however, whether the notes in this volume, which are the basis of her short essay on "Crabbe" in The Captain's Death Bed, are connected with this idea. Kirkpatrick notes in the preface to her Bibliography of Virginia Woolf that no prior publication of this essay has been found, although it is thought to have appeared first in a journal (rev. ed., 1967, p. x).

The Antigone (B.8) plays an important role in the description of Edward's emotional life in The Pargiters (see the "Third Chapter" and "Fourth Essay," dated, respectively, November 17, 23, 1932), and may belong with the other notes for The Pargiters. On September 6,1932 , for example, Woolf commented that she had recently tried to read Sophocles as she had read him when young-presumably in Greek - "but found all the words withdrawn like clouds into the sky" ( $L, \mathrm{~V}, 2628$ ). Woolf, however, continually returned to The Antigone throughout her life, and throughout this period; on October 29, 1934, she specifically noted that she was reading this play $(A W D)$.

The second half of the volume begins with notes about Captain Marryat (B.9), made presumably for Woolf's essay, "The Captain's Death Bed," which was written by September 13, 1935 (AWD) and published in the TLS on September 26 (Kp. C346). Woolf noted that she was reading Marryat on July 27, 1935 ( $L, \mathrm{~V}, 3053)$. It is possible that the remainder of the notes were also made in 1935, although the 
entry on Amber Innocent (B.13) is somewhat puzzling. The Hogarth Press published this poem in 1939, but Woolf had known its young author, Joan Easdale, since 1931, and might well have read a manuscript version several years earlier. In fact, two days after her mention of reading Marryat, the entire Easdale family visited her at Monk's House $(L, \mathrm{~V}, 3054)$.

The collection of entries with such diverse dates in this volume may be an illustration of Woolf's haphazard approach to binding her reading notes, or it may be related to the history of Three Guineas. Shortly after Woolf finished her essay on Marryat, she attended the Labour Party Conference at Brighton that broke "the dam between [her] and the new book" on women that had been on her mind since the beginning of 1935 (see $A W D$, January 1, October 16, 1935). It is possible, then, that during 1935 Woolf gathered together some of her earlier notes for The Pargiters and bound them in this notebook; or, she may have reread and noted works that she had already read before. Woolf clearly used these notes in writing Three Guineas, however; this is indicated by their reappearence in other of the Three Guineas notebooks and in the finished work. For this reason, this volume belongs among the volumes associated with Three Guineas: VII, XXVI, XXXIII, XXXIX, and LV-LX.

With the exception of the notes on The Antigone and the heading for the biography of Marryat, which are blue-gray, the ink throughout is black.

\section{A. Table of Contents}

1. Wright

Bott

Clough

Life of Astell

Captain Marryatt

$1 \mathrm{p}$, on cover.

B. ENTRIES

1. "Wright.": 6 pp., numbered $1-6$ by NYPL. Other entries on this work appear in XXXIII, B.9, and LVIII, B.27, 66.

Wright, Elizabeth Mary. The Life of Joseph Wright. Vol. I [of II]. Oxford Univ. Press, 1932.

2. "Mr. I.G. Homewood./Recs. of an/Octogenarian": 1 p., numbered 7 by NYPL. 
Homewood, I. G. Recollections of an Octogenarian. Murray, 1932.

3. "Crabbe": 1 p., numbered 8 by NYPL. The entry consists of notes for Woolf's essay, "Crabbe," published in The Captain's Death Bed, reading, "In our day C. wd have taken scholarships. In his: the letter to Burke landed him at Belvoir. Hence the contrasts in the Village. Realism \& aristocracy: a queer combination. The pauper \& manners. a good story about the D of R \& his brothers hat."

4. "Alan Bott/Irene Clephane/Our Mothers": 1 p., numbered 9 by NYPL. Another set of notes on this work appears in LVIII, B.62.

Bott, Alan, and Clephane, Irene. Our Mothers. A Cavalcade in Pictures, Quotation and Description of Late Victorian Women, 1870-1900. Gollancz, 1932.

5. "Life of Miss Clough": 8 pp., numbered 10-17 by NYPL. Another set of notes on this work appears in LV, B.2; a quotation from it appears as LVIII, B.56.

Clough, Blanche Athena. A Memoir of Anne Jemima Clough. Arnold, 1897.

6. "The real England is surely the scene where/all classes congregate in vigorous \&/spontaneous union-the army,/the navy, the hunting field ...": 1 p., numbered 18 by NYPL. Quotation, annotated "Sichel. The Sands of Time. 319."

Sichel, Walter. The Sands of Time. Recollections and Reflections. Hutchinson, 1923.

7. "Mary Astell./Florence M. Smith. PhD/Columbia University/ Press. 1916": 6 pp., numbered 19-24 by NYPL. Another entry on this work appears in XXVI, B.7.

Smith, Florence M. Mary Astell. New York: Columbia Univ. Press, 1916.

8. "Antigone": 2 pp., numbered $25-26$ by NYPL.

Sophocles. The Antigone. With Critical Notes, Commentary, and Translation in English Prose by R. C. Jebb. Cambridge: Cambridge Univ. Press, 1888. Vol. III of The Plays and Fragments.

9. "Life of Marryat/by daughter.": 11 pp., numbered 27-37 by NYPL. 
Marryat, Florence. Life and Letters of Captain Marryat. 2 vols. Bentley, 1872.

10. "P. Simple": 4 pp., numbered $38-41$ by NYPL.

Marryat, Captain [Frederick]. Peter Simple. 2 vols. Constable, 1929.

11. "Olla Podrida Jaeob Faithful": 2 pp., numbered $42-43$ by NYPL. (P. 42, 1 line only.)

Marryat, Captain [Frederick]. Olla Podrida. Routledge, 1875.

12. "P. \& P.": 1 p., numbered 44 by NYPL. (3 lines only.) Unidentified notes, reading, "The story of Simon in the home interesting: We are changing the conditions of nurses lives. But are we changing doctors."

13. "Joan Easdale/Amber. The sister-in law of Mark": 2 pp., numbered $45-46$ by NYPL. (P. 46, 1 line only.)

Easdale, Joan Adeney. Amber Innocent. A Poem. Hogarth Press, 1939.

14. "Fire of Life./Nevinson:": 1 p., numbered 47 by NYPL. 4 lines only, including the note, "I cannot endure to sit in a room while anyone is reading my stuff."

Nevinson, Henry W. Fire of Life. Gollancz, 1935.

\section{Holograph Reading Notes. Vol. 11. (Berg)}

All of the notes in this volume belong to the period between December 8, 1929, when Woolf was "free to begin reading Elizabethans-the little unknown writers, whom I, so ignorant am I, have never heard of, Puttenham, Webb, Harvey" $(D, \mathrm{III})$-and the completion of the three Elizabethan essays for The Common Reader: Second Series (1932): "The Strange Elizabethans," "Donne After Three Centuries," and "The Countess of Pembroke's Arcadia." On August 10,1931, she announced her intention to read all of Sidney, Donne, and Fulke Greville ( $L$, IV, 2419), and on November 16, 1931, she was "[furbishing] up two long Elizabethan articles to front a new Common Reader" $(A W D)$. By December 29, she was "so behindhand-I was going to write about Sidney, and cant get back into the mood" ( $L, I V, 2497)$, and on February 16, 1932, after much effort, she had "ffinished'-I use inverted commas ironically"-her essay on Donne ( $A W D$; see also, February 8, 1932, and $L, \mathrm{~V}, 2522,2523)$. 
There is a great deal of overlap between the entries in this volume and those in other volumes that date from this period, particularly Volumes XII and XX. The typed notes on Gabriel Harvey's Works (B.1) are almost identical to the handwritten notes on Harvey in XII, B.2. A full set of notes on Gosse's biography of Donne (B.4) appears in Volume XX, and a full set of notes on Donne's poems is found in Volume VIII. Other biographies of Sir Philip Sidney (Volume XX) complement the notes on Mona Wilson's biography in B.5, below. It is likely that most of the notes in this volume belong to the period in 1931 when Woolf was actually writing her essays. Wilson's biography of Sidney was not published until 1931, the typed notes on Harvey almost certainly succeed the handwritten ones, and B.10, headed "Some Elizabethans," is an outline for what became "The Strange Elizabethans."

The table of contents is written on the cover in black ink; the ink throughout is black.

\section{A. Table of Contents}

1. Harveys Works.

Harvey's Commonplace Book

Donne's Poems

Life of Sidney. M Wilson

Drummond on Jonson

1 p., on cover.

B. Entries

1. "Harvey Works.": 4 pp., numbered 3-6 by NYPL; numbered 1-4 by VW. Typed. The entry consists of notes on the first two volumes of Grosart's edition; the notes on Vol. II are headed "Pierces Supererogation." For an almost identical set of notes, see XII, B.2.

Harvey, Gabriel. Works. Ed. Alexander B. Grosart. Vols. I-II [of III]. Huth Library, 1884.

2. "Harvey Commonplace": 4 pp., numbered 7-10 by NYPL; pp. 8-10, which are typed, are also numbered 1-3 by VW.

Harvey, Gabriel. Commonplace Book. In Gabriel Harvey's

Marginalia. Ed. G. C. Moore Smith. Stratford: Shakespeare Head Press, 1913.

3. "Dekker.": 1 p., numbered 11 by NYPL. General notes on Dekker's language, based on The Wonderful Yeare, begin- 
ning, "English in the making: bubbling - one puts ones pen in \& draws out a blob of warm words-one makes words."

Dekker, Thomas. The Wonderful Yeare. [1603].

4. "Donnes Poems.": 2 pp., numbered $12-13$ by NYPL. General notes on Donne's poetry, including quotations from "Elegy VIII" and "Elegy IX" and references to Gosse's biography of Donne. Woolf's notes on the poems from this period appear in VIII, B.3, and her notes on Gosse's biography in $\mathrm{XX}, \mathrm{B} .12$.

a) Donne, John. The Poetical Works. Ed. Herbert J. C. Grierson. Oxford Univ. Press, 1929.

b) Gosse, Edmund. The Life and Letters of John Donne. Vol. I [of II]. Heinemann, 1899.

5. "Life of Sidney/M. Wilson.": 2 pp., numbered $14-15$ by NYPL. (P. 15, 2 lines only.)

Wilson, Mona. Sir Philip Sidney. Duckworth, 1931.

6. "Ben Jonson./Herford.": 1 p., numbered 16 by NYPL.

Herford, C. H., and Simpson, Percy. "Life of Ben Jonson." In Ben Jonson. Vol. I. Oxford: Clarendon Press, 1925.

7. "Ben Jonson. C $C^{\text {tions }}$ with Drummond": 1 p., numbered 17 by NYPL. The entry consists of five lines of notes on Sidney: "138 The Css of Rutland nothing inferior to her father Sir P.S. in poetry. Sir PS. was no pleasant man in countenance, his face being spotted with pimples."

[Jonson, Ben.] Ben Jonson's Conversations with William Drummond of Hawthornden. In Ben Jonson. Ed. C. H. Herford and Percy Simpson. Vol. I. Oxford: Clarendon Press, 1925.

8. "Harveys Letters": 1 p., numbered 18 by NYPL.

Harvey, Gabriel. Letter-Book... A.D. 1573-1580. Ed. Edward John Long Scott. Camden Society, 1884.

9. "Harvey Marginalia": 1 p., numbered 19 by NYPL. The notes are from the "Introduction."

Smith, G. C. Moore. "Introduction." In Gabriel Harvey's Marginalia. Stratford: Shakespeare Head Press, 1913.

10. "Some Elizabethans.": 1 p., numbered 20 by NYPL. The entry consists of notes on the Elizabethans and their prose style, including references to Gabriel Harvey's sister Mercy, the milkmaid, and to Donne's sermons. The notes, which are an outline for what became "The Strange Elizabethans," 
begin, "That we cant attempt the $\mathrm{E}^{\text {than }}$ grandiloquence because we haven't their scurrility \& plain speech to match it."

11. "Life of Wotton/Pearsall Smith": 1 p., numbered 21 by NYPL. 3 lines only, reading, "W. born 1568 Wotten gave his friends Italian furniture \& flower seeds."

Smith, Logan Pearsall. The Life and Letters of Sir Henry Wotton. 2 vols. Oxford: Clarendon Press, 1907.

\section{Holograph Reading Notes. Vol. 12. (Berg)}

"Elizabethans" and "Life as we have known it. (Cooperative Women)" accurately summarize the contents of this notebook. The "Elizabethans" included in this volume are Harvey, Webbe, and Puttenham-just those "little unknown writers," completely new to Woolf, whom she was "free to begin reading" on December 8, 1929: "This thought fills me with joy-no overstatement" $(D$, III). In fact, the list of Elizabethan writers and works that appears as B.1 below may well be that which Woolf records having made in this same December 8 diary entry: "So I stopped writing, . . \& \& made out a list of Elizabethan poets." Two days later, she described as her "greatest triumph" the achievement of "a quiet evening-in which to read Ellizabe]thans" ( $D$, III), and on December 16 , she was "vaguely thinking of some studies of Elizabethan characters" ( $L$, IV, 2117; see also $D$, III, December 26). A comment at the end of her notes on Puttenham (B.4) - "Might be two articles, one Webbe \& Harvey Puttenham \&c. The second, Sidney \& Penelope"-may well be connected with her vague plans in December 1929, plans, however, that were apparently not acted on until 1931 when she found herself moving "in the direction of the Elizabethans" ( $L, I V, 2399$, July 2$)$ and began to write "two long Elizabethan articles to front a new Common Reader" ( $A W D$, November 16). The notes on Harvey, Webbe, and Puttenham ultimately contributed to her portrait of "The Strange Elizabethans" and their language in The Common Reader: Second Series. Although Woolf read several biographies of Sidney between December 1929 and the publication of her book in 1932 (see Volumes XI and XX), the second article was not on Sidney and Penelope but on "'The Countess of Pembroke's Arcadia.'" More notes on Harvey, including a typed version of the notes in B.2 below 
and an outline headed "Some Elizabethans," also appear in Volume $\mathrm{XI}$.

The "Cooperative Women" found in this notebook are the authors of the essays in Life as We Have Known It, edited by Margaret Llewelyn Davies and published by Leonard and Virginia Woolf in March 1931. Woolf had received "the papers"-presumably the essays written by the working women-by June 6, 1929 (L, IV, 2036) but does not seem to have written her "Memories of a Working Women's Guild," meant to serve as an introduction to the collection, until May 1930 ( $D$, III, May 18). The original version was published in The Yale Review, September 1930 (Kp. C326); a revised version, incorporating some suggestions made by Margaret Llewelyn Davies, appeared as an "Introductory Letter" to the book. The history of the final version is told in a series of letters to Llewelyn Davies written between July and October 1931 ( L, IV, 2210, 2212, 2236, 2252).

The "Professions for Women \&c," listed with "Elizabethans \&c" on the cover of the notebook, may be a reference to the lecture Woolf delivered before the London/National Society for Women's Service, January 21, 1931. A short version of this speech appears as "Professions for Women" in The Death of the Moth and Other Essays (1942); a transcript of the longer version appears in The Pargiters (1977).

The table of contents on the cover of the notebook is in black ink; the list of contents on the first page is in blue-gray ink. The notes are all in purple ink.

\section{A. TABle of Contents}

1. Elizabethans \&c:

Professions for Women \&c

1 p., on cover.

2. Elizabethans

Life as we have known it. (Cooperative Women)

1 p., numbered 1 by NYPL.

B. ENTRIES

1. "Harvey. Gabriel,------1545? -- 1630": 1 p., numbered 2 by NYPL. The entry consists of a list of Elizabethan writers and works: 
b. d.

Harvey. Gabriel, _-__-__-__-_-_1545? -- 1630

Puttenham, George. _-__-_-_-_-_1530? -- 1600

Sidney, Sir Philip ___-_________-_1554 -- 1586

Spenser, Edmund, 1552 ? -- 1599

Webbe Wm.

flourished $16^{\text {th }}$ Century

Donne, John _-_-______-_ 1573 -- 1631

Paradise of Dainty Devices _-_-_-_-_-_-_ 1576.

Sidneys Apologie for Poesietry

Donnes Satires $1580-1$

Englands Helicon 1593

Marlowes Faust 1600

Loves Labours Lost $1588-90$.

Shakespeare

2. "Harvey.": 8 pp., numbered 3-10 by NYPL. The entry also includes the headings, "Harveys Letters" and "Pierces Supererogation." An almost identical set of notes on this work appears in XI, B.1.

Harvey, Gabriel. Works. Ed. Alexander B. Grosart. Vols. I-II [of III]. Huth Library, 1884.

3. "A Discourse of/English Poetrie: Webbe.": 3 pp., numbered 11-13 by NYPL. P. 13 is a typed transcript of the handwritten notes on the preceding two pages.

Webbe, William. A Discourse of English Poetrie. Ed. Edward Arber. Reprint of 1586 ed. Constable, 1895. English Reprints.

4. "The Art of English Poesie Puttenham": 1 p., numbered 14 by NYPL. The entry concludes with the note, "Might be two articles, one Webbe \& Harvey Puttenham \&c. The second, Sidney \& Penelope."

Puttenham, George. The Arte of English Poesie. Ed. Edward Arber. Reprint of 1589 ed. Constable, 1895. English Reprints.

5. "Co-operative Women": 3 pp., numbered $15-17$ by NYPL.

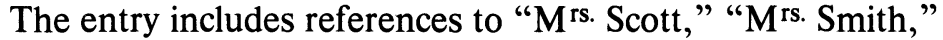
"Mrs. Wrigley," and "Mrs. Burrows. Fens," all of whom authored essays in Life as We Have Known It, ed. Margaret Llewelyn Davies, With an Introductory Letter by Virginia Woolf (Hogarth Press, 1931). 
6. "This is not a book - a string of remarks/needing to be helped out. by the [?imaginat]": 1 p., numbered 18 by NYPL. 4 lines only, continuing, "Not [ . . ]-not the looking glass mind: They give the facts." The entry consists of notes for either "Memories of a Working Women's Guild" or its revision, the "Introductory Letter" to Life as We Have Known It. See above, B.5.

\section{Holograph Reading Notes. Vol. 13. (Berg)}

On August 12, 1928, Woolf wrote in a letter to Saxon SydneyTurner that she was "reading six books at once, the only way of reading; since, as you will agree, one book is only a single unaccompanied note, and to get the full sound, one needs ten others at the same time" ( $L$, III, 1913). Perhaps she was exaggerating, but if so, not much, for the contents of this notebook range over a variety of subjects and illustrate the diversity of Woolf's reading at this time. The entries themselves can be dated approximately from May 1928 to August 1930. During this period, Woolf wrote (among other things) "Geraldine and Jane," "Phases of Fiction," "Dr. Burney's Evening Party," "Augustine Birrell," and "Fanny Burney's Half Sister," and decided not to write on Tolstoi and Scott. All of these are represented in this notebook.

More specifically, on May 31, 1928, Woolf's plans for her writing included "some very closely reasoned criticism; book on fiction; an essay of some sort (but not Tolstoy for the Times). Dr. Burney's evening party I think for Desmond" ( $D$, III; "Desmond" is Desmond MacCarthy, the editor of Life and Letters). In a letter to Vita Sackville-West on August 20, she says she has been working all day "at novels and novels. I read Proust, Henry James, Dostoevsky" ( $L$, III, 1918) -all in preparation for "Phases of Fiction," which was finally published in Bookman, April, May, and June 1929 (Kp. C312). The notes on Swann's Way (B.16) in this volume may be connected to this letter, although they are more likely linked to her desire to read Proust on November 28, 1928 ( $D$, III; she also speaks of reading Proust in May and June 1928 and again in May 1929: D, III). The notes on "Proust, Henry James, and Dostoevsky" are found in Volume XIV, as are more notes on Swann's Way; other notes for "Phases of Fiction" are in Volumes XIV, XXV, and XLVI. In spite of her decision not to write on Tolstoi in May, Woolf was reading 
War and Peace (B.6) at the end of 1928 and Anna Karenina in January 1929. "It is perfectly true," she wrote Vita on December 29, "that I cannot read War and Peace now with any gusto or enchantment," only to add in a postscript on January 3, "Tolstoi has risen again" ( $L$, III, 1976). Anna Karenina led her to declare that it was Tolstoi, not Wells and Galsworthy, who caused contemporary novelists to "break away": "How could we go on with sex and realism after that?... It is one brain, after all, literature; and it wants change and relief" ( $L$, IV , 1980).

The history of "Dr. Burney's Evening Party" begins with Woolf's mention of the essay on May 31, 1928, and her offer of it to Miss McAfee of the Yale Review on June 29 (L, III, 1907). On August 12, she was off to the London Library to find "the Maxims and Characters of Fulke Greville-not the F.G. but his descendant who occurs in connection with Miss Burney's father's marriage and playing the harpsichord" ( $L$, III, 1913); but in the beginning of October she wrote Miss McAfee that she could not do the article then because she could not "get the time I need for reading the books I want to read" ( $L$, III, 1937, 1940). Nevertheless, by October 27, she was going "to open Fanny Burney's diaries, \& work solidly at that article" ( $D$, III). Thus, most of the notes connected to the Burneys (B.9-15) were probably made between October 1928 and the publication of the essay in the New York Herald Tribune, July 21 and 28, 1929 (Kp. C313); several references to writing the article appear in her letters in January and February 1929 ( $L$, IV, 1981, 1985, 2005). One letter, after speaking of the need to look up dates, continues, "One can't simply invent the whole of Chelsea and King George the 3rd and Johnson, and Mrs Thrale I suppose. Yet after all, that's the way to write; and if I had time to prove it, the truth of one's sensations is not in the fact, but in the reverberation. When I have read three lines, I re-make them entirely, if they're prose, and not poetry; and it is this which is the truth" ( $L, I V, 1981)$. The last entry on Fanny Burney's Early Diary (B.21), which tells the story of Maria Allen Rishton, was almost certainly made in 1930 when Woolf wrote "Fanny Burney's Half-Sister," published in the TLS, August 28, 1930 (Kp. C324). On May 1, 1930, she was considering "Miss Burney's half sister's story" $(D$, III), which she wrote in part during July and August ( $L, I V, 2201,2215)$. Other notes related to the Burneys appear in Volume XLVI.

For the rest, the notes on Jane Welsh Carlyle and Geraldine Jewsbury (B.1-5) belong to her work for "Geraldine and Jane," published in the TLS, February 28, 1929 (Kp. C309); she was, or should have 
been, reading Jewsbury in November 1928 ( $D$, III, November 10, 28), and wrote the article in February 1929 ( $L$, IV, 2006). A letter written in response to praise of the essay in the beginning of March explains, "I daresay one could have found out more about Miss Jewsbury; I had only one volume of her letters to go upon. I could not read more than one of the novels, ... Her relation with Mrs Carlyle was interesting, and I had to be discreet" ( $L$, IV, 2007). Between August 1927 and February 1930, Woolf seems to have read several works by André Maurois, with the intention of writing an article on him (see $L$, III, 1793, 1806, 1976; D, III, February 16, 1930). The notes on Maurois' Climats (B.7) were probably made at the end of December 1928 ( $L$, III, 1976). The entries on Augustine Birrell (B.18-19) were made after July 17, 1929, when Woolf received a copy of the Collected Essays from Birrell ( $L$, IV, 2051). She was reading the work on November 18, 1929 ( $D$, III); her essay was published by the Yale Review in June 1930 (Kp. C323). The notes on Scott's Letter-Books (B.20) may well be those on the Scott book that Woolf agreed to review in April 1930, only to find that "now having read Scott, or the perky \& impertinent editor whom Hugh provides to dish up tasty fragments, I wont \& cant" ( $D$, III; May 1, 1930). Finally, the last entry in this volume, which mentions Dante, may relate to her obvious pleasure in reading The Inferno at the end of 1930 (D, III, August 20, September 24, October 27, December 22).

Two further comments on the contents of this notebook. A pencilled sketch of the addition to Monk's House that the Woolfs were planning to make in December 1928 appears among Woolf's notes on Zoe (B.5). "We had the architect yesterday," she wrote to Vita on December 29, "and the builder and I spent two hours in the attics, and we're planning rooms for me, rooms for Leonard; and a cabinet de toilette for Vita" ( $L$, III, 1976). The sketch bears this arrangement out. The other item of interest is the last entry in her notes on the letters of Geraldine Jewsbury to Jane Welsh Carlyle - "438 being always at hand to be talked to makes work impossible" (B.4). The difficulty experienced by women writers that Woolf hints at here is the same difficulty that she had described in her lectures about women and fiction in October 1928 and that she was in the process of elaborating in A Room of One's Own.

The two tables of contents are in black ink, as is the last entry. The majority of the notes are in blue-purple ink; B.8, B.14, and B.15 are in pencil. 
A. Table of Contents

1. Fanny Burney Early Diaries

$M^{\text {rs }}$ Carlyle

Miss Jewsbury

War \& Peace

Maurois

Birrell's Essays

Scott's Letter books.

1 p., on cover.

2. Fanny Burney-Early Diaries

$M^{\text {rs }}$ Carlyle

Miss Jewsbury

War \& Peace.

Climats. Maurois

Burney Diaries

" Early Diaries

Birrells Essays

Scott's Letter Books

1 p., numbered 1 by NYPL.

B. ENTRIES

1. "JWC-by Huxley.": 3 pp., numbered 2-4 by NYPL.

Carlyle, Jane Welsh. Letters to her Family, 1839-1863. Ed. Leonard Huxley. Murray, 1924.

2. "New Letters \& Memorials of JWC.": 2 pp., numbered 5-6 by NYPL.

Carlyle, Jane Welsh. New Letters and Memorials. Annotated by Thomas Carlyle. Ed. Alexander Carlyle. 2 vols. John Lane, 1903.

3. "Letters and Memorials.": 3 pp., numbered 7-9 by NYPL.

Carlyle, Jane Welsh. Letters and Memorials. Prepared for publication by Thomas Carlyle. Ed. James Anthony Froude. 3 vols. Longmans, 1883.

4. "Jewsbury Letters to JW/Carlyle.": 7 pp., numbered 10-16 by NYPL.

Jewsbury, Geraldine Endsor. Selections from the Letters ... to Jane Welsh Carlyle. Ed. Mrs. Alexander Ireland. Longmans, Green, 1892. 
5. "Zoe. 1845 Jewsbury": 2 pp., numbered $17-18$ by NYPL. On the reverse of p. 17 Woolf has drawn a plan for a new addition to Monk's House, which includes a study and a bath. See L, III, 1973, 1974, 1976; December 1928.

Jewsbury, Geraldine Endsor. Zoe. The History of Two Lives. Vol. I-II [of III]. Chapman \& Hall, 1845.

6. "War \& Peace": 1 p., numbered 19 by NYPL.

Tolstoi, Leo. War and Peace. Trans. Constance Garnett. Heinemann, 1904.

7. "Climats. Maurois": 1 p., numbered 20 by NYPL.

Maurois, André. Climats. Paris: Bernard Grasset, 1928.

8. "Mrs. Jarrett/36 Worthing Road, Southwater, Sussex": 1 p., numbered 21 by NYPL. (Heading only.)

9. "Miss Burney Diaries.": 5 pp., numbered 22-26 by NYPL. The entry begins with lists of volume and page references for "Mrs. Thrale," "Piozzi," "Johnson," "Mr. Greville," and "Mrs. Greville," all of whom attended "Dr. Burney's Evening Party." Most of the notes are from Volume II.

[Burney, Frances.] Diary and Letters of Madame D'Arblay. Ed. by her niece. 7 vols. Hurst \& Blackett, 1854.

10. "Early Diary/Greville": 2 pp., numbered $27-28$ by NYPL; the heading appears on p. 28. P. 27 consists of lists of volume and page references for "Greville" and "Mrs. Greville." More notes on this work appear below, B.12, B.14, and B.21.

Burney, Frances. The Early Diary: 1768-1778. Ed. Annie Raine Ellis. 2 vols. Bell, 1889.

11. "Dr. Burney Memoirs": 1 p., numbered 29 by NYPL. More notes on this work appear below, B.15.

[Burney, Frances.] D'Arblay, Madame. Memoirs of Dr. Burney. Vol. II [of III]. Moxon, 1832.

12. "Fanny Burney. Early Diaries": 7 pp., numbered $30-36$ by NYPL. P. 32 consists of the pencilled note, "[?Tomkins]. 2 Allan's [ . . ] ]," possibly a reference to a man called Tomkin who appears in The Early Diary, I, 82-83. More notes on this work appear above, B.10, and below, B.14 and B.21.

Burney, Frances. The Early Diary: 1768-1778. Ed. Annie Raine Ellis. 2 vols. Bell, 1889. 
13. "Johnson-Burney": 1 p., numbered 37 by NYPL. The entry consists of notes about Dr. Burney, Fanny Burney, and Greville found in the supplementary material of Boswell's Life of Johnson. One note, annotated incorrectly as "X.49"- "Dr. Burney's "habitual softness of manners' (Thrale)"-is from the "Anecdotes of Dr. Johnson, by Mrs. Piozzi," which appears in Vol. IX of the Life. At the bottom of the page appears the unidentified note: " 210 This is added merely to test the power of the pen. She wrote this after many days in bed, \& I think she was right to doubt her own powers. ..." This may refer to Woolf's six weeks in bed from January to March 1929.

Boswell, James. The Life of Samuel Johnson. New ed. To which are added Two Supplementary Volumes of Johnsoniana, by Hawkins, Piozzi, etc. Ed. John Wilson Croker. Vols. VII, VIII, IX. Murray, 1839.

14. "Helen \& Susan were musical-played/duets.": 1 p., numbered 38 by NYPL. Marginal notation, "ED/2/154." More notes on this work appear above, B.10 and B.12, and below, B.21.

Burney, Frances. The Early Diary: 1768-1778. Ed. Annie Raine Ellis. Vol. II [of II]. Bell, 1889.

15. "Burney had got to know the Ts in 1776?": 2 pp., numbered 38-39 by NYPL. Marginal notation, "M./2. 100." More notes on this work appear above, B.11.

[Burney, Frances.] D’Arblay, Madame. Memoirs of Dr. Burney. Vol. II [of III]. Moxon, 1832.

16. "Swanns Way.": 1 p., numbered 40 by NYPL. Another set of notes on this work appears as XIV, B.23.

Proust, Marcel. Swann's Way. Trans. C. K. Scott Moncrieff.

Vol. I [of II]. Chatto \& Windus, 1922.

17. "Notes in Fiction/Miss Mayor": 2 pp., numbered 41-42 by NYPL. The entry opens with the note, "One is reduced to an emotional state exactly as if one were hearing people talk. 173 a conversation in prose that reminds one of a scene in some $E^{\text {than }}$ play." This is followed by a long quotation from the novel, beginning, "'Oh, what a weary old world this is!"”

Mayor, F. M. The Squire's Daughter. Constable, 1929. 
18. "Birrell.": 5 pp., numbered $43-47$ by NYPL.

Birrell, Augustine. The Collected Essays and Addresses: 18801920. 3 vols. Dent, 1922.

19. "Et Cetera": 1 p., numbered 48 by NYPL. More notes on this work appear in XX, B.13.

Birrell, Augustine. Et Cetera. Chatto \& Windus, 1930.

20. "Scott's Letter books.": 2 pp., numbered 49-50 by NYPL. The entry includes a great deal of criticism of the format of the book.

Scott, Sir Walter. The Private Letter-Books. Ed. Wilfred Partington. Hodder \& Stoughton, 1930.

21. "Maria Rishton/(M ${ }^{\text {rs }}$ Ellis)": 3 pp., numbered $51-53$ by NYPL; the heading appears on p. 52. These notes are one source of "Fanny Burney's Half-Sister." Earlier notes on this work appear above, B.10, B.12, and B.14.

Burney, Frances. The Early Diary: 1768-1778. Ed. Annie

Raine Ellis. 2 vols. Bell, 1889.

22. "[?Studies] in literature./Reading Dante-": 1 p., numbered 54 by NYPL. 4 lines only, continuing, "A story about it - what happens to the mind-a room-people-interruptions-"

\section{Holograph Reading Notes. Vol. 14. (Berg)}

"I've suddenly become absorbed in a book about reading novels," Woolf wrote Vita Sackville-West on February 5, 1927, "and can't stop making up phrases" ( $L$, III, 1714). Some of these phrases, and notes on a good number of the novels read for this book, comprise the major part of this notebook. For almost three years Woolf's absorption in her book rose and fell. She first mentioned that she "must plan out [her] book on literature for the Press" on September 5, 1926: "Six chapters. Why not groups of ideas, under some single heading - for example. Symbolism. God. Nature. Plot. Dialogue. Take a novel \& see what the component parts are. Separate this, \& bring under them instances of all the books which display them biggest" ( $D$, III). Phases of Fiction was announced as forthcoming by the Hogarth Press in 1927 but was not completed until 1929 when it appeared in essay form in Bookman, April, May, and June 1929 (Kp. 
C312). In the interim, she was preoccupied with several other essays and books, including Orlando and A Room of One's Own. Woolf's extensive writing during these years, and the length of time she worked on "Phases of Fiction," account for the dispersion of her notes from this period over several notebooks, including Volumes XIII, XXV, XXVI, and, in particular, XLVI. The entries in XLVI almost directly parallel those in this volume.

Woolf, then, was reading novels-and commenting on her reading in her letters, diary, and reading notebooks-for almost three years, which complicates the dating of the entries. Some guidelines are available, however. At the end of August 1927, Woolf wrote two letters asking to borrow The Mysteries of Udolpho (B.3), as she was "stuck in Romance" ( $L$, III, 1800,1801$)$. She was reading the novel by August 29 , when she wrote, "So far, which is the end of Vol. one, I have met nothing to raise a laugh, except a hole in the drawing-room floor where the family papers seem to be kept. But why not? I expect Jane Austen went too far the other way" ( $L$, III, 1803). She repeated this sentiment, including the comparison with Austen, in a letter to Lytton Strachey on September 3 (L, III, 1807); notes on Northanger Abbey appear as B.4. At about this same time, Woolf also agreed to review Harold Nicolson's Some People and started to read about biography ( $L$, III, 1811, September 13, 1927; D, III, September 20, 1927; see B.1-2). The result was "The New Biography," which appeared in the New York Herald Tribune, October 30, 1927 (Kp. C290). In the beginning of October 1927, Woolf began writing Orlando and appears to have stopped working on her book on fiction. She did, however, publish a review of Praeterita (B.6) - "Ruskin Looks Back on Life, 'Praeterita': Serene Thoughts with the Echoes of Thunder," T.P.'s Weekly, December 3, 1927 (Kp. C293); and, also in December, she began reading Lord Chesterfield (B.7-8) for her review of his Characters entitled "An English Aristocrat," TLS, March 8, 1928 (Kp. C298; see $D$, III, December 20, 1927, and February 18, 1928; L, III, 1843).

By May 31, 1928, Woolf had essentially finished Orlando and was again planning her "book on fiction" ( $D$, III). In May and June, she was reading Proust ( $D$, III, May 31 , June 20 ), and on July 7 , she wanted to write about Sterne in her diary ( $D$, III). On August 12, she was "[scribbling] down whatever I can think of about Romance, Dickens \&c. must hastily [?] gorge on Jane Austen tonight \& dish up something tomorrow" ( $D$, III). On August 30, she was working "at novels and novels. I read Proust, Henry James, Dostoevsky" ( $L$, III, 1918); on August 31, she described "the cattle galloping 'like mad' as Dostoevsky would say," and was beginning Peacock; on September 
10, she was reading Moby Dick (D, III). All of these novelists are recorded in the second half of this volume, along with several others who appear in "Phases of Fiction."

The entry on Tristram Shandy (B.16), dated "27th Nov.," illustrates the complications and rewards of her reading notes at this time. The first part of the entry (pp. 36-40) consists of notes made at the end of 1926 (see Volume XXV, introduction); the latter part belongs to her reading of novels in the summer of 1928 and contains, as do all of the entries from this period, a large proportion of general notes about different styles of fiction. In the Tristram Shandy entry, as in the notebook as a whole, we can watch Woolf formulating ideas that structured the finished essay.

Interspersed with the notes for "Phases of Fiction" are a quotation about "Women" - the danger of their having a metaphysical purpose (B.9) - and notes on The Early Life of Thomas Hardy (B.19). The first entry is related to the lectures on women and fiction that Woolf began thinking about in January 1928, delivered in October 1928, and almost immediately turned into A Room of One's Own. The second entry belongs to Woolf's review, "Half of Thomas Hardy," published in the Nation \& Athenaeum, November 24, 1928 (Kp. C306).

The table of contents is typed on the cover of the notebook. Most of the entries are in blue-purple or blue-black ink, with two pages in black ink (B.7).

\section{A. Table of Contents}

1. Biography

Mysteries of Udolpho

Northanger Abbey

Bleak House

Praeterita

Lord Chesterfield

Silas Marner

What Maisie Knew

Proust

Tristram Shandy

Moby Dick

Hardys Life

Notes for Phases of fiction

Proust

1 p., on cover. Typed. 
B. ENTRIES

1. "Biography-/Lee": 2 pp., numbered $1-2$ by NYPL; numbered 1-2 by VW. (P. 2, 3 lines only.)

Lee, Sidney. Principles of Biography. Cambridge: Cambridge Univ. Press, 1911.

2. "H. Nicolson": 2 pp., numbered $3-4$ by NYPL; numbered 3-4 by VW.

Nicolson, Harold. Some People. Constable, 1927.

3. "Radcliffe. Ms. of Udolpho.": 1 p., numbered 5 by NYPL; numbered 5 by VW. Another set of notes on this novel appears in XXV, B.29; five lines of general notes appear as XLVI, B.4.

Radcliffe, Ann. The Mysteries of Udolpho. A Romance. Vol. II [of IV]. Robinson, 1794.

4. "Northanger Abbey.": 1 p., numbered 6 by NYPL; numbered 6 by VW. This entry includes general notes on Austen's use of dialogue to present character and her use of satire, and the reader's subsequent yearning for psychology: "therefore the [psychology] chapter should come next: then the stylists. Then the poets."

Austen, Jane. Northanger Abbey. Ed. R. W. Chapman. Oxford: Clarendon Press, 1923. Vol. V of The Novels of Jane Austen.

5. "Bleak House.": 1 p., numbered 7 by NYPL. General notes, beginning, "That the characters are so filled with gunpowder that they are split asunder." For more notes on this novel, see below, B.10, and XLVI, B.16.

Dickens, Charles. Bleak House. Chapman \& Hall, 1905. Vol. XI of The Works of Charles Dickens. Authentic Edition.

6. "Praeterita. Ruskin": 5 pp., numbered 8-12 by NYPL; numbered $1,1,1 \& 2,2$, and 3 by VW. Woolf's numbers correspond to the volume of the work noted on that particular page.

Ruskin, John. Praeterita. Outlines of Scenes and Thoughts perhaps Worthy of Memory in my Past Life. 3 vols. George Allen, 1899.

7. "Chesterfield": 7 pp., numbered 13-19 by NYPL; numbered $1,1,1,1,2,2,2$ by VW. Woolf's numbers correspond to the volume of the work noted on that particular page. The 
entry is also headed "Chesterfield's Letters." More notes on this work appear as XLVI, B.1.

Chesterfield, 4th Earl of [Philip Dormer Stanhope]. Letters.

Ed. Lord Mahon. Vols. I-II [of V]. Lippincott, 1892.

8. "Lord Chesterfields Characters": 1 p., numbered 20 by NYPL. Another set of notes on this work appears in XLVIII, B.8.

Chesterfield, 4th Earl of [Philip Dormer Stanhope]. Lord Chesterfield's Characters. Ed. Charles Whibley. Peter Davies, 1927. Little Books.

9. "Women.": 1 p., numbered 21 by NYPL. Quotation, annotated "Criterion. June," beginning, "Ly D.W. [Lady Dorothy Wellesley] has a metaphysical purpose, \& that is a dangerous obsession, especially with a woman, ..." This quotation reappears as a footnote near the end of Chapter 4 of $A$ Room of One's Own, illustrating the male voice that "[drags] even into the criticism of poetry criticism of sex."

Rev. of Matrix, by Lady Dorothy Wellesley. Criterion 7, no. 4 (June 1928): 160.

10. "Bleak House": 1 p., numbered 22 by NYPL. For more notes on this novel, see above, B.5, and XLVI, B.16. General notes, reading, "There are two remarkable cases of the music going on after the words have stopped: the French maid crossing the wet grass in bare feet: the soliciter who gave his gold watch to his clerk \& then killed himself."

Dickens, Charles. Bleak House. Chapman \& Hall, 1905. Vol. XI of The Works of Charles Dickens. Authentic Edition.

11. "Silas Marner": 2 pp., numbered 23-24 by NYPL.

Eliot, George. Silas Marner. [1861].

12. "What Maisie Knew. H.J.": 4 pp., numbered 25-28 by NYPL. (P. 28, 2 lines only.) The entry includes a large number of general notes about novels; one passage begins, "Novels are always about the conventions of some era" (p. 26).

James, Henry. What Maisie Knew. Heinemann, 1898.

13. "Proust. Guermantes.": 2 pp., numbered 29-30 by NYPL.

Proust, Marcel. The Guermantes Way. Trans. C. K. Scott Moncrieff. Vol. II [of II]. Chatto \& Windus, 1925.

14. "Dostoevsky. Possessed.": 4 pp., numbered 31-34 by NYPL. Another set of notes on this novel appears in XLVI, B.19. 
Dostoevsky, Feodor. The Possessed. Trans. Constance Garnett. Heinemann, 1916.

15. "Peacock. Crotchet Castle": 1 p., numbered 35 by NYPL.

Peacock, Thomas Love. Crotchet Castle. Oxford Univ. Press, 1924.

16. "Tristram Shandy": 10 pp., numbered $36-45$ by NYPL. Pp. 36-40 are also numbered $19-23$ by VW in blue pencil. $\mathrm{P}$. 36 is dated "(27th Nov.)." The entry includes a large number of general notes about Sterne's style and about the poetic novel.

Sterne, Laurence. The Life and Opinions of Tristram Shandy, Gent. In Works. Vols. I-II. Johnson, 1808.

17. "Moby Dick": 1 p., numbered 46 by NYPL.

Melville, Herman. Moby Dick. Cape, 1923.

18. "These start our minds off upon people./This is the danger of a novel./For it forces us into realism.": 2 pp., numbered 47-48 by NYPL. The entry consists of general notes for "Phases of Fiction."

19. "The Early Life of Thomas Hardy/1840-1891": 8 pp., numbered $49-56$ by NYPL.

Hardy, Florence Emily. The Early Life of Thomas Hardy, 1840-1891. Macmillan, 1928.

20. "Conclusion to Phases of Fiction.": 2 pp., numbered 57-58 by NYPL. General notes for "Phases of Fiction," beginning, "Style as an element." On the reverse of p. 56 appear three numbers, totalled, followed by $£ 500$-presumably a calculation of money earned from articles.

21. "Phases of Fiction": 1 p., numbered 59 by NYPL. The entry, which begins with the cancelled heading, "Women \& Fiction," consists of a long quotation and notes on Garnett's novel. The quotation begins, "Next day the little ketch weighed anchor-sailed down the estuary, \& then, with an East wind to help them, they made fine progress under the shelter of the Isle of Wight." One note reads, "What I dislike is the extreme wordiness of Bunny."

Garnett, David. No Love. Chatto \& Windus, 1929.

22. “Mirsky/Đoty/Quennett/Leave back plain.": 1 p., numbered 60 by NYPL. (Heading only.) 
23. "58 The integrity of eating a cake.": 2 pp., numbered 61-62 by NYPL. P. 62 is headed, "Proust/(translation)." More notes on this work appear in XIII, B.16.

Proust, Marcel. Swann's Way. Trans. C. K. Scott Moncrieff. Vol. I [of II]. Chatto \& Windus, 1922.

\section{Holograph Reading Notes. Vol. 15. (Berg)}

The contents of this notebook are odds and ends that probably belong with essays Woolf wrote in 1926 and 1927. The notes on Where Angels Fear to Tread (B.1) could have been made in conjunction with "The Novels of E.M. Forster," published in the Atlantic Monthly in November 1927 (Kp. C292). On February 2, 1927, Woolf had "to read all Morgan's novels, and so far cant open a book without being interrupted"; on March 8, she was writing the article; and on May 25, she recorded that she was having trouble finishing it ( $L$, III, 1711, 1726, 1762; see also D, III, February 12, 1927). Woolf reviewed Volume III of James Woodforde's Diary of a Country Parson in the New Republic, August 17, 1927 (Kp. C285). The entry on Woodforde in this notebook (B.3) includes notes on Volumes I-V of the Diary. The notes on Volumes I-III were probably made in 1927; the notes on Volumes IV (1929) and V (1931), were probably made when Woolf revised her essay for inclusion in The Common Reader: Second Series. The notes on The English Mail Coach (B.4) are harder to date. Woolf draws heavily on this work in her essay on De Quincey, "Impassioned Prose," published in the TLS, September 16, 1926 (Kp. C275). She began to mention De Quincey in her letters during February 1926 ( $L$, III, 1619-1620) and continued to work on him through the spring and summer, when she wrote to Vita Sackville-West: ". . . and my God Vita, if you happen to know do wire whats the essential difference between prose and poetry" ( $L$, III, 1656; see also $D$, III, May 11 , July 22, 1926). On September 13, 1926 , she noted in her diary that she had "spent 4 days last week hammering out de Quincey, which has been lying about since June" ( $D$, III). Nevertheless, a year later, in December 1927, she talks again of "trying to write about ... de Quincey" ( $L$, III, 1843). This may be an early reference to what became "De Quincey's Autobiography" in The Common Reader: Second Series. 
The table of contents is written on the cover in black ink. B.1 and the first part of B.3 (pp. 2-9) are in blue-purple ink; B.2 is in pencil; the remainder of the notes are in a brownish-black ink.

\section{A. Table of Contents}

1. Woodforde

\section{De Quincey}

1 p., on cover.

B. ENTRIES

1. "Angels. Forster": 1 p., numbered 1 by NYPL. The entry consists largely of general notes, beginning, "There is real character creation in Gino, as in Aziz."

Forster, E. M. Where Angels Fear to Tread. Edinburgh: Blackwood, 1905.

2. "Ibsen. The Wild Geese": 1 p., on the reverse of p. 1. (Heading only.)

3. "Woodforde": $10 \mathrm{pp}$., numbered $2-11$ by NYPL; pp. 3-8 numbered $1,1,2,2,3,3$ by VW. Woolf's numbers correspond to the volume of the work noted on that particular page. The notes that appear under the heading "Vol. 5" on pp. 10-11 are actually from Volume IV; the notes headed "6" on p. 11 are from Volume V. More notes on Volume IV appear in XLVIII, B.12; more notes on Volume I are in XIX, B.2.

Woodforde, James. The Diary of a Country Parson. Ed. John Beresford. Vols. I-V. 1758-1796. Oxford Univ. Press, 1924-1931.

4. "De Quincey:": 2 pp., numbered $12-13$ by NYPL. Marginal notation, p. 12, "Mail Coach."

De Quincey, Thomas. The English Mail Coach. In Works. Vol. IV. Edinburgh: Adam \& Charles Black, 1863.

\section{Holograph Reading Notes. Vol. 16. (Berg)}

The three tables of contents for this volume illustrate the continuing diversity of Woolf's reading in the last years of her life. Although 
the majority of the entries in the notebook pertain to her reading for the "Common History book" she conceived on September 12, 1940 $(A W D)$, the three tables of contents also list authors and works associated with her continued reading about women and war after the publication of Three Guineas in 1938, as well as her reading for Roger Fry: A Biography (1940), "The Leaning Tower" (1940), and other essays written in 1940 and 1941 . Woolf has cancelled the items in the tables of contents that are not actually included in this volume, and many of them appear elsewhere. The notebook as a whole should be read in conjunction with Volume XXXVII, which consists almost entirely of notes for her "Common History book" made at approximately the same time as those in this volume.

To begin with the missing entries: "Blackwell" and "Jex Blake" (A.1, A.2)-Dr. Elizabeth Blackwell and Sophia Jex-Blake-both reflect Woolf's involvement with women in the professions; notes on Blackwell appear in XXXVII, B.1; notes on Jex-Blake in VII, B.13, XXVI, B.4, and LX, B.57. "R.F. Reynolds" (A.1, A.2), "Reynold's Discourses" (A.3), and "Vision \& Design-Life" (A.3) all pertain to her reading for Roger Fry: A Biography. Notes on Fry's edition of Reynold's Discourses and on the life of Sir Edward Fry-possibly the "Life" mentioned here-are included among the loose pages in Volume XXVI (B.31, B.17); a brief entry on Vision and Design appears in XXXIX, B.1. "Sidney Smith" (A.1, A.2, A.3) was in Woolf's mind on March 21, 1940, as a possible article. On March 31 she was commenting on his talk; on April 2, she was "reading Sydney Smith-his life-with only one wish in the world: that I'd married him" ( $L, V I$, 3600 ); and on May 29, she "began Sidney Smith" ( $A W D$ ). There appear to be no reading notes on Smith, however; nor are there notes from this period about "Walpole" (A.3), although Woolf records having sent off her article on him in the May 29 diary entry. This article is presumably her review of Horace Walpole by R. W. Ketton-Cremer, published as "The Humane Art," New Statesman \& Nation, June 8, 1940 (Kp. C366). Earlier, however, during 1938 and 1939, she had read the Yale edition of Walpole's Correspondence and reviewed the Letters... to the Rev. William Cole (Kp. C358)-an "impertinence," she wrote the editor, "for I am a very casual and unlearned reader" ( $L$, VI, 3472, 3510). "MacNeice," the last of the missing entries (A.3), is Louis MacNeice, whose long poem "Autumn Journal" is featured in "The Leaning Tower," the lecture delivered by Woolf in May 1940 and published in Folios of New Writing, Autumn 1940 (Kp. C372). Woolf includes MacNeice in her plans for her lecture, which are outlined in her diary on February 11, 1940. 
The survivors from the first two lists of contents-"Thrale" and "Sévigné" - both belong to her reading at the end of 1940 and the beginning of 1941. "Mrs. Thrale," a review of the Clifford biography (B.9, 12), was published in the New Statesman \& Nation, March 8, 1941 (Kp. C374); on February 1, 1941, Woolf wrote Ethel Smyth that she "must earn 10 guineas reading a vast fat book about Mrs. Thrale. I'm in the 16th century, and its a wrench to jerk to the 18th" ( $L$, VI, 3685). Although Woolf's essay on "Madame de Sévigné" was written in May 1939, she was still reading Sévigné's Lettres (B.1) on September 14 and December 29, $1940(A W D)$, and included the Frenchwoman in a list of possible articles for her history book (see "Notes for Reading at Random," $A \& R, 375)$. The essay was published in The Death of the Moth and Other Essays (1942).

The remaining notes in this volume chart the development of "Anon" and "The Reader," the first two essays in Woolf's unfinished history of English literature, called, provisionally, Reading at Random and Turning the Page. (See $A \& R$.) Woolf's original idea for her "Common History book" was "to read from one end of literature including biography; and range at will, consecutively" ( $A W D$, September 12, 1940). On September 18, she began to outline a work that would begin with English literature before the Elizabethans and end with a chapter on the future ("Notes for Reading at Random," $A \&$ $R$ ). Her working notes end with an entry on Lady Anne Clifford's Diary, which is also noted in this volume (B.14). During the fall of 1940 , Woolf was reading or planned to read other people's histories of English literature, as well as the literature of the medieval and Elizabethan periods ( $A W D$, September 14, 17, October 12, 1940). On October 17, she was "filling [her] mind slowly with Elizabethans," and a month later, November 23, she was ready to begin "Anon" $(A W D)$. The first draft of this essay is, in fact, dated "24th Nov. 1940" ("Anon." Folder 1. Berg). She continued working on "Anon" and "The Reader" until her death on March 28, 1941, noting on January 1, 1941, that she had brought down "a handful of Elizabethans for my book" $(A W D)$ and asking Vita Sackville-West on February 4 to bring her a biography of Lady Anne Clifford "or any other Elizabethan" ( $L$, VI, 3689). On February 26, her " 'higher life' [was] almost entirely the Elizabethan play" $(A W D)$.

The Elizabethans and pre-Elizabethans who populate this volumeMalory, Latimer, Marlowe, Henslowe, Burton, and Lady Anne Clifford-all reappear in Woolf's drafts for "Anon" and "The Reader"; the historical works by Chambers, Nicoll, and G. B. Harrison provided the details for her re-creation of the English literary past. Given 
the chronology of the drafts for "Anon" and "The Reader," the notes in this volume are perhaps the last that Woolf made before she died.

The first two tables of contents, A.1 and A.2, appear on labels pasted on the spine and the front cover of the notebook. The ink throughout is black.

A. Table of Contents

1. Btaekwell

Jex Blake

f...

R.F. Reynolds

Sevigné

Sydney Smith

Label, on spine.

2. Btaekwell

Jex Btake

R.F. Reynolds

Sevigné

Sydney Smith

Thrale

$1 \mathrm{p}$., on cover.

3.

Reynolds Diseourses

Sévigné

Vision \& Design-Life

MaeNeiee

Sydney Smith: Peter Ps letters

Walpole

1-9-10. Medieval Stage-Chambers. A.

Nichols. British Drama.

11-20 Latimers Sermons.

21-22 Malory

23-27. Elizabethan Plays \& Players-

Harrison

Penelope Rich-Rawson

1 p., numbered 1 by NYPL. 
B. ENTRIES

1. "Sevigné": 2 pp., numbered $2-3$ by NYPL. (P. 3, 2 lines only.) More notes on this work appear in XXXVII, B.12 and LIV, B.2.

[Sévigné, Madame de.] Lettres de Madame de Sévigné, de sa famille et de ses amis. Ed. M. Monmerqué. New ed. Vol. IV [of XIV]. Paris: Hachette, 1862.

2. "Med Stage EK Chambers": 9 pp., numbered 4-12 by NYPL; numbered $1-9$ by VW.

Chambers, E. K. The Medieval Stage. 2 vols. Oxford: Clarendon Press, 1903.

3. "Nicoll. Nicoll. B Drama": 1 p., numbered 13 by NYPL; numbered 10 by VW. The entry begins with a question that recurs in Woolf's drafts for "Anon" and "The Reader": "When is the reader born? With Shakespeare?" More notes on this work appear below, B.7.

Nicoll, Allardyce. British Drama. An Historical Survey from the Beginnings to the Present Time. Harrap, 1925.

4. "Latimer.": 10 pp., numbered $14-23$ by NYPL; numbered $11-20$ by VW.

Latimer, Hugh. Fruitfull Sermons. Preached by the Right Reverand Father, and Constant Martyr of Jesus X, Master Hugh Latimer. Cotes, 1635.

5. "Malory": 2 pp., numbered 24-25 by NYPL; numbered 2122 by VW. The entry begins with notes on "Strachey./ xxvi"-Sir Edward Strachey's "Introduction" to the work.

Malory, Sir Thomas. Le Morte D'Arthur. With an Intro. by Sir Edward Strachey. Macmillan, 1868.

6. "Elizabethan Plays \& Players./G.B. Harrison.": 5 pp., numbered $26-30$ by NYPL; numbered $23-27$ by VW. More notes on this work appear below, B.8.

Harrison, G. B. Elizabethan Plays and Players. Routledge, 1940.

7. "Nicoll - British Drama": 1 p., numbered 31 by NYPL; numbered 28 by VW. More notes on this work appear above, B.3.

Nicoll, Allardyce. British Drama. An Historical Survey from the Beginnings to the Present Time. Harrap, 1925. 
8. "Rich Rawsen/Harrison": 1 p., numbered 32 by NYPL; numbered 29 by VW. More notes on this work appear above, B.6.

Harrison, G. B. Elizabethan Plays and Players. Routledge, 1940.

9. "98 attacks on $\mathrm{J}^{\mathrm{n}}$ immorality in Press": 1 p., numbered 33 by NYPL. The reference is to Dr. Johnson. More notes on this work appear below, B.12.

Clifford, James L. Hester Lynch Piozzi-Mrs. Thrale. Oxford: Clarendon Press, 1941.

10. "Tamberlaine": 1 p., numbered 34 by NYPL.

Marlowe, Christopher. Tamberlaine the Great. Part the First. In Elizabethan Tragedy: Six Representative Plays. Ed. George Rylands. Bell, 1933.

11. "Henslowe": 4 pp., numbered $35-38$ by NYPL. More notes on this work appear in XXXVII, B.10.

Henslowe, Philip. The Diary ... from 1591-1609. Ed. Walter W. Greg. 2 vols. Bullen, 1904-1908.

12. "Thrale": 14 pp., numbered $39-52$ by NYPL. P. 39 is also numbered 30 by VW, which indicates that this entry originally followed B.8, above. The notes on this work found in B.9, above, belong between pp. 41 and 42 of this entry.

Clifford, James L. Hester Lynch Piozzi-Mrs. Thrale. Oxford: Clarendon Press, 1941.

13. "Anat. of Melan": 2 pp., numbered 53-54 by NYPL. More notes on this work appear below, B.16.

Burton, Robert. The Anatomy of Melancholy. Ed. A. R. Shilleto. Vol. I [of III]. Bell, 1893.

14. "Clifford.": 2 pp., numbered 55-56 by NYPL.

Clifford, Lady Anne. Diary. With an Intro. by V. SackvilleWest. Heinemann, 1923.

15. "Clifford.": 1 p., numbered 57 by NYPL. More notes on this work appear in XXXVII, B.18.

Williamson, George C. Lady Anne Clifford. ... Her Life, Letters and Work. Kendal: Titus Wilson, 1922.

16. "Burton": 1 p., numbered 58 by NYPL. More notes on this work appear above, B.13.

Burton, Robert. The Anatomy of Melancholy. Ed. A. R. Shilleto. Vol. I [of III]. Bell, 1893. 


\section{Holograph Reading Notes. Vol. 17. (Berg)}

Woolf has labelled this notebook "Sir Thomas Browne's Letters," and dated it "November: 1936." The two entries both pertain to this work. The ink throughout is black.

\section{A. Table of Contents}

1. November: 1936

Sir Thomas Browne's Letters

1 p., numbered 1 by NYPL.

B. ENTRIES

1. "9 his coins increased.": 4 pp., numbered $2-5$ by NYPL. P. 2 is also numbered 1 by VW. The entry is also headed "Browne Letters" and "Sir T. Brown. Letters."

Browne, Sir Thomas. Letters. Ed. Geoffrey Keynes. Faber \& Faber, 1931. Vol. VI of Works.

2. "Silence pure [?godless]. Pillar of stone, eyeless . ..": 1 p., numbered 6 by NYPL. The entry appears to be a passage written in imitation of Browne's style by Woolf. Opposite $\mathrm{p}$. 6 appears the note, "[ . . . 1870."

\section{Holograph Reading Notes. Vol. 18. (Berg)}

Although most of the entries in this notebook can be dated fairly accurately in 1925, others are not as clear. The most confusing notes are those on Stendhal's Le Rouge et le noir (B.3). Woolf's review of several of Stendhal's works, ostensibly including this novel, appeared in Nation \& Athenaeum, July 5, 1924 (Kp. C249); the review itself, however, speaks explicitly only of Stendhal's Journals (see XIX, B.1). A year later, on June 27, 1925, Woolf wrote of her "power to make large sums by formulating views on Stendhal \& Swift," and on July 20 , Stendhal was part of her projected reading for that summer at Rodmell ( $D$, III). Although she may have been referring to Stendhal's Life of Henri Brulard (noted in B.10), there are other indications that she read Le Rouge et le noir at this time. One is the association of her notes on this novel with those made for the projected 
work called Lives of the Obscure, which she also mentions in the diary entry for July 20 (see B.5).

Other entries are easier to place in 1925. The Memoirs of Charles Mathews (B.6) are the source of "Sterne's Ghost," published in the Nation \& Athenaeum, November 7, 1925 (Kp. C269). Her notes on this work begin on the page headed "Lives of the Obscure," and may originally have been intended for her "history of England in one obscure life after another" ( $D$, III, July 20, 1925). Mathews, moreover, could have led Woolf to Tate Wilkinson's Memoirs (B.8), which she may well have read in 1925 and returned to a year later when she published "Jones and Wilkinson," Bermondsey Book, June 1926 (Kp. C274.1). The notes on Dobrée's introduction to Congreve's Comedies (B.9) almost certainly belong to her review of that work, Nation \& Athenaeum, October 17, 1925 (Kp. C268.1). And, although Woolf noted the publication of E. M. Forster's Passage to India (B.12) in June 1924 ( $L$, III, 1479), she specifically mentions that she is reading the novel on December 7, 1925: "I am reading The Passage to India; but will not expatiate here, as I must elsewhere. This book for the H.P. [Hogarth Press]: I think I will find some theory about fiction. I shall read six novels, \& start some hares. The one I have in view, is about perspective" ( $D$, III). The mention of perspective in the diary entry corresponds to her discussion of Forster's perspective in the reading notes below. The intended "book," Phases of Fiction, was eventually published as three articles in 1929 (Kp. C312). By December 1925, moreover, Woolf had agreed "to write a lecture, for school girls: 'how should one read a Book?' and this, by a merciful dispensation, seems to me a matter of dazzling importance and breathless excitement" ( $L$, III, 1596; early November? 1925). Criticism and theories of criticism were clearly on her mind and may account for her notes on Gourmont and I. A. Richards (B.2, B.7), as well as for the entry "How to Read" (B.4).

With the exception of p. 13, which is pencilled, all of the notes are in purple ink.

\section{B. ENTRIES}

1. "Cameron.": 1 p., numbered 1 by NYPL. The remainder of the entry reads, "Lord Darling/81 Albert Hall Mansions/ Mr. Austen Chamberlain." Unidentified.

2. "Promenade Littéraires. de Gourmont/20 a great critic needs as much genius as a great novelist.": 1 p., numbered 2 by NYPL. (Heading only.) 
Gourmont, Rémy de. "M. Brunetière." In Promenades Littéraires. 3rd ser. Paris: Mercure de France, 1909.

3. "Rouge et le Noir Stendhal": 2 pp., numbered 3-4 by NYPL. The entry includes several general notes about this novel, as well as a bracketed passage beginning, "(one of the amusing things is to track your author down-)." See below, B.4.

Stendhal. Le Rouge et le noir. Ed. Jules Marsan. 2 vols. Paris: Champion, 1923.

4. "How to Read": 1 p., numbered 5 by NYPL. General notes, beginning, "One of the amusing things is to track your author down-To see what he goes for." The entry includes an example from Le Rouge et le noir. See above, B.3.

5. "Lives of the Obscure. Story of 2 Noble Lives": 1 p., numbered 6 by NYPL. Quotation, annotated "July 30th 1859 . Lady Waterford," " $3 / 43$," beginning, "I am sorry indeed to hear of Anthony Thompson's loss of mind, or rather of memory; ..."

Hare, Augustus J. C. The Story of Two Noble Lives. Being Memorials of Charlotte, Countess Canning, and Louisa, Marchioness of Waterford. Vol. III [of III]. George Allen, 1893.

6. "Memoirs of Charles Mathews.": 4 pp., numbered 6-9 by NYPL. This entry, which is also headed "Sternes Room," is the source of Woolf's article, "Sterne's Ghost." The entry includes a reference to "The Wandering Patentee' by Tate Wilkinson," a four-volume "history of the Yorkshire Theatres from 1770 to the present time" (1795). It is unclear whether Woolf ever read this work.

Mathews, Mrs. [Anne]. Memoirs of Charles Mathews, Comedian. 2nd ed. Vols. I-II [of IV]. Bentley, 1839.

7. "Principles of Literary Criticism/Richards.": 1 p., numbered 10 by NYPL.

Richards, I. A. Principles of Literary Criticism. Kegan Paul, 1925.

8. "Tate Wilkinson. Memoirs.": 3 pp., numbered 11-13 by NYPL. P. 13 is headed "Jones \& Wilkinson," the title of Woolf's article on this work.

Wilkinson, Tate. Memoirs of his Own Life. Vol. I [of IV].

York: 1790. 
9. "Congreve. Dobrée": 1 p., numbered 14 by NYPL. The notes are on Dobrée's "Introduction" to the Comedies.

Dobrée, Bonamy. "Introduction." In William Congreve. Comedies. Oxford Univ. Press, 1925.

10. "Brulard": 1 p., numbered 15 by NYPL.

Stendhal. The Life of Henri Brulard. Trans. Catherine Alison Phillips. Cape, 1925.

11. "The Rape of the Lock.": 2 pp., numbered 16-17 by NYPL.

Pope, Alexander. The Rape of the Lock. Etchells \& MacDonald, 1925.

12. "Novels": 1 p., numbered 18 by NYPL. The entry consists of notes on E. M. Forster's Passage to India, beginning, "Question of perspective: Morgan uses two: his people become mystic. The old lady in P. to I. 266. This is somehow wrong."

Forster, E. M. Passage to India. [1924].

\section{Holograph Reading Notes. Vol. 19. (Berg)}

Greeks, Elizabethans, and contemporaries vie for attention in this volume of reading notes, placing it squarely among the six notebooks that record Woolf's preparation for what became The Common Reader (1925). The progression of her critical book, originally called Reading or Reading and Writing, is recorded in Volumes XXX, XXXVIII, XLIX, XXV, XIX, and XLVII. Although it is unclear how the division of notes into these volumes occurred-whether, for example, Woolf bound her notes on the Greeks and the Elizabethans as she made them; or, more likely, collected them when she began to write the essays; or, also a possibility, bound them a good deal later in a general organization of notes - the entries in this volume can for the most part be dated from the end of 1923 through the autumn of 1924. These dates make this notebook the fifth of the six volumes related to The Common Reader; it should be used in conjunction with Volume XXV, which also contains a large number of notes on the Greeks and Elizabethans.

The Elizabethan playwrights, who to some extent dominate this volume, appear to have been a late addition to The Common Reader and suggest the 1924 date. On August 17, 1923, Woolf made a list of 
possible essays for her critical book that included the Greeks, but not the Elizabethans per se $(D$, II). She had by this time planned to write on at least some Elizabethans-on August 28, 1922, she was going to "end upon the Odyssey because of the Elizabethans" $(D$, II) - but the Elizabethans she had in mind may have been Hakluyt, the Verneys, and Sir Thomas Browne, the figures she had already embodied in her essay, "Reading" (1919). In fact, "Hakluyt \& Eliza[bethan]s" appears after "Pastons: \& Odyssey" in an earlier list of essays for "Reading" found in XLIX, B.25. In 1923, however, Woolf was clearly reading Elizabethans, including the playwrights, although she rarely mentions them in her diary or letters. On March 17, 1923, she read The Silent Woman $(D, \mathrm{II})$, which she almost certainly reread at a later time in conjunction with Jonson's other plays (B.29-34). On May 11, 1923 , she asks, "shall I plunge into early Elizabethans, of whom I am appallingly ignorant?" $(D$, II), and on August 10 , she is planning to read Marlowe ( $L$, III, 1417). After that, she makes only a few scattered references to reading or writing about the Elizabethans ( $D$, II, December 19, 1923; February 3, April 5 \& 15, 1924) until September 4,1924 , when she speaks of reading "a good many Elizabethan plays which I'm going to write about" ( $L$, III, 1496). By January 6, 1925, she had written "a note on an E[lizabe]than play-for which I have been reading plays all this year" $(D$, III $)$.

By September 1924, Woolf's chapter on Hakluyt and the Elizabethans had become "Some Elizabethans," and it was going to integrate Hakluyt and the prose writers with the playwrights and Donne. An outline for this essay, "Notes for Some Elizabethans \& Montaigne," appears in this notebook (B.22), along with notes on Lady Anne Clifford's Diary, Harrison's Description of England in Shakspere's Youth, and the Verney Memoirs (B.3, 42, 43); notes on Donne and Shakespeare (B.14-16, 40); notes on criticism of the Elizabethan period (B.9); and notes on a variety of Elizabethan plays and playwrights. Woolf's decision to divide "Some Elizabethans" into two essays, the second one specifically on the plays, came sometime between the first drafts for the essay, which are found in a manuscript dated January 7, 1924 (Reviews, 1924. In [Mrs. Dalloway. Fragments.] Berg), and the mention of her article on September 4, 1924. Drafts of the essays after they were separated are found in another manuscript, dated November 22, 1924 (Reviews, 1924. In [Mrs. Dalloway (corrections)]. Berg). "Notes on an Elizabethan Play" was first published in the TLS, March 5, 1925 (Kp. C259).

A second set of entries places this volume in 1924-the notes Woolf made for reviews published in the Nation \& Athenaeum be- 
tween May and July 1924: "Mr. Benson's Memories" (B.7), May 10, 1924 (Kp. C246.3); a review of Robert Smith Surtees (B.8), June 21, 1924 (Kp. C246.6); and "Stendhal," a review that includes his Journal (B.1), July 5, 1924 (Kp. C249).

A third set of notes illustrates Woolf's reactions as a "contemporary." At some point after the publication of "How it Strikes a Contemporary" in April 1923 (Kp. C231), Woolf began to collect examples of the "Contrary blasts of praise and blame" that characterize contemporary criticism $(C R, 295)$. With the exception of the Pound quotation (B.6), all of the examples recorded in this volume (B.5, $10-11,13,48)$ were taken from reviews published between October and December 1923. Two of these, B.10 and B.48, appear as footnotes in the revised version of the essay published in The Common Reader. The other contemporary in this notebook, the Reverend Sayce (B.46), provided Woolf with the "George Eliot quotation" listed in the table of contents.

The remaining entries, those on the Greeks, are more difficult to pin down. Woolf had begun talking about her Greek essay, finally called "On Not Knowing Greek," by August 16, 1922 (D, II), and continued to read "the Greeks" for the next two and a half years. Unlike the Elizabethans, in whom she delighted, she often needed "some compulsion" to read "for the Greek chapter" ( $D$, II, July 28, 1923). On November 3, 1923, however, the statement "I must read Sophocles," continues, "After 20 years, I now know how to read Greek quick (with a crib in one hand) \& with pleasure" ( $D$, II; see B.44, 49-54). On November 16, she was reading Euripides (B.45, 47), and on February 23, 1924, The Birds (B.35; D, II). The latter work was read in part to compare Greek comedy to Ben Jonson's plays (B.29-34): "It seems to me that this is the thing thats missing to make Greek literature complete-laughter. But its very sharp delicate laughter, after the English" (B.35). The notes on Racine's Phèdre (B.41) may have had their origin in Woolf's comment in 1922 that she wanted to read Racine to compare with Sophocles (D, II, August 28).

The table of contents pasted on the front cover was clearly made after the entries and indicates the difficulties in dating Woolf's notes. Not only does her index contain unnumbered items, but the entries themselves are no longer in the order Woolf gave to them when she collected and numbered them; moreover, many unlisted entries have been included in the notebook as it now exists. The table of contents is written in black ink, faded. Woolf's page numbers are in pencil; the entries are in purple ink. 
A. Table of Contents

1. Page

1 Greene. Friar Bacon \& Friar Bungay

2. Jonson. The Alchemist

3 " Sad Shepherd

4 " Volpone

6 " The Silent Woman

7 Ezra Pound, quotation from.

8. Bartholomew Fair. Jonson Bartholomew Fair

9. Aristophanes The Birds.

10. Beaumont \& Fletcher. The Maids Tragedy.

12 "The Faithful Shepherdess.

13 Donne. Elegies.

14 Gosse. on the Trefoil. quotation

15 Harrison, Jane. Ancient Art \& Ritual.

16 Clifford, Lady A. Diary of.

18 Saintsbury. Hist of Elizabethan Literature.

20 Harrison's description of England.

24 Verney Memoirs.

25 Sophocles. Philoctites. in French

26 Euripides. The Bacchae. in Greek

28 Sayce. G. Eliot quotation.

32 Macaulay, R., Eliot, Bennett. Quotations.

33 Specimen passages. Sophocles.

34 Sophocles. Antigone in French

Oedipus Colonus

Oedipus Rex

Trachiniae. Ajax

Dekker (Witch of Ed.)

Old Fortunatus

Ford Tis Pity

The Broken Heart

Dekker

The Wonderful Year.

1 p., on cover.

B. ENTRIES

1. "Stendhal./Journal.": 3 pp., numbered $1-3$ by NYPL. The entry includes notes on the "Introduction" by Henri Debraye. 
Stendhal. Journal. Ed. Henri Debraye \& Louis Royer. Vol. I.

Paris: Champion, 1923.

2. "A Diary of a Country Parson/James Woodforde. -17581781.": 1 p., numbered 4 by NYPL. More notes on this work appear in XV, B.3.

Woodforde, James. The Diary of a Country Parson. Ed. John

Beresford. Vol. I. 1758-1781. Oxford Univ. Press, 1924.

3. "The Diary of Lady Anne Clifford.": 2 pp., numbered 5-6 by NYPL; numbered $16-17$ by VW.

Clifford, Lady Anne. Diary. With an Intro. by V. SackvilleWest. Heinemann, 1923.

4. "Ancient Art \& Ritual. Harrison": 1 p., numbered 7 by NYPL; numbered 15 by VW. 4 lines only, reading, "75. Tragedies of A. S. \& E. were played in early April. Tragedy originated with the leaders of the dithyramb. wh. was a spring ritual. The dithyramb is a spring song at a spring festival."

Harrison, Jane E. Ancient Art and Ritual. Butterworth, 1918.

5. "The Trefoil ... is a book of very great/beauty \& permanent value. Ed. Gosse.": 1 p., numbered 8 by NYPL; numbered 14 by VW. (Heading only.) The line is a quotation from Gosse's review of Benson's book. This quotation also appears as B.13, below.

Gosse, Edmund. Rev. of The Trefoil, by Arthur Christopher

Benson. Sunday Times, December 2, 1923, p. 8.

6. "The Little Review. Ezra Pound.": 1 p., numbered 9 by NYPL; numbered 7 by VW. The entry consists of a quotation from an article by Pound about Henry James, beginning, "The Times Literary Supplement had got so groggy that something had to be done."

Pound, Ezra. "In Explanation." Little Review 5, no. 4 (August 1918): 5. Henry James number.

7. "Memories \& Friends./AC Benson. 16/n/Murray": 1 p., numbered 10 by NYPL.

Benson, Arthur C. Memories and Friends. Murray, 1924.

8. "Robert Smith Surtees/by Himself \& Ed Cuming:": 1 p., numbered 11 by NYPL.

Surtees, Robert Smith, and Cuming, E. D. Robert Smith Surtees. Edinburgh: Blackwood, 1924. 
9. "Hist of Elizabethan Lit. Saintsbury.": 5 pp., numbered 12-16 by NYPL; numbered 18-19, 21-23 by VW.

Saintsbury, George. A History of Elizabethan Literature. Macmillan, 1887.

10. "Told by an Idiot. by Rose Macaulay.": 1 p., numbered 17 by NYPL; numbered 32 by VW. Quotation, annotated "Oct $31^{\text {st }}$ (2) Sylvia Lynd. Daily News," beginning, "'It should be read as the Tempest should be read, \& as Gullivers Travels shd. be read, ...",

Lynd, Sylvia. "Miss Macaulay's Masterpiece." Rev. of Told by an Idiot, by Rose Macaulay. Daily News, November 1, 1923 , p. 7.

11. "This novel (Riceyman Steps) carries with it an/assurance of immortality.": 1 p., numbered 17 by NYPL; numbered 32 by VW. Quotation, annotated "N.G.R.S. /Nov. $3^{\text {rd/The Weekly }}$ Westminster."

N.G.R.S. "Metropolitans." Rev. of Told by an Idiot, by Rose Macaulay, and Riceyman Steps, by Arnold Bennett. Weekly Westminster, November 3, 1923, pp. 28, 30.

12. "The Electric Magneto Torch.": 1 p., numbered 17 by NYPL; numbered 32 by VW. Information from an advertisement.

13. "The trefoil is a book of very great beauty \&/permanent value. Ed. Gosse/of AC Benson's Trefoil": 1 p., numbered 17 by NYPL; numbered 32 by VW. (Heading only.) The quotation is from Gosse's review of Benson's book. See above, B.5.

Gosse, Edmund. Rev. of The Trefoil, by Arthur Christopher Benson. Sunday Times, December 2, 1923, p. 8.

14. “Donne./Grierson.": 2 pp., numbered $18-19$ by NYPL. (P. 19, 2 lines only.) The entry consists of notes from Grierson's "Introduction" and "Commentary"; notes on Donne's poems appear below, B.40.

Grierson, Herbert J. C. Introduction and Commentary. Vol. II of The Poems of John Donne. Oxford: Clarendon Press, 1912.

15. "Twelfth Night": 1 p., numbered 20 by NYPL.

Shakespeare, William. Twelfth Night: or, What You Will. 
16. "These plays, after all, are comedies of intrigue; . . ": 1 p., numbered 20 by NYPL. Marginal notation, "Raleigh/S re 136."

Raleigh, Walter. Shakespeare. Macmillan, 1907.

17. "The Two Noble Kinsmen. Beaumont \&/Fletcher": 2 pp., numbered $21-22$ by NYPL. The entry includes the note, "(Father says cf. Cym. II. 3,)," which suggests she was reading her father's edition of the plays, The Works of Beaumont and Fletcher, ed. George Darlay (1839/1840). See Holleyman \& Treacher, V/s, I, 4.

Beaumont, Francis, and Fletcher, John. The Two Noble Kinsmen.

18. "Webster/The Duchess of Malf.": 3 pp., numbered 23-25 by NYPL.

Webster, John. The Duchess of Malfi.

19. "Tis Pity. Ford": 1 p., numbered 26 by NYPL. The entry includes notes such as, "On the psychology of the characters," which are references to Ellis's "Introduction" to the play. More notes on this play appear below, B.23.

Ford, John. 'Tis a Pity She's a Whore. In John Ford. Ed. Havelock Ellis. Vizetelly, 1888. Mermaid Series.

20. "The White Devil. Webster.": 3 pp., numbered 27-29 by NYPL. A note at the bottom of p. 27 reads, "(The play is not divided into acts)," which suggests Woolf may have been using her father's copy of The Works of John Webster, ed. Alexander Dyce (1871). See Holleyman \& Treacher, $\mathrm{V} / \mathrm{s}, \mathrm{I}, 32$. More notes on this play appear in XXV, B.2.

Webster, John. The White Devil.

21. "Misanthrope. Moliere.": 1 p., numbered 30 by NYPL. The entry consists largely of general notes, beginning, "Reading Misanthrope after Webster, the extreme simplicity of the plot impresses me. All the large emotions hang on very slight movements. In Webster there are too many trees."

Molière, Jean Baptiste de. Le Misanthrope.

22. "Notes for Some Elizabethans \& Montaigne": 1 p., numbered 31 by NYPL. The entry consists of notes for an essay on the Elizabethans, beginning, "First: love of hyperbole \& splendour, combined with laughter," which are the basis of 
"The Elizabethan Lumber Room" and "Notes on an Elizabethan Play."

23. "Ford. The Bre/Tis Pity she's a Whore.": 2 pp., numbered 32-33 by NYPL. More notes on this play appear above, B.19.

Ford, John. 'Tis a Pity She's a Whore. In John Ford. Ed. Havelock Ellis. Vizetelly, 1888. Mermaid Series.

24. "Kyd. The Spanish Tragedy": 2 pp., numbered 34-35 by NYPL. P. 35 is numbered 2 by VW. The entry begins with the heading, "The Plot," and includes notes on Schick's "Preface" to the play. More notes on this play appear in XXV, B.6.

Kyd, Thomas. The Spanish Tragedy. Ed. J. Schick. Dent, 1898.

25. "Old Fortunatus. Dekker.": 1 p., numbered 36 by NYPL.

Dekker, Thomas. Old Fortunatus. In Thomas Dekker. Ed. Ernest Rhys. Vizetelly, 1887. Mermaid Series.

26. "Dekker. Witch of Edmonton": 2 pp., numbered 37-38 by NYPL. The entry, which includes a reference to "Ernest Rhys. Mermaid Series," begins, "This is odd, because its apparently about real people, of the lower classes, \& at the present time-all unlikely in $E^{\text {than }}$ drama."

Dekker, Thomas. The Witch of Edmonton. In Thomas Dekker.

Ed. Ernest Rhys. Vizetelly, 1887. Mermaid Series.

27. "Ford./The Broken Heart.": 2 pp., numbered 39-40 by NYPL. The entry includes references to Ellis's "Introduction" to the play.

Ford, John. The Broken Heart. In John Ford. Ed. Havelock Ellis. Vizetelly, 1888. Mermaid Series.

28. "Greene/Friar Bacon \& Friar Bungay.": 1 p., numbered 41 by NYPL; numbered 1 by VW.

Greene, Robert. Friar Bacon and Friar Bungay.

29. "The Alchemist Ben Jonson": 1 p., numbered 42 by NYPL; numbered 2 by VW. The entry begins, "The difficulty of BJ. is his hard intellectual wit, his restless chops and changes."

Jonson, Ben. The Alchemist. 
30. "Ben Jonson. The Sad Shepherd": 1 p., numbered 43 by NYPL; numbered 3 by VW. The entry ends with a reference to "Gregory Smith./B.J./206." See below, B.31.

Jonson, Ben. The Sad Shepherd; or, A Tale of Robin Hood.

31. "a romantic play, which was a xxx what Jonson/had set out to destroy.": 1 p., numbered 43 by NYPL; numbered 3 by VW. Marginal notation, "Gregory Smith/B.J./206." The play is The Sad Shepherd. See above, B.30. Other notes on this work appear below, B.32 and B.34.

Smith, G. Gregory. Ben Jonson. Macmillan, 1919.

32. "Volpone. Ben Jonson": 2 pp., numbered 44-45 by NYPL; numbered $4-5$ by VW. The entry ends with a reference to "Smith/109": G. Gregory Smith's Ben Jonson. See above, B.31.

Jonson, Ben. Volpone; or, The Fox.

33. "The Silent Woman. Ben Jonson.": 1 p., numbered 46 by NYPL; numbered 6 by VW.

Jonson, Ben. Epicoene; or, The Silent Woman.

34. "Bartholomew Fair Jonson.": 2 pp., numbered 47-48 by NYPL. P. 47 is also numbered 8 by VW. The entry includes the note, "Tremendous volubility \& power of vituperation," with the marginal notation, "Page in/big edition/ 328." The entry ends with references to "Smith/118," and "Smith/117": G. Gregory Smith's Ben Jonson. See above, B.31.

Jonson, Ben. Bartholomew Fayre.

35. "Aristophanes The Birds": 1 p., numbered 49 by NYPL; numbered 9 by VW. The entry includes the note, "Translated by Rogers," and notes on Rogers' "Introduction" to the play. Woolf could have been using either of the editions listed below.

Aristophanes. The Birds. Trans. Benjamin Bickley Rogers. Bell, 1920.

or, The Comedies of Aristophanes. The Greek Text, revised and translated ... by Benjamin Bickley Rogers. Vol. III. Bell, 1913.

36. "Ford. The Lover's Melancholy": 2 pp., numbered $50-51$ by NYPL. (P. 51, 2 lines only.) 
Ford, John. The Lover's Melancholy. In John Ford. Ed. Havelock Ellis. Vizetelly, 1888. Mermaid Series.

37. "Beaumont \& Fletcher./The Maids Tragedy.": 2 pp., numbered $52-53$ by NYPL; numbered $10-11$ by VW.

Beaumont, Francis, and Fletcher, John. The Maid's Tragedy.

38. "The Faithful Shepherdess.": 1 p., numbered 54 by NYPL; numbered 12 by VW. General notes, beginning, "This seems to me much emptier \& less moving than The Maids Tragedy. He is a limpid musical writer, who keeps it up well, but is not stirring."

Fletcher, John. The Faithful Shepherdess.

39. "Dekker. The Wonderful/Year.": 1 p., numbered 55 by NYPL. 4 lines only, reading, "The question about $\mathrm{E}^{\text {than }}$ prose is the rhythm. The sentence must be very long. 38 Thus obviously it lends itself to accumulation-\& solemnities. repetitions: ornamental. description:"

Dekker, Thomas. The Wonderful Yeare. [1603].

40. "Donne": 7 pp., numbered 56-62 by NYPL. P. 56 is numbered 13 by VW. More notes on this work appear above, B.14.

Donne, John. Poems. Ed. Herbert J. C. Grierson. 2 vols. Oxford: Clarendon Press, 1912.

41. "Phedre Racine": 2 pp., numbered 63-64 by NYPL. Woolf was reading a French edition of the work.

Racine, Jean. Phèdre.

42. "Harrisons description of England": 1 p., numbered 65 by NYPL; numbered 20 by VW.

Harrison, William. Description of England in Shakspere's Youth. Ed. Frederick J. Furnivall. Vol. I [of II]. New Shakspere Society, 1877.

43. "The Verney Memoirs:": 1 p., numbered 66 by NYPL; numbered 24 by VW.

Verney, Frances Partenope, and Verney, Margaret M., eds. Memoirs of the Verney Family During the Seventeenth Century. Vol. I [of II]. Longmans, Green, 1904.

44. "Philoctetes (in French).": 1 p., numbered 67 by NYPL; numbered 25 by VW. 
Sophocles. Philoktetes. In Sophocle. Trans. Leconte de Lisle. Paris: Alphonse Lemerre, n.d.

45. "The Baccae./In Greek.": 2 pp., numbered 68-69 by NYPL; numbered $26-27$ by VW. The entry includes unidentified notes about Euripides' life and work; the edition of the play is unspecified. More notes on this play appear below, B.47.

Euripides. The Bacchae.

46. "Sayce.": 1 p., numbered 70 by NYPL; numbered 28 by VW. The entry includes a passage, annotated " 181 ," that reads, "Trubner told me afterwards that it (GE's [George Eliot's] marriage to $\mathbf{M}^{\mathrm{r}}$. Cross) was due to certain letters wh. she had discovered in one of the drawers of Lewes' writing desk, \& wh. caused an entire revulsion of feeling."

Sayce, A. H. Reminiscences. Macmillan, 1923.

47. "Bacchae.": 3 pp., numbered 71-73 by NYPL; numbered 29-31 by VW. P. 73 is headed "The Bacchae/(Tyrrell)," and consists of two lines of notes on Tyrrell's "Introduction." The entry begins with the general note: "My thought is that Euripides had the beginnings of the subjective mind in him-was mystical, \& fond of metaphors. Now metaphors are necessary directly you deal with thought. Sophocles deals with action." More notes on this play appear above, B.45.

Euripides. The Bacchae. Ed. Robert Yelverton Tyrrell. Macmillan, 1892.

48. "For the rest one can only say that if $/ \mathrm{M}^{\mathrm{r}}$ Eliot had been pleased to write in/demotic English ...": 1 p., numbered 74 by NYPL. The entry consists of a quotation, annotated "C.P./M.G. Oct. 31 st 1923." The remainder of the first sentence reads, "The Waste Land' might not have been, as it just is to all but anthropologists, \& literati, so much waste paper."

C. P. Rev. of The Wasteland, by T. S. Eliot. Manchester Guardian, October 31, 1923, p. 7.

49. "Specimen passages.": 1 p., numbered 75 by NYPL; numbered 33 by VW. The entry consists of three passages from Sophocles' plays, annotated "Sophocles. Ajax," "670," “(Jebb)"; "O.C./670"; and "780 Antigone." The numbers are line numbers. 
Sophocles. The Tragedies. Trans. Sir Richard C. Jebb. Cambridge: Cambridge Univ. Press, 1904.

or, The Ajax. The Oedipus Coloneus. The Antigone. With critical Notes, Commentary, and Translation in English Prose by R. C. Jebb. Cambridge: Cambridge Univ. Press, 1896, 1885, 1888. Vols. VII, II, and III of The Plays and Fragments.

50. "Antigone/(in French)": 1 p., numbered 76 by NYPL; numbered 34 by VW.

Sophocles. Antigone. In Sophocle. Trans. Leconte de Lisle.

Paris: Alphonse Lemerre, n.d.

51. "Oedipus Coloneus/(in French)": 1 p., numbered 77 by NYPL; numbered 35 by VW.

Sophocles. Oidipous a Kolônos. In Sophocle. Trans. Leconte de Lisle. Paris: Alphonse Lemerre, n.d.

52. "Oedipus King": 2 pp., numbered $78-79$ by NYPL; numbered $36-37$ by VW. P. 79 is also numbered 1 by VW, and headed "Sophocles. Oedipus Rex/(French)."

Sophocles. Oidipous-Roi. In Sophocle. Trans. Leconte de Lisle. Paris: Alphonse Lemerre, n.d.

53. "Sophocles./Trachiniae/(in French)": 1 p., numbered 80 by NYPL; numbered 38 by VW.

Sophocles. Les Trakhiniennes. In Sophocle. Trans. Leconte de Lisle. Paris: Alphonse Lemerre, n.d.

54. "Ajax in French.": 1 p., numbered 81 by NYPL; numbered 39 by VW. (3 lines only.)

Sophocles. Aias. In Sophocle. Trans. Leconte de Lisle. Paris: Alphonse Lemerre, n.d.

\section{Holograph Reading Notes. Vol. 20. (Berg)}

The majority of the notes in this volume are related to essays that appeared in The Common Reader: Second Series (1932). With the exception of "The Countess of Pembroke's Arcadia" and "Donne After Three Centuries," however, these essays had already been published previous to their appearance in Woolf's book. It is possible that Woolf made the notes in this volume between February and July 1932 when she was reworking essays for inclusion in The Common 
Reader; but, given the fullness of the entries, it is more likely that these notes were made for the original essays and collected here. Almost all of the entries overlap with entries on the same subject in other volumes.

The notes on Hardy's prefaces and poems (B.1-3, 5) are difficult to date because of their separation from the fuller set of notes on Hardy's novels in Volume XLII. As noted in the introduction to that volume, Woolf started reading and talking about Hardy in 1919, although her article, "Thomas Hardy's Novels," was not published until January 19, 1928 (TLS; Kp. C294). Four and a half years later, on June 29, 1932, she had "just finished Hardy" $(A W D)$ for inclusion in The Common Reader.

The notes on Beau Brummell (B.6-8) and Dorothy Wordsworth (B.9-11) clearly belong to Woolf's original preparation for her articles on these figures: "Beau Brummell," Nation \& Athenaeum, September 28, 1929 (Kp. C315), and "Dorothy Wordsworth," Nation \& Athenaeum, October 12, 1929 (Kp. C317). Both of these were reprinted in October 1929 in the New York Herald Tribune as part of a series on four "figures" from the end of the eighteenth century. Woolf recorded reading "Beau Brummell's life" in February 1929 ( $L$, IV, 1997, 2002), and appears to have read Dorothy Wordsworth's Journals in May 1929. This latter supposition is based on an aside in Woolf's notes on the Journals: "This was written by a gold pen, which I don't think quite as good as my old one" (B.11). On May 2, 1929, Woolf wrote to Clive Bell with "a new lizard-green pen, a slippery sort of pen, golden, laxative, loose-tongued" ( $L$, IV, 2025), and on May 15, she began a diary entry in order to test, and complain of, a new gold pen ( $D$, III). We do know, however, that she wrote the piece on Dorothy Wordsworth during the summer of 1929: "The last [article] was Dorothy Wordsworth, and if the written word could cure rheumatism, I think her's might. ... Have you ever read her diaries, the early ones, with the nightingale singing at Alfoxden [Somerset], and Coleridge coming in swollen eyed-to eat a mutton chop? ... I like them very much; but I cant say I enjoy writing about them, nine pages close pressed. How can one get it all in?" ( $L, I V$, 2057). All four articles were "finished" by August 19. More notes on Brummell are found in Volume IX, which also contains notes for "Cowper and Lady Austen" and "Mary Wollstonecraft" - the other two articles in this series.

The biographies of Donne (B.12) and Sidney (B.14-15) belong to the Elizabethan articles written "to front [her] new Common Reader" $(A W D$; November 16,1931$)$ and overlap with similar entries in 
Volume XI. Woolf had begun, with great excitement, to read Elizabethans at the end of 1929 ( $D$, III, December 8, 10, 26), while "vaguely thinking of some studies of Elizabethan characters" ( $L, \mathrm{IV}$, 2117). In July 1931, her mind was "leading [her] away from contemporary life in the direction of the Elizabethans" ( $L, I V, 2399)$, and on August 10, she should have been reading "all Donne, all Sidney, all ... Lord Brooke [Fulke Greville]" ( $L$, IV, 2419). In early December 1931, she hoped to visit Penshurst, Sidney's home-a desire not fulfilled until June 1940; by the end of the month, she was "going to write about Sidney, and cant get back into the mood" ( $L$, IV, 2477, 2497). According to her diary, she was composing "two long Elizabethan articles"-presumably including "The Countess of Pembroke's Arcadia" "-in November, 1931 ( $A W D$, November 16), although she appears not to have finished them until the beginning of next year. "Donne After Three Centuries" was written in February $1932(L, \mathrm{~V}$, 2522, 2523; $A W D$, February 8, 16).

For the rest, the notes on Birrell's Et Cetera (B.13) almost certainly belong with the entries on Birrell's essays in Volume XIII, B.19, which were made in preparation for her essay on "Augustine Birrell," Yale Review, June 1930 (Kp. 323; see L, IV, 2051; D, III, November $18,1929)$. The biography of Montaigne noted in B.4 may be connected with her visit to his tower-the Chateau de Montaigne-in April 1931 (see, e.g., L, IV, 2360). Finally, the notes on "(Hazlitt)," listed in the table of contents (A.2) but missing from the actual entries, can be read in Volume XXII. Woolf was reading Hazlitt throughout 1930 for her essay, "Wm. Hazlitt the Man," published in September 1930 (Kp. C325), and reprinted in The Common Reader.

The two tables of contents are written in black ink, "(Hazlitt)" only appearing in pencil. The entries are in various shades of Woolf's purple ink-some more blue, some more black-with an occasional note in black ink.

\section{A. Table of Contents}

1. Brummell

Dorothy Wordsworth

Life of Donne. Gosse

Philip Sidney. Addleshaw

Philip Sidney. Greville

1 p., on cover. 
2. Life of Donne.

(Hazlitt)

Life of Sir. P. Sidney. Addleshaw.

Greville's Life of Sidney

1 p., numbered 1 by NYPL.

B. ENTRIES

1. "As some of these novels of Wessex Life ...": 1 p., numbered 2 by NYPL. Quotation, annotated "Preface to A Laodician."

Hardy, Thomas. "Preface." A Laodician. [1891].

2. "Let me repeat that a novel is an impression,/not an argument; \& there the matter must rest; . . . /Preface to Tess": 1 p., numbered 2 by NYPL. (Heading only.) More notes on the novel and the "Preface" appear in XLII, B.11.

Hardy, Thomas. "Preface." Tess of the D'Urbervilles. [1892].

3. "Unadjusted impressions have their value ...": 1 p., numbered 2 by NYPL. The entry includes a quotation, annotated "Preface to Poems Past and Present. (75)," and notes on two poems, "Night in the Old Home" and "A Wet Night," from Time's Laughingstocks and Other Verses.

Hardy, Thomas. Collected Poems. Macmillan, 1919.

4. "At the age of $38 \mathrm{M}$. retired ...": $2 \mathrm{pp}$., numbered 3-4 by NYPL; numbered $2-3$ by VW. The entry is also headed "Life. Montaigne." More notes on this work appear in XXVI, B.23, on a page numbered 1 by VW.

Bonnefon, Paul. Montaigne. L'Homme et l'oeuvre. Bordeaux: Gounouilhou, 1893.

5. "Desparate Remedies. Hardy": 1 p., numbered 5 by NYPL. More notes on this novel appear in XLII, B.9 and B.12.

Hardy, Thomas. Desparate Remedies. New ed. Macmillan, 1903. Vol. VII of The Wessex Novels.

6. "Brummell.": $13 \mathrm{pp}$., numbered 6-18 by NYPL. The entry includes references to the "Memoir of Crabbe," "Moores Life of Sheridan," and the "Life of Byron. Moore," all of which are mentioned in Jesse's book.

Jesse, Captain [William]. The Life of George Brummell, Esq. 2 vols. Nimmo, 1886. 
7. "Hariette Wilson.": 1 p., numbered 18 by NYPL. The entry begins with a list of page references for Beau Brummell in Wilson's Memoirs.

Wilson, Harriet. Memoirs of Herself and Others. Ed. James Laver. Peter Davies, 1929.

8. "The fact then after his retirement no one brought out his peculiar qualities.": 1 p., numbered 19 by NYPL. General notes for Woolf's essay on Beau Brummell. See above, B.6-7.

9. "Dorothy Wordsworth": 7 pp., numbered 20-26 by NYPL. The entry ends with the comment, "M. Woll [Mary Wollstonecraft] branches out to reform the world D $\mathrm{W}^{\text {th }}$ here \& now; the thing before one. Eno' to realise it." More notes on this work appear below, B.11.

Wordsworth, Dorothy. Journals. Ed. William Knight. 2 vols. Macmillan, 1897.

10. "Lee. D.Wth": 1 p., numbered 27 by NYPL. The notes are on De Quincey's description of Dorothy Wordsworth in his Recollections of the Lakes and Lake Poets.

Lee, Edmund. Dorothy Wordsworth. The Story of a Sister's Love. James Clarke, 1886.

11. "D. Wordsworth": 2 pp., numbered $28-29$ by NYPL. More notes on the Journals appear above, B.9.

Wordsworth, Dorothy. Journals. Ed. William Knight. Vol. II [of II]. Macmillan, 1897.

12. "Life of Donne/Gosse": 3 pp., numbered 30-32 by NYPL. Other notes on this work appear in XI, B.4, and in LVIII, B.6.

Gosse, Edmund. The Life and Letters of John Donne. 2 vols. Heinemann, 1899.

13. "Birrell/Et Cetera": 1 p., numbered 33 by NYPL. More notes on this work appear in XIII, B.19.

Birrell, Augustine. Et Cetera. Chatto \& Windus, 1930.

14. "Sir Philip Sidney/Life of by Addleshaw": 4 pp., numbered 34-37 by NYPL.

Addleshaw, Percy. Sir Philip Sidney. Methuen, 1909. 
15. "Greville's Sidney": 3 pp., numbered $38-40$ by NYPL. The entry includes several general observations about Elizabethan prose.

Greville, Sir Fulke. Life of Sir Philip Sidney. Ed. Nowell Smith. Oxford: Clarendon Press, 1907.

\section{Holograph Reading Notes. Vol. 21. (Berg)}

Although difficult to pin down, the notes in this volume almost certainly belong to Woolf's reading and writing from the end of 1939 through 1940. Woolf recorded that she was reading Freud and "Freud on Groups"-i.e., Group Psychology and the Analysis of the Ego (B.3) - on December 2 and 18, 1939 ( $A W D$ ), but she was also reading Freud on February 9, 1940. Two days later, on February 11, she outlined her ideas for her lecture on "The Leaning Tower" school of poets: "The idea struck me that the Leaning Tower school is the school of auto-analysis after the suppression of the 19th century. ... Also I got the idea of cerebration" $(A W D)$. "Cerebration" is included in the list that constitutes the first entry in this volume, a list that may be connected with ideas for her writing during this period. "The Leaning Tower," for example, was given as a lecture in May 1940, revised in August, and published in the Autumn 1940 issue of Folios of New Writing, edited by John Lehmann (Kp. C372). Another item on this list, "Jack Hills," refers to the husband of Woolf's halfsister, Stella Duckworth; Woolf was writing about him in her memoir, "A Sketch of the Past," in June 1940 (Moments of Being [1976]). Other items on this list-"Shakespeare," "Spenser," and "Country books"-may well be related to Woolf's ideas for "Anon," the first chapter of her history of English literature begun in September 1940. (For the history of this work, see the introductions to Volumes XVI and XXXVII.) The ideas recorded in the notes on Harrison's Description of England in Shakspere's Youth in this volume (B.6) are similar to those in the early outlines for her history book, dated "18th Sept. $1940 "$ ("Notes for Reading at Random," $A \& R$ ), as well as in "Anon" itself. Finally, the notes on women and war in B.4 belong to her early thinking for her essay, "Thoughts on Peace in an Air Raid," New Republic, October 21, 1940 (Kp. C369). Woolf had begun to formulate her ideas by mid-December 1939 and shared them in letters to Shena, Lady Simon, dated December 16, 1939 and January 
22, 1940 ( $L, \mathrm{VI}, 3574,3580)$. For more notes on this subject, see Volumes XXXVI, XXXVII, B.3., and XXXIX, B.3. All the notes in this volume are in black ink.

B. ENTRIES

1. "M \& T./Telegraphese:/The desire of every writer not to/be a writer": 1 p., numbered 1 by NYPL. The entry consists of a list of phrases and authors. See the introduction to this volume for more details. The list in full reads:

$M$ \& $T$.

Telegraphese:

The desire of every writer not to be a writer

Cerebration:

Eyelessness.

Shakespeare.

Spenser.

Country books.

[?Connannt] Jack Hills

Royalty

2. "The point of view of any individual/is bound to be not a birds eye/view but an insects eye view, ...": 1 p., numbered 2 by NYPL. 7 lines only, continuing, "the view of an insect too on a green blade, which oscillates violently with local gusts of wind." The entry consists of notes that are related to her reading of Freud, B.3 below.

3. "Freud. Group Psy. \& the/Ego.": 2 pp., numbered 3-4 by NYPL. See above, B.2, and below, B.4.

Freud, Sigmund. Group Psychology and the Analysis of the Ego. Trans. James Strachey. International Psycho-Analytic Press, 1922; 2nd ed., Hogarth Press, 1940.

4. "Notes. that the herdsman has/given the herd money when he/opened the professions.": 3 pp., numbered 4-6 by NYPL. Notes on women in relation to war and society. The references to the "herdsman" and "the herd" may come from Freud's Group Psychology and the Analysis of the Ego, one chapter of which is entitled "The Herd Instinct"; see above, B.3. The entry includes a passage that reads, "For now the male has also [...] his attributes in Hitler, \& is fighting 
against them. Is this the first time a sex has turned against its own specific qualities? Compare with the woman movement."

5. "So crowded/were they/with new/experiences . . .": 1 p., numbered 7 by NYPL. The entry consists of notes that may well be connected with those on Harrison's Description of England in Shakspere's Youth, B.6 below.

6. "Harrison": 1 p., numbered 8 by NYPL. More notes on this work from this period appear in XXXVII, B.3.

Harrison, William. Description of England in Shakspere's Youth. Ed. Frederick J. Furnivall. Vol. I [of II]. New Shakspere Society, 1877.

\section{Holograph Reading Notes. Vol. 22. (Berg)}

The faded names on the cover of this notebook, "Hazlitt" and "Christina Rossetti," describe the contents-notes that Woolf made for her essays, "Wm. Hazlitt the Man" and "I am Christina Rossetti," both written in 1930 and then included in The Common Reader: Second Series. Woolf worked on her Hazlitt essay for nine months. On September 8, 1930, as she "[drove] a paper fastener through the 14 pages" of her essay, she lamented the hard work and amount of time given to it: "I began reading Hazlitt in January I think. And I am not sure that I have speared that little eel in the middle-that marrow-which is one's object in criticism" ( $D$, III; see also April 29, May 18, August 25, 1931; and L, IV, 2179, 2201, 2224). The one mention of reading Hazlitt occurs in a letter dated May 13, 1930 (2179). The essay was published in the New York Herald Tribune, September 7, 1930, and, in a revised version, in the $T L S$, September 18, 1930 (Kp. C325). Although Woolf's article was a review of a new edition of Hazlitt's works, edited by P. P. Howe, only one volume of this edition-dated 1932 and therefore read after the original essay was published-appears below.

"My brain is too energetic," Woolf complained on October 15, 1930; "it works; it throws off an article on Christina Rossetti ..." (D, III). This article, a review of two biographies including the Sandars' one noted in this volume (B.18), was published first in the Nation \& Athenaeum, December 6, 1930 (Kp. C328). On December 12, she responded to Ottoline Morrell's praise of the piece, "I was impressed 
by Christina-but what nonsense these lives of her are!" ( $L$, IV, 2285). Later, while putting the final touches on The Common Reader: Second Series, Woolf noted that she "should now attack Ch. Rossetti" ( $A W D$, June 29, 1932).

The two names on the cover (A.1) are in black ink; the list of contents on the first page (A.2) is blue; the list of Hazlitt's works (B.1) is blue-black; and the remainder of the notes, except those on the last two pages which are black, are blue-purple.

\section{A. Table of Contents}

1. Hazlitt

Christina Rossetti

$1 \mathrm{p}$. , on cover.

2. Life of Hazlitt.

Hazlitt. Literary Remains (Talfourd)

Liber Amoris

The Round Table

English Poets

Table Talk

Patmore on Hazlitt

Travels \& Picture Galleries

Life of C. Rosetti: Sandars.

1 p., numbered 1 by NYPL.

B. ENTRIES

1. "List of Books.": 1 p., numbered 2 by NYPL. The entry consists of a list of Hazlitt's works.

2. "Hazlitt. Life./(1867)": 6 pp., numbered 3-8 by NYPL.

Hazlitt, W. Carew. Memoirs of William Hazlitt. 2 vols. Bentley, 1867.

3. "The Hazlitts. vol. 1": 1 p., numbered 9 by NYPL.

Hazlitt, W. Carew. The Hazlitts. Edinburgh: Ballantyne, Hanson, 1911.

4. "Lit. Remains./(Lytton \& Talfourd)": 1 p., numbered 10 by NYPL. The notes are on the introductory material by E. L. Bulwer and Sergeant Talfourd.

Bulwer, E. L. "Some Thoughts on the Genius of William Hazlitt." Talfourd, Sergeant. "Some Thoughts upon the 
late William Hazlitt." In Literary Remains of the Late William Hazlitt. Vol. I. Saunders \& Otley, 1836.

5. "Liber Amoris": 1 p., numbered 11 by NYPL. The entry includes notes on the "Introduction" and on the Liber Amoris, followed by a reference to Mrs. Hazlitt's "Journal of my Trip to Scotland," which is also included in this volume. The entry ends with a note about Mrs. Hazlitt from the $D N B$ entry on William Hazlitt.

a) Hazlitt, William. Liber Amoris or the New Pygmalion. With an Intro. by Richard le Gallienne. Privately printed, 1894.

b) Stephen, Leslie. "Hazlitt, William." $D N B$ (1891).

6. "The Round Table": 3 pp., numbered 12-14 by NYPL.

Hazlitt, William. The Round Table. Sampson Low \& Marston, 1869.

7. "English Poets.": 2 pp., numbered $15-16$ by NYPL.

Hazlitt, William. Lectures on the English Poets. Taylor \& Hessey, 1818.

8. "Table Talk.": 3 pp., numbered 17-19 by NYPL. More notes on this work appear below, B.10 and B.16.

Hazlitt, William. Table Talk. Original Essays on Men and Manners. 3rd ed. Ed. by his son. 2 vols. Templeman, 18451846.

9. " $[\ldots]$. When you come to know the world half so well as I do, . . ": 1 p., numbered 20 by NYPL. The entry begins with a cancelled quotation, annotated "Diary 1-116," and continues under the heading, "Conversations of Northcote."

Hazlitt, William. Conversations of James Northcote, R. A. Ed. Edmund Gosse. Bentley, 1894.

10. "Table Talk.": 1 p., numbered 21 by NYPL. More notes on this work appear above, B.8, and below, B.16.

Hazlitt, William. Table Talk. Original Essays on Men and Manners. 3rd ed. Ed. by his son. Vol. II [of II]. Templeman, 1846.

11. "Patmore.": 3 pp., numbered 22-24 by NYPL.

Patmore, P. G. "William Hazlitt." In My Friends and Acquaintance. Vols. II-III. Saunders \& Otley, 1854. 
12. "Plain Speaker": 2 pp., numbered $25-26$ by NYPL.

Hazlitt, William. The Plain Speaker. Opinions on Books, Men, and Things. Vol. I [of II]. Colburn, 1826.

13. "But if $\mathrm{H}$. is not a perfect essayist he is a/very queer combination.": 1 p., numbered 27 by NYPL. General notes for Woolf's essay, "Wm. Hazlitt the Man."

14. "Picture Galleries \& Travels.": 1 p., numbered 28 by NYPL.

Hazlitt, William. Sketches of the Principle Picture Galleries in England and Notes of a Journey Through France and Italy. Ed. P. P. Howe. Dent, 1932. Vol. X of The Complete Works.

15. "Notes. Hazlitt.": 1 p., numbered 29 by NYPL. General notes on Hazlitt, with references to the "Plain speaker." See above, B.12.

16. "TT. 1": 1 p., numbered 30 by NYPL. More notes on this work appear above, B.8 and B.10.

Hazlitt, William. Table Talk. Original Essays on Men and Manners. 3rd ed. Ed. by his son. Vol. I [of II]. Templeman, 1845.

17. "The Fight.": 1 p., numbered 31 by NYPL.

Hazlitt, William. "The Fight" and "On Reading Old Books." In Selected Essays. Ed. George Sampson. Cambridge: Cambridge Univ. Press, 1917.

18. "Life of Christina Rossetti/Sandars.": 4 pp., numbered 32-35 by NYPL.

Sandars, Mary F. The Life of Christina Rossetti. Hutchinson, 1930.

19. "C. Rossetti. Poems": 3 pp., numbered $36-38$ by NYPL. P. 36 includes a quotation about Rossetti's prosody, annotated "(Saintsbury)," which begins, "The metre of the principal poem (G.M.) may be best described as dedoggerelised Skeltonic, ..." This passage, from George Saintsbury's History of English Prosody (1910; III, 153), is quoted by Sandars, p. 109. See above, B.18.

Rossetti, Christina Georgina. Poetical Works. With Memoir and Notes etc. by William Michael Rossetti. Macmillan, 1904. 


\section{Holograph Reading Notes. Vol. 23. (Berg)}

Although there is no single unifying element for the entries in this notebook, they can be dated from 1932 to, perhaps, 1934, and related in part to Woolf's preparation for The Pargiters. The Novel-Essay Portion of "The Years." What suggests this connection most clearly is the cancelled item in her table of contents (A.2) - "Life of Joseph Wright" - which Woolf was reading on July 13, 1932 ( $A W D$ ). Joseph Wright became the model for Mr. Gabbit, Sam Hughes, and Mr. Brooke in the novel sections of The Pargiters and appears in his own right in the "Sixth Essay" (see Mitchell A. Leaska's "Introduction" to The Pargiters, pp. xi-xvi). Woolf's original notes on Wright now appear in Volume X, B.1. Woolf began to write her new work on women on October 11, 1932 (Leaska, p. xvii), and by November 2, she had "entirely remodelled my 'Essay.' It is to be an Essay-Novel, called The Pargiters-and it's to take in everything, sex, education, life etc: . . from 1880 to here and now" $(A W D)$. The twenty-three pages of notes on R. H. Gretton's Modern History of the English People 1880-1922 in this volume (B.1) were very likely made as part of her collection of "facts" for her book. Moreover, the "Fifth Essay" of The Pargiters contains a reference to Montaigne's view that "the passion of a woman was by nature stronger than that of a man; but was repressed, very painfully by the rigours of convention" (Pargiters, 109) - a view that could easily have been based on the passages from Montaigne recorded in this notebook (B.2). Woolf alludes to Montaigne in another context in her diary on August 20, 1932, which suggests she was reading him at that time. Finally, the last sentences of The Pargiters read: "This was June 1880. Mr. Gladstone was in power; Mr. Bradlaugh had declined to take the oath; and at the head of the Irish party was a new leader, Charles Stewart Parnell" (Pargiters, 159). Parnell (B.3), then, was on Woolf's mind in December 1932 when she wrote these lines; she records reading about Parnell on January 15, 1933, and, a year and a half later contemplated writing a play on the Parnells or a biography of Mrs. Parnell ( $A W D$, August 21, 1934).

For the rest, the entry on Goldsmith (B.6) probably belongs with those in Volumes LIII and LXVII that were made in preparation for Woolf's essay, "Oliver Goldsmith," TLS, March 1, 1934 (Kp. C342). Woolf was reading Goldsmith in April and May 1933 when she recorded that her desire to write The Pargiters was interferring with her article on Goldsmith ( $A W D$, April 6, 15, May 30, 31, 1933). The 
note on "Colour in Poetry" (B.4) seems to be part of an interest in colour imagery that emerges in other notes around this time as well; see, for example, XLV, B.5 and B.14 (1935), where Woolf talks of "the colour sense" and notes examples of visual imagery in poetry.

Both tables of contents are in black ink, as are most of the notes. The entry on Gretton (B.1) has some blue-gray ink and some pencilled notes, as does B.5.

\section{A. Table of Contents}

1. Modern History. Gretton Parnell

$1 \mathrm{p}$. , on cover.

2. Modern History of the Eng. People-Gretton.

\section{tife of Joseph Wright}

Life of Charles Stewart Parnell

Colour in Poetry: Shakespeare \& Herrick

1 p., not numbered.

\section{B. Entries}

1. "Gretton.": 23 pp., not numbered.

Gretton, R. H. A Modern History of the English People 18801922. Martin Secker, 1930.

2. "Montaigne": 2 pp., not numbered. The second page is headed, "On Some Lines of Virgil." The notes are about women, and include a passage- "After knowing that they are incomparably more capable \& ardent in the sexual act than we ..."-that may have inspired Woolf's reference to Montaigne's view of female sexuality in the "Fifth Essay" of The Pargiters.

Montaigne, Michel de. "On Some Lines of Virgil." In Essays. Trans. E. J. Trechmann. Vol. II. Oxford Univ. Press, 1927.

3. "Parnell": 4 pp., not numbered.

O'Brien, R. Barry. The Life of Charles Stewart Parnell. 2 vols. Smith, Elder, 1898.

4. "Colour in Poetry.": 1 p., not numbered. The entry begins with a quotation annotated "Julius Caesar Act. 2. Sc.1""As dear to me as are the ruddy drops/That visit my sad heart"-and continues with notes on "Herrick." 
5. "Pilgrims Progress": 3 pp., not numbered.

Bunyan, John. The Pilgrim's Progress from This World to That

Which is to Come. Ed. James Blanton Wharey. Oxford:

Clarendon Press, 1928.

6. "Goldsmith. Poems.": 2 pp., not numbered. The entry includes notes on The Traveller and The Deserted Village. For more notes on these poems, see LXVII, B.10-12.

Goldsmith, Oliver. The Traveller; or a Prospect of Society and

The Deserted Village. In The Miscellaneous Works. Ed. James

Prior. Vol. IV. Murray, 1837.

\section{Holograph Reading Notes. Vol. 24. (Berg)}

All of the notes in this volume are for articles published in the New Statesman \& Nation between September 1939 and October 1940: "White's Selborne," September 30, 1939 (Kp. C361); "Gas at Abbotsford," January 27, 1940 (Kp. C364); "The Man at the Gate," a review of Coleridge the Talker, October 19, 1940 (Kp. C368); and "Sara Coleridge," October 26, 1940 (Kp. C370). A letter to Raymond Mortimer, Literary Editor of the New Statesman, on September 7, 1939, notes, "I've an idea or two at the back of my mind for a possible article-perhaps Gilbert White into whom I've plunged by way of a respite, or theres an obscure autobiography that I unearthed at the local library-theres an account of a party at Abbotsford that might be made amusing" ( $L, \mathrm{VI}, 3550)$. In May 1940, Woolf was "reading Coleridge through" in the Pickering edition, as well as "masses of Coleridge and Wordsworth letters" ( $L, \mathrm{VI}, 3608 ; A W D$, May 29). In July, she noted both that her Coleridge was beneath her and that she could not "stop reading Coleridge" ( $A W D$, July 26; $L$, VI, 3620). In September, still "deep in Coleridge," the bombing of her London house made her ask, "How can one settle into Michelet and Coleridge?" ( $L, \mathrm{VI}, 3462 ; A W D$, September 18). Nevertheless, on October 2, she "had a nice gallop this morning with ColeridgeSara" $(A W D)$. More reading notes on father and daughter intermingle with drafts of the two Coleridge essays in MH/B.5b (Sussex).

The ink throughout is black, including Woolf's page numbers. 
B. ENTRIES

1. "Coleridge as/Talker.": 4 pp., numbered $1-4$ by NYPL; numbered 33-36 by VW. (P. 4, 3 lines only.)

[Coleridge, S. T.] Coleridge the Talker. A Series of Contemporary Descriptions and Comments. Ed. R. W. Armour and R. F. Howe. Oxford Univ. Press, 1940.

2. "The past, the present $\&$ the future all mixed their light.": 1 p., numbered 5 by NYPL; numbered 37 by VW. The entry consists of notes for Woolf's article "Sara Coleridge," including an unidentified page reference.

3. "White (1784)": 11 pp., numbered 6-16 by NYPL; numbered 14-24 by VW.

White, Gilbert. The Works in Natural History. Ed. W. Markwick. 2 vols. White, 1802.

4. "White. Life DNB.": 1 p., numbered 17 by NYPL; numbered 25 by VW.

Newton, Alfred. "White, Gilbert." DNB (1900).

5. "Notes poems \&c.": 1 p., numbered 18 by NYPL; numbered 26 by VW.

White, Gilbert. Observations on Various Parts of Nature. In The Natural History of Selbourne... To which are added The Naturalist's Calendar, Miscellaneous Observations, and Poems. Vol. II. Arch, etc., 1822.

6. "Bewick.": 3 pp., numbered 19-21 by NYPL; numbered 2729 by VW. (P. 21, 1 line only.) This work provided Woolf with the title and details for her article "Gas at Abbotsford."

[Bewick, William.] Life and Letters of William Bewick, Artist. Ed. Thomas Landseer. 2 vols. Hurst \& Blackett, 1871.

\section{Holograph Reading Notes. Vol. 25. (Berg)}

The notes in this volume span six years and several of Woolf's works. The notebook itself is a composite. The first group of entries (B.1-25) can be dated from 1922 to 1924 and includes notes on the Greeks and Elizabethans for The Common Reader (1925); the second group (B.26-30) was made in 1927 and is for the most part related to 
her reading for "Phases of Fiction" (1929). The last group (B.31-41) also contains notes for "Phases of Fiction," but these were made at the end of 1926 or during the first part of 1927 . Woolf herself distinguished the earlier notes from the later ones by providing two distinct sets of page numbers.

Judging by the contents and dates of the entries on the Greeks and Elizabethans, this notebook is the fourth of six volumes of reading notes Woolf made for the critical work that became The Common Reader. (See as well Volumes XXX, XXXVIII, XLIX, XIX, and XLVII.) On August 28, 1922, Woolf outlined her projected reading for the Greek chapter in her critical work: "Some Homer: one Greek play; some Plato; Zimmern; Sheppard, as text book; Bentley's Life. If done thoroughly, this will be enough. ... Then there's the Anthology. All to end upon the Odyssey because of the Elizabethans. And I must read a little Ibsen to compare with Euripides-Racine with Sophocles-perhaps Marlowe with Aeschylus" ( $D$, II).

Once she had her outline, Woolf began slowly to read, and notes on several of these works appear in this volume. On October 4, 1922, she recorded having read five books of the Odyssey (B.23), noting that she could "read Greek now steadily.... I shall read the Trilogy \& some Sophocles \& Euripides \& a Plato dialogue: also the lives of Bentley \& Jebb" $(D$, II $)$. On October 14, she wanted to read Aeschylus, begin Zimmern, and make "a hasty end of Bentley"-either De Quincey's "Richard Bentley" (B.14), Monk's Life of Richard Bentley (LXIX, B.1), or both. ". . . how to read Aeschylus," she muses in this same diary entry, "I don't quite know: quickly, is my desire, but that, I see, is an illusion." And an illusion it was. On November 7, she complained of not having been able to read for her Greek chapter; on November 13, she was trying to "make out what Aeschylus wrote"; on November 27, she was stealing time from the Agamemnon; and on December 3, she wrote, "I should be at Aeschylus, for I am making a complete edition, text, translation, \& notes of my own-mostly copied from Verrall, but carefully gone into by me" ( $D$, II). Her "edition" of the Agamemnon is now in a separate manuscript in the Berg Collection: [Holograph English translation Aeschylus' Agamemnon, and her marginal MS notes]. Only one short entry on the Agamemnon (B.24) appears below.

On January 7, 1923, Woolf made yet another list-this time of what she would have read by the end of the month: "Odyssey (6 books) Agamemnon: Oedipus Tyrannus, Zimmern [B.22], Jebb's Homer-Life of Jebb, \& some dialogue of Plato's? [B.20]" ( $D$, II). Four months later, on May 11, with the Greek chapter still unwritten, 
Woolf began to talk of reading the Elizabethans as well. Other notes for "On Not Knowing Greek" are found in Volumes XLIX, XLVII, and in particular, XIX.

Throughout the remainder of 1923 and 1924, Woolf continued to read both Greek and Elizabethan literature, the latter with great pleasure and delight. In August 1923, she was reading Marlowe (B.8, 12-13; see $L$, III, 1417), and on November 3, she compared the experience of being in London to that of reading Shakespeare ( $D, \mathrm{II}$; see also December 19, 1923; February 3, April 5, 15, 1924). "I spent this morning writing a note on an E[lizabe]than play," she recorded on January 6, 1925, "for which I have been reading plays all this year" ( $D$, III). Although this notebook contains several entries on Elizabethan playwrights, entries on Shakespeare and Spenser, and entries on critical studies of the Elizabethan period, the majority of her notes on the Elizabethans appear in Volume XIX. Other Elizabethan entries appear in Volume XLVII, including notes on Richard III and King John that are connected to those headed "Richard 2nd. King John $\mathrm{Sh}^{\text {re }}$," below (B.7). Woolf talked about reading these plays on August 15, 1924 ( $D$, II).

During the summer of 1923, Woolf was also reading Conrad (B.3) in preparation for her article, "Mr. Conrad: A Conversation," Nation \& Athenaeum, September 1, 1923 (Kp. C239; see D, II, July 28, 1923; L, III, 1413, 1415). This conversation (between Penelope Otway and David Lowe) prompted her to develop the "brilliant idea ... of embedding [her critical essays] in Otway conversation" in order to make them into a book ( $D$, II, August 17, 1923). By September 5, however, she had given up this idea - "slightly dashed by the reception of [her] Conrad conversation"-and "began for the 5th but last time, I swear, what is now to be called The Common Reader" ( $D$, II). Other notes from 1923 are interspersed with her reading for her critical book, including notes for "Sir Thomas Browne," a review of the Golden Cockerel Press edition of his works (B.21), TLS, June 28, 1923 (Kp. C235; see D, II, June 4); and notes for "The Compromise," a review of The Life of Mrs. Humphrey Ward (B.5), New Republic, January 9, 1924 (Kp. C242).

Four years later, on August 21, 1927, Woolf wrote to Saxon Sydney-Turner asking to borrow The Mysteries of Udolpho as she was "writing about Romance-a silly thing to do; but then Leonard and Dadie have started a series, and my summer is being ruled by the need of writing a book for it on fiction" ( $L$, III, 1800). "I am reading," she continues in her letter, "a new classic every night," and mentions Scott and Trollope as two of the novelists on her mind. 
Novels by Trollope and Scott, as well as The Mysteries of Udolpho (which she was reading by August 29: $L$, III, 1803), all appear in this notebook (B.26, 27, 29); more notes on novels and novelists for "Phases of Fiction," published finally in Bookman, April, May, and June 1929 (Kp. C312), are found in Volumes XIII, XIV, XXVI, and LXVI. The other entry in this volume from 1927 is that on E. M. Forster's Aspects of the Novel (B.30), which was made in preparation for her review of the work, "Is Fiction an Art?" New York Herald Tribune, October 16, 1927 (Kp. C288). A note on the back of one of the pages on Forster - "Hemingway/Shelley/Morgan"-is a reference to this review and to two others Woolf wrote for the Herald Tribune: "An Essay in Criticism," a review of Men Without Women, by Ernest Hemingway, October 9, 1927 (Kp. C287); and "Not One of Us," a review of Shelley: His Life and Work, by Walter Edwin Peck, October 23, 1927 (Kp. C289). Woolf talked about writing these reviews in letters written during September 1927 ( $L$, III, 1805, 1810; D, III, September 20).

The final entries in the notebook can almost certainly be dated at the end of 1926. Several of them belong to Woolf's initial spurt of energy when she began to plan "Phases of Fiction" and found herself "making up phrases" ( $L$, III, 1714; see also $D$, III, September 5, 1926). One example of her phrase making occurs in B.37, headed "Fiction," where Woolf mentions or alludes to Defoe, Maupassant, and Sterne (B.31, 33). We know that she was reading Tristram Shandy in November and December 1926 ( $D$, III, November 23, December $11 ; L$, III, 1696); her notes on this novel, dated " 27 th Nov.," are now found in XIV, B.16, on pages numbered 19-23 by Woolf. These numbers indicate that they were originally located between entries 33 and 34 in this volume.

The remaining entries are easier to place. On December 11, 1926, Woolf was reading Yeats's autobiography (B.34; D, III), and on Christmas Day, she was reading Gide's memoirs, Si le grain ne meurt (B.35; L, III, 1696). Earlier, on September 13, 1926, Woolf recorded in her diary that she had spent "4 days last week hammering out de Quincey, which has been lying about since June. . . I shall do Cobden Sanderson \& Mrs Hemans" ( $D$, III). Notes on De Quincey, Cobden-Sanderson, and Mrs. Hemans appear below, B.39-41; her essay on De Quincey, "'Impassioned Prose,'" was published in the $T L S$, September 16, 1926 (Kp. C275); her review of The Journals of Thomas James Cobden-Sanderson, "The Cosmos," appeared in Nation \& Athenaeum, October 9, 1926 (Kp. C276). 
The composite character of this notebook is reflected in both the variety of inks and the profusion of page numbers. The entries made between 1922 and 1924 are in Woolf's purple ink, with a few notes on the Odyssey in black ink. Of the later entries, B.26-27 and B.3441 are in a blue-gray ink, with some pencilled notes; B.28-32 are blue-purple. The two sets of page numbers that Woolf made when she collected the notes, 1-46 (B.11-25) and 1-46 (B.26-41), respectively, are in blue pencil. The other page numbers were made at the same time and are in the same ink as the notes themselves.

\section{B. ENTRIES}

1. "Marivaux. Sainte Beuve.": 1 p., numbered 1 by NYPL. The entry is annotated, "C. de L./9/343."

Sainte-Beuve, C. A. "Marivaux." In Causeries de lundi. 3rd ed. Vol. IX. Paris: Garnier Frères, 1862.

2. "White Devil. Webster": 3 pp., numbered 2-4 by NYPL. The entry includes a great number of general notes on this play, and on drama as a genre. One note, for example, reads, "The possibility is that the mind is always becoming more $\&$ more subtle; \& this business of making people speak becomes too crude." More notes on this play appear in XIX, B.20.

Webster, John. The White Devil.

3. [Conrad]: 15 pp., numbered 5-19 by NYPL.

a) "Chance. (1914)": 1 p., numbered 5 by NYPL; numbered 1 by VW. More notes on this work appear below, B.3.j.

Conrad, Joseph. Chance. Methuen, 1914.

b) "Conrad": 1 p., numbered 6 by NYPL. The entry consists of a list of Conrad's works: "Almayer's Folly \& Tales of Unrest./Outcast of the Islands./ Nigger of the Narcissus \& Typhoon./Lord Jim."

c) "Author's Note to Tales of Unrest": 1 p., numbered 6 by NYPL.

Conrad, Joseph. "Author's Note." In Tales of Unrest.

Dent, 1923. Uniform Edition.

d) "Preface to Almayers Folly": 1 p., numbered 6 by NYPL. 2 lines only: "I am content to sympathize with common mortals no matter where they live." 
Conrad, Joseph. “Author's Note." In Almayer's Folly. Dent, 1923. Uniform Edition.

e) "Note to Outcast of the Islands": 1 p., numbered 7 by NYPL. The entry includes a long quotation about fiction, beginning, "It must strenuously aspire to the plasticity of sculpture...."

Conrad, Joseph. "Author's Note." In An Outcast of the Islands. Dent, 1923. Uniform Edition.

f) "Lord Jim./apparently his favourite./The Nigger of the Narcissus.": 1 p., numbered 8 by NYPL. (Heading only.)

g) "The Nigger of the Narcissus.": 3 pp., numbered 911 by NYPL. The entry includes a large number of general notes on this novel. On p. 11, for example, where Woolf is summing up her impressions, she notes: "The limitations of the life are that only certain types are dealt with-(but this is invariable) No women."

Conrad, Joseph. The Nigger of the "Narcissus." Dent, 1923. Uniform Edition.

h) "Typhoon \&c": 4 pp., numbered 12-13, 15-16 by NYPL. The entry consists of notes on Amy Forster, To-morrow, Falk, and Typhoon.

Conrad, Joseph. Typhoon and Other Stories. Dent, 1923. Uniform Edition.

i) "The Editor mueh regrets he eannot use the enelosed.": 1 p., numbered 14 by NYPL. (Heading only.)

j) "Chance.": 2 pp., numbered 17-18 by NYPL. P. 17 is also numbered 2 by VW. More notes on this work appear above, B.3.a. The name "Nicholas Challis" appears on the reverse side of p. 16. P. 18 begins with the general note, "Conrad certainly an aristocrat. See Marlow. Preface to Youth. he was a gentleman-Nobody can deny that. N. of N. \& Nostromo according to C. stand apart from the rest of his work." The first part of this note is annotated "ix," and appears in the "Author's Note" to Youth and Two Other Stories. 
1. Conrad, Joseph. Chance. Methuen, 1914.

2. Conrad, Joseph. "Author's Note." In Youth: A Narrative and Two Other Stories. Dent, 1923. Uniform Edition.

k) "Nostromo. a tale of the Seaboard./by Joseph Conrad./Dent \& Son Ltd 10/6 n": 1 p., numbered 19 by NYPL. At the top of the page Woolf has written in pencil, "I have always attended to my business [J W ... l." The entry consists of a heavily cancelled draft of a review of the Dent edition of Conrad's novels.

Conrad, Joseph. Nostromo. A Tale of the Seaboard.

Dent, 1923. Uniform Edition.

4. "Shakespeare./Life of Sidney Lee": 1 p., numbered 20 by NYPL; numbered 1 by VW.

Lee, Sidney. A Life of William Shakespeare. Smith, Elder, 1899. Illustrated Library Edition.

5. " $\mathrm{M}^{\mathrm{rs}} \mathrm{H}$ Ward. b. June 1851": 4 pp., numbered 21-24 by NYPL. P. 21 is also numbered 1 by VW.

Trevelyan, Janet P. The Life of Mrs. Humphrey Ward. Constable, 1923.

6. "Kyd's Spanish Tragedy": 2 pp., numbered 25-26 by NYPL.

(P. 26, 3 lines only.) The entry consists mainly of general notes, beginning, "Seems to me very free, forcible, but too ingenius already - too much plot (for me)," and includes notes on Schick's "Preface." More notes on this play appear in XIX, B.24.

Kyd, Thomas. The Spanish Tragedy. Ed. J. Schick. Dent, 1898.

7. "Richard $2^{\text {nd }}$. King John. She": 1 p., numbered 27 by NYPL.

Shakespeare, William. Richard II.

8. "Marlowe": 5 pp., numbered $28-32$ by NYPL. The entry includes a large number of general notes. More notes on Marlowe appear below, B.12-13.

a) "Tamburlaine. pt. 2.": 1 p., numbered 28 by NYPL.

b) "Dr. Faustus.": 1 p., numbered 28 by NYPL.

c) "Tamburlaine, pt. 2.": 2 pp., numbered 29-30 by NYPL.

d) "The Jew of Malta.": 2 pp., numbered 31-32 by NYPL. (P. 32, 3 lines only.) 
Marlowe, Christopher. Tamburlaine, Pt.II, Dr. Faustus, and The Jew of Malta. In Works. Ed. C. F. Tucker Brooke. Oxford: Clarendon Press, 1910.

9. "Sterne. Sentimental Journey": 2 pp., numbered 33-34 by NYPL. P. 34 is also numbered 2 by VW.

Sterne, Laurence. A Sentimental Journey Through France and Italy. In The Novels . . of Laurence Sterne. George Newnes, 1905.

10. "Shre. Venus \& Adonis./Rape of Lucrece.": 2 pp., numbered 35-36 by NYPL. The entry ends with a reference to and notes on Sidney Lee's biography of Shakespeare. More notes on Lee's biography appear above, B.4.

a) Shakespeare, William. Venus and Adonis and The Rape of Lucrece.

b) Lee, Sidney. A Life of William Shakespeare. Smith, Elder, 1899. Illustrated Library Edition.

11. "Lawrence. The Fox.": 1 p., numbered 37 by NYPL; numbered 1 by VW. General notes about Lawrence, beginning, "The possibility may be, it strikes me in reading Lawrence, that some people may get much further on these suggestions than others."

Lawrence, D. H. The Fox. [1923].

12. "Marlowe. Hero \& Leander.": 1 p., numbered 38 by NYPL; numbered 2 by VW. The entry includes notes on Brooke's "Introduction" to the poem. More notes on Marlowe appear above, B.8, and below, B.13.

Marlowe, Christopher. Hero and Leander. In Works. Ed.

C. F. Tucker Brooke. Oxford: Clarendon Press, 1910.

13. "Oxford Edition 1913./Marlowe. Tamburlaine.": 3 pp., numbered $39-41$ by NYPL; numbered 3-5 by VW. The entry includes notes from Brooke's "Introduction" to the play. More notes on Marlowe appear above, B.8 and B.12.

Marlowe, Christopher. Tamburlaine, Pt. I. In Works. Ed.

C. F. Tucker Brooke. Oxford: Clarendon Press, 1910.

14. "De Quinceys Life of Bentley.": 1 p., numbered 42 by NYPL; numbered 6 by VW.

De Quincey, Thomas. "Richard Bentley." In Studies on Secret Records, Personal and Historic. James Hogg, 1857. Vol. VII of De Quincey's Works. Selections Grave and Gay. 
15. "Symonds. Shakespere's Predecessors": 9 pp., numbered 4351 by NYPL; numbered 7, 7-14 by VW.

Symonds, John Addington. Shakspere's Predecessors in the English Drama. Smith, Elder, 1884.

16. "Ben Jonsons Talks with Drummond/Patterson's Edition": 1 p., numbered 52 by NYPL; numbered 15 by VW.

[Jonson, Ben.] Ben Jonson's Conversations with William Drummond of Hawthornden. Ed. R. F. Patterson. Blackie, 1923.

17. "Art of Hardy/Lionel Johnson.": 1 p., numbered 53 by NYPL; numbered 16 by VW.

Johnson, Lionel. The Art of Thomas Hardy. John Lane, The Bodley Head, 1923.

18. "Spenser. (Payne Colliers Edition)": 1 p., numbered 54 by NYPL; numbered 17 by VW. The entry consists of notes on Spenser's life and on The Shepherds Calendar.

a) Collier, J. Payne. "The Life of Spenser." In The Works of Edmund Spenser. Ed. J. Payne Collier. Vol. I. Bell \& Daldy, 1862.

b) Spenser, Edmund. The Shepheardes Calender. In Works. Ed. J. Payne Collier. Vol. I. Bell \& Daldy, 1862.

19. "Beckfords Thoughts on Hunting": 2 pp., numbered 55-56 by NYPL; numbered $19-20$ by VW. A pencilled note, cancelled, at the top of this page reads, "Date of $[\ldots] \& \mathrm{C}$. c. 1380-2."

Beckford, Peter. Thoughts on Hunting. Chapman \& Dodd, 1923.

20. "Euthyphron.": 2 pp., numbered $57-58$ by NYPL; numbered 21-22 by VW.

Plato. Euthyphro.

21. "Sir Thomas Browne.": 8 pp., numbered 59-66 by NYPL. Pp. $59-60,62-66$ are also numbered $23-29$ by VW.

a) "Johnson on./5 When the living might exceed the dead.": 1 p., numbered 59 by NYPL; numbered 23 by VW. The entry includes general notes on "The Cockerell Edition" and notes on Urn Burial. "Johnson on" in the beginning of the entry is a reference to "Dr. Johnson's Life of Sir Thomas Browne" (1756). 
Browne, Sir Thomas. Hydriotaphia: Urne Buriall. Waltham St. Lawrence: Golden Cockerel Press, 1923.

b) "Sir T. Browne.": 1 p., numbered 60 by NYPL; numbered 24 by VW. General notes for her review of the Golden Cockerel edition of Browne's works.

c) "Urn Burial.": 3 pp., numbered 61-63 by NYPL. Pp. 62-63 are also numbered $25-26$ by VW. (P. 61, 3 lines only.) The heading appears on p. 62. Woolf was reading the work in two different editions, the second of which she annotated "new/ed," a reference to the Golden Cockerel edition.

1. Browne, Sir Thomas. Hydriophaphia: Urn Burial. Ed. Sir John Evans. Chiswick Press, 1893.

2. Browne, Sir Thomas. Hydriophaphia: Urne Buriall. Waltham St. Lawrence: Golden Cockerel Press, 1923.

d) "The Garden of Cyrus.": 2 pp., numbered $64-65$ by NYPL; numbered 27-28 by VW.

Browne, Sir Thomas. The Garden of Cyrus. Waltham St. Lawrence: Golden Cockerel Press, 1923.

e) "Religio Medici": 1 p., numbered 66 by NYPL; numbered 29 by VW. The entry is annotated "my/ed."

Browne, Sir Thomas. Religio Medici. In Works. Ed. Simon Wilkin. Vol. II. Pickering, 1835.

22. "Greek Commonwealth/Zimmern": 8 pp., numbered 67-74 by NYPL; numbered $30-37$ by VW. Pp. 68-74 are also numbered $2-8$ by Woolf in the same ink as the entry.

Zimmern, Alfred E. The Greek Commonwealth. Politics and Economics in Fifth-Century Athens. Oxford: Clarendon Press, 1911.

23. "The Odyssey": 7 pp., numbered $75-81$ by NYPL; numbered $38-44$ and $1-7$ by VW. The last set of numbers are in the same ink as the entry. Woolf's notations are for book and line number. Passages written in Greek suggest that she was reading the work in the original, or in a dual-language edition.

Homer. The Odyssey. Books 1-6. 
24. "Aeschylus./Agamemnon.": 1 p., numbered 82 by NYPL; numbered 45 by VW. 1 line only, reading, "170 he has made wisdom shall be established by means of suffering."

Aeschylus. Agamemnon.

25. "Murray: Ancient Greek Lit": 1 p., numbered 83 by NYPL; numbered 46 by VW.

Murray, Gilbert. A History of Ancient Greek Literature. [1897].

26. "Barchester Towers. Trollope.": 2 pp., numbered 84-85 by NYPL; numbered 1-2 by VW. The entry ends with the pencilled note, "Hawthorne \& Trollope. Auto. I. 195," a reference to a passage written by Hawthorne about Trollope and quoted in Trollope's Autobiography, pp. 192-195. For notes on the Autobiography, including Woolf's notice of the Hawthorne passage, see XXVI, B.32.

Trollope, Anthony. Barchester Towers. Collins Clear-Type Press, n.d.

27. "The Bride of Lammermoor": 2 pp., numbered $86-87$ by NYPL; numbered 3-4 by VW.

Scott, Walter. The Bride of Lammermoor. In Tales of my Landlord. 3rd ser. Vol. I-II. Edinburgh: Constable, 1819.

28. "Stevenson/Master of Ballantrae": 3 pp., numbered 88-90 by NYPL; numbered 5-7 by VW. The entry begins with general notes on "romance" and comparisons of Stevenson to Scott and Defoe: "The feeling that where Scotts words have come pouring out, Stevenson's are picked out of notebooks."

Stevenson, Robert Louis. The Master of Ballantrae. [1891].

29. "Mysteries of Udolpho": 2 pp., numbered 91-92 by NYPL; numbered 8-9 by VW. More notes on this work appear in XIV, B.3, and XLVI, B.4.

Radcliffe, Ann. The Mysteries of Udolpho. A Romance. Vols. I-II [of IV]. Robinson, 1794.

30. "Aspects of Fiction": 5 pp., numbered 93-97 by NYPL; numbered $10-14$ by VW. On the reverse of p. 94 appears the list, "Hemingway/Shelley/Morgan," a reference to three reviews Woolf published in the New York Herald Review in October 1927: "An Essay in Criticism," a review of Men Without Women, by Ernest Hemingway; "Is Fiction an Art?" a review of Aspects of the Novel, by E. M. Forster; and "Not 
One of Us," a review of Shelley: His Life and Work, by Walter Edwin Peck" (Kp. C287-289).

Forster, E. M. Aspects of the Novel. Arnold, 1927.

31. "Roxanna": 1 p., numbered 98 by NYPL; numbered 15 by VW.

Defoe, Daniel. Roxana, or, The Fortunate Mistress. Simpkin, Marshall, Hamilton, Kent, 1926. Vol. XXV of the Abbey Classics.

32. "The Triumphs of Sara/WE Norris": 2 pp., numbered 99-100 by NYPL; numbered $16-17$ by VW. The entry includes general notes comparing this novel to Defoe's Roxana.

Norris, W. E. The Triumphs of Sara. Hutchinson, 1920.

33. "Maupassant": 1 p., numbered 101 by NYPL; numbered 18 by VW. The entry begins, " 270 brings out the form \& colour with little words ([? F de F])." Notes unidentified.

34. "Yeats. Auto.": 2 pp., numbered 102-103 by NYPL; numbered $24-25$ by VW.

Yeats, W. B. Autobiographies: Reveries over Childhood and Youth and The Trembling of the Veil. Macmillan, 1926.

35. "Gide": 4 pp., numbered 104-107 by NYPL; numbered 2629 by VW.

Gide, André. Si le grain ne meurt. 3 vols. Paris: Editions de la nouvelle revue française, 1924.

36. "Aristotle Poetics.": 2 pp., numbered 108-109 by NYPL; numbered 30-31 by VW. (P. 109, 2 lines only.)

Aristotle. The Poetics. Trans. S. H. Butcher. In S. H. Butcher. Aristotle's Theory of Poetry and Fine Art. 2nd and 3rd eds. Macmillan, 1892, 1902.

37. "Fiction": 1 p., numbered 110 by NYPL; numbered 32 by VW. The entry consists of notes for "Phases of Fiction," beginning, "The real. Plague of London \& Maupassant," and including references to Laurence Sterne, Tristram Shandy, and satire.

38. "Ibsen. Master Builder.": 1 p., numbered 111 by NYPL; numbered 33 by VW.

Ibsen, Henrik. The Master Builder. Trans. Edmund Gosse and William Archer. Heinemann, 1907. Vol. X of The Collected Works. Uniform Edition. 
39. "De Quincey": 1 p., numbered 112 by NYPL; numbered 34 by VW. The entry consists of general notes on De Quincey, with the marginal notations "Auto. 183" and "LS." The latter is a reference to Leslie Stephen's essay on De Quincey. The particular "autobiography" referred to in the first notation is unclear. Woolf's notes after "Auto. 183" read, "Size \& number-magnifying. Often the scenes, like the $\mathrm{dog}$, are better in memory than fact-they tell more than they seem to tell."

Stephen, Leslie. "De Quincey." In Hours in a Library. 1st ser. [1874].

40. "Cobden Sanderson.": 7 pp., numbered 113-119 by NYPL; numbered $35-41$ by VW. The entry includes references to "The Kosmos."

Cobden-Sanderson, Thomas James. The Journals . . 18791922. 2 vols. R. Cobden-Sanderson, 1926.

41. "Mrs. Hemans./Memoir of. by her sister.": 5 pp., numbered 120-124 by NYPL; numbered 42-46 by VW.

[Hughes, Mrs. Harriet.] Memoir of the Life and Writings of Mrs. Hemans, by her sister. Edinburgh: Blackwood; London: Cadell, 1839. Vol. I of The Works of Mrs. Hemans.

\section{Holograph Reading Notes. Vol. 26. (Berg)}

This volume, the last of the twenty-six volumes of "Holograph reading notes" catalogued together in the Berg Collection, consists of loose pages and "booklets" (i.e., sets of pages held together by dry welding) that date from various periods in Woolf's career. Several of the entries are listed in the tables of contents for other volumes and have page numbers that correspond to their place in the original volume. Some entries clearly belong with notes on the same work that appear elsewhere; other entries, as indicated by Woolf's pagination, were once part of an unspecified set of notes. There is, however, some coherence among individual groups of entries, including a set of notes for Three Guineas and a set for Roger Fry: A Biography. Moreover, the booklets-each a few pages only-suggest that the notes within the particular booklet were made at approximately the same time. 
The first two entries are the most difficult to date. Both are headed "Novels. Form," and both deal generally with questions of form as well as with specific works by Goldsmith (B.1) and Henry James (B.2). They may, however, belong to the period when Woolf was thinking about "form" for her article "On Re-reading Novels" (19211922; Kp. C228), which is based in part on Percy Lubbock's book, The Craft of Fiction, noted below, B.33. This supposition is supported by Woolf's pages numbers, which indicate that the notes were originally part of Volume XXXVIII (1918-1922). One thing is certain: the entry on The Vicar of Wakefield does not belong with the notes on Goldsmith in Volumes XXIII, LIII, and LXVII that were made in 1933 in the black ink she used almost exclusively from the mid-thirties on. The entry on Goldsmith in this volume is in the purple ink of her earlier notes.

After these, the identifications are clearer. Entries B.3-16 were all made as part of Woolf's preparation for Three Guineas and can be dated between January 1935, when she began to talk of her new book "on being despised" ( $A W D$, January 1$)$, and its completion in February 1938. (See Volumes VII, X, XXXIII, XXXIX, and LV-LX for other notes on Three Guineas.) Several of the entries can be placed in 1937 and 1938, based on the date of publication of the works noted; the Letters inform us that Woolf was reading George Sand's autobiography (B.14) during the summer of 1937 ( $L$, VI, 3256, 3265) and Chateaubriand's Memoirs (B.10) in the beginning of 1938 ( $L, \mathrm{VI}, 3348,3368)$. When the entries in this volume reappear in the " 3 bound volumes of Press Cuttings \& extracts collected or copied by VW relative to $3 \mathrm{Gs"} \mathrm{(MHP} \mathrm{Catalogue),} \mathrm{they} \mathrm{are} \mathrm{in} \mathrm{the}$ third volume, LX. Moreover, all of the works noted below appear in the list of authors, titles, and subjects (VII, B.12) that Woolf almost certainly made in conjunction with "the bibliography and notes" $(A W D$, October 12,1937). Finally, with the exception of the notes on Chateaubriand (B.10), all of the works in this volume reappear in some form in Three Guineas.

The next set of notes, B.17-20, is related to Woolf's preparations for Roger Fry: A Biography, and was made after August 1935 when she began to read Fry's papers ( $A W D$, August 21). One entry (B.18), a list of the other Fry entries, is dated "Oct: 1936," which may be the date of the notes as well. (Notes on Fry dated "October 1936" also appear in Volume LXI; other notes are found in XXXIX and LXII-LXVI.) The entry on Fry's "Introduction" to Reynolds' Discourses, however, which appears later in this volume (B.31), is harder to date. This work appears in the tables of contents for Volume XVI, 
along with other notes that belong to the late thirties, and may well have been read or reread by Woolf while she was writing the biography in 1938 and 1939.

The notes on Henry James - The Wings of the Dove and the ghost stories (B.21) - are easier to pinpoint. Woolf wrote on August 29, 1921 , that she was reading James's novel for the first time ( $L$, II, 1186); by September 12, she had "finished the Wings of the Dove, \& make this comment. His manipulations become so elaborate towards the end that instead of feeling the artist you merely feel the man who is posing the subject" ( $D, \mathrm{II}$; the comments continue for several more lines). She was "struggling with Henry James' ghost stories for The Times" on November 15, 1921 ( $D$, II), in preparation for the article published in the $T L S$, December 22, 1921 (Kp. C225). The November 15 diary entry continues, "Then I must do Hardy"-and notes on Hardy and "The Hardy article" appear among her notes for The Wings of the Dove (B.21.a). The notes on James were originally part of Volume XXXVIII, where they are listed in the table of contents as appearing on pages 33-38-Woolf's page numbers for the notes below.

The notes on The Antiquary (B.22) were originally part of Volume XLVII, where the table of contents shows they appeared on pages 20-23-the same numbers found below. Many of the notes in this entry reappear in her article on The Antiquary, Nation \& Athenaeum, November 22, 1924 (Kp. C256). The notes on the biography of Montaigne (B.23), numbered 1 by Woolf, belong with the two pages of notes on this work numbered 2-3 in XX, B.4. Volume XX contains entries that date from approximately 1928 to 1930 .

Maupassant and Shakespeare, the subjects of B.24 and B.25, were both on Woolf's list of "books read or in reading," October 2, 1934: "Troilus/Pericles/Taming of the Shrew/Cymbeline," and "scraps" of Maupassant $(A W D)$. During September 1934, Woolf was also reading Maupassant's autobiography, Sur L'Eau, noted in Volume XLV, B.3. On December 28, 1935, she was thinking of writing an article on Gray $(A W D)$, perhaps based on the notes on Gray below (B.26-27), which are dated "Oct. 31st/1935."

The next four entries, B.28-31, which include notes on Defoe, royalty, and Roger Fry, are all in one booklet that is difficult to date. It is possible they belong to 1939, the date Leonard Woolf gives for Woolf's essay on "Royalty" that was published for the first time in The Moment and Other Essays; or they might belong to the end of 1934 when Woolf reviewed The Story of my Life, by Marie, Queen of Roumania, in an article also entitled "Royalty" (Time and Tide, 
December 1, 1934; Kp. C345), and began reading Roger Fry. The entry on Trollope's Autobiography (B.32) is also undated, but it may correspond to her notes on Trollope's novel, Barchester Towers (in XXV, B.26; dated 1927), which end, "Hawthorne \& Trollope. Auto. I. 195." Woolf was referring to a description of Trollope by Hawthorne that appears in full in the notes on the Autobiography below. Woolf also read-or recalled-Trollope's Autobiography in 1934 when she was drafting an essay on biography and autobiography (see MH/ B.5a, Sussex).

In contrast to the previous entries, the fourteen pages of notes on Percy Lubbock's The Craft of Fiction (B.33) can be placed with certainty between the end of 1921 and the publication of her essay, "On Re-reading Novels," TLS, July 20, 1922 (Kp. C228). Woolf began to speak of her "essay upon Mr. Percy Lubbock" on December 2, 1921 ( $L$, II, 1205), and had clearly read the work by February 15, 1922, when she "disagreed violently" with Lytton Strachey "about Percy Lubbock's book" ( $D$, II). She appears to have written the article in June 1922 ( $L$, II, 1254; $D$, II, June 23). "Fiction, Craft of. Lubbock," is listed in the table of contents for Volume XLIX, and two lines of cancelled notes - "Sketch the different ways of telling a story. Then say how Richardson, Meredith, H.J. did it"-appear on the page numbered 71 by Woolf in that notebook (XLIX, B.20). These lines are almost certainly the conclusion of the notes, numbered $56-69$ by Woolf, in this volume.

The last entry, on Volume I of Meredith's Letters (B.34), should be used in conjunction with the notes on Volume II in XLVI, B.9; both sets were probably made in preparation for "The Novels of George Meredith," TLS, February 9, 1928 (Kp. C297).

Woolf's ink and page numbers vary from entry to entry: B.1-2 are in purple ink, with blue pencil page numbers; B.3-20 are in black ink throughout; B.21.a is in purple ink and pencil, with blue pencil numbers; B.21.b-g are in purple ink, with blue pencil numbers; B.22-23 are in purple ink, the first with blue pencil numbers; B.24-32 are in black ink throughout; B.33 is in black and purple ink, with blue pencil numbers; B. 34 is in purple ink.

\section{B. ENTRIES}

1. "Novels. Form/(Vicar of Wakefield) Goldsmith": 1 p., numbered 1 by NYPL; numbered 7 by VW. The entry consists of general notes, beginning, "The social machinery seems to have imposed a pretty sharp mould upon $18^{\text {th }}$ Cent. 
fiction: Witness Vicar of Wakefield (wh. in parts reminds me of The Diary of a Nobody)," and notes on Goldsmith's novel.

Goldsmith, Oliver. The Vicar of Wakefield. In The Miscelleneous Works. Ed. James Prior. Vol. III. Murray, 1837.

2. "Novels. (Form)": 1 p., numbered 2 by NYPL; numbered 18 by VW. The entry consists of general notes about "the novel," beginning, "Undoubtedly tea parties, dinner parties, (I mean the social machinery of the age) imposes form upon novels," and includes a quotation annotated " $\mathrm{H}$. James, criticising Transformation by Hawthorne," "166."

James, Henry. Hawthorne. Macmillan, 1879.

3. "The gospels show us that Our Lord regarded men \&/women alike as members of same spiritual/kingdom . ..": 3 pp., numbered $3-5$ by NYPL. More notes on this work appear below, B.6, and in LXI, B.8.

The Archbishop's Commission. The Ministry of Women. The Church Assembly, 1935.

4. "Sophia Jex Blake. by Margaret Todd [ . . ]. 1918": 1 p., numbered 6 by NYPL; numbered 8 by VW. More notes on this work appear in VII, B.13 (on pages numbered 5-7 by VW), and in LX, B.57.

Todd, Margaret. The Life of Sophia Jex-Blake. Macmillan, 1918.

5. "Hilary Newitt. Women Must Choose.": 1 p., numbered 7 by NYPL; numbered 9 by VW.

Newitt, Hilary. Women Must Choose. The Position of Women in Europe Today. Gollancz, 1937.

6. "Ministry of Women": 5 pp., numbered $8-12$ by NYPL; pp. 8-10 numbered $10-12$ by VW. The entry is also headed, "Grensted," a reference to "Certain Psychological and Physiological Considerations, by Professor Grensted, D.D.," included in this work. More notes on this work appear above, B.3, and in LXI, B.8.

The Archbishop's Commission. The Ministry of Women. The Church Assembly, 1935.

7. "Astell": 1 p., numbered 13 by NYPL; numbered 14 by VW. More notes on this work appear in X, B.7. 
Smith, Florence M. Mary Astell. New York: Columbia Univ. Press, 1916.

8. "Occupations for W. RS.": 2 pp., numbered 14-15 by NYPL; numbered $15-16$ by VW. (P. 15, 1 line only.)

Strachey, Ray. Careers and Openings for Women. A Survey of Women's Employment and a Guide for those Seeking Work. Faber \& Faber, 1935.

9. "From One Century to Another/E. Haldane.": 2 pp., numbered $16-17$ by NYPL; numbered $17-18$ by VW. Entry annotated "(Alex. Maclehose \& Co/1937)." More notes on this work appear in LX, B.71.

Haldane, Elizabeth. From One Century to Another. Reminiscences. Maclehose, 1937.

10. "Chateaubriand on Reveries": 1 p., numbered 18 by NYPL; numbered 19 by VW. Quotation, annotated " $2 / 160$," "M D'O. T.," reading, "I wished for great renown in order that it might rise to my mother in heaven, \& that the angels might carry her my holy expiation." More notes from this work appear in XLV, B.12.

Chateaubriand, François René de. Memoires d'Outre Tombe. Vol. II [of VI]. Paris: Garnier Frères, n.d.

11. "Nichols./Vol 1./Illustrations of Lit. Hist.": 1 p., numbered 19 by NYPL; numbered 20 by VW. Quotation, annotated "137," beginning, "22nd Oct. 1768. Another application there is-more extraordinary-Miss Chudleigh solicits permission to be received into the reading-room."

Nichols, John. Illustrations of the Literary History of the Eighteenth Century. Vol. I [of VIII]. Nichols, 1817.

12. "Last Flight./by Amelia Earhart. arranged by George Palmer/ Putnam": 2 pp., numbered 20-21 by NYPL; numbered 21, 23 by VW.

Earhart, Amelia. Last Flight. Arranged by George Palmer Putnam. Harrap, 1938.

13. "Conquest of the Past. The Autobiography/of Prince Hubertus Loewenstein. 1938": 1 p., numbered 22 by NYPL; numbered 22 by VW.

Loewenstein, Prince Hubertus. Conquest of the Past: Autobiography. Faber \& Faber, 1938. 
14. "George Sand.": 1 p., numbered 23 by NYPL. Quotation, annotated "2./240.," beginning, "Tantes les existences sont solidaires les unes des autres, ..." This quotation also appears in LX, B.20.

Sand, George. Histoire de ma vie. Vol. II [of X]. Paris: Michel Levy Frères, 1856.

15. "The fact that 4 mothers still/die for every 1000 children/ Spectator. June $5^{\text {th }} 1937^{\prime \prime}: 1$ p., numbered 24 by NYPL. (Heading only.) The date for the article is actually June 4, 1937. This entry reappears in LX, B.21.

"Maternal Mortality." Spectator, June 4, 1937, p. 1039.

16. "Butler.": 2 pp., numbered $25-26$ by NYPL.

Fawcett, Millicent G., and Turner, E. M. Josephine Butler. Her Work and Principles and their Meaning for the Twentieth Century. Association for Moral and Social Hygiene, 1927.

17. "Life of Ed. Fry": 2 pp., numbered 28-29 by NYPL. More notes on this work appear below, B.20.

Fry, Agnes. A Memoir of the Right Honorable Sir Edward Fry. Oxford Univ. Press, 1921.

18. "Oct: 1936/Roger Fry": 1 p., numbered 30 by NYPL. The entry consists of the titles of two works related to Roger Fry, both of which are noted in this volume: "Paper in French about Josette," and "Sir Edward Fry: Life" (B.17, $19,20)$. A reference to "Letters" is cancelled.

19. "Roger. Josette./(from Nessa's copy)": 6 pp., numbered 3136 by NYPL. The entry consists of notes on an unpublished essay written by Roger Fry about Josette Coatmellec after her death in 1924. "Nessa" is Vanessa Bell.

20. "Ed Fry.": 3 pp., numbered 37-39 by NYPL. More notes on this work appear above, B.17.

Fry, Agnes. A Memoir of the Right Honorable Sir Edward Fry.

Oxford Univ. Press, 1921.

21. [Henry James]: 7 pp., numbered $40-46$ by NYPL; pp. 40 , 42-46 numbered $33-38$ by VW.

a) "The Wings of a Dove/Henry James.": 2 pp., numbered $40-41$ by NYPL; p. 40 numbered 33 by VW. General notes on James, Hardy, and Meredith as novelists, beginning, "Question what 'form' meant to H.J. Contrast to Thomas Hardy." P. 41 includes 
a passage that begins, "The Hardy article in three stages: youth: maturity: finality."

James, Henry. The Wings of the Dove. [1902].

b) "James/Ghost Stories/The Turn of the Screw/1898":

1 p., numbered 42 by NYPL; numbered 34 by VW.

James, Henry. The Turn of the Screw. Heinemann, 1898.

c) "Henry James/Ghost Stories/The Real Thing/1893/ The Way it Came. 1896": 1 p., numbered 43 by NYPL; numbered 36 by VW.

James, Henry. "The Way it Came." In Embarrassments. Heinemann, 1896.

d) "H. James./Ghost Stories./The Great Good Place": 1 p., numbered 44 by NYPL; numbered 37 by VW. James, Henry. "The Great Good Place." In The Soft Side. Methuen, 1900.

e) "The Private Life.": 1 p., numbered 45 by NYPL; numbered 38 by VW. General notes only. James, Henry. "The Private Life." [1893].

f) "Owen Wingrave": 1 p., numbered 45 by NYPL; numbered 38 by VW. General notes only.

James, Henry. "Owen Wingrave." [1893].

g) "Sir Edmund Orme.": 1 p., numbered 46 by NYPL; numbered 35 by VW.

James, Henry. "Sir Edmund Orme." In The Altar of the Dead ... and Other Tales. Macmillan, 1909. Vol. XVII of The Novels and Tales.

22. "Scott. Antiquary": 4 pp., numbered $47-50$ by NYPL; numbered $20-24$ by VW. P. 50 consists of general notes on Scott, beginning, "The things about Scott are: he no longer influences anyone: Stendhal, Dostoevsky, Tolstoy, Meredith, therefore Flaubert, Jane Austen, perhaps do."

Scott, Walter. The Antiquary. [1816].

23. "Life of Montaigne:/Bonnefon. 1893": 1 p., numbered 51 by NYPL; numbered 1 by VW. More notes on this work appear in XX, B.4.

Bonnefon, Paul. Montaigne. L'Homme et l'oeuvre. Bordeaux:

Gounouilhou, 1893. 
24. "Maupassant/L'humble vérité": 1 p., numbered 52 by NYPL. The entry includes a quotation, annotated "Maupassant, to his mother," "168 (Dumesnil)," and notes headed "Une Vie."

a) Dumesnil, René. Guy de Maupassant. Paris: Armand Colin, 1933.

b) Maupassant, Guy de. Une Vie. L'Humble vérité. Paris: Louis Conard, 1908.

25. [Shakespeare]: $12 \mathrm{pp}$., numbered $53-56,58-65$ by NYPL. P. 57 is blank.

a) "Troilus \& Cressida.": 2 pp., numbered 53-54 by NYPL. The entry includes notes from Deighton's "Introduction."

Shakespeare, William. Troilus and Cressida. Ed.

K. Deighton. Methuen, 1906. The Arden Shakespeare.

b) "The Taming of the Shrew.": 2 pp., numbered 55-56 by NYPL.

Shakespeare, William. The Taming of the Shrew. Ed.

R. Warwick Bond. Methuen, 1904. The Arden

Shakespeare.

c) "Pericles.": 2 pp., numbered 58-59 by NYPL.

Shakespeare, William. Pericles. Ed. K. Deighton. Methuen, 1907. The Arden Shakespeare.

d) "Titus Andronicus": 1 p., numbered 60 by NYPL.

Shakespeare, William. Titus Andronicus. Ed. H. Bellyse Baildon. Methuen, 1904. The Arden Shakespeare.

e) "Coriolanus.": 3 pp., numbered $61-63$ by NYPL.

Shakespeare, William. The Tragedy of Coriolanus. Ed. W. J. Craig and R. H. Chase. Methuen, 1922. The Arden Shakespeare.

f) "Timon of Athens": 2 pp., numbered 64-65 by NYPL.

Shakespeare, William. Timon of Athens. Ed. K. Deighton. Methuen, 1905. The Arden Shakespeare.

26. "Grays Letters": $17 \mathrm{pp}$., numbered $66,68-83$ by NYPL. The entry is dated on p. 66 , "Oct 31 st/1935."

Gray, Thomas. Correspondence. Ed. Paget Toynbee and Leonard Whibley. 3 vols. Oxford: Clarendon Press, 1935.

27. "Mitfords Edition. Gray.": 1 p., numbered 67 by NYPL; numbered 1 by VW. 
Mitford, John. "The Life of Thomas Gray." In The Works of Thomas Gray. Ed. John Mitford. Vol. I. Pickering, 1836.

28. "Lee. Life of Defoe.": 1 p., numbered 84 by NYPL.

Lee, William. Daniel Defoe: His Life and Recently Discovered

Writings. Vol. I [of III]. Hotten, 1869.

29. "Merry Wives of Windsor": 1 p., numbered 85 by NYPL. (Heading only.)

30. "The Daily Telegraph./The Prince of Wales picked up a wet plate $\&$ got the paint on his fingers.": 1 p., numbered 86 by NYPL. The entry consists of notes about royalty.

31. "1905/R.F. Reynolds Discourses.": 1 p., numbered 87 by NYPL. The entry consists of notes on Fry's "Introduction."

Fry, Roger. "Introduction." In Sir Joshua Reynolds. Discourses on Painting and the Fine Arts. Seeley, 1905.

32. "Life of Trollope": 5 pp., numbered 88-92 by NYPL. For another reference to this work, see XXV, B.26.

Trollope, Anthony. An Autobiography. 2 vols. Edinburgh: Blackwood, 1883.

33. "The Craft of Fiction/Lubbock.": 14 pp., numbered 93-106 by NYPL; numbered 56-69 by VW. Interspersed with her notes on Lubbock's book are general notes about novels and novelists for her article "On Re-reading Novels." Two lines of notes for this essay appear in XLIX, B.20, on a page numbered 71 by VW.

Lubbock, Percy. The Craft of Fiction. Cape, 1921.

34. "Meredith.": 1 p., numbered 107 by NYPL; numbered 20 by VW. Notes on Volume II of this work appear in XLVI, B.9.

Meredith, George. Letters. Ed. by his Son [William Maxse Meredith]. Vol. I [of II]. Constable, 1912.

\section{XXVII. [Diary] Holograph Notebook, Unsigned. Christmas 1904-May 31, 1905. No. 3. (Berg)}

The three entries in this volume are among the earliest of the reading notes. They are written, in black ink, at the back of a diary that Woolf kept from January to May 1905, during which time she was beginning to review on a regular basis for the Guardian, the 


\section{$\underline{\text { XXVIII ] }}$}

Academy, and the Times Literary Supplement, as well as teaching English history at Morley College. Woolf's reading notes for her reviews during this period appear in Volume XXXV; the notes on Freeman and Dicey in this volume are part of her preparation for the "English history lectures for my women" ( $L$, I, 227; April 1905). On May 10, she noted in the diary part of this notebook that she had read Freeman's first volume: "It amuses me, as English History always does, \& Freeman is a good manly writer with no nonsense about him." The front part of this notebook also contains lists of articles written or contemplated by Woolf during 1904 and the beginning of 1905 and a list of the books she read in January 1905.

\section{B. ENTRIES}

1. "Freemans History of the Norman Conquest/vol. 5.": 2 pp., not numbered; on the reverse of the pages numbered 173, 171 by NYPL. More notes on this work appear below, B.3.

Freeman, Edward A. History of the Norman Conquest of England. Vol. V [of VI]. Oxford: Clarendon Press, 1876.

2. "Dicey/Law or/Opinion/vol.1./56-": 1 p., not numbered; on the reverse of the page numbered 170 by NYPL. The heading is in the margin and is a reference to A. V. Dicey's Lectures on the Relations Between Law and Public Opinion During the Nineteenth Century; the entry, however, consists of general notes, unidentified, about the legal status of women in the eighteenth century and about the perceived danger of women's colleges.

3. "Freeman 5. 81.": 2 pp., not numbered; on the reverse of the pages numbered 169, 168 by NYPL. More notes on this work appear above, B.1.

Freeman, Edward A. History of the Norman Conquest of England. Vol. V [of VI]. Oxford: Clarendon Press, 1876.

\section{Choephori of Aeschylus. Edited by A. W. Verrall. Holograph Reading Notes, Dated January 1907. (Berg)}

The table of contents for the notes in this volume indicates both the subject and the date: Aeschylus's The 'Choephori,' read or begun 
in January 1907. The notes appear at the back of "[Mrs. Dalloway] Holograph notes, unsigned, dated Nov. 9, 1922-Aug. 2, 1923."

\section{A. Table of Contents}

1. Choephori

of Aeschylus

Edited by

A. W. Verrall.

Jan: 1907

1 p., not numbered.

B. Entries

1. "Orestes:": $15 \mathrm{pp}$., the first 14 numbered $1-14$ by VW. The last page is unnumbered.

Aeschylus. The 'Choephori.' With an Introduction, Commentary, and Translation by A. W. Verrall. Macmillan, 1893.

\section{Holograph Reading Notes, January 1909-March 1911. (Berg)}

Although the date "January./1909." appears at the top of the table of contents for this volume, the entries seem to range from November 1908 to March 1911. During August 1908, Woolf read St. Simon $(L, I, 426)$, whose name is listed and cancelled both in the table of contents and in her notes on Hamlet (B.6). She read Romeo and Juliet (B.3) in November 1908 ( $L, \mathrm{I}, 456)$ and Cowper (B.5) during December and January 1908/1909 ( $L, I, 464)$. In January, she records having "talked for long stretches about Tolstoy" (B.4; L, I, 466). The entry on Macbeth (B.9) notes that she read the play in a train travelling through Switzerland and France; Woolf went to Italy both in September 1908 and April/May 1909. The entries on Laurence Sterne and Oliver Wendell Holmes (B.10-14) were made during the summer of 1909 in preparation for her reviews of biographies of the two writers: "Sterne," TLS, August 12, 1909 (Kp. C35), and "Oliver Wendell Holmes," TLS, August 26, 1909 (Kp. C37). The works by Emerson, Crabbe, and Keats noted in B.15-18 all appear in the list of her reading in B.19, dated "Oct," 1909. In March 1910, Woolf published a review of Emerson's Journals (TLS, March 3, 1910; Kp. C44). 
The notes and page numbers are in blue/gray ink; the lists of her reading in B.1 and B.19 include pencilled notes.

These notes are found in the back of "[Night and day. Chapters 11-17] Holograph draft."

A. Table of Contents

1.

January.

1909.

Loves Cross Currents. 1. Keats letters to F. Brawne. 24

Romeo \& Juliet. $\quad$ 2. The Rehearsal. Buckingham 27

Anna Karenine.

3. Tartufe.

29

Cowpers Letters.

4. Conduct of Life.

25

Hamlet.

5. The Way of the World

St. Simon

7.

Lear.

8

Othello.

10

Macbeth.

12

$x$ Tristram Shandy

13

$x$ Sentimental Journey.

15

x Autocrat of Breakfast 17

$x$ Table.

$\mathrm{x}$ Professor

18.

$x$ Elsie Venner

19

The Borough.

20

$x$ Emerson's Life.

.21

$x$ for reviews

$1 \mathrm{p}$. , not numbered.

B. ENTRIES

1. "Suggestions": 1 p., not numbered. The entry consists of a list of authors and titles, presumably of works that Woolf intended to read:

Crawshaw.

Prometheus Unbound

Collins.

Memoirs of Carlo Gozzi.

Boissier. Caesar?-Tacitus.

Casanova

Ibsen

Maeterlinck 
Synge

Racine

Moliere

2. "Loves Cross Currents./Swinburne.": 1 p., numbered 1 by VW. General notes, beginning, "Swinburne has his own prose-ends with [ . . ] very often - a great swell \& break in sentences."

Swinburne, Charles Algernon. Love's Cross Currents: A Year's Letters. [1905].

3. "Romeo \& Juliet.": 1 p., numbered 2 by VW. General notes, beginning, "Who shall say anything of Romeo \& Juliet? Do I dare?-in private: it seems to me very immature work ."

Shakespeare, William. Romeo and Juliet.

4. "Tolstoy./Anna Karenine.": 1 p., numbered 3 by VW. General notes, beginning, "There seems to me, on first sight, a remarkable cleanness about his work." There are no references to the translation or edition; Woolf's spelling of "Karenine," however, suggests she may have read a French translation.

Tolstoi, Leo. Anna Karenina.

5. "Cowpers Letters.": 1 p., numbered 4 by VW. Entry dated "Dec." The entry begins, "A great book which I read, as a sparrow sips, in bed at night." This suggests that she may have been reading the four-volume edition of the Correspondence edited by Thomas Wright (1904), which is listed in Holleyman \& Treacher, V/s, I, 4.

Cowper, William. Correspondence.

6. "Hamlet.": 3 pp., numbered 5-7 by VW. The entry includes notes on the play and on A. C. Bradley's analysis of Hamlet, beginning on p. 6: "Bradleys chief points are that people who make Hamlet a weak sentimentalist are wrong." On p. 7 appears the cancelled heading, "Saint Simon."

a) Shakespeare, William. Hamlet, Prince of Denmark.

b) Bradley, A. C. Shakespearean Tragedy. [1904].

7. "Lear.": 2 pp., numbered 8-9 by VW. General notes, beginning, "One realises that Lear has always been stormy. His daughters have suffered from it."

Shakespeare, William. King Lear. 
8. "Othello.": 2 pp., numbered $10-11$ by VW. General notes, beginning, "This seems to me to be simpler than the other tragedies, because Othello \& Desdemona stand out above all the rest; and draw all interest to them."

Shakespeare, William. Othello, The Moor of Venice.

9. "Macbeth.": 1 p., numbered 12 by VW. General notes, beginning, "I hesitate to write of this play, because I read it in the train, ..."

Shakespeare, William. Macbeth.

10. "Tristram Shandy.": 2 pp., numbered $13-14$ by VW, and 1 p., on the reverse of $p$. 12. The notes on the reverse of $p .12$ are headed "Facts," and include dates for Sterne's life and works.

Sterne, Laurence. The Life and Opinions of Tristram Shandy, Gent. In Works. Vols. I-II. Johnson, etc., 1808.

11. "Sentimental Journey.": 2 pp., numbered 15-16 by VW.

Sterne, Laurence. A Sentimental Journey Through France and Italy. In Works. Vol. II. Johnson, etc., 1808.

12. "The Works of Oliver Wendell Holmes./Autocrat of the Breakfast Table.": 1 p., numbered 17 by VW.

Holmes, Oliver Wendell. The Autocrat of the Breakfast Table.

With an Introduction by Leslie Stephen. Macmillan, 1903.

13. "The Professor at the Breakfast Table.": 1 p., numbered 18 by VW.

Holmes, Oliver Wendell. The Professor at the Breakfast Table. Samson Low, etc., 1891. Vol. II of The Writings of Oliver Wendell Holmes. Riverside Edition.

14. "Elsie Venner.": 1 p., numbered 19 by VW. General notes, beginning, "This is simply breakfast table talk with a thread of story."

Holmes, Oliver Wendell. Elsie Venner; a Romance of Destiny. [1861].

15. "The Borough.": 1 p., numbered 20 by VW. General notes, beginning, "My first reading of Crabbe; I read him with unexpected pleasure, sitting by an open window, for the most part."

Crabbe, George. The Borough. [1810]. 
16. "Life of Emerson./Cabot.": 3 pp., numbered $21-23$ by VW; and $2 \mathrm{pp}$. on the reverse of pp. 20 and 21 . Entry dated

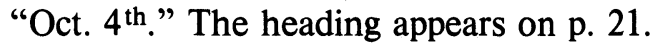

Cabot, James Eliot. A Memoir of Ralph Waldo Emerson. 2 vols. Boston: Houghton Mifflin, 1887.

17. "Keats Letters to F.B.": 1 p., numbered 24 by VW. General notes, beginning, "They must be read. They show him strong and gentle." Woolf was probably reading the collection edited by Buxton Forman in 1878, or the 2nd ed., 1889.

Keats, John. Letters . . to Fanny Brawne. [1878; 1889].

18. "Conduct of Life-Society \& Solitude./Emerson.": 2 pp., numbered $25-26$ by VW.

Emerson, Ralph Waldo. "The Conduct of Life" and "Sociey and Solitude." In Works. Ed. John Morley. Vol. V. Macmillan, 1883.

19. "Oct: Emersons Life- 2. vols.": 1 p., on the reverse of p. numbered 25 by VW. The entry is a list of books either read or to be read by Woolf:

Emersons Life- 2. vols.

Society \& Solitude 1-

Manfred- 1 vol.

Master Builder

Masques \& Phases

Green Shutters

Middlemarch 1 vol.

Waste

Crabbe Borough.

Keats Letters to F.B.

20. "The Rehearsal./Duke of Buckingham.": 1 p., numbered 27 by VW. General notes, beginning, "Very much rougher \& less well written than the Critic; but has a broader humour; \& some sayings that are beyond Sheridan."

Buckingham, 2nd Duke of [George Villiers]. The Rehearsal.

21. "The Way of the World.": 1 p., numbered 28 by VW.

Congreve, William. The Way of the World.

22. "Tartufe.": 1 p., numbered 29 by VW. General notes, beginning, "After reading English comedies, the astonishing ma- 
turity of Moliere strikes one." There is no indication of whether Woolf was reading a French or an English edition.

Molière, Jean Baptiste de. Tartuffe.

23. "Ibsen. The play of general ideas.": 1 p., numbered 30 by VW. Entry dated "1911." General notes on Ibsen, with a reference to "The Wild Duck."

Ibsen, Henrik. The Wild Duck.

24. "Le Depit Amoureux.": 1 p., numbered 31 by VW. Entry dated "March. 1911." General notes, beginning, "One begins by feeling trapped in a tiny heart." There is no indication whether Woolf was reading a French or an English edition.

Molière, Jean Baptiste de. Le Depit Amoureux.

\section{XXX. [A Writer's Diary] Holograph Notebook. November 16, 1918-January 24, 1919. (Berg)}

This particular set of reading notes appears at the opposite end of a notebook that Woolf later used as a part of her diary for 1918 and 1919. As a result, the reading notes do not have their own entry in the Berg catalogue. The date, "Jan. 14 th 1918," attached to the first of the reading notes, as well as the interest in critical essays shown throughout the volume, suggest that this is the first of six volumes that pertain to The Common Reader (1925). Although Woolf had not yet begun to talk about writing a critical book, several of the works that appear in reading lists in this volume (B.2, B.5) reappear as entries in the next two volumes of Common Reader notes: XXXVIII, which contains a series of quotations and notes from critics past and present, and XLIX, which includes ideas for Reading, the original title for the work. (Later notes for The Common Reader appear in Volumes XXV, XIX, and XLVII.)

Almost all of the entries in this notebook can be dated in 1918. On January 11, Woolf recorded having finally received a copy of Colvin's "Life of Keats" (B.2; see D, I). On February 4, she took her review of Coleridge's Table Talk and Omniana (B.3-4) to the Times; "Coleridge as Critic" was published in the $T L S$ on February 7, 1918 (Kp. C101). On March 2, she records having read Morley's Recollections (B.6) during February $(D, \mathrm{I})$, and her notes on this work provide a 
sidelight on her reading at that time. They conclude with a criticism of Morley as a "super butler": "Literature becomes infinitely decorus; \& I find it a relief to turn to the novels of L. Merrick, about chorus girls, where at least something seems alive \& quick \& irresponsible." A letter written on February 25, 1918, records her reactions to reading "the works of Leonard Merrick, a poor unappreciated second rate pot-boiling writer of stories about the stage" ( $L$, II, 910). The same letter records that she had begun reading Sophocles (B.10), and she continued to read Sophocles until at least December 1918 ( $L$, II, 978; $D$, I, December 17, 1918).

The table of contents was probably compiled as she read the works themselves; it is written variously in turquoise and purple ink. The page numbers, with the exception of the last entry, are turquoise; the entries are in turquoise and purple ink.

\section{A. Table of Contents}

1.

Page

Wordsworth's Preface to Lyrical Ballads.--1

Colvin's Life of Keats. . . . ....................... 3.

Coleridges Table Talk \& Omniana ........... 7.

Lord Morleys Reminiscences ................. 11

Endymion ............. 12

Dryden. Essay in Dramatic Poesy. 16.

Shelley's Defense of Poetry 19.

Oedipus Coloneus 21

$1 \mathrm{p} .$, not numbered.

B. ENTRIES

1. "Wordsworth's Preface to Lyrical Ballads/1800 (W's Literary Criticism-Frowde 1905)": 2 pp., numbered 1-2 by VW. Entry dated "Jan. 14th $1918 . "$

Wordsworth, William. "Preface to Lyrical Ballads" (1800). In Wordsworth's Literary Criticism. Ed. Nowell C. Smith.

Frowde, 1905.

2. "Colvin's Life of Keats.": 4 pp., numbered 3-6 by VW, and 3 pp., on the reverse of pp. $2,3,4$. The notes on the opposite sides are references to other works that are mentioned in Colvin's text: a) "Coleridge Biog. Lit.": S. T. Coleridge, Biographia Literaria; b) "Essays \& Studies by Mary Suddard./1912"; and c) "Preface to Alastor./Henry Crabb Rob- 
inson Diaries": P. B. Shelley, "Preface" to Alastor or The Spirit of Solitude; Henry Crabb Robinson, Diary, Reminiscences, and Correspondence. Notes on the Biographia Literaria and on Robinson's Diary appear in XXXVIII, B.5 and B.19, along with a set of notes on Keats's Letters, edited by Colvin (B.22).

Colvin, Sidney. Johin Keats. His Life and Poetry, his Friends, Critics, and After-Fame. Macmillan, 1917.

3. "Coleridges Table Talk \& Omniana./Omniana. (in my edition)": 1 p., numbered 7 by VW.

Coleridge, Samuel Taylor. Omniana. In The Literary Remains. Ed. Henry Nelson Coleridge. Vol. I. Pickering, 1836.

4. "Table Talk-Oxford Edition. 1918.": 4 pp., numbered 7-10 by VW.

Coleridge, Samuel Taylor. The Table Talk and Omniana. With a note ... by Coventry Patmore. Oxford Univ. Press, 1917.

5. "Sidneys Apologie./14th Chap of Biog. Lit:/W ths preface to the 2nd Ed. of L.B./Shelley's Defence.": 1 p., on the reverse of the page numbered 10 by VW. (Heading only.) The entry consists of a list of critical works that Woolf perhaps planned to read in preparation for her own critical book. The references are to Sir Philip Sidney, Apologie for Poetrie; S. T. Coleridge, Biographia Literaria, Ch. 14, which includes a history and defence of the Lyrical Ballads; William Wordsworth, "Preface" to Lyrical Ballads, 2nd ed. (1800); and P. B. Shelley's Defence of Poetry. Notes on Sidney's Apologie appear in XLVII, B.5; notes on the Biographia Literaria in XXXVIII, B.5; notes on Wordsworth's "Preface" in B.1, above; and notes on Shelley's Defence in B.9, below.

6. "Morley. Recollections. vol. 1.": 1 p., numbered 11 by VW. The entry ends with a general note, beginning, "What a thick shady, solemn book this is-the autobiography of a super butler; ..."

Morley, John, Viscount. Recollections. Vol. I [of II]. Macmillan, 1917.

7. "Endymion.": 4 pp., numbered $12-15$ by VW. Entry annotated "Oxford Edition. Buxton Forman."

Keats, John. Endymion: A Poetic Romance. In The Complete Poetical Works. Ed. H. Buxton Forman. Frowde, 1907. Oxford Edition. 
8. "Dryden. Essay of Dramatic Poetry./Edited by Ker. Oxford. 1900.": 3 pp., numbered 16-18 by VW; and 1 p., on the reverse of p. 16. More notes on Dryden's Essays appear in XLIX, B.29.

Dryden, John. An Essay of Dramatic Poesy. In Essays. Ed. W. P. Ker. Vol. I. Oxford: Clarendon Press, 1900.

9. "Shelley's Defence of Poetry./(This is in the small edition of Letters \& Essays/Edited by $M^{\text {rs }}$ Shelley).": 2 pp., numbered $19-20$ by VW.

Shelley, Percy Bysshe. A Defence of Poetry. In Essays, Letters from Abroad, Translations and Fragments. Ed. Mrs. Shelley. Vol. I. Moxon, 1840.

10. "Oedipus Coloneus./606-615": 1 p., numbered 21 by VW. The numbers in the heading are line references.

Sophocles. The Oedipus Coloneus. With Critical Notes, Commentary, and Translation into English Prose by R. C. Jebb. Cambridge: Cambridge Univ. Press, 1885. Vol. II of The Plays and Fragments.

\section{Modern Novels (Joyce). Holograph Notebook, Unsigned and Undated. (Berg)}

On March 5, 1919, Woolf noted in her diary that she had to read "The entire works of Mr James Joyce, Wyndham Lewis, Ezra Pound so as to compare them with the entire works of Dickens \& Mrs. Gaskell" $(D, I)$. In this entry, she was very likely planning for her essay on "Modern Novels," published in the TLS, April 10, 1919 (Kp. C147). Her notes on Ulysses (which she read in The Little Review: B.3), on May Sinclair's review of Dorothy Richardson's novels (B.2), and on Thackeray's Pendennis (B.5) in this notebook, as well as the "Sketches of Article" (B.4), all contributed to that essay. (On May 16, 1919, she returned The Little Review, which she apparently did not subscribe to herself, to Mary Hutchinson: $L$, VI, 1046a.) Three years later, when Woolf read Ulysses as a completed book and thought it a "mis-fire" ( $D$, II, September 6, 1922), she compared it again to Thackeray's Pendennis, which she seems to have reread at the same time and found, in some ways, "more illuminating" ( $D$, II, September 26, 1922; see also August 16, 22, 26, September 3, 1922). 
The notes on The Life and Letters of William Thomson, Archbishop of York (B.6) were made for her review of this work, "The Soul of an Archbishop," Athenaeum, May 9, 1919 (Kp. C151). These two articles locate this notebook between March and May 1919.

A label reading "MODERN NOVELS (Joyce)," and the title, "MODERN NOVELS," both appear on the cover of the notebook in black ink; the notes are black as well.

A typescript of this notebook appears in the Monk's House Papers, Sussex, as MH/B.3f.

B. ENTRIES

1. "Order of Ulysses/I-claret red./II-pale blue ...": 1 p., not numbered. The entry is annotated "Modern Novels"; it consists of a list of numbers from I-VII, each one followed by a color. This list corresponds to the seven episodes of James Joyce's Ulysses that Woolf read in The Little Review. See below, B.3.

2. "Reality is thick \& deep.": 1 p., not numbered. Marginal notation, "Miss/Sinclair/Little/Review." The entry appears on the same page as B.1. The notes include a reference to "Remy de Gourmont, Promenades Litteraires" which is a reference to the passages from Gourmont's essays, "L'Originalité de Maeterlinck" and "La Leçon de Sainte-Antoine" [Promenades Littéraires, Series 5 and 3] quoted by May Sinclair in her review.

Sinclair, May. "The Novels of Dorothy Richardson." The Little Review 5, no. 12 (April 1918): 3-11.

3. "Ulysses James Joyce": 5 pp., not numbered. The entry begins on the same page as B.1 and B.2; it consists of notes on the first seven episodes of Ulysses, published in The Little Review from March to October 1918. A note at the end of the entry reads, "Tristram Shandy Would my objections apply to T.S? I believe Johnson was outraged by TS T.S. has a warmer temperature than Ulysses."

Joyce, James. Ulysses.

I. The Little Review 4, no. 11

(March 1918): 3-22.

II. The Little Review 5, no. 12

(April 1918): 32-45.

III. The Little Review 6, no. 1

(May 1918): 31-45. 
IV. The Little Review 6, no. 2 (June 1918): 39-52.

V. The Little Review 5, no. 3 (July 1918): $37-49$.

VI. The Little Review 5, no. 5 (Sept. 1918): 15-37.

VII. The Little Review 5, no. 6 (Oct. 1918): 26-51.

4. "Sketches of Article.": 5 pp., not numbered, including one page opposite that with the heading. (Fifth page, 2 lines only.) The entry consists of notes for Woolf's essay on "Modern Novels," beginning, "No one has any wish to abuse the ancients."

5. "Its a very queer convention that makes us/believe that people talked or felt or lived as/J.A. \& Thack. \& Dickens make them-the only/thing is that we're used to it": 1 p., not numbered. Marginal notation, "Pendennis." The entry begins on the last page of B.4, and is related to her notes for "Modern Novels." See above, B.4.

Thackeray, William Makepeace. The History of Pendennis. Vol. I [of II]. Bradbury \& Evans, 1849.

6. "The Life \& Letters of/William Thomson. Archbishop of York": 2 pp., not numbered.

Thomson, Ethel H. The Life and Letters of William Thomson, Arch-Bishop of York. The Bodley Head, 1919.

\section{XXXII. [Flush] Holograph and Typewritten Reading Notes, Unsigned and Undated. (Berg)}

With two exceptions, all the entries in this volume record Woolf's reading and ideas for Flush: A Biography (1933). After its publication, she claimed that "Flush [was] only by way of a joke. I was so tired after the Waves, that I lay in the garden and read the Browning love letters, and the figure of their dog made me laugh so I couldn't resist making him a Life" ( $L, \mathrm{~V}, 2707$, February 23, 1933). The book, then, originated in the summer of 1931, and by September, Woolf was asking Vita Sackville-West for a picture of her spaniel in connection with what she called her "little escapade" ( $L, I V, 2436)$. During the following year, however, while she worked to complete The 
Common Reader: Second Series and suffered the death of Lytton Strachey, whom she had meant to parody and amuse by her biography, she appears to have stopped writing Flush, if not reading for it. Then, in July 1932, she was again "[nibbling] at Flush" ( $L, \mathrm{~V}$, 2615), and by October, she was "enjoying [her] writing, word by word, hugely" ( $L, \mathrm{~V}, 2640)$. On December 23, 1932, she bemoaned "four months of work and heaven knows how much reading - not of an exalted kind either" for the book; and on January 26, 1933, Flush, she swore, "was despatched" ( $A W D)$.

The other entries-one on Scott's Ivanhoe (B.18) and one a list that reads "Flush/Ivanhoe/Dekker" (B.21) -almost certainly belong to the summer or fall of 1931 when Woolf recorded taking Ivanhoe to bed with her ( $L, I V, 2426$, September 2$)$ and was reading for her Elizabethan essays in The Common Reader. In a letter written December 12,1931, Woolf speaks of collecting her thoughts on Sir Walter Scott as if she were contemplating a critical piece on his work $(L, I V$, 2482).

The mixture of inks and the typewritten versions of notes that also exist in holograph indicate both the sporadic nature of Woolf's reading for her life of Flush and the care she took over the details. The notes are in various shades of blue, purple, and black ink, pencil, and type.

\section{A. TABle of Contents}

1. Flush

1 p., numbered 1 by NYPL.

B. ENTRIES

1. "Brownings:": 2 pp., numbered 2-3 by NYPL. (P. 3, 2 lines only.) More notes on this work appear below, B.13, B.15, and B.17.

Browning, Elizabeth Barrett. Letters. Ed. F. G. Kenyon. Vol. I [of II]. Smith, Elder, 1897.

2. "Last Chapter": 2 pp., numbered 4-5 by NYPL. General notes for Chapter V of Flush: A Biography, beginning, "Mrs. B. on the rock. The house at Pisa."

3. "Flush. Browning Letters": 2 pp., numbered 6-7 by NYPL. Typed. More notes on this work appear below, B.12. 
Browning, Robert, and Browning, Elizabeth Barrett. Letters: 1845-1846. Ed. Robert W. B. Browning. 2 vols. Smith, Elder, 1899.

4. "Letters to Mrs B's Sister.": 2 pp., numbered 7-8 by NYPL. Typed. More notes on this work appear below, B.14.

Browning, Elizabeth Barrett. Letters to her Sister 1846-1859. Ed. Leonard Huxley. Murray, 1929.

5. "British Dogs.": 1 p., numbered 9 by NYPL. The entry consists of notes on spaniels. More notes on this work appear below, B.16 and B.19.

Dalziel, Hugh. British Dogs. 2nd ed. Vol. I [of III]. Upcott Gill, 1870.

6. "Life of Miss Mitford.": 1 p., numbered 10 by NYPL. More notes on this work appear below, B.11.

[Mitford, Mary Russell.] The Life of Mary Russell Mitford... . Related in a Selection from her Letters to her Friends. Ed.

A. G. L'Estrange. Vols. I-II [of III]. Bentley, 1870.

7. "Letters": 1 p., numbered 11 by NYPL. More notes on this work appear below, B.10.

Mitford, Mary Russell. Letters. Ed. H. Chorley. 2nd ser. Vol. I [of II]. Bentley, 1872.

8. "Miss Mitford Life/DNB.": 1 p., numbered 12 by NYPL.

Lee, Elizabeth. "Mitford, Mary Russell." DNB (1894).

9. "EBB's Letters to/Horne.": 3 pp., numbered 13-15 by NYPL.

Browning, Elizabeth Barrett. Letters ... Addressed to Richard

Hingist Horne. Ed. S. R. Townsend Mayer. 2 vols. Bentley, 1877.

10. "Miss Mitford Letters.": 1 p., numbered 16 by NYPL. More notes on this work appear above, B.7.

Mitford, Mary Russell. Letters. Ed. H. Chorley. 2nd ser. Vol. I [of II]. Bentley, 1872.

11. "Miss Mitfords Life.": 1 p., numbered 17 by NYPL. More notes on this work appear above, B.6.

[Mitford, Mary Russell.] The Life of Mary Russell Mitford ... Related in a Selection from her Letters to her Friends. Ed.

A. G. L'Estrange. Vol. III [of III]. Bentley, 1870. 
12. "519 The duty owed by the individual to society/523 cd not touch her dinner-": 1 p., numbered 18 by NYPL. (Heading only.) More notes on this work appear above, B.3.

Browning, Robert, and Browning, Elizabeth Barrett. Letters: 1845-1846. Vol. I [of II]. Smith, Elder, 1899.

13. "Flush": $5 \mathrm{pp}$., numbered 19-23 by NYPL. The entry is also headed, "Mrs. B's Letters." P. 19 consists of page references for Flush. More notes on this work appear above, B.1, and below, B.15 and B.17.

Browning, Elizabeth Barrett. Letters. Ed. F. G. Kenyon. Vol. I [of II]. Smith, Elder, 1897.

14. "Mrs. B.'s Letters to her Sister": 3 pp., numbered 24-26 by NYPL. More notes on this work appear above, B.4.

Browning, Elizabeth Barrett. Letters to her Sister 1846-1859.

Ed. Leonard Huxley. Murray, 1929.

15. "Kenyon's Letters": 3 pp., numbered 27-29 by NYPL. More notes on this work appear above, B.1 and B.13, and below, B.17.

Browning, Elizabeth Barrett. Letters. Ed. F. G. Kenyon. 2 vols. Smith, Elder, 1897.

16. "British Dogs": 1 p., numbered 30 by NYPL. More notes on this work appear above, B.5, and below, B.19.

Dalziel, Hugh. British Dogs. 2nd ed. Vol. I [of III]. Upcott Gill, 1870.

17. "Mrs. Browning's Letters": 1 p., numbered 31 by NYPL. More notes on this work appear above, B.1, B.13, and B.15.

Browning, Elizabeth Barrett. Letters. Ed. F. G. Kenyon. Vol. II [of II]. Smith, Elder, 1897.

18. "Ivanhoe.": 1 p., numbered 32 by NYPL. 5 lines only, reading, "The design: flat; pictorial. A story teller rather ashamed of telling stories. Chose to tell it, because he thought that the Scottish stories palled. his dialogue when not in dialect so bad."

Scott, Walter. Ivanhoe. [1819].

19. "British Dogs": 1 p., numbered 33 by NYPL. Typed. The entry includes notes found in the other entries on this work, B.5 and B.16, above. 
Dalziel, Hugh. British Dogs. 2nd ed. Vol. I [of III]. Upcott Gill, 1870.

20. "difficulties of making out Flushs ancetsry": 1 p., numbered 34 by NYPL. Typed. General notes for Flush: A Biography.

21. "Flush./Ivanhoe/Dekker": 1 p., numbered 35 by NYPL. (Heading only.)

\section{XXXIII. [Three Guineas] Holograph Reading Notes, Unsigned and Undated. (Berg)}

Of the eleven Three Guineas notebooks, this is perhaps the most cohesive, consisting of a series of annotated quotations and notes all of which appear in the text or the footnotes of the finished book. All of the entries are made on the same kind of paper-pages torn from a spiral notepad with the perforations at the top-and all of the notes are found in at least one other notebook, the majority of them in Volume LIX, the second of the " 3 bound volumes of Press Cuttings \& extracts ... relative to $3 \mathrm{Gs}$." In fact, two groups of entries, B.1-5 and B.11-22, correspond almost exactly to entries in Volume LIX: B.46, B.52-53, B.55, and B.57-68. These details suggest that Woolf gathered the material in this volume from other notes when she was actually writing Three Guineas during 1937-possibly in preparation for her "bibliography and notes" (see $A W D$, October 12, 1937). Even here, however, the chronology of the notebooks is uncertain; it is also possible that the notes in this volume preceded those in the " 3 bound volumes." Other passages, for example, copied on similar paper to that in this volume, appear in LX, B.73-77, the last of the " 3 bound volumes," immediately after an entry on Broadbent (B.72) that corresponds to B.8 in this volume. The specific cross-references are listed in the individual entries below. (For the other Three Guineas notes, see Volumes VII, X, XXVI, XXXIX, and LV-LX.)

With the exception of B.15, which is in pencil, all the notes are in black ink.

B. ENTRIES

1. "Synge Or Yeats Dramatis Personae./127.": 1 p., numbered 1 by NYPL. Quotation, beginning, "How often I have wished that he might live long enough to enjoy that communion 
with idle, charming \& cultivated women ...." This quotation also appears in LIX, B.46.

Yeats, W. B. The Death of Synge. In Dramatis Personae. Macmillan, 1936.

2. "About the year 1848 they (the P./daughters) committed the unpardonable solecism of/driving down Regent St. in a/ hansom cab/Paxton \& the bachelor duke/288.": 1 p., numbered 2 by NYPL. (Heading only.) This quotation also appears as LIX, B.51.

Markham, Violet R. Paxton and the Bachelor Duke. Hodder \& Stoughton, 1935.

3. "There is no limit to the cruelties/men will inflict for the sake/of gain/BR. Freedom \& . . /250": 1 p., numbered 2 by NYPL. (Heading only.) This quotation also appears as LIX, B.52.

Russell, Bertrand. Freedom and Organization: 1814-1914. Allen \& Unwin, 1934.

4. "Miss Weeton": 2 pp., numbered 3-4 by NYPL. Quotations annotated "XVII" and "14," "Miss Weeton. Journal of a/Governess - 1807-1811./Ed. Edward Hall/Ox U. P." The quotations begin, "Why are not females permitted to study physic, divinity, anatomy, \&c, \&c . .. ," and "Oh! how I have burned to learn Latin, French, the Arts ...." These quotations also appear in LIX, B.53.

Weeton, Miss [Ellen]. Journal of a Governess 1807-1811. Ed. Edward Hall. Oxford Univ. Press, 1936.

5. "Pages from the Past/Lord Desart.": 1 p., numbered 5 by NYPL. 2 lines only, reading, "Lady M. Lascelles had allowance of $£ 100$ in the 60ties?" This note also appears as LIX, B.55.

Desart, Earl of [H.J.A. Cuffe]. A Page from the Past. Memories ... by himself and his daughter, Lady Sybil Lubbock. Cape, 1936.

6. "Women, I think, ought not/to sit down to table with men; . . .": 1 p., numbered 6 by NYPL. Quotation, annotated "58-9." This quotation also appears as LVIII, B.4.

Joad, C.E.M. Under the Fifth Rib: A Belligerent Autobiography. Faber \& Faber, 1932. 
7. "I have also a feeling that girls'/schools ...": 4 pp., numbered 6-9 by NYPL. Quotations and notes, annotated "Things Ancient \& Modern./by C. A Alington, 216-17," "p. 186," and "Alington. 163." The second two quotations begin, "Of their body, Lord Rosebury was the most distinguished ....," and "Following out the suggestion of one of the Prime Minister's Committees on Education, ..." All three reappear in B.22, below, and in LIX, B.68. The first quotation is the basis of VII, B.5.

\section{Alington, C. A. Things Ancient and Modern. Longmans, Green, 1936.}

8. "The Life of Sir William Broadbent,/KCV.O F.R.S Edited by his daughter/ME Broadbent, p. 242.": 2 pp., numbered 10-11 by NYPL. Quotations, annotated "p. 242" and "p. 252 ," beginning, "I have taken a good deal over $£ 13,000$ during the year ...," and "It is literally true to say that for many years, during the busiest months of the London season, ..." The first quotation also appears as LX, B.72.

[Broadbent, Sir William.] The Life of Sir William Broadbent.

Ed. M. E. Broadbent. Murray, 1909.

9. "The Life of Joseph Wright/by Elizabeth Mary Wright/Vol. 1. 315": 1 p., numbered 12 by NYPL. Quotation, beginning, "I have always held woman far higher than man in God's creation ...." Quotations from this work also appear as LVIII, B.27 and B.66; notes on the book appear in X, B.1.

Wright, Elizabeth Mary. The Life of Joseph Wright. Vol. I lof II]. Oxford Univ. Press, 1932.

10. "Antony. (Viscount Knebworth)./by tor the Earl of Lytton.": 2 pp., numbered 13-14 by NYPL. Quotations, annotated "20," "Feb. 24th 1916," and " 355 ," beginning, " $\mathrm{He}$ is telling us some lovely yarns about the front now ...," and "We talked of the League of Nations \& the prospects of peace \& disarmament." Quotations from this work also appear as B.18, below, and in LIX, B.11 and B.64.

Lytton, Earl of [Victor A.G.R.]. Antony (Viscount Knebworth). A Record of Youth. By his father. Peter Davies, 1935.

11. "freshmen of 1881 ...": 1 p., numbered 15 by NYPL. Quotation, annotated "Anthony Hope \& his/Books. Sir C/Mallet," "38." This quotation also appears as LIX, B.57. 
Mallet, Sir Charles. Anthony Hope and his Books. Hutchinson, 1935.

12. "Above all, the years he had spent in/leading a varied life at a minimum expense ...": 1 p., numbered 16 by NYPL. Quotation, annotated "Gino Watkins/JM Scott," "59." This quotation also appears as LIX, B.58.

Scott, J. M. Gino Watkins. Hodder \& Stoughton, 1935.

13. "The girls then were supposed to lead/very much chaperoned \& sheltered/lives.": 2 pp., numbered 17-18 by NYPL. Quotations, annotated "Bright Armour/Monica Salmond," "18" and "20." The second quotation begins, "I called at two hospitals (shadowed by my maid ...." These quotations also appear in LIX, B.59.

Salmond, Monica. Bright Armour. Memories of Four Years of War. Faber \& Faber, 1935.

14. "Being a Bishop": 2 pp., numbered 19-20 by NYPL. Quotations, annotated "Life of Charles Gore/G.L. Prestige," "240-1," and "353," beginning, "He was a reformer \& a prophet ...," and "Men do not value ministrations which are gratuitous." These quotations also appear in LIX, B.60; other quotations from this work appear as LIX, B.13.

Prestige, G. L. The Life of Charles Gore. Heinemann, 1935.

15. "Reflections \& Memories/Sir John Squire/1935": 1 p., numbered 21 by NYPL. Quotation, annotated "p. 10," beginning, "...; \& the women, content with the prospect of a municipal vote as widow-householders, ..." This quotation also appears as LIX, B.61.

Squire, Sir John. Reflections and Memories. Heinemann, 1935.

16. "The Life of an Artist./Margaret Collyer.": 4 pp., numbered 22-25 by NYPL. Quotations and notes, annotated "7982 ," beginning, "End of the Victorian era.-Why the female of the species shd. never be given the same advantages as the male is difficult to understand." Two sets of notes on these pages appear as LIX, B.12 and B.62.

Collyer, Margaret. Life of an Artist. An Autobiography. Philip Allen, 1935.

17. "The Days before Yesterday.": 2 pp., numbered 26-27 by NYPL. Quotation, annotated "Lord Frederic Hamilton/ 1920 ," "322," beginning, "In my mother's young days be- 
fore her marriage, ..." This quotation also appears as LIX, B.63.

Hamilton, Lord Frederic. The Days Before Yesterday. Hodder \& Stoughton, 1920.

18. "Captain Rowland Phillips has been here/today giving us some lovely tips . . .": 2 pp., numbered 28-29 by NYPL. Quotations, annotated "Antony. 20," and "Antony. 77." The second quotation begins, "But this is the crowning blow. I've got my xxii \& I've not got into Pip-" Quotations from this work also appear as B.10, above, and in LIX, B.11 and B.64.

Lytton, Earl of [Victor A.G.R.]. Antony (Viscount Knebworth). A Record of Youth. By his father. Peter Davies, 1935.

19. "'political' genius in the hitherto downtrodden./244 English Fabric/F.J. Harvey Darton.": 1 p., numbered 30 by NYPL. (Heading only.) Quotations from this work are found in LIX, B.65.

Darton, F. J. Harvey. English Fabric. A Study of Village Life. George Newnes, [1935].

20. "He went to his Chambers about half past/nine ...": 5 pp., numbered 30-34 by NYPL. Quotations and notes, annotated "Sir Ernest Wild/KC./R.J. Blackham," "91," “95," and "260." Other notes on this work appear as LIX, B.66.

Blackham, Robert J. Sir Ernest Wild. Rich \& Cowan, 1935.

21. "Oil Paint \& Grease Paint/Laura Knight": 1 p., numbered 35 by NYPL. Quotations and notes, annotated " 47 ," and " 45 ," beginning, "If the men worked from the human figure I had to go into the Antique Room ...," and "Women were not allowed to draw from the nude." Another set of notes on this work appears as LIX, B.67.

Knight, Laura. Oil Paint and Grease Paint. Autobiography. Nicholson \& Watson, 1936.

22. "Things Ancient \& Modern./Alington.": 4 pp., numbered 3639 by NYPL. Quotations, annotated "163," "186," and "217," beginning, "Following out the suggestion of one of the PM. C tees on Edc ${ }^{n}$. ..," "Lord R. endowed a history scholarship ....," and "I have also a feeling that girls schools . . . " All three quotations appear in B.7, above, 
and in LIX, B.68. The third quotation is the basis of VII, B.5.

Alington, C. A. Things Ancient and Modern. Longmans, Green, 1936.

\section{Monk's House Papers/A.21. (Sussex)}

The Monk's House Papers Catalogue lists this notebook as "VS. [Virginia Stephen] Greek and Latin Studies." The first entry, her notes on Juvenal's Satire I, is dated "Dec. 1 1 st 1907"; the dates on the subsequent entries run through 1908 to " $25^{\text {th }}$ May" 1909. At the end of the entries, Woolf added the comment, "Read over again, Jan. 1917." The envelope containing this notebook also contains a torn sheet of blue paper, with notes beginning, "The gold June rising from dirt, from dried earth." This fragment is undated.

A large portion of the notes in this volume are translations of the texts or notes based on the editors' introductions; but Woolf also comments in her own voice while translating, and almost every entry concludes with general notes on the work. Another set of notes from this period, headed "Cheophori of Aeschylus./edited by A.W. Verrall/Jan. 1907," appears at the back of the manuscript listed as "[Mrs. Dalloway] Holograph notes" (Berg) and as Volume XXVIII, above.

Pages 1-10 are numbered in blue pencil; all the rest of the page numbers, and most of the notes, are in black ink. Some of the notes on the Odyssey (B.4) are in regular and blue pencil. Pages 9-10 are blank, indicating perhaps that Woolf meant to go on with her notes on Juvenal.

\section{A. Table of Contents}

1. The Satires of Juvenal.

Satire I. page 1. His reason for writing satire.

Satire 3. " 2. Why a man may not live in Rome.

Satire 6. " 7. On Woman.

The Odyssey of Homer. 11.

Books 1, 2, 3, 4.

Books 5, 6 .

Books 6, 7

13

Books 7, 8 .

Book 9.

Ajax: Sophocles. 62.

The Frogs. 74.

The Phaedrus. 77. 
Book 10.

17

Book 11

19.

Book 12.

22.

Book 13

24

Book 14

24

Book 15

27.

Book 16.

29.

Book 17.

31.

Book 18.

33

Book 19.

Book 20.

35

Book 21.

36

Book 22.

37

Book 23.

38

Book 24.

39

Ion of Euripides. $\quad 42$.

Symposium. $\quad 53$

$4^{\text {th }}$ Georgic 60 .

Frogs Aristophanes $\quad 63$

1 p., not numbered.

B. ENTRIES

1. "Juvenal./Satire I.": 1 p., numbered 1 by VW. Entry dated "Dec. $1^{\text {st }} 1907 . "$

Juvenal. Satire $I$.

2. "Satire. 3.": 5 pp., numbered $2-6$ by VW.

Juvenal. Satire III.

3. "Second Book. Satire 6.": 2 pp., numbered 7-8 by VW. (Page 8,3 lines only.)

Juvenal. Satire VI.

4. "Odyssey.": $31 \mathrm{pp}$., numbered 11-41 by VW, and $3 \mathrm{pp}$., on the reverse of pp. 22, 23, and 37. Entry dated on p. 11, "(Feb. 27 th 08)." The notes begin, "(Begun in Greece, 1906-\& the first four books were read there-so I give only a summary of them)." The remainder of the notes consists of translations and comments.

Homer. The Odyssey. Books 1-24.

5. "End of Odyssey./15th May. 08.": 1 p., numbered 41 by VW. General notes on the Odyssey, beginning, "This is a charac- 
teristic ending; as though the voice, simply, had finished speaking, the sun having set, \& it being time for bed." See above, B.4.

6. "Ion of Euripides./A.W. Verrall.": 9 pp., numbered $42-50$ by $\mathrm{VW}$, and $5 \mathrm{pp}$., on the reverse of pp. 42, 43, 46, 48, and 49. Entry dated on p. 42 , "May $18^{\text {th }}$ ", and on p. 50 , at the end of the notes, "5th June 08."

Euripides. The Ion. With a Translation into English Verse, and an Introduction and Notes by A. W. Verrall. Cambridge: Cambridge Univ. Press, 1890.

7. "The Ion": 2 pp., numbered 51-52 by VW. General notes on Euripides' The Ion, beginning, "The chief puzzle in the play, of course, is-what view did Euripides take of the conduct of Apollo?" See above, B.6.

8. "Plato. Symposium.": 7 pp., numbered 53-59 by VW, and 2 pp., on the reverse of pp. 52 and 55. Entry dated on p. 59, at the end of the notes, " $15^{\text {th }}$ July $08 . "$

Plato. The Symposium.

9. "Virgil. $4^{\text {th }}$ Georgic.": 2 pp., numbered $60-61$ by VW, and 2 pp., on the reverse of pp. 59 and 60 . Entry dated on page 60 , "28 th July."

Virgil. The Fourth Georgic.

10. "Ajax. Sophocles.": 7 pp., numbered 62, 64-65, 67-70 by $\mathrm{VW}$, and 1 p., on the reverse of p. 65. Entry dated on p.

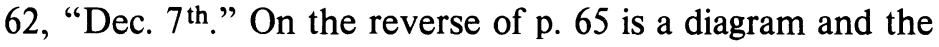
notes that explain it: "A-Chorus of Salaminean Sailors. B. tent of Ajax. C. Odysseus \& Athena. D. Ships \& sea."

Sophocles. The Ajax. With Critical Notes, Commentary, and Translation in English Prose by R. C. Jebb. Cambridge: Cambridge Univ. Press, 1896. Vol. VII of The Plays and Fragments.

11. "Ajax.": 2 pp., numbered 71-72 by VW. General notes on Sophocles' Ajax, beginning, "The story of the Ajax is as follows: ..."; and continuing "The impression left by the play is complex of course. I should say that the points which Sophocles had in view were to represent an ide heroic human being in conflict with law: \& the first part of the play is the best." See above, B.10. 
12. "Jebbs introduction.": 1 p., numbered 73 by VW. The entry consists of notes on R. C. Jebb's "Introduction" to Sophocles, The Ajax.

Jebb, R. C. "Introduction." In Sophocles. The Ajax. With Critical Notes, Commentary, and Translation in English Prose by R. C. Jebb. Cambridge: Cambridge Univ. Press, 1896. Vol. VII of The Plays and Fragments.

13. "Frogs:": 1 p., numbered 74 by VW. Entry dated "Jan: $11^{\text {th: }}$ 09."

Aristophanes. The Frogs. Greek text revised with a Translation, Introduction and Commentary by Benjamin Bickley Rogers. Bell, 1902.

14. "Bickley Rogers on Af Frogs.": 2 pp., numbered 75-76 by VW. The entry consists of notes on Benjamin Bickley Rogers' "Introduction" to Aristophanes' The Frogs. Rogers' "Introduction" concludes with passages from "The Growth and Influence of Classical Greek Poetry," lectures delivered in 1892 by R. C. Jebb, which are noted by Woolf on p. 76 . See above, B.13.

15. "Notes": 1 p., numbered 77 by VW. Entry dated " $25^{\text {th }}$ May." On the reverse of p. 76, facing this entry, are unidentified numbers. The entry 'consists of notes on Plato's Phaedrus. It is possible that Woolf was reading the edition that belonged to her brother Thoby Stephen, listed in Holleyman \& Treacher (V/s, I, 46): Plato, The Phaedrus, with English notes and dissertations by W. W. Thompson (Bibliotheca Classica, 1868).

Plato, The Phaedrus.

16. "Read over again, Jan. 1917. an interval of nearly/ten years.": 1 p., numbered 79 by VW. (Heading only.)

17. "The golden June rising from dirt, from/dried earth, ...": 1 p., not numbered. The entry consists of notes on a torn sheet of blue paper, found in the envelope that contains this notebook. The remainder of the notes read: "\& the midges, staining the sky, making a net a veil, slowly dreamily: gilding shopwindows staining faces, \& turning the pavements to beaten brass." 


\section{Monk’s House Papers/B.1a. (Sussex)}

The description of this notebook in the Monk's House Papers Catalogue reads "1905-6. Virginia Stephen's ms notes on ca. 45 books read for review in The Guardian, the Academy, Times, and Speaker." The notes are almost exclusively on books that Woolf read, and usually reviewed, between January 1905 and July 1906. Almost every entry includes a notation indicating the day she made the notes and the periodical for which she was reviewing the book. The actual date and place of publication of the review appear in brackets in the individual descriptions of entries below.

While many of the reviews of the books recorded in this notebook are listed in the second edition of Kirkpatrick's Bibliography of Virginia Woolf (1967), a substantial number of them are not. In those cases, my identifications must be read as tentative. Where the review does not appear in Kirkpatrick, other sources of information about her reading or reviewing are given in the description of the entry. One source of information is Woolf's correspondence during this period that mentions, for example, that she is reviewing "books from the Times, the Academy, the Guardian" ( $L, I, 251$, November 9, 1905), and that she has "never been without 3 books in hand since I came back. The Times sends me one novel every week" ( $L$, I, 252, November 10, 1905). Another source of information about this period is the manuscript notebook, "[Diary] No. 3" (Berg), dated "Christmas, 1904-May 31, 1905." This diary both records the books she is reading and reviewing on a day-by-day basis, and lists, in the back, her "Work Done" in 1905 until the time she stopped making entries. Another list of reviews, this time of books she reviewed for The Guardian during 1905, appears below as B.36. In this list, each title is followed by the word-count for the review; at the bottom, the words are totalled and the sum $\mathbf{£ 3 . 9 -}$ - written next to it.

Most of the notes in this volume are made in pencil. Often the heading and/or the date appear in black ink; the periodical is usually written in pencil. The notations of the date and periodical are usually placed above the heading in the top corners of the page, or above and below the heading. The page numbers are in black ink from 1 through 101; the rest are in pencil.

\section{B. ENTRIES}

1. "A Belle of the Fifties/Memoirs of M $^{\text {rs }}$ Clay of Alabama/put into narrative form by Ada Sterling/Heinemann/10/6 net.": 
9 pp., numbered 1-9 by VW. Entry annotated "(Guardian)," "24th Jan: 1905." ["A Belle of the Fifties." Guardian, February 8, 1905, p. 247. Kp. C05.]

[Clay, Virginia Clopton.] A Belle of the Fifties: Memoirs of Mrs. Clay of Alabama. Put into narrative form by Ada Sterling. Heinemann, 1905.

2. "Cambridge Modern Hist, United States": 1 p., on the reverse of p. 1. See above, B.1.

Wilson, Woodrow. "States Rights. (1850-1860)." In The Cambridge Modern History. Vol. VII: The United States. Ed. A. W. Ward, G. W. Prothero, and Stanley Leathes. Cambridge: Cambridge Univ. Press, 1903.

3. "The Golden Bowl./Henry James./Methuen: 6/-": 13 pp., numbered 10-22 by VW, and $1 \mathrm{p}$., on the reverse of p. 9 . Entry annotated "Guardian," " 7 th Feb:." The notes on the reverse of p. 9 read, "Henry James the master of a point of view. Typical Americans \& Italians." ["Mr. Henry James's Latest Novel." Guardian, February 22, 1905, p. 339. Kp. C06.]

James, Henry. The Golden Bowl. Methuen, 1905.

4. "The Dickens Country/Frederic G. Kitton/Adam \& Charles Black. 6/.": 3 pp., numbered 23-25 by VW. Entry annotated "The Times," "15th Feb:." ["Literary Georgraphy." TLS, March 10, 1905, p. 81. Kp. C1.]

Kitton, Frederic G. The Dickens Country. Adam \& Charles Black, 1905.

5. "The Thackeray Country./Lewis Melville. Adam \& Charles Black/6/.": 2 pp., numbered 25-26 by VW. Entry annotated "The Times." ["Literary Geography." TLS, March 10, 1905, p. 81. Kp. C1.]

Melville, Lewis. The Thackeray Country. Adam \& Charles Black, 1905.

6. "Good photographs./Neither T. nor D. had a country in the sense that/Scott or $\mathrm{Ch}$. Brontë had one.": 2 pp., numbered 26-27 by VW. Notes on Thackeray and Dickens for her review, "Literary Georgraphy," based on the books recorded in B.4 and B.5, above.

7. "Barham of Beltana./W.E. Norris./Methuen \& Co. 6/-": 2 pp., numbered $28-29$ by VW. Entry annotated "The Times," 
"4th March." ["'Barham of Beltana."” TLS, March 17, 1905, p. 90. Kp. C1.1.]

Norris, W. E. Barham of Beltana. Methuen, 1905.

8. "By Beach and bogland./Jane Barlow. T. Fisher Unwin 6/-":

1 p., numbered 30 by VW. (6 lines only.) Entry annotated "The Guardian," "9th March." Woolf mentions this work in "[Diary] No. 3," both on Saturday, March 11, and in the list of books under "1905" at the back. [Review. Guardian, March 22, 1905, pp. 507-508.]

Barlow, Jane. By Beach and Bogland: Some Irish Stories. Unwin, 1905.

9. "Nancy Stair./Elinor MacCartney Lane. Heinemann 6/-": 2 pp., numbered 31-32 by VW. Entry annotated "Guardian." Woolf mentions this work in "[Diary] No. 3," both on Sunday, March 12, and in the list of books under "1905" at the back. [Review. Guardian, May 10, 1905, p. 803.]

Lane, Elinor MacCartney. Nancy Stair. Heinemann, 1905.

10. "Catherine de Medici \& the French Reformation/Edith Sichel. Constable. 15/-": 15 pp., numbered 33-47 by VW. Entry annotated "12 th March," "Times." Her review of this book was not published. See "[Diary] No. 3," Friday, March 10 and Sunday, March 12; and $L$, I, 221. The entry ends with general notes on the work, pp. 46-47, beginning, "Miss Ss object to rescue a few vivid facts or remains impression-to throw some light upon the characters of an age \& thus indirectly upon its events. Question how far this serves a useful purpose."

Sichel, Edith. Catherine de Medici and the French Reformation. Constable, 1905.

11. "French Reformation/Cambridge Modern Hist. 280.": 2 pp., on the reverses of pp. 32 and 33. See above, B.10.

Tilley, A. A. "The Reformation in France." In The Cambridge Modern History. Vol. II: The Reformation. Ed. A. W.

Ward, G. W. Prothero, and Stanley Leathes. Cambridge:

Cambridge Univ. Press, 1903.

12. "The Fortunes of Farthings": 2 pp., numbered 48-49 by VW. Entry annotated "Times," "18 th March." ["The Fortunes of Farthings." TLS, March 31, 1905, p. 106. Kp. C1.2.]

Dawson, A. J. The Fortunes of Farthings. Harper, 1905. 
13. "Letters from Catalonia/by Rowland Thirlmere/2 vols: 24/Hutchinson \& Co.": 4 pp., numbered $50-53$ by VW. Entry annotated "Times," "28 th April." On the reverse of p. 49 are pencil notes: "3 [ . . ] = 1-9." ["Journeys in Spain." $T L S$, May 26, 1905, p. 167. Kp. C2.]

Thirlmere, Rowland. Letters from Catalonia and Other Parts of Spain. Hutchinson, 1905.

14. "The Land of the Blessed Virgin/William Somerset Maugham./ Heinemann": 3 pp., numbered 53-55 by VW. ["Journeys in Spain." TLS, May 26, 1905, p. 167. Kp. C2.]

Maugham, William Somerset. The Land of the Blessed Virgin. Sketches and Impressions in Andalusia. Heinemann, 1905.

15. "A Dark Lantern./[ . . ] Elizabeth Robins. Heinemann. 6/-": 1 p., numbered 56 by VW. Entry annotated "Guardian." The entry ends with the note, "emotion necessarily crudecf. Ch. Bronte. 255. eyes grow red when angry." [Review. Guardian, May 24, 1905, p. 899. Kp. C1.3.]

Robins, Elizabeth. A Dark Lantern. Heinemann, 1905.

16. "Rose of Lone Farm/Elinor Hayden. 6/- Smith Elder": 1 p., numbered 57 by VW. Entry annotated " $24^{\text {th }}$ June," "Guardian." [Review. Guardian, July 19, 1905, p. 1224.]

Hayden, Elinor G. Rose of Lone Farm. Smith, Elder, 1905.

17. "Five Genation of Eng/Famous Women of Wit \& Beauty": 1 p., numbered 58 by VW. (Heading only.) Entry annotated "Academy.," "August." See L, I, 244, n.1. ["Their Passing Hour." Academy, August 26, 1905, pp. 871-872.]

Fyvie, John. Some Famous Women of Wit and Beauty. A Georgian Galaxy. Constable, 1905.

18. "The Letter Killeth. A.C. Inchbold./S.W. Parthope \& Co.": 4 pp., numbered 58-61 by VW, and $1 \mathrm{p}$., on the reverse of $\mathrm{p}$. 59. Entry annotated "Times," "7th Oct:." ["The Letter Killeth." TLS, October 27, 1905, p. 359.]

Inchbold, A. C. The Letter Killeth. A Romance of the Sussex Downs. Partridge, 1905.

19. "The Devil's Due./G.B. Burgin": 1 p., numbered 62 by VW. Entry annotated "Oct. 14th," "Guardian." For a reference to Woolf's review, see below, B.36. [Review. Guardian, November 1, 1905, p. 1851.]

Burgin, G. B. The Devil's Due. A Romance. Hutchinson, 1905. 
20. "Lone Marie. W.E. Norris": 1 p., numbered 63 by VW. Entry annotated " $17^{\text {th }}$ Oct.," "Guardian." For a reference to Woolf's review, see below, B.36. [Review. Guardian, November 1,1905 , p. 1851.]

Norris, W. E. Lone Marie. Macmillan, 1905.

21. "The Brown House \& Cordelia/Margaret Booth": 1 p., numbered 64 by VW. Entry annotated "18 $18^{\text {th }}$ Oct.," "Guardian." For a reference to Woolf's review, see below, B.36. [Review. Guardian, December 6, 1905, p. 2086.]

Booth, Margaret. The Brown House and Cordelia. Edward Arnold, 1905.

22. "A Flood Tide. Mary Debenham./Arnold.": 2 pp., numbered 65-66 by VW, and 1 p., on the reverse of p. 64. Entry annotated " $23^{\text {rd }}$ Oct.," "Times." The notes on the reverse of $p$. 64 include Woolf's calculations of how many years ago the novel was set and numbers indicating the possible lengths of reviews: "Novels/1 column/800/500/300." ["A Flood Tide." $T L S$, November 17, 1905, p. 397.]

Debenham, Mary. A Flood Tide. Edward Arnold, 1905.

23. "The Tower of Siloam.": 1 p., numbered 67 by VW. Entry annotated "Guardian," "2 $24^{\text {th }}$ Oct." For a reference to Woolf's review, see below, B.36. [Review. Guardian, December 20, 1905 , p. 2172.]

Graham, Mrs. Henry. The Tower of Siloam. Alston Rivers, 1905.

24. "The House of Mirth./Edith Wharton. Macmillan \& Co. 6/-": $2 \mathrm{pp}$., numbered 68-69 by VW. Entry annotated " $25^{\text {th }}$ Oct.," "Guardian." For a reference to Woolf's review, see below, B.36. [Review. Guardian, November 15, 1905, p. 1940.]

Wharton, Edith. The House of Mirth. Macmillan, 1905.

25. "The Making of Michael. Mrs. Fred/Reynolds": 1 p., numbered 70 by VW. Entry annotated "29th Oct:," "Times." ["The Making of Michael." TLS, November 7, 1905, p. 397.]

Reynolds, Mrs. Fred. The Making of Michael. George Allen, 1905.

26. "The Voice of the South. Gilbert Watson.": 4 pp., numbered 71-74 by VW. Entry annotated "Guardian," " $30^{\text {th }}$ Oct." 


\section{$[\mathrm{XXXV}]$}

For a reference to Woolf's review, see below, B.36. ["A Description of the Desert." Guardian, December 6, 1905, p. 2085.]

Watson, Gilbert. The Voice of the South. Hurst \& Blackett, 1905.

27. "The Debtor/Mary E. Wilkins.": 2 pp., numbered $75-76$ by VW. Entry annotated "Nov. 6"t ", "Guardian/Times." ["The Debtor." TLS, November 17, 1905, p. 396.]

Freeman, Mary E. Wilkins. The Debtor. Harper, 1905.

28. "Mansie Wauch./D.M. Moir (reprint fr. 1828)": 1 p., numbered 77 by VW, and $1 \mathrm{p}$., on the reverse of p. 76. Entry annotated "Nov: $9^{\text {th }}$, "Guardian." For a reference to Woolf's review, see below, B.36. ["'Delta." Guardian, December 13, 1905, p. 2131.]

Moir, D. M. The Life of Mansie Wauch, Taylor in Dalkeith. Written by Himself. Edinburgh: Blackwood, 1905.

29. "Wilhelmina, Morgravine of Baireuth/Edith Cuthell. 2 vols": $21 \mathrm{pp}$., numbered $78-98$ by VW, and $3 \mathrm{pp}$., on the reverse of pp. 77, 78, 82. Entry annotated "Academy.," "Nov:

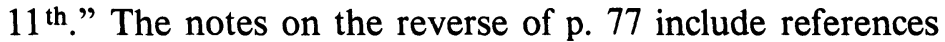
to three works about Wilhelmina and her brother, Frederick the Great, all of which appear in the introduction to Cuthell's book and reappear in the first paragraph of Woolf's review: Memoires de La Morgravine de Baireuth; C. A. Sainte-Beuve, "La Morgrave de Bareith. Sa correspondance avec Frederic," in Causeries de lundi; and Thomas Carlyle, History of Friedrich II of Prussia, called Frederick the Great. Carlyle's work is noted below, B.30. Woolf refers to Cuthell's book in $L, \mathrm{I}, 251$. ["The Sister of Frederick the Great." Academy, January 13, 1906, pp. 35-36.]

Cuthell, Edith E. Wilhelmina, Morgravine of Baireuth. 2 vols. Chapman \& Hall, 1905.

30. "Carlyle. F. the G": 1 p., numbered 99 by VW. (7 lines only.) The notes are on Wilhelmina, Morgravine of Baireuth, Frederick the Great's sister. See above, B.29.

Carlyle, Thomas. History of Friedrich II of Prussia, called Frederick the Great. Vol. V \& VI [of VII]. Chapman \& Hall, 1869. 
31. "Modern Europe.": 2 pp., numbered $99-100$ by VW. The entry consists of notes on the "Prussian kingdom" in relation to Frederick the Great and his sister Wilhelmina. See above, B.29.

Lodge, Richard. A History of Modern Europe. 1453-1878. Murray, 1885.

32. "Dan the Dollar. Shan F. Bullock. .": 3 pp., numbered 101103 by VW. Entry annotated "Times," "21 st Nov." ["Two Irish Novels." TLS, December 15, 1905, p. 445.]

Bullock, Shan F. Dan the Dollar. Dublin: Maunsel, 1905.

33. "The Red haired Woman. Louise Kened Kenny.": 4 pp., numbered 104-107 by VW. Entry annotated " $24^{\text {th }}$ Nov.," "Times." Woolf mentions having reviewed this book in $L$, I, 255. ["Two Irish Novels." TLS, December 15, 1905, p. 445.]

Kenny, Louise. The Red Haired Woman. Her Autobiography. Murray, 1905.

34. "Lectures \& Essays. Canon Ainger. 2. vols": 12 pp., numbered 108-119 by VW. Entry annotated "Dec. $3^{\text {rd }}$," "Speaker." On the reverse of p. 111 appears a reading plan: "Wed. Lect: \& Es . . . /Thurs/Fri/Sat." Woolf mentions being asked to review this book in $L, I, 254$. ["A Nineteenth-Century Critic." Speaker, January 6, 1906, p. 352.]

Ainger, Alfred. Lectures and Essays. 2 vols. Macmillan, 1905.

35. "After His Kind./M. Sturge Henderson": 1 p., numbered 120 by VW. Entry annotated "Dec: $17^{\text {th }}$," "The Guardian." For a reference to Woolf's review, see below, B.36. [Review. Guardian, January 10, 1906, p. 89.]

Henderson, M. Sturge. After his Kind. Duckworth, 1905.

36. "Night Walk. 800": 1 p., numbered 120 by VW. The entry consists of a list of titles and figures that record the number of words in Woolf's reviews for The Guardian in the latter half of 1905. The list reads: "Night Walk. 800/ Mansie Wauch 1500/ Devils Due 300/ Lone Marie 300/ Brown House 300/ Tower of Siloam 300/ House of Mirth 500/ Voice of the South 800/ After his Kind 300/ 15,000 [ . . ] $=£$ 3.9."

37. "Jan.: $16^{\text {th }}$ 1906. Guardian/(main part)/Seven vols. of plays $\&$ poems/1. King William the $1^{\text {st. }} /$ Arthur Dillon. Elkin Ma- 
thews.": 3 pp., numbered $121-123$ by VW. Woolf wrote that she had been sent " 7 volumes of poetry and tragedy to review" in $L, I, 260$. ["The Poetic Drama." Guardian, April 18, 1906, p. 651.]

Dillon, Arthur. King William I. The Conqueror. Elkin Mathews, 1905.

38. "Aurelian./by Spencer Moore./Longmans \& Co. 4/6. net.": 2 pp., numbered 124-125 by VW. This entry is the second of the "Seven vols. of plays \& poems": see above, B.37. On the reverse of p. 124 appears a reading schedule for the seven works, beginning, "Thurs. W. 1 st/Fri. Aurelian." ["The Poetic Drama." Guardian, April 18, 1906, p. 651.]

Moore, Spencer. Aurelian. A Drama of the Later Empire... in Prose and Verse. Longmans, Green, 1905.

39. "Sir Thomas More./Archibald Douglas Fox. 5/net/ Constable.": 1 p., numbered 126 by VW. This entry is the third of the "Seven vols. of plays \& poems": see above, B.37. ["The Poetic Drama." Guardian, April 18, 1906, p. 651.]

Fox, Archibald Douglas. Sir Thomas More. An Historical Play in Five Acts. Constable, 1905.

40. "The Little Mermaid/Alexandra V. Herder/Elkin Mathews": 1 p., numbered 127 by VW. This entry is the fourth of the "Seven vols. of plays \& poems": see above, B.37. ["The Poetic Drama." Guardian, April 18, 1906, p. 651.]

Herder, Alexandra Von. The Little Mermaid. A Play in Three Acts. Elkin Mathews, 1906.

41. "The City./by Arthur Upson": 1 p., numbered 128 by VW. This entry is the fifth of the "Seven vols. of plays \& poems": see above, B.37. ["The Poetic Drama." Guardian, April 18, 1906, p. 651.]

Upson, Arthur. The City: A Poem Drama, and Other Poems. New York: Macmillan, 1905.

42. "Plays \& Poems/Paul Hookham": 2 pp., numbered 129-130 by VW. This entry is the sixth of the "Seven vols. of plays \& poems": see above, B.37. ["The Poetic Drama." Guardian, April 18, 1906, p. 651.]

Hookham, Paul. Plays and Poems. Kegan Paul, Trench, Trubner, 1905. 
43. "The Two Arcadias./Rosalind Travers.": 2 pp., numbered 131132 by VW. This entry is the seventh of the "Seven vols. of plays \& poems": see above, B.37. ["The Poetic Drama." Guardian, April 18, 1906, p. 651.]

Travers, Rosalind. The Two Arcadias. Plays and Poems. Brimley Johnson \& Ince, 1905.

44. "A Supreme Moment./Mrs. Hamilton Synge": 2 pp., numbered 133-134 by VW. Entry annotated "Feb: 3 $3^{\text {rd }}$ " "Times." ["A Supreme Moment." TLS, February 16, 1906, p. 52.]

Synge, Mrs. Hamilton. A Supreme Moment. Unwin, 1905.

45. "The Scholars Daughter/Beatrice Harraden.": 2 pp., numbered 135-136 by VW. Entry annotated "Feb: 10 th," "Times." ["The Scholar's Daughter." TLS, February 16, 1906, p. 52.]

Harraden, Beatrice. The Scholar's Daughter. Methuen, 1906.

46. "The House of Shadows./R.J. Farrer./Edward Arnold 6/-": 2 pp., numbered 137-138 by VW. (P. 138, 4 lines only.) Entry annotated "Feb: 17th," "The Times." ["The House of Shadows." TLS, March 9, 1906, p. 84.]

Farrer, Reginald J. The House of Shadows. Edward Arnold, 1906.

47. "The Authors Progress/Adam Lorimer": 1 p., numbered 139 by VW. Entry annotated "Feb: 23rd," "Guardian." [Review. Guardian, July 25, 1906, p. 1254.]

Lorimer, Adam. The Author's Progress or The Literary Book of the Road. Edinburgh: Blackwood, 1906.

48. "Blanche Esmead./Mrs. Fuller Maitland.": 1 p., numbered 140 by VW. Entry annotated "Times. March. 17th." ["Blanche Esmead." TLS, March 23, 1906, p. 104.]

Maitland, Ella Fuller. Blanche Esmead: A Story of Diverse Temperaments. Methuen, 1906.

49. "A Woman of Wit \& Wisdom./A. CC. Gaussen.": 4 pp., numbered 141-144 by VW. Entry annotated "Guardian. March. 18 th." ["The Bluest of the Blue." Guardian, July 11, 1906, p. 1179.]

Gaussen, Alice C. C. A Woman of Wit and Wisdom: A Memoir of Elizabeth Carter. Smith, Elder, 1906. 
50. "English Voyages of $16^{\text {th }}$ Cent./Walter Raleigh.": 4 pp., numbered $145-148$ by VW, and $2 \mathrm{pp}$., on the reverse of pp. 144 and 146. Entry annotated "March. 23 $3^{\text {rd }}$," "Speaker." On the reverse of p. 144 are general notes on Raleigh, beginning, "The simplicity. Ennumeration. something that really happened. something quite new." ["Trafficks and Discoveries." Speaker, August 11, 1906, pp. 440-441.]

Raleigh, Sir Walter. The English Voyages of the Sixteenth Century. Glasgow: Maclehose, 1906.

51. "Elizabeth Barrett Browning/in her letters. Percy Lubbock.": 4 pp., numbered 149-152 by VW. Entry annotated " 2 nd April," "Speaker." ["Poets' Letters." Speaker, April 21, 1906, pp. 63-64. Kp. C4.]

Lubbock, Percy. Elizabeth Barrett Browning in her Letters. Smith, Elder, 1906.

52. "Robert Browning \&/Alfred Domett./F.G. Kenyon": 2 pp., numbered $153-154$ by $\mathrm{VW}$, and $1 \mathrm{p}$., on the reverse of $\mathrm{p}$. 152. Entry" annotated " 5 th April Speaker." On the reverse of p. 152 appears the note "End of A Guardian Angel," a reference to the poem by Browning, "A Guardian Angel," that includes an allusion to Domett in the last lines. The poem is discussed by Kenyon on p. 140. ["Poets' Letters." Speaker, April 21, 1906, pp. 63-64. Kp. C4.]

Kenyon, Frederic G. Robert Browning and Alfred Domett. Smith, Elder, 1906.

53. "The Face of Clay./H.A. Vachell.": 1 p., numbered 155 by VW. Entry annotated "Times: April $8^{\text {th }}$." ["The Face of Clay." TLS, April 13, 1906, p. 133.]

Vachell, Horace Annesley. The Face of Clay. Murray, 1906.

54. "Fenwicks Career./Mrs. H. Ward.": 3 pp., numbered 156-158 by VW. (P. 158, 1 line only.) Entry annotated "Guardian. $3^{\text {rd }}$ May." In $L, I, 264$, Woolf talks of sending her "H Ward to the Speaker, but I see they have a review already." It is unclear whether Woolf's review was published.

Ward, Mrs. Humphrey. Fenwick's Career. Smith, Elder, 1906.

55. "A House of Letters./Edited by Ernest Betham.": 3 pp., numbered 159-161 by VW, and 1 p., on the reverse of p. 158 . Entry annotated "May $11^{\text {th }}$," "Speaker." The reverse of $p$. 158 consists of the name "Coleridge," some of whose let- 
ters appear in this collection. No review of this work appears in the Speaker.

Betham, Ernest, ed. A House of Letters. Jarrold, 1905.

56. "Wordsworths Guide to the Lakes./Selincourt": 5 pp., numbered 162-166 by VW. Entry annotated "The Times.," "May 21st." The entry includes notes on de Selincourt's "Introduction." ["Wordsworth and the Lakes." TLS, June 15,1906 , p. 216. Kp. C5.]

Wordsworth, William. Guide to the Lakes. 5th ed. (1835). Ed. Ernest de Selincourt. Frowde, 1906.

57. "Months at the Lakes./HD. Rawnsley.": 2 pp., numbered 167-168 by VW. Entry annotated "The Times.," "May 25th." ["Wordsworth and the Lakes." TLS, June 15, 1906, p. 216. Kp. C5.]

Rawnsley, H. D. Months at the Lakes. Glasgow: Maclehose, 1906.

58. "Mrs. Grundys Crucifix:/Vincent Brown.": 1 p., numbered 169 by VW. Entry annotated "Times," "27th May." ["Mrs. Grundy's Crucifix." TLS, June 22, 1906, p. 226.]

Brown, Vincent. Mrs. Grundy's Crucifix. Hutchinson, 1906.

59. "The Compromise. D. Gerard": 1 p., numbered 170 by VW. Entry annotated "The Times.," "June fune 10"th." ["The Compromise." TLS, June 15, 1906, p. 217.]

Gerard, Dorothea. The Compromise. Hutchinson, 1906.

60. "Henry Ryecroft": 3 pp., numbered $171-173$ by VW. Entry annotated "[(for Guardian (private)]." ["'The Private Papers of Henry Ryecroft,' by George Gissing." Guardian, February 13, 1907, pp. 282-283.]

Gissing, George. The Private Papers of Henry Ryecroft. Constable, 1903.

61. "A German Pompadour./by Marie Hay. Constable. 12/6": 2 pp., numbered 174-175 by VW. Entry annotated "Academy," "27th June." ["Sweetness-Long Drawn Out." Academy, July 28, 1906, p. 81.]

Hay, Marie. A German Pompadour. Being the extraordinary history of Wilhelmine von Gravenitz, landhofmeisterin of Wirtemberg. Constable, 1906. 
62. "Coniston": 2 pp., numbered $176-177$ by VW. Entry annotated "Times.," "9th July." ["Coniston." TLS, July 13, 1906, p. 249.]

Churchill, Winston. Coniston. Macmillan, 1906.

63. “Auto. of De Quincey.": 1 p., numbered 178 by VW.

De Quincey, Thomas. Autobiographic Sketches. Vol. I [of II].

Edinburgh: James Hogg, 1853. Vol. I of De Quincey's Writings. Selections Grave and Gay.

\section{Monk's House Papers/B.2a. (Sussex)}

The notes in this volume were made from approximately the end of 1939 to, perhaps, January 1941. In an unpublished diary entry for January 3, 1940, Woolf not only mentions reading J. S. Mill's Autobiography (B.4) but also comments that she has copied a passage from it into a volume called, she says, deceptively, the Albatrossthe same title that appears on the spine of this notebook (see "[A Writer's Diary.] Jan. 3, 1940-Dec. 29, 1940." Berg). Woolf continued to read Mill during January and February. On January 26, she recorded "enjoying" Burke (B.7): "I shall tune up on the French Revolution" $(A W D)$. On February 9, she was still "[grinding] at Burke and Mill" $(A W D)$, although she must have been heartened by Harold Laski's opinion that " 3 gs. [was] the greatest book since Mill" ( $L$, VI, 3585). The diary includes a mention of "HALF" (i.e., Herbert Fisher), on November 5, 1940, although no mention of a book. On January 26, 1941, she noted that she would read "a good rather rocky book-viz: Herbert Fisher," but it is unclear whether this refers to Pages from the Past (B.6). The dates of publication for the other works noted all place them between 1939 and 1941.

The "List of Roger's books" referred to in the table of contents does not appear in the notebook itself. Roger Fry: A Biography was published in 1940.

The majority of the entries in this notebook consist of quotations about men, women, war, and politics similar to those found in Three Guineas. Woolf continued to collect material relevant to her arguments even after the book was published, in part, perhaps, in preparation for the essay on women and peace that she was asked to write for America at the end of 1939; as Woolf explained to Shena, Lady Simon, on January 22, 1940, her views on peace were necessarily 


\section{[ XXXVI]}

connected with her views on war ( $L$, VI, 3580). Ultimately, this article became "Thoughts on Peace in an Air Raid" (New Republic, October 21, 1940; Kp. C369), which includes quotations from Frank Lushington's autobiography recorded in B.8, below. For more notes pertaining to this essay, see XXI, B.4, XXXVII, B.2, and XXXIX, B.3.

A label pasted on the spine of the notebook reads:

The

\begin{tabular}{l} 
Albatross \\
\hline Letters \& \\
Memoir \\
\hline Marriott \\
\hline 1839.
\end{tabular}

The pages are numbered 3-12 and 19-48 in black ink; the entries, except for B.1, which is in pencil, are also in black ink.

\section{A. Table of Contents}

1. List of Roger's books. 1.

$\begin{array}{lll}\text { Jennie Lee } & 3 & \\ \text { Tom Bridges } & 5 & \\ \text { Mill. Auto } & 6 . & \text { Liberty } 5 \\ \text { Buttons. } & 8 & \end{array}$

1 p., not numbered.

B. ENTRIES

1. "Tomorrow is a new day. by Jennie Lee/1939.": 2 pp., numbered $3-4$ by $\mathrm{VW}$.

Lee, Jennie. Tomorrow is a New Day. Cresset Press, 1939.

2. "War was his natural element'/Times on Tom Bridges. $7^{\text {th }}$ Dec 39": 1 p., numbered 5 by VW. (Heading only.)

"Lieut.-General Sir Tom Bridges." Obituary. The Times, December 7, 1939, p. 11.

3. "But the man, \& still more the woman ...": 1 p., numbered 5 by VW. Two quotations, annotated "Mill Liberty 123," and "Mill: 18579." The second quotation begins, "188. The almost despotic power of husbands over wives needs not be enlarged upon here, ..."

Mill, John Stuart. On Liberty. Parker, 1859. 
4. "Mill. Autoy.": 2 pp., numbered 6-7 by VW. Quotation, annotated " 44 ," beginning, "The This lesson of keeping my thoughts to myself at that early age, was attended with some moral disadvantages. ..."

Mill, John Stuart. Autobiography. Longmans, Green, Reader \& Dyer, 1873.

5. "Buttons./Portrait of a Painter./Lasto László": 2 pp., numbered 8-9 by VW. (P. 9, 3 lines only.) Quotations, annotated "240" and "271-2." The first one begins, "I see that you are going to paint my button. Come nearer \& you will perceive that it is not an ordinary button, but has a very fine wavy inlaid line." The second quotation begins, "The portrait completely satisfied Canon Commanger \& $\mathrm{M}^{\text {rs }}$ Commanger, but the Field Marshall himself ... was worried."

Rutter, Owen. Portrait of a Painter. The Authorized Life of Philip de László. Hodder \& Stoughton, 1939.

6. "Politicians. HALF. Pages fr. the Past": 1 p., numbered 9 by VW. Quotation, annotated "214," beginning, "The great ideas wh. move the world \& exalt the character rarely come from the politicians."

Fisher, H.A.L. Pages from the Past. Oxford: Clarendon Press, 1939.

7. "Burke. 105. Rev. in France.": 1 p., numbered 10 by VW. Quotations, the second annotated "97." The first consists of a passage from Ecclesiastics 38, beginning, "The wisdom of a learned man cometh by opportunity of leisure," and the second begins, "It cannot escape observation, that when men are too much confined to professional $\&$ faculty habits, ..."

Burke, Edmund. Reflections on the Revolution in France. In Works. Vol. V. Rivington, 1803.

8. "To fight against a real enemy, ...": 2 pp., numbered 11-12 by VW. Quotations, annotated "Portrait of a Young Man. Franklin Lushington," "251-252," "286," and "259."

Lushington, Franklin. Portrait of a Young Man. Faber \& Faber, 1940. 


\section{Monk's House Papers/B.2c. (Sussex)}

The major portion of this notebook (B.3-11, 13-19) consists of notes Woolf made for her "Common History book," provisionally called Reading at Random or Turning the Page, between September 12, 1940, and her death on March 28, 1941. In fact, the books recorded here were among her original reading for the new work and provided many of the ideas in the manuscript headed "Notes for Reading at Random," as well as reappearing in her drafts for the first two chapters, "Anon" and "The Reader." Critical texts of both "Notes for Reading at Random" and the two chapters were published in " 'Anon' and 'The Reader': Virginia Woolf's Last Essays" ( $A \& R)$; additional reading notes for her "Common History" fill Volume XVI.

On September 12, 1940, Woolf "conceived, or re-moulded, an idea for a Common History book - to read from one end of literature including biography; and range at will, consecutively" ( $A W D)$. During the next few weeks she recorded in her diary the progress of the reading that enabled her to begin writing "Anon," the first chapter of her book, on November 24, 1940 (see $A W D$, September 14 and 17, October 12, November 23, 1940; and "Anon. Folder 1" [Berg], which is dated "24th Nov. 1940"). On October 17, she was "filling [her] mind slowly with Elizabethans" $(A W D)$; and on October 26, she began Trevelyan's History of England (B.6), the work that provided her with the opening sentence of "Anon": "For many centuries after Britain became an island' the historian says 'the untamed forest was king" " $(A \& R, 382$; for references to Trevelyan, see "[A Writer's Diary.] Jan. 3, 1940-December 29, 1940," Berg, entries dated October 26, November 5, and November 15, 1940). Later, on January 1, 1941, she recorded both having read about "the Great fire" (B.11) and salvaging from London "a handful of Elizabethans for my book" $(A W D)$. On February 4, she asked Vita Sackville-West for a biography of Lady Anne Clifford (B.18; L, VI, 3689); and on February 26, her " 'higher life' [was] almost entirely the Elizabethan play" $(A W D)$.

Perhaps the most important document in connection with this volume is "Notes for Reading at Random," which is dated on the first page " $18^{\text {th }}$ Sept. 1940." The outlines and ideas in this manuscript include references to several of the authors, works, or themes noted below: William Harrison, the author of the Description of England in Shakspere's Youth (B.3), a pivotal character in Woolf's portrayal of historical change; Spenser, and by implication The Faerie Queene (B.1415); witches (B.5); Madame de Sévigné (B.12); and Lady Anne 
Clifford (B.19), an old friend of Woolf's and her model of the early reader.

For the rest, the notes on Elizabeth Blackwell and The Ladies of Alderley that introduce the volume (B.1-2) were made either in conjunction with Three Guineas (1938) or as a continuation of her interest in its subject. At the end of 1939, for example, she had "promised to write something for America" about women and warultimately, "Thoughts on Peace in an Air Raid" (see L, VI, 3574, 3580). Woolf began reading the Lettres de Madame de Sévigné, de sa famille et de ses amis (B.12), the remaining entry in this volume, in September 1938, and continued to read them throughout the next two and a half years. On September 14, 1940, just after her decision to write a "Common History book," she mentions that she is reading Sévigné, and on December 29, 1940, while preparing "Anon," she again reached for the Lettres $(A W D)$. A note at the end of the Sévigné entry suggests a link between the Frenchwoman and the Elizabethans: "Colloquial language that comes straight from talk. not only there were people who talked, but the writer cd [?use] talk. Compare with Lady Anne B"-i.e., Lady Ann Bacon, whose uncolloquial prose in her letters to her sons is a major topic of "Anon." More notes on Sévigné's Lettres appear in XVI, B.1, and LIV, B.2.

A blue paper label pasted on the spine of the notebook reads:

Friday

March

11th

1938

Vol. I.

The ink throughout is black.

B. ENTRIES

1. "Pioneer Work ... Blackwell": 4 pp., numbered 1-4 by VW.

Blackwell, Dr. Elizabeth. Pioneer Work in Opening the Medical Profession to Women. Autobiographical Sketches. Longmans, Green, 1895.

2. "Income of girls: see Ladies of Alderly/for allowance given to Lady/Stanley ...": 1 p., not numbered. The entry consists of general notes on women and war, including a reference to "Maude Roydon in I have Been Young." The entry ends, "For Outsider: news. manufacture of toy soldiers for the buttonhole: to balance white feathers." 
a) [Stanley.] The Ladies of Alderley. Being the Letters between Maria Josepha, Lady Stanley of Alderley, and... Henrietta Maria Stanley. Ed. Nancy Mitford. Chapman \& Hall, 1938.

b) Swanwick, H. M. I Have Been Young. Gollencz, 1935.

3. "Reading at Random.": 2 pp., not numbered. Marginal notation, "Harrison." Reading at Random was the original title for Woolf's unfinished history of English literature. More notes on Harrison made at this time appear in XXI, B.6.

Harrison, William. Description of England in Shakspere's Youth.

Ed. Frederick J. Furnivall. 2 vols. New Shakspere Society, 1877-1878.

4. "An Elizabethan Journal-G. B. Harrison.": 4 pp., not numbered. The entry begins on the second page of B.3. The fourth page begins with the comment, "The nimbus of ignorance may have been favourable to the creative imagination."

Harrison, George B. An Elizabethan Journal . . 1591-1594. Constable, 1928.

5. "Books.": 1 p., not numbered. The entry consists of a list of titles of books about the Elizabethan and medieval periods, most of them original source material. Entries a-g appear as sources in G. B. Harrison's An Elizabethan Journal . . . 15911594 , noted above, B.4. Woolf may have planned to read these works for "Anon."

a) "Birch's Memoirs: 2 vols. 1754": Thomas Birch. Memoirs of the Reign of Queen Elizabeth from the Year 1581 until her Death. 2 vols. (1754).

b) "Fugger News Letters. (1926)": The Fugger News Letters. 2nd ser. Ed. Victor von Klarwill. Trans. L.S.R. Byrne. (1926).

c) "Henslowes Diary. Greg. 1904-7.": Henslowe's Diary. Ed. W. W. Greg. 2 vols. (1904-1908). See below, B.10.

d) "The Bodley Head. 4to Vol IX. Scot. Witches": King James the First. Daemonology (1597); and News from Scotland (1591). Ed. G. B. Harrison. (1924). Bodley Head Quartos, IX.

e) "Witches of Warboys. in/Transcript of the Registers of the Co/of Stationers of London 1554-1640./ Ar- 
ber 5 vols II. 633": The Most Strange and Admirable Discovery of the Three Witches of Warboys (1593). Recorded in A Transcript of the Registers of the Company of Stationers of London; 1554-1640 A.D. Ed. Edward Arber. (1875). II, 633.

f) "Death of $\mathrm{Ch}$ Marlowe. Leslie Hotson": J. Leslie Hotson. The Death of Christopher Marlowe (1925).

g) "Giffard Dialogue about Witches": George Giffard. $A$ Dialogue Concerning Witches and Witchcraft (1593).

h) "Defoe's Letters on Magic": Possibly, Daniel Defoe. A System of Magick; or A History of the Black Art (1727).

i) "Scott on Demonology": Possibly, Sir Walter Scott. Letters on Demonology and Witchcraft; Addressed to J. G. Lockhart, Esq. (1830).

j) "Medieval English Nunneries/Eileen Power": Eileen Power. Medieval English Nunneries, c. 1275 to 1535 (1922).

k) "Percy's Reliques. Brave Lord Willoughby:/The Winning of Cales: The Spanish/Ladies Love: $E^{\text {than }}$ Wars": Thomas Percy, Ed. Reliques of Ancient English Poetry (1765).

6. "Trev" History.": 2 pp., not numbered.

Trevelyan, George Macaulay. History of England. Longmans, Green, 1926.

7. "Coriolanus.": 1 p., not numbered.

Shakespeare, William. Coriolanus.

8. "Caxton b. about 1420": 1 p., not numbered. Marginal notation, "Med/[ . . ]." The entry consists of notes on Caxton's printing press. Source unidentified.

9. "Spenser/Payne Collier": 1 p., not numbered. (2 lines only.) The entry consists of a description of Spenser-"a little man with short hair, a small band \& cuffs. Aubrey"-which is found in Collier's "Life of Spenser," p. clv.

Collier, J. Payne. "The Life of Spenser." In The Works of Edmund Spenser. Ed. J. Payne Collier. Vol. I. Bell \& Daldy, 1862.

10. "Henslowes Diary": 2 pp., not numbered. More notes on this work appear in XVI, B.11. 
Henslowe, Philip. The Diary ... from 1591-1609. Ed. Walter W. Greg. 2 vols. Bullen, 1904-1908.

11. "Fire of London./Music": 1 p., not numbered. Quotation, annotated "Pepys 1666/2nd Sept. 1666 fire began." The passage - "Hardly one lighter or boat in three that had the goods of a house in, but there was a pair of virginals in it"-appears in Pepys' diary for "2d Sept 1666." It is uncertain whether Woolf was reading Pepys himself, or another source.

12. "Madame de Sevigné": 1 p., not numbered. Entry annotated "6./43. (1679)." More notes on this work appear in XVI, B.1, and LIV, B.2.

[Sévigné, Madame de.] Lettres de Madame de Sévigné, de sa famille et de ses amis. Ed. M. Monmerqué. New ed. Vol. VI [of XIV]. Paris: Hachette, 1862.

13. "Wm $\mathrm{Sh}^{\text {re }}$ EK Chambers.": 1 p., not numbered. Entry annotated "1./55."

Chambers, E. K. William Shakespeare: A Study of Facts and Problems. Vol. I [of II]. Oxford: Clarendon Press, 1930.

14. "Spenser F Q.": 2 pp., not numbered. The first page consists of notes on Books III and IV of The Faerie Queene; the second page consists of general notes about this work, beginning, "a dream world, a sea world, in which a veil swims before us."

Spenser, Edmund. The Faerie Queene. [Books III-IV]. In Works. Ed. J. Payne Collier. Vol. III. Bell \& Daldy, 1862.

15. "Bacon Essays.": 2 pp., not numbered. The entry includes notes on the "Preface" by W. A. Wright.

Bacon, Sir Francis. Essays and Colours of Good and Evil. Ed.

W. Aldis Wright. Macmillan, 1862.

16. "Wyndham. Sonnets.": 1 p., not numbered. Quotation, annotated "xxix from Rowland White to Sir Robert Sidney." The quotation is from a letter from Rowland White to Sir Robert Sidney, dated 1599, about noblemen "going to plays everyday" rather than to court. It appears in Wyndham's "Introduction" on p. xxix. Beneath the quotation appears the note, "Gossip from a Muniment Room/Lady Newdigate Newdegate," which is a work referred to several times 
by Wyndham in relation to Mary Fytton, once considered a model for the dark lady of the sonnets. See below, B.17.

Wyndham, George. "Introduction." In The Poems of Shakespeare. Methuen, 1898.

17. "Gossip fr. a Muniment Room/Lady N N./Newdigate-Newdegate": 2 pp., not numbered.

Newdigate-Newdegate, Lady [Anne Emily]. Gossip from a Muniment Room. Being Passages in the Lives of Anne and Mary Fytton 1574 to 1618. David Nutt, 1897.

18. "Lady Clifford": 1 p., not numbered. 3 lines only, reading, "terrene \& earthly matters - the double adjective-a great desire to commemorate \& monumentalise." More notes on this work appear in XIV, B.15.

Williamson, George C. Lady Anne Clifford... Her Life, Letters and Work. Kendal: Titus Wilson, 1922.

\section{Monk's House Papers/B.2d. (Sussex)}

On November 15, 1921, Woolf wrote in her diary, "if only I could find energy to tackle the Paston letters, I must start Reading" ( $D$, II). Reading, or Reading and Writing, was the name of the critical work-ultimately The Common Reader-that she began in earnest about this time: "Then I'm wondering how to shape my Reading book; the more I read of other peoples criticism the more I trifle; can't decide; nor need I just yet. But how I enjoy the exercise of my wits upon literature-reading it as literature" ( $D$, II, May 23, 1921). Thirty-six pages of notes on The Paston Letters enliven this notebook, as well as a series of sayings, quotations, and ideas culled from "other peoples criticism" and ranging from Plato's Symposium to T. S. Eliot's The Sacred Wood. Among these quotations is Johnson's statement about the role of "the common reader" that provided the title and the theme of the finished book.

While it is unclear exactly when she bound the notes and provided the alphabetical index that appears as the table of contents for this volume, we can date many of the individual entries. The notes on Hakluyt's Voyages and Froude's English Seamen of the Sixteenth Century (B.12-13) were made in December 1918 for her article on these books, "Trafficks and Discoveries," TLS, December 12, 1918 (Kp. C133; D, I, December 3, 7, 1918). On September 12, 1919, she 


\section{$[\underline{X X X V I I I]}$}

wrote in her diary and in a letter that she was reading a bit of Sir Thomas Browne (B.2) and that she had sent for his books ( $D, \mathrm{I} ; L$, II, 1081). Some of the material recorded in the entries on Hakluyt, Froude, and Thomas Browne recurs in her essay "Reading," which mentions the year 1919 as if it were the time of writing (CE, II, 26).

On November 4, 1920, Woolf was reading Plato's Symposium (B.17; $L$, II, 1150), and on December 5, 1920, she asked, "Why do I read Coleridge? Is it partly the result of Eliot whom I've not read ..." ( $D$, II). The unread Eliot work was The Sacred Wood, which had recently been reviewed by Leonard Woolf. As Olivier Bell notes about this passage in the Diary, Eliot's book begins, "Coleridge was perhaps the greatest of English critics." Woolf eventually read both critics (B.5, 8). On February 16, 1921, she was reading Dorothy Wordsworth (B.24, 25), whom on March 13 she "can't begin" ( $D$, II); it is unclear whether the latter reference is to reading Dorothy Wordsworth or writing about her. "Candide" and "Keats' Letters" (B.21, 22) were among "the classics" Woolf planned to read on a trip to Cornwall at the end of March 1921 (D, II, March 22), and a letter written on March 28 records her reading of Candide ( $L$, II, 1172). In April, she wanted to read Swift (B.20), though the work is unspecified. Her notes on Ben Jonson and Shakespeare $($ B.14, 18) are dated in the text June 1921 and August 1921. On December 8, 1921, she mentions that Roger Fry's reading aloud of a quotation from the French philosopher Benda (B.1) had started off a wide-ranging discussion $(D$, II).

Another light is shed on this notebook by what does not appear in it -in this case, the notes on Goldsmith and James listed in the table of contents but absent from the text. Both sets, however, are now part of Volume XXVI. A page headed "Novels. Form/(Vicar of Wakefield) Goldsmith" and numbered 7 by Woolf, and the following page, numbered 18 and headed "Novels (Form)" [XXVI, B.1-2], are almost certainly the missing pages $17-18$ in this volume. The missing James entry-Woolf's notes on The Wings of the Dove and on the ghost stories, both of which she read in the autumn of 1921-appears as XXVI, B.21, on pages numbered 33-38 by Woolf.

Finally, on January 3, 1922, Woolf recorded, "its my evening with the Pastons. Tonight my reading begins" (B.26-28). The dates of the entries in this notebook, as well as the comment in her diary on August 16, 1922, that she had already written " 4 thousand words of reading . . . a quick sketch of Pastons, supplied by books" $(D, \mathrm{II})$, indicate that this volume is the second of the six Common Reader notebooks. It should be read in conjunction with Volumes XLIX, 
$\mathrm{XXV}, \mathrm{XIX}, \mathrm{XLVII}$, and, in particular, XXX, which contains a similar set of notes on critics and criticism.

The table of contents appears on the cover of the notebook, written in black ink. The page numbers are in blue pencil. The majority of the notes are in blue-purple ink. Several of the page references in Woolf's notes are obscured by the binding of the notebook.

A. Table of Contents

\begin{tabular}{|c|c|c|}
\hline 1. $\mathrm{A}$ & Arnold. & 19 \\
\hline B & Benda. Belphégor & 1 \\
\hline & Browne. & 9 \\
\hline & Blake & 42 \\
\hline $\mathrm{C}$ & Chaucer & 12 \\
\hline & Coleridge & 15 \\
\hline D & & \\
\hline E. & Eliot & 20 \\
\hline F. & Fiction & \\
\hline & Froude & 30 \\
\hline G. & Gourmont & $16-21$ \\
\hline & Goldsmith & 17 \\
\hline $\mathrm{H}$ & Hakluyt & 23 \\
\hline $\mathbf{J}$ & Johnson. & 22 \\
\hline & Jonson. & 32 \\
\hline & James & 33 \\
\hline $\mathbf{M}$ & Mallarmé & 21 \\
\hline $\mathbf{P}$ & Plato & 41 \\
\hline & Pastons. & 52 \\
\hline $\mathrm{S}$ & Swift & 45 \\
\hline & Shakespeare. & 39 \\
\hline V. & Voltaire & 46 \\
\hline W. & Wordsworth & \\
\hline & $\begin{array}{l}\text { Dorothy } \\
\text { cover. }\end{array}$ & 48 \\
\hline
\end{tabular}

B. Entries

1. "Criticism Benda/Belphegor/Benda": 8 pp., numbered 1-8 by VW. Included in the notes are several quotations and extracts about women's influence on contemporary French society and esthetics, women's art, and the nature of "l'âme masculine"-associated with reason-and the feminine soul, 


\section{[ XXXVIII ]}

venerated by modern women, which is "immune from reasoning - it is all passion, instinct intuition."

Benda, Julien. Belphégor. Essai sur l'esthétique de la présente société française. Paris: Emile-Paul, 1918.

2. "Sir Thomas Browne.": 3 pp., numbered 9-11 by VW.

Browne, Sir Thomas. Religio Medici. In Works. Ed. Simon Wilkin. Vol. II. Pickering, 1835.

3. "Chaucer: Prose": 1 p., numbered 12 by VW. Entry annotated "M. Arnold./English Poets. xxxii," “38," "40." More notes on this work appear below, B.7.

Arnold, Matthew. "General Introduction." In The English Poets. Ed. Thomas Humphrey Ward. Vol. I. Macmillan, 1880.

4. "Chaucer. Eit. Hist. C.": 1 p., numbered 13 by VW. Marginal notation, "Lowell./Chaucer./267/My Study/Windows."

Lowell, James Russell. "Chaucer." In My Study Windows. Boston: Osgood, 1871.

5. "Coleridge./Poetry": 2 pp., numbered $14-15$ by VW. Marginal notation, p. 14, "B.L./v. 2." P. 15 is headed, "Coleridge. Biog. Lit."

Coleridge, Samuel Taylor. Biographia Literaria. Or Biographical Sketches of my Literary Life and Opinions. 2nd ed. 2 vols. Pickering, 1847.

6. "Style. Gourmont": 1 p., numbered 16 by VW. Quotation, annotated "33," "Prob. du Style."

Gourmont, Rémy de. Le Probleme du style. Questions d'art, de littérature et de grammaire. Paris: Mercure de France, 1902.

7. "Criticism of Contemporaries": 1 p., numbered 19 by VW. Entry annotated "M.A. Eng. Poets," "46." More notes on this work appear above, B.3.

Arnold, Matthew. "General Introduction." In The English Poets. Ed. Thomas Humphrey Ward. Vol. I. Macmillan, 1880.

8. "Eliot Criticism": 1 p., numbered 20 by VW. Entry annotated "Sacred Wood."

Eliot, T. S. The Sacred Wood. Essays on Poetry and Criticism. Methuen, 1920.

9. "Art of Writing": 1 p., numbered 21 by VW. Quotation, annotated "R. de Gourmont./Prom. Lit. 4th Series,/80." 
Gourmont, Rémy de. "Villiers de L'Isle-Adam." In Promenades Littéraires. 4th ser. Paris: Mercure de France, 1912.

10. "Abolie la prétention, esthetiquement une erreur . ..": 1 p., numbered 21 by VW. Quotation, annotated "Mallarmé Vers et Prose," "185." The entry appears under the general heading, "Art of Writing." See above, B.9.

Mallarmé, Stéphane. Vers et Prose. Paris: Perrin, 1893.

11. "Criticism": 1 p., numbered 22 by VW. Quotation, annotated "Johnson. Lives of the Poets." This passage, which begins "In the character of his elegy [Gray's], I rejoice to concur with the common reader ... .," is that which provided Woolf with the title for her critical book. See "The Common Reader," in The Common Reader (1925).

Johnson, Samuel. "Gray." In The Lives of the English Poets. [1792].

12. "Hakluyt. Vol. I.": 7 pp., numbered $23-29$ by VW. Pp. 23-27 are also numbered $1-5$ by VW in the same ink as the entry. The entry includes notes on Hakluyt's "Dedications" in Vols. I and II.

Hakluyt, Richard. Collection of The Early Voyages, Travels, and Discoveries of the English Nation. Vols. I-III [of V]. R. H. Evans, etc., 1809-1810.

13. "Froude. English Seamen.": 2 pp., numbered 30-31 by VW. P. 31 is also numbered 2 by VW in the same ink as the entry.

Froude, James Anthony. English Seamen in the Sixteenth Century. New ed. Longmans, Green, 1896.

14. "Bartholomew Fair/Ben Jonson.": 1 p., numbered 32 by VW. Entry dated "June 21." The top part of the page is missing. General notes, beginning, "A difficult scattered work." For a later set of notes on this play, see XIX, B.34.

Jonson, Ben. Bartholomew Fayre.

15. "Measure for Measure./Points made by Brandes (Vol 2: 70) are:-": 1 p., numbered 39 by VW. See below, B.16 and B.18.

Brandes, Georg. "Measure for Measure." In William Shakespeare: A Critical Study. Vol. II. Heinemann, 1898.

16. "Measure for Measure./M.M. cont": 1 p., numbered 40 by VW. General notes comparing plays and novels, beginning, 
"In a play there is no background of the contriver." The notes include references to Measure for Measure. See above, B.15, and below, B.18.

17. "Plato": 1 p., numbered 41 by VW. The entry consists of notes in Greek, annotated "Symposium," and an English translation, annotated "Shelley." The English reads: "for everyone, even if before he were ever so undisciplined, becomes a poet as soon as he is touched by love."

a) Plato. The Symposium.

b) Shelley, Percy Bysshe. The Banquet. Translated from Plato.

18. "Measure for Measure. Shakespeare.": 2 pp., numbered 4344 by VW. Entry dated "June/1921." The entry begins with a reference to an article on Hamlet in the TLS: "June 1921. Someone says in the Times today that Hamlet was a version of James 1st: Shre elaborated his weakness, melancholy, \& impotence." The remainder consists of general notes, beginning, "The subtlety of M. for M." For more notes on Measure for Measure, see above B.15 and B.16.

a) "Hamlet and History." Rev. of Hamlet and the Scottish Succession, by Lilian Winstanley. TLS, June 2, 1921, pp. 245-246.

b) Shakespeare, William. Measure for Measure.

19. "Sayings \& Quotations.": 1 p., numbered 42 by VW. (4 lines only.) Quotation, annotated "Blake. Written in copy of $\mathrm{W}^{\text {ths }}$ Poems./See Crabb Robinson. Rem. (1827.)." The reference is to a marginal notation made by William Blake in Crabb Robinson's copy of Wordsworth's poetry, recorded by Robinson in his diary for 1827 . The quotation reads: "Natural objects always did \& now do weaken, deaden, \& obliterate imagination in me."

Robinson, Henry Crabb. Diary, Reminiscences, and Correspondence. Ed. Thomas Sadler. [1869].

20. "Gulliver's Travels. Swift.": 1 p., numbered 45 by VW. The notes include the quotation from the end of Part II, Chapter VI, "A Voyage to Brobdingnag," in which the King of Brobdingnag refers to "the bulk of your natives" as "the most pernicious race of little odious vermin that nature ever suffered to crawl upon the surface of the earth." This is followed by general notes, beginning, "The satire of actual detail: Parliament \& court: seems to me less interest- 
ing than the satire of human nature." Woolf may have been reading the work in Swift: Selections from his Works, ed. Henry Craik, Vol. II (Oxford: Clarendon, 1893).

Swift, Jonathan. Gulliver's Travels. [1726].

21. "Sayings:/“Oh! quel homme supérieur!": 1 p., numbered 46 by VW. Two quotations, annotated "Candide. Voltaire," "289" and "309."

Voltaire. Candide, ou l'optimisme. Paris: Didot, 1800. Vol. I. of Romans de Voltaire.

22. "I think poetry should surprise by a fine excess, ...": 1 p., numbered 46 by VW. Quotations, annotated "Keats. Letters. 77." The entry appears under the general heading, "Sayings:" See above, B.21.

Keats, John. Letters ... to his Family and Friends. Ed. Sidney Colvin. Macmillan, 1891.

23. "Women Writers R. de Gourmont": 1 p., numbered 47 by VW. Quotation, annotated "Prom. Littéraries./La Prose de

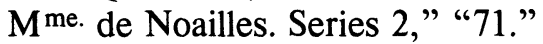

Gourmont, Rémy de. "La Prose de Madame de Noailles." In Promenades Littéraires. 2nd ser. Paris: Mercure de France, 1906.

24. "Dorothy Wordsworth": 1 p., numbered 48 by VW. The entry consists of three passages from Wordsworth's poems about Dorothy. The first, beginning, "She gave me eyes, she gave me ears," is annotated "Orchard. 1801." The second begins, "She in the midst of all preserved me still/A poet ...," and the third is a single phrase, "Thy wild eyes." More notes on Dorothy Wordsworth appear below, B.25.

a) Wordsworth, William. "The Orchard" (1801).

b) Wordsworth, William. The Prelude; or, The Growth of a Poet's Mind. XI, 345-347. [1850].

c) Wordsworth, William. "Lines Composed a Few Miles above Tintern Abbey" (1798).

25. "My sister when she first heard the voice of the/sea ...": 4 pp., numbered $48-51$ by VW. Marginal notation, "Harper." The entry begins under the heading "Dorothy Wordsworth." See above, B.24. The notes are about Dorothy.

Harper, George McLean. William Wordsworth: His Life, Works, and Influence. 2 vols. Murray, 1916. 
26. "1422-1509/Paston Letters. Vol. I. James Gairdner. 1904": 25 pp., numbered $52-58,60-77$ by $\mathrm{VW}$, and $1 \mathrm{p}$., on the reverse of $p$. 75. The notes on the reverse of $p$. 75 consist of a genealogy of the Pastons. The entry includes notes on Gairdner's "Introduction," which forms the first volume of the Letters. More notes on The Paston Letters appear below, B.28, and in XLIX, B.5-7.

[Paston.] The Paston Letters. A.D. 1422-1509. Ed. James Gairdner. Vols. I-IV [of VI]. Chatto and Windus, 1904. New Complete Library Edition.

27. "Green's History/(Pastons)": 1 p., numbered 59 by VW. See above, B.26, and below, B.28. The entry consists of notes on a single passage, annotated " 222 ," beginning, "The hundred years which follow Crecy \& Canterbury Tales are years of the deepest gloom -"

Green, John Richard. A Short History of the English People.

New ed. Macmillan, 1888.

28. "Pastons. 1469./Old Edition": 10 pp., numbered 78-87 by VW. More notes on The Paston Letters appear above, B.26, and in XLIX, B.5-7.

[Paston.] The Paston Letters. 1422-1509 A.D. Ed. James Gairdner. Vols. II-III [of III]. Edward Arber, 1874-1875. Annotated Reprints.

\section{Monk's House Papers/B.2f. (Sussex)}

A note by Leonard Woolf placed in this notebook records: "This is a loose-leaf notebook in which Virginia Woolf made notes of various kinds, mainly about what she was writing or thought of writing. In this page [10] she has jotted down rough notes for an essay on reviewing." The notebook is in fact a composite. At one end, Woolf has written rough drafts for Reviewing (1939) and "Lewis Carroll" (published December 9, 1939; Kp. C363). These drafts are not included among the entries. At the other end of the notebook, Woolf made the entries listed below. Most of these are difficult to date exactly. Her essay on "Why Art To-day Follows Politics" (B.2) was published in The Daily Worker, December 14, 1936 (Kp. C347). The notes on Roger Fry's Vision and Design (B.1) could have been made any time after November 1934, when the idea of writing a biography 
of Fry became a reality, until the publication of the work in 1940. As late as August 7, 1939, for example, she was "condensing Vision and Design" $(A W D)$. (Woolf's other notes on Fry appear in Volumes XXVI and LXI-LXVI.)

A similar uncertainty surrounds the notes on women and war in B.3, which appear to have been made at two different times. One set - the second and fourth pages-are clearly associated with Three Guineas and can be placed between October 1935, when she began to write The Next War, and the publication of the book in 1938. I tend to place them in the early stages, however, in part because of a mention on the fourth page of "the Brighton Conference"-a reference to the Labour Party Conference at Brighton, September 30 to October 2, 1935. This conference spurred her to transform what was previously called On Being Despised into The Next War: "Did I say the result of the L.P. at Brighton was the breaking of that dam between me and the new book, so that I couldn't resist dashing off a chapter" ( $A W D$, October 15, 1935). By October 27, she was "[dashing] off scene after scene." On January 3, 1936, she had decided to call the book Answers to Correspondents, and on March 18, "Letter to an Englishman"; by March 24 she was completely absorbed in Two Guineas (sic; $A W D$ ). Other examples of her early ideas for Three Guineas are found in Volume LVI; the remainder of the Three Guineas notes are in Volumes VII, X, XXVI, XXXIII, and LV-LX.

The second set of notes about women and war, intermixed with those for Three Guineas, belongs to late 1939 or 1940, when Woolf began to formulate her views on peace for an article she had been asked to write; as she remarked to Shena, Lady Simon, these were inseparable from her views on war $(L, \mathrm{VI}, 3580)$. Her ideas were eventually published as "Thoughts on Peace in an Air Raid" (New Republic, October 21, 1940; Kp. C369). More notes for her essay appear in XXI, B.4, XXXVII, B.2, and Volume XXXVI.

The notes on Lewis Carroll's Letters (B.4) were almost certainly made in conjunction with her review of The Complete Works of Lewis Carroll in December 1939; she was reading Carroll in early October $(L, \mathrm{VI}, 3556)$.

The notes are all in black ink, as is the one page number.

\section{B. ENTRIES}

1. "Index/Vision \& Design. (1920.)": 1 p., numbered 1 by VW. Fry, Roger. Vision and Design. Chatto \& Windus, 1920. 
2. "I have been asked to explain as shortly as I can/what is at present the relation between the artist \&/politics.": 4 pp., not numbered. The entry consists of notes for "Why Art To-day Follows Politics."

3. "by no means/[?certain that WW I is ... ]": 5 pp., not numbered. The entry begins on the reverse of the last page of B.2. The notes, many of which are almost illegible, are on men, women, politics, and war. The first, third, and fifth pages appear to have been written in 1939 or 1940, and include references to "1939-1914" and " 25 years after last war." The second and fourth pages contain notes for Three Guineas. The second page begins, "Our consciousness holds about 1000 years. The things we look at differ according to the medium through wh. we see them"; continues with references to "institutions wh. are most often seen by the educated class. Colleges-Eton: then How differently they look, if you have been there"; and concludes with the note, "1. My advice will be [worthless]/2. My check will be small." The fourth page mentions both "the Brighton Conference" and pictures of "childrens mutilated bodies." The question being asked is how to fight both Mr. Asquith and war.

4. "L-C Letters": 1 p., not numbered.

Carroll, Lewis. A Selection from the Letters... to his Child Friends. Ed. Evelyn M. Hatch. Macmillan, 1933.

\section{Monk's House Papers/B.2h. (Sussex)}

A label on the cover of this notebook provides the title: "Congreve/Comedies"; and a note on the first page supplies the date: "June 1937/Congreve." On June 1, 1937, Woolf recorded in her diary that she was going to do Congreve for the "Lit. Sup."; and on June 22, she was about to read Love for Love, which she did on June $23(A W D)$. "If you want sheer joy read" Congreve, she told Ottoline Morrell on June 27 ( $L, \mathrm{VI}, 3265)$. The entire notebook is devoted to notes for her article on Congreve, "Congreve's Comedies: Speed, Stillness and Meaning," published in the TLS, September 25, 1937 (Kp. C352).

The notes are in black ink, with the occasional pencil note. 


\section{A. Table of Contents}

1. Congreve Comedies $1 \mathrm{p}$. , on cover

2. June 1937 Congreve

1 p., not numbered.

B. ENTRIES

1. "Congreve./The Old Bachelor.": 2 pp., not numbered.

Congreve, William. The Old Bachelor. In Comedies. Ed. Bonamy Dobrée. Oxford Univ. Press, 1925.

2. "The double dealer": $3 \mathrm{pp}$., not numbered. The entry begins on the second page of B.1. Included in the entry are notes on "The Epistle Dedicatory."

Congreve, William. The Double Dealer. In Comedies. Ed. Bonamy Dobrée. Oxford Univ. Press, 1925.

3. "Love for Love. Congreve": 5 pp., not numbered. More notes on this play appear below, B.8.

Congreve, William. Love for Love. In Comedies. Ed. Bonamy Dobrée. Oxford Univ. Press, 1925.

4. "The [emphasis] of ...": 1 p., not numbered. (5 lines only.) The entry appears on the reverse of the last page of B.3. Pencil notes, mostly illegible.

5. "Congreve/sat with his hat drawn over his eyes. Gosse": 1 p., not numbered. (Heading only.) Marginal notation, "Gosse/ 112."

Gosse, Edmund. Life of William Congreve. 2nd ed. Heinemann, 1924.

6. "to dare to write only to the Few Refin'd!": 3 pp., not numbered. Marginal notation, "Way of/the/World." The entry starts on the same page as B.5, under the general heading "Congreve." The entry begins with notes on Richard Steele's verses on The Way of the World, included in Dobrée's edition of the play. More notes on this play appear below, B.10.

a) Steele, Richard. "To Mr. Congreve, occasion'd by his comedy called The Way of the World." In The Comedies 
of William Congreve. Ed. Bonamy Dobrée. Oxford Univ. Press, 1925.

b) Congreve, William. The Way of The World. In Comedies.

Ed. Bonamy Dobrée. Oxford Univ. Press, 1925.

7. "freedom of conversation 'is the only certain means of attaining to the perfection of dialogue'.": $2 \mathrm{pp}$., not numbered. Marginal notation, first page, "Preface to/Way of W./338." The second page is headed, "The plot." The entry is based on Congreve's "Dedication" to The Way of the World.

Congreve, William. "To the Right Honourable Ralph, Earl of Mountague." In Comedies. Ed. Bonamy Dobrée. Oxford Univ. Press, 1925.

8. "Congreve-Letters": 1 p., not numbered. The entry consists of notes on Love for Love. More notes on this play appear above, B.3.

Congreve, William. Love for Love. In Comedies. Ed. Bonamy Dobrée. Oxford Univ. Press, 1925.

9. "The beauty that is independent of/morals . ..": 4 pp., not numbered. The entry begins under the general heading "Congreve-tetters," B.8, above, and consists of general notes on Congreve. The second page begins, "Article might run: the artist who has written 4 comedies by 30 must learn in writing, unconsciously."

10. "Way of the World": 3 pp., not numbered. (3rd page, 2 lines only.) More notes on this play appear above, B.6.

Congreve, William. The Way of The World. In Comedies. Ed.

Bonamy Dobrée. Oxford Univ. Press, 1925.

11. "Foresight the Astrologer.": 1 p., not numbered. The entry begins on the third page of B.10. General notes on Congreve, including references to The Double Dealer and Love for Love.

\section{Monk's House Papers/B.2i. (Sussex)}

With the exception of the reference to Madeleine, One of Love's Jansenists, by Hope Mirrlees, which Woolf reviewed on October 9, 1919 (Kp. C169; cf. L, II, 1083, and D, I, September 28, 1919), the whole of this notebook is devoted to reading notes for Woolf's long 
essay on George Eliot, published in the TLS, November 20, 1919 (Kp. C175). By January 1919, Woolf had begun "reading through the whole of George Eliot, in order to sum her up, once and for all, upon her anniversary" ( $L$, II, 1010); at that time, however, she had "only made way with her life"-The Life of George Eliot by J. W. Cross (B.2). Throughout the year, she noted in her diary and her letters that she had to read or was reading George Eliot $(D, \mathrm{I}$, March 5 , October 19,$1919 ; L$, II, $1075,1081,1084)$, specifically mentioning Middlemarch on November 1, 1919 (D, I).

A label in black ink on the cover of the notebook reads "GEORGE ELIOT." What I have listed as the table of contents, A.2, is for the most part a list of Eliot's works, some of which are checked off to denote that Woolf planned to or had read them. A column for page numbers is included but not filled in. Most of the notes are in blue ink, with some in black ink or pencil.

A. Table of Contents

1. GEORGE ELIOT

$1 \mathrm{p}$., on cover.

2. George Eliot.

$\mathrm{x}$ Life by Cross.

Page

Works of G.E.

$x$ Scenes of Clerical Life

$x$ Adam Bede

$x$ Mill on the Floss

Brother Jacob

Silas Marner

Romola

Felix Holt

Middlemarch

Deronda

Theophrastus Such

1 p., not numbered.

B. ENTRIES

1. "Madeleine,/One of Love's Jansenists/Collins.": 1 p., not numbered. (Heading only.) The reference is to Hope Mirrlees' novel, Madeleine, One of Love's Jansenists, reviewed by Woolf in October 1919. 
2. "b: Nov. 22 1819.": 10 pp., not numbered, and 6 pp., on the reverse of the pages. The notes that appear on the reverse sides record the dates and titles of Eliot's novels, and computations of her age when she wrote them. On the last page, Woolf sums up her impressions, beginning, "oddly beautiful, spiritual effect of the whole-very sensitive-immense deep seated vitality, slowly thrusting up."

Cross, J. W. George Eliot's Life as Related in her Letters and Journals. 3 vols. Edinburgh: Blackwood, 1885.

3. "Scenes of Clerical Life": 2 pp., not numbered.

Eliot, George. Scenes of Clerical Life. Edinburgh: Blackwood, n.d. Vol. IV of the Novels of George Eliot.

4. "Adam Bede": 2 pp., not numbered.

Eliot, George. Adam Bede. 2 vols. Edinburgh: Blackwood, 1895. The Works of George Eliot. Standard Edition.

5. "You may dislike her heroines ...": 1 p., not numbered, on the reverse of the second page of B.4. (6 lines only.) The entry consists of notes in blue pencil on George Eliot's heroines: "You may dislike her heroines but you don't get the full flavour unless you consider them. The religious sense in women. It seems to me to [deepen]."

6. "Middlemareh. Mill on Floss.": 2 pp., not numbered. (2nd page, 3 lines only.)

Eliot, George. The Mill on the Floss. [1860].

7. "Silas Marner.": 1 p., not numbered. The entry begins on the second page of B.6.

Eliot, George. Silas Marner. [1861].

8. "Middlemarch": 1 p., not numbered.

Eliot, George. Middlemarch. A Study of Provincial Life. Vols. I-II [of III]. Edinburgh: Blackwood, 1878. The Works of George Eliot. Cabinet Edition.

\section{Monk's House Papers/B.2j. (Sussex)}

The title "HARDY" on the cover of this notebook describes its entire contents: notes made on Hardy's novels and stories, as well as on a critical work about him, in preparation for the article published 
as "Thomas Hardy's Novels," TLS, January 19, 1928 (Kp. C294). The reading notes themselves, however, belong to the period between February 14, 1919, when Bruce Richmond asked Woolf to "be ready with an article on Hardy's novels whenever the evil day [of his death] comes" ( $D$, II, August 9, 1921, n.2), and January 22, 1921, when Woolf recorded that she would finish the article tomorrow $(D$, II). Her diary and letters for those years contain numerous plans to read Hardy, as well as laments that she had not yet written the article: "I pray he sits safe \& sound by his fireside at this moment" ( $D$, II, December 11, 1921; see also $D$, I, March 5, July 12, 1919; $L$, II, 1074, 1141; D, II, March 22, November 15, 25, December 17, 1921). Woolf appears to have read The Mayor of Casterbridge in August 1920 ( $L$, II, 1141), but whether this reading was the source of the notes in this volume is uncertain. On August 9, 1921, she noted that she was "Indeed . . . reading Hardy for my famous article-the one I am always talking about" ( $D$, II), and it is possible that the majority of the entries in this volume were made between between August 1921 and Christmas 1921. Woolf spent her time at Rodmell that Christmas writing "with steady stoicism my posthumous article upon Hardy" ( $D$, II, January 3, 1922). Never satisfied, she may have revised the article in December 1923 ( $D$, II, December 19). In July 1926, Woolf visited Hardy, taking The Mayor of Casterbridge with her to read on the train ( $D$, III, July 25); and in January 1928, after Hardy's death, she "[furbished] up the Hardy" for publication ( $D$, III, January 17). More notes on Hardy appear in Volume XX.

The list that comprises A.2 of the table of contents is a list of Hardy's works, with the date of publication and " $x$ 's" marking those novels that Woolf had read or planned to read. "HARDY" (A.1) is written on a label in black ink; the list of Hardy's works (A.2) is in blue-gray ink, and the " $x$ 's" are in turquoise ink. The entries are in various inks-blue-gray, turquoise, black, and blue-purple; in pencil; and in blue pencil. The majority, however, are in blue-purple ink. Under the Greenwood Tree (B.2) has two sets of notes in different inks, the second beginning, "re-read"; the original notes are turquoise, the second set is blue-purple. Five pages have been torn out of the notebook between B.5 and B.6.

The page references in Woolf's notes correspond to two editions of The Wessex Novels: that published by Osgood, Mcllvaine in 1895 and 1896 and that published by Macmillan in 1902 and 1903. I have listed the latter edition. The volume numbers are the same in both sets. 


\section{A. Table of Contents}

1. HARDY

1 p., on cover.

2. Hardy b: 1840 .

1871. Desperate Remedies.

1872. Under Greenwood Tree. $\mathrm{x}$

1873. A Pair of Blue Eyes.

1874. Far from the Madding Crowd. $\mathrm{x}$

1876. Hand of Ethelberta.

1878. Return of the Native $\mathrm{x}$

The Works Novels of Thomas Hardy

1880. The Trumpet Major. $\mathrm{X}$

1881. A Laodicean.

1882. Two on a Tower.

$\mathrm{x}$

1883. Romantic Adventures of a Milkmaid.

1886. The Mayor of Casterbridge. $\mathrm{x}$

1887. The Woodlanders. $\mathrm{x}$

1888. Wessex Tales. $\mathrm{x}$

1891. A Group of Noble Dames. (1890) X

1891. Tess of the D'Urbervilles. $\mathrm{X}$

1894. Life's Little Ironies. X

1896. Jude the Obscure. (1894-5) x

1897. The Well-Beloved (1892)

1898. Wessex Poems.

1901. Poems of Past \& Present.

1903 )

$-6\}$ Dynasts

$-8\}$

1909. Time's Laughing Stocks

1 p., not numbered.

B. ENTRIES

1. "Thomas Hardy./Lascelles Abercrombie./first pubd 1912.": 3 pp., not numbered.

Abercrombie, Lascelles. Thomas Hardy: A Critical Study. Martin Secker, 1919.

2. "Under the Greenwood Tree. 1872.": 2 pp., not numbered. The second page is on the reverse of the first. The entry consists of two sets of notes on the novel, the second one 
beginning, "re-read/'Autumns of 50 years ago' This applies to many of $\mathrm{H}$. books."

Hardy, Thomas. Under the Greenwood Tree. A Rural Painting of the Dutch School. Macmillan, 1903. Vol. XVI of The Wessex Novels.

3. "Far from the Madding Crowd 1874.": 2 pp., not numbered.

Hardy, Thomas. Far from the Madding Crowd. Macmillan, 1902. Vol. II of The Wessex Novels.

4. "The Mayor of Casterbridge. 1886": 2 pp., not numbered.

Hardy, Thomas. The Mayor of Casterbridge. The Life and Death of a Man of Character. Macmillan, 1902. Vol. III of The Wessex Novels.

5. "Wessex Tales./Interlopers at the Knap": 1 p., not numbered. 4 lines only, reading, "What is the meaning of a plot? does instead of form? a love of coincidence that becomes fantastic."

Hardy, Thomas. "Interlopers at the Knap." Wessex Tales. [1896].

6. "Two on a Tower./1882": 2 pp., not numbered.

Hardy, Thomas. Two on a Tower. Macmillan, 1902. Vol. V of The Wessex Novels.

7. "The Return of the Native./1878": 5 pp., not numbered. The entry begins with a partial list of Hardy's novels. On the bottom of the fourth page are general notes, beginning, "A kind of intense angular character \& honesty in the scenes but the queerness very great. A tendency to woodenness even priggishness in his heroes-seems more at ease with the women."

Hardy, Thomas. The Return of the Native. Macmillan, 1902.

Vol. VI of The Wessex Novels.

8. "Jude the Obscure 1894-5": 1 p., not numbered. (7 lines only.)

Hardy, Thomas. Jude the Obscure. Macmillan, 1903. Vol. VIII of The Wessex Novels.

9. "Desperate Remedies": 2 pp., not numbered.

Hardy, Thomas. Desperate Remedies. Macmillan, 1903. Vol. XII of The Wessex Novels. 
10. " "of love, it may be said, the less earthly the less demonstrative." ": 1 p., not numbered. The entry consists of quotations from Hardy's novels.

a) "'of love, it may be said, ..." ": Quotation, annotated "of Clym \& Mrs. Yeobright/Return of N. 232": The Return of The Native. See above, B.7.

b) "Well, poor soul; she's helpless to hinder that or anything now, answered Mother Cuxsom.": Quotation, annotated "M. of C. 144": The Mayor of Casterbridge. See above, B.4.

11. "The spirit of pagan nature crowning the country people./The wounded birds in the wood": 2 pp., not numbered. The entry begins on the same page as B.10. The notes are on Tess of the D'Urbervilles, and include notes on Hardy's "Explanatory Note to the First Edition" and "Preface to the Fifth and Later Editions." No page references are given, but Woolf probably used the edition that corresponds to the others in the series of Wessex Novels that she read. More notes on Tess appear in XX, B.2.

Hardy, Thomas. Tess of The D'Urbervilles. [1891].

12. "Why should we not stand still, says I to myself . ..": 1 p., not numbered. The entry consists of random quotations and phrases from Hardy's novels.

a) "Why should we not stand still ...": Quotation, annotated "D.R. 450": Desperate Remedies. See above, B.9.

b) "Under the Gre. W./A rural painting of the Dutch school.": A reference to the full title of Under the Greenwood Tree. See above, B.2.

c) "Toller Down/To persons standing alone on a hill ...": Phrases from Far from the Madding Crowd. See above, B.3.

d) "Fitzpiers. Grace. Marty South.": Characters in The Woodlanders. (Heading only.)

Hardy, Thomas. The Woodlanders. [1887].

13. "The immortal puzzle-given the man \& the/woman, how to find a basis for their sexual/relation - is left where it stood;": $2 \mathrm{pp}$., not numbered. The entry consists of random notes on Hardy's novels. 
a) "The immortal puzzle ...": General notes, unidentified. The entry continues in part, "-given the man \& the woman, how to find a basis for their sexual relation-is left where it stood; he takes for granted the 'disparity' of the lovers, \& sanctity of marriage, ..."

b) "The importance of the home Corn trade.": A reference to The Mayor of Casterbridge. See above, B.4.

c) "This good fellowship-camaraderie-usually/occurring through similarity of pursuits ...": Quotations, the second one annotated "F.M.C. 469": Far From the Madding Crowd. See above, B.3.

d) "Swithin, who was stable as a giant in all that/appertained to nature ...": Quotation, annotated "281 T. on a T.": Two on a Tower. See above, B.6.

14. "It was a spot wh. returned upon the memory of/those who loved it with an aspect of peculiar/\& kindly congruity.": 4 pp., not numbered. The entry begins on the second page of B.13, with a quotation that is annotated "R. of N." The notes are on The Return of the Native. More notes on this novel appear above, B.7.

Hardy, Thomas. The Return of the Native. Macmillan, 1902.

Vol. VI of The Wessex Novels.

\section{Monk's House Papers/B.2k. (Sussex)}

On January 1, 1920, Woolf commented in a letter that "My next work will be on Henry James' letters, I think-unless someone else has done it for me during the influenza. I shan't be sorry, since I'm stuck in the Ambassadors" ( $L$, II, 1107). On April 2 she wrote to Vanessa Bell that she had "been reading Henry James' letters till my brain rings and swings" ( $L$, II, 1126; see also, $D$, II, April 10, 1920). Her review of the letters was published as "The Letters of Henry James," TLS, April 8, 1920 (Kp. C190), and occasioned the attack on her style by A. B. Walkley, the dramatic critic for The Times, recorded in her diary on April 15, 1920.

The covering page of the notebook bears the title "Henry James/ Letters" in black ink; the entries are in black ink, turquoise ink, and pencil. 


\section{A. Table of Contents}

1. Henry James

Letters

1 p., on cover.

B. ENTRIES

1. "Henry James. Letters": 14 pp., not numbered. (Last page, 1 line only.)

James, Henry. Letters. Ed. Percy Lubbock. 2 vols. Macmillan, 1920.

2. "Vol 2. 223./On Refusing to be a godfather -": 7 pp., not numbered. The entry begins on the last page of B.1, and consists of random quotations and notes from Henry James's letters, arranged under headings by Woolf. See above, B.1.

3. "dining room-/hall-": $1 \mathrm{p}$., not numbered. The entry consists of a list of areas of the house, possibly Monk's House, and possibly those designated for painting. In late February 1920 , she was painting the dining room "pomegranate colour" ( $L$, II, 1123).

\section{Monk's House Papers/B.2.l. (Sussex)}

The entries in this volume can be located accurately in July and August 1919. On July 12, 1919, Woolf noted in her diary that she should be reading Herman Melville ( $D$, I; B.1-3): her centenary article on Melville appeared in the TLS on August 7, 1919 (Kp. C161). References to South Sea Bubbles (B.4) also appear in this essay. On July 19, during the peace celebrations, she was reading Walpole (B.7-12; D, I, July 20 and 24, 1919); her review of the Supplement to the Letters of Horace Walpole appeared in the TLS, July 31, 1919 (Kp. C159).

The notes on the inside of the back cover, which begin, "The brushed up Sunday appearance even of polar bears," were made in preparation for her article on "The Royal Academy" in the Athenaeum, August 22, 1919 (Kp. C164). In this entry, she is "working out the pictures," as she wrote Vanessa Bell on July 17, 1919 ( $L$, II, 1068). Her letter mentions "Cocaine," a painting by Alfred Priest of a man lying in the lap of a woman in pink satin, as one of her favor- 
ites; an "interpretation" of "Cocaine" appears in her notes (B.13) and reappears in the finished essay, along with many of the other details recorded below.

The names "H. MELVILLE/H. WALPOLE" are written in turquoise ink on a label on the cover of the notebook. The entries are in the same ink.

\section{A. TABle of Contents}

1. H. MELVILLE H. WALPOLE $1 \mathrm{p}$. , on cover.

B. ENTRIES

1. "Typee first issued 1846.": 1 p., not numbered, on the inside of the front cover. ( 7 lines only.) The entry consists of titles and dates connected with Melville's novels and life.

2. "Typee/Herman Meltville": 3 pp., not numbered.

Melville, Herman. Typee. Life in the South Seas. Ed. W. P. Trent. Society for Promoting Christian Knowledge, 1903.

3. "Omoo": 3 .pp., not numbered, and 1 p., facing that with the heading. The facing page consists of the note, "Omoo summer 1842."

Melville, Herman. Omoo. A Narrative of Adventures in the South Seas. Dent, 1908. Everyman Edition.

4. "South Sea Bubbles./by the Earl \& the Doctor.": 2 pp., not numbered. (2nd page, 2 lines only.)

[Herbert, George C., 13th Earl of Pembroke, and Kingsley,

G. H.] South Sea Bubbles, by the Earl and the Doctor. Richard Bentley, 1872.

5. "Henry James./Pacific too beautiful to be beautiful when reproduced.": 1 p., not numbered. (Heading only.) The entry appears as an insert on the first page of B.4.

James, Henry. "Preface." In Rupert Brooke. Letters from America. Sidgwick and Jackson, 1916.

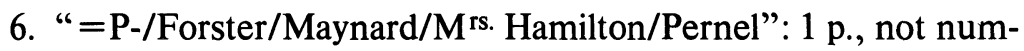
bered. (Heading only.) The entry appears on the page facing the first page of B.7. The people referred to are E. M. Forster, John Maynard Keynes, Mary Agnes Hamilton, the 
writer, and Pernel Strachey, all of whom Woolf entertained and wrote about in her diary or letters in July and August 1919.

7. "Supplement to the Letters of/Horace Walpole./Edited by Paget Toynbee.": 2 pp., not numbered. More notes on this work appear below, B.10 and B.12.

Walpole, Horace. Supplement to the Letters. Ed. Paget Toynbee. Vol. I [of II]. Oxford: Clarendon Press, 1918.

8. "Hours in a Library-Walpole./187 W. pretended not to write for/fame-an amateur.": 1 p., not numbered. (Heading only.) The entry appears as an insert on the top of the second page of B.7.

Stephen, Leslie. "Horace Walpole." In Hours in a Library. 2nd ser. Smith, Elder, 1876.

9. "Miss Berry/Walpole: Cunningham's Edition": 1 p., not numbered.

Berry, Miss Mary. "Advertisement to the Letters Addressed to the Misses Berry [1840]." In The Letters of Horace Walpole, Earl of Orford. Ed. Peter Cunningham. Vol. I. Richard Bentley, 1857.

10. "116. weary of politics-defeat $H$ of C.": 4 pp., not numbered. More notes on this work appear above, B.7, and below, B.12.

Walpole, Horace. Supplement to the Letters. Ed. Paget Toynbee. 2 vols. Oxford: Clarendon Press, 1918.

11. "Horace Walpole-by/Austin Dobson": 2 pp., not numbered. (2nd page, 6 lines only.)

Dobson, Austin. Horace Walpole. A Memoir. Osgood, Mcllvaine, 1893.

12. "Additions \& Corrections to/W's Letters.": 1 p., not numbered. (4 lines only.) The entry appears on the second page of B.11. More notes on this work appear above, B.7 and B.10.

Walpole, Horace. Supplement to the Letters. Ed. Paget Toynbee. Vol. II [of II]. Oxford: Clarendon Press, 1918.

13. "The brushed up Sunday appearance even of/polar bears": 1 p., not numbered. The entry appears on the inside of the back cover, and consists of notes for her essay on "The Royal Academy" (Kp. C164). 


\section{Monk's House Papers/B.2m. (Sussex)}

The first page of this notebook both announces its initial subject"Notes for/A Discourse for 4 voices"-and provides a date- "Oct: 16 $6^{\text {th }}$ 1934." The notes for her "Discourse" and those on The Faerie Queene, the major work recorded in this volume, can in fact be dated from October 1934 to March 1935. "A Discourse for 4 voices" may well have been a working title for the new critical book Woolf was planning at this time. On October 14, 1934, she recorded in her diary that she had planned "the romantic chapter of notes"; on October 29, she was reading Antigone, which is quoted under the general heading "Notes for Discourse" (B.2); and on November 1, after talking of her critical book, she notes, "I must now do biography and autobiography" - the subject of B.3 below (see $A W D$ ). Maupassant's Sur L'Eau, referred to in the notes on autobiography and biography, had previously been quoted by Woolf in her diary entry for September 12, 1934, when she was contemplating Roger Fry's death and her reactions to it ( $A W D$; see also, October 2,1934$)$.

The notes on biography and autobiography in this notebook are almost certainly one source of her essay, "The Art of Biography." Although the essay was not published until April 1939 (Atlantic Monthly, Kp. C359), when Woolf was absorbed by writing her own biography of Roger Fry, the ideas are similar. In her notes, she comments on the disparity between fact and fiction in biography, compares the "reality" of Hamlet and of Boswell's Johnson, and questions what biography can and cannot do. "Even Dr. Johnson as created by Boswell," she writes in the essay, "will not live as long as Falstaff as created by Shakespeare" ( $C E$, IV, 227).

Woolf's notes on The Faerie Queene (B.4-6, 8-11), which comprise a large portion of this notebook, can be dated from her textual notations between January 20 and March 11, 1935. On the latter day, she recorded that she had stopped reading Spenser and had begun Chateaubriand's Memoires, the subject of the following entry (B.11-12). A diary entry for January 23, 1935, expresses her initial delight in reading The Faerie Queene - "I shall write on it" ( $A W D)$; a later entry, dated February 27, expresses her "strong desire to stop reading F.Q.: to read Cicero's letters and the Chateaubriand Memoirs. As far as I can see, this is the natural swing of the pendulum. To particularise after the generalisation of romantic poetry" $(A W D)$.

Woolf's essay on "The Faery Queen" was not published until 1947, when Leonard Woolf included it in The Moment and Other 
Essays; but at least one central theme of the piece- "The mind has many layers, ... The faculty we employ upon poetry at the first reading is sensual; the eye of the mind opens" $(C E, \mathrm{I}, 14)$-is anticipated by two entries in this volume. In B.5, which consists of general notes on Spenser and poetry, Woolf wrote, "Perhaps all our first impressions of poetry are visual"; and in B.14, she speculated, "Different layers of the mind in reading poetry. I think it is true that in man the Colour sense is first touched: roused. Thus in Murder in the Cathedral I am stirred-my senses quickened-first by the purple bullfinch ...\&c. Then by by the white sail on the grey sea." Woolf read T. S. Eliot's Murder in the Cathedral at the end of June 1935 ( $L, \mathrm{~V}, 3037$, 3042 ); on October 25, 1935, she wrote Julian Bell, "I am reading old plays; do you find that your mind works oddly, about poetry? I can read it for an hour with rapture but without understanding a word. And the first of my senses to wake is the colour sense" ( $L, \mathrm{~V}$, 3072).

The title "Four Voices/Faery Queen," which appears on a label pasted on the cover of the notebook, is written in black ink, as are all of the notes.

\section{A. Table of Contents}

1. Four Voices

Faery Queen

$1 \mathrm{p}$., on cover.

2. Notes for

A Discourse for 4 voices.

Realism

Romance

Psychology

Poetry.

Oct: $16^{\text {th }}$

1934

$1 \mathrm{p} .$, not numbered.

\section{B. ENTRIES}

1. "Biography.": 1 p., not numbered. Entry dated "Oct. $16^{\text {th." }}$ The entry consists of notes on biography, beginning, "That the bio ${ }^{r}$ [biographer] is doing two incompatible things. he is providing us with sterile \& fertile." The notes include a comparison of Hamlet and Boswell's Life of Samuel Johnson 
and refer to "Morleys Gladstone" and "Churchills Marlborough": John Morley, The Life of William Ewart Gladstone (1903); and Winston Churchill, Marlborough: His Life and Times (1933-1938).

2. "Notes for Discourse.": 1 p., not numbered. The entry begins, "The difference between gore gold coins \& flecked with gold 'flecked' gives the horses ear shape"; and includes a quotation that is annotated "Antigone 89."

Sophocles. The Antigone. With Critical Notes, Commentary, and Translation in English Prose by R. C. Jebb. Cambridge: Cambridge Univ. Press, 1888. Vol. III of Sophocles. The Plays and Fragments.

3. "'I' sitting at the table, the elements in $I$ /have taken rather a different disposition.": 1 p., not numbered. The entry includes references to "Autobiography"; to "Biography. That what starts us wanting to know about Maupassant is the conflict of 2 things in him -the emotion \& the hardness"; and to "Sur L'Eau": Guy de Maupassant, Sur L'Eau (1888).

4. "Faery Queen.": 1 p., not numbered. Marginal notation, "Jan. 20th/1935." The notes are on Book I, Cantos 1-5. Woolf's references are to the volume, page, and stanza number, in that order. More notes on this work appear below, B.6, B.8, and B.10.

Spenser, Edmund. The Faerie Queene. [Book I.] In Works.

Ed. J. Payne Collier. Vol. I. Bell \& Daldy, 1862.

5. "Perhaps all our first impressions of poetry/are visual.": 1 p., not numbered. General notes about poetry, with references to Spenser. See above, B.4.

6. "271/19 possible humour./the satyres.": 7 pp., not numbered. The notes are on Book I, Canto 6 to Book III, Canto 1 of The Faerie Queene. More notes on this work appear above, B.4, and below, B.8 and B.10.

Spenser, Edmund. The Faerie Queene. [Books I-III.] In

Works. Ed. J. Payne Collier. Vols. I-II. Bell \& Daldy, 1862.

7. "Withered Rose, faded rose,/Milky Rose [?thorny] Rose": 2 pp., not numbered. (2nd page, 2 lines only.) The entry begins on the last page of B.6, headed "FQ/362/1 Spenser as feminist." The notes, which are cancelled in blue pencil, are for the 1910 chapter of The Years (1937). 
8. "FQ/S. as feminist.": 1 p., not numbered. The entry begins on the second page of B.7. The notes are on Book III, Cantos 4-5 of The Faerie Queene. More notes on this work appear above, B.4 and B.6, and below, B.10.

Spenser, Edmund. The Faerie Queene. [Book III.] In Works.

Ed. J. Payne Collier. Vol. II. Bell \& Daldy, 1862.

9. "F.Q./Jonson on Spenser. Discoveries": 1 p., not numbered. (Heading only.) Entry annotated "Warton 1/154." The references are probably to Ben Jonson's comments on Spenser in Timber; or Discoveries Made upon Men and Matter (1640), and to Thomas Warton's Observations on the Faerie Queene of Spenser (1754).

10. "334 difficult to prove that a manufacturer/of green cloth subsisted at Lincoln/in the faery reign of Arthur.": 5 pp., not numbered. The entry begins on the same page as B.9. The notes are on The Faerie Queene, Book III, Canto 6 to Book IV, Canto 7, and include the reference: "See STC. Preface to Lectures on Shre \& Milton. 1856. xlvi." This reference appears as a footnote to the lines, "And made him dreame those two disloyalle were:/The things that day most minds, at night doe most appeare" (The Faerie Queene, IV.iii.43; the footnote directs the reader to J. Payne Collier's "Preface" in S. T. Coleridge, Seven Lectures on Shakespeare and Milton, ed. J. Payne Collier (1856).

Spenser, Edmund. The Faerie Queene. [Books III-IV.] In Works. Ed. J. Payne Collier. Vols. II-III. Bell \& Daldy, 1862.

11. "March 11th/I have decided to stop reading FQ./at the end of the $4^{\text {th }}$ book/because I am completely out of the mood.": 2 pp., not numbered. The entry begins on the last page of B.10, and includes the note, "It looks to me as if there were a regular cycle of (at any rate) my taste"; this idea is also found in $A W D$, February 27, 1935. The notes continue, "What has formed is a desire for something particular, which I am gratifying by reading Chateaubriand, Memoires"; see below, B.12.

12. "M. d'O.-T.": 1 p., not numbered. Quotation, annotated "Vol. 1/78." More notes on this work appear in XXVI, B.10. 
Chateaubriand, François René de. Mémoires d'Outre-Tombe. New ed. Ed. Edmund Biré. Vol. I [of VI]. Paris: Garnier Frères, n.d.

13. "Hopkins Letters to Dixon": 1 p., not numbered. (5 lines only.)

[Hopkins, G. M. \& Dixon, R. W.] The Correspondence of Gerard Manley Hopkins and Richard Watson Dixon. Ed. Claude Colleer Abbott. Oxford Univ. Press, 1935.

14. "Different layers of the mind/in reading poetry": $1 \mathrm{p}$., not numbered. General notes on poetry, including references to "the Colour sense" in man, and to "Murder in the Cathedral": T. S. Eliot, Murder in the Cathedral (1935).

15. "Auden. The Poets Tongue": 1 p., not numbered. The entry appears on the same page as B.14.

Auden, W. H., and Garrett, John. "Introduction." In The

Poet's Tongue. An Anthology. Vol. I. Bell, 1935.

16. "Gunning": 1 p., not numbered. Entry annotated "Reminiscences of the Un ${ }^{y}$, Town \&/County of $C^{\text {rd }}$ fr the year 1780/ by Henry Gunning MA/Christ College./1855." More notes on this work appear in LV, B.12, and LIX, B.90.

Gunning, Henry. Reminiscences of the University, Town, and County of Cambridge from the Year 1780. 2nd ed. Vol. I [of II]. Bell, 1855.

\section{Monk's House Papers/B.2n. (Sussex)}

What is particularly interesting about this notebook are the two tables of contents listing works that appear not in this volume but elsewhere. Most of the entries can be dated from the end of 1927, through 1928, to the beginning of 1929. During this period Woolf was writing articles on Lord Chesterfield, on Meredith, on Sterne's Sentimental Journey, on Dorothy Osborne's Letters, on Julian Hawthorne's Shapes that Pass, and on "Dr. Burney's Evening Party," all of which are mentioned or noted in this notebook. Several of the essays originally written at this time were then revised for inclusion in The Common Reader: Second Series (1932). In 1928, moreover, she was reading for her "book on fiction," which finally appeared as "Phases of Fiction" in 1929, and preparing the lectures on women 
and fiction that became $A$ Room of One's Own (1929). Given the large amount of reading, rereading, writing, and revising that Woolf did for all of these works, it is not surprising that her notes from this period are scattered among several notebooks, including Volumes XIII, XIV, XXV, XXVI, and XLVIII.

More specifically, on December 20, 1927, Woolf noted that she should be reading Lord Chesterfield's letters (B.1; D, III; L, III, 1843), probably in connection with her review of The Characters of Lord Chesterfield, published originally in the TLS, March 8, 1928 ("An English Aristocrat," Kp. C298). The notes on Meredith's novels and letters (B.5-9) were made in preparation for "The Novels of George Meredith," TLS, February 9, 1928 (Kp. C297). Although she mentions writing about Meredith on January 17, 1928 (D, III), she wrote on February 12 that she "was forced to read all Meredith in a week. I did get through three of them" ( $L$, III, 1859). The entries on Sterne (B.11-14) were part of her preparation for her essay on $A$ Sentimental Journey, first published in the New York Herald Tribune, September 23, 1928 (Kp. C303); in July, she had recorded a desire to write on Sterne ( $D$, III, July 7$)$.

On May 31, 1928, Woolf noted that she wanted to write both her book on fiction, which she had been working on intermittently since September 1926, and "Dr. Burney's Evening Party" ( $D$, III). The entries on novels in this volume almost certainly reflect her revival of interest in "Phases of Fiction" once Orlando was done. (For the history of "Phases of Fiction," see Volumes XIII and XIV; other notes appear in Volume XXV.) She had read Udolpho (B.4) in August and September 1927 ( $L$, III, 1803, 1807), but the notes in this volume, general observations only, were probably made during the summer of 1928. On August 12, 1928, she was "[scribbling] down whatever I can think of about Romance, Dickens, \&c. must hastily [?] gorge on Jane Austen tonight \& dish up something tomorrow" ( $D$, III); Dickens and Austen are noted in B.16 and B.18, respectively. A reference to "Dostoevsky" (B.19) on August 31 ( $D$, III) would suggest that she was reading or had read him recently. "Phases of Fiction" was finally published in Bookman, April, May, and June 1929 (Kp. C312).

"Dr. Burney's Evening Party" was also published in 1929 (New York Herald Tribune, July 21 and 28, 1929; Kp. C313), but Woolf began to read for the essay during the summer and fall of 1928. She first mentioned the essay on May 31, 1928 ( $D$, III), collected books for it in August ( $L$, III, 1913), complained that she could not find the time to read them in the beginning of October ( $L$, III, 1937, 
1940), and finally declared that she would "open Fanny Burney's diaries, \& work solidly at that article" on October 27 ( $D$, III; see also $L$, IV, 1981, 1985, 2005, for references to writing the essay). The notes on Fanny Burney and her Friends, Thraliana, and The Anecdotes of the Late Dr. Johnson (B.17, 20, 21) are part of this work; other notes on the Burneys appear in XIII, B.9-15.

Several of the "missing" items listed in the second table of contents (A.2) help both to date the notebook and to provide information about the sources for A Room of One's Own. "Shapes that Pass. Hawthorne" (A.2) refers to Julian Hawthorne's reminiscences, which Woolf reviewed in November 1928 ("Memories," Kp. C305.2); she appears to have read the book in France at the end of September $(L$, III, 1932). On September 17, 1928, she was reading Dorothy Osborne (A.2), whose "Shepherdesses singing" played a role in her evocation of a country wedding five days later ( $D$, III); her review of The Letters of Dorothy Osborne to William Temple was first published on October 24, 1928 (Kp. C304). The notes on this work are found in Volumes XLVIII and LII. Dorothy Osborne's letters also appear in $A$ Room of One's Own, along with an allusion to Fanny Burney's habit of sewing in the morning and writing in the afternoon. This habit is recorded in Woolf's notes on Fanny Burney and her Friends, B.17.

A Room of One's Own evolved from the two lectures on women and fiction that Woolf first mentioned in her diary on January 17, 1928 $(D$, III) and delivered in late October 1928. By early November, she was thinking of transforming the lectures into a book on women $(D$, III); she began to write this work almost immediately and had completed it by May 12, 1929 ( $D$, III). With this in mind, the "Miss Davies" in A.2 can probably be identified as Emily Davies-a reference to Emily Davies and Girton College by Barbara Stephen. Woolf had reviewed this book in April 1927 ("Two Women," Kp. C282); on October 7, 1928, however, while writing her lectures, she asked Margaret Llewelyn Davies to lend her "a copy of [her] Aunt's life" ( $L$, III, 1936), and later quoted from this work in A Room of One's Own. Moreover, the "Quotation from Life and Letters" referred to in A.2 is almost certainly the one that appears in A Room of One's Own as an example of the kind of criticism still applied to women writers: "If, like the reporter, you believe that female novelists should only aspire to excellence by courageously acknowledging the limitations of their sex (Jane Austen and, in our own time, Mrs. Virginia Woolf have demonstrated how gracefully this gesture can be accomplished)." (In her book, Woolf omitted the reference to herself.) Woolf commented on "the condescending phrase used about women novelists 'limita- 
tions' in Life and Letters" in her diary on September 10, 1928 (D, III); the source was a review of H. du Coudray's Another Country in Life and Letters 1, no. 3 (August 1928): 221-222. (The same reporter responsible for this comment reviewed $A$ Room of One's Own eighteen months later in Life and Letters ["New Novels," vol. 3, no. 19 (December 1929): 551-554]. The article begins with the reviewer's horror at finding himself quoted "amid acid commentary" in Woolf's book, when "curiously enough, my unhappy sentence was inspired by a wholehearted admiration of Mrs. Woolf." He then spends most of the next three pages defending his position.) Similarly, the "Quotation about Lady Dudley" (A.2), which appears without identification among the entries in this volume (B.22), finds a place in her book.

The table of contents listed below as A.2 appears on the second page of the notebook and was probably made close to the time the notes were made; it is written in blue ink. The table of contents that appears on a label on the cover of the notebook, A.1, is typed, and is closer to the actual contents of the notebook; it was probably made at a later time. Most of the entries are in blue or blue-purple ink.

\section{A. TABLe of Contents}

1. Lord Chesterfield Letters

Udolpho

Merediths Novels

Sternes Letters

Sentimental Journey

Bleak House

Pride and Prejudice

The Possessed

Moby Dick

Thraliana

Anecdotes of Dr Johnson

Small House at Allington

1 p., on cover. Typed.

2. 1 Life in Fiction

2 Udolpho

3 Bleak House.

4 Letters of Lord Chesterfield.

5 De Quincey's Diary.

6 Meredith.

7 Sterne Letters 


\section{Miss Davies}

9 Swan Song. Galsworthy

10. Bleak House.

11 Tristram Shandy

12 Quotation from Life \& Letters

13 Dorothy Osborne's Letters

14 Shapes that Pass. Hawthorne.

15 Thraliana - Anecdotes of Dr. Johnson.

16 Quotation about Lady Dudley

17 The Small House at Allington.

1 p., not numbered, appearing also as B.2, below.

B. ENTRIES

1. " $L^{d}$ Chesterfields Letters.": 1 p., numbered 1 by VW. The first part of the entry consists of notes on Lord Mahon's "Preface," written in 1845. Among the notes on Mahon is the quotation, "Tyrawley \& I have been dead these two years, but we don't choose to have it known!" The passage is annotated by Woolf "Boswell's Life of Johnson, April 3, 1773," and is quoted by Mahon, p. xxiv, n. More notes on this work appear in XIV, B.7.

Chesterfield, 4th Earl of [Philip Dormer Stanhope]. Letters. Ed. Lord Mahon. Vol. I [of V]. Lippincott, 1892.

2. "1 Life in Fiction": 1 p., not numbered. Table of Contents. See above, A.2.

3. "Being Like Life in fiction": 1 p., not numbered. General notes on "belief" and "reality" in the novel, beginning, "The truth is Belief is the only test. If we can [?film] a tiger, it is right."

4. "Udolpho.": 1 p., not numbered. 5 lines only, reading, "The extreme vagueness of language is necessary. The wonderful: it is quite easy to believe in a certain amount of wonder. Scenes of peasants dancing; all in groups: statuesque, distant. no dialogue." More notes on the novel appear in XIV, B.3, and XXV, B.29.

Radcliffe, Ann. The Mysteries of Udolpho. A Romance. [1794].

5. "Richard Feverel. Mer. Vol 1": 4 pp., not numbered.

Meredith, George: The Ordeal of Richard Feverel. 3 vols.

Chapman \& Hall, 1859. 
6. "Beauchamp's Career. Meredith.": 2 pp., not numbered. The notes end with a general comment, beginning, "Given up at Vol. 1 because of the intolerable long windedness."

Meredith, George. Beauchamp's Career. Vol. I [of III]. Chapman \& Hall, 1876.

7. "Harry Richmond Meredith": 5 pp., not numbered. The entry includes general notes on Meredith's strengths and weaknesses.

Meredith, George. The Adventures of Harry Richmond. [1871].

8. "Meredith Egoist": 3 pp., not numbered.

Meredith, George. The Egoist. Kegan Paul, 1880.

9. "Meredith's Letters": 1 p., not numbered. Marginal notation, "Vol 2." For notes on Vol. I, see XXVI, B.34.

Meredith, George. Letters. Ed. by his Son [William Maxse Meredith]. Vol. II [of II]. Constable, 1912.

10. "That his optimism is wrong.": 1 p., not numbered. General notes on George Meredith. See above, B.5-9.

11. "Letters of L Sterne": 1 p., not numbered. More notes on this work appear below, B.13.

Sterne, Laurence. Letters. Oxford: Shakespeare Head Press, 1927.

12. "Sterne. Sentimental Journey/(Crosses Life.": 2 pp., not numbered. (1st page, 7 lines only; 2nd page, 3 lines only.)

Cross, Wilbur L. The Life and Times of Laurence Sterne. Vol. II [of II]. New Haven: Yale Univ. Press, 1925.

13. "Letters": 1 p., not numbered. The entry begins on the second page of B.12, headed "Crosses Life." More notes on this work appear above, B.11.

Sterne, Laurence. Letters. Oxford: Shakespeare Head Press, 1927.

14. "Sen' Journey": 3 pp., not numbered. Source unidentified.

Sterne, Laurence. A Sentimental Journey Through France and Italy. [1768].

15. "24/Middle Way/NW11": 1 p., not numbered. (Heading only.) The entry appears on the reverse of the first page of B.14.

16. "Bleak House.": 3 pp., not numbered. More notes on this novel appear in XIV, B.5 and B.10. The entry consists 
largely of general notes on the novel and Dickens' technique. One note begins, "This is what one may call a parent idea: upon which his characters are buds or shoots."

Dickens, Charles. Bleak House. Chapman \& Hall, 1905. Vol. XI of The Works of Charles Dickens. Authentic Edition.

17. "Fanny Burney \& her Friends.": 1 p., not numbered. 4 lines only, reading, "29 FB. never indulged herself with reading or writing except in the afternoons; always scrupulously devoting her time to needlework till after dinner."

[Burney, Fanny.] Fanny Burney and her Friends. Select Passages from her Diary and Other Writings. Ed. L. B. Seeley. Seeley, 1890.

18. "Jane Austen. P \& Prej": 1 p., not numbered.

Austen, Jane. Pride and Prejudice. Dent, 1906. Everyman Edition.

19. "Turgenev. Lear of the Steppes/Dostoevsky. The Possessed":

1 p., not numbered. More notes on this novel appear in XIV, B.14.

Dostoevsky, Feodor. The Possessed. Trans. Constance Garnett. Heinemann, 1916.

20. "Thraliana": 1 p., not numbered. (3 lines only.)

Hughes, Charles. Mrs. Piozzi's Thraliana. With numerous extracts hitherto unpublished. Simpkin, Marshall, Hamilton, Kent, 1913.

21. "Anecdotes of Dr Johnson.": 2 pp., not numbered. The entry begins on the same page as B.20.

Piozzi, Hester Lynch [Mrs. Thrale]. Anecdotes of the Late Samuel Johnson, LL.D., during the last twenty years of his life. Cadell, 1786.

22. "With quick/decision she assumed/at once the reins of management of/large estates \& the part/of a devoted wife": 1 p., not numbered. (Heading only.) The entry appears on the reverse of the second page of B.21. In the original, the last word is "nurse," not wife.

"Georgina Lady Dudley." Obituary. The Times, February 4, 1929, p. 17.

23. "Small House at A. Trollope.": 2 pp., not numbered. The first page consists of 6 lines of general notes on the novel, reading, "The thing is that perhaps the highest qualities of 
a novelist are shown in scenes like the [?scholar] onesmall things about people-low in tone-a natural liveliness-no emphases-all true of T."

Trollope, Anthony. The Small House at Allington. 2 vols. Bell, 1906. Vols. V and VI of The Barsetshire Novels.

24. "W \& F. 150": 1 p., not numbered. The entry appears on the reverse of the first page of B.23, and consists of a list of figures, probably of money earned for her articles.

\section{Monk's House Papers/B.2o. (Sussex)}

On August 3, 1924, Woolf was planning "a systematic beginning, I daresay the 80th, upon the Common Reader, who might be finished in a flash I think, did I see the chance to flash \& have done with it" $(D$, II). Several of the entries in this notebook record notes connected with essays for her Common Reader - "The Pastons and Chaucer," "On not Knowing Greek," and "Notes on an Elizabethan Play" - and these should be used in conjunction with Volumes XXX, XXXVIII, XLIX, XXV, and XIX. It is unclear exactly when, during the three years Woolf worked on these essays (1922-1924), she made the notes collected here, but given the dates of the other notes in this volume they appear to be rather late. The entries on Sophocles (B.19, 22) may date from November 3, 1923, when Woolf was reading him "(with a crib in one hand) \& with pleasure" ( $D, \mathrm{II})$; and we know that she read Romeo and Juliet (B.23) and King John (B.25) in June and August 1924 (D, II, June 21, August 15; see XXV, B.7, for notes on Richard II also made in August 1924). The "translated Plato" she was planning to read on August 3, 1924, as part of her work for finishing The Common Reader, may well be The Protagorus (B.32).

An interesting sidelight on the development of The Common Reader occurs in a note headed "Donne" (B.31): "This essay should be ... put into the mouth of Mary Bickley, an obscure woman 1845. her diary." Although Woolf read and extensively noted Donne's poems while preparing her critical book (see XIX, B.14 and B.40) and was, according to this entry, planning to include him, the essay was never written. Nevertheless, the note illustrates her desire to find a framework for her essays that would place the literature in the context of 
its readers. "Mary Bickley," however, unlike the Pastons of "The Pastons and Chaucer," appears to be a fiction.

For the most part, the remaining notes in this volume belong to the period between August 1924 and April 1925, and they record the diversity of Woolf's writing at that time. On August 15, 1924, Woolf noted that the death of Conrad broke into her calculations for completing The Common Reader and Mrs. Dalloway, which she was also revising at that time (see B.28); the result was her leader on Conrad for the $T L S$, August 14, 1924 (Kp. C252), which incorporates the comments on Some Reminiscences found in this volume (B.34). Other entries were made for a series of articles published in the Nation \& Athenaeum between September 27, 1924, and April 25, 1925: "Appreciations," a review of Figures in Modern Literature (B.21), September 27, 1924 (Kp. C254); "Restoration Comedy," a review in part of Dobrée's book on Restoration Comedy (B.16), October 18, 1924 (Kp. C258); a review of Richard Hakluyt (B.15), October 25, 1924 (Kp. C255.3); a review of Smoke Rings and Roundelays (B.14), October 25, 1924 (Kp. C255.4); and a review of $A$ Player under Three Reigns (B.6), April 25, 1925 (Kp. C262.2). Her article on "Olive Schreiner" (B.12) was published in the New Republic on March 18, 1925 (Kp. C260).

The notes on "Scott. Antiquary. 20" listed in the table of contents but missing from the entries are found in XXVI, B.22: five pages, numbered 20-24 by Woolf. Her essay on The Antiquary, which incorporates many of these notes, appeared in the Nation \& Athenaeum, November 22, 1924 (Kp. C256).

The last entry in the notebook, headed "Conclusion," is unnumbered and unlisted in the table of contents. It consists of notes for the final section of $A$ Room of One's Own that were probably made some time between November 1928, when she began writing the book, and its publication in November 1929. The notes are a fairly accurate outline of the end of Chapter 6, starting from: "Here, then, Mary Beton ceases to speak. She has told you how she reached the conclusion - the prosaic conclusion-that it is necessary to have five hundred a year and a room with a lock on the door if you are to write fiction or poetry" $(R O O)$.

The table of contents, in blue ink, appears on an ordinary sheet of paper that acts as the front cover of the notebook. The lines on either side of the column of page numbers are in blue pencil, as are the page numbers within the volume. Most of the notes are in blue ink, with an occasional gray-blue note. Pages 26-27 are missing. 
A. Table of Contents

1. Otway. Venice Preserv'd. 1 Dryden All for Love 2 Shakespeare Antony \& Cleo. 4 Sidney. Defence of Poesie 6 On Tragedy. Dixon 9 Chapman Bussy D'Ambois 15 Ibsen Hedda Gabler $\quad 18$ Scott. Antiquary 20

Schreiner 25

Red Gauntlet 26

Scotts Biogs. of Novelists 28

Hakluyt $\quad 30$

Dobree Restoration Comedy. 32 Antigone 36

Priestley Mod. Lit 41

$\mathrm{Sh}^{\text {re }}$ Romeo \& Juliet $\quad 47$

Order of Sres plays 48

King John 49

Buckinghams Auto: 51

Richard 2 ${ }^{\text {nd }} \quad 52$

Richard 3 rd 55

Nun Priests Tale Chaucer 58

Plato Protagorus. $\quad 60$

Prelude Wordsworth 62

$M^{\text {rs }}$ Carter 64

Nigger of Narcissus $\quad 70$

$1 \mathrm{p}$. , on cover.

B. ENTRIES

1. "Otway. Dryden/Elizabethan Plays-\&c./Venice Preserv'd/Otway": 1 p., numbered 1 by VW.

Otway, Thomas. Venice Preserved; or, The Plot Discovered.

2. "There are obviously people like Cleopatra who/stand for something in human nature, \& so/get built up by general consent": 3 pp., numbered 1-3 by VW. The entry begins under the general heading, "Otway. Dryden/Elizabethan Plays-\&c," and then, "Love All for Love/Dryden." See above, B.1. The entry includes notes on the differences 
between Elizabethan and eighteenth-century drama: "Is this French, or fiction beginning, or what?"

Dryden, John. All for Love; or The World Well Lost.

3. "Antony \& Cleopatra. Shakespeare.": 1 p., numbered 4 by VW. (6 lines only.) General notes, beginning, "Of course, the first thing is the immensely greater richness \& subtlety of Cleo. in particular."

Shakespeare, William. Antony and Cleopatra.

4. "Specimens./Chapman./The Gods": 1 p., numbered 5 by VW.

(3 lines only.) The notes consist of a quotation from Bussy D'Ambois that appears in "Notes on an Elizabethan Play": "Man is a tree that hath no top in cares,/No root in comforts; all his power to live/Is given to no end, but t'have power to grieve." More notes on this play appear below, B.8.

Chapman, George. Bussy D'Ambois. In Works. Ed. Richard Herne Shepherd. Vol. I. Chatto \& Windus, 1874.

5. "Sidney. The Defence of Poesie.": 2 pp., numbered 6-7 by VW.

Sidney, Sir Philip. Defence of Poesie. In The Countess of Pembroke's Arcadia. 10th ed; with his Life and Death ... and som other new Additions. Calvert \& Pierrepont, 1655.

6. "A Player under 3 reigns./Forbes Robertson. 21/-": 1 p., numbered 8 by VW.

Forbes-Robertson, Sir Johnston. A Player under Three Reigns. Unwin, 1925.

7. "Tragedy W. MacNeile Dixon": 6 pp., numbered 9-14 by VW.

Dixon, W. MacNeile. Tragedy. Edward Arnold, 1924.

8. "Chapman Bussy D'Ambois": 2 pp., numbered 15-16 by VW. More notes on this play appear above, B.4.

Chapman, Geroge. Bussy D'Ambois. In Works. Ed. Richard Herne Shepherd. Vol. I. Chatto \& Windus, 1874.

9. "Buekingham The Rehearsal": 1 p., numbered 17 by VW. 2 lines only, both cancelled: "written produced in 1671. Written to ridicule the rhyming mouthing plays of Dryden."

Buckingham, 2nd Duke of [George Villiers]. The Rehearsal. 
10. "Johnson. Life of Cowley.": 1 p., numbered 17 by VW.

Johnson, Samuel. "Cowley." In The Lives of the English Poets. Ed. Arthur Murphy. Longman, etc., 1792. Vol. IX of Works. New ed.

11. "Ibsen. Hedda Gabler": 2 pp., numbered 18-19 by VW. The entry consists almost entirely of general notes, one passage beginning, "But then there is the question of beauty. . . . poetry in the midst of prose."

Ibsen, Henrik. Hedda Gabler. Trans. Edmund Gosse and William Archer. Heinemann, 1907. Vol. X of The Collected Works. Copyright Edition.

12. "African Farm. \& Letters": 1 p., numbered 25 by VW. The entry begins with two lines of general notes on The Story of an African Farm: "probably has the quality of an autobiography-vivid-the odd exaggerated humour." The rest of the notes are on the Letters.

a) Schreiner, Olive. The Story of an African Farm. [1883].

b) Schreiner, Olive. Letters ... 1876-1920. Ed. S. C. Cronwright-Schreiner. Unwin, 1924.

13. "Scotts Biographies/On Novels./Fielding (107)": 1 p., numbered 28 by VW. Quotation, beginning, "The worst evil to be apprehended from the perusal of novels is, that the habit is apt to generate an indisposition to real history \& useful literature; ..."

Scott, Sir Walter. "Henry Fielding." In Biographical Memoirs of Eminent Novelists, and Other Distinguished Persons. Edinburgh: Cadell, 1834. Vol. III of The Miscellaneous Prose Works.

14. "Smoke Rings \& Roundelays.": 1 p., numbered 29 by VW.

Partington, Wilfred. Smoke Rings and Roundelays. Blendings from Prose and Verse since Raleigh's Time. Castle, 1924.

15. "Sheldon Press. Pioneers of Progress./Foster Watson D.Litt./ Hakluyt. 2/6.": 2 pp., numbered 30-31 by VW.

Watson, Foster. Richard Hakluyt. Sheldon Press, 1924. Pioneers of Progress Series.

16. "Dobree. Restoration Comedy": 2 pp., numbered 32-33 by VW.

Dobrée, Bonamy. Restoration Comedy: 1660-1720. Oxford: Clarendon Press, 1924. 
17. "Redgauntlet": 1 p., numbered 34 by VW. 4 lines only, reading, "Vol/I/212 his dialogue in dialect so good," followed by a quotation.

Scott, Sir Walter. Redgauntlet. Vol. I [of III]. Edinburgh: Constable, 1824.

18. "The Plain Dealer Wycherley": 1 p., numbered 35 by VW. 4 lines only, reading, "a copy to some extent of Misanthrope: but all bursting \& over brimming; no subtle points. He refers to the Country Wife, \& its indecency, with great good sense."

Wycherley, William. The Plain Dealer.

19. "Antigone Sophocles/in Greek.": 4 pp., numbered 36-39 and 1-4 by VW. More notes on this work appear below, B.22.

Sophocles. The Antigone. With Critical Notes, Commentary, and Translation in English Prose by R. C. Jebb. Cambridge: Cambridge Univ. Press, 1888. Vol. III of Sophocles. The Plays and Fragments.

20. "Thistleton,/Horne,/Mitchell": 1 p., numbered 40 by VW. The entry consists of a list of twenty-nine names, unidentified.

21. "Figures in Modern Lit./Priestley": 5 pp., numbered 41-45 by VW, and $1 \mathrm{p}$., on the reverse of p. 44.

Priestley, J. B. Figures in Modern Literature. The Bodley Head, 1924.

22. "Antigone.": 1 p., numbered 46 by VW. (3 lines only.) More notes on this play appear above, B.19.

Sophocles. The Antigone. With Critical Notes, Commentary, and Translation into English Prose by R. C. Jebb. Cambridge: Cambridge Univ. Press, 1888. Vol. III of Sophocles. The Plays and Fragments.

23. "Romeo \& Juliet.": 1 p., numbered 47 by VW. 3 lines only, reading, "There is of course perfect character drawing in Capulet \& the old nurse. Cap. We have a triffling foolish banquet towards." The quotation is from Act I, Scene v.

Shakespeare, William. Romeo and Juliet.

24. "All Sh res work done between $27 \& 47 ": 2$ pp., numbered 47-48 by VW. Marginal notation, "Sidney Lee./DNB." The entry consists mainly of a list of Shakespeare's works. The heading on p. 48 is " $\mathrm{Sh}^{\mathrm{re}}$. Order of Plays."

Lee, Sidney. "Shakespeare, William." DNB (1897). 
25. “King John. Shakespeare.": 2 pp., numbered $49-50$ by VW. Shakespeare, William. King John.

26. "Buckinghams Auto.": 1 p., numbered 51 by VW. Quotation, annotated "1.60."

Buckingham, James Silk. Autobiography. Vol. I [of II]. Longman, Brown, Green, \& Longmans, 1855.

27. "Shakespeare. Richard $2^{\text {nd": }} 2$ pp., numbered $52-53$ by VW. More notes on this play appear in XXV, B.7.

Shakespeare, William. Richard II.

28. "Her passion for places./He hesitates to open her letter because it will break in/upon this imagination of her.": $1 \mathrm{p}$., numbered 54 by VW. The entry consists of notes for Peter Walsh's musings about Clarissa Dalloway while in his hotel room before dinner: Mrs. Dalloway (1925).

29. "Shakespeare. Richard 3rd": 3 pp., numbered 55-57 by VW.

Shakespeare, William. Richard III.

30. "Nun Priest's Tale. Chaucer": 1 p., numbered 58 by VW. The entry includes notes on the "Nun's Priest's Tale" and a quotation, annotated "p. 190," from the "Clerk of Oxford's Tale": "And she set doun her water pot anon/Beside the threshfold in an oxe's stalle." For more notes on The Canterbury Tales, see XLIX, B.14.

Chaucer, Geoffrey. "Nun's Priest's Tale" and "Clerk of Oxford's Tale." The Canterbury Tales. In Works. Ed. Alfred W. Pollard, etc. Macmillan, 1898. The Globe Edition.

31. "Donne": 1 p., numbered 59 by VW. (3 lines only.) The entry consists of notes for an unwritten essay on Donne: "This essay should be in the put into the mouth of Mary Bickley, an obscure woman 1845. her diary."

32. "Plato/Protagorus/(Jowett)": 2 pp., numbered $60-61$ by VW. Woolf may well have read the English translation in Dialogues, translated by Benjamin Jowett (1871).

Plato. The Protagorus.

33. "Wordsworth. Prelude/Book 7. London": 1 p., numbered 62 by VW. The entry consists of a transcription of lines 458465 , followed by the comment, "Good quotation for one of my books." 
Wordsworth, William. The Prelude, or Growth of a Poet's Mind. An Autobiographical Poem. Book VII. "Residence in London." Edward Moxon, 1850.

34. "but C. ehose loved the Latin, not Saxon side, of English.": 1 p., numbered 63 by VW. Marginal notation, "Rems."

Conrad, Joseph. Some Reminiscences. Eveleigh Nash, 1912.

35. "Memoirs by Pennington. Mrs. Carter.": 5 pp., numbered 64-68 by VW.

Pennington, Montagu. Memoirs of the Life of Mrs. Elizabeth Carter. 2nd ed. Vol. I [of II]. Rivington, 1808.

36. "Nigger of N.": 1 p., numbered 70 by VW.

Conrad, Joseph. The Nigger of the Narcissus. A Tale of the Sea. Heinemann, 1898.

37. "Conclusion": 1 p., not numbered. The entry consists of notes for the final pages of A Room of One's Own, beginning, "These are my notes. Add. destroy. Conclusionmoney \& a room of your own."

\section{Monk's House Papers/B.2p. (Sussex)}

On January 27, 1932, Woolf wrote to Donald Brace postponing the publication date of The Common Reader: Second Series: "I have now gone through the material, and I find there is more work to do than I expected. I think I could make a more complete book of it also by adding one or two fresh articles" $(L, \mathrm{~V}, 2514)$. The entries in this volume record some of the reading that led to the "fresh articles" on the Elizabethans and De Quincey in the finished book, as well as the rereading that accompanied her revisions of previously published essays.

Several of the entries, however, are difficult to pinpoint in the history of her second critical book. The long entry on Sidney's Arcadia, for example, which includes a page headed "Arcadia/Plan of Article," and the notes on Dekker and Lady Anne Clifford (B.1-3), all belong to the new essays written for the book - "The Countess of Pembroke's Arcadia," "The Strange Elizabethans," and "Donne After Three Centuries"-but whether they preceded her attempt in November 1931 "to furbish up two long Elizabethan articles to front" her book is unclear ( $A W D$, November 16$)$. In her early plans, pos- 
sibly as early as December 1929, one projected article was on Sidney and Penelope Rich, a plan supported by her reading of several biographies of Sidney (see Volumes XII, XI, XX, and VIII for the history of the Elizabethan essays). Later, in August 1931, Woolf spoke of reading "all Sidney," and planned, in early December, a visit to Penshurst; by the end of December, however, she was complaining that she could not "get back in the mood" to write the essay on Sidney ( $L$, IV $, 2419,2477,2497)$. It is possible, then, that the decision to focus on the Arcadia was a late one and that the notes on this work were made in the last half of 1931 or in the beginning of 1932.

The notes on the biography of Lady Anne Clifford have a similar history. On April 13, 1930, Woolf apologized to Helen McAfee of The Yale Review for not having done the Lady Clifford-presumably one of her projected studies of Elizabethan characters ( $L$, IV, 2166). A year later, on July 2, 1931, she told McAfee that she was again being drawn to the Elizabethans and "may at last go into the Lady Clifford Diaries which have been on my shelves for more than a year" ( $L$, IV, 2399); by September 7, she was "deep in Lady [Anne] Clifford" $(L, I V, 2430)$. As it turned out, however, Lady Anne played a prominent role in the drafts of Woolf's essay on Donne's poetry as one of the noble women who served as patrons to and readers of the poeta role she plays to a lesser degree in the finished piece-but she did not command an essay of her own. (For one example of her prominence, see the notebook now at Sussex, MH/B.2e, which includes "Corrections \& Additions to Second Common Reader" dated January 1932.) Nevertheless, Anne Clifford continued to inform Woolf's vision of the Elizabethan woman and reader; she reappears in the reading notes in Volumes XVI and XXXVII as a prelude to her appearance in Woolf's last essay, "The Reader" ( $A \& R)$.

For the rest, the notes on De Quincey and the "Sketch of Article" (B.9-11) are the source of "De Quincey's Autobiography"-another fresh article-which was finished on June 28, $1932(A W D)$. The remaining notes in this volume-on Robinson Crusoe (B.4), Dorothy Osborne's Letters (B.5-6), Swift's Journal to Stella (B.7), Lord Chesterfield (B.8), and James Woodforde's Diary (B.12) - all pertain to essays that Woolf had written and published in the preceding seven years and then revised for her book. (Where applicable, I have indicated the location of Woolf's original notes.) Although it is difficult to be certain, the entries in this volume were probably made when Woolf revised the essays, and not for the originals; the notes on Volume IV of Woodforde's Diary, for example, were clearly made after its publication in 1929, and not for the review of Volume III 
that Woolf published in 1927 . We can, then, tentatively date these entries between November 16, 1931, when Woolf began to "go through the whole long list of those articles," and July 11, 1932, when she records the completion of the book $(A W D)$. Given her despairing lament of February 8, "Why did I ever say I would produce another volume of Common Reader? It will take me week after week, month after month" $(A W D)$, and her declaration on April 1 that all her articles bored her "to a kind of dancing agony at the futility of all criticism" ( $L, V, 2562)$, it is no surprise to find in her July 11 diary entry that the completion of the essays brought her not glory but the determination never to write a similar book.

The cover of the notebook, with its list of contents in black ink on one side, bears the title "Flush" (also in black ink) on the other side. Woolf had begun writing Flush by August 10, 1931 (AWD), and drafts for " "The Countess of Pembroke's Arcadia," dated February 22, 1932, appear in the same manuscript as notes for Flush: "[The Life, character and opinions of Flush the Spaniel.] Holograph fragment of opening chapter" (Berg). The notes are all in black or blue ink.

\section{A. Table of Contents}

1. Dekker

Lady A. Clifford

Arcadia

Robinson Crusoe

Temple's Life

Dorothy Osborne

Swifts Journals

Chesterfields Characters

1 p., on cover.

2. Dekker. The Wonderful Year.

Life of Lady Anne Clifford

Sidneys Arcadia

Robinson Crusoe

Temples Life

Dorothy Osbornes Letters

Swift's Journal

Chesterfields Characters

De Quinceys Autobiography

1 p., not numbered. 


\section{B. Entries}

1. "Dekker The/Wonderful Year": 1 p., not numbered. The entry begins, "What was the common form of $\mathrm{E}^{\text {than }}$ prosewhat was the staple?" For other notes on this work from this period, see XI, B.3.

Dekker, Thomas. The Wonderfull Yeare 1603. Reprint of the 1603 edition. The Bodley Head, 1924. Bodley Head Quartos, No. 8.

2. "b. 1590-d. 1676": 3 pp., not numbered. The second and third pages are headed "Ly Clifford" and "Ly A. Clifford." The top right corner of the first page has been torn off. The notes focus on Lady Anne's education and her love of books.

Williamson, George C. Lady Anne Clifford ... Her Life, Letters and Work. Kendal: Titus Wilson, 1922.

3. "Sidneys Arcadia": 12 pp., not numbered. The ninth page, which is headed "Arcadia./Plan of Article," begins, "Sidney was not going to think of what was before his eyes." For other notes on this work, see VIII, B.2.

Sidney, Sir Philip. The Countess of Pembroke's Arcadia. 10th ed., with his Life and Death... and som other new Additions. Calvert \& Pierrepont, 1655.

4. "Robinson Crusoe": 4 pp., not numbered. For the original notes, see IV, B.1.

Defoe, Daniel. The Life and Strange Adventures of Robinson Crusoe. Facsimilie reprint of the first edition published in 1719. Ed. Austin Dobson. Elliot Stock, 1883.

5. "Life of/Temple/Dorothy Osborne": 4 pp., not numbered, and $1 \mathrm{p}$., on the reverse of the third page. The note on the reverse is "The Remains of/M"rs. Brunton," a work referred to by Courtenay, II, 173, n., for a description of the beauty of English women. The reference is to Mary Brunton's "Extracts from a Journal," in Emmeline, with Some Other Pieces (1819).

Courtenay, Thomas Peregrine. Memoirs of the Life, Works, and Correspondence of Sir William Temple, Bart. 2 vols. Longman, etc., 1836.

6. "Dorothy Osbornes Letters": 3 pp., not numbered. For other notes on this work, see LII, B.1. 
Osborne, Dorothy. Letters ... to William Temple. Ed. G. C. Moore Smith. Oxford: Clarendon Press, 1928.

7. "Swifts Letters Journal to Stella": 3 pp., not numbered. For earlier notes on this work, see V, B.3.

Swift, Jonathan. Journal to Stella. Ed. J. K. Moorhead. Dent, 1924. Everyman Edition.

8. "Lord Chesterfields Characters": 1 p., not numbered. For other notes on this work, see XIV, B.8.

Chesterfield, 4th Earl of [Philip Dormer Stanhope]. Lord Chesterfield's Characters. Ed. Charles Whibley. Peter Davies, 1927. Little Books.

9. "De Quinceys Autobiography": 1 p., not numbered. The entry consists of general notes on De Quincey, beginning, "D $\mathrm{Q}$. is about himself in the past; not about himself now," followed by a passage annotated "(4/Op. Eater)."

De Quincey, Thomas. Confessions of an English Opium-Eater.

Ed. Richard Garnett. Kegan Paul, Trench, 1885.

10. "Autobiographic Sketches.": 4 pp., not numbered. The entry begins under the general heading, "De Quinceys Autobiography." See above, B.9.

De Quincey, Thomas. Autobiographic Sketches. Vol. I [of II].

Edinburgh: James Hogg, 1853. Vol. I of De Quincey's

Works. Selections Grave and Gay.

11. "Sketch of Article.": 1 p., not numbered. General notes on De Quincey, beginning, "That he has to generalise." The article is "De Quincey's Autobiography." See above, B.9-10.

12. "Woodforde.": 1 p., not numbered. (6 lines only.) Marginal notation, "4/1793." More notes on this volume of Woodforde's Diary appear in XV, B.3.

Woodforde, James. The Diary of a Country Parson. Ed. John Beresford. Vol. IV. 1793-1796. Oxford Univ. Press, 1929.

\section{Monk's House Papers/B.2q. (Sussex)}

The ten pages of notes headed "Reading" or "Reading/Misc.," the list of essays for her projected critical book, and the preponderance of notes on the Pastons and Chaucer all identify this notebook as 
the third of the six notebooks associated with the development of The Common Reader (1925). (For the other notebooks, see XXX, XXXVIII, XXV, XIX, and XLVII.) Most of the entries can be dated in 1922. On November 15, 1921, Woolf wrote that "if only [she] could find energy to tackle the Paston letters, [she] must start Reading"; on January 3, 1922, it was her "evening with the Pastons. Tonight my reading begins" ( $D, \mathrm{II})$. The initial notes on The Paston Letters are found in Volume XXXVIII, B.26 and B.28; the entries in this volume (B.3, 5-7), containing as they do specific references for her essay, probably belong to the summer and fall of 1922 when she prepared and wrote "The Pastons and Chaucer." On July 22, an allusion to "The Nun's Priest's Tale" in her Diary is attributed to her Chaucer reading (B.14-18; D, II). On August 3, she announced "the beginning, the true not spurious beginning, of Reading this morning" $(D$, II) - possibly the " 4 thousand words of reading . . . a quick sketch of Pastons, supplied by books" written by August 16 ( $D$, II; see B. 4 and 8 for the reference books). In this same entry, she planned to "do Chaucer" and by the end of her stay at Rodmell, October 4, she had-temporarily-finished "the Chaucer chapter" and "read Chaucer \& the Pastons" ( $D$, II; see also $D$, II, May 11 , July 28, 1923).

"Certainly," she mused at this same time, "I enjoy my reading with a purpose," and began immediately to outline her reading for her chapter on the Greeks ( $D$, II, October 4, 1922). Among the works listed is a life of Bentley; she read the first chapters of this work by October 8 , and decided on October 14 to bring Bentley to "a hasty end" as he "is not really much to my purpose" ( $D$, II). These references are most likely to Monk's Life of Richard Bentley, noted below, B.1 (see also XXV, B.14, for notes on De Quincey's essay on Bentley). Despite her rejection of Bentley, however, he reappears in an early plan for her Greek essay "First introduction \& Bentley" ( $D$, II, November 7), and he earned his own essay in The Common Reader.

The notes at the end of this volume headed "Reading/Misc." (B.24, 26-28, 30-35), and the list of essays for her critical book beginning "Introductory. Briggs \& Byron" (B.25), almost certainly belong to the first half of 1922 when Woolf read Lord Byron's Correspondence, Peacock's novels, and Dostoevsky - all of whom appear in her miscellaneous notes-and wrote the essay headed "Reading/ 'Introductory. Byron \& Mr. Briggs'," which is dated in the text "Spring 1922." "Peacock is what I like. You don't know how good he is," she wrote Lytton Strachey on February 11, 1922 ( $L$, II, 1215; D, II, February 14, 15, 1922); and one of her notes for Reading begins, 
"Perhaps Peacock's is the perfect way of rendering character" (B.28). "I cant read Byron's letters," another note begins, "without wishing to know who Major John Cartwright (1740-1829) was . .." (B.27); Woolf read Byron's Correspondence in February 1922 ( $L$, II, 1220, $1223 ; D$, II, February 18, 1922). On March 12, she was "writing out the preface to Reading," called "Byron and Mr. Briggs," an experience described on March 24 as writing "with the usual fabulous zest" $(D$, II). The original of this essay, a corrected typescript, is found at Sussex (MH/B.11d); "Byron and Mr. Briggs," edited by Edward A. Hungerford, was published in The Yale Review 68, no. 3 (Spring 1979). References to Shakespeare's Troilus and Cressida (B.23) and to Dryden's criticism (B.29) also appear in this essay.

Other entries in this volume record Woolf's notes for articles published between July and September 1922, some of which then appeared in The Common Reader: "Jane Austen Practising" (B.2122), New Statesman, July 15, 1922 (Kp. C227); "On Re-reading Novels" (B.20), TLS, July 20, 1922 (Kp. C228); "Modern Essays," a review of Modern English Essays (B.13), TLS, November 30, 1922 (Kp. C229); and "Eliza and Sterne" (B.11-12), TLS, December 14, 1922 (Kp. C230). Woolf began reading Percy Lubbock's Craft of Fiction, included in "On Re-reading Novels" and listed in the table of contents (A.1), in December 1921 ( $L$, II, 1205), but she did not begin planning her essay until June 1922 ( $L$, II, 1254; D, II, February 15 , June 23,1922 ). With the exception of one short note below (B.20), the notes on Lubbock's book are found in XXVI, B.32. The notes on Ernest Rhys' Modern English Essays were made between October 4 and November 8, 1922 (D, II, October 4, 14, November 7, 1922; L, II, 1316).

Two sidelights on Woolf's writing during this period are provided by a map of Green Park and Bond Street (B.19) and by a line from Catullus's farewell to his brother addressed by Woolf to her brother, Thoby Stephen (B.9). The map of Green Park was almost certainly made in conjunction with "Mrs. Dalloway in Bond Street," published in July 1923 (Kp. C238). Woolf had begun this story by April 1922, wrote it throughout that summer, and finished it by October 4 ( $L$, II, 1238; $D$, II, June 23, August 16, 28, and October 4, 1922). On October 14, 1922, she recorded that "Mrs Dalloway has branched into a book" $(D$, II). The quotation from Catullus's lament on the death of his brother, "Atque in perpetuum, frater, ave atque vale" (Catullus 101 ), is followed by the line "Julian Thoby Stephen (1881-1906)." Coming as it does at the same time that she was finishing Jacob's Room (see, for example, $D$, II, June 23, July 17, 1922), this note 
suggests not only that Woolf thought of her brother in connection with the novel but that she may have contemplated dedicating it to him, using these lines as an epigraph.

The alphabetical table of contents on the front cover of the notebook is in black ink, and was probably made when the notes were bound. The numbers are in blue pencil, with an occasional entry numbered in the original ink as well. Most of the notes are in blue-purple ink.

\section{A. Table of Contents}

1. Austen. Love \& Freindship

Bentley. Boswell Young.

Canterbury Tales. Chaucer \& his England.

Essays, Modern.

Fiction, Craft of. Lubbock.

Gloys \& Pastons.

Meredith

Reading, notes for.

Sterne's Eliza. $S^{\text {re }}$ Troilus \& Cressida.

$1 \mathrm{p}$., on cover.

\section{B. ENTRIES}

1. "Bentley/Life of Richard Bentley. D.D./by Monk/by James Henry Monk. D.D./Ld Bishop of Gloucester./2 vols. 1833": 4 pp., numbered 1-4 by VW. (P. 4, 2 lines only.)

Monk, James Henry. The Life of Richard Bentley, D.D. 2nd ed. 2 vols. Rivington, 1833.

2. "Bs address/27 Brunswick Sq re": 1 p., not numbered, on the reverse of p. 1. The notes consist of two addresses, the second one being "Powys' address,/East Chaldon/Dorset."

3. "References wanted.": 1 p., numbered 5 by VW. The entry consists of a list of items about the Pastons, some with volume and page references to The Paston Letters. The references are "wanted" for her essay on "The Pastons and Chaucer." See below, B.5-7.

4. "Chaucer \& his England/G.G. Coulton": 2 pp., numbered 6-7 by VW.

Coulton, G. G. Chaucer and his England. Methuen, 1908.

5. "Pastons": 2 pp., numbered 8-9. The page references for these notes correspond to Vols. I-III of the 1872-1875 
edition of The Paston Letters, which Woolf noted as $\mathrm{OE}$, and to Vol. IV of the 1904 edition. More notes on the Pastons appear below, B.6-7; another set of notes appears in XXXVIII, B.26 and B.28.

a) [Paston.] The Paston Letters. 1422-1509 A.D. New ed. Ed. James Gairdner. 3 vols. Edward Arber, 1872-1875. Annotated Reprints.

b) [Paston.] The Paston Letters. A.D. 1422-1509. Ed. James Gairdner. Vol. IV [of VI]. Chatto \& Windus, 1904. New Complete Library Edition.

6. "Gloys": 3 pp., numbered 10-12 by VW. Gloys was Margaret Paston's priest and friend, and the notes in this entry record his role in the Paston Letters. More notes on the Pastons appear above, B.5, and below, B.7; another set of notes appears in XXXVIII, B.26 and B.28.

[Paston.] The Paston Letters. 1422-1509 A.D. New ed. Ed. James Gairdner. 3 vols. Edward Arber, 1872-1875. Annotated Reprints.

7. "Pastons/Last 2,000 words.": 2 pp., numbered $13-14$ by VW. This entry consists of notes and references that reappear in the final section on the Pastons in "The Pastons and Chaucer." The first group of notes are on Vols. II-IV of the 1904 edition, including some cross-references to the "O.E.": the 1872-1875 edition. The remainder of the notes, marked "OE," are on Vols. II and III of the 1872-1875 edition. More notes on the Pastons appear above, B.5-6; another set of notes appears in XXXVIII, B.26 and B.28.

a) [Paston.] The Paston Letters. A.D. 1422-1509. Ed. James Gairdner. Vols. II-IV [of VI]. Chatto \& Windus, 1904. New Complete Library Edition.

b) [Paston.] The Paston Letters. 1422-1509 A.D. New ed. Ed. James Gairdner. Vols. II-III [of III]. Edward Arber, 1872-1875. Annotated Reprints.

8. "The Pastons \& their England/by H.S. Bennett.": 3 pp., numbered $15-17$ by VW.

Bennett, H. S. The Pastons and their England. Studies in an Age of Transition. Cambridge: Cambridge Univ. Press, 1922.

9. "Atque in perpetuum, frater, ave atque vale./Julian Thoby Stephen/(1881-1906)/Atque in perpetuum, frater, ave atque vale": 1 p., not numbered, on the reverse of p. 17 . (Heading only.) All three lines are cancelled. The quotation 
is the last line of Catullus's lament for his dead brother (Catullus 101); Julian Thoby Stephen, Woolf's older brother, had died in 1906.

10. "Young Boswell.": 3 pp., numbered $18-20$ by VW, and $1 \mathrm{p}$., on the reverse of p. 18. P. 18 is also numbered 1 by VW. The notes on the reverse of p. 18 are headed "Zélide," a reference to Isabella de Zuylen, "Zélide," with whom Boswell was in love.

Tinker, Chauncey Brewster. Young Boswell. Putman's, 1922.

11. "Sterne/Sterne's Eliza./Life by Melville.": 1 p., numbered 21 by VW.

Melville, Lewis. The Life and Letters of Laurence Sterne. 2 vols. Stanley Paul, 1911.

12. "Sterne/Sterne's Eliza./Arnold Wright \& W. Lutley Sclater": 9 pp., numbered 22-30 by VW. Pp. 23-26 are also numbered $2-5$ by VW.

Wright, Arnold, and Sclater, William Lutley. Sterne's Eliza. Heinemann, 1922.

13. "Modern English Essays.": 5 pp., numbered 31-35 and 1-5 by VW. The entry includes notes on Rhys' "Introduction."

Rhys, Ernest, ed. Modern English Essays. 5 vols. Dent, 1922.

14. "Chaucer./Life.": 1 p., numbered 36 by VW. (3 lines only.) The entry consists of a list of events and dates in Chaucer's life.

15. "The Canterbury Tales.": 2 pp., numbered $37-38$ by VW. The entry consists of a list of The Canterbury Tales, with a brief description of each one.

16. "Chaucer.": 1 p., numbered 39 by VW. General notes on The Canterbury Tales, with references to "The Squire's Tale" and "The Prologue." The notes begin, "His poetry is a kind of enchantment-by wh. I mean that he makes his birds \& landscapes delightful, not only human beings."

Chaucer, Geoffrey. The Canterbury Tales. In The Complete Works. Ed. Walter W. Skeat. Vol. IV. Oxford: Clarendon Press, 1894.

17. "Chaucer/Troilus \& Cressida": 1 p., numbered 40 by VW. 1 line only: "Book I/line/279 Chaucers young woman again."

Chaucer, Geoffrey. Troilus and Criseyde. 
18. "Chaucer": 15 pp., numbered $41-55$ by VW. The entry consists of notes on the following Canterbury Tales, annotated either by page or line number:

a) "Chaucer/Manciple": 1 p., numbered 41 by VW. Notes on "The Manciple's Tale."

b) "Chaucer./Canterbury Tales./Prologue.": 1 p., numbered 42 by VW. Notes on "The Prologue."

c) "The Knights Tale.": 1 p., numbered 42 by VW. Notes on "The Knight's Tale."

d) "Chaucer/The Nun Priests Tale/of the Cock \& the Hen": 2 pp., numbered 43-44 by VW. (Page 44, 4 lines only.) Notes on "The Prologue of the Nun's Priest's Tale" and "The Nun's Priest's Tale."

e) "The Physician's Tale.": 1 p., numbered 44 by VW. Notes on "The Physician's Tale."

f) "The Prologue of the Pardoners Tale": 1 p., numbered 44 by VW. Notes on "The Prologue of the Pardoner's Tale."

g) "Chaucer/The Pardoner's Tale is the story of the 3 men who/wanted to kill death, \& killed each other": 1 p., numbered 45 by VW. Notes on "The Pardoner's Tale."

h) "Chaucer/W of B./332": 1 p., numbered 46 by VW. "W of B." is a marginal notation. Notes on "The Wife of Bath's Prologue."

i) "Chaucer": 1 p., numbered 47 by VW. A partial list of The Canterbury Tales, with brief comments.

j) "The Knights Tale. Palamon \& Arcite.": 2 pp., numbered 48-49 by VW. (P. 49, 4 lines only.) Notes on "The Knight's Tale."

k) "Miller": 1 p., numbered 49 by VW. Notes on "The Miller's Tale."

1) "Chaucer/The Monks Prologue.": 1 p., numbered 50 by VW. Notes on "The Monk's Prologue."

m) "Chaucer/Wife of Bath's Tale.": 1 p., numbered 51 by VW. Notes on "The Wife of Bath's Tale."

n) "The Somonour": 1 p., numbered 51 by VW. The heading is a marginal notation. Notes on "The Summoner's Tale." 
o) "The Clerk of Oxford's tale is in complete contrast to the/Somonours": 1 p., numbered 52 by VW. Notes on "The Clerk's Tale."

p) "The Merchant's Tale.": 2 pp., numbered $52-53$ by VW. Notes on "The Merchant's Tale."

q) "The Squires Tale.": 1 p., numbered 53 by VW. Notes on "The Squire's Tale."

r) "Chaucer/The Franklin's Tale.": 2 pp., numbered 5455 by VW. (P. 55, 2 lines only.) Notes on "The Franklin's Tale."

s) "The Second Nun's Tale.": 1 p., numbered 55 by VW. (3 lines only.) Notes on "The Second Nun's Tale."

t) "The Canon's Yeoman's Tale.": 1 p., numbered 55 by VW. Notes on "The Canon's Yeoman's Tale."

Chaucer, Geoffrey. The Canterbury Tales. In The Complete Works. Ed. Walter W. Skeat. Vol. IV. Oxford: Clarendon Press, 1894.

19. Holograph map of "Green Park," "Stratton St," and "Bond Street": 1 p., not numbered, on the reverse of p. 47. The map was probably made in conjunction with Mrs. Dalloway's walk in "Mrs. Dalloway in Bond Street," published in Dial 75, no. 1 (July 1923) [Kp. C238].

20. "Sketch the different ways of telling a story./Then say how Richardson, Meredith, H.J. did it": 1 p., numbered 71 by VW. (Heading only.) Both lines of notes are cancelled. The entry appears under the general heading "Austen" (see below, B.21), and consists of notes for "On Re-reading Novels," based in part on Percy Lubbock's The Craft of Fiction. The rest of the notes on this work, listed above in A.1, appear in XXVI, B.32, numbered 56-69 by VW.

21. "Austen/Love \& Freindship/Jane Austen.": 2 pp., numbered 71-72 by VW.

Austen, Jane. Love and Freindship. In Love and Freindship, and Other Early Works. With a preface by G. K. Chesterton. Chatto \& Windus, 1922.

22. "History of England": 2 pp., numbered $72-73$ by VW.

Austen, Jane. The History of England from the Reign of Henry the 4th to the Death of Charles the 1st. In Love and Freind- 
ship, and Other Early Works. With a preface by G. K. Chesterton. Chatto \& Windus, 1922.

23. "Troilus \& Cressida.": 2 pp., numbered $74-75$ by VW. The entry begins, "The words-the words - the words-."

Shakespeare, William. Troilus and Cressida.

24. "Reading/Misc./a seholar": 1 p., numbered 76 by VW. (4 lines only.) The entry consists of notes for Reading, her projected critical book, reading, "ignorance: inability to hold facts $\&$ think [ . . . ] could wd. be a scholar in the making. But scholars need making: we never feed it."

25. "1 Introductory. Briggs \& Byron": 1 p., numbered 77 by VW. The entry consists of a list of essays for her projected critical book. The list reads:

1 Introductory. Briggs \& Byron

2. Pastons: \& Odyssey

3 Hakluyt \& Elizas [Elizabethans]

4. Shakes re

5. Đss of Neweastle Sir T. Browne.

6. Restoration: I. D $\mathrm{D}^{\text {ss }}$ of Newcastle.

7. 18 th Cent.

9 The $[\ldots]$. .

10 Ourselves.

Pastons: Gammer Gurton. Pastons. Greece. Plays. Odyssey.

26. "Reading/Misc.": 1 p., numbered 78 by VW. The entry consists of notes for Reading, her projected critical book, beginning, "How a reader at the age of 60 looks back through his mind \& sees not single books, but groups"; and concluding, "To see what lit. looks like to a common reader-"

27. "Reading Misc.": 1 p., numbered 79 by VW. The entry consists of notes for Reading, her projected critical book, beginning, "I cant read Byron's letters, for instance, without wishing to know who Major John Cartwright (1740-1829) was who challenged Hobhouse to a duel at the age of 80." The notes conclude, "See Life \& Cor. of Major Cartwright by Miss F.D.C." The first reference is to Lord Byron's Correspondence, Chiefly with Lady Melbourne, Mr. Hobhouse, The Hon. Douglas Kinnaird, and P. B. Shelley, ed. John Murray (Murray, 1922), II, 115, which mentions Cartwright and includes a footnote directing the reader to the Life and Correspondence of Major Cartwright, by Miss F. D. Cartwright. 
28. "Reading": $1 \mathrm{p}$., numbered 80 by VW. The entry consists of notes for Reading, her projected critical book, beginning, "Perhaps Peacock's is the ideal way of rendering character"; and including notes on "Dostoevsky: Qy. whether the D. psychology can be understood by the English; whether the effect on Eng lit (at any rate now) has not been bad."

29. "Dryden./Preface to Fables.": 1 p., numbered 81 by VW. The entry includes a reference to and a quotation from Chaucer.

Dryden, John. "Preface to the Fables." In Essays. Ed. W. P. Ker. Vol. II. Oxford: Clarendon Press, 1900.

30. "Reading/Misc": 1 p., numbered 82 by VW. The entry consists of notes for Reading, her projected critical book, beginning, "Whether it is possible to read know Greek \& dig potatoes-doubtful. Compare the instantaneous impression got from $\mathrm{Sh}^{\text {re }}$ \& the impression got from Jebbs Sophocles."

31. "Reading./Misc.": 1 p., numbered 83 by VW. The entry consists of notes for Reading, her projected critical book, beginning, "True that the 'big things of life' are ... always the big things of life: but ... have to be re-discovered afresh by each generation...."

32. "Reading/Misc.": 1 p., numbered 84 by VW. The entry consists of notes for Reading, her projected critical book, on different kinds of reading. One passage begins, "One grades one's feelings," and includes comparisons of her feelings on reading Dr. Johnson, Dante, Religio Medici, Scott's Diary, and Milton.

33. "Reading Conception/Misc. Ideas.": 1 p., numbered 85 by VW. The entry consists of notes for Reading, her projected critical book, beginning, "The conception: This is a projection from you."

34. "Reading. Journalism/Misc. Ideas./Journalistic criticism": 1 p., numbered 86 by VW. The entry consists of notes for Reading, her projected critical book, beginning, "The great defect of journalism is that it pre puts the writer on good terms with the public." Another note reads: "How to review a novel. One should say he's a poor devil, \& his work worthless: but one shd. place him in his line."

35. "Reading./Miscellaneous ideas./Shakespeare": 1 p., numbered 87 by VW. The entry consists of notes for Reading, her 
projected critical book, beginning, "The way to do the $\mathrm{Sh}^{\text {re }}$ chapter is this: say that one walks up to Sh${ }^{\text {re }}$ quite openly."

36. "The life of the Rev. Joseph Blanco White/Written by himself with portions/of his correspondence. Edited by/John Hamilton Thom./3 vols. Chapman. 1845": 1 p., not numbered.

[White, Joseph Blanco.] The Life of Joseph Blanco White,

Written by Himself, with Portions of his Correspondence. Ed.

John Hamilton Thom. Vol. I [of III]. Chapman, 1845.

\section{Monk's House Papers/B.3a. (Sussex)}

This volume consists of five pages of notes on the Memoirs of the Life of John Mytton, more likely for her review of the book in 1926 than for her revision of the essay for The Common Reader: Second Series. The review appeared as "The Life of John Mytton," Vogue 67, no. 5 (early March 1926) (Kp. C272).

The notes are in purple ink.

B. ENTRIES

1. "Life of John Mytton": 5 pp., not numbered.

Nimrod [Charles James Apperley]. Memoirs of the Life of the Late John Mytton, Esq. New ed. Edward Arnold, 1925.

\section{Monk's House Papers/B.3b. (Sussex)}

Although the cover sheet, which reads "Feb: 1935/Purgatorio," may date the five pages of notes on Dante in this volume, Woolf had been reading The Divine Comedy since at least August 20, 1930: "I am reading Dante, \& I say, yes, this makes all writing unnecessary. This surpasses 'writing' as I say about Shre. I read the Inferno for half an hour at the end of my own page [The Waves]: \& that is the place of honour" $(D$, III). On September 24, 1930, she announced that her "present view of reading [Dante] is to elongate immensely. I take a week over one canto" ( $D$, III) - a seemingly accurate prediction of her pace. On August 30, 1934, for example, she was complaining that writing the last scenes of The Years-her next novelprevented her from reading Dante, and on April 1, 1935, she added, 
"At this rate I shall never finish the Purgatorio. But what's the use of reading with half one's mind running on Eleanor and Kitty" - two of the characters in The Years $(A W D)$. In fact, several entries in the diary about Dante link her reading of him to her thoughts about The Years, which she was writing and revising throughout this period: "Isn't it odd? Some days I can't read Dante at all after revising .... other days I find it very sublime and helpful. Raises one out of the chatter of words" ( $A W D$, December 3, 1934; see also, January 19, March 16, 27, 1935). In the end, Dante found his way into the novel; the third page of her notes on the Purgatorio below contains the passage that appears at the end of the 1911 section of The Years:

Che per quanti si dice piu li nostro, tanto possiede piu di ben ciascuno.

For by so many more there are who say "ours", So much the more of good doth each possess.

The passage is from Canto $\mathrm{XV}$, lines 55-56, and appears on pages 182 and 183 of the dual-language text used by Woolf.

All the notes are in black ink.

\section{A. Table of Contents}

1. Feb: 1935

\section{Purgatorio}

$1 \mathrm{p}$. , on cover.

B. ENTRIES

1. "How can it be that a good when/shared, shall make the greater/number of possessors richer . ..": 5 pp., not numbered. The notes are in Italian and English.

Alighieri, Dante. Purgatorio. The Italian ed. by Hermann Oelsner. Trans. Thomas Okey. Dent, 1900. The Temple Classics. Reprinted in La Divina Commedia. Dent, 1933.

\section{Monk's House Papers/B.3c. (Sussex)}

The notes on Dorothy Osborne's Letters . . to William Temple that fill this volume may well be those listed in the table of contents for 
Volume XLVI (A.2) but missing from the entries. Woolf noted in her diary on September 17, 1928, that she "was to have read Dorothy Osborne," whose "shepherdesses singing" appear in Woolf's vision of "the heart of England" evoked by a country wedding five days later $(D$, III). On September 25, she wrote to Leonard Woolf from France asking if he had "done Dorothy Osborne" ( $L$, III, 1927). Her review of the letters appeared in the New Republic on October 24, 1928 (Kp. C304). Another set of notes on this work, probably made when she revised the essay for inclusion in The Common Reader: Second Series, appears in XLVIII, B.6.

The notes are in blue ink.

B. ENTRIES

1. "Dorothy Osborne": $10 \mathrm{pp}$., not numbered. The entry includes notes on G. C. Moore Smith's "Introduction."

Osborne, Dorothy. Letters ... to William Temple. Ed. G. C.

Moore Smith. Oxford: Clarendon Press, 1928.

\section{Monk's House Papers/B.3d. (Sussex)}

Woolf's essay on Oliver Goldsmith, the subject of this volume of notes, appeared as a review of The Citizen of the World and The Bee, $T L S$, March 1, 1934 (Kp. C342). Woolf mentioned that she was both reading and writing about Goldsmith during April 1933 ( $A W D$, April $6,25)$ and then appears to have abandoned the piece while traveling in Italy during May. By the end of the month, however, despite the trip and the interference of her desire to write The Pargiters, she was back at work on her "half finished article" ( $A W D$, May 30, 31). (An entry on Goldsmith is mixed in with reading notes made for The Pargiters in Volume XXIII.) By August 17, 1933, Woolf had completed and sent the article to Helen McAfee of The Yale Review ( $L, \mathrm{~V}$, 2780), who rejected it, in Woolf's words, as "not a subject likely to be of particular interest in America" ( $L, V, 2797$, September 27, 1933). Ironically, another set of notes on Goldsmith's works is now housed in the Beinecke Manuscript Library at Yale University (LXVII).

All the notes are in black ink. 


\section{A. Table of Contents}

1. Goldsmith

1 p., on cover.

B. ENTRIES

1. "Goldsmith Life/Forster.": 2 pp., not numbered. More notes on this work appear below, B.3 and B.7.

Forster, James. The Life and Times of Oliver Goldsmith. Vol. I [of II]. Bickers, 1877.

2. "Goldsmith in/Cunningham.": 1 p., not numbered. (6 lines only.) The notes are on Goldsmith's "Essay XI. Beau Tibbs, A Character (cont)," and "Essay XIV. On the Increased Love of Life with Age."

Goldsmith, Oliver. Essays. Ed. Peter Cunningham. Murray, 1854. Vol. III of The Works of Oliver Goldsmith.

3. "Forster. Life": 1 p., not numbered. More notes on this work appear above, B.1, and below, B.7.

Forster, James. The Life and Times of Oliver Goldsmith. Vol. I [of II]. Bickers, 1877.

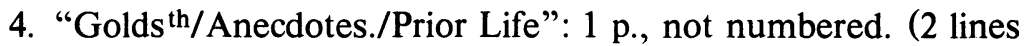
only.) The notes, annotated " $2 / 410$," read, "grotesque ourang-outang figure-' Tickle." The quotation is from a letter mocking Goldsmith, signed Tom Tickle, found in Prior's Life, II, 408-409 n.

Prior, James. The Life of Oliver Goldsmith, M.B. Vol. II [of II]. Murray, 1837.

5. "Boswell. I": 5 pp., not numbered. The second and third pages are typed. Another entry on Johnson and Goldsmith appears in LXVII, B.2.

Boswell, James. The Life of Samuel Johnson, L.L.D. Ed. George Birkbeck Hill. Vols. I-III [of VI]. Oxford: Clarendon Press, 1887.

6. "Essay.": 1 p., not numbered. General notes for her essay on Goldsmith, beginning, "And if the [style] fails to satisfy it is because too much of the essayist [?lays] above it: morality ...."

7. "Goldsmith Thackeray on.": 1 p., not numbered. (3 lines only.) The entry, annotated "F.2/423," reads, "The bed- 
room a closet without any light in it. It quite pains us to think of the kind old fellow dozing off there. WMT." These notes refer to a letter written by W. M. Thackeray about Goldsmith, quoted in Forster, II, $423 \mathrm{n}$.

Forster, James. The Life and Times of Oliver Goldsmith. Vol. II [of II]. Bickers, 1877.

\section{Monk's House Papers/B.3e. (Sussex)}

On April 11, 1939, Woolf recorded that she was "reading Sévigné, professionally, for that quick amalgamation of books that I intend.... Also I'm reading Rochefoucauld" ( $A W D$ ). She had begun reading Sévigné by September 1938 and was still reading the letters at the end of 1940 , but it is likely that these notes belong to the period of the April 1939 diary entry. In January 1939, Woolf had written, "I am reading Sévigné, that leads to Michelet; that to Saint Simon; and I see Rabelais at the turn of the corner" ( $L, \mathrm{VI}, 3481)$; by June, she was "still midway through her" ( $L, V I, 3520)$. (For other notes on Sévigné's Lettres, see XVI, B.1, and XXXVII, B.12). Notes headed "Civilization; or, $\mathbf{M}^{\text {me }}$ de Sevigné written during the crisis of Sept 1938" appear in a manuscript at Sussex (MH/B.2b); her essay on "Madame de Sévigné," however, was written in May 1939 (L, VI, 3514) and published in The Death of the Moth and Other Essays (1942). The "quick amalgamation of books" of the 1939 diary entry became, at the end of 1940, a history of English literature provisionally called Reading at Random. In an early outline for this work, Woolf included as a "separate article" "The French Madame de Sevigné./La R $\mathbf{R}^{\mathbf{d}}$ [La Rochefoucauld] \&c" ("Notes for Reading at Random," $A \& R, 375)$.

The last entry, B.3, a summary of Roger Fry's aesthetic theory, belongs with the writing of Roger Fry: A Biography and could easily have been made in 1939 while she was writing the book. A letter written four years previously, when Woolf began reading for the biography, includes a similar passage: "I'm deep in Roger Fry and trying to master his aesthetics. What he says is if you cut off your practical senses, the aesthetic then work" $(L, \mathrm{~V}, 3090)$.

A label pasted on the cover of the notebook reads "La Rochefoucauld." The label and the entries are in black ink. 
B. ENTRIES

1. "La Rochefoucauld.": 1 p., not numbered. The entry consists of unidentified notes on La Rochefoucauld, beginning, "had 3 periods: the heroic; the worldly; \& recollection $\left(\mathrm{M}^{\text {me }} \mathrm{de}\right.$ LaFayette)."

2. "Sévigné": 1 p., not numbered.

[Sévigné, Madame de.] Lettres de Madame de Sévigné, de sa famille, et de ses amis. Ed. M. Monmerque. New ed. Vol. IV [of XIV]. Paris: Hachette, 1862.

3. "'All art depends upon cutting off the/practical responses to the sensations of/ordinary life, thereby setting free a pure $\&$ as it were disembodied/[ . . ] of the spirit": 1 p., not numbered. (Heading only.) A summary of Roger Fry's aesthetic theory, possibly based on Vision and Design (1920).

\section{Monk's House Papers/B.16a. (Sussex)}

On January 28, 1937, Woolf "began Three Guineas" (AWD)began, that is, writing the book on women and war that had been simmering in her mind since the end of 1935 (see the introduction to Volume XXXIX). She had, by this time, also collected a great deal of the material that furnished her with the facts and quotations that are the basis of her arguments and her footnotes. Because she began collecting this material as early as 1931, when she first conceived of her new book on women, and continued to gather it while she wrote The Years, it is difficult to know exactly when the notes entered in this volume-as well as other volumes-were made. Some of the entries, however, can be dated or speculated about. The first entry, for example, which consists of notes for the second chapter of Three Guineas, has the marginal notation, "1937/1919/18" - a reference to the number of years that women have been allowed to practice the professions, and a recurring theme in Chapter II. This entry, then, may have been made around June 22, 1937, when Woolf was contemplating "the Prof. [Professional] Chapter: then the final" $(A W D)$. Others of the entries (B.3-7, 9) were clearly made in or after 1936. On June 7, 1936, for example, Woolf was "reading all Macaulay with rapture," and she continued to read him throughout that summer 
( $L$, VI, 3141, 3155). She read Blunt's Diaries in July 1936 ( $L$, VI, 3152-3153), and on August 14, she was "[sinking] deeper and deeper in Lynn Linton-and am entirely enthralled" ( $L$, VI, 3161). The notes on Miss Clough (B.2), on the other hand, may belong to the early thirties when Woolf was planning The Pargiters; a quotation from the biography of Clough appears in the first of the " 3 bound volumes containing Press Cuttings \& extracts collected or copied by VW relative to $3 \mathrm{Gs}$ " (LVIII), which consists of material collected before the beginning of 1933. Eight more pages of notes on this biography are found in Volume $\mathrm{X}$, included among the entries made in 1932.

Several of the notes and quotations found in this notebook reappear, in part or in whole, in other notebooks and/or in one of the " 3 bound volumes" below. Entries B.3-7 recur in the same order in Volume II of the " 3 bound volumes" (LIX, B.85-89); B.12 reappears as LIX, B.90. I have indicated these repetitions in the descriptions of the individual entries. (For a comprehensive list of Woolf's notes for Three Guineas, see Volumes VII, X, XXVI, XXXIII, XXXIX, and LVI-LX.)

All of the notes are in black ink, as are the few page numbers.

\section{B. ENTRIES}

1. "If you have only 250 \& have to earn it you cant do/much": $2 \mathrm{pp}$., not numbered. The entry consists of notes for Chapter Two of Three Guineas, ending, "That is the end of the Second Guinea. The Third." A marginal notation reads, "1937/1919/18": a calculation of the number of years women have been allowed in the professions. After the heading, the entry continues, "learning how to cook $\mathrm{M}^{\mathrm{r}}$ Joads' dinner before he dies. Why are they so poor? Is it native incapacity or prejudice."

2. "Life of Miss Clough.": 8 pp., not numbered. Another set of notes on this work appears in X, B.5; a quotation from this work appears as LVIII, B.56.

Clough, Blanche Athena. A Memoir of Anne Jemima Clough. Edward Arnold, 1897.

3. "Wilfred Blunt./My Diaries.": 2 pp., not numbered. Quotations, annotated "Part 2/21st April 1901," and " $15^{\text {th }}$ Nov: 1910." The first quotation reappears in LIX, B.85. The 
second quotation records Blunt's intense dislike of the first Post-Impressionist Exhibition, held in 1910.

Blunt, Wilfred Scawen. My Diaries. Being a Personal Narrative of Events, 1888-1914. Part Two: 1900-1914. Martin Secker, 1920.

4. "Sophia Lonsdale./Compiled by Violet Martineau.": 1 p., not numbered. Quotation, annotated "103," beginning, "I have often been asked what I think of Cathedral Establishments, ..." This quotation reappears in LIX, B.86.

Martineau, Violet. Recollections of Sophia Lonsdale. Murray, 1936.

5. "Daily Herald. Aug. $1^{\text {st }} 1936 . /$ 'Stand up to dictators' . ..": 1 p., not numbered. The entry consists of notes on two newspaper articles about dictatorship: in Germany and in the home. Woolf's notes include the passage, "\& then we turn the page \& read: "My husband insists that I call him "Sir" '..." These notes reappear in LIX, B.87.

"M.P.s' Parting Advice to Ministers-'Stop Yielding to Dictators'" and "Made Wife Call Him 'Sir'." Daily Herald, August 1, 1936, pp. 4, 9.

6. "Marys conduct was really a signal instance/of that perfect distinterestedness and self devotion/of which man seems to be incapable,/but which is sometimes found in woman.": 1 p., not numbered. (Heading only.) Quotation, annotated "Macaulay. Hist. vol 3. 278." This quotation reappears in LIX, B.88.

Macaulay, Thomas Babington. History of England. Vol. III. Longmans, Green, 1898. Vol. III of The Works of Lord Macaulay. Albany Edition.

7. "On another day at this time he wrote/a one thousand six hundred word/article on Nietzsche, . ..": 1 p., not numbered. The entry is on the same page as B.6. Quotation, annotated "198/The Lost Historian. A Memoir of/Sir Sidney Low. Desmond Chapman-/Huston./1886." This quotation reappears in LIX, B.89.

Chapman-Huston, Major Desmond. The Lost Historian. A Memoir of Sir Sidney Low. Murray, 1936.

8. "[ . . ] W. by Sat": 1 p., not numbered, on the reverse of B.6 and B.7. (2 lines only.) Unidentified. 
9. "In Paris since the war, as in most/cities of the west, it is women's/view of life wh. prevails.": 1 p., not numbered. Quotation, annotated "Aspects of Wilde./Vincent O'Sullivan," "198."

O'Sullivan, Vincent. Aspects of Wilde. Constable, 1936.

10. "Layard/Mrs. Lynn Linton.": 5 pp., the last two numbered 1-2 by VW. The entry ends with a note headed, "(George Eliot. Williams. p. 79," which begins, "The dislike was mutual \& began early." "The passage records the mutual dislike of Marian Evans/George Eliot and Lynn Linton as described in Williams's biography. Williams's source was Eliot's diary.

a) Layard, George Somes. Mrs. Lynn Linton. Her Life, Letters, and Opinions. Methuen, 1901.

b) Williams, Blanche Colton. George Eliot. A Biography. Macmillan, 1936.

11. "James Silk Buckingham./Ralph E. Turner. 1934": 1 p., not numbered. The notation " $3 \mathrm{G}$." appears in the upper right corner.

Turner, Ralph E. James Silk Buckingham, 1786-1855: A Social Biography. Williams \& Norgate, 1934.

12. "Unreformed Cambridge/Winstanley.": 1 p., numbered 3 by VW. The entry consists of the titles of three works on the University of Cambridge: a) Denys A. Winstanley, Unreformed Cambridge: A Study of Certain Aspects of the University in the Eighteenth Century (Cambridge: Cambridge Univ. Press, 1935); b) J. W. Clark, ed., Endowments of the University of Cambridge (Cambridge: Cambridge Univ. Press, 1904); c) Henry Gunning, Reminiscences of the University, Town, and County of Cambridge From the Year 1780, 2 vols. (Bell, 1855). References to the latter two works reappear in LIX, B.90; notes on Gunning appear in XLV, B.16.

13. "The Age of the Chartists/1832-1854/Hammonds.": 4 pp., numbered 4-7 by VW.

Hammond, J. L., and Hammond, Barbara. The Age of the Chartists, 1832-54. A Study of Discontent. Longmans, Green, 1930.

14. "Life of Bishop Burnet/Clarke \& Foxcroft. 1907": 1 p., not numbered. Quotation, annotated "436," beginning, "The 
feminine boarding school of the day, with its trivial curriculum, was his aversion,..."

Clarke, T.E.S., and Foxcroft, H. C. A Life of Gilbert Burnet, Bishop of Salisbury. Cambridge: Cambridge Univ. Press, 1907.

\section{Monk's House Papers/B.16b. (Sussex)}

The majority of the notes collected in this volume are not reading notes but random ideas and sketches for her writing, including Three Guineas. It is extremely difficult to date these notes, or even to be sure what they are for. Entry 2, for example, which consists of notes on "the moderns," includes phrases that seem to predict "The Leaning Tower" (1940), although it is unlikely they were made that late. I suspect that most of the notes in this volume belong to the period after the Labour Party Conference at Brighton, September 30 to October 2, 1935 (mentioned in B.4), when Woolf began "dashing off" chapters and scenes for her book on women and war (see $A W D$, October 5, 27, 1935, March 24, 1936, and the introduction to Volume XXXIX). She continued recording ideas for this book until January 1937 when she began to write what we know as Three Guineas (see $A W D$, November 3, 1936, and January 28, 1937).

Several of the sketches found in this notebook made their way, either directly or indirectly, into the finished work. The search for new words in B.1, including a replacement for "feminist," suggests the moment in Three Guineas when the writer burns the word "feminist" to celebrate the new-found unity between men and women in their fight against war, even while lamenting that she cannot yet call the words "Tyrant, Dictator" equally obsolete $(3 G, 184,186)$. The bonfires that burn throughout the book may have originated with her notes in B.3, headed "The Burning of the Vote." The reference to "The horror of war. The Spanish photographs" in B.6 suggests Woolf's comments at the beginning of Three Guineas about the power of photographs, in this case those sent by the Spanish government, to evoke emotions of "horror and disgust" $(3 G, 20-21)$; Woolf had received "a packet of photographs from Spain all of dead children, killed by bombs" on November 16, 1936 (L, VI, 3189). (For other sketches and ideas for Three Guineas, see Volume XXXIX; notes for Three Guineas also appear in Volumes VII, X, XXVI, XXXIII, LV, and LVII-LX.) 
Woolf continued to create new words-and to collect materialafter the book was complete; notes at Sussex headed "Supplement to the Dictionary of the English Language" (MH/B.4) include definitions of "The Straddlebug Foot in both worlds. Wangler:," "The Peeker. This miserable little word has been coined to denote the peeper in at private houses," and "? a word for those who put living people into books." The first page of this later manuscript is headed "Quotations fr. current books (1938)"; the remainder of the page is blank. See Volume XXXVI for some later quotations.

All of the notes are in black ink.

B. ENTRIES

1. "Glossary. [Hermannob ... ]/of both sexes ...": 1 p., not numbered. The entry consists of notes on the possibility of creating new words and meanings. One note reads, "let us substitute for feminist the word -"; another, "Soldier = Gutsgruzzler. Heroism = Botulism. a Hero = Bottle."

2. "The reason why there is no criticism:/because no one can deal with the intellect \&/the emotions": 1 p., not numbered. The entry consists of notes on "the moderns," including a note on "Why there is no poetry because the moderns are trying to appeal to the simple people: but ... also to the intellect."

3. "The Burning of the Vote./A Comedy/Scene Hampstead Heath": $2 \mathrm{pp}$., not numbered. The entry consists of notes or sketches for various scenes depicting ideas later embodied in Three Guineas. The second page reads, "Voices of Victorian mothers wailing. The children answering. A record breaker passes. We will not dine. Joad \& Wells. May the Lord make us truly thankful. But who is the Lord. A transparency appears. 10,000 a year. The Arch. of Cant. The dappled dawn. The Do not raise monuments. Let us not praise famous women." The reference to "Joad" is to his statement, quoted in Three Guineas, "Women, I think, ought not to sit down to table with men" (C.E.M. Joad, Under the Fifth Rib: A Belligerent Autobiography [1932], quoted in 3G, Ch. III, n.4.) The reference to "Wells" is most likely to H. G. Wells's comments about women in his Experiment in Autobiography (1934) that appear in Three Guineas, one of them sandwiched between comments by Joad $(3 G, 79-80)$. 
4. "The meeting at Brighton./The upshot of it was m. [men] think war necessary.": $2 \mathrm{pp}$., not numbered. The entry consists of notes on men and war, women and peace. The reference in the heading is to the Labour Party Conference at Brighton, September 30 to October 2, 1935, where the pacifists were defeated. The first page includes the note, "Cheques for one guinea ... all moonshine." The second page begins, "Money \& power. patriotism."

5. "1 The Vision of England./ 2./ That leads to/What": 1 p., not numbered. (Heading only.)

6. "The horror of war./The Spanish photographs.": 1 p., not numbered. The entry consists of notes on war.

7. "Francis \& Riversdale Grenfell. A Memoir/John Buchan. 1920": 2 pp., not numbered. The entry consists of quotations about the glory of being a soldier. The first one, annotated "189," begins, "I have had the happiest possible life, \& have always been working for war; ..."

Buchan, John. Francis and Riversdale Grenfell. A Memoir.

Thomas Nelson, 1920.

\section{Monk's House Papers/B.16e. (Sussex)}

This volume, a spiral notebook, can be dated fairly accurately after the end of March 1937; it includes notes for Three Guineas and Roger Fry: A Biography. By this date, Woolf was well into the first draft of Three Guineas and planning her biography of Fry. The precision of dating rests upon the first entry, headed "The inflated brown bug" and consisting of notes on "J.B.," the newspaper reporter who followed the Woolfs to Rodmell on March 27, 1937, in an attempt to get material for an article. The phrases in this entry are the same as those in her diary entry for March 28, 1937, and in the poem, "Fantasy upon a Gentleman who Converted his Impressions of a Private House into Cash." Both of these appear in Appendix B of Quentin Bell's Virginia Woolf: A Biography, Vol. II (1972). A cutting of a newspaper article about Woolf, signed "J.B.," appears in LX, B.54.

The notes are in black ink. 
B. ENTRIES

1. "The inflated brown bug": 1 p., not numbered. The first part of the entry, which continues, "inflated with blood. Mark on the wall. comes steals appears. Wants to be 'seen.' looks [?roundish/reddish] full of blood. Sits there slides off: makes notes," consists of notes on "J.B.," the newpaper reporter, who is the subject of a diary entry (March 28, 1937) and of the poem, "Fantasy upon a Gentleman who Converted his Impressions of a Private House into Cash." See Quentin Bell, Virginia Woolf: A Biography (1972), II, Appendix B. The remainder of the entry is a list of Woolf's books, ending with The Years.

2. "She was living on $£ 12$ a month": 2 pp., not numbered. Entry annotated "Letters to a friend/Winifred Holtby./Edited by Alice Holtby/Jean McWilliam/Collins. 1937."

Holtby, Winifred. Letters to a Friend. Ed. Alice Holtby and Jean McWilliam. Collins, 1937.

3. "The Professions:/Lady Lovelace the Siren. The bird in the cage": 1 p., not numbered. 4 lines only, continuing, "But we must make a different contribution. 'We' are the only people who can criticise: the wage earners." The notes pertain to Three Guineas; the reference is to Mary, Countess of Lovelace, whose article, "Fifty Years. Society and the Season: The Chaperoned Age," appears as LVIII, B.36.

4. "The interest of these facts is great.": 3 pp., not numbered. The entry consists of notes for Three Guineas.

5. "Many private people bught ordered/gave commissions": 1 p., not numbered. The entry consists of notes for Roger Fry: A Biography.

\section{Monk's House Papers/B.16f. Vol. 1. (Sussex)}

This notebook is the first of the " 3 bound volumes containing Press Cuttings \& extracts collected or copied by VW relative to $3 \mathrm{Gs"}$ (MHP Catalogue). From the moment in January 1931 that Woolf conceived of her "sequel to A Room of One's Own" ( $A W D$, January 20), she began to amass her "facts." By February 1932, she tells us, she had "collected enough powder to blow up St. Pauls" $(A W D)$. 
Nor did she stop collecting material then; the last entry in the third volume is dated December 20, 1937, by which time she had abandoned The Pargiters, published The Years, and was preparing the final draft of Three Guineas. It is not clear at exactly what point between January 1931 and the publication of Three Guineas in 1938 Woolf decided to paste her material into these notebooks; nor is it certain whether the " 3 bound volumes" evolved over the period or were created all at once. Although the entries within the volumes are not arranged in chronological order, there are fairly sharp distinctions among them. The first contains material dating from 1931 to the beginning of 1933, and a few entries with an earlier date. (In dating these entries, I am referring to the dates provided in the cuttings or by Woolf for a cutting, and to the date of publication of the books.) The second volume begins after a gap of almost two years and consists, as does the third, of material dating from 1935, 1936, and 1937, with a few entries from 1933 and 1934. (For more detailed information, see the introductions to Volumes LIX and LX.) Given the selfcontained nature of the first volume, it is possible that Woolf compiled it when she was first working on The Pargiters and then created the other two volumes when she began to organize her material for Three Guineas.

The question of dating the " 3 bound volumes" is further complicated by the duplication of entries, particularly of quotations, in other of Woolf's reading notebooks. Some of the entries, such as the quotations from The Life of Joseph Wright in this volume (B.27, 66), may have been extracted from the more extensive reading notes that appear in other notebooks. (In the case of Wright, these notes are in $X$, B.1.) On the other hand, the quotation from Wright in XXXIII, B.9, may well have been extracted from this volume when Woolf was preparing the text and footnotes for Three Guineas. It is therefore often difficult to tell whether the appearance of a quotation or set of notes in the " 3 bound volumes" precedes or succeeds its appearance in another notebook. (For information on the other notebooks that intersect with the " 3 bound volumes," see Volumes VII, X, XXVI, XXXIII, and LV-LVII.)

This notebook, however, the earliest of the " 3 bound volumes," is fairly well-defined, being devoted to material collected before January 1933, first for her speech on professions for women ("Speech Before the London/National Society for Women's Service, January 31, 1931") and then for what is now The Pargiters. The Novel-Essay Portion of "The Years." (Both texts appear in The Pargiters.) As such, it is invaluable for identifying the sources of her facts and allusions in 
both of these works. Along with the quotations from The Life of Joseph Wright, an important source for The Pargiters, it contains notes on many of the "scores-I might boldly say thousands-of old memoirs," biographies, and autobiographies that allowed her to re-create the past (Pargiters, 9). Among these are: The Life of Mary Kingsleywhose only "paid-for education" was German lessons (B.40); In the Days of Miss Beale - when the physical education in girls' schools consisted of "dancing and the study of deportment" (B.49); A Victorian Childhood-during which Mrs. Annabel Huth Jackson's brother left her to go to school at Bournemouth (B.43); and "Fifty Years/Society and the Season/The Chaperoned Age"-Lady Lovelace's memories of her younger years (B.36). And this is just a sampling.

Woolf has also included in this notebook cuttings of two reviews of her earlier book on women, A Room of One's Own (1929; B.24, 34), and a cutting of her essay, "Two Women" (1927), on Emily Davies and Lady Augusta Stanley (B.35). When dated, the other newspaper and magazine cuttings in this notebook are from 1930 to 1933, which is also the period when most of the books included were published. Woolf had, in fact, begun to copy newspaper headlines into her diary on November 11, 1930 - "to give this book [the diary] continuity," she claimed $(D$, III); to collect articles was a next logical step. Four of the entries-B.27 and B.66 (Wright), B.56 (Clough), and B.62 (Bott and Clephane)-are quotations or facts from books that are recorded more extensively in Volume $\mathrm{X}$. These and other crossreferences are indicated in the individual entries.

Although we cannot be certain when Woolf made the entries that actually appear in this notebook, some information about her reading is available in her letters and diary. On July 12, 1931, for example, Woolf referred to Ethel Smyth and herself as "Miss Beale and Miss Buss" ( $L, I V, 2404$ and n.4) - an allusion to the anonymous nineteenth-century rhyme about these two leaders in women's education. Her use of this allusion may well be linked to her reading of the biography of Miss Beale, which is quoted in B.49. Again, the quotation from Elizabeth Barrett Browning's Letters (B.42) is almost certainly linked to her reading for Flush: A Biography (1933), possibly in the summer of 1931. On September 7, 1931, Woolf asked to borrow "the Ellen Terry Shaw letters" (B.69) from Vita Sackville-West ( $L$, IV, 2430); and on November 15, 1931, she recorded reading "Dizzy"i.e., Benjamin Disraeli's Coningsby (B.29; L, IV, 2470). Since Woolf mentions this novel in connection with Middlemarch and Trollope, it is possible that she was reading Victorian novels as a background for the Victorian scenes in The Pargiters. "I'm going to read science," 
Woolf then declared on December 6, 1931, "Wells and Huxley, and a man called Heard" ( $L$, IV, 2476), and she was indeed reading The Science of Life, by H. G. Wells, Julian Huxley, and G. P. Wells (B.10) at Christmas ( $L$, IV , 2492, 2493; see B.11, 13-14, for more of her reading of science). That Christmas, she dipped as well into Goethe ( $L, \mathrm{IV}, 2493)$, who is quoted in B.32.

In February 1932, Woolf began to read in manuscript various chapters of Ethel Smyth's biography, Female Pipings in Eden (1933), the source of the Einstein quotation in B.17 ( $L, \mathrm{~V}, 2522,2743$, 2746). Also during February 1932, she wrote her essay on "Donne After Three Centuries" in which she alludes to the passage about Donne's family life at Mitcham recorded in Gosse's life of the poet and noted below, B.6. Then, on July 13, 1932, Woolf finished the love letters of "old Joseph Wright and old Lizzie Wright" ( $A W D$; B.27, 66), the work that was so influential in the development of The Pargiters. On October 2, she was reading D. H. Lawrence's Letters (B.47) "with the usual sense of frustration" $(A W D)$; she had finished them-"no, I'm not enthusiastic"-by November $3(L, V$, 2656). A week later, on November 10, she wrote to Margaret Llewelyn Davies, "Do you remember showing me a letter from W. Bagehot to your aunt [Emily Davies, the founder of Girton], about women being servants, or something like that? I am re-writing a speech I made to some young professional women, and I want to quote it" $(L, \mathrm{~V}, 2664)$. This letter, recorded in B.8, is alluded to in The Pargiters (p. 34) and quoted in Three Guineas (Ch. I, n.23).

By December 22, 1932, Woolf was taking a break from writing The Pargiters but was "reading 20 books at once-masses of books" ( $L$, $\mathrm{V}, 2683$ ) - a statement well borne out by the reading notes. One of the books, J. M. Murry's Reminiscences of D. H. Lawrence (B.73), read early in 1933 and the last entry in this notebook, evoked her special wrath: "Murry's last spurt of oil and venom and other filth seemed to me his foulest" ( $L, \mathrm{~V}, 2704)$. For the rest, although it is difficult to date the notes on books published previous to 1931, it is likely that the entries were made during 1931 and 1932, even if the work had originally been read earlier. As Woolf herself said, The Pargiters released "a torrent of fact" that she had been unaware was in her: "I must have been observing and collecting these 20 yearssince Jacob's Room anyhow" ( $A W D$, December 19, 1932).

Two labels on the cover of this notebook read "NOTES \& CUTTINGS," and "I." Woolf herself provided an almost comprehensive "INDEX" of the material collected in this volume (A.2), as well as pasting a selected list of entries on the front cover (A.1). Both of 
these lists were probably made after the notebook was completed, although the "INDEX," which is for the most part typed, ends with a series of handwritten entries that may have been added later. The short list on the cover, as well as the x's and the circled page numbers in the "INDEX," show Woolf culling the material she wanted from the larger mass for inclusion in Three Guineas. References to Three Guineas in the descriptions of entries are almost always to footnotes and are listed by chapter and footnote number: $3 G$, II, n. 30 .

The notebook itself is a loose-leaf two-ringed notebook, with a hard cover. Woolf pasted both the cuttings and the extracts-which are written or typed on a smaller piece of paper-onto the sheets that comprise the numbered pages of the notebook. Most of the extracts are typed. With two exceptions, Woolf's page numbers are in blue pencil. The list on the front cover is in black ink; the "INDEX" is typed and in black ink. (The "INDEX" is reproduced here in the exact format of the original.) When Woolf has supplied the source and/or date of a cutting, this information is preceded by "annotated"; otherwise, the documentation for a cutting is that provided in the cutting itself. All quotations that are not labelled "Heading only" continue in Woolf's entry.

\section{A. Table of Contents}

1. Joad. w. [women] not to dine 2 Bagehot on Girton

4

B. Russell on science \& sadism 6

MaCardie on dress

12

C.S. on male rule

15

Goe [Goethe]

23

Lady Lovelace

29

Mary Kingsley

33

Winston on future

49

Lord Hugh 51

Crit of war

59

Young $\mathrm{W}^{\mathrm{n}}$ [Women] \& church 62

Wright

60-1

$1 \mathrm{p}$., on cover.

2. INDEX

\&\&\&\&\&\&\&\&

I. . Change in family. Beveridge

I. . The unemployed and sterility 
2... Joad. Women not to dine

2... Sullivan. Women not companions

3... Donne; family at Mitcham

3. O. Baldwin on school

4... Bagehot on Girton

4... Roberts on Abortion

6... Evolution. Wells

6. . . Medical men and sadism

7... Sullivan on Love

7... Sullivan on scientific men

8. . . Russell on scientific partisans

8... Huxley on males and birth

9... Bowdler on propriety

9. . Macready on women eating

10 ... Einstein on devotion to truth

11 Mullens on women smoking

12. . Macardie on dress

13... Tolstoy on seduction

14... Desmond on Richardson

15. . Civil service on male rule

16. . . Squire on Room

17. . War stories

18. . Girls more accurate than men

18a. . Joseph Wright on women

19. . . Civil service success

20... Mens vanity Coningsby

21. Womens cruelty

22... Desmond on Grandison

23... Women must lead Goethe

24. . . St John Er. on women

26. .. Desmond on Room

27. . . VW on Miss Davies

29 .. . Lady Lovelace

$30 .$. Judge on laws inequality

$31 .$. Women and crime

32. . Gerhardi on women

33... Mary Kingsley

34. .. Eton Masters

35... Mrs Browning on college

36. . . Mrs Huth Jackson

37. . . Miss Robins on stage

38. .. Women and war VW 
39... The six child scale VW

40 D.H.L. on need of women

41. . marriage service VW

42. . Physical education in 40ties

43. . . Cigarette in I888

44. . Education. Wodehouse

45. . Clare College JMK.

46... Somerville and money

46... Rooms at Somerville

47... Gibbon on Oxford

48. . . Miss Clough's eloquen

49... Winston on fiture

$51 .$. Winston on Lord Hugh

$52 .$. Winston on life

$53 .$. Winston on painting

54... Flocking back to Church

55... Liberty at Girton

56. .. Mr Gladstone on Chasti

57... Women in Civil Service

58... Women in Universities. Leathes

59. . . Cost of war. Pankhurst

60 ... Mrs. Wright \& Tom Wright

61. J. Wright on Civilization

62 Young women in church

63 GBS. definition of A Lady

64. Doctor's wives \& delicacy

62. Upton Sinclair on sex

66 Octavia Hill on anonymity

1 p., not numbered. Typed and handwritten.

B. ENTRIES

1. "The Position of the Woman Student": 3 pp., numbered 270-273. Cutting from a book on Oxford, inserted in the front of the notebook. Source unidentified.

Morrison, Elizabeth. "The Position of the Woman Student."

2. "'Woman has forged ahead so much in psort,/industry, social and political life ...": 1 p., numbered 1 by VW. Entry annotated "Changes in Family Life./Sir W. Beveridge and others." The notes are on statements made about changes in the family by "an acetylene welder," a "Civil Servant," 
and "a farmer's wife," quoted by Beveridge in the chapter entitled "The Enduring Family," p. 133.

Beveridge, Sir William and Others. Changes in Family Life. Allen \& Unwin, 1932.

3. "The argument of the million make unemployed": 1 p., numbered 1 by VW. Typed notes, continuing, "and their no contribution to art science or discovery Why? is it possible that education and environment count?"

4. "Women, I think, ought not to sit down to table with men; ...": 1 p., numbered 2 by VW. Typed quotation, annotated "Jaod. Under the Fifth Rib 58." This quotation also appears as XXXIII, B.6.

Joad, C.E.M. Under the Fifth Rib. A Belligerent Autobiography. Faber \& Faber, 1932.

5. "With very few exceptions, I have not found that/women make good companions.": 1 p., numbered 2 by VW. Typed quotation, annotated "But for the Grace of God/jWN Sullivan I20." More quotations from this work appear below, B.12.

Sullivan, J.W.N. But for the Grace of God. Cape, 1932.

6. "While he left his wife and xxxxx/the steadily growing army of babies at Mitcham, he himself had a 'lodging' or apartment in the Strand": 1 p., numbered 3 by VW. Typed quotation, annotated "Gosse Donne I I46." Woolf's notes on this work appear in XX, B.12.

Gosse, Edmund. The Life and Letters of John Donne. Vol. I [of II]. Heinemann, 1899.

7. "I remember when my gradmother used occasionally/to watch us playing games ...": 1 p., numbered 3 by VW. Typed quotation, annotated "Oliver Baldwin. The Questing/Beast. 23."

Baldwin, Oliver. The Questing Beast. Grayson \& Grayson, 1932.

8. "To Miss Emily Davies re Girton College": 1 p., numbered 4 by VW. Typed quotation, annotated "Walter Bagehot," from a letter from Bagehot to Emily Davies "who had asked for his help in founding Girton" $(3 G, \mathrm{I}, \mathrm{n} .23)$. The quotation begins, "I assure you I am not an enemy of women," and concludes, "2,000 years hence you may have 
changed it all, but the present women will only flirt with men, and quarrel with one another." Private letter, then in the possession of Margaret Llewelyn Davies; see $L, \mathrm{~V}$, 2664.

9. "From my own fairly large experience...": 1 p., numbered 5 by VW. Two quotations about abortion, annotated "Dr. Harry Roberts. N.S. Feb. 13 1932."

Roberts, Harry. "The Sanctity of Human Life." New Statesman \& Nation, February 13, 1932, pp. 193-194.

10. "The one sure thing of which the spectacle of/Evolution convinces us is that things will not/remain as they are ...": 1 p., numbered 6 by VW. Typed quotation, annotated "Science of Life I. 270." The quotation is from Book III: "The Incontrovertible Fact of Evolution."

Wells, H. G., Huxley, Julian, and Wells, G. P. The Science of Life. A Summary of Contemporary Knowledge about Life and its Possibilities. Vol. I [of III]. Amalgamated Press, 1929.

11. "The views of medical men on pregnancy, child-/birth, and lactation were until fairly recently/impregnated with sadism.": 1 p., numbered 6 by VW. Typed quotation, annotated "B. Russell The Scientific Outlook 17." Another quotation from this work appears below, B.13.

Russell, Bertrand. The Scientific Outlook. Allen \& Unwin, 1931.

12. ". . . the strain of supporting for hours at a time/the companionship of one of my 'conquests' has/sometimes left me more dead than alive.": 1 p., numbered 7 by VW. Typed quotations, annotated "Sullivan But fir the Grace of God. I2I" and "Sullivan i07." Another entry on this work appears above, B.5.

Sullivan, J.W.N. But for the Grace of God. Cape, 1932.

13. "There is, in the modern world, a great body/of well-attested knowledge on all kinds of/subjects, ...": 1 p., numbered 8 by VW. Typed quotation, annotated "B.R." Another quotation from this work appears above, B.11.

Russell, Bertrand. The Scientific Outlook. Allen \& Unwin, 1931.

14. "How fantastic is the scene of the microscopic drama ...": 1 p., numbered 8 by VW. Typed quotation, annotated "Hux- 
ley. What Dare I think? p 75." The quotation concludes, "There is no generation of life by the masculine principle in a mere soil provided by the female...."

Huxley, Julian S. What Dare I Think? The Challenge of Modern Science to Human Action and Belief. Chatto \& Windus, 1931.

15. "bove all avoid everything with the least tendency/to indelicacy or indecorum.": 1 p., numbered 9 by VW. Typed quotation, annotated "J. Bowdler. I23."

Bowdler, Thomas. Memoir of the Life of John Bowdler, Esq. Printed by A. \& R. Spottiswoode for private circulation, 1824.

16. "How disenchanting in the female character/is a manifestation of relish for/the pleasures of the table!'": 1 p., numbered 9 by VW. (Heading only.) Typed quotation, annotated "Macreadys Diaries 363."

[Macready, William Charles.] Macready's Reminiscences, and Selections from his Diaries and Letters. Ed. Sir Frederick Pollock. Vol. I [of II]. Macmillan, 1875.

17. "Einstein to E. Smyth. Saturday Review./June 8th I93I": 1 p., numbered 10 by VW. Typed quotation from a letter written to Ethel Smyth by Albert Einstein, dated "Potsdam, June 8th, 1931," quoted on p. 23 of Smyth's book. The quotation begins, "I have always contended that women have every right, and should b granted every opportunity, to take part in all branches of intellectual endeavour."

Smyth, Ethel. Female Pipings in Eden. Peter Davies, 1933.

18. "A PERIL TO WOMEN./SURPRISE RESULT OF TOBACCO TEST.": 1 p., numbered 11 by VW. Newspaper cutting, beginning, "A survey of 5,000 maternity cases in Washington reveals that in no case where the mother was a cigarette smoker could she nurse her baby."

19. "Nature has decreed that the leadership/of physical strength and intellectual/achievement shall normally belong to men." ": 1 p., numbered 12 by VW. Newspaper cutting, fragment. The quotation is by Judge MacCardie, who is also quoted on "women's instinct for dress."

20. "A well-known instance of his unscrupulousness/with a peasant girl on his estate is given in his/diary.": 1 p., numbered 
13 by VW. Cutting from the Saturday Review about Tolstoy. Fragment only.

Nicholson, A.P.N. Letter. Saturday Review, January 24, 1931, p. 122.

21. "He succeeded in creating for himself/a little nest in which he was coddled by/women whom he repaid in kind.": 1 p., numbered 14 by VW. Newspaper cutting from an article about Samuel Richardson, by Desmond MacCarthy. Fragment only. For the complete article, see below, B.31.

22. "WHITEHALL STORM OVER A WOMAN/SHOULD SHE CONTROL BIG LABOUR EXCHANGE?/MINISTRY STAFF VIEW": 1 p., numbered 15 by VW. Newspaper cutting, annotated "8th April 1932 Standard [Evening Standard]," p. 3.

23. "WOMAN APPOINTED LIBRARIAN/ELEVEN COMMITTEE MEMBERS RESIGN": 1 p., numbered 15 by VW. Newspaper cutting, annotated "Feb./12 1932."

24. "Books of the Day./MEN, WOMEN AND TRUTH./'A Room of One's Own.' by Virginia Woolf. (Hogarth Press. 5s.)/(By J.C. SQUIRE.)": 1 p., numbered 16 by VW. Newspaper cutting, annotated "Observer/Dec 22 '29." The cutting is a review of Woolf's book, A Room of One's Own.

25. "By Guess \& by God. Comm/Cromie": 1 p., numbered 17 by VW. Quotations, beginning, "'Men,' he said, 'it looks as if our chances of breaking adrift are very small. ..."' The quotations are about Commander Cromie, and appear in the text on pp. 130-131.

Carr, William Guy. By Guess and by God. The Story of the British Submarines in the War. Hutchinson, 1930.

26. " 'MACHINES PREFER GIRLS'/MORE ACCURATE THAN MEN/The New Accountancy": 1 p., numbered 18 by VW. Newspaper cutting, which quotes "Sir Herbert Austin . . . in connection with an exhibition of British accounting and tabulating machines."

27. "The world may talk of the 'weaker sex' as much/as it likes, the whole idea is based on a false/conception . ..": 1 p., numbered $18 \mathrm{~A}$ by VW. Typed quotation, annotated on the reverse of the typed sheet "I896/Life of Jxxx Joseph Wright 
vol I 3I5." Notes on this work appear below, B.66, and in X, B.1; another quotation appears in XXXIII, B.9.

Wright, Elizabeth Mary. The Life of Joseph Wright. Vol. I lof II]. Oxford Univ. Press, 1932.

28. "COVETED POST WON BY WOMAN/CIVIL SERVICE SUCCESS": 1 p., numbered 19 by VW. Newspaper cutting, annotated "May 16 1932," about "Miss N.F.E. Cracknell" becoming the private secretary of Sir Frederick Leith-Ross, Chief Economic Advisor to the Government, and thereby becoming "the first woman appointed to assist in dealing with economic subjects."

29. "Talk to a man about himself $\&$ he is generally captivated./ That is the real way to win him.": 1 p., numbered 20 by VW. Quotation, annotated "Coningsby 158."

Disraeli, Benjamin. Coningsby, or The New Generation. [1844].

30. "WOMEN AND GLADIATORS": 1 p., numbered 21 by VW. Newspaper cutting, about women's behavior at a wrestling match. The article concludes, “... and I think war would be more cruel if all the combatants were women."

31. "THE WORLD OF BOOKS/SIR CHARLES GRANDISON/ BY DESMOND MacCARTHY/'The Shakespeare Head Edition of Samuel Richardson: Sir Charles Grandison." ": 1 p., numbered 22 by VW. Newspaper cutting, Sunday Times, February 14, 1932. The final paragraph of the article reappears above as B.21.

32. "The Mystic Chorus in Faust./The things that must pass/Are only Symbols; ...": 1 p., numbered 23 by VW. Quotation. The passage, the final chorus in Part II of Goethe's Faust, is from the Stawell and Dickinson text [3G, II, n.30].

Stawell, F., and Dickinson, G. Lowes. Goethe and Faust. An Interpretation. With passages newly translated into English verse. Bell, 1928.

33. "The young in the North are discovering/now that the present confusions of our in-/dustrial system ...": 2 pp., numbered 24-25 by VW. Newspaper cutting, 1931, about the detrimental effects of women's entering business, both on themselves and on industry.

34. "THE WORLD OF BOOKS./AN OLIVE-BRANCH./"A Room of One's Own.' By Virginia Woolf. (Hogarth Press. 5s.)/by 
DESMOND MacCARTHY.": 1 p., numbered 26 by VW. Newspaper cutting, Sunday Times, January 26, 1930. The cutting is a review of Woolf's book, A Room of One's Own.

35. "TWO WOMEN/by VIRGINIA WOOLF.": 2 pp., numbered 27-28 by VW. Cutting, Nation \& Athenaeum, April 23, 1927, pp. 78-79. The cutting is of Woolf's review of Emily Davies and Girton College, by Lady Stephen, and Letters of Lady Augusta Stanley, ed. by the Dean of Windsor and Hector Bolitho.

36. "[F]IFTY YEARS/[SO]CIETY AND THE SEASON/THE CHAPERONED AGE/By Mary Countess of Lovelace": 1 p., numbered 29 by VW. Newspaper cutting, beginning, "For a picture of social life fifty years ago I can only draw upon a limited experience, first as a girl before 1880 and as a young married woman after that date."

Lovelace, Mary, Countess of. "The Chaperoned Age." The Times, March 9, 1932, pp. 13-14.

37. "EQUALITY OF THE SEXES ONLY A MYTH/WIVES THE LAW'S FAVOURITES/By His Honour JUDGE McCLEARY.": 1 p., numbered 30 by VW. Newspaper cutting, Daily Telegraph, February 17, 1932, beginning, "The physical differences between a man and a woman and the essential variance in their objects and ambitions in life render it impossible to compare the one with the other without qualifications."

38. "Women are known to be actively concerned in increasing/ numbers in crimes of blackmail, ...": 1 p., numbered 31 by VW. Typed quotation, annotated "Cecil Bishop, late of CiD/Women and Crime. p. 5."

Bishop, Cecil. Women and Crime. Chatto \& Windus, 1931.

39. "When, from time to time, I take up my pen to suggest in the Press that women/have no position to speak of in literature, female writers spring at me/like hyenas, \& tear me with their claws. I, however, survive.": 1 p., numbered 32 by VW. Typed quotation, annotated "William Gerhardi Memoirs of a Polyglot 320." Handwritten notes at the end of the entry read: "The poet as lapdog. A profession that shd. be closed now by women. Egerias, \&c."

Gerhardi, William. Memoirs of a Polyglot. Duckworth, 1931. 
40. "I don't know if I ever revealed to/you the fact that being allowed to learn German/was all the paid-for education I ever had. $£ 2,000$ was spent on my brother's, I still hope/ not in vain.": 1 p., numbered 33 by VW. (Heading only.) Typed quotation, annotated "Life of Mary Kingsley/Stephen Gwynn. I5."

Gwynn, Stephen. The Life of Mary Kingsley. Macmillan, 1932.

41. "Eton Masters.": 1 p., numbered 34 by VW. Typed notes, annotated "Oars Wars and Horses by V. Nickalls. 82." The notes are from p. 28 of the text.

Nickalls, Major Vivian. Oars, Wars and Horses. Hurst \& Blackett, 1932.

42. "Mrs Browning on the Princess. No one wants/the idiotic college system to go on.": 1 p., numbered 35 by VW. (Heading only.) Typed notes, annotated "Letters. Kenyon. I. 367." The notes are from Elizabeth Barrett Browning's letter to Miss Mitford, May 28, 1848, in which she discusses Tennyson's The Princess. See below, B.52. Notes on the Letters made for Flush: A Biography appear in Volume XXXII.

Browning, Elizabeth Barrett. Letters. Ed. F. G. Kenyon. Vol. I [of II]. Smith, Elder, 1897.

43. "Adrian was now at $\mathrm{Mr}$ Wests school at Bournemotuh.": $1 \mathrm{p}$., numbered 36 by VW. Typed quotation, annotated "36 AVC: Mrs. H. Jac son."

Jackson, Annabel Huth. A Victorian Childhood. Methuen, 1932.

44. "But we had further seen how freedom in the/practice of our art, how the bare/opportunity to practice it at all,/depended, for the actress, on considerations/humiliatingly different from those that/confronted the actor.": 1 p., numbered 37 by VW. Quotation, annotated "29-30/Theatre \& Friendship/Letters from HJ. to E. Robins:" The quotation is from Robins' commentary.

Robins, Elizabeth. Theatre and Friendship. Some Henry James Letters. Cape, 1932.

45. "Political creed; why should I kill women/killing women the logical necessity; but I won't.": 1 p., numbered 38 by VW. Typed notes on women and war, including "War not needed. by women. No party possible at present." 
46. "Is Gof English?": 1 p., numbered 39 by VW. Typed notes, beginning, "The six child scale. All professions run on that True of literuatre. That's why they don't fit women."

47. "It is hopeless for me to try to do anything/without I have a woman at the back of me ...": 1 p., numbered 40 by VW. Typed quotations, annotated "Letters of D.H. Lawrence./ 93-94."

Lawrence, D. H. Letters. Ed. Aldous Huxley. Heinemann, 1932.

48. "Marriage service. Savages in tail coats.": 1 p., numbered 41 by VW. Typed notes, including the sentence, "The woman has no worldly goods must therefore give her body." The notes conclude, "A solemn moment, really marriage."

49. "Physical education was represented by dancing and the/study of deportment . . .": 1 p., numbered 42 by VW. Typed quotation, annotated " $F$. Cecile Steadman In the days of Miss Beale." A note at the end of the quotation reads, "(daughters of educated people at the year 1848." The quotation is on p. 1 of the text.

Steadman, F. Cecily. In the Days of Miss Beale. A Study of Her Work and Influence. Burrow, 1931.

50. "In August I888 ... we went for a walk on the front/and to my astonishment we passed in the/gathering darkness a woman smoking a cigarette ...": 1 p., numbered 43 by VW. Typed quotation, annotated "Memories of a misspent youth Grant/Richards. 2I7."

Richards, Grant. Memories of a Misspent Youth, 1872-1896.

With an Introduction by Max Beerbohm. Heinemann, 1932.

51. "HOW I WAS EDU[CATED]/The Valuable Habit of Leisure $\operatorname{Re}[\ldots$. . ]/Foreign Langual . . . ]/By HELEN WODEHOUSE": 1 p., numbered 44. Cutting, fragment of an article by Dr. Helen Wodehouse, Professor of Education at Bristol University, 1930.

52. "On tiptoe seem'd to touch upon a sphere/Too gross to tread, $\&$ all male minds perforce/Sway'd to her from their orbits as they moved,/And girdled her with music.": 1 p., numbered 45 by VW. (Heading only.) Quotation, from Part VII of Tennyson's The Princess.

Tennyson, Alfred. The Princess; A Medley. [1847]. 
53. "Clare College: 2 vols./at a rumoured cost of $£ 6,000 ": 2$ pp., numbered 45-46 by VW. Entry annotated "Jan 17" and "J.M. Keynes." The notes on p. 46 are a typed transcript of the notes on the reverse of the sheet pasted onto p. 45. See below, B.54.

Keynes, J. M. "Clare College." Rev. of Clare College, 13261926, ed. Mansfield D. Forbes. Nation \& Athenaeum, January 17,1931 , pp. 512-513.

54. "Somerville received with pa hetic gratitude/the 7,000 which went to it last year from the/Jubilee gift and a private bequest ...": 1 p., numbered 46 by VW. Typed quotations. The second one begins, "When I lived out during my last year at/Somerville ...," and is annotated "The Nation Jan I7." See above, B.53.

Brittain, Vera. "A Woman's Notebook." Nation \& Athenaeum, January 17, 1931, pp. 508-509.

55. "The fellows or monks of my time were decent easy men, who/supinely enjoyed the gifts of the founder; ...": $1 \mathrm{p}$., numbered 47 by VW. Typed quotation, annotated "Gibbon Memoirs of my life and writings. 24-25." Edition unidentified.

Gibbon, Edward. Memoirs of my Life and Writings. [1796].

56. "Womens eloquence.": 1 p., numbered 48 by VW. Typed quotations, the first one annotated "Memoir of AJ Clough. 332 ," beginning, "What could have been simpler than the words in hich she summed up the good of three years taring training at college." Notes on this work appear in $\mathrm{X}$, B.5, and LV, B.2.

Clough, Blanche Athena. A Memoir of Anne Jemima Clough. Edward Arnold, 1897.

57. "Certain it is that while men are gathering/knowledge and power with ever-increasing and mea/measurless speed, their virtues and their/wisdom have not shown any notable improvement/as the centuries have rolled.": 1 p., numbered 49 by VW. Typed quotation, annotated " 279 Thoughts and Adventures/W. Churchill." More quotations from this work appear below, B.59.

Churchill, Winston S. Thoughts and Adventures. Butterworth, 1932 . 
58. "Valentine in [ . . ]/of [ . . ]. 175": 1 p., numbered 50 by VW. Pencilled quotation, unidentified. The quotation reads: "You dealt me, when you lost your honour,/The deepest wound of all./Now I will go to God through death,/A soldier answering the call."

59. "induced me to assist Lord Hugh in the prolonged/and successful obstruction of the D. Wifes/Sister Bill of I90I in the Grand Committee.": 3 pp., numbered 51-53. Typed quotations, annotated " 58 Thoughts and Adventures/W. Churchill"; "I9 Thoughts and Advs. W. Chuuchil"; and "311 W.C." More quotations from this work appear above, B.57.

Churchill, Winston S. Thoughts and Adventures. Butterworth, 1932.

60. "FLOCKING BACK TO CHURCHES/BISHOP PREDICTS A REVIVAL/'SOME DAY SOON'": 1 p., numbered 54 by VW. Newspaper cutting, Sunday Times, which includes quotations from Dr. H. A. Wilson, Bishop of Chelmsford.

61. "THIS FREEDOM/WOMEN STUDENTS DELIGHTED": 1 p., numbered 55 by VW. Newspaper cutting, annotated " $20^{\text {th}} /$ Nov./1932," about "the modifications in the rules governing social intercourse" between students at Girton and Newnham and the Cambridge undergraduates.

62. "Girton behan I873/clerkships in the Post Office savings bank/ I88I ...": 1 p., numbered 56 by VW. Entry annotated "Our Mothers./Bott \&/Clephane." More notes on this work appear in X, B.4.

Bott, Alan, and Clephane, Irene. Our Mothers. A Calvacade in Pictures and Quotation and Description of Late Victorian Women. Gollancz, 1932.

63. "CIVIL SERVICE WOMEN/PREFERENCES AND DISLIKES/By T.J. CURTIN": 1 p., numbered 57 by VW. Newspaper cutting.

64. "DOES UNIVERSITY EDUCATION FIT MODERN WOMEN FOR LIFE?/By SIR STANLEY LEATHES": 1 p., numbered 58 by VW. Newspaper cutting, Daily Telegraph, July 26, 1932.

65. "Total cost of war; to this country/£II,076,600,000": 1 p., numbered 59 by VW. Typed notes, annotated "Sylvia Pankhurst. The Home Front 446." 
Pankhurst, E. Sylvia. The Home Front. A Mirror to Life in England during the World War. Hutchinson, 1932.

66. "Mrs. Wright. 20": 2 pp., numbered $60-61$ by VW. Typed. More notes on this work appear in X, B.1; quotations appear above, B.27, and in XXXIII, B.9.

Wright, Elizabeth Mary. The Life of Joseph Wright. Vol. I lof II]. Oxford Univ. Press, 1932.

67. "There are dangers in 'Puritanism'; \& there are/compensations.": 1 p., numbered 62 by VW. Quotations, annotated "Candid Reminiscences. Upton Sinclair. p. 62. 3" and "Upton Sinclair 63."

Sinclair, Upton. Candid Reminiscences. My First Thirty Years.

T. Warner Laurie, 1932.

68. "YOUNG WOMEN AND THE CHURCH/"A SUSPICION THAT THEY ARE NOT WANTED'": 1 p., numbered 63 by VW. Newspaper cutting, annotated " $10^{\text {th }}$ Jan/1933," about Canon F. R. Barry's speech at "a conference arranged by the Anglican Group for the ordination of women to the historic Orders of the Church's Ministry."

69. "A lady is-or in Ellen Terrys generation was-/a person trained to the utmost attainable degree/in the art and habit of concealing her feelings ...": 1 p., numbered 64 by VW. Typed quotations, annotated "GBS. Ellen Terry and B.S XI" and "XV GBS."

Shaw, George Bernard. "Preface." In Ellen Terry and Bernard

Shaw: A Correspondence. Ed. Christopher St. John. New

York: Fountain Press; London: Constable, 1931.

70. "In the 'seventies of last century, Miss/Jess (Jex) Blake and her associates were/vigorously fighting the battle for admission/of women to the medical profession . ..": 1 p., numbered 64 by VW. Typed quotation, annotated "The Doctors Second Thoughts. J/Sir James Crichton-Browne 74."

Crichton-Browne, Sir James. The Doctor's Second Thoughts.

Ernest Behn, 1931.

71. “A POET IN A RAGE./'The Georgiad.' By Roy Campbell. (Boriswood, Ltd. 5s.)/(By EDWARD THOMPSON.)": 1 p., numbered 65 by VW. Newspaper cutting. Review of The Georgiad, by Roy Campbell. 
72. "To a Quaker Friend 1874.": 1 p., numbered 66 by VW. Quotation, annotated "Life of Octavia Hill. by C.E. Maurice [ . . ] ] p. 262 307." The quotation begins, "You \& I know that it matters little if we have to be the out-of-sight piers driven deep in the marsh, on wh. the visible ones are carried that support the bridge." The entry also includes the note, "Rem of a [ . . ]/of [ . . ]. 92," which is unidentified.

Maurice, C. Edmund. Life of Octavia Hill, as Told in her Letters. Macmillan, 1913.

73. "I am not moved at all by the chatter of female voices/wh. declare that Lawrence is their leader, \& that/where he has led they have followed.": 1 p., numbered 67 by VW. Quotation, annotated " $\mathrm{R}$ ces of DHL by/M. Murry. 180."

Murry, John Middleton. Reminiscences of D. H. Lawrence. Cape, 1933.

\section{Monk's House Papers/B.16f. Vol. 2. (Sussex)}

Volume 2 of "the 3 -bound volumes containing Press Cuttings \& extracts collected or copied by VW relative to $3 \mathrm{Gs}$ " (MHP Catalogue) gathers material that ranges in date from February 1, 1932, to May 12, 1937. The majority of the entries, however, belong to the period after September 1935. There is, essentially, a gap of almost two years between volume 1 of these notebooks (LVIII), which ends at the beginning of 1933, and volumes 2 and 3. During this period, Woolf appears not to have gathered or saved articles or quotations to the same extent that she had earlier, or did later. The scarcity of material for 1933 and 1934 can perhaps be accounted for by Woolf's decision in the beginning of 1933 to abandon the essay part of her novel-essay, The Pargiters, and to write a novel instead: "Today I finished-rather more completely than usual-revising the first chapter. I'm leaving out the interchapters-compacting them in the text" $(A W D$, February 2, 1933; see also, Mitchell A. Leaska's "Introduction" to The Pargiters, xvii).

It is likely, then, that the renewal of entries in 1935 corresponds to the resurgence of Woolf's desire "to write On being despised," her essay on women, in the beginning of that year ( $A W D$, January 1 , 1935). This desire, and the desire to write an antifascist pamphlet, 
were on her mind throughout the year and erupted in a spate of writing and planning for The Next War after she attended the Labour Party Conference at Brighton, September 30 to October 2, 1935: "Did I say the result of the L.P. at Brighton, was the breaking of that dam between me and the new book, so that I couldn't resist dashing off a chapter" ( $A W D$, October 15). Woolf's absorption in her "new book" after the conference is recorded not only by the large number of entries in the " 3 bound volumes" but also by comments in her diary recording her enthusiasm and by the sketches and reading notes she began to make after this date (see Volumes XXXIX and LVI).

There are few published references to the entries that appear in this volume. On August 12, 1933, Woolf noted that she had been "reading Faber on Newman" $(A W D)$-i.e., Geoffrey Faber's Oxford Apostles (B.95); on September 3, she was "reading a stuck up humbug called Faber on Newman with fury" ( $L, \mathrm{~V}, 2787)$. It is not clear, however, whether the notes recorded in this volume were made in 1933 or whether she hunted out remembered passages later on. The notes on Gibbon's descriptions of Oxford (B.94) may have been made between November 1936 and June 1937 when Woolf read "all Gibbon" for her two articles on him (Kp. C348, C350; see, e.g., L, VI, 3194, 3247); but a similar note from the Memoirs, taken from the same unidentified edition, appears in Volume LVIII (1931-1932). Again, we know that Woolf was reading the New Testament at the beginning of 1935 ( $A W D$, January $1 ; L, \mathrm{~V}, 2973,2978$ ); but the notes on 1 Corinthians and Titus (B.92-93) could also have been made in 1937 in conjunction with her visit to St. Paul's Cathedral on March 21. Woolf recorded her impressions of this visit in a vivid set of notes (B.91) that, among other things, draws comparisons between the religious service and military ceremonies. Woolf was "about to attempt to read the Life of Bishop Gore" (B.13, 60) on October 24, 1935 ( $L, V, 3071)$; and we know she read both Blunt's Diaries and Macaulay's works (B.85, 88) during June and July 1936 (L, VI, 3152-3153, 3141, 3155).

One other note. On January 3, 1936, Woolf was thinking of calling her book Answers to Correspondents $(A W D)$; a year earlier, in January 1935, she had complained to Ethel Smyth that "never do I get any letter ... of pure affection. All the rest implore, command, badger, worry." Among her examples are "that d---d ass Elizabeth Bibesco" ( $L, \mathrm{~V}, 2973)$, and it is possible that the letter to Woolf from Bibesco in this notebook (B.81) is the source of her anger. On March 19, 1935 , however, she wrote again of "Elizabeth Bibesco's rudeness" $(L, \mathrm{~V}, 3001)$, this time in connection with a projected antifascist 
exhibition, and the letter in question could easily be about such an exhibition. Several leters from correspondents asking for contributions of various sorts are included in this notebook, and to many Woolf responded positively. On February 23, 1936, for example, she wrote to Pernel Strachey, Principal of Newnham, to offer her services as a patron of the college (B.10; L, VI, 3107), and she herself was associated with a request for contributions to support the library founded by the London and National Society for Women's Service (see, e.g., $L$, VI, 3391, 3392, 3394, 3397, 3401).

There is a fair amount of overlap of entries in this notebook with entries found elsewhere; in all cases, the duplicated notes appear in Three Guineas and record quotations or facts that are an important part of her argument. Some notes, such as those on the Earl of Lytton's biography of his son, Antony (Viscount Knebworth). A Record of Youth, appear twice in this notebook and reappear in two other notebooks as well. Several groups of entries in this volume are also duplicated, either in whole or in part, in other volumes. Almost all of the entries in Volume XXXIII are also found in this volume: XXXIII, B.1-5 corresponds to B.46, B.51-53, and B.55 below; while XXXIII, B.11-22 corresponds to B.57-68 below. Other cross-references between the two volumes exist as well. Again, entries B.3-7 and B.12 in Volume LV correspond to B.85-90 in this volume.

The cover of this notebook has two labels pasted on it: one reads " 2 " and is written in blue pencil; the other has a short list of selected entries written on it in black ink (A.1). As in the first of the " 3 bound volumes," LVIII, Woolf has provided an "INDEX" of the material in the notebook (A.2), which is marked in different color pencils and ink where Woolf wanted to note an entry for use in Three Guineas. Both lists were probably made after the notebook was compiled.

With two exceptions (B.12, 96), the cuttings and extracts are pasted onto the pages of the notebook, the extracts having first been written or, more often, typed on another piece of paper. The "INDEX" is with one exception typed. (It is reproduced here in the exact format of the original.) Most of the page numbers are in blue pencil, although a few are typed and one (B.82) is in ordinary pencil. When Woolf has supplied the source and/or date for a cutting, this information is preceded by "annotated"; otherwise, the documentation for a cutting is that provided in the cutting itself. All quotations that are not labelled "Heading only" continue in Woolf's entry. 
A. Table of Contents

1. Pommer 20

Lord Londonderry - --_--_----- 23

decoration for desk --_---_----- 25

$\mathrm{W}^{\mathrm{n}}$ [women's] football --_-_----- 33

Miss Weeton --_-_-_-_-_--- 37

Pendennis AEF --_---_--_---- 37

Gore on Bishops: Gratuitous ----- 38

Squire on window breaking --_--- 38

Collyer on RA --_-_-_-_-_--- 39

Wild on Barrister --_--_------ 40

Knight on artists ------------- 41

Alington on Eton \& Ed ${ }^{\text {n }}$ [education] -- 41

Thompson on Cam ----------- 42

Church on War --_-_-_-_---- 49

G. Bell youth ------------ 52

Macaulay on disint [erestedness]: ----- 54

Low on journalism ------------ 54

Joad on peace, w. \& food -_-

Honours in 1937

Pommer 20

Allowances at College 38

Bristol dec ${ }^{\mathrm{n}}$ [decoration] 54

$1 \mathrm{p}$., on cover.

2. INDEX

1... Oxford; keep book open to all

1 ... womens dress at funeral of King

2. .. demand for book to build church

3... Lord Hewart on England and liberty

12... ditto cont.

4. . Nat council of $w$. on $\mathrm{L}$. of $\mathrm{N}$.

5... head dresses for men

5... women and mens work and marriage

6. . . Should women work?

6. .. Women flyers

7... Newnham wants money to rebuild

8. . . manly qualities need war. Antony Lytton

9.... Women painters difficulties at R.A. Collyier

11 .. . Bishop Gore on liberty.

11... ditto on need for womens vote 
i2. . . Telegraphits object to women

13. . Miss Bevan on dead end at Cambridge

13. . . Times on Powder and jam. W. at Oxford.

14. . . Oxfords income

14. . . women shd. not imitate men. cd. rebuild world.

15 . . w. shd not be clerks

16. . . BBC. on sex psychology

17. . Joad on ws failure

18. . . Huxley on need for whole life

19. . . More money for Universities

19. . . The capitalist system.

20. . woman in prison for insulting Nazis

20. . . Hitler and a nation of men.

21... Huxley and the Mandrill. The advertising sex

22. . . Will of millionaire.

22. . . Hitler on duty of $w$.

23. . . Lord Londonderry says the world is wrong

24. . . Duff Cooper and the Church; soldiers heroes

25 ... The new decoration for the desk

26. . . Baldwin has never seen apple blossom

27. . . The provost of Kings and his coach

28. . War and writers

29. . . The Interl. Peace Campaign

30. . . Churchill and TE Lawrence. heroes

31... Pensions for spinsters impractciable

32. . . No coronets for peeresses

33. .. womens football wrong

34 . . . aughter who will not go home

34. . . Democracy at stake

35 . . equal pay for women

36. . . Yeats on gentleman

36... Siren as consoler of genius Yeats

36. . . Mrs Glyn on creme de la creme barriers broken by

SA War

36. . . women benefacotrs to Univs. Sir JS

36. . G.M. on reviews.

37. . . Paxtons in Regent st.

37. . . BR. on greed of gain

37. . . Miss Weeton on governesses

37. . . Lord Howard on bird bill and W. Institutes

37. . . Lady M. Lascelles allowance

37. . . Pendennis AEF 
38. . a alloance at Balliol in $\mathbf{1 8 8 0}$

38. .. . Gino Watkins allowance at Cambridge 400

38. ... Chaperonage before war Monica Salmond

38. ... Gore on Bishops.

38. . . Gore on ministrations wh. are gratuitous

38. ... Squire on window smashing.

39. ... Collyer on women at RA.

39. .. . Hamilton on drunkenness in high life

39 .... Antony and bombs.

40. . Womens institutes political instinct of $w$.

40. . . Sir Ernest Wild life as barrister.

39. the money earned by a KC.

39 .... Wild on influence

$41 .$. W. artists and nude Laura Knight.

41... Alinton on Eton

41... Alington on the need of different education

42. . . Song from Pendennis

42. . . Thompson on Cambridge. degrees \&c.

43... How one gets on in medicine.

44. . . Picture of Pope

45. . . Different fashions for heralds and Ascot

46. . . Heralds

47. . . Nazi blood and race theory

48. . Privacy in the press; an unhappy reporter

49. . . Cavalry relics

The 49... The Church and War.

50... The Church and War.

50... Weight of Peers clothes. and tradition

51. . Elixabeth Bibescos letter about Hitler. 52-Honours in 1937

52. . . Housemans sister did accounts

52. . . Gertrude bell s youth

54. . . Party funds. Honours

54. . . Miss Lonsadle on Cathedral society

54. . . Dictators in H.of C. Also in Home. woman and husband who wants eher to call him $\mathrm{Sir}$

54. . . Disinterestedness. Macaulay

54. The professional writer. How much Low wrote in a d

55. . . Sermon in St Pauls. Palm Sunday 1937

56. .. St Pauls episteles on womens duty

57.... Gibbon on Oxford.

57... Pusey at oxfrdo; success 
57. . Newman gets a fellowship.

58. .. Joad on women; peace; food.

2 pp., not numbered. Typed and handwritten.

\section{B. ENTRIES}

1. “[OXFO]RD'S HINT/'KEEP BOOK OF SCIENCE OPEN TO ALL'": 1 p., numbered 1 by VW. Newspaper cutting, annotated "March $4^{\text {th }} 36$," describing Oxford's address of congratulations to Heidelberg University on its five hundred-fiftieth anniversity.

2. "DRESS FOR GUESTS AT FUNERAL/OFFICIAL ORDER": 1 p., numbered 1 by VW. Newspaper cutting, on the dress to be worn at the funeral services for George V.

3. "Deane Congregational Church/Wigan Road, Bolton": 1 p., numbered 2 by VW. Holograph letter to "Mrs Woolf" from "William McNeill," pastor of the church, asking her to contribute one of her books to a money-raising bazaar in aid of eight Congregational churches. The letter is dated "23 rd January, 1936."

4. "LORD HEWART ON ENGLAND-HOME OF LIBERTY/ 'A CASTLE THAT WILL BE DEFENDED TO THE LAST" ": 1 p., numbered 3 by VW. Newspaper cutting, October 19, 1935, on "Lord Hewart, the Lord Chief Justice of England, .... proposing the toast of 'England' at the banquet of the Society of St. George at Cardiff."

5. "NATIONAL COUNCIL OF WOMEN/SUPPORT FOR BRITISH ACTION": 1 p., numbered 4 by VW. Newspaper cutting, October 16,1935, on the "annual conference of the National Council of Women." The action referred to in the headline is the "declaration of British policy made by the Foreign Secretary at Geneva" supporting the Covenant of the League of Nations.

6. Photograph of "MAJOR FEY": 1 p., numbered 5 by VW. Newspaper cutting, annotated "Oct $18^{\text {th }} 1935 . "$

7. "THE 'GOOD OLD TIMES'": 1 p., numbered 5 by VW. Newspaper cutting, annotated "22 nd Jan 36." Letter to the Editor of the Daily Telegraph, signed "SIXTY-FIVE," on the reality of the "good old times" and the writer's feeling that there is "nothing to regret in the passing of the old ideas." 
8. "SHOULD WOMEN WORK?": 1 p., numbered 6 by VW. Newspaper cutting, annotated "Jan 20th D.T. [Daily Telegraph] 1936." Letter to the Editor, signed "WM. H. COLLIN," agreeing that "woman has too much liberty," and that her liberty came with the war.

9. “WOMAN FLIER'S RECORD/MISS GOWER A FIRST CLASS NAVIGATOR/ONLY WOMAN TO HOLD CERTIFICATE": 1 p., numbered 6 by VW. Newspaper cutting, December 10, 1935.

10. "NEWNHAM COLLEGE,/CAMBRIDGE.": 1 p., numbered 7 by VW. Typed letter to "Mrs Woolf" from "J.P. Strachey" asking her to join the Committee of Patrons who will launch Newnham's first public appeal for money. Letter dated "19th February 1936."

11. "Antony.": 1 p., numbered 8 by VW. Typed quotations, annotated " 355 " and " 282 ," on the need for armies and on the differences between men and women. Another entry on this work appears below, B.64; both sets of notes in this volume appear in a single entry in XXXIII, B.10; a third set of notes appears as XXXIII, B.18.

Lytton, Earl of [Victor A.G.R.]. Antony (Viscount Knebworth). A Record of Youth. By his father. Peter Davies, 1935.

12. "The Life of an artist./Margaret Collyer. 79-82": 2 pp., numbered $9-10$ by VW. The entry begins, "Why the female of the species should never be given the same advantages as the male it is difficult to understand." Similar notes on these pages appear as B.62, below, and as XXXIII, B.16.

Collyer, Margaret. Life of an Artist. An Autobiography. Philip Allen, 1935.

13. "Could they use their liberty in such a manner that free/men would be equally efficient with tme [men] who for the/purposes of war had s consented to surrender freedom?": $1 \mathrm{p}$., numbered 11 by VW. Typed quotations and notes, annotated "428 Life of Gore," and "336-7." The second quotation begins, "Gore was a keen supporter of the women's movement, ..." Another set of notes on this work appears below, B.60; and a third set as XXXIII, B.14.

Prestige, G. L. The Life of Charles Gore. Heinemann, 1935. 
14. “OBJECTION TO WOM[EN] TELEGRAPHISTS/PROTEST BY UNION": 1 p., numbered 12 by VW. Newspaper cutting, annotated "Oct/19th/1935."

15. "PRIDE WITHOUT ARROGANCE": 1 p., numbered 12 by VW. Newspaper cutting annotated "Lord Hewart/[ . . . ] Oct 19th 1935." This cutting and another headed "SMILES INSTEAD OF ANGER" are both fragments of the article that appears in its entirety above, B.4. These fragments record Lord Hewart's praise of the "Loyalty, courtesy, tolerance towards opponents" displayed by Englishmen "trained in English schools and English universities."

16. "It was a very safe and comfortable job,/but a complete dead end as women are not full members/of the University at Cambridge and all the better/jobs were automatically closed to me.": 1 p., numbered 13 by VW. (Heading only.) Typed quotation, annotated "Extract from private letter/Miss FA Bevan Kingsbury Lodge Branch/Road St Albans."

17. "The Powder and the Jam": 1 p., numbered 13 by VW. Newspaper cutting, annotated "Jan 12th $1935 /$ Times/Jan. 12th," recording the writer's view that "The married women have had plenty of jam, their rights; it is their turn now for some of the powder, their responsibilities." The "powder" at issue is "the Law Reform (Married Women and Tortfeasors) Bill," which would make married women responsible for their own debts.

18. "OXFORD UNIVERSITY FINANCES/BALANCE OF f7,264": 1 p., numbered 14 by VW. Newspaper cutting.

19. "Woman's Handicap": 1 p., numbered 14 by VW. Newspaper cutting, annotated "Feb. $13^{\text {th }} 1935$." Letter to the Editor, signed "CYRIL CHAVENTRE," stating that "Leontine Sagan's article on the invisible barrier that women have to face in business and professional life reveals that the mentality of even outstanding women is essentially dependent, not creative," and criticizing women's "slavish imitation of men" when they "have the opportunity to build a new and better world."

20. "WOMEN AND CLERICAL UNEMPLOYMENT": 1 p., numbered 15 by VW. Newspaper cutting. Letter to the Editor, signed "F.R.A. SHORTIS," stating the writer's opinion that "a considerable amount of distress" among the clerical 
workers "could be relieved by the policy of employing men instead of women, wherever possible."

21. "The Psychology of the Sexes/By Professor CYRIL BURT": 1 p., numbered 16 by VW. Cutting, The Listener, February 1, 1933, pp. 179-180.

22. "WOMEN OF TO-DAY AND TO-MORROW/By a ManC.E.M. Joad": 1 p., numbered 17 by VW. Cutting, Everyman, January 12, 1934, p. 12.

23. "LOP-SIDEDNESS OF SCIENCE/PROF. JULIAN HUXLEY ON MIXED PHILOSOPHIES": 1 p., numbered 18 by VW. Newspaper cutting, annotated "Times/Feb 12 36," beginning, "The organization of scientific research and its application in this country was described as lop-sided by Professor Julian Huxley in an address on 'Science and the Problems of Society'...."

24. "MORE MONEY FOR UNIVERSITIES/GRANT IN-

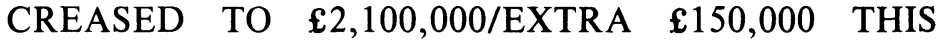
YEAR": 1 p., numbered 19 by VW. Newspaper cutting, Daily Telegraph, annotated "Feb 29th 1936."

25. "THE CAPITALIST SYSTEM": 1 p., numbered 19 by VW. Newspaper cutting, annotated "Times/Oct 15 1935." Letter to the Editor, signed "Mr. E.R. HARDCASTLE," quoting a definition of the capitalist system by "The late Dr. Cannan, who was of course not a Socialist," in his book, Wealth.

26. Photograph of "Count Ciano in flying kit": 1 p., numbered 20 by VW. Newspaper cutting.

27. "'THE THORN OF HA[TRED]'/OUTSPOKEN ESSEN WOMAN ARRESTED": 1 p., numbered 20 by VW. Newspaper cutting, annotated "12 Aug. 19[ . . ]," beginning, "Frau Pommer, the wife of a Prussian mines official at Essen, has been arrested and is to be tried on a charge of insulting and slandering the State and the Nazi movement." " "The thorn of hatred," she said, "'has been driven deep enough into the people by the religious conflicts and it is high time that the men of to-day disappeared.'"

28. “'A NATION OF MEN'/THE FÜHRER'S BOAST/SPEECH TO NAZI OLD GUARD": 1 p., numbered 20 by VW. Newspaper cutting, The Times, annotated " $12^{\text {th }}$ Aug/1935," 
quoting a speech by Hitler that included the phrase, "He who wishes to disturb our peace will no longer fight against a nation of pacifists but against a nation of men."

29. "THE LISTENER/help them to be recognised by others of their kind.": 1 p., numbered 21 by VW. Cutting, fragment of the article "The Colours of Animals," by Julian Huxley, The Listener, June 10, 1936, pp. 1099-1100. The cutting is of p. 1100, and includes two photographs: one shows how "The male mandrill advertises his fighting qualities by his face-décor, and so warns off rivals"; the other illustrates "The male Argus pheasant advertising his attractions to his mate."

30. "WILL OF ANOTHER MILLIONAIRE": 1 p., numbered 22 by VW. Newspaper cutting, annotated "9th Sept. 1936/D.T. [Daily Telegraph]," about the fourth person, Mr. Harold L. Cohen, "whose estate has been admitted to probate this

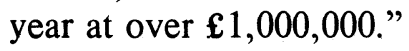

31. "PRAISE FOR WOMEN/THEIR PART IN THE 'NAZI TRIUMPH" ": 1 p., numbered 22 by VW. Newspaper cutting, annotated "Sept. $13^{\text {th }} 1936$. S. Times," beginning, "Herr Hitler praised the women's part in enabling the Nazi movement to triumph when he addressed the Nazi Women's League."

32. "WORLD'S PROGR[ESS] CHECKED/LORD LONDONDERRY'S VIEW": 1 p., numbered 23 by VW. Newspaper cutting, annotated "D.T. [Daily Telegraph]/July 11 th/1936," about Lord Londonderry's speech at the graduation ceremony at Queen's University, Belfast, in which he stated that "at no time in our history had the future appeared so dark and menacing."

33. "WAR MINISTER'S CHALLENGE TO THE CHURCH/ LEADERS WHO SPREAD PACIFISM/'SHOULD BE REPROVED AND DENOUNCED'": 1 p., numbered 24 by VW. Newspaper cutting, annotated "April $21^{\text {st }} 36$," beginning, "Mr. A. Duff Cooper, Minister for War, in a speech here to-night, called upon the leaders of the Church of England to denounce the 'insidious doctrine of pacifism' as heresy. He was addressing a territorial recruiting meeting of 3,000 people in the Free Trade Hall," Manchester. 
34. "DECORATIONS WILL NOT BE WORN": 1 p., numbered 25 by VW. Newspaper cutting, annotated "April 21 st/36," describing the ranks and decorations in Germany, including "The Award of the Silver Shield . . . created by President Hindenburg for scientists and other distinguished civilians": "a large silver plaque ... usually placed on the writing desk of the recipient."

35. "It is quite true that some day you will have/someone fighting this seat who has not got a/record of so many years' service behind him as I/have.": 1 p., numbered 26 by VW. Newspaper cutting, annotated "Baldwin/Times April 20th 1936." The entry is a fragment of a speech given by the Prime Minister, Mr. Baldwin, to the annual meeting of the Bewdley Division Unionist Association.

36. "THE PROVOST OF KING'S AND HIS COACH": 1 p., numbered 27 by VW. Newspaper cutting, annotated "Times/Oct 3rd1936." Letter to the Editor, signed "IAN MALCOLM," asking the whereabouts of the Cambridge yellow coach and the Eton yellow coach that were used in the past when the Provost of King's College, Cambridge, visited Eton.

37. "WAR AND WRITERS": 1 p., numbered 28 by VW. Printed sheet, dated "25.7.36," beginning, "Modern war and preparations for war are hostile to the arts, and most of all to writing." The sheet continues, "The time has come for all those who care for the well-being of our civilization to take resolute action for peace." This sheet is the Manifesto of The International Peace Campaign. See below, B.38.

38. "INTERNATIONAL PEACE CAMPAIGN": 1 p., numbered 29 by VW. Typed letter to Virginia Woolf from "(Dame Adelaide Livingstone)/Vice-Chairman, British National Committee," requesting support for the International Peace Campaign and Woolf's signature on the Manifesto that appears above as B.37.

39. "MIGHT HAVE BEEN CONQUEROR OF THE EAST/MR. CHURCHILL AND T.E. LAWRENCE/MAN WHO 'FLEW BEST IN HURRICANE'": 1 p., numbered 30 by VW. Newspaper cutting, Daily Telegraph, annotated "Oct $5^{\text {th }}$ 1936," beginning, "Mr. Winston Churchill expressed the opinion at Oxford on Saturday that if the Great War had lasted a few years longer T.E. Lawrence-Lawrence of Ara- 
bia-might have realized Napoleon's young dream of conquering the East."

40. "PENSIONS FOR SPINSTERS/MINISTERS SAY PLAN NOT

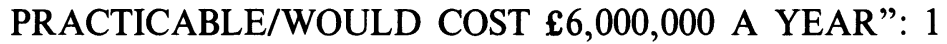
p., numbered 31 by VW. Newspaper cutting, annotated "July 29th 1936," about the Spinsters' Pension Association's request for "pensions for spinsters at the age of 55." The cutting also includes an article headed "DOMINIONS' PART IN EMPIRE DEFENCE/MR. BRUCE CALLS FOR BIGGER EFFORT/REAL HOPE FOR THE WORLD'S PEACE."

41. "NO CORONETS FOR PEERESSES/Coronation Order by The Earl Marshall/JEWELLED TIARAS TO BE WORN":

1 p., numbered 32 by VW. Newspaper cutting, on the dress to be worn by peers and peeresses at the coronation of George VI, May 12, 1937.

42. "GIRLS' FOOTBALL IS JUST TOO POPULAR": 1 p., numbered 33 by VW. Newspaper cutting, annotated "Daily/ Herald," "Aug. 15/1936," beginning, "Official football circles here [Wellingborough, Northants] regard with anxiety the growing popularity of girls' football."

43. "DAUGHTER WHO WILL NOT RETURN HOME/MAINTENANCE DISPUTE": 1 p., numbered 34 by VW. Newspaper cutting, annotated "D.T. [Daily Telegraph] 1936 Aug $31^{\text {st }}$," about the nonmaintenance of a daughter, aged 24, by her parents.

44. "DEMOCRACY AT STAKE": 1 p., numbered 34 by VW. Newspaper cutting. Letter to the Editor, expressing "sympathy with the Spanish Government and people," and asking the English Government to "take every legitimate opportunity of pursuing towards such a foreign Government the traditional British policy of sympathetic benevolence." The letter is signed by thirty-three people, among them "Leonard Woolf" and "Virginia Woolf." The entry also includes a slip from the "General Press Cutting Association," indicating that the cutting is from the Daily Telegraph, August 20, 1936.

45. "EQUAL PAY FOR WOMEN./'IT WOULD BE TO MEN'S ADVANTAGE" ": 1 p., numbered 35 by VW. Newspaper cutting, Observer, annotated "Sept 13 th/1936," beginning, 
"Mrs. Barbara Gould, speaking at a luncheon ... of the National Union of Women Teachers, said it was up to women to convince men that it was to their advantage to give women equal pay."

46. "Ireland has grown sterile, because power has passed/to men who lack the training which requires a certain/amount of wealth . ..": 1 p., numbered 36 by VW. Typed quotations, annotated "Dramatis Personae. Yeats. 107" and "Yeats D.P. 127." The second quotation is about "that communication with idle, charming cultivated women which Balzac . . . calls 'the chief consolation of genius.' " The second quotation is also found in XXXIII, B.1.

Yeats, W. B. Estrangement and The Death of Synge. In Dramatis Personae. Macmillan, 1936.

47. "after helping to remove your furs ...": 1 p., numbered 36 by VW. Typed notes, annotated "Elinor Glyn. Romantic Adventure. 68 " and "68. E.G. R.A."

Glyn, Elinor. Romantic Adventure. Autobiography. Nicholson \& Watson, 1936.

48. "The lodge at Queens.": 1 p., numbered 36 by VW. Typed notes, annotated "Essays in Ecc. Biog. Sir J.S. 572" and "Ecc. Biog. 574."

Stephen, Sir James. Essays in Ecclesiastical Biography. Longmans, Green, 1891.

49. "I might ec ntually hope to reach a position wh. would/give me 300 pounds a year, a stable for my horse, . . ": 1 p., numbered 36 by VW. Typed quotation, annotated "60 life of Ld. M.T." Source unidentified.

50. "... for though reviwers do not teach one how to/write they tell whether a book is likely to be/appreciated or despised.": $1 \mathrm{p}$., numbered 36 by VW. (Heading only.) Typed quotation, annotated "Life of George Moore. Hone. 348."

Hone, Joseph. The Life of George Moore. With an account of his last years by his cook and housekeeper, Clara Warville. Gollancz, 1936.

51. "About the year 1848 they (the Paxton daughters)/committed the unpardonable solecism of driving/down regent Street in a hansom cab./Paxton and the bachelor Duke. 288.": 1 p., 
numbered 37 by VW. (Heading only.) Typed quotation, which also appears as XXXIII, B.2.

Markham, Violet R. Paxton and the Bachelor Duke. Hodder \& Stoughton, 1936.

52. "There is no limit men will inflict for the sake of/gain. BR. Freedom and 250": 1 p., numbered 37 by VW. (Heading only.) This quotation also appears as XXXIII, B.3.

Russell, Bertrand. Freedom and Organization: 1814-1914. Allen \& Unwin, 1934.

53. "Why are not females permitted to study physic, divi/nity, astronomy, \&c \&c ...": 1 p., numbered 37 by VW. Typed quotations, annotated "Miss Weeton. xvll," and "Weeton. Journal of a governess./1807-1811. Ox U. Press." These quotations also appear in XXXIII, B.4.

Weeton, Miss [Ellen]. Journal of a Governess 1807-1811. Ed. Edward Hall. Oxford Univ. Press, 1936.

54. "All along I may say it was the women who carried this/little measure through against the persistent indiff/erence, ridicule and hostility of many of the men ...": 1 p., numbered 37 by VW. Typed quotation, annotated "Theatre of Life. Ld Howard of Penrith. vol 2 619/(on the (Bord Bill) of 1933 [i.e., the Bird Protection Act of 1933]."

Howard, Lord [Esme], of Penrith. Theatre of Life. Vol. II. Life Seen from the Stalls 1905-1936. Hodder \& Stoughton, 1936.

55. "Lady M. Lascelles had an allowance of $\mathfrak{£}$ Ioo in the/si ties?/ Pages from the past Lord Desart.": 1 p., numbered 37 by VW. (Heading only.) Typed. This note also appears as XXXIII, B.5.

Desart, Earl of [H.J.A. Cuffe]. A Page from the Past. Memories ... by himself and his daughter, Lady Sybil Lubbock. Cape, 1936.

56. "'Years before ... John Pendennis, whose darling pro/ject it had been to give his son a university education, ...": 1 p., numbered 37 by VW. Typed quotation, continuing in part, "had begun laying by a store of money wh. he called Arthur's Education Fund. Year after year in his book his executors found entries of sums vested as A.E.F." The quotation appears in Vol. I of the novel, p. 174. More notes from Pendennis appear below, B.69. 
Thackeray, William Makepeace. The History of Pendennis. Vol.

I [of II]. Bradbury \& Evans, 1849.

57. "about $i 881 /$ Balliol had still traditions of frugality . . . /Men could live there on 200 a year ...": 1 p., numbered 38 by VW. Typed quotation, annotated "Antony Hope. and his books./Sir C. Mallet p. 38." Another entry on this work appears as XXXIII, B.11.

Mallet, Sir Charles. Anthony Hope and his Books. Hutchinson, 1935.

58. "Above all, the years he had spent in leading a varied/life at a minimum of expesne (while at Cambridge he never/spent more than the $£ 400$ yearly allowance ...": 1 p., numbered 38 by VW. Typed quotation, annotated "Gino Watkins. J.M. Scott. 59." This quotation reappears as XXXIII, B.12.

Scott, J. M. Gino Watkins. Hodder \& Stoughton, 1935.

59. "The girls then were soppused to lead very much chaper/oned and shelterred lives.": 1 p., numbered 38 by VW. Typed notes and quotations, annotated "(1914 Bright Armour. Monica Salmond. pas 18-20." This entry also appears as XXXIII, B.13.

Salmond, Monica. Bright Armour. Memories of Four Years of War. Faber \& Faber, 1935.

60. "He was a reformer and a prophet, . .": 1 p., numbered 38 by VW. Typed quotations, annotated "Life of Gore. by Prestige. 240-1 (bishop of Worcestr" and "353 Gore." The second quotation reads, "Men do not value ministrations which are gratuitous." These notes also appear as XXXIII, B.14; another set of notes on this book appears above, B.13

Prestige, G. L. The Life of Charles Gore. Heinemann, 1935.

61. ".... and the women, content with the prospect of/a municipal vote as widow-householders, had not begun/that campaign of burning, whipping, and picture-/slashing which was finally to prove to both Front/benches their eligibility for the Franchise./Ref ctions and memories. Squire. p. 10. 1935.": 1 p., numbered 38 by VW. (Heading only.) Typed. This quotation also appears as XXXIII, B.15.

Squire, Sir John. Reflections and Memories. Heinemann, 1935.

62. "Life of an artist. end of Victorian era.": 1 p., numbered 39 by VW. Typed notes, annotated "The Life of an artist. 
Margaret Collyer/79-82." Another entry on these pages appears above, B.12; a third set of notes appears as XXXIII, B.16.

Collyer, Margaret. Life of an Artist. An Autobiography. Philip Allen, 1935.

63. "In my mothers young days before he marriage, the old/harddrinking habits of the Regency and of the/18th century still persisted.": 1 p., numbered 39 by VW. Typed quotation, annotated "Lord F. hamilton. The days before yesterday/ 1920/322." This quotation also appears as XXXIII, B.17.

Hamilton, Lord Frederic. The Days Before Yesterday. Hodder \& Stoughton, 1920.

64. "Captain Rowland Phillips has been here today giving us/ some lovely tips.": 1 p., numbered 39 by VW. Typed quotation, annotated "Antony. 20." This quotation also appears in XXXIII, B.10 and B.18. Another set of notes on this work appears above, B.11.

Lytton, Earl of [Victor A.G.R.]. Antony (Viscount Knebworth). A Record of Youth. By his father. Peter Davies, 1935.

65. "They are wholly autonomous and wholly spontaneous.": 1 p., numbered 40 by VW. Typed quotations, annotated "248" and "244. English Fabric. F.J. Harvey Daryon." The passages are about the Women's Institutes. Another entry on this work appears as XXXIII, B.19.

Darton, F. J. Harvey. English Fabric. A Study of Village Life. George Newnes, [1935].

66. "He went to his chambres about half past nine ...": 1 p., numbered 40 by VW. Typed quotations and notes, the first one annotated "Sir Ernest Wild. KC. 91/R.J. Rackham." All the rest of the notes on p. 40 are on this work. Another set of notes on this work appears as XXXIII, B.20.

Blackham, Robert J. Sir Ernest Wild, K.C. Rich \& Cowan, 1935.

67. "If the men worked from the living figure I had to go/into the Antique room ...": 1 p., numbered 41 by VW. Typed quotations and notes, annotated "O.P. 47," and "Oil paint and grease paint./Laura Knight." Similar notes appear as XXXIII, B.21. 
Knight, Laura. Oil Paint and Grease Paint. Autobiography. Nicholson \& Watson, 1936.

68. "Following out the suggestion of one of the PM. Cttee/on Education the Provost and fellows in my time/decided that all scholarships at Eton should be of a/fixed value, ...": 1 p., numbered 41 by VW. Typed quotations and notes, the first one annotated "T.A and Mo. Alington. p 163." The rest of the notes on p. 41 are on this work. Two sets of notes on this work appear in Volume XXXIII, B.7 and B.22; another set appears in VII, B.5.

Alington, C. A. Things Ancient and Modern. Longmans, Green, 1936.

69. "Although I enter not/Yet round about the spot/Sometimes I hover ...": 1 p., numbered 3842 by VW. Typed verses, annotated "Pendennis. 315." The verses are entitled "The Church Porch." More notes from Pendennis appear above, B.56.

Thackeray, William Makepeace. The History of Pendennis. Vol. I [of II]. Bradbury \& Evans, 1849.

70. "The income of the (Cam.) university from all sources/ha increased from about $\mathfrak{£ 6 0 , 0 0 0}$ in 1900 to/£2I2,000 in 1930.": 2 pp., numbered $3842-43$ by VW. Typed notes, annotated "Sir JJ Thompson. 296," "297," and "86 Recollections and Reflections/Sir JH J Thompson. FRs OM."

Thompson, Sir J. J. Recollections and Reflections. Bell, 1936.

71. "Becoming a Harley Street man consists in spending/£300 a year on a room and a share in a doormaid.": 1 p., numbered 43 by VW. Typed quotation, annotated "The Invader. Kenneth Walker./1936. Lovat Dickson."

Walker, Kenneth. The Intruder: An Unfinished Self-Portrait. Lovat Dickson, 1936.

72. “. . . IN PALESTINE”: 1 p., numbered 3944 by VW. Newspaper cutting, photograph of "The POPE on his throne in St. Peter's, Rome, during the service held in celebration of his 79th birthday."

73. “. . IN LONDON-CROWD AT THE BANK": 1 p., numbered 4045 by VW. Newspaper cutting, Daily Telegraph, May 30, 1936. Photographs of women at the races, including "Mrs. Dorothy Sandes" and "Miss Diana Bethell." 
74. "PROCLAIMING THE CORONATION OF KING EDWARD IN LONDON": 1 p., numbered 446 by VW. Newspaper cutting, Daily Telegraph, May 30, 1936. Photographs of "The Heralds proclaiming the date of the Coronation ...."

75. "NAZI 'BLOOD \& RACE' THEORY/History Re-written to Define for Germany her Destiny as a Nation/by William Teeling.": 1 p., numbered 4247 by VW. Newspaper cutting, Daily Telegraph, February 3, 1937.

76. "PRIVACY IN THE PRESS": 1 p., numbered 4348 by VW. Cutting, annotated "NS. [New Statesman \& Nation]/Jan 30th/1937." Letter to the Editor, signed "UNHAPPY REPORTER," beginning, "Your editorial paragraph concerning the crucifying by certain newspapers of the relatives of those who meet with violent deaths or other misfortunes does not overstate the foulness of this ever-growing practice."

77. "CAVALRY RELICS/EXHIBITION OF TROPHIES": 1 p., numbered 4449 by VW. Newspaper cutting, annotated "Observer, $/ 7^{\text {th }}$ Feb./37."

78. "THE CHURCH AND WAR/ASSEMBLY DEBATE ON PACIFISM/STRENGTH FOR PEACE": 1 p., numbered 44 49 by VW. Newspaper cutting, annotated "Feb. 6 ${ }^{\text {th }} 1937$," about the debate and vote in the Church Assembly on "the question of peace and national service." For another report, see B.79, below.

79. "If We Had Been Pacifists in 1914-/'HITLER WOULD BE IN WHITEHALL'/Good Samaritan Might Have Laid About Him": 1 p., numbered 4550 by VW. Newspaper cutting, annotated "E.S. [Evening Standard] Feb. 5 $5^{\text {th }}$ 1937," beginning, "The Church Assembly, meeting in London today, passed a resolution deploring general world rearmament, welcoming the declared policy of the Government to adhere to the Covenant of the League, and stating: 'This assembly recognizes the right of the government to maintain such force as the Imperial Parliament deem necessary for the pursuance of this policy, and believes that so long as this policy is maintained Christian citizens may bear arms in the service of their country." "

80. "19 lb CLOTHES AT CORONATION/WHAT SOME PEERS MUST WEAR/NEW COIFFURE FOR PEERESSES": 1 p., 
numbered 4550 by VW. Newspaper cutting, Daily Telegraph, February 17, 1937. The coronation is George VI's.

81. "BABINGTON,/FROME": 1 p., numbered 4651 by VW. Holograph letter to "Mrs. Woolf," from "Elizabeth Bibesco," reading, "There will of course be a section dealing with women under the Nazi regime. I am afraid that it had not occured to me that in matters of ultimate importance even feminists could wish to segregate and label the sexes. It would seem to be a pity that sex alone should be able to bring them together."

82. "i47 men and 7 women received honours/in the New Years list 1937/Feb. 25th 1937": 1 p., numbered 4752 by VW. (Heading only.) Typed.

83. "Ourreturn from fockbury to our original home at/Brom grove was shortly followed by a period of/serious finacial strain.": 1 p., numbered 52 by VW. Typed quotation, annotated "L. Housman. The Unexpected Years,/94," describing how Housman's sister bore "the main brunt" of helping their father with his paperwork.

Housman, Lawrence. The Unexpected Years. Cape, 1937.

84. "i889-i892/The earlier Letters of Gertrude bell. 2i7": 2 pp., numbered $52-5348$ by VW. Typed notes, beginning, "Gertrude could never go out in London without a female freind or, failing that, a maid."

Bell, Gertrude. The Earlier Letters. Ed. Elsa Richmond. Ernest Benn, 1937.

85. "Party funds. Honours./Blunt Diaries. Part 2. 21st April 1901": $1 \mathrm{p}$., numbered 54 by VW. Typed quotation. This quotation also appears in LV, B.3.

Blunt, Wilfred Scawen. My Diaries. Being a Personal Narrative of Events, 1888-1914. Part Two: 1900-1914. Martin Secker, 1920.

86. "Horror of Church": 1 p., numbered 54 by VW. Typed quotation, annotated "Sohia Lonsdle dale Compiled n Violet Martineau. 103," beginning, "I have often been asked what I think of Cathedral Establishments, ..." This quotation also appears in LV, B.4.

Martineau, Violet. Recollections of Sophia Lonsdale. Murray, 1936. 
87. "Dictaors.": 1 p., numbered 54 by VW. Typed notes, beginning, "Sir E.F. Fletcher urged the House of Commons to 'stand up to dictators' reported in D.H. Aug. 1st 1936 'My husband insists that I call him "Sir", said a woman at the Bristol Police Court yesterday, when she applied for a maintenance order....'" The notes are on two articles that appeared in the Daily Herald, August 1, 1936. Another set of notes on these articles appears in LV, B.5.

"M.P.s' Parting Advice to Ministers-'Stop Yielding to Dictators'" and "Made Wife Call Him 'Sir'." Daily Herald, August 1, 1936, pp. 4, 9.

88. "Disinterestedness.": 1 p., numbered 54 by VW. Typed quotation, annotated "Macaulay. Hist. vol. 3. 278," beginning, "Mary's conduct was really a signal instance of that perfect disinterestednes ...." This quotation also appears as LV, B.6.

Macaulay, Thomas Babington. History of England. Vol. III. Longmans, Green, 1898. Vol. III of The Works of Lord Macaulay. Albany Edition.

89. "Porfessional writing": 1 p., numbered 54 by VW. Typed quotation, annotated "The lost Historian A Memoir of Sir Sidney Low. Desmond/Chapman-Huston. 198 1936," beginning, "On another day at this time he wrote a one thousand six hundred word article on Nietzsche, ..." This quotation also appears as LV, B.7.

Chapman-Huston, Major Desmond. The Lost Historian. A Memoir of Sir Sidney Low. Murray, 1936.

90. "Note on Cambridge": 1 p., numbered 54 by VW. Typed notes, reading, "Endowments of the University of Cambridge by JW Clark. Gunnings Rems. of the Uni. Town and County of C. 1854 Trinity and John the rich coleges." The references in these notes are to a) J. W. Clarke, ed., Endowments of the University of Cambridge (Cambridge: Cambridge Univ. Press, 1904); and b) Henry Gunning, Reminiscences of the University, Town and County of Cambridge, 2 vols. (Bell, 1855). Another entry listing these works appears as LV, B.12; notes on Gunning appear in XLV, B.16.

91. "St. Pauls. Sunday 21st March 1937": 2 pp., numbered 55-56 by VW. Typed. The entry consists of a description of the service and the sermon at St. Paul's Cathedral, Palm Sun- 
day, 1937. A program of the service is found in LX, B.11. The notes begin, "i0 30. Dean and family arrive. sit on to,b in robes. like surgeons, carrying leather cases. choir comes in. the procession half military; ...." The entry also includes the note, "Suddenly the men in the choir-much like Austen Chamberlain all turn their backs like a squad of soldiers."

92. "St Paul to the Corinthians.": 1 p., numbered 56 by VW. Typed quotations on women's need to keep their heads covered in church and on women's silence in church.

1 Cor. 11:4-15 and 14:34-35.

93. "St Paul to Titus.": 1 p., numbered 56 by VW. Typed quotation on the duties of "aged" and "young women."

Titus 2:3-5.

94. "Gibbon on Oxford.": 1 p., numbered 57 by VW. Typed quotations, beginning, "The schools of Oxford and Cambridge were founded in a dark age of false and barbarous science;" and "the fellows of Magdalen.. Their conversation stagnated in a round of college business, Tory politics, personal anecdotes, and private scandal." Edition unidentified. Another set of notes about Oxford from this work appears in LVIII, B.55.

Gibbon, Edward. Memoirs of my Life and Writings. [1796].

95. "Pusey at Oxford.": 1 p., numbered 57 by VW. Typed notes, annotated "i31" and "i822 Oxford Apostles. Georffrey/ Faber. 69."

Faber, Geoffrey C. Oxford Apostles. A Character Study of the Oxford Movement. Faber \& Faber, 1933.

96. " $209 / \mathrm{I}$ doubt whteher at any time during the past/fifty years young women have been more politically/apathetic, more socially indifferent than at the/present time.": 2 pp., numbered $58-59$ by VW. Typed quotations and notes, annotated on p. 59 "The Testament of Joad. 1937."

Joad, C.E.M. The Testament of Joad. Faber \& Faber, 1937. 


\section{Monk's House Papers/B.16f. Vol. 3. (Sussex)}

This notebook, the third of the " 3 bound volumes containing Press Cuttings \& extracts collected or copied by VW relative to $3 \mathrm{Gs"}$ (MHP Catalogue), begins with an entry dated by Woolf "June 11th 1937," and ends with a newspaper cutting from December 20, 1937. Although the entries in this volume range from February 6, 1933, to December 20, 1937, the largest portion date from mid-1937 to the end of the year. By that time, the first draft of Three Guineas was done, and Woolf was working on the notes. An entry in her diary for October 12, 1937, records the intensity of this moment: "This is the first morning I write, because at 12 , ten minutes ago, I wrote what I think is the last page of Three Guineas. Oh how violently I have been galloping through these mornings! It has pressed and spurted out of me. . . I I must now add the bibliography and notes" ( $A W D$ ). By January 9, 1938, she had "'finished' the last chapter of Three Guineas" ( $A W D)$, presumably the revisions; and by February 4, 1938, Leonard had read the work.

There are at present almost no specific published references to the entries in this volume, in part because the majority of the entries are newspaper cuttings and not extracts from books. One exception is the quotation from George Sand's autobiography (B.20), a work that Woolf read with great pleasure in June 1937; by June 27, she was in the fifth volume $(L, V I, 3256,3261,3265)$. An entry in her diary for April 13, 1935, however, when she was thinking about On Being Despised, mentions "the horror of the legal profession: its immense wealth: its conventions: a Royal Commission now sitting: its hideous hoariness and so on: worth going into one of these days: and the medical profession and the osteopaths-worth a fling of laughter" $(A W D)$. Entry B.46, below, shows her recording this interest: "Letters on Hospital/and doctors N.S. Ap il i3th 1935/Comission on Kimgs Bench/Osteopaths. April 1935." The first part of this entry is a reference to a series of Letters to the Editor, headed "Voluntary Hospitals," which appeared in the New Statesman \& Nation, April 13, 1935; the journal had already printed several articles about hospitals. Similarly, a letter to Philippa Strachey on July 13, 1937, records Woolf's reactions to Pippa's letter in the Spectator about unequal pensions for men and women (B.26, 36; L, VI, 3273).

One other entry, B.54, a cutting of an article about Woolf, deserves note. This profile is signed "J.B." almost certainly the "J.B.," also called "John Bug," who is the target of her verses, "Fantasy upon a Gentleman who Converted his Impressions of a Private House into 
Cash." (See Quentin Bell, Virginia Woolf: A Biography, II, Appendix $\mathrm{B}$, for these verses, as well as for a diary entry, dated March 28, 1937, describing the reporter's visit to Monk's House.) In the Index, A.2, this entry is listed as " $37 .$. Beever on me."

Most of the material in this notebook does not appear elsewhere; where cross-references to other volumes exist, they are listed in the description of the individual entry. Other notes for Three Guineas are found in Volumes VII, X, XXVI, XXXIII, XXXIX, and LV-LVIX.

As in volumes 1 and 2 of the " 3 bound volumes" (LVIII and LIX), a label pasted on the front cover of the notebook contains a short list of entries in black ink (A.1); a more extensive index, typed and handwritten, with several entries circled or underlined, appears inside the notebook (A.2). The shifting margin of the larger index, as well as the fact that the four written entries are interspersed (in sets of two) among the typed entries, suggests that Woolf may have made this index, at least the latter part, at different times as she added more material to the notebook. (The index is reproduced here in the exact format of the original.) The list on the cover was almost certainly made when the notebook was complete. All of the cuttings are pasted onto the pages of the notebook, as are most of the extracts. Entries B.73-77 are written on lined pages torn from a spiral notepad with the perforations at the top; these pages are identical to those in Volume XXXIII. Some of the extracts, B.1-5, B.81, are typed directly onto the larger pages of the notebook. All the page numbers are in blue pencil, with the exception of that for B.81, which is in red ink. When Woolf has supplied the source and/or date for a cutting, this information is preceded by "annotated"; otherwise, the documentation for a cutting is that provided in the cutting itself. All quotations that are not labelled "Heading only" continue in Woolf's entry.

\section{A. TABle of Contents}

1. Maternal death rate ..... 3

Ly Baldwin \& child birth ... $\quad 6$

Almeria ... 9-10

Gruggers on W [women] ..... 11

George Sand ...... 11

death in child birth --_---- 11

Income of Labour Party ---_--- 12

Middlesex Hospital _-_-_-_--- 13

Miss Clarke on no cups _------ 19

Culture desinteressee --_----- 24 
$\mathrm{M}^{\text {rs }}$ Drummond on suffrage $\quad---\quad 39$

Jex Blake --_-_-_-_-_---- 41-2

no recruiting for $w$ -

public \& reviewers -_-_-_-_--- 46

Natural \& Eternal Law _-_----- 47

ordaining women --_-_----- 48

school girls \& Church -------- 49

Peepholes at Trinity --------- 52

Broadbent --_-_-_-_-_---- 52

Miss Cornwallis a pariah _-_---- 54

Charles Kingsley _-_-_-_----- 62

GBS \& feathers 60

Antigone --

Madrid 20

$1 \mathrm{p}$. , on cover.

2. 1... Times on virtues of Tattoo

1... Womes dislike of same dress

1 ... Oxford clinging to revenues.

1... College amenities

2... Thackeray On being Found out.

3. . . Maternity death rate. amenities for nurses

3... The lie detector

3... Blue uniform for soldiers

4. . . Postemen want smarter clothes.

4. .. Do wo en want babies to be soldiers? Birth cont.

5. .. Service at St Pauls.

6. .. Number of careers; arctic inspector.

6. . . Lady Baldwin and pain of childbirth. Anatg analgesics almost unknown in 1929

7. .. Mr B's last speech

8. . . Lady Simons snub.

8. . Pratt wont be $\mathrm{x}$ tested driving by women.

9. .. Almeria Havoc.

10. . . ditto

11... W's love of economic dependence

11... Magdalen fellows attitude to $w$. in college

11. . . George Sand on Community

11... Deaths in Childbirth 1937

12... Income of the Socialist party

12. . Three womens church colleges closed for lack of funds 
13. . Middlesex hospital; refuses legacy to found w. scholars

13. . . Oysters, taste of women growing for.

14. . Pippa on conspiracy of silence. Pensions bill.

$15 .$. death rate of men and women. metabolism.

16. . . Task of Churches.

17. . vicar resigns because the congre; wont turn to the east

17 . . why wom. wont have children. War.

18... perfumers on woms. nail varnishing.

19. .. Outsiders ex s. Miss Clarke on no cups.

20... The martyrdom of Madrid

21... Cleaning five miles of floor. Avergae working w

22 Poor porspects for women vets

23. . . Pensions bill. Pippas circular

24. . . Seule la culture desinterress

24. . . Internat. Peace campaign leaflet

25. . . Newnhams ball. Sept. 1937. Funds for coll.

26. .. Ws cricket. No games against men.

26. . . Labour party on arms. Dalton. Oct. 1937

27. . W. MPs have missed their chance. March 1936

28 . . . Soviet $w$. beat men as air pilots

29 ... the six point group

30. . G. women in prison as hostages for husbands

31... Medical profs. Letters in NS

31. . Mrs Booth on women; Rita on women and chivalry

32. . . Religion. the great blooshedd r. White devil

35 Arch. Davidson \& the Play

147

33. . . Preserving relics. Lenins body.

34. . . Work of the Nat. Council for Eqaul Citi

36. . . Comment on Antony. Educating Arthur

37. . Beever on me.

38. Aatred of w. 1935 lectures by men.

39 Mrs Drummond on Suffragettes

40 ditto

41... Sophia Jex Blake and her father

42. . ditto

43. . Call for more Women MPs. A womans party. 19

43. . no recruting for any womens corps Oct 1937

44. . . More Army recruits. Oct. 1937

45. . . W. drs. demand for more schools.

46. The public \& reviewers. Jerrold. 
47 new uniforms for soldeirs

47. . . the Natural and Eternal Law in Germany

48. . . marriage of clergy

48. . . case for ordaining women

49. . . Bishops on modern books

49. . . Churches crying out for full service.school girls dissatisfied with Church

50... Womens Service Soci. Aims.

51... Writers Soc. for Culture to attack anti culture

52. . . Peepholes at Trinity

52 . . . Boradbent on doctors

53. . Inge on progrss. Where to? The no.of things a person can do a criterion of civilisation

54. . . Miss Cornwallis calls herself a pariah and laughs at men who give honours

54. . . Aims of Cheltenham

56. .. true prophets are obscure men.Maine.

56. . . Miss Martineau glad to lose her gentility and work

57. . . The wifes position in England discussed at L. of Nations. claim that home making should be paid

58. . time it took to get vote and guardian. of chil.

59... Picture of Dons eating.

60... GBS on white faether and w's pugnaicyt

61... The Lord mayors show and judges dress.

62. . . Charles Kingsley on slum teaching: \& Queens Coll.

62... The Antigone.

63. . . Mayoress darning socks

64. . . Cambridge scholarshio lists

65. . . do. . do.

2 pp., not numbered. Typed and handwritten.

\section{B. ENTRIES}

1. "Times on Tattoo/June 11th 1937": 1 p., numbered 1 by VW. Typed quotation, beginning, "The ideal of the Armty is not War, $\mathbf{x x x}$ nor are wars made by so diers-at any rate by ritish soldiers," and concluding, "... and it is of these things, the ultimate nobilities of human valour defying the powers of darkness, that the Tattoo, in masque and symbol, makes its demonstration." The notes are from an editorial about the Aldershot Tattoo. 
"King's Champions." Editorial. The Times, June 11, 1937, p. 17.

2. "Womens dress at ascot. Vaxhell.": 1 p., numbered 1 by VW. Typed quotations, annotated "H.A. Vachell. Distant Fields, 187," and "do 186-7 1937."

Vachell, Horace Annesley. Distant Fields. A Writer's Autobiography. Cassell, 1937.

3. "State of Oxford inardly. Herbert warren": 1 p., numbered 1 by VW. Typed notes, annotated "H.W. of Magdalen. Laurie Magnus./p. 47," "48 do," and "Herbert Warren of Magdalen. by Laurie Magnus."

Magnus, Laurie. Herbert Warren of Magdelen, President and Friend 1853-1930. Murray, 1932.

4. "College amenities": 2 pp., numbered 1-2 by VW. Typed notes, annotated "True Thomas by Thomas Wood. i59."

Wood, Thomas. True Thomas. Cape, 1936.

5. "On being Found out": 1 p., numbered 2 by VW. Typed quotation, annotated "Thackeray, Roundabout Papers," reading, "What a wonderful and beautiful provision o nature it has been that, for the most part, our woma[n] kind are not endowed with the faculty of finding us out! They dont doubt, and probe, and weigh, and take your measure...."

Thackeray, William Makepeace. "On Being Found Out." In Roundabout Papers. [1862].

6. "MATERNITY DEATH RATE/LORD HORDER'S APPEAL": 1 p., numbered 3 by VW. Newspaper cutting, annotated "DT [Daily Telegraph] June 10 th/1937," about Lord Horder's call at the Cardiff Royal Infirmary for "a new maternity department. The mortality among expectant mothers, he said, remained too high."

7. "THE 'LIE-DETECTOR' IN ACTION/TEST ON CONDEMNED MAN": 1 p., numbered 3 by VW. Newspaper cutting, annotated "March $3^{\text {rd }}$ 1937/Times," beginning, "Joseph Rappaport, who lay under the sentence of death in Chicago, yesterday pinned his last hope of life on his ability to defeat the 'lie-detector' 14 hours before the time set for his execution. He failed and was executed early today."

8. "Anti-Aircraft Division and of the expan-/sion of the 1st AntiAircraft Division.": 1 p., numbered 3 by VW. Newspaper 
cutting, March 17, 1937. The entry consists of a fragment of an article describing a speech by Mr. Duff Cooper, the Minister of War, about Britain's defences. Included in this fragment is a section headed "REGULAR ARMY/Better Conditions"; these conditions include "a more attractive uniform."

9. "POSTMEN WANT TO BE SMARTER/UNION'S DEMAND TO POSTMASTER-GENERAL/IMPROVEMENTS IN CUT SUGGESTED": 1 p., numbered 4 by VW. Newspaper cutting, annotated "Feb/27th 1937 ," beginning, "Smartly-cut uniforms for the postal workers are being demanded by the Union of Postal Workers."

10. "WOMEN DIVIDED ON 'MORE BABIES' CAMPAIGN/ 'CANNON FODDER FOR NEXT WAR'/FAMILY ALLOWANCE PROPOSAL": 1 p., numbered 4 by VW. Newspaper cutting, annotated "DT. [Daily Telegraph]/Friday March $/ 5^{\text {th }} 1937$," beginning, "Vigorous arguments for and against a campaign to increase the birth rate were put forward yesterday by women delegates at the annual meeting of the National Council for Equal Citizenship at Millicent Fawcett Hall, Westminster." The article also reports that "The resolution to check the declining population passed."

11. "ST. PAUL'S CATHEDRAL./SUNDAY NEXT BEFORE EASTER. 21st MARCH, 1937./PALM SUNDAY.": 1 p., numbered 5 by VW. The entry consists of the printed program for the church service. For Woolf's description of this service, see LIX, B.91.

12. "WOMAN INSPECTOR IN THE ARCTIC": 1 p., numbered 6 by VW. Newspaper cutting, annotated "N[ . . . ]./March/ $9^{\text {th }} 1937$," about the posts available for women through the Women's Employment Federation, organizing secretary Mrs. Oliver Strachey.

13. "LADY BALDWIN": 1 p., numbered 6 by VW. Newspaper cutting, The Times. Letter to the Editor, signed "C.S. WENTWORTH STANLEY,/Chairman House Committee./ The City of London Maternity Hospital . . . ," about Lady Baldwin's achievement in introducing "analgesics (pain deadeners) for normal maternity cases in the wards." The article also includes the information that "there are some 700,000 births in the United Kingdom annually." At the 
bottom of the page, Woolf has written, " 700,000 births./4 die in every $1000 / 700 / 4 / 2,800$ die yearly." For the source of her figure "4 die in every 1000," see below, B.21.

14. "MR. BALDWIN'S LAST SPEECH AS PRIME MINISTER/ Great Ovation at Empire Dinner/COMMONWEALTH LEAD TO WORLD/'Britain Never Guided by Logic'": 1 p., numbered 7 by VW. Newspaper cutting, Daily Telegraph, May 25, 1937.

15. "Militarist Education Minister": 1 p., numbered 8 by VW. Newspaper cutting, beginning, "I see that Lady Simon, the wife of Sir Ernest Simon, detects a fell purpose in the appointment of Lord Stanhope to be President of the Board of Education. She points out that Lord Stanhope has filled four minor Ministerial posts connected with the fighting services."

16. "MOTOR LEARNER DRIVERS/MEN AND WOMEN TESTERS": 1 p., numbered 8 by VW. Newspaper cutting, annotated "June $3^{\text {rd }}$ 1937/Times," reporting a debate in Parliament, including much laughter, about whether male or female learner drivers "should be given the option of male or female testers."

17. "FIRST FULL ACCOUNT OF ALMERIA HAVOC $/ 8,000$ RENDERED HOMELESS BY GERMAN BOMBARDMENT/ $\$ 200,000$ DAMAGE: BRITISH CONSUL'S FLAT DESTROYED": 2 pp., numbered 9-10 by VW. Newspaper cutting, Daily Telegraph, June 5, 1937.

18. "Womens love of economic dependence": 1 p., numbered 11 by VW. Typed quotation, annotated "probably by Orage in the New Age. Chesterton. p.xxx/vii. A.R. Orage. Philip Mairet. Dent/Aug. 1936," beginning, "We have never known a man who was not, openly or secretly, proud of being able to support women; ..." The quotation is found in Chesterton's "Introduction" to Mairet's biography of Orage.

Chesterton, G. K. "Introduction." In Philip Mairet. A. $R$. Orage. A Memoir. Dent, 1936.

19. "The Fellows attitude to Oxford and women": 1 p., numbered 11 by VW. Typed notes, annotated "Times obituary of H.W. Greene. Feb. 6th 1933," beginning, " 'He marked his disapproval of the admission of women to the Univer- 
sity by refusing to enter his beloved Collges or City, until 1926." "Greene was "familiarly called Grugger."

"Mr. H. W. Greene: Revision of Liddell and Scott." Obituary. The Times, February 6, 1933, p. 14.

20. "George Sand on Community/vol.2 240 Memoires de ma Vie": 1 p., numbered 11 by VW. Typed quotation, beginning, "Toutes les existences sont solidaires les unes des autres, ..." This quotation also appears as XXVI, B.14.

Sand, George. Histoire de ma Vie. Vol. II [of X]. Paris: Michel Levy, 1856.

21. "Deaths in Childbirth": 1 p., numbered 11 by VW. Typed note, reading, "The fact that $\mathrm{xx} 4$ mothers still die for every one thousand children Spectator June 5th 1937." The date for the article is actually June 4, 1937. This entry also appears in XXVI, B.15.

"Maternal Mortality." Spectator, June 4, 1937, p. 1039.

22. "PARTY FINANCES/£30,000 IN SALARIES": 1 p., numbered 12 by VW. Newspaper cutting, annotated "Sept/1937," "DT [Daily Telegraph]," beginning, "More than $£ 30,000$ out of an income of $£ 50,153$ received by the Socialist party in 1936 was expended in officials' salaries."

23. "THREE CHURCH COLLEGES TO CLOSE/WOMEN TEACHERS' TRAINING": 1 p., numbered 12 by VW. Newspaper cutting, beginning, "Three of the 17 Church of England training colleges for women teachers in this country are to be closed owing to financial difficulties."

24. "MIDDLESEX HOSPITAL SCHOOL/A CENTENARY VOLUME/THE STORY OF THE MIDDLESEX HOSPITAL MEDICAL SCHOOL./By H. CAMPBELL THOMSON. (Murray. 10s. 6d.)": 1 p., numbered 13 by VW. Newspaper cutting, annotated "Times/17th Aug. 1935." The entry consists of a fragment of an article that includes the statement, "This exclusion of women [the barring of women midwives] has remained the traditional attitude." The article also describes the hospital's refusal to allow "Miss Garrett, afterwards Dr. Garrett Anderson," to study there.

25. " A MONTH WITH AN ' $R$ ' IN IT/GROWING POPULARITY OF OYSTERS WITH WOMEN": 1 p., numbered 13 by VW. Newspaper cutting, annotated "Sept $1^{\text {st }} 1937$," which in- 
cludes the statement, "It was stated in London yesterday that in the last few years women had developed a great taste for oysters, largely because of their slimming properties."

26. "A CONSPIRACY OF SILENCE": 1 p., numbered 14 by VW. Cutting, Spectator, annotated "July $9^{\text {th }} 1937 . "$ Letter to the Editor, signed "P. Strachey," beginning, "Many hundreds of thousands of men and women have been participating in an endeavour to induce the Government to abandon the provision in the new Contributory Pensions Bill for the black-coated workers which for the first time introduces a differential income limit for men and women entrants." For another comment on this bill, see below, B.36.

27. "THE SEX RATIO/ECONOMIC IMPORTANCE OF CONTROL": 1 p., numbered 15 by VW. Newspaper cutting, annotated "Sept. $3^{\text {rd }} 1937$," reporting "the presidential address to the Zoology Section" by Professor F.A.E. Crew.

28. "Conferences/A WAY OF LIFE/TASK BEFORE THE CHURCHES/SEEKING UNITY AT OXFORD": 1 p., numbered 16 by VW. Newspaper cutting on "The first of the plenary sessions of the Conference of the Universal Christian Council on Church, Community, and State, held in the Oxford Town Hall ... ," and its "ecumenical nature." "Here," the article continues, "they [the delegates] all profess and stand for a Christian unity in and against the modern world of the warring nations and races."

29. "VICAR TO RESIGN/LIVING WITH MODERN AMENITIES WANTED": 1 p., numbered 17 by VW. Newspaper cutting, about the resignation of the Rev. W. Hope Gill, Vicar of Loudwater and Flackwell Heath, Bucks: "His two chief reasons are that no support has been given to the scheme of employing a whole-time woman worker and an assistant curate, and also difficult domestic circumstances in running the large vicarage."

30. "Sir-I can tell Mr. Harry Campbell why/women refuse to have children in these/times.": 1 p., numbered 17 by VW. Newspaper cutting, annotated "DT [Daily Telegraph]. Sept $6^{\text {th }}$ 1937." Letter to the Editor, signed "EDITH MATURIN-PORCH," about why women are refusing to have children. 
31. "PAINTED FINGER-NAILS": 1 p., numbered 18 by VW. Newspaper cutting, annotated "Times/Aug 5 1937." Letters to the Editor, signed "R. HASLAM JACKSON, Editor, Perfumery and Toiletry," and "J. WHEELER WILLIAMS," about the pros and cons of nail varnish.

32. "Times. Sept $24^{\text {th }} 1937 . ": 1$ p., numbered 19 by VW. The entry consists of notes and a quotation from an article reporting the address made by Miss E. R. Clarke, of the Board of Education, on "The Development of the Movement to Improve the Physical Fitness of the Nation." The notes record Miss Clarke's statement that the lack of cups or awards for womens' sports teams has not been a deterrent, "for each year the numbers of players steadily continued to increase."

"Happiness from Good Health." The Times, September 24, 1937, p. 14.

33. "THE MARTYRDOM OF MADRID./inedited witnesses by Louis Delaprée/MADRID/1937": 1 p., numbered 20 by VW. Printed pamphlet, 47 pp. Louis Delaprée was a French journalist in Madrid.

34. "CLEANING 5 MILES OF FLOOR/THE AVERAGE WIFE'S ANNUAL WORK/WOMAN'S HINTS TO SALESMEN": 1 p., numbered 21 by VW. Newspaper cutting, September 29, 1937, reporting a speech by Mrs. Eileen Murphy, Home Service Director of the British Commercial Gas Association, at the Association's Conference. Among other things, "Mrs. Murphy advised salesmen to remember that all women were not alike."

35. "POOR PROSPECTS FOR WOMEN 'VETS'/LIMIT ON TRAINEES": 1 p., numbered 22 by VW. Newspaper cutting, annotated "DT [Daily Telegraph]," "1 1 st Oct. 1937," about the opening of The Royal Veterinary College on November 9. The article includes the statement, "An official of the college told a representative of THE DAILY TELEGRAPH AND MORNING POST yesterday that the reason for the limitation [of women to 50] was that the prospects of women students after they had qualified were not good."

36. "London \& National Society for Women's Service": 1 p., numbered 23 by VW. Printed circular, signed "P. STRA- 
CHEY, Secretary," and dated "19th June, 1937." The circular asks the members of the society and its friends to write to the Minister of Health to oppose "the differential income-limit proposed for men and women under the Bill" - the "Widows', Orphans' and Old Age Contributary Pensions (Voluntary Contributors) Bill, 1937." For another comment on this bill, see above, B.26.

37. "Seule la culture désintéressée peut garder le Monde de sa ruine": 1 p., numbered 24 by VW. (Headline only.) Newspaper cutting.

38. "INTERNATIONAL PEACE CAMPAIGN": 1 p., numbered 24 by VW. Printed pamphlet, 4 pp., describing the International Peace Campaign and asking for a contribution.

39. "The attainment of the $\mathfrak{5} 50,000$ mark was announced by the/ Hon. Treasurer in a letter to The Times on 14 July.": 1 p., numbered 25 by VW. Printed pamphlet, 4 pp., addressed on the second page "TO ALL NEWNHAM STUDENTS PAST AND PRESENT," and dated "October 1937." The pamphlet is a report on the Building Fund Appeal; it is pasted in with the last page on top.

40. "WOMEN'S CRICKET 'HERE TO STAY'/NO GAMES AGAINST MEN": 1 p., numbered 26 by VW. Newspaper cutting, annotated "Oct $6^{\text {th }}$. 37," "DT [Daily Telegraph]." The article is a report of a speech by "Miss M.E. Hide, captain of the English Women's Cricket Team ... at a luncheon given in London by the British Sportsmen's Club."

41. "CHAIRMAN'S ADDRESS/'OUR COUNTRY MUST BE POWERFULLY ARMED'": 1 p., numbered 26 by VW. Newspaper cutting, October 5, 1937, annotated "LP Ann. Con. [Labour Party Annual Conference] at Bournemouth," beginning, "Mr. Hugh Dalton, M.P., in his address as chairman, said that in the grim situation, not of the Labour party's making, with which they were confronted our country must be powerfully armed." The cutting is in two parts.

42. "Women M.P.s have missed their Chance/says ROBERT BERNAYS, M.P.": 1 p., numbered 27 by VW. Newspaper cutting, Evening Standard, March 20, 1936, p. 7, beginning, "I have never seen more glaringly illustrated the failure of women in the House of Commons than in the series of 
momentous debates which were included this week on the problems of peace and national defence."

43. "SOVIET WOMEN BEAT MEN AS AIR PILOTS/NOT AFFECTED BY GREAT HEIGHT/'SPECIALLY SUITED FOR FIGHTING" ": 1 p., numbered 28 by VW. Newspaper cutting, Daily Telegraph, annotated "Aug/14/1935," and datelined "Moscow."

44. "GERMAN GIRL'S 1,900 MILES' FLIGHT/TURKEY \& BACK IN A DAY": 1 p., numbered 28 by VW. Newspaper article, which appears in the same cutting as B.43 above. The cutting is from the Daily Telegraph, annotated "Aug/ 14/1935."

45. "THE SIX POINT GROUP": 2 pp., numbered 29-30 by VW. Typed letter to "Virginia Woolf," signed "Monica [Whately]," describing the plight of women in Germany, especially in the German prisons, and asking Woolf to "take part in a Deputation of prominent women to the German Ambassador" in an attempt to save these women. The letter is dated "7th June, 1935."

46. "Letters on Hospital/and doctors N.S. Ap il i3th 1935/Commission on Kimgs Bench/Osteopaths. April 1935": 1 p., numbered 31 by VW. (Heading only.) Typed. The first part of the entry is a reference to a series of Letters to the Editor, headed "Voluntary Hospitals," in the New Statesman \& Nation, April 13, 1935, pp. 518-519. The last part of the entry may refer to the bill before a Select Committee about osteopaths that was withdrawn by its promoters at the end of April 1935.

47. "She held that intellectually woman was man's equal/and that where it was not so, the inferiority was due/ro [to] disadvantages of training, a lack of opportunity,/rather than to any shortcomings of nature. p.83 v.L": 1 p., numbered 31 by VW. Typed notes, annotated "Gods Soldier Life of Gen. Booth. St John Ervine." The "she" in this passage is Catherine Mumford Booth; the quotation appears on p. 123.

Ervine, St. John. God's Soldier: General William Booth. Vol. I [of II]. Heinemann, 1934. 
48. "Neither respect nor admiration now signalise her/attitude.":

$1 \mathrm{p}$., numbered 31 by VW. Typed notes, annotated "Rems. of a Lit Life. Rita. Mrs/Desmond Humphreys. 258."

Rita [Mrs. Desmond Humphreys]. Recollections of a Literary Life. Arnold Melrose, 1936.

49. "Religion; oh how it is/commeddled with/policy. The first/ bloodshed in the/world happened/about religion./The White Devil/147.": 1 p., numbered 32 by VW. (Heading only.) The entry is a quotation from the play, spoken by Flamineo, III.iii.37-39. The next line reads, "Would I were a Jew."

Webster, John. The White Devil.

50. "PRESERVERS OF LENIN'S BODY/PERMANENT TASK OF TWO SCIENTISTS/METHODS A SECRET": $1 \mathrm{p}$., numbered 33 by VW. Newspaper cutting, beginning, "Yesterday - the tenth anniversay of Lenin's death-Professors Vosobief and Zbarski were awarded the 'Order of Lenin' for their 'exceptional services in the cause of preserving Lenin's body." "

51. "NATIONAL COUNCIL FOR EQUAL CITIZENSHIP/116, Thames House, Millbank, S.W.1/WORK AND PROGRAMME": 1 p., numbered 34 by VW. Printed information sheet, dated "February, 1936," beginning, "The National Council for Equal Citizenship is a direct descendant of the National Union of Women's Suffrage Societies of which Dame Millicent Fawcett was president."

52. "The Archb shop was not a frequneter of the theatre.": 1 p., numbered 35 by VW. Typed quotations, annotated " 9 Miss Mary Mills./Life of A. Davidson 122-1213. vol 2 Randall Davidson. by G.K.A. Bell./Oxford Press 1935." The first part of the notation is a reference to Miss Mary Mills, who supplied the passage quoted by Bell, p. 1213, beginning, "It was an anxious experiment, but succeeded ...." The quotations in this entry are from pp. 1211-1213.

Bell, G.K.A. Randall Davidson, Archbishop of Canterbury. Vol. II [of II]. Oxford Univ. Press, 1935.

53. "ANTONY": 1 p., numbered 36 by VW. Cutting, New Statesman \& Nation. Letter to the Editor, signed "T. PHILIP TOYNBEE," beginning, "I found Mr. Cyril Connolly's review of the Earl of Lytton's book both interesting and mov- 
ing." The letter continues, "This product of the governing class and the Public School is more to be pitied than envied or despised. He is a person of tremendous possibilities, but the cards have been stacked against him from the start. . . Is there any solution for the contemporary Antony Knebworth without a revolution in the educational system of the country?" The book referred to is Antony (Viscount Knebworth). A Record of Youth, by his father, the Earl of Lytton (1935). Woolf's notes on this work appear in XXXIII, B.10 and B.18, and in LIX, B.11 and B.64.

54. "VIRGINIA WOOLF": 1 p., numbered 37 by VW. Newspaper cutting, signed "J.B." The article is a profile of Woolf, beginning, "Kindly and very gracious, but has been known to give you coffee one night and cut you dead in a Bloomsbury 'bus next morning-all because planning her next novel makes her as absent-minded as any professor." The "J.B." of this article, called "Beever" in A.2 above, may be the reporter who appears as "John Bug" in Woolf's poem, "Fantasy upon a Gentleman who Converted his Impressions of a Private House into Cash": Quentin Bell, Virginia Woolf: A Biography (1972): II, Appendix B.

55. "Are Women So Hateful?": 1 p., numbered 38 by VW. Cutting, annotated "1 $1^{\text {st }}$ Feb/1935/Every/man." The article, by "H. Pearl Adam," describes the "recent outbreaks against women" apparent in such books as Mr. Michael Arlen's Men Dislike Women and Mr. Michael Egan's The Dominant Sex, and asks if "it needs a war to bring the sexes into real comradeship?"

56. "'Votes for Women'/FLORA DRUMMOND tells how she 'Saw the Start' of the movement for Woman's Suffrage.": 2 pp., numbered $39-40$ by VW. Cutting, The Listener, August 25, 1937, pp. 405-407.

57. "Sophia Jex-Blake./by Margaret Todd.": 2 pp., numbered 4142 by VW. Typed. More notes on this work are found in VII, B.13, and XXVI, B.4.

Todd, Margaret. The Life of Sophia Jex-Blake. Macmillan, 1918.

58. "CALL FOR MORE WOMEN M.P.S/EDUCATING MEN LEGISLATORS/PIN MONEY FALLACY": 1 p., numbered 43 by VW. Newspaper cutting, annotated "DT [Daily 
Telegraph]. 23 $3^{\text {rd }}$ Oct/37," beginning, "A conference of the Women's Freedom League at Caxton Hall, Westminister, yesterday urged the need for more women in the House of Commons."

59. "THE WAR OFFICE AND WOMEN'S CORPS": 1 p., numbered 43 by VW. Newspaper cutting, annotated "Times./ 22 nd/Oct./37," beginning, "It was stated yesterday at the War Office that the Army Council have no intention of opening recruiting for any women's corps." The cutting also includes an article with the headline, "MORE ARMY RECRUITS."

60. "GIRL MEDI[ . . ]/DEMAND FOR MORE SCHOOLS/OPPOSITION TO THE MIXED CLASSES": 1 p., numbered 44 by VW. Newspaper cutting, annotated "E. [Evening] News/ $25^{\text {th }}$ March/1937," beginning, "Women doctors and their younger sisters, the girl medical students, are pressing more and more strongly for greater training facilities in London."

61. "Georgian Adbeture. Douglas jerrold. Collins 1937/p.283-298/ There are no critics in whom the public have any more/ confidence.": 1 p., numbered 46 by VW. Typed notes.

Jerrold, Douglas. Georgian Adventure. Collins, 1937.

62. "A DRAMATIC CRITIC FOR 40 YEARS/TRIBUTE TO MR. LITTLEWOOD": 1 p., numbered 46 by VW. Newspaper cutting, annotated "Dec/6th/1937/Times," describing the "complimentary dinner by members of The Critics' Circle to Mr. S.R. Littlewood, who until recently was dramatic critic of the Morning Post."

63. "NEW UNIFORMS FOR ARMY/SMARTER 'WALKING OUT' DRESS/EQUIPMENT TO BE LIGHTER": 1 p., numbered 47 by VW. Newspaper cutting, December 14, annotated "1937 DT [Daily Telegraph]," beginning, "Soldiers are to have smarter walking-out uniforms. The whole question of clothing and equipment is now being considered by a special War Office Committee. ... The authorities have come to the conclusion that smartness in dress and bearing, which are bound up with tradition, influence greatly the potential recruit."

64. "LIFE IN MODERN GERMANY/DR. WOERMANN ON THE STATE'S AIMS/STATUS OF WOMEN": 1 p., num- 
bered 47 by VW. Newspaper cutting, annotated " $16^{\text {th }}$ Dec 37./Times," beginning, "Dr. E. Woermann, Counsellor of the German Embassy, gave a lecture on present-day Germany at the Royal United Service Institution yesterday." Under the headline "DUTY TO FAMILY," the article reports Dr. Woermann as follows: "To believe that a woman's principal work was family life and bringing up the young generation was simply to return to natural and eternal law." "

65. "Letters to the Editor/MARRIAGE OF CLERGY/THE MEMORIAL AND THE APOSTLES": 1 p., numbered 48 by VW. Newspaper cutting, The Times, annotated " $16^{\text {th }}$ Dec." Letters to the Editor, signed "ATHELSTAN RILEY" and "ST. JOHN ERVINE," about whether the clergy should be celibate.

66. "THE CHURCH AS A FAMILY/CASE FOR ORDINATION OF WOMEN": 1 p., numbered 48 by VW. Newspaper cutting, beginning, "The decline of churchgoing among the rising generation was discussed on Saturday at a meeting organized by the Anglican Group for the ordination of women to the historic ministry of the Church ...." Another report of this meeting appears below, B.68.

67. "BISHOP AND MODERN BOOKS": 1 p., numbered 49 by VW. Newspaper cutting. Letter to the Editor, signed "MARJORIE BOWEN," in response to attacks on her books by Dr. Wilson and the Bishop of Chelmsford. One paragraph begins, "The subject is one of general interest. By what authority do the clergy attack the works of artists and authors?"

68. "WOMEN AS CLERGY/'CHURCHES CRYING OUT FOR FULL MINISTRY" ": 1 p. numbered 49 by VW. Newspaper cutting, annotated " $21^{\text {st }}$ Nov./37," "Sunday Times," beginning, "The Rev. Paul Gibson, Principal of Ridley Hall, Cambridge, said at a meeting in London yesterday that churches in many parts of the world were crying out for full ministry for women." The article is a report of the meeting of the Anglican Group for the Ordination of Women, which is also the subject of B.66.

69. "LONDON AND NATIONAL SOCIETY FOR WOMEN'S SERVICE.": 1 p., numbered 50 by VW. Printed informa- 
tion sheet, dated "April, 1935," and headed "WHAT IS THIS SOCIETY?" The entry is annotated "founded/1929."

70. "INTERNATIONAL ASSOCIATION OF WRITERS FOR THE DEFENCE OF CULTURE/Chairman: C. Day Lewis": 1 p., numbered 51 by VW. Printed circular, announcing a meeting of the Association at the University of London Club Conference Hall, Monday, November 1st [1936], "to discuss present and future activities," some of which are described.

71. "PEEPHOLES/A party at cambridge in 1907 ...": 1 p., numbered 52 by VW. Typed notes, annotated "From One Century to another. E. Haldane. p. 235." Another set of notes on this work appears in XXVI, B.9.

Haldane, Elizabeth S. From One Century to Another. Reminiscences. Maclehose, 1937.

72. "BROADBENT DOCTORS": 1 p., numbered 52 by VW. Typed quotation, annotated "The life of Sir William Broadbent/KCVO. FRS, edited by his daughter ME Broadbent, 1909 ," beginning, "I have taken a good deal over $£ 13,000$ during the year, but this cannot possibly be maintained, and while it lasts it is slavery." The quotation appears on p. 243 of the work. This quotation also appears in XXXIII, B.8.

[Broadbent, Sir William.] The Life of Sir William Broadbent.

Ed. by his Daughter, M. E. Broadbent. Murray, 1909.

73. "Times Nov. 23 rd 1937?/Dr Inge on price of Progress": 1 p., numbered 53 by VW. The notes are on a report of "The Rickman Godlee lecture at University College," delivered by Dr. W. R. Inge. Woolf has added the "1937?" in pencil; the rest of the entry is in ink.

"Dr. Inge on Price of Progress." The Times, November 23, 1937, p. 19.

74. "Beale./4/5 not always as reverent as they/appeared on the surface.": 1 p., numbered 54 by VW.

Raikes, Elizabeth. Dorothea Beale of Cheltenham. Archibald \& Constable, 1908.

75. "The Best of Me. Basil/Maine. 77.": 1 p., numbered 56 by VW. Quotation, annotated "1937," reading, "The true prophets of our time (save that this is too grand-sounding a description) are obscure men, passionate yet patient men of vision." 
Maine, Basil. The Best of Me. A Study in Autobiography. Hutchinson, 1937.

76. "Martineau. Davies./6. We had lost our gentility/glad because she cd work.": 1 p., numbered 56 by VW. (Heading only.) The reference is to a passage in Harriet Martineau's Autobiography, Vol. I, where she describes her family's financial ruin and the freedom it brought her. The passage is quoted by Barbara Stephen in Emily Davies and Girton College, p. 6, n.2. Woolf had reviewed this book in 1927 ("Two Women"; Kp. C282).

Stephen, Barbara. Emily Davies and Girton College. Constable, 1927.

77. "Linda P. Littlejohn. . /Listener. 10th Nov. 1937.": 2 pp., numbered $57-58$ by VW. The entry consists of notes on a report of a talk given by Linda P. Littlejohn on the BBC, October 7, 1937, during which she argued that the status of homemaker should be raised legally to that of a profession. The notes begin, "We have had W. Civil \& Pol Status [Women's Civil and Political Status] before the League only since 1935 ...," and conclude, on p. 58, "It took 60 years to give women the vote. 100 to give w. equal guardianship of their children."

78. "The OXFORD APPEAL COMMITTEE": 1 p., numbered 59 by VW. Newspaper cutting, with photographs. The caption under the photos begins, "Following Lord Nuffield's first gift $-£ 2,000,000$ for medical research-Oxford, needing extensions in other departments, had decided to issue a public appeal for money."

79. "As I See It/By BERNARD SHAW/Broadcast to the Empire on November 2": 1 p., numbered 60 by VW. Cutting, The Listener, November 10, 1937, pp. 997-998. The article begins, "What about this danger of war which is making us all shake in our shoes at present?"

80. "THE LORD MAYOR'S SHOW/CITY PAGEANTRY IN SUNSHINE/TABLEAUX OF EMPIRE": 1 p., numbered 61 by VW. Newspaper cutting, The Times, annotated "Nov. $10^{\text {th }} 1937 . "$

81. "Kingsley on ds work in slums": 1 p., numbered 62 by VW. Typed quotation, annotated "Charles Kingsley, 1819-1875 by Margaret Ferrand/Thorp, Princeton Univ. Press. 1937 p. 
12." The quotation begins, ".. and the girls have their $\mathbf{x x x}$ heads carmmed full of schools, and district visiting, and babay linen, and penny clubs. Confound!!!” More notes on this work appear below, B.83.

Thorp, Margaret Ferrand. Charles Kingsley 1819-1875. Princeton: Princeton Univ. Press, 1937.

82. "Antigone.": 1 p., numbered 62 by VW. Typed notes.

Sophocles. The Antigone. With Critical Notes, Commentary, and Translation in English Prose by R. C. Jebb. Cambridge: Cambridge Univ. Press, 1881. Vol. III of The Plays and Fragments.

83. "Kingsley/65 . ... He did begin however on May 13th (1844)/ to lecture weekly at Queens College ...": 1 p., numbered

62 by VW. More notes on this work appear above, B.81.

Thorp, Margaret Ferrand. Charles Kingsley 1819-1875. Princeton: Princeton Univ. Press, 1937.

84. "Mayoress Would Not Darn Socks for War/SPEECH UPSETS ARSENAL EMPLOYEES": 1 p., numbered 63 by VW. Newspaper cutting, Evening Standard, December 20, 1937 , p. 13, beginning, "There is a mild storm in Woolwich because of remarks made by the new Mayoress of Woolwich, Mrs. Kathleen Rance," a member of the Peace Pledge Union, a pacifist organization.

85. "UNIVERSITY NEWS/OXFORD AND CAMBRIDGE SCHOLARSHIPS": 1 p., numbered 64 by VW. Newspaper cutting, on college elections, including Girton and Newnham.

86. "UNIVERSITY NEWS/SCHOLARSHIPS AND EXHIBITIONS/OXFORD AND CAMBRIDGE LISTS": 2 pp., numbered $64-65$ by VW. Newspaper cutting, The Times, December 20, 1937, on college elections.

\section{Monk's House Papers/B.17a. (Sussex)}

Roger Fry died on September 9, 1934. By November 21, Woolf had been asked to write his biography and had agreed to read his papers $(A W D)$; nine months later, on August 21, 1935, she recorded, "Margery Fry comes on Friday with her hands full of papers, 
she says. Another book" $(A W D)$. By September 18, she was "facing [her] 3 large boxes of Fry" ( $L, \mathrm{~V}, 3063)$; on October 4 , she had begun "to read a huge collection of Roger's letters" ( $L, \mathrm{~V}, 3066)$; and on October 15, 1935, she was reading "Roger between tea and dinner" $(A W D)$. Woolf continued to read and extract Fry's letters, books, and manuscripts from August 1935 until the time she finished Roger Fry: A Biography in March 1940.

Although this long preparation complicates the dating of her notes on Fry, there are some guidelines. This notebook, for example, contains an outline for the biography (B.4), headed "Possible Scheme of RF" and dated "Oct 1935," which begins, "1. Poppy/Memoir"; this entry corresponds to her comment on October 27, 1935, "Yesterday we walked across Ken Wood to Highgate and looked at the two little old Fry houses. That's where Roger was born and saw the poppy. I think of beginning with that scene. Yes, that book shapes itself" $(A W D)$. Another entry (B.6), also preliminary notes, is dated "Oct 1936." The notes on the report of the Archbishop's Commission on The Ministry of Women (B.8) belong to Woolf's reading for Three Guineas (1938), as do the notes on The Antigone that are listed in one of the tables of contents but not included among the entries themselves.

Woolf has three separate lists of the contents of this notebook, each one slightly different and each one containing material that does not in fact appear here, although it can be found elsewhere. Given the length of time that she worked on her biography, going back to her notes and adding more, this confusion is not surprising. As she herself noted on September 22, 1938, "my books are in a muddle. Yes, at this moment, there are packets of letters to V.B. 1910-1916packets of testimonials for the Oxford Slade-endless folders, each containing different letters, press cuttings and extracts from books" $(A W D)$. The notes on Fry's letters to Sir E. Fry (A.1) are in LXIV, B.1, and LXV, B.4; the actual notes on Rothenstein on Fry (A.3) are in LXII, B.3; and the notes on Fry's early articles (A.3) are in LXII, B.1. Nine blank pages occur between B.1 and B.2, as if Woolf intended to continue extracting from Trevelyan's letters here; instead, the other extracts are in LXIV, B.7. (For other entries on Fry, see Volumes XXVI, XXXIX, and LXII-LXVI.) Scattered notes on Fry, moreover, can also be found in manuscripts unrelated to the reading notes, particularly the early Between the Acts manuscripts in the Berg Collection. Fifteen pages for her biography, for example, including notes on Vision and Design, are mixed in with notes for Between the Acts dated "Aug. 23" [1939]. 
Two of the tables of contents are labels pasted on the cover of the notebook: A.1 on the spine and A.2 on the front. The lists are written in black ink, as are the entries. B.1 also includes pencil notes.

\section{A. Table of Contents}

1. R.F.

Bellini

W. Rothenstein

Letters to -

Sir E. Fry

1893

R's Books

Label, on spine of cover.

2. Roger.

The Antigene-

Rothenstein.

1 p., on cover.

3. Roger Fry

\section{Bellini.}

Sketch for life.

Rothenstein on Roger.

Early articles in Athenaeum \& Pilot

(1900 -

1 p., not numbered.

B. ENTRIES

1. "To Bob.": 5 pp., not numbered. The entry consists of extracts from Roger Fry's letters to Robert C. Trevelyan, dated 1895 ? to 1899. More notes on these letters appear in LXIV, B.7.

2. "Roger": 2 pp., numbered 1-2 by VW. The entry consists of an outline of Roger Fry's life.

3. "Bellini": 2 pp., not numbered.

Fry, Roger E. Giovanni Bellini. At the Sign of the Unicorn, 1899.

4. "Possible Scheme of RF.": 5 pp., not numbered. The entry is annotated "Oct 1935," and consists of a sketch or outline for her biography of Roger Fry. 
5. "Letters to V.B. 1924-5-6": 1 p., not numbered. The entry consists of general notes on Roger Fry's letters to Vanessa Bell. More notes on these letters appear in LXIV, B.17 and LXVI, B.2.

6. "Oct 1936/The method should be to find out what his/qualities were ...": 1 p., not numbered. 4 lines only, continuing, "\& proceed to illustrate them by events. to be very free with sequence of facts."

7. "Roth". Vol 1/76, 176, 208, 273,/325 ..": 1 p., not numbered. (Heading only.) The entry appears on the reverse of B.6 and consists of page numbers that correspond to references to Roger Fry in Sir William Rothenstein's Men and Memories: Recollections, Vol. I: 1872-1900 (1931). Woolf's notes on this work appear in LXII, B.2 and B.5.

8. "At present a married priest is able to/fulfill the requirements of the ordination/service ...": 2 pp., not numbered. Quotations, annotated "111. Practical Considerations./The Ministry of Women./Report of the Archs Commn/1935/p.32," and "vi." The second quotation begins, "We are of the opinion that the Church needs to be more fully alive than at present to the value of the varied contribution wh. women have to offer." More notes on this work appear as XXVI, B.3 and B.6.

The Archbishop's Commission. The Ministry of Women. The Church Assembly, 1935.

\section{Monk's House Papers/B.17b. (Sussex)}

A large portion of this notebook is devoted to Woolf's notes on Roger Fry's early articles in The Pilot and The Athenaeum, 19001906; these notes are the basis of Chapter V, "Work," in Roger Fry: A Biography (1940). One source of these articles was almost certainly the "endless folders, each containing different letters, press cuttings and extracts from books" ( $A W D$, September 22, 1938) that Woolf began to receive from Margery Fry during 1935 ( $A W D$, August 21, 1935; $L, \mathrm{~V}, 3085$ ) and continued to receive during the next few years. In August 1937, for example, she had "written to Margery to tell her to find more articles" ( $L$, VI, 3286). A year later, in August 
1938, she responded to Ben Nicolson's offer "to read and annotate Roger Fry's articles": "I have only a selection of them here, and I'm finding them so important at the point I've reached that I think I must keep them and anyhow read them myself" ( $L, V I, 3431$ ). Several collections of cuttings, including many of those Woolf noted below, are now among the Fry Papers at King's College, Cambridge; others are not. In making my identifications of the notes, I have relied upon Roger Fry: An Annotated Bibliography of the Published Writings (Garland Publishing, 1979), by Donald A. Laing, who based his identifications on the marked files of The Athenaeum, the signatures in The Pilot, and the marked cuttings among the Fry Papers at King's College.

Most of the notes on the early articles are very short-consisting of only a phrase or a few lines-although on occasion Woolf copied out longer passages. (Later, opposite a number of the entries, Woolf wrote an identifying word or phrase in red or blue pencil.) Often the entries run into each other, with no break except the end of a line; occasionally notes on the same article are divided by large spaces on the page or between two pages. I have given only the beginning of each entry, which consists of all of the material between it and the beginning of the next listed entry, however separate the notes may appear on the actual page. A typed index of the first part of Woolf's notes on the early articles appears in the front of the notebook (A.2). The indexed pages are numbered $1-10$ by Woolf in blue pencil. Pages 9-10 are typed; the rest of the notes are in black ink.

The remaining entries in this volume, with the exception of that on Jepson's autobiography (B.4), are associated in one way or another with the summer of 1938. On July 12, Woolf told William Rothenstein that she was about to reread the first volume of his memoirs (B.2, 5): "I remembered your account of meeting [Fry] in Paris" ( $L$, VI, 3417). Later that month she wrote to R. C. Trevelyan asking him for information about the years during which he had shared a house with Fry on Beaufort Street: "The letters then are mostly to his mother; and that means a great deal is left out" ( $L, V I$, 3420,3424 ; see B.3 for those letters).

All of the notes are in black ink, as is the index pasted on the spine of the notebook (A.1); twenty-eight blank leaves exist between B.3 and B.4. Other notes on Fry are found in Volumes XXVI, XXXIX, LXI, and LXIII-LXVI. 
A. TABle of Contents

1. Roger

$\begin{array}{ll}\text { Fry } & \\ \text { Other } & \text { Jepson } \\ \text { On } & \text { W.R. }\end{array}$

Early Arts

Extracts

Label, on spine of cover.

2. page Early Articles in Athenaeum and Pilot

i Sargeant precis writer; compared with Watts

i Japanese art

2 The Royal Academy; expertise

3 expertise; old masters; Verlaine and Maeterlinck

4 John. (1903)

4 Womens instinct

5 scientific argument about reflections

5 abuse of Poynter; of Boldini

6 John Collier; Rodin like poetry or music; Turner

7 Rafaellis stciks. The Old R As better. Abuse of Goodall

7 Hanging pictures badly; Max Beerbohm.

8 Wanted a dict aor at Nat Gall. Need of sympathy with extremes. Trustees of Nat. Gall. Committee compromise

9 Compromise in art. Rokeby Venus. English sketching

9 First sight of Cezanne. Jan i3 1906

9 Tempera society. What does the RA stand for?

10 A tax to buy pictures. John. Wit. Portraiture in England. Conders decline o5

1 p., not numbered. Typed.

B. Entries

1. "Early Articles.": 19 pp., the first 10 numbered $1-10$ by VW. This long entry consists of Woolf's notes on Roger Fry's articles in The Athenaeum and The Pilot, 1900-1906.

a) "Chinese at White ${ }^{p}$ Gallery.": 1 p., numbered 1 by VW. Marginal notation, "Athen/189/1901."

[Fry, Roger.] "Chinese Art at the Whitechapel Gallery." Athenaeum, August 3, 1901, p. 165. 
b) "Sargent at New Gall.": 1 p., numbered 1 by VW. Marginal notation, "nd."

R.E.F. [Roger Fry]. "The New Gallery." Pilot, May 5, 1900, pp. 291-292.

c) "Importance of Japanese Art.": 1 p., numbered 1 by VW. Marginal notation, "The Pilot/1900."

Fry, Roger E. "At the Paris Exhibition." Pilot, July 28, 1900, pp. 109-110.

d) "Early articles./Admiration of Delacriox declining.": 1

p., numbered 2 by VW. Marginal notation, "Paris/ Sept. 1900/Pilot."

Fry, Roger E. "At the Paris Exhibition. III." Pilot, September 8, 1900, pp. 299-301.

e) "reviewed books on Le. da Vinci": 1 p., numbered 2 by VW. (Heading only.) Marginal notation, "1903."

[Fry, Roger.] "Two Books on Leonardo da Vinci." Rev. of Leonardo da Vinci, by Dr. Georg Gronau, and Leonardo da Vinci, by Adolph Rosenberg. Trans. J. Lohse. Athenaeum, July 11, 1903, pp. 66-67.

f) "Corrects Mr. Wyllies theories by L. da/Vinci-about reflections in water.": 1 p., numbered 2 by VW.

[Fry, Roger.] Rev. of Nature's Laws and the Making of Pictures, by W. L. Wyllie. Athenaeum, July 18, 1903, pp. 98-99.

g) " "The Expulsion of Heresy by Palma/Giovane figures in his list as a Tintoretto.": 1 p., numbered 2 by VW.

[Fry, Roger.] Rev. of Jacopo Robusti, called Tintoretto, by J.B. Stoughton Holborn. Athenaeum, August 8, 1903, pp. 197-198.

h) "The RA. analogy if we suppose a/theatre, endowed by the state for the/production of classical drama, ...": 2 pp., numbered 2-3 by VW. P. 3, 1 line only: "The present chaotic condition of the arts." Marginal notation p. 2, "1904"; marginal notation p. 3, "Athen/1904."

[Fry, Roger.] "The Chantrey Bequest." Athenaeum, July 2, 1904, p. 22.

i) "Recollection of a/Rnyal Acad" n/by/Horsley": 1 p., on the reverse of p. 2. (Heading only.) A review of 
Recollections of a Royal Academician, by J. C. Horsley, R.A., ed. Mrs. E. Helps, appeared in the Athenaeum, June 18,1904 , pp. 792-793, but there is no indication Fry wrote this review.

j) “[ . . ] Press praised. Interest in printing": 1 p., numbered 3 by VW. (Heading only.) Fry praised various presses for their reproductions of art works.

k) "a close inspection will reveal a patina/wh., we may confidently say, no forger cd/imitate": 1 p., numbered 3 by VW. Marginal notation, "1904."

[Fry, Roger.] "Sienese Art at the Burlington Fine-Arts Club." Athenaeum, June 4, 1904, pp. 728-729.

1) "power of finding in commonplace events ...": 1 p., numbered 3 by VW. Marginal notation, "1902."

[Fry, Roger.] "The Royal Society of Painter-Etchers." Athenaeum, March 22, 1902, p. 378.

m) "Early Arts/We shd like to add one name to his/list of those modern artists . ..": 1 p., numbered 4 by VW. Marginal notation, "Sept 12th/1903"; textual notation, "On Holmes. Pictures \& Picture Collecting." The entry includes a passage about women's instincts and art that begins, "The fact is that women seldom learn," and continues, in part, "But if they have good taste they rarely sophisticate itthey have an instinct, a certainty \& rapidity of judgment which not even the most gifted men can emulate."

[Fry, Roger.] Rev. of Pictures and Picture Collecting, by C. J. Holmes. Athenaeum, September 12, 1903, pp. 355-356.

n) "Early Articles./a highly scientific argument $\&$ dispute as to/reflections in still water.": 1 p., numbered 5 by VW. (Heading only.) The reference is to Fry's correction of L. W. Wyllie's theory in his review of Nature's Laws and the Making of Pictures: see above, B.1.f. Wyllie responded in the Athenaeum, July 25, 1903 , p. 134; Fry responded in two further articles:

[Fry, Roger.] “'Nature's Laws and the Making of Pictures.'" Athenaeum, August 1, 1903, p. 164; and "On Reflections in Still Water." Athenaeum, August 15,1903 , p. 227. 
o) "on the Pres. of the RA. Poynter.": 1 p., numbered 5 by VW. Marginal notation, "1903."

[Fry, Roger.] "Sir E. J. Poynter's Drawings." Athenaeum, November 7, 1903, p. 621.

p) "approved of Orchardson. New Gallery/\& of Watts $M^{\text {rs }}$ Cavendish Bentinck.": 2 pp., numbered 5-6 by VW. Marginal notation p. 5, "Nov. 1903"; marginal notation p. 6, "Athen:/1903."

[Fry, Roger.] "Society of Portrait Painters at the New Gallery." Athenaeum, November 14, 1903, p. 657.

q) "Old Masters at Bn House.": 1 p., numbered 6 by VW. Marginal notation, "1904."

[Fry, Roger.] "The Old Masters at Burlington House (Third Notice)." Athenaeum, January 30, 1904, p. 153.

r) "Rodin La Defense": 1 p., numbered 6 by VW. Marginal notation, "1902."

[Fry, Roger.] Paragraph beginning, "Since we wrote on the collection of statuettes at the Fine-Art Gallery ..." Athenaeum, April 5, 1902, p. 442.

s) "gives Turner a very high place. A/paper wh. allowed of wiping out/with ease \& pleasure.": 1 p., numbered 6 by VW. Marginal notation, "1903."

[Fry, Roger.] "Water-Colour Drawings at Mssrs. Agnew's." Athenaeum, February 21, 1903, pp. 248-249.

t) "Early Articles/Raffaelli's new solid sticks like/pastels, but made with oil.": 1 p., numbered 7 by VW. Marginal notation, "Athen./Feb. 1903."

[Fry, Roger.] "The Holland Fine-Art Gallery." Athenaeum, February 7, 1903, p. 183.

u) "of $\mathrm{M}^{\mathrm{r}}$ Goodall": 1 p., numbered 7 by VW.

[Fry, Roger.] Rev. of The Reminiscences of Frederick Goodall, R.A. Athenaeum, July 26, 1902, pp. 131132.

v) " 'One might as well read one of $\mathrm{M}$ r/Max Beerbohms essays . ..": 1 p., numbered 7 by VW. Marginal notation, "1901"; annotated at the end of the entry, "Glasgow Ex. Aug./1901."

[Fry, Roger.] "The Glasgow Exhibition. I." Athenaeum, August 17, 1901, pp. 227-228. 
w) "Early Arts/At Hertford House.": 1 p., numbered 8 by VW. Marginal notation, "Pilot/1900."

Fry, Roger E. "Hertford House." Pilot, July 14, 1900, pp. 43-44.

x) "Nat. Gallery. no picture can be acquired/without the consent of all the Trustees.": 2 pp., numbered 8-9 by VW. (P. 9, 3 lines only.) Typed. Marginal notation p. 8, "1902"; marginal notation p. 9, "1902."

[Fry, Roger.] "The Administration of the National Gallery." Athenaeum, August 2, 1902, p. 165.

y) "The Rokeby Venus.": 1 p., numbered 9 by VW. Typed. Marginal notation, "1905."

[Fry, Roger.] "Three Exhibitions. Messrs. Agnew's Gallery." Athenaeum, November 11, 1905, p. 653.

z) "Sketching in water colours has long been recog/nised aborad as on of our national vices, ...": 1 p., numbered 9 by VW. Typed. Marginal notation, "1905."

[Fry, Roger.] "Amateur Drawings." Athenaeum, December 9, 1905, pp. 806-807.

aa) "The New Gallery. International Society show.": 1 p., numbered 9 by VW. Typed. Marginal notation, "Jan i3 1906." The entry includes notes on Cézanne and the Impressionists.

[Fry, Roger.] "The New Gallery." Athenaeum, January 13,1906, pp. 56-57.

bb) "The Tempera Society ...": 1 p., numbered 9 by VW. Typed. Marginal notation, "1905."

[Fry, Roger.] "The Tempera Society." Athenaeum, June 24, 1905, pp. 791-792.

cc) "What does the Academy stand for? What tradition/ does it uphold?": 1 p., numbered 9 by VW. Marginal notation, "1906." According to the Athenaeum files, this article was written not by Fry but by Laurence Binyon.

[Binyon, Laurence.] "Academicians at the Carfax Gallery." Athenaeum, January 20, 1906, p. 85.

dd) "The scheme is to place a tax of one per cent/on all sales of works of art, ...": 1 p., numbered 10 by VW. Typed. Marginal notation, "1906"; textual notation, "Jan 6 1906." 
[Fry, Roger.] "Our National Collections." Athenaeum, January 6, 1906, p. 25.

ee) "The New English Art Club./Mr John, on the other hand, has this curious inexplicable interest in beauty.": 1 p., numbered 10 by VW. Typed. Marginal notation, "nd."

[Fry, Roger.] "The New English Art Club." Athenaeum, October 21, 1905, pp. 547-548.

ff) "Returning once more to that curiously prolific/and various master, Mr. Cook's Giorgione-": 1 p., numbered 10 by VW. (Heading only.) Typed. Marginal notation, "1905."

[Fry, Roger.] "The Burlington Fine-Arts Club." Athenaeum, December 2, 1905, p. 769.

gg) "Portraiture is the one really living form of painting/ in England-": 1 p., numbered 10 by VW. Typed. Marginal notation, "1905."

[Fry, Roger.] "The Portrait Painters at the New Gallery." Athenaeum, November 18, 1905, p. 692.

hh) "arti es Gothic Arcitecture and on Ivories": 1 p., numbered 10 by VW. (Heading only.) Unidentified.

ii) "We wish that we could think that the qulity of hs/ work had imp oved in the same ratio with his/ productivity, . . .": 1 p., numbered 10 by VW. Typed. Marginal notation, "1905." The reference is to "Condor."

[Fry, Roger.] "The Leicester Gallery." Athenaeum, December 16, 1905, pp. 842-843.

jj) "Early articles/On Watts.": 1 p., not numbered. Marginal notation, "Athenaeum./Nov. 22/1902."

[Fry, Roger.] "The Society of Portrait Painters at the New Gallery." Athenaeum, November 22, 1902, pp. 689-690.

kk) "Pesellino \& Catina./Whether a picture is a genuine Perugio . . ": 1 p., not numbered. Marginal notation, "Jan 11 190?." The entry appears on the same page as B.1.jj.

[Fry, Roger.] "Thie Old Masters at Burlington House.

I." Athenaeum, January 11, 1902, pp. 57-58. 
11) "The NEAC .. The more serious \& strenuous/of the younger artists send their work ...": 1 p., not numbered. Marginal notation, "Nov 15 1902." The entry appears on the same page as B.1.jj.

[Fry, Roger.] "The New English Art Club." Athenaeum, November 15, 1902, pp. 656-657.

$\mathrm{mm}$ ) "who was H.M.F. on Vauxhall Bridge?": 1 p., not numbered. The entry appears on the same page as B.1.jj. The reference is to an article found among Fry's cuttings at King's College, Cambridge, headed "Vauxhall Bridge": Athenaeum, November 29, 1902, p. 729. The cutting is annotated "H.M.F." in orange pencil, a reference to $\mathrm{H}$. M. Fletcher, who reviewed for the Athenaeum.

nn) "Praise for Sir Joshua Angerstein Children": 1 p., not numbered. (Heading only.) The entry appears on the same page as B.1.jj.

[Fry, Roger.] "Exhibition on Behalf of the Artists' Benevolent Institution." Athenaeum, November 29, 1902, p. 729.

oo) "Whether a picture is by Francia or/Amico Aspertini": 1 p., not numbered. (Heading only.) The entry appears on the same page as B.1.jj.

[Fry, Roger.] "The Old Masters at Burlington House.

II." Athenaeum, January 18, 1902, pp. 89-90.

pp) "NEAC. an important $\mathrm{Ex}^{\mathrm{n}}$ : because/of the younger groups-": 1 p., not numbered. Marginal notation, "1904." The entry appears on the same page as B.1.jj.

[Fry, Roger.] "New English Art Club." Athenaeum, November 19, 1904, pp. 700-701.

qq) "Early Articles/The Burlington Magazine.": 1 p., not numbered. Marginal notation, "Athenaeum./March 28 th/1903."

[Fry, Roger.] "The 'Burlington Magazine'." Athenaeum, March 28, 1903, p. 409.

rr) "Small Ex ${ }^{\text {ns }}$ article RA-new groupings": 1 p., not numbered. Marginal notation, "Nov. 12 1904" and "Nov. 1904." The entry appears on the same page as B.1.qq. 
[Fry, Roger.] "The Society of Twelve: Mr. Strang at the Dutch Gallery." Athenaeum, November 12, 1904, p. 664.

ss) "very long review of Berenson. an/astonishing monument.": 1 p., not numbered. (Heading only.) The entry appears on the same page as B.1.qq. The "Second Notice" of Berenson's book appeared in the Athenaeum, December 3, 1904, pp. 769-771.

[Fry, Roger.] Rev. of The Drawings of the Florentine Painters, classified, criticized, and studied as Documents in the History and Appreciation of Tuscan Art. With a copious Catalogue Raisonne, by Bernhard Berenson. 2 vols. (First Notice.) Athenaeum, November 12, 1904, pp. 662-663.

tt) "The Chantrey Bequest. Impossible for a whole/C thee to buy pictures ..": 1 p., not numbered. Marginal notation, "Aug 20 1904." The entry appears on the same page as B.1.qq.

[Fry, Roger.] "The Chantrey Bequest." Athenaeum, August 20, 1904, pp. 248-249.

uu) "Early Articles/Ricketts The Prado": 1 p., numbered 3 by VW. Marginal notation, "Ath:/Aug 6/1904." The identifying phrase opposite this entry reads, "The critics function."

[Fry, Roger.] Rev. of The Prado, by C. S. Ricketts. Athenaeum, August 6, 1904, pp. 180-181.

vv) "of the Ionides Collection. It is by no/means a millioners collection:": 1 p., numbered 3 by VW. Marginal notation, "July $23^{\text {rd }} / 1904$."

[Fry, Roger.] "Additions to the National Collections." Athenaeum, July 23, 1904, pp. 118-119.

ww) "Early Articles./Ex ${ }^{n}$ of French Primitives ...": 1 p., not numbered. Marginal notation, "Athen/April 1904."

[Fry, Roger.] "Exhibition of French Primitives in the

Pavillon de Marsan. I." Athenaeum, April 30, 1904, p. 568.

xx) "Early Articles./Death of Watts.": 1 p., not numbered. Marginal notation, "Ath./July 9/1904."

[Fry, Roger.] "G.F. Watts." Athenaeum, July 9, 1904, pp. 53-54. 
yy) "Enthusiasm for Max Bms Caricatures.": 1 p., not numbered. Marginal notation, "May/28th/1904." The entry appears on the same page as B.1.xx.

[Fry, Roger.] Rev. of The Poets' Corner, by Max Beerbohm. Athenaeum, May 28, 1904, p. 695.

zz) "Still hopes that the Chantrey trustees/will buy good pictures.": 1 p., not numbered. (Heading only.) The entry appears on the same page as B.1.xx.

[Fry, Roger.] Rev. of The Administration of the Chantrey Bequest, by D. S. MacColl. Athenaeum, April 9, 1904 , pp. $470-471$.

aaa) "to Goldie/Early/Articles./M. Bussy's pastels.": 1 p., not numbered. Marginal notation, "Athen./1903."

[Fry, Roger.] "M. Bussy's Pastels." Athenaeum, June 27, 1903, p. 824.

bbb) "Old Silver at the F. Arts Society": 1 p., not numbered. The entry appears on the same page as B.1.aaa.

[Fry, Roger.] "Old Silver at the Fine-Art Society's." Athenaeum, December 27, 1902, p. 864.

ccc) "On Old Masters. HF. pencilled": 1 p., not numbered. (Heading only.) Marginal notation, "Jan 1903." The entry appears on the same page as B.1.aaa. "HF." is H. F. Fletcher, another reviewer for the Athenaeum; the initials appear in the same cutting that contains Fry's article on the Old Masters.

[Fry, Roger.] "The Old Masters at Burlington House.

III." Athenaeum, January 24, 1903, pp. 120-121.

ddd) "Poynters ignorance: proceeds to use his own/indifference to the work of the younger $\& /$ more promising sculptors ....": 1 p., not numbered. Marginal notation, "1903." The entry appears on the same page as B.1.aaa.

[Fry, Roger.] Paragraph beginning, "Much discussion has been aroused of late by the conflict of two schemes ..." Athenaeum, January 31, 1903, p. 155.

eee) "The vapid complementary style now/popular-in criticism.": 1 p., not numbered. (Heading only.) The entry appears on the same page as B.1.aaa. The ar- 
ticle, which is unheaded, begins, "Sir Martin Conway ..."

[Fry, Roger.] Rev. of The Domain of Art, by Sir Martin

Conway. Athenaeum, March 15, 1902, p. 343.

fff) "Shannon, Whistler, Legros, Strang/over \& over again. Always admires Watts.": 1 p., not numbered. (Heading only.) The entry appears on the same page as B.1.aaa.

ggg) "Early Arts./No one cd accuse Herr Hans Petersen,/ for instance ...": 1 p., not numbered. Marginal notation, "Athen $\mathrm{m} / 1901 . "$

[Fry, Roger.] "The International Society's Exhibition." Athenaeum, November 2, 1901, pp. 601-602.

hhh) "McEvoy, Orpen": 1 p., not numbered. (Heading only.) The entry appears on the same page as B.1.ggg. It is possible that Woolf is referring to Fry's article on "The New English Art Club," Athenaeum, April 20, 1901, pp. 505-506, which devotes a large amount of space to these two painters.

iii) "The Academy becomes every year a more \&/more colossal joke ...": 2 pp., not numbered. The entry begins on the same page as B.1.ggg. Marginal notation first page, "Pilot./May/1900"; marginal notation second page, "Pilot./1900."

Fry, Roger. "Royal Academy." Pilot, May 12, 1900, pp. 321-322.

jjj) "More praise for Watts/Loch Ness.": 2 pp., not numbered. Marginal notation, first and second page, "Pilot/1900." The entry appears on the second page of B.1.iii.

Fry, Roger. "The New Gallery. (Second Notice)." Pilot, May 19, 1900, pp. 353-354.

kkk) "Mr. Watts ... comes out at the end/a pure \& rapturous lover, not of/truth or virtue, as he wd have us/believe, but of beauty.": 1 p., not numbered. The entry appears on the second page of B.1.jjj.

[Fry, Roger.] "The New Gallery. (First Notice)." Athenaeum, April 27, 1901, pp. 536-537.

2. "Rothenstein": 1 p., not numbered. Another entry on this work appears below, B.5. 
Rothenstein, Sir William. Men and Memories: Recollections. Vol. I: 1872-1900. Faber \& Faber, 1931.

3. " $R$ to his Mother/29 Beaufort Street.": 14 pp., not numbered, including pencilled notes on the page facing the first page of the entry. The entry consists of notes on Roger Fry's letters to his mother, Lady Fry, 1891-1896; it is followed by twenty-eight blank leaves.

4. "Memories of an Edwardian E. Jepson. 1937": 1 p., not numbered. The entry consists of a quotation, annotated " 42 ," beginning, "In those days too I used to meet Roger Fry, most often with Selwyn Image ..."; and a list of page references without notes.

Jepson, Edgar. Memories of an Edwardian and Neo-Georgian.

Richards, 1937.

5. "WR. Men \& Memories": 10 pp., not numbered. Another entry on this work appears above, B.2.

Rothenstein, Sir William. Men and Memories: Recollections. Vols. I-II: 1872-1922. Faber \& Faber, 1931-1932.

\section{Monk's House Papers/B.17c. (Sussex)}

In this notebook, Woolf has collected quotations and notes by and about Roger Fry. Two of the entries (B.3 and B.5) - both extracts from Fry's letters to G. Lowes Dickinson-are taken from letters that are annotated more fully in LXV, B.1, Woolf's original notes on the letters. Their reappearance here suggests that these entries may belong to the period after Woolf began "reading and re-reading [her] Roger notes" in preparation for writing Roger Fry: A Biography ( $A W D$, June 1, 1937). Another entry, B.11, which describes the toast list from a banquet Fry attended in New York, appears almost verbatim in the finished work.

Woolf may have compiled the entries in this volume during the summer and fall of 1938. On August 7, she was "deep . . in art history" and writing about it; on October 8, she described "reading [Fry's] books one after another. . . . For instance Cezanne-a miracle" ( $L$, VI, 3428, 3454). Two entries can be dated exactly-those on the Post-Impressionist Exhibition of 1910 as reported in The Times (B.14-15). On Tuesday, September 27, 1938, in the midst of the Munich crisis, Woolf "went to the London Library to look up some 
papers about Roger. I sat in the basement with the Times open of the year 1910" ( $L$, VI, 3447). But even there she could not escape the horror of those days, brilliantly described in the remainder of this letter to her sister.

The list of contents pasted on the spine of the cover (A.1), which includes cancelled entries, illustrates how Woolf shuffled her notes around as she used them. (For the other Fry notes, see Volumes XXVI, XXXIX, LXI-LXII, and LXIV-LXVI.) The index pasted on the front of the cover (A.2) corresponds to the actual entries in the notebook, with the exception of the notes on "The Omega, twenty years after. Age no guide to art," which are not included. All of the entries, except the last two, are typed; the larger table of contents, A.2, is typed through the last two entries, which are in black ink. The smaller table of contents, A.1, the page numbers, and the last two entries are all in black ink.

\section{A. Table of Contents}

1. Roger:

Eharateer in

tetters. Misc.

Early Articles

Seeing Pictures

Carfax Show

Life of Sargent

Omega $20 \mathrm{y}^{\text {rs }}$ after

Times on PIP [Post-Impressionist Painting]

Label, on spine of cover.

2. Ida's character

Feeling for Art at Cambridge (1895)

Lectures at Toybee Hall

He had not heard of Cézanne when a student at Paris.

Music in Youth.

Seeing pictures in Germany

Contemporary criticism of R's pictures. Carfax Gallery.

Artists critisied by R. im Athen 1902

Dinners in New York 1905 Toast list

The Omega, twenty years after. Age no guide to art.

Sargent: connection with NEAC. on PIP. \& Roger.

The Times on $1^{\text {st }}$ P.I.P. 1910-11.

$1 \mathrm{p}$., on cover. Typed and handwritten. 
B. ENTRIES

1. "ROGER FRY/Born, 14 December 1866/Died, 9 September, 1934": 3 pp. Printed program for the memorial service for Roger Fry, "Thursday, 13 September, 1934." The program is laid into the front of the notebook.

2. "THE YEARS": 1 p., not numbered. (Heading only.) The entry is typed on a sheet of paper that is laid into the front of the notebook.

3. "Idas character/It is the strangest most fascinating creature-": 1 p., numbered 1 by VW. Typed extract from a letter from Roger Fry to G. Lowes Dickinson. More notes on this letter appear in LXV, B.1, on a page numbered 4, letter annotated "Chelsea Sept 25th 1893."

4. "A picture show at Cambridge. (1895).": 1 p., numbered 2 by VW. Typed extract from a letter from Roger Fry to Helen Coombe, later Helen Fry, beginning, "MacColl has been up and just looked in ...." This letter is dated 1895 in Woolf's Roger Fry: A Biography, Chapter IV, and [November-December 1896] in the Letters of Roger Fry, ed. Denys Sutton (Chatto \& Windus, 1972), I, 168.

5. "On lectures at Toynbee hall": 1 p., numbered 2 by VW. Typed notes on a letter from Roger Fry to G. Lowes Dickinson, beginning, "An analysis gives the following constituents Pue [pure] gas 95\% Truisms 40\%." More notes on this letter appear as LXV, B.1, on a page numbered 3, letter annotated "Roger to Goldie/n.d."

6. "Cezanne typescript 1927": 1 p., numbered 3 by VW. Typed quotation, beginning, "More than thirty years ago the present writer was working as an art student in Paris." Unidentified.

7. "Music in youth": 1 p., numbered 3 by VW. Typed quotation, annotated "Musical Confessions of an Outsider. The Music Bulletin/May 1926," beginning, "When I was quite young, I did not care for music...."

Fry, Roger. "Musical Confessions of an Outsider." Music Bulletin 8, no. 5 (May 1926): 138-140.

8. "Seeing pictures in Germany": 1 p., numbered 4 by VW. Typed quotation, annotated "Speech about East Anglia," beginning, "I have just been on a tour of the German 
galleries." The extract is from a talk delivered in Norwich, East Anglia, about the poverty of the provincial museums in England.

Fry, Roger. "East Anglia." MS. Roger Fry Papers. King's College, Cambridge.

9. "Westmonster Gazeete. B.N. criticism of R's pictures.": 1 p., numbered 4 by VW. Typed quotation. The exhibition was at the Carfax Gallery.

B. N. "Mr. Roger Fry's Exhibition." Westminster Gazette, April 29, 1903, p. 2.

10. "Artists criticsed by R. in Athen. 1902": 1 p., numbered 4 by VW. Typed notes, beginning, "Mr Callow, Mr Albert Goodwin, Mr Mattew Hale, ..." The notes are on a single article by Fry.

[Fry, Roger.] "The Royal Society of Painters in Water Colours." Athenaeum, May 3, 1902, p. 569.

11. "Wednesday 11th Jan. 1905. Annual dinner Amer. Inst of Archi/tects": 1 p., numbered 4 by VW. The entry, which continues, " $\mathrm{R}$ sat beweteen $\mathrm{Mr} \mathrm{W}$ Lanfan and rep. Sherman and drew pictures on his very substantial Toast list," describes a banquet attended by Roger Fry in New York, January 11, 1905. This banquet reappears in Roger Fry: $A$ Biography, at the end of Chapter V.

12. "New English Art Club. Sargent. 90": 1 p., not numbered. Typed notes, annotated "Sargent Hon E Charteris. 1927." The notes contain a reference to "Sargents letter to nation. jan 7 1911"-a letter written by Sargent about Roger Fry and the Post-Impressionist painters, published in The $\mathrm{Na}$ tion, January 11, 1911. The letter is quoted by Charteris, pp. 191-192. The entry ends with the comment, "E.C..... striking and undistinguised as an illustrator and non-existent as an artist. Transformations p. 135"-a transcription of the final sentence in Roger Fry's essay on Sargent in Transformations (1926), quoted by Charteris on p. 194.

Charteris, Hon. Evan. John Sargent. Heinemann, 1927.

13. "Times.": 3 pp., numbered 1-3 by VW. Quotations, annotated "Sat Oct/1 st 1910," and "Nov. 7th/1910," about the Post-Impressionist Exhibition organized by Roger Fry at the Grafton Gallery, November 1910-January 1911. 
a) "The 'Post-Impressionists'." The Times, October 1, 1910, p. 13.

b) “'Post-Impressionist' Painting." The Times, November 7, 1910, p. 12.

14. "Times then occupied with/Memorials to King Edward./Canada \& Reciprocity.": 1 p., not numbered. The entry consists of a list of articles that appeared in The Times on October 1, 1910 and November 7, 1910, the same days that The Times published articles about the Post-Impressionist Exhibition. See above, B.13.

\section{Monk's House Papers/B.17d. (Sussex)}

On November 21, 1934, it was decided that Margery Fry would "write to the N.S. [New Statesman] asking for letters," presumably by and about Roger Fry, her brother, and that Woolf would then go through them for her biography of Fry $(A W D)$. These letters were among the papers Margery Fry brought to Woolf in August 1935. By October 14, Woolf had begun to read Fry's letters to his family"very stiff"-and to Basil Williams - "some . . extremely amusing" ( $L, \mathrm{~V}, 3069)$. On October 22, she was "plodding through the [Robert] Bridges letters" ( $A W D$ ); and on December 1, she was "now reading the letters to Helen [Anrep]" ( $L, \mathrm{~V}, 3085)$. By January 30, 1936, she had "made notes and extracts" of all the letters to Helen Anrep, Vanessa Bell, and G. L. Dickinson ( $L$, VI, 3101), and on May 2, 1936, she reports having "read and extracted the whole lot" ( $L$, VI, 3126). Woolf continued to read and extract Fry's letters as she planned and wrote Roger Fry: A Biography; she did not receive the letters to William Rothenstein (B.18), for example, until July 1938 ( $L$, VI, 3418), and on January 9, 1939, she was reading "the packets of old letters that still remain!" ( $L$, VI, 3476). Taken together, these letters were Woolf's major source.

All of the entries in this notebook are notes made on or extracts from Roger Fry's letters to various correspondents. (Other notes on Fry's letters, etc., are found in Volumes XXVI, XXXIX, LXI-LXIII, and LXV-LXVI.) The only exception is the letter written by Julian Bell to Woolf about Fry, a large portion of which appears in the biography (see $L, \mathrm{~V}, 3085$, and $L, \mathrm{VI}, 3126$ [May 2, 1936], in which she notes that this letter was being typed). Several of the entries, 
B.2-3 and B.5, are extracts from letters to Helen Anrep that Woolf has noted more fully elsewhere. In two of these entries, B.3 and B.5, she has provided a page number to indicate from where the extract was copied, and these numbers correspond to her page numbers for the letters to Anrep in XLVI, B.4. This suggests that she made at least some of the notes in this volume during the latter stages of the preparation of her book. Perhaps the major entry in this volume is the forty-six pages of notes and extracts from Fry's letters to Vanessa Bell (B.17), Woolf's sister, who introduced Fry to Woolf and who remained one of his closest friends until his death. Several more pages of notes on the letters to Vanessa, unidentified in the text, are found in "[Between the Acts] Holograph fragment, dated Sept. 16 [1938]" (Berg Collection).

The different kinds of paper and the mixture of handwritten and typed entries indicate the diverse times that Woolf made these notes. The first five entries, B.1-5, are not attached to the two rings of the notebook. This would explain why the three indexes of the contents - the typed label pasted on the spine of the notebook (A.1); the index pasted on the front cover, typed with the exception of the last name, which is written in red ink (A.2); and the list of names and dates, again typed with the exception of the last name-do not include entries 1 to 5. The indexes are, however, an accurate guide to the contents of the rest of the notebook. The notes, when written, are in black ink; the numbers tend to be in the same ink or type as the entry, with the exception of B.17, where the numbers are in red pencil.

\section{A. Table of Contents}

1. A. MacColl

B. Williams

Bridges

Pamela

J's lette

V.B.

Label, on spine of cover, top half missing. Typed.

2. Extracts from letters to:

Bob Trevelyan

Powles

Louis

Bertie Russell

MacColl 
Mrs MacColl

Basil Williams

Robert Bridges

Pamela Fry

Julains letter about Roger

Vanessa Bell

W. Rothenstein

1 p., on cover. Typed and handwritten.

B. ENTRIES

1. "to Sir Edward": 6 pp., numbered 1, 3-7 by VW. Extracts from Roger Fry's letters to his father, Sir Edward Fry, 1893-1912. More notes on these letters appear in LXV, B.4.

2. "Quotations for Cezanne chapter": 1 p., not numbered. Typed. Extracts from Roger Fry's letters to Helen Anrep, all of which correspond to passages from these letters found in LXVI, B.4.

3. "Quotations/Cassis \& Le Mas": 2 pp., not numbered. Notes on and extracts from Roger Fry's letters to Helen Anrep. Each entry includes a page number that corresponds to Woolf's notes on the letters to Anrep, LXVI, B.4.

4. "Roger Fry.": 4 pp., not numbered. The entry consists of passages, heavily corrected, about Fry's love of reading and his reaction to World War I.

5. "13. Ly Frys character-what a tragedy that makes of life": 1 p., numbered 2 by VW. Notes on and extracts from Roger Fry's letters to Helen Anrep. Each entry has a page notation that corresponds to Woolf's original notes on the letters to Anrep, LXVI, B.4.

6. "Letters to Bob Trevelyan/1895-1932": 1 p., not numbered. Typed and handwritten. The entry is an index to the remaining entries in this notebook. It lists the recipients and dates of the letters from Fry noted below:

Bob Trevelyan - 1895-1932

Powles-1924-31

Louis -1932

Bertie Russell-1930-33

MacColl-1901xxxx-1922 
Mrs MacColl-1922-1918

Basil Williams-1891-1933

R. Bridges $-1891-1926$

Pamela-1917-i933

Julian's letter about Roger

Vanessa Bell 1916-1934

Duncan Grant 1914 ...

7. "Bob. Trev. 1895": 7 pp., not numbered. Typed and handwritten. Extracts from Roger Fry's letters to Robert C. Trevelyan, 1895-1932. More notes on these letters appear as LXI, B.1.

8. "Letters to Powles. 1924": 2 pp., not numbered. Extracts from Roger Fry's letters to L. C. Powles, and an extract, dated "Dec. 2. 31," about Powles, which appears in Fry's letter to Lewis Fry, December 2, 1931: Letters of Roger Fry, ed. Denys Sutton (Chatto \& Windus, 1972), II, 665.

9. "1932/Letter to Louis": 1 p., not numbered. Extract from a letter from Roger Fry, presumably to Lewis Fry.

10. "1930-33/To Bertie Russell": 1 p., not numbered. Extracts from Roger Fry's letters to Bertrand Russell.

11. “1901 1895/Letters to MacColl.": 5 pp., not numbered. Extracts from Roger Fry's letters to D. S. MacColl, 1901-1924.

12. "To $\mathrm{M}^{\text {rs }}$ MacColl. 1924": 3 pp., not numbered. Extracts from letters to Andrée Desirée MacColl, dated 1924 and 1918.

13. "1891(?)/To Basil Worsfold Williams.": 16 pp., not numbered. Extracts from Roger Fry's letters to Basil Williams, 1891-1894.

14. “To m Robert Bridges. 1929": 3 pp., not numbered. Typed. Extracts from Roger Fry's letters to Robert Bridges, 18911929.

15. "1917-19/To Pamela.": 4 pp., the 2nd to the 4th page numbered $2-4$ by VW. Typed. Extracts from Roger Fry's letters to his daughter, Pamela Fry Diamand, 1917-1933.

16. "Julian letter on Roger": $4 \mathrm{pp}$., the 2nd to the 4th pages numbered 2-4 by VW. Typed. Extracts from a letter written to Virginia Woolf by Julian Bell about Roger Fry.

17. "Letters to V.B. 1916": 46 pp., numbered 1-46 by VW. Typed and handwritten. Extracts from Roger Fry's letters 
to Vanessa Bell, 1914-1933. P. 46 is headed, "Notes on the Roger. V.B. Letters." Another entry on these letters appears as LXI, B.5, and an extract from a late letter as LXVI, B.2.

18. "To W. Roth.": 2 pp., the first page numbered 47, cancelled. Typed. Extracts from Roger Fry's letters to William Rothenstein, 1899-1911.

19. "To Duncan Grant.": 1 p., not numbered. Typed. Extracts from Roger Fry's letters to Duncan Grant, dated 1914 and "n.d."

\section{Monk's House Papers/B.17e. (Sussex)}

The four entries in this notebook are all notes on Roger Fry's letters, made in preparation for Roger Fry: A Biography (1940). In this case, the letters are to four of his major correspondents: his old Cambridge friend, G. Lowes Dickinson; his wife, Helen Fry; his close French friends and collaborators, Charles and Marie Mauron; and his father, Sir Edward Fry. Woolf read the letters to Helen Fry after December 6, 1935 ( $L, \mathrm{~V}, 3085)$, and those to Dickinson between December 19, when they were still missing $(L, \mathrm{~V}, 3088)$ and January 30, 1936, when she records having finished them ( $L$, VI, 3101). Earlier, on January 19, she noted, "What an odd pair-Roger and Goldie!" ( $L$, VI, 3099) - a comment based on her reading of their correspondence. As the different sets of page numbers show, however, Woolf must have read the letters to Dickinson at several different times over the next four years. The confused order of the pages probably indicates that she took them out of the notebook as she needed them while planning or writing the book. She did not receive the letters to the Maurons - "over a hundred"-until the end of 1936 ( $L, \mathrm{VI}, 3189$ ). Extracts from the letters to Dickinson appear in Volume LXIII, as does an extract from the letters to Helen Fry. More notes on the letters to Fry's father are in LXIV; more notes for the biography are found in XXVI, XXXIX, LXI-LXII, and LXVI.

Two labels indicate the contents of this notebook: one, in black ink, is pasted on the spine (A.1); the other, typed and in black ink, is pasted on the front cover (A.2). Most of the entries are typed; when written, they are in black ink. 


\section{A. Table of Contents}

1. Early letters

to

Sir E. Fry

Label, on spine of cover.

2. Letters to

Goldie

Helen Fry

XXXXXXXXXX

Charles \& Marie

Mauron

$1 \mathrm{p}$. , on cover. Typed and handwritten.

B. ENTRIES

1. "Goldie 1891? -": 33 pp., numbered 13, 1-17, 21-22, 25, $1-2,4,3,5-9,24,10,26$ by VW. Typed. Notes on and extracts from Roger Fry's letters to G. Lowes Dickinson, 1888-1920. Two extracts from these letters appear as LXIII, B.3 and B.5.

2. "Roger to Helen Fry 1906-": 2 pp., numbered 1-2 by VW. Typed. Notes on and extracts from Roger Fry's letters to Helen Fry, 1906-1909, and one letter, on p. 1, to his mother, Lady Fry. Another entry on the letters to Helen Fry appears as LXIII, B.4; other notes on the letters to Lady Fry are in LXII, B.3.

3. "to M. Mauron. July 1921": $16 \mathrm{pp}$., the first six numbered $1-6$ by VW. Typed and handwritten. Notes on and extracts from Roger Fry's letters to Charles and Marie Mauron, 1919-1934. The 13th page is headed, "Quotations on POLITICS from Mauron letters"; the 14th page is headed, "Political Views. to Mauron."

4. "To E. Fry": 4 pp., not numbered. Notes on and extracts from Roger Fry's letters to his father, Sir Edward Fry, 1886-1895. More notes on these letters appear as LXIV, B.1. 


\section{Monk's House Papers/B.17f. (Sussex)}

On December 1, 1935, Woolf wrote to her nephew Julian Bell, "I am now reading the letters [of Roger Fry] to Helen [Anrep], and get more and more involved in his mind and character, for though he is a bad letter writer mostly, to her he was extremely free and easy and self analytic" ( $L, V, 3085)$. Fry's letters to Helen Anrep, the source of the majority of notes in this volume, were clearly of major importance to Woolf in writing her biography of Fry. Six sets of notes exist, five of them numbered separately; the six sets were then renumbered consecutively by Woolf. References to these letters appear as B.1 in this notebook; three sets of extracts from the letters appear in Volume LXIV. The label pasted on the spine of the cover indicates the letters to Helen Anrep as the only contents of the notebook, again emphasizing their importance. All of the notes are typed, as are the original numbers; the second set of numbers are written in black ink. (Other notes on Fry appear in Volumes XXVI, XXXIX, and LXI-LXV.)

The label on the cover is in black ink, as are entries B.1-2. B.3, which is typed and bears the number 11 in black ink, appears to be the missing page from the letters to Anrep, which are numbered $1-10,12-67$. The entry is an extract from Fry's letter to G. B. Shaw that probably got mixed in with the Anrep letters and was later removed.

\section{A. TABle of Contents}

1. Extracts

from

$\underline{\text { Letters }}$

to

Helen

Anrep

1924

to

1934

Label, on spine of cover.

B. ENTRIES

1. "To Helen.": 2 pp., the second page numbered 2 by VW. The entry consists of a list of references to Roger Fry's letters 
to Helen Anrep. The notations that appear with the references are to the page numbers for Woolf's notes on the letters, B.4, below.

2. "April 19th 34": 1 p., not numbered. Extract from a letter from Roger Fry to Vanessa Bell, beginning, "I've been a beast not just to say a word of how delightful it was being with you-I dont think I ever enjoyed it more." For the background of this letter, see Woolf's notes on the letters to Vanessa Bell, which conclude with the note, "Stays at Charleston in April 1934. Never enjoyed it more" (LXIV, B.17).

3. "Bernard Shaw": 1 p., numbered 11 by VW. Typed. Extract from an undated letter from Roger Fry to George Bernard Shaw, beginning, "It must be about 40 years since I first met you at Cambridge when you came to lecture on socialism."

4. "EXTRACTS FROM LETTERS./Helen Anrep . . 1924": 67 pp., numbered after the first page 1-10, 12-67 by VW. Typed. Notes on and extracts from Roger Fry's letters to Helen Anrep, 1924-1934. The notes are divided into six separate sets, which were then renumbered consecutively by Woolf. Extracts from these letters, most of them with page references to the consecutive set of numbers, appear in LXIV, B.2, B.3, and B.5. A list of references to these letters appears above, B.1.

\section{Notes on Oliver Goldsmith. (Yale)}

Woolf would have appreciated the irony of Yale University's possession of her reading notes on Oliver Goldsmith - a gift to the University from the friends of Helen McAfee, a long-time editor of The Yale Review. In September 1933, McAfee rejected Woolf's essay on Goldsmith because, as Woolf put it, "Goldsmith is not a subject likely to be of particular interest in America" ( $L, \mathrm{~V}, 2797)$. Woolf's response to McAfee, as indicated in the last quotation, was slightly acerbic. Commenting that she was next committed to an essay on Turgenev for the $T L S$, she continued, "In England-or rather in the Literary Supplement-we have a habit of reviving old writers from time to time with no particular reason." 
Woolf worked intermittently on her essay on Goldsmith during the spring of 1933 ( $A W D$, April 6, 25; May 30, 31). The essay was finished by August 17, when Woolf sent it to McAfee, but it was not published until March 1, 1934, when it appeared in the TLS (Kp. C342). Another set of notes on Goldsmith for this essay comprises Volume LIII; a single entry on Goldsmith appears among Woolf's notes for The Pargiters, the work that so obsessed her at this time that it almost interfered with the writing of the essay (XXIII, B.6).

The ink throughout is black.

\section{A. Table of Contents}

1. Goldsmith

1 p., on cover.

B. ENTRIES

1. "Goldsmith/The Bee.": 2 pp., not numbered. More notes on this work appear below, B.3.

Goldsmith, Oliver. The Bee. In The Miscellaneous Works. Ed. James Prior. Vol. I. Murray, 1837.

2. "Johnson on inaccuracy.": 1 p., not numbered. Quotation, annotated " $3 / 15$," reading, "Let him deny what is said, \& let the matter have a fair chance of discussion. But if a man cd. say nothing against a character but what he can prove, history could not be written; for a great deal is known of men of wh. proof cannot be brought." Johnson's remark was sparked by a contested story in one of Goldsmith's works. More notes on Johnson and Goldsmith appear in LIII, B.5.

Boswell, James. The Life of Samuel Johnson, L.L.D. Ed.

George Birkbeck Hill. Vol. III [of VI]. Oxford: Clarendon Press, 1887.

3. "G ${ }^{\text {th }} / 1 / 138 /$ very good when he describes a person": 1 p., not numbered. More notes on this work appear above, B.1.

Goldsmith, Oliver. The Bee. In The Miscellaneous Works. Ed. James Prior. Vol. I. Murray, 1837.

4. "Essays." 2 pp., not numbered. The entry begins on the same page as B.3. The second page ends with the note, "The Origin of Poetry (skipped)" - a reference to one of Goldsmith's essays. 
Goldsmith, Oliver. Essays. In The Miscellaneous Works. Ed. James Prior. Vol. I. Murray, 1837.

5. "G ${ }^{\text {th }}$ Essays.": 1 p., not numbered. General notes, beginning, "That G. plays the flute in the window. Essays are the product of a talkative age." The entry ends, "Good advice. All conveyed by the speaking voice."

6. "State of Polite Learning": 2 pp., not numbered.

Goldsmith, Oliver. An Enquiry into the Present State of Polite Learning in Europe. In The Miscellaneous Works. Ed. James Prior. Vol. I. Murray, 1837.

7. "Vicar of W.": 2 pp., not numbered.

Goldsmith, Oliver. The Vicar of Wakefield. In The Miscellaneous Works. Ed. James Prior. Vol. III. Murray, 1837.

8. "The Good humoured Man": 1 p., not numbered. 2 lines only, reading, "179 was G. the man himself 179 Life but a froward child \&c."

Goldsmith, Oliver. The Good-Natured Man. In The Miscellaneous Works. Ed. James Prior. Vol. IV. Murray, 1837.

9. "She Stoops to Conquer": 1 p., not numbered. The entry appears on the same page as B.8., and begins with the note, "That $\mathrm{G}^{\text {th }}$ wanted to keep in touch with ordinary life-not all wit."

Goldsmith, Oliver. She Stoops to Conquer. In The Miscellaneous Works. Ed. James Prior. Vol. IV. Murray, 1837.

10. "The Deserted Village": 1 p., not numbered.

Goldsmith, Oliver. The Deserted Village. In The Miscellaneous Works. Ed. James Prior. Vol. IV. Murray, 1837.

11. "Deserted Village. Traveller": 1 p., not numbered. (5 lines only.) General notes, reading, "The cool palette of the $18^{\mathrm{h}}$ Century with browns, \& bitterns \& evening females-but all the same very positive, \& eloquent. The calmness yet rather refreshing. Some only silhouette \& rhetoric \& reason."

12. "The Traveller": $2 \mathrm{pp}$., not numbered. The entry begins on the same page as B.11.

Goldsmith, Oliver. The Traveller; or, A Prospect of Society. In The Miscellaneous Works. Ed. James Prior. Vol. IV. Murray, 1837. 
13. "Retaliation": 1 p., not numbered. (5 lines only.) The entry appears on the second page of B.12, and includes a reference to a footnote attributed to Malone: "The last lines G. wrote. Had meant to have ended with his own character."

Goldsmith, Oliver. "Retaliation." In The Miscellaneous Works. Ed. James Prior. Vol. IV. Murray, 1837.

14. "Citizen of the World": $7 \mathrm{pp}$., not numbered. Woolf was reading this work in two editions. The first page and the last three are from the "Big/Ed": The Miscellaneous Works; the other three pages are from the "(Small/Ed)." The notes from the second set, however, do not correspond to the Everyman Edition of The Citizen of the World and The Bee (1934), the ostensible basis for her "review" in the $T L S$. A general note on the sixth page reads, "Gold ${ }^{\mathrm{h}}$ always opposed to extremes-too balanced. That is perhaps his weakness: cant exceed. twits philosophers: twits scientists. The $18^{\text {th }}$ Century reason $\&$ good taste is a little depressing. Oh if only they wd be violent, obscure. romantic. not moral."

Goldsmith, Oliver. Letters of a Citizen of the World. In The Miscellaneous Works. Ed. James Prior. Vol. II. Murray, 1837. 



\section{APPENDIX A: \\ LIST OF NOTEBOOKS}

In the following list, the notebooks in the Berg Collection are designated by their titling in the card catalogue in the New York Public Library. For Volumes I-XXVI, however, which are filed as a unit under "Holograph reading notes. Vols. 1-26," I have added a brief description of the major contents of the notebook, using where applicable the essay or book that grew from the notes. The descriptions of the Sussex notebooks are those given in the Monk's House Papers Catalogue (July 1972). The single notebook in the Beinecke Rare Book and Manuscript Library at Yale University is designated by its catalogue title. Each notebook is preceded by its volume number in the guide.

\section{Berg Collection, New York Public Library}

I. Holograph reading notes. Vol. 1. "The Novels of Turgenev."

II. Holograph reading notes. Vol. 2. "Joseph Addison."

III. Holograph reading notes. Vol. 3. "The Novels of Defoe."

IV. Holograph reading notes. Vol. 4. "Robinson Crusoe."

V. Holograph reading notes. Vol. 5. "Swift's Journal to Stella."

VI. Holograph reading notes. Vol. 6. "The Historian and 'The Gibbon" " and "Reflections of Sheffield Place."

VII. Holograph reading notes. Vol. 7. Three Guineas.

VIII. Holograph reading notes. Vol. 8. "The Reverend William Cole: A Letter"; "The Countess of Pembroke's Arcadia""; "Donne After Three Centuries."

IX. Holograph reading notes. Vol. 9. "Cowper and Lady Austen"; "Beau Brummell"; "Mary Wollstonecraft."

$\mathrm{X}$. Holograph reading notes. Vol. 10. Notes for The Pargiters and, later, Three Guineas; "The Captain's Death Bed."

XI. Holograph reading notes. Vol. 11. "The Strange Elizabethans"; "Donne After Three Centuries"; "The Countess of Pembroke's Arcadia.'" 


\section{[ APPENDIX A ]}

XII. Holograph reading notes. Vol. 12. "The Strange Elizabethans"; Introductory Letter to Life as We Have Known It.

XIII. Holograph reading notes. Vol. 13. "Phases of Fiction"; "Geraldine and Jane"; "Dr. Burney's Evening Party" and "Fanny Burney's Half Sister"; "Augustine Birrell."

XIV. Holograph reading notes. Vol. 14. "Phases of Fiction"; "The New Biography"; Ruskin's Praeterita; "Lord Chesterfield's Letters to his Son"; A Room of One's Own.

XV. Holograph reading notes. Vol. 15. E. M. Forster, James Woodforde, De Quincey.

XVI. Holograph reading notes. Vol. 16. "Anon" and "The Reader"; "Madame de Sévigné"; "Mrs. Thrale."

XVII. Holograph reading notes. Vol. 17. Sir Thomas Browne's Letters.

XVIII. Holograph reading notes. Vol. 18. Stendhal; "Sterne's Ghost"; "Jones and Wilkinson."

XIX. Holograph reading notes. Vol. 19. "On Not Knowing Greek"; "The Elizabethan Lumber Room"; "Notes on an Elizabethan Play"; "How it Strikes a Contemporary."

XX. Holograph reading notes. Vol. 20. "Beau Brummell"; "Dorothy Wordsworth"; Hardy; "Donne After Three Centuries"; "The Countess of Pembroke's Arcadia"”; "Augustine Birrell."

XXI. Holograph reading notes. Vol. 21. Freud and William Harrison.

XXII. Holograph reading notes. Vol. 22. "Wm. Hazlitt the Man"; "'I am Christina Rossetti.',

XXIII. Holograph reading notes. Vol. 23. The Pargiters; Goldsmith.

XXIV. Holograph reading notes. Vol. 24. "The Man at the Gate"-Coleridge; "Sara Coleridge"; "White's Selborne"; "Gas at Abbotsford."

XXV. Holograph reading notes. Vol. 25. "On Not Knowing Greek"; "Bentley"; "Notes on an Elizabethan Play"; "Sir Thomas Browne"; "Mr. Conrad: A Conversation"; "Phases of Fiction"; De Quincey's "Impassioned Prose"; "The Cosmos."

XXVI. Holograph reading notes. Vol. 26. A composite of loose pages: Three Guineas; Roger Fry; "Henry James' Ghost Stories"; "The Antiquary"; Maupassant; Shakespeare; Gray; "On Re-reading Novels." 
XXVII. [Diary] Holograph notebook. Unsigned. Christmas, 1904May 31, 1905. No. 3. Notes beginning from the back.

XXVIII. Choephori of Aeschylus. Edited by A. W. Verrall. Holograph reading notes, dated Jan: 1907.

XXIX. Holograph reading notes, Jan. 1909-March 1911. In [Night and Day] Chapts. 11-17.

XXX. [A Writer's Diary] Holograph notebook. Nov. 16, 1918Jan. 24, 1919. Notes beginning from the back.

XXXI. Modern Novels (Joyce). Holograph notebook, unsigned and undated.

XXXII. [Flush] Holograph and typewritten reading notes, unsigned and undated.

XXXIII. [Three Guineas] Holograph reading notes, unsigned and undated.

\section{Monk's House Papers, University of Sussex Library}

XXXIV. MH/A.21. VS. Greek and Latin Studies. Notes on Juvenal, Satires 1, 3, 6. The Odyssey, The Ion of Euripides, The Symposium, The 4th Georgic, and Ajax of Sophocles, the Frogs. Dec. 1st 1907-Jan. 11 1909. Note added in Jan. 1917.

XXXV. MH/B.1a. 1905-6. Virginia Stephen's ms notes on ca. 45 books read for review in The Guardian, the Academy, Times, \& Speaker. Leather-bound note book.

XXXVI. MH/B.2a. Small blue loose-leaf book with notes on books by or about Jennie Lee, Tom Bridges, Mill Autobiography, Buttons.

XXXVII. MH/B.2c. Ring-back notebook (broken) containing Reading Notes on An Elizabethan Journal (G.B. Harrison), Trevelyan's History, Coriolanus, Henslowe's Diary, Fire of London, Mme de Sévigné, Spenser Faery Queen, Bacon, Newdigate, \&c.

XXXVIII. MH/B.2d. File containing $87 \mathrm{pp}$ of ms Reading Notes, listed on cover by VW.

XXXIX. MH/B.2f. Spiral-back notebook with note by LW [Leonard Woolf]: 'This is a loose-leaf notebook in which Virginia Woolf made notes of various kinds, mainly about what she was writing or thought of writing. In this page 
she has jotted down rough notes for an essay on reviewing' (p. 10). At back, notes concerning Roger Fry.

XL. MH/B.2h. Paper-bound sheets: reading notes on Congreve Comedies.

XLI. MH/B.2i. Paper-bound reading notes entitled: George Eliot.

XLII. $\quad \overline{M H} /$ B.2j. Paper-bound reading notes entitled: Hardy.

XLIII. MH/B.2k. Paper-bound reading notes entitled: Henry James/Letters.

XLIV. MH/B.2l. Paper-bound reading notes entitled: $\underline{H}$. Melville/H. Walpole.

XLV. MH/B.2m. Loose-leaf notes entitled: Four Voices/Faery Queen (1934).

XLVI. MH/B.2n. Loose-leaf notes on various books, headed by Lord Chesterfield's Letters.

XLVII. MH/B.2o. Loose-leaf notes on various books, headed by Otway, Venice Preserv'd.

XLVIII. MH/B.2p. Loose-leaf notes on various books, headed Dekker.

XLIX. MH/B.2q. Loose-leaf notes on various books, headed by Austen, Love \& Friendship.

L. MH/B.3a. 4 loose pp ms notes for Jack Mytton (C 272).

LI. MH/B.3b. Notes on Purgatorio, dated Feb 1935. 5 loose pp ms.

LII. MH/B.3c. Notes on Dorothy Osborne. 10 loose pp ms.

LIII. MH/B.3d. Notes on Goldsmith. 12 loose pp ms \& ts.

LIV. MH/B.3e. Notes on La Rochefoucauld \& Mme de Sévigné. Ring-back binder, $3 \mathrm{pp} \mathrm{ms}$.

LV. MH/B.16a. [Three Guineas] 27 loose pp ms, reading notes for 3 Guineas.

LVI. MH/B.16b. [Three Guineas] 10 loose pp ms; includes notes for 'The Burning of the Vote,' a Comedy.

LVII. MH/B.16e. [Three Guineas] Spiral-back notebook (covered by VW), 8 pp ms. P.1: 'The inflated brown bug'; notes on W. Holtby, 'Letters to a Friend'; notes for 3 Gs (?).

LVIII-LX. MH/B.16f. [Three Guineas] 3 bound volumes containing Press Cuttings \& extracts collected or copied by VW relative to 3 Gs.

LXI. MH/B.17a. [Roger Fry] Covered loose-leaf book labelled on spine: R.F./Bellini/Letters to Sir E. Fry 1893 - R's Books Ms notes. 


\section{[ APPENDIX A ]}

LXII. MH/B.17b. [Roger Fry] Covered loose-leaf book labelled on spine: Roger Fry/Early Art $\mathrm{s} /$ Extracts. Ms notes.

LXIII. MH/B.17c. [Roger Fry] Covered loose-leaf book labelled on spine: Roger/Misc. Early Articles ... Ts \& ms notes.

LXIV. MH/B.17d. [Roger Fry] Large covered loose-leaf book labelled on front: Extracts from letters to: Bob Trevelyan (\&c) Ms \& ts.

LXV. $\overline{\mathrm{MH}} / \mathrm{B} .17 \mathrm{e}$. [Roger Fry] Large covered loose-leaf book labelled on front: Letters to Goldie/Helen Fry/Charles \& Marie Mauron.

LXVI. MH/B.17f. [Roger Fry] Large covered loose-leaf book labelled on spine: Extracts from Letters to Helen Anrep/ 1924 to $193467 \mathrm{pp}$ ts.

\section{Yale University Library \\ (Beinecke Rare Book and Manuscript Library)}

LXVII. Notes on Oliver Goldsmith. 22 pp. 


\section{APPENDIX B: CHRONOLOGICAL CHART}

Virginia Woolf's reading notebooks do not fall into any simple chronological order. Her notes for a single year are often spread through several notebooks, and individual notebooks often contain entries from several different years. The following chart provides' a chronological map of the notebooks. Reading horizontally, users can identify which volumes contain notes from a particular year; reading vertically, they can see how many years a single notebook spans. When a notebook includes material that cannot with certainty be assigned a definite date, all the possible years are provided. For example, Volume XLII, notes on Hardy, appears in the rows for 1919 to 1921 as well as 1929; Volume XXVI, a composite of loose pages, is listed after each year that pertains to its entries. Volumes LXI-LXVI, Woolf's notes for Roger Fry: A Biography, have all been listed as ranging from 1935 to 1940.

Within the map, the volumes have been arranged in such a way as to suggest, where possible, the interconnections among them. The notebooks that chart the development of The Common Reader, for example (XXX, XXXVIII, XLIX, XXV, XIX, XLVII), are grouped to indicate the progression of Woolf's reading for that work. With the exception of Volumes XXVI and LXI (one entry), the notebooks that contain material for Three Guineas (VII, X, XXXIII, XXXIX, LVLX) are grouped together between 1931 and 1938. Similar groupings exist for "Phases of Fiction" and Woolf's reading for The Common Reader: Second Series.

The notebooks fall into two groups: 1905 to 1911 and 1918 to 1941. No notes are recorded in this guide for 1912 through 1917. 


\section{YEAR}

$\begin{array}{lr}1905 \text { XXVII } & \text { XXXV } \\ 1906 & \text { XXXV } \\ 1907 \text { XXVIII } & \text { XXXIV } \\ 1908 \text { XXIX } & \text { XXXIV } \\ 1909 \text { XXIX } & \text { XXXIV } \\ 1910 & \end{array}$

1911 XXIX

1912

1913

1914

1915

1916

1917

1918 XXX XXXVIII

1919 XXXVIII XXXI III II XLIV XLI XLII

1920 XXXVIII XLIII XLII

1921 XXXVIII XLIX XLII

XXVI

1922 XXXVIII XLIX XXV XIX

XXVI

$1923 \quad$ XXV XIX XLVII

$1924 \quad$ XVIII XXV XIX XLVII $\quad$ XXVI

$1925 \mathrm{~V} \quad \mathrm{XVIII} \quad \mathrm{XLVII}$

1926 IV L XVIII XV XXV

1927 XIV XLVI XV XXV XXVI

1928 XIV XLVI XIII LII $\quad$ XXVI

1929 XIV XLVI XIII IX XX XII XLVII

$1930 \quad$ XIII XX XII XXII XXVI

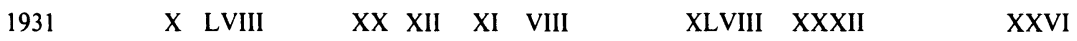

1932 XXIII $X$ LVIII $\quad X X \quad$ XI VIII XXII XLVIII XXXII

1933 XXIII X LVIII $\quad$ LIX LX LIII LXVII I

1934 XXIII $X \quad$ LIX $\quad$ LX $\quad$ XLV

$1935 \quad X \quad$ XXXIII XXXIX LV LVI $\quad$ LIX $\quad$ LX $\quad$ XLV LI $\quad$ LXI-LXVI $\quad$ XXVI

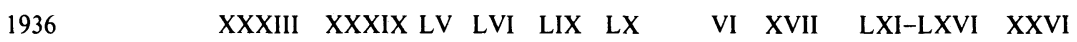

1937 LVII VII $\quad$ XXXIII XXXIX LV LVI LIX LX $\quad$ VI $\quad$ XL $\quad$ LXI-LXVI XXVI

$1938 \quad$ VII XXXIII XXXIX LIV XXXVII $\quad$ LXI-LXVI XXVI

1939 XXIV XXI XXXIX LIV XXXVII XXXVI $\quad$ LXI-LXVI XXVI

1940 XXIV XXI XVI XXXVII XXXVI $\quad$ LXI-LXVI XXVI

1941

XVI XXXVII XXXVI 


\section{GENERAL INDEX}

The General Index lists the authors and subjects included in the sixty-seven volumes of reading notes and my general introduction. References to the latter are to page numbers; other references are to volume and entry number (e.g., II, B.1). An " $i$ " following a volume number (II, i) refers to the introduction of that particular volume. Items found in the tables of contents to a volume (A) are included only if they do not appear in the entries (B). For the most part Virginia Woolf's essays and books are listed by subject rather than title in the General Index. A separate Title Index to Virginia Woolf's Published Works appears at the end of the General Index.

Abercrombie, Lascelles, Thomas Hardy, XLII, B.1

abortion, LVIII, B.9

Adam, H. Pearl, "Are Women So Hateful?"

LX, B.55

Addison, Joseph, 6

Addison (Courthope), II, B.11

“Addison"'(Johnson), II, B.2

“'Addison, Joseph, D.D." (Stephen), II, B. 1

Cato, II, B.3

"The Life and Writings of . . ." (Macaulay), II, B.4, 5, 7

Pope on, II, B.8

Sir Roger de Coverley, II, i, B.9

The Spectator, II, i, B.9, 10

Spence's anecdotes about, II, B.6

The Tatler, II, B.5

VW essay on, II, i

Addleshaw, Percy, Sir Philip Sidney, XX, B. 14

addresses, XIII, B.8; XLVI, B.15; XLIX, B. 2

Adeane, J. H., The Girlhood of Maria Josepha Holroyd, VI, B.16

Aeschylus:

Agamemnon, XXV, i, B.24

The Choephori, XXVIII, i, B.1

“Aeschylus, Agamemnon, Holograph English translation of"' (VW), XXV, i aesthetics:

French, XXXVIII, B.1

of Roger Fry, LIV, i, B.3

Ainger, Alfred, Lectures and Essays, XXXV, B.34

Aitken, George A., ed., Later Stuart Tracts, III, B.8

“Albatross, The," VW heading, XXXVI, i

Alighieri, Dante, 18

The Inferno, XIII, i

Purgatorio, LI, i, B.1

VW on, XIII, i, B.22; XLIX, B.32

Alington, C. A., Things Ancient and Modern, VII, B.5, 12; XXXIII, B.7, 22; LIX, B.68

Amberley Papers, The, VI, i, B.17

Anderson, Elizabeth Garrett, LX, B.24

"Anon"' (VW), 17-18, 26

“' 'Anon' and 'The Reader,', VW notes for, XVI, i, B.3; XXI, i, B.5, 6; XXXVII, i

Anrep, Helen, Roger Fry's letters to, LXIV, i, B. 2, 3, 5; LXVI, i, B.1, 4

"Answers to Correspondents," VW title for Three Guineas, XXXIX, i; LIX, i

Antony Viscount Knebworth, see Knebworth Apperley, Charles James, see Nimrod Archbishop's Commission, The Ministry of Women, VII, B.12; XXVI, B.3, 6; LXI, B. 8 


\section{[ INDEX ]}

Aristophanes, 15-16

The Birds, XIX, i, B.35

compared to English humor, XIX, i

The Frogs, XXXIV, B.13-14

Aristotle, The Poetics, XXV, B.36

Arlen, Michael, Men Dislike Women, LX, B. 55

army:

Aldershot Tattoo, LX, B.1

cavalry relics, LIX, B.77

Duff Cooper on, LX, B.8

ideal of, LX, B.1

Labour party support for, LX, B.41

more recruits for, LX, B.59

need for, LIX, B. 11

uniforms for, LX, B.8, 63

women recruits for, LX, B.59

Arnold, Matthew, "General Introduction' to

The English Poets, XXXVIII, B.3, 7

art, and politics, LIX, B.37; LX, B.37, 70

VW on, XXXIX, i, B.2

"Art of Writing," VW heading, 20;

XXXVIII, B.9, 10

Astell, Mary, VII, B.12; X, B.7; XXVI, B.7

Auden, W. H., "Introduction" to The

Poet's Tongue, XLV, B.15

Austen, Jane, 15

The History of England, XLIX, B.15

Love and Friendship, XLIX, B.21

Northanger Abbey, XIV, i, B.4

Pride and Prejudice, XLVI, B.18

VW essay on, XLIX, i

VW on, XIV, B.4

autobiography, VW on, XLV, i, B.3;

XLVIII, B.9, 11

Bacon, Sir Francis, Essays and Colours of Good and Evil, XXXVII, B.15

Bagehot, Walter, letter to Emily Davies, LVIII, i, B.8

Baldwin, Lady Lucy, LX, B.13

Baldwin, Oliver, The Questing Beast, LVIII, B.7

Baldwin, Stanley, LIX, B.35; LX, B.14

Barlow, Jane, By Beach and Bogland, XXXV, B.8

Bartholomew, Lily and Percy, IX, B.16

Beale, Dorothea, LVIII, i, B.49; LX, B.74

Beau Brummell:

The Life of . . . (Jesse), XX, B.6
VW essay on, IX, i; XX, i

VW notes for essay, IX, B.6; XX, B.8

in Wilson's Memoirs, XX, B.7

Beaumont, Francis:

The Maid's Tragedy, XIX, B.37

The Two Noble Kinsmen, XIX, B.17

Beckford, Peter, Thoughts on Hunting, XXV, B.19

Bell, Gertrude, The Earlier Letters, LIX, B.84

Bell, G.K.A., Randall Davidson, Archbishop of Canterbury, LX, B.52

Bell, Julian, letter to VW about Roger Fry, LXIV, i, B.16

Bell, Quentin, Virginia Woolf: A Biography, LVII, i, B.1; LX, i, B.54

Bell, Vanessa, Roger Fry's letters to, LXI, B.5; LXIV, i, B.17; LXVI, B.2

Bellini, Giovanni, Roger Fry on, LXI, B.3

Benda, Julien, Belphégor, XXXVIII, i, B.1

Bennett, Arnold, Riceyman Steps, XIX, B. 11

Bennett, H. S., The Pastons and Their England, XLIX, B.8

Benson, Arthur Christopher: Memories and Friends, XIX, i, B.7 The Trefoil, XIX, B.5, 13

Bentley, Richard: The Life of . . . (Monk), XLIX, i, B.1 "Richard Bentley', (De Quincey), XXV, i, B.14 VW essay on, XLIX, i

Berry, Miss Mary, "Advertisement" to Walpole's Letters, XLIV, B.9

Betham, Ernest, ed., A House of Letters, XXXV, B.55

Between the Acts (VW), 11, 18, 25-26

"[Between the Acts] Holograph fragment" (VW), LXIV, i

Bevan, F. A., letter to VW, LIX, B.16

Beveridge, Sir William, Changes in Family Life, LVIII, B.2

Bewick, William, Life and Letters of ... , XXIV, i, B.6

Bibesco, Elizabeth, letter to VW, LIX, i, B.81

Bickley, Mary, 17, 21; XLVII, i, B.31

Binyon, Laurence, LXII, B.1cc

biography, VW on, 7; X, i; XIV, i; XLV, i, B. 1, 3; XLIX, B.27; LXI, B.6 
Birch, Thomas, Memoirs of the Reign of Queen Elizabeth, XXXVII, B.5

Birrell, Augustine:

Collected Essays and Addresses, XIII, i, B.18; XX, i

Et Cetera, XIII, B.19; XX, i, B.13

Bishop, Cecil, Women and Crime, LVIII, B.38

Blackham, Robert J., Sir Ernest Wild, VII, B.12; XXXIII, B.20; LIX, B.66

Blackwell, Elizabeth, XVI, i, A.1, A.2 Pioneer Work in Opening the Medical Profession to Women, XXXVII, i, B.1

Blake, William, XXXVIII, B.19

Blunt, Wilfred Scawen, My Diaries, LV, i, B.3; LIX, B.85

Bonnefon, Paul, Montaigne, XX, i, B.4; XXVI, i, B.23

Booth, Catherine Mumford, LX, B.47

Booth, Margaret, The Brown House and Cordelia, XXXV, B.21, 36

Booth, General William, LX, B.47

Boswell, James:

biography of (Tinker), XLIX, B.10

The Life of Samuel Johnson, VI, B.4; XIII, B.13; XLV, i, B.1; XLVI, B.1; LIII, B.5; LXVII, B.2

Bott, Alan, Our Mothers, X, i, B.4; LVIII, B.62

Bowdler, John, LVIII, B.15

Bowdler, Thomas, Memoir of the Life of John Bowdler, LVIII, B.15

Bradley, A. C., Shakespearean Tragedy, XXIX, B.6

Brandes, Georg, William Shakespeare, XXXVIII, B.15

Bridges, Robert, Roger Fry's letters to, LXIV, i, B.14

Bridges, Sir Tom, obituary of, XXXVI, B.2

Brighton Conference, see Labour party

Brittain, Vera, "A Woman's Notebook," LVIII, B.54

Broadbent, Sir William, The Life of ... , VII, B.12; XXXIII, B.8; LX, B.72

Brontë, Charlotte, IX, B.2

Brooke, C. R. Tucker, ed., The Works of Christopher Marlowe, XXV, B.12, 13

Brooke, Rupert, Letters from America, XLIV, B.5
Brown, Vincent, Mrs. Grundy's Crucifix, XXXV, B.58

Browne, Sir Thomas:

“Dr. Johnson's Life of ... ," XXV, B.21a

The Garden of Cyrus, XXV, B.21d imitation of, XVII, B.2

Letters, XVII, i, B.1

Religio Medici, XXV, B.21e; XXXVIII, i, B.2; XLIX, B.32

Urn Burial, XXV, B.21a, 21c

VW essay on, XXV, i, B.21b

Browning, Elizabeth Barrett, 8, 23

Elizabeth Barrett Browning in her Letters (Lubbock), XXXV, B.51

Letters, XXXII, B.1, 13, 15, 17; LVIII, i, B. 42

Letters: 1845-1846, XXXII, B.3, 12

Letters Addressed to Richard Hingist Horne, XXXII, B.9

Letters to her Sister, XXXII, B.4, 14 on The Princess (Tennyson), LVIII, B.42

Browning, Robert:

Letters: 1845-1846, XXXII, B.3, 12

Robert Browning and Alfred Domett, XXXV, B.52

Brummell, G. B., see Beau Brummell

Brunètiere, Ferdinand, XVIII, B.2

Brunton, Mary, "Extracts from a Journal," XLVIII, B.5

Buchan, John, Francis and Riversdale Grenfell, LVI, B.7

Buckingham, Duke of (George Villiers), The Rehearsal, XXIX, B.20; XLVII, B.9

Buckingham, James Silk: James Silk Buckingham, 1786-1855

(Turner), LV, B.11

Autobiography, XLVII, B.26

Bullock, Shan F., Dan the Dollar, XXXV, B.32

Bulwer, E. L., "Some Thoughts on the Genius of William Hazlitt," XXII, B.4

Bunyan, John, Pilgrim's Progress, XXIII, B.5

Burgin, G. B., The Devil's Due, XXXV, B.19, 36

Burke, Edmund, Reflections on the Revolution in France, XXXVI, i, B.7

Burnet, Gilbert, Bishop of Salisbury, LV, B.14 


\section{[ INDEX ]}

Burney, Dr. (Charles):

in Boswell's Life of Samuel Johnson, XIII, B.13

Memoirs of . . . (D'Arblay), XIII, B.11, 15

VW essay on, IX, B.5; XIII, i, B.9; XLVI, $\mathrm{i}$

Burney, Frances (Fanny):

in A Room of One's Own, XLVI, i, B.17

in Boswell's Life of Samuel Johnson, XIII, B.13

Diary and Letters of Madame D'Arblay, XIII, B.9

The Early Diary, XIII, B.10, 12, 14, 21

Fanny Burney and her Friends, XLVI, i, B.17

Memoirs of Dr. Burney, XIII, B.11, 15

"Burning of the Vote, The," VW entry,

LVI, i, B.3

Burt, Cyril, "The Psychology of the

Sexes," LIX, B.21

Burton, Robert, The Anatomy of Melancholy, XVI, i, B.13, 16

Butler, Josephine, VII, B.12; XXVI, B.16

Butts, Mary, The Crystal Cabinet, VII, i, B.6, 12

Byron, Lord George Gordon:

Correspondence, XLIX, i, B.27

Life of . . . (Moore), XX, B.6

"Byron and Mr. Briggs" (VW), 12; XLIX, i, B. 25

Cabot, James Eliot, A Memoir of Ralph

Waldo Emerson, XXIX, B.16

Cambridge Modern History, The, 7; XXXV, B.2, 11

Cambridge University:

allowances at, LIX, B.58

Clare College, LVIII, B.53

in the eighteenth century (Winstanley), LV, B.12

endowments of (Clark), LV, B.12; LIX, B. 90

Gibbon on, LIX, B.94

Girton College, LVIII, B.8. See also Davies, Emily

income of, LIX, B.70

jobs for women at, LIX, B.16

King's College, LIX, B.36
Newnham College, LIX, i, B.10; LX, B.39

Peepholes, LX, A.2, B.71

reminiscences of (Gunning), XLV, B.16;

LV, B.12; LIX, B.90

scholarships, LX, B.85, 86

social intercourse at, LVIII, B.61

Campbell, Roy, The Georgiad, LVIII, B.71

Canning, Charlotte, Countess, XVIII, i, B.5

capitalist system, LIX, B.25

Carlyle, Jane Welsh:

Letters and Memorials, XIII, B.3

Letters to her Family, XIII, B.1

New Letters and Memorials, XIII, B.2

Selections from the Letters of Geraldine Jewsbury to ..., XIII, B.4

VW essay on, XIII, i

Carlyle, Thomas, History of . . . Friedrich II of Prussia, XXXV, B.29, 30

Carr, William Guy, By Guess and by God, LVIII, B.25

Carroll, Lewis:

The Complete Works, XXXIX, i

Letters to his Child Friends, XXXIX, i, B. 4

Carter, Mrs. Elizabeth, XXXV, B.49;

XLVII, B.35

Cartwright, Major John, XLIX, B.27

Catullus, XLIX, i, B.9

Caxton, William, printing press, XXXVII, B.8

"Cerebration," VW heading, XXI, i, B.1

Cézanne, Paul, Roger Fry on, LXIII, B.6

Chambers, E. K.:

The Medieval Stage, XVI, i, B.2

William Shakespeare, XXXVII, B.13

Chaplin, Henry, VII, i, B.7, 12

Chapman, George, Bussy D'Ambois, XLVII, B.4, 8

Chapman-Huston, Major Desmond, The Lost Historian, LV, B.7; LIX, B.89

Charteris, Hon. Evan, John Sargent, LXIII, B. 12

Chateaubriand, François René de, Memoires d'Outre Tombe, VII, i, B.12; XXVI, i, B.10; XLV, i, B.11, 12

Chaucer, Geoffrey:

Arnold on, XXXVIII, B.3

The Canterbury Tales, XLVII, B.30;

XLIX, i, B.15, 16, 18 
Chaucer, Geoffrey (cont.)

"Chaucer" (Lowell), XXXVIII, B.4

Chaucer and His England (Coulton), XLIX, B.4

Dryden on, XLIX, B.29

life of, XLIX, B.14

Troilus and Criseyde, XLIX, B.17

Chesterfield, Lord (Philip Dormer Stanhope):

Characters, XIV, B.8; XLVIII, B.8

Letters, XIV, B.7; XLVI, B.1

VW essay on, XIV, i; XLVI, i; XLVIII, i

Chesterton, G. K., "Introduction"' to $A$. $R$.

Orage (Mairet), LX, B.18

childbirth:

analgesics for, LX, B.13

maternity death rate, XXVI, B.15; LX, B.6, 13, 21

"Spectator on," VW entry, VII, B.12

views of medical men on, LVIII, B.11

children:

equal guardianship of, LX, B.77

"more babies" campaign, LX, B.10

nonmaintenance of, LIX, B.43

women refusing to have, LX, B.30

church, the:

called on to reject pacifism, LIX, B.33

as family, LX, B.66

fund raising for, LIX, B.3

"horror of" (VW heading), LIX, B.86

ordination of women, LVIII, B.68; LX,

B.66, 68

revival of interest in, LVIII, B.60

seeks unity, LX, B.28

training colleges for women closed, LX, B. 23

on war, LIX, B.78, 79; LX, B.28

women in, XXVI, B.3, 26; LXI, B.8

See also clergy

Churchill, Winston (American author), Coniston, XXXV, B.62

Churchill, Winston S.:

Marlborough, XLV, B.1

on T. E. Lawrence, LIX, B.39

Thoughts and Adventures, LVIII, B.57, 59

circulars (sent to VW), LX, B.39, 51, 69,

70. See also letters (to VW); manifestoes

"Civilization" ("Madame de Sévigné”), LIV, i

civil service, VII, B.4; LVIII, B.21, 28, 63

Clark, J. W., ed., Endowments of the Uni- versity of Cambridge, LV, B.12; LIX, B.90

Clarke, T.E.S., A Life of Gilbert Burnet, Bishop of Salisbury, LV, B.14

Clay, Virginia Clopton, A Belle of the Fifties, XXXV, B.1

Cleopatra, VW on, XLVII, B.1, 2

Clephane, Irene, Our Mothers, X, i, B.4; LVIII, B.62

clergy:

attack on works of artists and authors, LX, B.67

celibacy vs. marriage of, LX, B.65

vicar resigns living, LX, B.29

Clifford, Lady Anne, 5, 8-9

Diary, XVI, i, B.14; XIX, i, B.3

Lady Anne Clifford (Williamson), XVI, i, B.15; XXXVII, i, B.18; XLVIII, i, B.2

VW's interest in, 5; XLVIII, i

Clifford, James L., Hester Lynch Piozzi-

Mrs. Thrale, XVI, i, B.9, 12

Clough, Anne Jemima, X, i, B.5; LV, i, B.2; LVIII, B.56

Clough, Blanche Athena, A Memoir of Anne Jemima Clough, X, i, B.5; LV, i, B.2;

LVIII, B.56

Coatmellec, Josette, Roger Fry on, XXVI, B.18, 19

Cobden-Sanderson, Thomas James, Journals, XXV, i, B.40

Cole, William, The Blecheley Diary, VIII, B.1

Coleridge, Samuel Taylor, 17

Biographia Literaria, XXX, B.2, 5; XXXVIII, B.5

Coleridge the Talker, XXIV, i, B.1

in The House of Letters (Betham), XXXV, B.55

Omniana, XXX, B.3

The Table Talk and Omniana, XXX, B.3, 4

VW essays on, XXIV, i; XXX, i

Coleridge, Sara, XXIV, i, B.2

"College amenities," VW heading, LX, B.4

Collier, J. Payne, XLV, B.10

"The Life of Spenser," XXV, B.18a; XXXVII, i, B.9

Collyer, Margaret, Life of an Artist, VII, B.12; XXXIII, B.16; LIX, B.12, 62

"Colour in Poetry," VW entry, 13; XXIII, i, B.4 
color sense, VW on, 13; XLV, i, B.14

Colvin, Sidney, John Keats, XXX, i, B.2

"Common History book" (VW), 4. See also " 'Anon' and 'The Reader',

Common Reader, The (VW), 15, 16-17, 20 21

Common Reader, The: Second Series (VW), 20

Congreve, William:

Comedies, XVIII, i, B.9

The Double Dealer, XL, B.2, 11

Life of . . (Gosse), XL, B.5

Love of Love, $\mathrm{XL}, \mathrm{B} .3,8,11$

The Old Bachelor, XL, B.1

Steele on, XL, B.6

"To the Right Honourable Ralph, Earl of Mountague," XL, B.7

VW essays on, XVIII, i; XL, $\mathrm{i}$

VW notes for essay, XL, B.4, 9, 11

The Way of the World, XXIX, B.21; XL, B.6, 7, 10

Conrad, Joseph:

Almayer's Folly, XXV, B.3d

Amy Forster, XXV, B.3h

Chance, XXV, B.3a, 3j

Falk, XXV, B.3h

on fiction, XXV, B.3e

list of works, $\mathrm{XXV}, \mathrm{B} .3 \mathrm{~b}$

Lord Jim, XXV, B.3f

The Nigger of the Narcissus, XXV, B.3g;

XLVII, B.36

Nostromo, XXV, B.3k

An Outcast of the Islands, XXV, B.3e

Some Reminiscences, XLVII, i, B.34

Tales of Unrest, XXV, B.3c

To-morrow, XXV, B.3h

VW essays on, XXV, i; XLVII, i

VW on, XXV, B.3f, 3g, 3j, 3k

Youth and Other Stories, XXXV, B.3j

Coombe, Helen, see Fry, Helen

Cooperative Women, Life as We Have

Known It, XII, i, B.5, 6

Corinthians, LIX, i, B.92

"Corrections and Additions to the Second

Common Reader" (VW), XLVIII, i

Coudray, H. du, Another Country, XLVI, i, A. 2

Coulton, G. G., Chaucer and His England, XLIX, B.4
"Countess of Pembroke's Arcadia, The" (VW), 4-5

"Country in London, The," VW diary entry, 5-6, 11

Courtenay, Thomas Peregrine, Memoirs of Sir William Temple, XLVIII, B.5

Courthope, William J., Addison, II, B.11

Cowley, Abraham, XLVII, B.10

Cowper, William:

Correspondence, IX, B.1; XXIX, i, B.5

The Life of . . (Wright), IX, i, B.4

The Task, IX, i, B.3

VW essay on, IX, $\mathrm{i}$

VW on, IX, B.6

Crabbe, George:

The Borough, XXIX, B.15

"Memoir of . . .," XX, B.6

VW essay on, $\mathrm{X}, \mathrm{i}$

VW on, X, B.3

Crichton-Browne, Sir James, The Doctor's Second Thoughts, LVIII, B.70

criticism, VW on, V, i; XIV, B.9; XVIII, i; XIX, i; XXII, i; XXXVIII, i; XLV, i;

XLVI, i; XLVII, i, B.31; XLVIII, i; XLIX, i, B.24, 26-27, 30-35; LVI, B.2;

LXVII, i. See also journalism; reading; reviewing

Cross, J. W., George Eliot's Life, XLI, B.2

Cross, Wilbur L., The Life and Times of Laurence Sterne, XLVI, B.12, 13

culture:

International Association of Writers for the Defence of . . , LX, B.70

"seule la ... désinteressée," newspaper headline, LX, B.37

Cuming, E. D., Robert Smith Surtees, XIX, i, B.8

Curtin, T. J., "Civil Service Women," LVIII, B.63

Cuthell, Edith E., Wilhelmina, Morgravine of Baireuth, XXXV, B.29

Dalziel, Hugh, British Dogs, XXXII, B.5, 16,19

Dante, see Aligheri, Dante

D'Arblay, Madame, see Frances Burney

Darton, F. J. Harvey, English Fabric, XXXIII, B.19; LIX, B.65

Davidson, Randall, Archbishop of Canterbury, LX, B.52 
Davies, Emily:

Emily Davies and Girton College, XLVI, i, LVIII, B.35; LX, B.76

letter from Bagehot, LVIII, i, B.8

Life of . . . (Stephen), IX, i, B.8

Dawson, A. J., The Fortunes of Farthings, XXXV, B.12

Debenham, Mary, A Flood Tide, XXXV, B.22

Defoe, Daniel, 14-15

compared to Norris, XXV, B.32

compared to Stevenson, XXV, B.28

Daniel Defoe (Lee), XXVI, B.28

"Defoe, Daniel" (Stephen), III, B.4

"The Education of Women," III, B.8, 9

The Life, Adventures, and Piracies of

Captain Singleton, III, B.2

The Life of Colonel Jack, III, B.3, 9

The Life of . . . (Wright), III, B.1, 5, 9

Moll Flanders, III, i, B.7

"Preface to the Eighth Volume of the Review," III, B.8

Robinson Crusoe, 21; IV, i, B.1; XLVIII, i, B.4

Roxana, III, B.6; XXV, B.31, 32

A System of Magick, XXXVII, B.5

VW essays on, III, i; IV, i; XLVIII, i

VW on, III, B.10

on his work, III, B.3

Deighton, K., Introductions to Shakespeare's plays, XXVI, B.25a, 25c, $25 \mathrm{f}$

Dekker, Thomas, XXXII, i, B.21

Old Fortunatus, XIX, B.25

The Witch of Edmonton, XIX, B.26

The Wonderful Yeare, XI, B.3; XIX, B.39; XLVIII, i, B.1

Delapré, Louis, The Martyrdom of Madrid, LX, B.33

De Quincey, Thomas:

Autobiographic Sketches, XXXV, B.63;

XLVIII, i, B.10

Confessions of an English Opium-Eater, XLVIII, B.9

“De Quincey" (Stephen), XXV, B.39

Diary, XLVI, A.2

The English Mail Coach, XV, i, B.4

Recollections of the Lakes and Lake Poets, XX, B. 10

“'Richard Bentley," XXV, i, B.14
VW essays on, XV, i; XXV, i; XLVIII, i VW on, XXV, B.39; XLVIII, B.9, 11

Desart, Earl of (H.J.A. Cuffe), A Page from the Past, VII, B.12; XXXIII, B.5; LIX, B.55

Devonshire, Duchess of, VW on, IX, B.6

Diamand, Pamela Fry, Roger Fry's letters to, LXIV, B.15

"[Diary] Christmas 1904-May 31, 1905, No. 3"' (VW), XXVII, i; XXXV, i

Dicey, A. V., Lectures on the Relation Between Law and Public Opinion, XXVII, i, B. 2

Dickens, Charles:

Bleak House, XIV, B.5, 10; XLVI, B.16

David Copperfield, V, i, B.7

Kitton on, XXXV, B.4

VW on, XIV, B.5; XXXV, B.6; XLVI, B.16

Dickinson, G. Lowes, 23

Goethe and Faust, LVIII, i, B.32

Roger Fry's letters to, LXIII, i, B.3, 5; LXV, i, B.1

dictators, 24; LV, B.5; LVI, i; LIX, B.87

Dictionary of National Biography, 6-7 Addison, Joseph (Stephen), II, B.1 Defoe, Daniel (Stephen), III, B.4 Hazlitt, William (Stephen), XXII, B.5 Mitford, Mary Russell (Lee), XXXII, B.8 Shakespeare, William (Lee), XLVII, B.24

Dillon, Arthur, King William I, XXXV, B.37

"Discourse for 4 voices, A," VW title for book, 17; XLV, i, A.2

Disraeli, Benjamin, Coningsby, LVIII, i, B. 29

Dixon, Richard Watson, The Correspondence of Gerard Manley Hopkins and . . . , XLV, B.13

Dixon, W. MacNeile, Tragedy, XLVII, B.7

Dobrée, Bonamy:

"Introduction" to Congreve's Comedies, XVIII, i, B.9

Restoration Comedy, XLVII, i, B.16

Dobson, Austin, Horace Walpole, XLIV, B.11

doctors:

nurses and, X, B.12

osteopaths, LX, i, B.46 
See also medical profession; men, as doctors; women, in medicine

Domett, Alfred, XXXV, B.52

Donne, John, 5, 21, 23

The Life and Letters of . . (Gosse), XI, B.4; XX, B.12; LVIII, i, B.6

Poems, VIII, i, B.3; XIX, B.14, 40

Poetical Works, XI, B.4

VW essay on, VIII, i; XI, i

VW notes for unwritten essay, XLVII, $i$, B.31

VW on, XI, B.4

"Donne After Three Centuries" (VW), 9

Dostoevsky, Feodor:

The Possessed, XIV, B.14; XLVI, B.19

VW on, XLIX, B.28

drama, VW on, 13, 15-16; XIX, B.21;

XXV, B.2; XXIX, B.20, 22-24;

XXXVIII, B.16; XL, B.9; XLVII, B.2, 3,

9, 18. See also Elizabethan drama; novels dress, 23-24

at Ascot, LIX, B.73; LX, B.2

"Buttons," XXXVI, B.5

for coronation of George VI, LIX, B.41, 80

of Count Ciano, LIX, B.26

for funeral of George V, LIX, B.2

of Heralds, LIX, B.76

of Major Fey, LIX, B.6

of Pope, LIX, B.72

See also uniforms

Drummond, Flora, "Votes for Women," LX, B.56

Drummond, William, XXV, B.16

Dryden, John, 16

All for Love, XLVII, B.2

An Essay of Dramatic Poesy, XXX, B.8

"Preface to the Fables," XLIX, i, B.29

Dudley, Lady Georgina, obituary of, XLVI, i, A.2, B.22

Duff Cooper, Alfred, LIX, B.33; LX, B.8

Dumesnil, René, Guy de Maupassant, XXVI, B.24a

Durant, W. Clark, A Supplement to the Memoirs of Mary Wollstonecraft, IX, B.11

Earhart, Amelia, Last Flight, VII, B.12; XXVI, B.12
Easdale, Joan Adeney, Amber Innocent, X, i, B.13

education, see men, education of; women, education of

Egan, Michael, The Dominant Sex, LX, B.55

Einstein, Albert, letter to Ethel Smyth,

LVIII, B.17

"Electric Magneto Torch, The," XIX, B.12

Eliot, George, 15

Adam Bede, XLI, B.4

compared to Henry James, XIV, B.12

George Eliot (Williams), LV, B.10

George Eliot's Life as Related in her Letters and Journals (Cross), XLI, i, B.2

Middlemarch, XLI, i, B.8

The Mill on the Floss, XLI, B.6

Sayce on, XIX, i, B.46

Scenes of Clerical Life, XLI, B.3

Silas Marner, XIV, B.11; XLI, B.7

VW essay on, XLI, i,

VW on, XLI, B.2, 5

Eliot, T. S.:

Murder in the Cathedral, XLV, i, B.14

The Sacred Wood, XXXVIII, i, B.8

The Wasteland, XIX, i, B.48

Elizabethan drama, VW on, 15-16, 20; XIX, i, B.26, 29, 38; XXV, i, B.2, 6;

XXXVII, B.16; XXXVIII, B.18; XLVII, i, B.3. See also "Notes on an Elizabethan Play"; Shakespeare, William; "Some Elizabethans and Montaigne"

"Elizabethan Lumber Room, The" (VW), 9 , 16-17, 20; XIX, B.22

Elizabethan period, book list, XXXVII, B.5

Elizabethan prose, VW on, 3, 11, 20; XI, B.3, 10; XIX, B.39; XX, B.15; XXXV, B.50; XXXVII, i; XLVIII, B.1. See also "Some Elizabethans",

Elizabethan writers, VW on, 15, 16, 20; XI, i, B.10; XII, i, B.1, 4; XVI, i; XIX, i, B.22; XX, i; XXXVII, B.4; XLVII, i list, XII, B.1

Ellis, Havelock, ed., John Ford, XIX, B.19, $22,27,36$

Emerson, Ralph Waldo:

"The Conduct of Life," XXIX, B.18

A Memoir of . . (Cabot), XXIX, B.16

"Society and Solitude," XXIX, B.18

VW essay on, XXIX, i 
England:

Lord Hewart's toast to, LIX, B.4, 15

"The real . . .," X, B.6

vision of, VW heading, LVI, B.5

English history, lectures by VW, 7; XXVII, i

English literature, VW history of, 4, 7-8; XVI, i; XXI, i; XXXVII, i. See also “" 'Anon' and 'The reader',"

English women, beauty of, XLVIII, B.5

Ervine, St. John, LX, B.65

God's Soldier: General William Booth, LX, B.47

Eton, LVIII, B.41; LIX, B.36. See also Alington, C. A.

Euripides, 5, 11

The Bacchae, 11; XIX, B.45, 47

The Ion, XXXIV, B.6-7

Evolution, LVIII, B.10. See also science

Faber, Geoffrey C., Oxford Apostles, LIX, i, B.95

family life:

changes in (Beveridge), LVIII, B.2

Donne and, 5; LVIII, B.6

"Fantasy upon a Gentleman . . ." (VW), LVII, B.1; LX, i, B.54

Farrer, Reginald J., The House of Shadows, XXXV, B.46

Fawcett, Millicent G., LX, B.10, 51

Josephine Butler, VII, B.12; XXVI, B.16

feminist, VW on word, LVI, i, B.1

fiction, VW on, I, 4, 10, 12, 13; XIII, i, B.17; XIV, i, B.4, 5, 10, 12, 16, 18, 20; XV, B.1; XVIII, i, B.12; XXV, i, B.10, 28, 32, 37; XXVI, i, B.1-2, 21a, 22, 33; XXIX, B.4; XXXI, i, B.3-5; XXXII, B.18; XXXV, B.3; XXXVIII, B.16; XLII, B.5; XLVI, i, B.3-4, 10, 16, 23; XLVII, B.12; XLIX, i, B.20, 28. See also novels

Fielding, Henry, XLVII, B.13

finger-nail polish, LX, B.31

Fisher, H.A.L., Pages from the Past, XXXVI, i, B. 6

Fletcher, John:

The Faithful Shepherdess, XIX, B.38

The Maid's Tragedy, XIX, B.37

The Two Noble Kinsmen, XIX, B.17

Flush, VW notes for book, XXXII, B.2, 20
Forbes-Robertson, Sir Johnston, A Player Under Three Reigns, XLVII, i, B.6

Ford, John:

The Broken Heart, XIX, B.27

The Lover's Melancholy, XIX, B.36

'Tis a Pity She's a Whore, XIX, B.19, 23

Forster, E. M., 21

Aspects of the Novel, XXV, i, B.30

Passage to India, XVIII, i, B.12

VW essays on, XV, i; XXV, i

VW heading, XLIV, B.6

VW on, XVIII, B.12

Where Angels Fear to Tread, XV, i, B.1

Forster, James, The Life and Times of Oliver Goldsmith, LIII, B.1, 3, 7

Fox, Archibald Douglas, Sir Thomas More, XXXV, B.39

Foxcroft, H. C., A Life of Gilbert Burnet, Bishop of Salisbury, LV, B.14

Frederick the Great, XXXV, B.29-31

Freeman, Edward A., History of the Norman Conquest of England, XXVII, B.1, 3

Freeman, Mary E. Wilkins, The Debtor, XXXV, B.27

Freud, Sigmund:

Group Psychology and the Analysis of the Ego, XXI, i, B.2-4

VW note on, I, B.11

Froude, James Anthony, English Seamen in the Sixteenth Century, XXXVIII, i, B.13

Fry, Agnes, A Memoir of Sir Edward Fry, XXVI, B.17, 20

Fry, Sir Edward:

A Memoir of . . . (Fry), XVI, i; XXVI, B. 17, 20

Roger Fry's letters to, LXI, A.1; LXIV, B. 1; LXV, B. 4

Fry, Helen Coombe, Roger Fry's letters to, LXIII, B.4; LXV, B.2

Fry, Lewis, Roger Fry's letters to, LXIV, B.8, 9

Fry, Margery, LXI, i; LXII, i; LXIII, i; LXIV, i

Fry, Lady Mariabella, Roger Fry's letters to, LXII, B.3; LXV, B.2c

Fry, Pamela, see Diamand, Pamela

Fry, Roger:

aesthetics of, LIV, i, B.3

at American Institute of Architects dinner, LXIII, i, B.11 
articles by, LXII, i, B.1; LXIII, B.7, 10

Cézanne typescript 1927, LXIII, B.6

"East Anglia," speech by, LXIII, B.8

essay on Josette Coatmellec, XXVI, B.18, 19

exhibition at Cartax Gallery, LXIII, B.9

Giovanni Bellini, LXI, B.3

"Introduction" to Reynolds' Discourses, XVI, i, A.1-3; XXVI, i, B.31

in John Sargent (Charteris), LXIII, B.12

John Sargent letter about, LXIII, B.12

"J. S. Sargent,"' in Transformations,

LXIII, B.12

Julian Bell on, LXIV, i, B.16

Letters of . . . (ed. Sutton), LXIII, B.4; LXIV, B.6, 8

letters to Andrée Desirée MacColl, LXIV, B.12

letters to Basil Williams, LXIV, i, B.13

letters to Bertrand Russell, LXIV, B.10

letters to Charles and Marie Mauron,

LXV, i, B.3

letters to D. S. MacColl, LXIV, B.11

letters to Duncan Grant, LXIV, B.19

letters to his father (Sir Edward Fry), LXI,

A.1; LXIV, B.1; LXV, B.4

letters to G. Lowes Dickinson, LXIII, i,

B.3, 5; LXV, i, B.1

letters to Helen Anrep, LXIV, i, B.2, 3,

5; LXVI, i, B.1, 4

letters to Helen Coombe Fry, LXIII, B.4;

LXV, B. 2

letters to L. C. Powles, LXIV, B.8

letters to Lewis Fry, LXIV, 8, 9

letters to his mother (Lady Fry), LXII, i,

B.3; LXV, B.2

letters to Pamela Fry Diamand, LXIV,

B. 15

letters to Robert Bridges, LXIV, i, B.14

letters to Robert C. Trevelyan, LXI, B.1;

LXIV, B.7

letters to Vanessa Bell, LXI, B.5; LXIV, i, B.17; LXVI, B.2

letters to William Rothenstein, LXIV, i, B. 18

letter to Bernard Shaw, LXVI, B.3

list of books, XXXVI, i, A.1

memorial service program, LXIII, B.1

in Memories of an Edwardian and Neo-

Georgian (Jepson), LXII, B.4 in Men and Memories (Rothenstein), LXI, B.7; LXII, B.2, 5

"Musical Confessions of an Outsider,"

LXIII, B.7

political views of, LXV, B:3

Post-Impressionist Exhibition, LXIII, i, B.12, 13, 14

Roger Fry (Laing), LXII, i

Vision and Design, XVI, i; XXXIX, i,

B. 1

VW notes for biography of, XXVI, B.18;

LVII, i, B.5; LXI, B.2, 4, 6; LXIII,

B.11; LXIV, B.4

Fugger News Letter, The, XXXVII, B.5

Fuseli, Henry, The Life and Writings of

. . . , IX, B.11

Fytton, Anne and Mary, XXXVII, B.16, 17

Fyvie, John, Some Famous Women of Wit and Beauty, XXXV, B.17

Gairdner, James, ed., The Paston Letters, XXXVIII, B.26, 28; XLIX, B.3, 5-7

Galsworthy, John, Swan Song, XLVI, A.2

Garnett, David, No Love, XIV, B.21

Garnett, Edward, "Introduction"' to Turgenev, Fathers and Children, I, B.7

Garrett, John, 'Introduction"' to The Poet's Tongue, XLV, B.15

Gaskell, Elizabeth, Life of Charlotte Brontë, IX, B. 2

Gaussen, Alice C. C., A Woman of Wit and Wisdom, XXXV, B.49

Gerard, Dorothea, The Compromise, XXXV, B.59

Gerhardi, William, Memoirs of a Polyglot, LVIII, B.39

Germany:

awards and decorations, LIX, B. 34

bombardment of Almeria, LX, B.17

destiny as a nation, LIX, B.75

Heidelberg University, LIX, B.1

plight of women in, LX, B.45

See also Nazi movement

Gibbon, Edward, VI

The Autobiographies of . . . (ed. Murray), VI, B.15

Autobiography of . . . (ed. Bury), VI, B.1, 3, 9

in Boswell's Life of Samuel Johnson, VI, B. 4 
Gibbon, Edward, VI (cont.)

Decline and Fall of the Roman Empire, VI, B.8, 12, 14

Gibbon (Mowatt), VI, B.11

"'The Historian and 'The Gibbon,', ' VW notes for essay, VI, i, A.2, B.2-5, 13

Memoirs of My Life and Writings, VI, B.6; LVIII, B.55; LIX, B.94

The Memoirs of the Life of . . (ed. Birkbeck Hill), VI, B.10, 13

The Private Letters of. . . (ed. Prothero), VI, B.5, 13, 18

in Read's Historical Studies, VI, B.10

"Reflections at Sheffield Park," VW notes for essay, VI, i, A.2, B.16-19

A Vindication of Some Passages, VI, B.7 VW essays on, VI, $i$

Walpole on, VI, B.13

Gibbon, Hester, VI, i, B.18, 19

Gide, André, Si le grain ne meurt, XXV, $\mathrm{i}$, B. 35

Gisborne, Thomas, An Enquiry into the Duties of the Female Sex, VII, B.12, 14

Gissing, George, The Private Papers of Henry Ryecroft, XXXV, B.60

Gladstone, William Ewart, XLV, B.1

"Glossary," VW notes on new words, LVI, i, B.1

Gloys (Priest), in The Paston Letters, XLIX, B.6

Glyn, Elinor, Romantic Adventure, LIX, B.47

Godwin, William:

Memoirs of Mary Wollstonecraft, IX, B.10, 11

William Godwin (Paul), IX, B.7

Goethe, Johann Wolfgang, LVIII, B.32

Goldsmith, Oliver, 9-10

The Bee, LXVII, B.1, 3

in Boswell's Life of Johnson, LIII, B.5; LXVII, B.2

The Deserted Village, XXIII, B.6; LXVII, B.10, 11

Essays, LIII, B.2; LXVII, B.4

The Good-Natured Man, LXVII, B.8

An Inquiry into the Present State of Polite Learning in Europe, LXVII, B.6

Letters of a Citizen of the World, LXVII, B. 14

The Life and Times of . . (Forster), LIII, B. $1,3,7$
The Life of . . (Prior), LIII, B.4

"Retaliation," LXVII, B.13

She Stoops to Conquer, LXVII, B.9

Thackeray on, LIII, B.7

The Traveller, XXIII, B.6; LXVII, B.11, 12

The Vicar of Wakefield, XXVI, i, B.1; XXXVIII, i; LXVII, B.7

VW essay on, XXIII, i; LIII, i; LXVII, $i$

VW on, XXVI, B.1; LIII, B.6; LXVII,

B.5, 9, 11, 14

“' 'Good Old Times,' The,'” newspaper cutting, LIX, B.7

Gore, Charles, VII, B.12; XXXIII, B.14;

LIX, i, B.13, 60

Gosse, Edmund:

The Life and Letters of John Donne, 23;

XI, B.4; XX, B.12; LVIII, B.6

Life of William Congreve, XL, B.5

review of The Trefoil (Benson), XIX, B.5, 13

Gourmont, Rémy de, 19

"La Leçon de Sainte Antoine,"' 19; XXXI, B.2

“M. Brunètiere,"' XVIII, i, B.2

"L'Originalité de Maeterlinck,"' 19; XXXI, B.2

Le Probleme du style, XXXVIII, B.6

"La Prose de Madame de Noailles," XXXVIII, B.23

"Villiers de L'Isle-Adam," XXXVIII, B.9

Graham, Mrs. Henry, The Tower of Siloam; 8; XXXV, B.23, 36

Grant, Duncan, Roger Fry's letters to, LXIV, B.19

Gravenitz, Wilhelmine von, XXXV, B.61

Gray, Thomas:

Correspondence, XXVI, B.26

Johnson on, 20; XXXVIII, B.11

"The Life of . . "' (Mitford), XXVI, B.27

VW essay on, XXVI, i

Greek literature, VW on, 15-16; X, i; XIX, i, B.47; XXV, i; XXXIV, B.5, 7, 11; XLVII, i

Green, John Richard, A Short History of the English People, XXXVIII, B.27

Greene, H. W., obituary of, LX, B.19

Greene, Robert, Friar Bacon and Friar Bungay, XIX, B.28 


\section{[ INDEX ]}

Grenfell, Francis and Riversdale, LVI, B.7

Grensted, Professor D. D., "Certain Psychological and Physiological Considerations," XXVI, B.6. See also The Ministry of Women

Gretton, R. H., A Modern History of the English People, XXIII, i, B.1

Greville, Fulke and Mrs., at Dr. Burney's evening party, XIII, i, B.9, 10, 13

Greville, Sir Fulke, Life of Sir Philip Sidney, $\mathrm{XX}, \mathrm{B} .15$

Grierson, Herbert J. C., ed., The Poems of John Donne, VIII, B.3; XIX, B.14, 40

Gunning, Henry, Reminiscences of the University, Town, and County of Cambridge, XLV, B.16; LV, B.12; LIX, B.90

Gwynn, Stephen, The Life of Mary Kingsley, LVIII, B.40

Hakluyt, Richard, 3, 12

Richard Hakluyt (Watson), XLVII, i, B. 15

Collection of the Early Voyages, . . . , XXXVIII, i, B.12

Haldane, Elizabeth S., From One Century to Another, XXVI, B.9; LX, B.71

Hamilton, Lord Frederic, The Days Before Yesterday, VII, B.12; XXXIII, B.17; LIX, B.63

Hamilton, Mary Agnes, VW heading, XLIV, B. 6

Hammond, Barbara and J. L., The Age of the Chartists, LV, B.13

Hardy, Florence Emily, The Early Life of Thomas Hardy, XIV, i, B.19

Hardy, Thomas:

The Art of . . . (Johnson), XXV, B.17

Collected Poems, XX, B.3

Desperate Remedies, XX, B.5; XLII, B.9, $12 \mathrm{a}$

The Early Life of . . (Hardy), XIV, i, B. 19

Far from the Madding Crowd, XLII, B.3, $12 \mathrm{c}, 13 \mathrm{c}$

"Interlopers at the Knap," XLII, B.5

Jude the Obsure, XLII, B.8

A Laodician, XX, B.1

list of works, XLII, A.2, B.7

The Mayor of Casterbridge, XLII, i, B.4, $10 \mathrm{~b}, 13 \mathrm{~b}$
The Return of the Native, XLII, B.7, 10a, 14

Tess of the D'Urbervilles, XX, B.2; XLII, B.11

Thomas Hardy (Abercrombie), XLII, B.1

Two on a Tower, XLII, B.6, 13d

Under the Greenwood Tree, XLII, B.2, $12 \mathrm{~b}$

VW essay on, XX, i; XXVI, i; XLII, i

VW notes for essay, XXVI, B.21a; XLII, B.2, 5, 7, 13a

Wessex Tales, XLII, B.5

The Woodlanders, XLII, B.12d

Hare, Augustus J. C., The Story of Two Noble Lives, XVIII, i, B.5

Harper, George McLean, William Wordsworth, XXXVIII, B. 25

Harraden, Beatrice, The Scholar's Daughter, XXXV, B.45

Harrison, George B.:

An Elizabethan Journal, XXXVII, B.4, 5

Elizabethan Plays and Players, XVI, i, B.6, 8

Harrison, Jane E., Ancient Art and Ritual, XIX, B.4

Harrison, William, Description of England in Shakespeare's Youth, XIX, B.42; XXI, i, B.5, 6; XXXVII, i, B.3

Harvey, Gabriel:

Commonplace Book, XI, B.2

Letter-Book, XI, B.8

Marginalia, XI, B.2, 9

VW on, XI, i

Works, XI, B.1; XII, B.2

Harvey, Mercy, XI, B.10

Hawthorne, Julian, Shapes That Pass, XLVI, i, A. 2

Hawthorne, Nathaniel:

Hawthorne (James), XXVI, i, B.2

on Trollope, XXV, B.26; XXVI, B.32

Hay, Marie, A German Pompadour, XXXV, B.61

Hayden, Elinor G., Rose of Lone Farm, XXXV, B.16

"Hayley, Life of,"' VI, A.2

Hazlitt, W. Carew:

The Hazlitts, XXII, B.3

Memoirs of William Hazlitt, XXII, B.2

Hazlitt, William:

Bulwer on, XXII, B.4 
Hazlitt, William (cont.)

Conversations of James Northcote, XXII, B.9

"Hazlitt, William" (Stephen), XXII, B.5 in The Hazlitts (W. C. Hazlitt), XXII, B.3 Lectures on the English Poets, XXII, B,7 Liber Amoris, XXII, B.5 list of books, XXII, B.1

Memoirs of . . .(W. C. Hazlitt), XXII, B.2

Notes of a Journey Through France and Italy, XXII, B.14

Patmore on, XXII, B.11

The Plain Speaker, XXII, B.12, 15

The Round Table, XXII, B.6

Selected Essays, XXII, B.17

Sketches of the Principle Picture Galleries in England, XXII, B.14

Table Talk, XXII, B.8, 10, 16

Talfourd on, XXII, B.4

VW essay on, XX, i, A.2; XXII, i

VW notes for essay, XXII, B.13, 15

Hazlitt, Mrs. William (Sarah Stoddart), XXII, B.5

"Journal of My Trip to Scotland," XXII, B.5

Hemans, Mrs. Felicia, XXV, i, B.41

Hemingway, Ernest, Men Without Women, XXV, i, B.30

Henderson, M. Sturge, After His Kind, XXXV, B.35, 36

Henslowe, Philip, The Diary of . . . XVI, i, B.11; XXXVII, B.10

herd instinct, VW on, XXI, B.4. See also Freud

Herder, Alexandra von, The Little Mermaid, XXXV, B.40

Herford, C. H., Ben Jonson, XI, B.6, 7

Herrick, Robert, 13; XXIII, B.4

Hewart, Gordon, Lord, LIX, B.4, 15

Hill, George Birkbeck, VI, B.10, 13

Hill, Octavia, LVIII, B.72

Hills, John Waller, XXI, i

history, VW on, 7-8, 22; XVI, i; XXI, i, B.5; XXVII, i; XXXV, B.10; XXXVII, i

Hitler, Adolf, LIX, B.28, 31

Holmes, Oliver Wendell:

The Autocrat of the Breakfast Table, XXIX, B.12

Elsie Venner, XXIX, B.14
“Oliver Wendell Holmes" (Townsend), XXIX, i

The Professor at the Breakfast Table, XXIX, B.13

VW essay on, XXIX, i

Holroyd, Maria Josepha, Lady Stanley of Alderley, VI, i, B.16-18; XXXVII, B.2

Holtby, Winifred, Letters to a Friend, LVII, B. 2

Homer, The Odyssey, XXV, i, B.23; XXXIV, B.4-5

Homewood, I. G., Recollections of an Octogenarian, X, B.2

Hookham, Paul, Plays and Poems, XXXV, B.42

Hone, Joseph, The Life of George Moore, LIX, B.50

honors, LV, B.2; LIX, B.34, 82, 85; LX, B.50

Hope, Anthony, VII, B.12; XXXIII, B.11; LIX, B.57

Hopkins, Gerard Manley, The Correspondence of . . . and Richard Watson Dixon, XLV, B. 13

Hotson, J. Leslie, The Death of Christopher Marlowe, XXXVII, B.5

Housman, Lawrence, The Unexpected Years, LIX, B.83

Howard, Lord Esme, Theatre of Life, LIX, B.54

“How Should One Read a Book?" (VW), $12-13,14,15,21,24$

"How to Read," VW entry, 11-12; XVIII, B. 4

Hughes, Charles, Mrs. Piozzi's Thraliana, XLVI, B.20

Hughes, Mrs. Harriet, Memoir of Mrs. Hemans, XXV, i, B.41

humor, VW on, 15-16; XIX, B.29, 34, 35; XXIX, B.20

Humphreys, Mrs. Desmond, see Rita

Hungerford, Edward A., ed., "Byron and Mr. Briggs," XLIX, i

Huxley, Julian:

"The Colours of Animals," LIX, B.29

"Science and the Problems of Society," LIX, B.23

The Science of Life, LVIII, i, B.10

What Dare I Think? LVIII, B.14 
Ibsen, Henrik:

Hedda Gabler, XLVII, B.11

The Master Builder, XXV, B.38

The Wild Duck, XV, B.2; XXIX, B.23

Inchbold, A. C., The Letter Killeth, XXXV, B.18

Inge, Dr. W. R., LX, B.73

International Association of Writers for the Defence of Culture, LX, B.70

International Peace Campaign, LIX, B.37, 38; LX, B.38

Jackson, Annabel Huth, A Victorian Childhood, LVIII, i, B.43

Jacob's Room, and Thoby Stephen, XLIX, i, B.9

James, Henry, 15

compared to George Eliot, XIV, B.12

The Golden Bowl, XXXV, B.3

"The Great Good Place,"' XXVI, B.21d

Hawthorne, XXVI, B.1

Letters, XLIII, i, B.1, 2

"Owen Wingrave," XXVI, B.21f

Pound on, XIX, B.6

Preface to Brooke's Letters from America, XLIV, B.5

"The Private Life," XXVI, B.21e

"Sir Edmund Orme," XXVI, B.21g

Theatre and Friendship (Robins), LVIII, B. 44

The Turn of the Screw, XXVI, B.21b

VW essays on, XXVI, $i$; XXXVIII, $i$, A.1; XLIII, i

VW on, XXVI, i; XLIX, B.20

"The Way it Came," XXVI, B.21c

What Maisie Knew, XIV, i, B.12

The Wings of the Dove, XXVI, i, B.21a; XXXVIII, i

James I, Daemonology and News from Scotland, XXXVII, B.5

J. B. (New York Times reporter), LVII, i, B.1; LX, i, A.2, B.54

Jebb, R. C.:

ed., The Ajax (Sophocles), XXXIV, B.10, 12

ed., The Antigone (Sophocles), XLV, B.1; LX, B.82

"The Growth and Influence of Classical Greek Poetry," XXXIV, B.14
Jepson, Edgar, Memories of an Edwardian and Neo-Georgian, LXII, B.4

Jerrold, Douglas, Georgian Adventure, LX, B.61

Jesse, Captain William, The Life of George Brummell, XX, B.6

Jewsbury, Geraldine Endsor:

Selections from the Letters to Jane Welsh Carlyle, XIII, B.4

VW essay on, XIII, i

Zoe, XIII, B.5

Jex-Blake, Sophia, XIV, i, A.1, 2; LVIII, B.70

The Life of . . (Todd), VII, B.12, 13; XXVI, B.4; LX, B.57

Joad, C.E.M.:

The Testament of . . , , LIX, B.96

Under the Fifth Rib, VII, B.12; XXXIII, B.6; LVI, B.3; LVIII, B.4

"Women of To-day and To-morrow," LIX, B.22

Johnson, Lionel, The Art of Thomas Hardy, XXV, B. 17

Johnson, Samuel:

"'Addison,"' II, B.2

Anecdotes of the Late . . (Piozzi), XLVI, i, B.21

in Burney's Diary, XIII, B.9

in Clifford, Hester Lynch Piozzi, XVI, B.9

on the common reader, XXXVIII, $\mathrm{i}, \mathrm{B} .11$

"Cowley," XLVII, B.10

"Gray," XXXVIII, i, B.11

The Life of . . (Boswell), VI, B.4; XIII, B.13; XLV, i, B.1; XLVI, B.1; LIII, B.5; LXVII, B.2

Life of Sir Thomas Browne, XXV, B.21a

VW on, XLIX, B.32

Jonson, Ben, 15

The Alchemist, XIX, B.29

Bartholomew Fayre, XIX, B.34; XXXVIII, B.14

Ben Jonson (Smith), XIX, B.31, 32, 34

Conversations with William Drummond, XXV, B.16

Epicoene; or, The Silent Woman, XIX, B.33

Greek comedy compared to, XIX, i

"Life of Ben Jonson" (Herford \& Simpson), XI, B.6, 7 
Jonson, Ben (cont.)

The Sad Sheperd, XIX, B.30, 31

Timber, XLV, B.9

Volpone, 11; XIX, B.32

journalism, VW on, XLIX, B.34; LVII, i,

B.1. See also criticism; reviewing

"Journal of Mistress Joan Martyn, The," (VW), 7

Joyce, James, Ulysses, 18; XXXI, i, B.1, 3 compared to Tristram Shandy, XXXI, B.3

Juvenal, Satires, XXXIV, B.1-3

Keats, John:

Endymion, XXX, B.7

John Keats (Colvin), XXX, i, B.2

Letters to Fanny Brawne, XXIX, B.17

Letters to his Family and Friends, XXXVIII, i, B.22

Kenny, Louise, The Red Haired Woman, XXXV, B.33

Kenyon, Frederic G., Robert Browning and Alfred Domett, XXXV, B.52

Ketton-Cremer, F. W., Horace Walpole, XVI, i

Keynes, John Maynard:

"Clare College," LVIII, B.53

VW heading, XLIV, B.6

Kingsley, Charles, LX, B.81, 83

Kingsley, G. H., South Sea Bubbles, XLIV, B.4

Kingsley, Mary, LVIII, i, B.40

Kitton, Frederic G., The Dickens Country, XXXV, B.4, 6

Knebworth, Antony Viscount:

Antony (Viscount Knebworth) (Lytton), VII, B.12; XXXIII, B.10, 18; LIX, B.11, 64

Toynbee on LX, B.53

Knight, Laura, Oil Paint and Grease Paint, VII, B.12; XXXIII, B.21; LIX, B.6?

Kyd, Thomas, The Spanish Tragedy, XIX, B.24; XXV, B.6

Labour party:

Brighton Conference, $\mathrm{X}, \mathrm{i}$; XXXIX, i, B.3; LVI, i, B.4; LIX, i

Bournemouth Conference, LX, B.41

Laing, Donald A., Roger Fry, LXII, i

Lane, Elinor MacCartney, Nancy Stair, XXXV, B.9
La Rochefoucauld, Duk de (François de Marsillac), LIV, i, B.1

László, Philip de, XXXVI, B.5

Latimer, Hugh, Fruitful Sermons, XVI, i, B.4

law:

"natural and eternal," LX, B.64

and public opinion, XXVII, i, B.2

See also legal profession

Law, William, VI, B.19

Lawrence, D. H.:

The Fox, XXV, B.11

Letters, LVIII, i, B.47

Reminiscences of . . . (Murry), LVIII, i, B.73

VW on, XXV, B.11

Lawrence, T. E., LIX, B.39

Layard, George Somes, Mrs. Lynn Linton, LV, i, B. 10

"Leaning Tower, The" (VW), 25; XVI, i; XXI, i; LVI, i

Leaska, Mitchell A., ed., The Pargiters, X, i; XXIII, i; LIX, i

Leathes, Sir Stanley, "Does University Education Fit Women for Life?' LVIII, B.64

Lee, Edmund, Dorothy Wordsworth, XX, B. 10

Lee, Elizabeth, "Mitford, Mary Russell," XXXII, B.8

Lee, Jennie, Tomorrow is a New Day, XXXVI, B.1

Lee, Sidney:

A Life of William Shakespeare, XXV, B.4, 10

Principles of Biography, XIV, B.1

"Shakespeare, William," XLVII, B.24

Lee, William, Daniel Defoe, XXVI, B.28

Le Gallienne, Richard, XXII, B.5

legal profession, VW on, LX, i. See also men, in legal profession

Lenin, LX, B.50

letters (to VW), LIX, i, B.3, 10, 16, 38, 81; LX, B.45; LXVI, i, B.16. See also circulars; manifestoes

Letter to an Englishman, VW title for Three Guineas, XXXIX, i

Lewis, C. Day, LX, B.70

lie-detector test, LX, B.7

"Life in Fiction," VW entry, XLVI, A.2, B.2, 3 


\section{[ INDEX ]}

Linton, Mrs. Lynn, LV, i, B.10

L'Isle-Adam, Villiers de, XXXVIII, B.9

Littlewood, S. R., LX, B.62

"Lives of the Obscure," VW heading, XVIII, i, B.5

Livingstone, Dame Adelaide, letter to VW, LIX, B.38

Llewelyn Davies, Margaret, ed., Life as We Have Known It, XII, i, B.5, 6

Lodge, Richard, A History of Modern Europe, 7 ; XXXV, B.31

Loewenstein, Prince Hubertus, Conquest of the Past, VII, B.12; XXXVI, B.13

Londonderry, Marchioness of (Edith H.V.T Stewart), Henry Chaplin, VII, i, B.7, 12

London/National Society for Women's Services, LX, i, B.36, 69; VW speech to, LVIIII, i

Lonsdale, Sophia, LV, B.4; LIX, B.86

Lord Mayor's Show, LX, B.80

Lorimer, Adam, The Author's Progress, XXXV, B.47

Lovelace, Mary, Countess of, LVII, B.3 "The Chaperoned Age,"' LVII, B.3; LVIII, i, B.36

Low, Sir Sidney, LV, B.7; LIX, B.89

Lowell, James Russell, "Chaucer," XXXVIII, B.4

Lubbock, Percy:

The Craft of Fiction, XXVI, i, B.33;

XLIX, i, A.1, B. 20

Elizabeth Barrett Browning in her Letters, XXXV, B.51

Lubbock, Lady Sybil, A Page from the Past, VII, B.12; XXXIII, B.5; LIX, B.55

Lushington, Franklin, Portrait of a Young Man, XXXVI, i, B.8

Lyly, John, Euphues, 16

Lynd, Sylvia, "Miss Macaulay's Masterpiece,' XIX, i, B.10

Lytton, Earl of (Victor A.G.R.), Antony (Viscount Knebworth), VII, B.12; XXXIII, B.10, 18; LIX, B.11, 64; LX, B.53

McAfee, Helen, of The Yale Review, XIII, i; XLVIII, i; LIII, i; LXVII, i

Macaulay, Rose, Told by an Idiot, XIX, B.10, 11
Macaulay, Thomas Babington:

History of England, VII, i, B.2, 12; LV, i, B.6; LIX, i B.88

"The Life and Writings of Addison," II, B.4, 5, 7

MacCarthy, Desmond: editor of Life and letters, XXX, i review of A Room of One's Own, LVIII, B.34 on Samuel Richardson, LVIII, B.21, 31

MacColl, Andrée Desiré, Roger Fry's letters to, LXIV, B.12

MacColl, D. S., Roger Fry's letters to, LXIV, B.11

MacNeice, Louis, XVI, i, A.3

McNeill, William, letter to VW, LIX, B.3

Macready, William Charles, Reminiscences, LVIII, B.16

Magnus, Laurie, Herbert Warren of Magdalen, LX, B.3

Mahon, Lord (Philip Henry Stanhope), Preface to Chesterfield's Letters, XLVI, B.1

Maine, Basil, The Best of Me, LX, B.75

Mairet, Philip, A. R. Orage, LX, B.18

Maitland, Ella Fuller, Blanche Esmead, XXXV, B.48

male voice, in criticism of poetry, $\mathrm{VW}$ on, XIV, B.9

Mallarmé, Stéphane, Vers et prose, XXXVIII, B. 10

Mallet, Sir Charles, Anthony Hope and His Books, VII, B.12; XXXIII, B.11; LIX, B. 57

Malory, Sir Thomas, Le Morte D'Arthur, XVI, i, B.5

manifestoes (sent to VW), LIX, B.37. See also circulars; letters

Marie, Queen of Roumania, The Story of my Life, XXVI, i

Marivaux, Pierre, XXV, B.1

Markham, Violet R., Paxton and the Bachelor Duke, VII, B.12; XXXIII, B.2; LIX, B.51

Marlborough, Duke of (John Churchill), XLV, B.1

Marlowe, Christopher: death of, XXXVII, B.5 Dr. Faustus, XXV, B.8b

Hero and Leander, XXV, B.12

The Jew of Malta, VI, B.3; XXV, B.8d 
Marlowe, Christopher (cont.)

Tamberlaine, XVI, i, B.10; XXV, B.8a, $8 \mathrm{c}, 13$

marriage, VW on, VII, B.4; LVIII, B.48

Marryat, Florence, Life and Letters of Captain Marryat, X, B.9

Marryat, Captain Frederick:

Life and Letters of . . . (Marryat), X, B.9 Olla Podrida, X, B.11

Peter Simple, X, B.10

VW essay on, $\mathrm{X}, \mathrm{i}$

Martineau, Harriet, Autobiography, LX, B.76

Martineau, Violet, Recollections of Sophia Lonsdale, LV, B.4; LIX, B.86

Mathews, Anne, Memoirs of Charles Mathews, XVIII, i, B.6

Mathews, Charles, XVIII, i, B.6

Maugham, William Somerset, The Land of the Blessed Virgin, XXXV, B.14

Maupassant, Guy de, XXV, B.33, 37

Guy de Maupassant (Dumesnil), XXVI, i, B.24a

Sur L'Eau, XLV, i, B.3

Une Vie, XXVI, i, B.24b

Maurice, C. Edmund, Life of Octavia Hill, LVIII, B.72

Maurois, André:

Climats, XIII, i, B.7

Tourgueniev, I, B.3

Mauron, Charles and Marie, Roger Fry's letters to, LXV, i, B.3

Mayor, F. M., The Squire's Daughter, XIII, B.17

medical profession, VW on, LX, i. See also doctors; men, as doctors; women, in medicine

Medieval period, VW book list, XXXVII, B.5

Melville, Herman:

Moby Dick, XIV, i, B.17

Omoo, XLIV, B.3

Typee, XLIV, B.2

VW essay on, XLIV, $i$

VW on, XLIV, B.1

Melville, Lewis:

The Life and Letters of Laurence Sterne, XLIX, B.11

The Thackeray Country, XXXV, B.5, 6 men: as accountants, LVIII, B.26

as advertising sex, 24; LIX, B.29

as air pilots, LX, B.43

clerical unemployment and, LIX, B.20

as doctors, XXXIII, B.8; LIX, B.71; LX, B.72

education and, XXXIII, B.7, 11, 12, 22;

XXXVI, B.4, 7; LVIII, B.40, 41, 43,

55; LIX, B.15, 48, 56, 57, 58, 68, 94;

LX, B.3, 4, 19, 53

intellect compared with women, LVIII,

B.19; LX, B.47

Judge McCleary on, LVIII, B.37

leadership of vs. women, LVIII, B.19

as motor learner drivers, LX, B.16

pride in supporting women, LX, B.18

vanity of, XXXVI, B.5; LVIII, B.29

war and, XXI, B.4; XXXIII, B.10, 18; XXXVI, B.2, 8; XXXIX, B.3; LVI, B.7; LVIII, B.25, 58; LIX, B.11, 64 See also male voice; $\mathrm{VW}$ indexes, LVIII, A.1-2; LIX, A.1-2; LX, A.1-2

Meredith, George, 13-14

The Adventures of Harry Richmond, XLVI, B.7

Beauchamp's Career, XLVI, B.6

The Egoist, XLVI, B.8

Letters, XXVI, B.34; XLVI, B.9

The Ordeal of Richard Feverel, XLVI, B.5

VW essay on, XLVI, i

VW on, XXVI, B.21a; XLVI, B.10;

XLIX, B. 20

Merrick, Leonard, XXX, i

Mill, John Stuart:

Autobiography, XXXVI, i, B.4

On Liberty, XXXVI, B.3

millionaires, LIX, B.30

Milton, John, VW on, XLIX, B.32

Ministry of Women, The, VII, B.12; XXVI, B.3, 6; LXI, B.8

Mirrlees, Hope, Madeleine, One of Love's Jansenists, XLI, i, B.1

Mitford, John, "The Life of Thomas Gray," XXVI, B.27

Mitford, Mary Russell:

Letters, XXXII, B.7, 10

The Life of . . , XXXII, B.6, 11

"Mitford, Mary Russell"' (Lee), XXXII, B.8 
Mitford, Nancy, The Ladies of Alderley, XXXVII, B.2

“Modern Novels"' (VW), 18-20; XXXI, i, B.4, 5

Moir, D. M., The Life of Mansie Wauch, XXXV, B.28, 36

Molière, Jean Baptiste de, 15 compared to English comedy, XIX, B.21 Le Depit Amoureux, XXIX, B.24

The Misanthrope, XIX, B.21

Tartuffe, XXIX, B.22

Monk, James Henry, The Life of Richard Bentley, XLIX, i, B.1

Monk's house:

list of areas needing painting, XLIII, B.3 sketch for additions to, XIII, i, B.5

Montaigne, Michel de:

Montaigne (Bonnefon), XX, i, B.4; XXVI, i, B.23

"On Some Lines of Virgil," XXIII, i, B. 2

Moore, George, LIX, B.50

Moore, Spencer, Aurelian, XXXV, B.38

Moore, Thomas, XX, B.6

Morley, John:

The Life of William Ewart Gladstone, XLV, B.1

Recollections, XXX, i, B.6

Morrison, Elizabeth, "The Position of the Woman Student," LVIII, B.1

Mowatt, R. B., Gibbon, VI, B.11

"Mr. Conrad: A Conversation"' (VW), 4

Mrs. Dalloway, VW notes for, XLVII, i, B. 28

"'[Mrs. Dalloway corrections]" (VW), XIX, i

“[Mrs. Dalloway. Fragments]” (VW), XIX, i

"Mrs. Dalloway in Bond Street," VW map for, XLIX, i, 19

Murray, Gilbert, A History of Ancient Greek Literature, XXV, B.25

Murry, John Middleton, Reminiscences of D. H. Lawrence, LVIII, i, B.73

Mytton, John, L, i, B.1

"Narrow Bridge of Art, The" (VW), 20

National Council for Equal Citizenship, LX, B.10, 51

National Council of Women, LIX, B.5
Nazi movement, LIX, B.27, 28, 31, 75, 81; LX, 64. See also Germany

Nevinson, Henry W., Fire of Lifo, X, B.14

Newdigate-Newdegate, Lady (Anne Emily), Gossip from a Muniment Room, XXXVII, B.16, 17

Newitt, Hilary, Women Must Choose, VII, B.12; XXVI, B.5

Newton, Alfred, "White, Gilbert," XXIV, B. 4

Next War, The, VW title for Three Guineas, XXXIX, i; LIX, i

Nichols, John, Illustrations of the Literary History of the Eighteenth Century, VII, B.12; XXVI, B.11

Nicholson, A.P.N., LVIII, B.20

Nickalls, Major Vivian, Oars, Wars and Horses, LVIII, B.41

Nicoll, Allardyce, British Drama, XVI, i, B.3, 7

Nicolson, Harold, Some People, XIV, i, B.2

Nightingale, Florence:

Cassandra, IX, i, B.8

Nimrod (Charles James Apperley), Memoirs of the Late John Mytton Esq., L, i, B.1

Noailles, Madame de, XXXVIII, B.23

Norris, W. E.:

Barham of Beltana, XXXV, B.7

compared to Defoe, 14; XXV, B.32

Lone Marie, XXXV, B.20, 36

The Triumphs of Sara, XXV, B.32

"Notes for Reading at Random" (VW), XVI, i; XXI, i; XXXVII, i; LIV, i. See also " 'Anon' and 'The Reader' ,'

"Notes on an Elizabethan Play," VW notes for essay, XIX, B.22. See also Elizabethan drama

Novels, compared to plays, $13,16,20$; XIII, B.17; XXXVII, B.16. See also drama; fiction

nurses, and doctors, $\mathrm{X}, \mathrm{B} .12$

O'Brien, R. Barry, The Life of Charles Stewart Parnell, XXIII, i, B.3

Omega, The, Roger Fry and, LXIII, i, A.1

On Being Despised, VW title for book, XXVI, i; XXXIX, i; LIX, i; LX, i

"On Not Knowing Greek" (VW), 16

"'On Re-reading Novels," VW notes for essay, XXVI, B.32; XLIX, B.20 


\section{[ INDEX ]}

Orage, A. R., LX, B.18

Osborne, Dorothy:

in A Room of One's Own, XLVI, i

Letters to William Temple, XLVI, i, A.2;

XLVIII, i, B.6; LII, i, B.1

in Memoirs of Sir William Temple,

XLVIII, B.5

VW essay on, XLVI, i; XLVIII, i; LII, i

O'Sullivan, Vincent, Aspects of Wilde, LV, B.9

Otway, Thomas, Venice Preserved, XLVII, B. 1

Overton, J. H., William Law, VI, B.19

Oxford University:

address to Heidelberg University, LIX, B. 1

appeal for money, LX, B.78

Balliol College, LIX, B.57

finances, LIX, B.18

Gibbon on, LVIII, B.55; LIX, B.94

Greene on, LX, B.19

Magdalen College, LIX, B.94; LX, B.3

position of women students at, LVIII, B.1

Pusey at, LIX, B.95

scholarships, LX, B.85, 86

Somerville College, LVIII, B.54

Warren at, LX, B.3

pacifism, LIX, B.28, 33, 37, 38, 78, 79;

LX, B.38, 84

paintings, VW notes on, 18; XLIV, i, B.13

Pankhurst, E. Sylvia, The Home Front, LVIII, B.65

Pargiters, The (VW), 4, 21-22

early titles for, 7

VW notes for, LVIII, B.3, 45, 46, 48

Parnell, Charles Stewart, XXIII, i, B.3

Parnell, Mrs. Charles Stewart, XXIII, i

Partington, Wilfred, Smoke Rings and Roundelays, XLVII, i, B.14

Pastons, The:

Letters (ed., Gairdner), XXXVIII, i, B.26, 28; XLIX, i, B.3, 5-7

The Pastons and their England (Bennett), XLIX, B.8

"Pastons and Chaucer, The" (VW), 17

Patmore, P. G., My Friends and Acquaintance, XXII, B.11

patronage, VW on, 5, 9; X, B.3; XLVIII, i; LVIII, B.39
Paul, C. Kegan, ed.:

Letters to Imlay (Wollstonecraft), IX, B.12

William Godwin, IX, B.7

Paul, Saint, VII, B.1

Pavlovsky, Isaac, Souvenirs sur Tourquéneff, I, B.1

Paxton, Sir Joseph, VII, B.12; XXXIII, B.2; LIX, B.51

peace, VW on, XXI, i, B.4; XXXVI, i; XXXIX, i, B.3; LVI, B.4. See also pacifism

Peacock, Thomas Love:

Crotchet Castle, XIV, B.15

VW on, XLIX, i, B.28

Peck, Walter Edwin, Shelley, XXV, i, B.30

Pembroke, Earl of (George C. Herbert), South Sea Bubbles, XLIV, B.4

Pennington, Montagu, Memoirs of Mrs. Elizabeth Carter, XLVII, B.35

Pepys, Samuel, XXXVII, B.11

Percy, Thomas, ed., Reliques of Ancient English Poetry, XXXVII, B.5

"Phases of Fiction," VW notes for essay, 14-15, 21; XIV, i, B.4, 10, 12, 16, 18, 20, 21; XXV, B.28, 32, 37; XLVI, B.3, 4

photographs (newspaper cuttings), LIX, B.6, 26, 29, 72-74; LX, B.78

Piozzi, Hester Lynch (Mrs. Thrale): Anecdotes of the Late Samuel Johnson, XIII, B.13; XLVI, i, B.21

Hester Lynch Piozzi-Mrs. Thrale (Clifford), XVI, i, B.9, 12

Mrs. Piozzi's Thraliana (Hughes), XLVI, i, B. 20

Plato, 5

The Banquet, tr. Shelley, XXXVIII, i, B.17

Euthyphro, XXV, i, B.20

The Phaedrus, XXXIV, B.15

The Protagorus, XLVII, i, B.32

The Symposium, XXXIV, B.8; XXXVIII, i, B.17

plays, compared to novels, $13,16,20$; XIII, B.17; XXXVII, B.16. See also drama; Elizabethan drama

poet, as lapdog, VW entry, LVIII, B.39

poetry, VW on, 13; XV, i; XXIII, i, B.4; XXXVII, B.12; XLV, i, B.2, 5, 14; 
XLVII, B.11; XLIX, B.16; LVI, B.2; LXVII, B.11

"Poetry, Fiction and the Future" (VW), 20 politicians, LV, B.3; LVIII, B.59; LIX, B.4, $15,32,33,35,54,85$; LX, B.14, 15, 22, $26,41,42$

VW heading, XXXVI, B.6

politics, VW on, 22, 24; XXXIX, B.2, 3; LVIII, B.3, 45

Pope, Alexander, 6 on Addison, II, B.8

The Rape of the Lock, XVIII, B.11

Portland, Duke of (William J.A.C.J.C. Bentinck), Men, Women, and Things, VII, i, B.8, 12

Post-Impressionist Exhibition, LV. B.3; LXIII, B.12, 14, 15

Pound, Ezra, on Henry James, XIX, i, B.6

Power, Eileen, Medieval English Nunneries, XXXVII, B.5

Powles, L. C., Roger Fry's letters to, LXIV, B.8

press, the, privacy in, LIX, B.76

Prestige, G. L., The Life of Charles Gore, VII, B.14; XXXIII, B.14; LIX, B.13, 60

Priest, Alfred, "Cocaine"' (a painting), XLIV, i

Priestley, J. B., Figures in Modern Literature, XLVII, i, B.21

Prior, James, The Life of Oliver Goldsmith, LIII, B.4

"Professions for Women" (VW), 22; XII, i, A.1

prose, VW on, XV, i; XXIX, B.2; XXXVII, i, B.18; XLVII, B.11; LIII, B.6; LXVII, B.6. See also Elizabethan prose

Proust, Marcel:

The Guermantes Way, XIV, i, B.13

Swann's Way, XIII, i, B.16; XIV, i, B.23

puritanism, LVIII, B.67

Pusey, Edward Bouverie, LIX, i, B.95

Puttenham, George, The Arte of English Poesie, 20; XII, B.4

Racine, Jean, Phèdre, XIX, i, B.41

Radcliffe, Ann, The Mysteries of Udolpho, XIV, i, B.3; XXV, i, B.29; XLVI, i, B.4

Raikes, Elizabeth, Dorothea Beale of Cheltenham, LX, B.74
Raleigh, Sir Walter, The English Voyages of the Sixteenth Century, XXXV, B.50

Raleigh, Sir Walter (Professor uf English Literature), Shakespeare, XIX, B.16

Rawnsley, H. D., Months at the Lakes, XXXV, B.57

Read, Meredith, Historical Studies in Vaud, Berne and Savoy, VI, B.10

"The Reader"' (VW), 9. See also " 'Anon' and 'The Reader',

readers, VW on role of, $10,16-17,25$

"Reading"' (1919; VW), 4, 11

Reading:

VW notes for book, 17; XLIX, B.24-28, 30-35

VW title for The Common Reader, XIX, i; XXX, i; XXXVIII, i; XLIX, i

reading, VW on, XIII, i, B.22; XVI, B.3; XVIII, i, B.3, 4; XIX, i; XXV, i; XLV, i, B.11, 14; XLVII, i; XLIX, i, B.24, 2627, 30-33; LI, i; LVIII, i. See also criticism; journalism; reviewing

Reading and Writing, VW title for The Common Reader, XIX, i; XXXVIII, i

Reading at Random, VW title for book, 4; XVI, i; XXXVII, i, B.3; LIV, i. See also "' Anon' and 'The Reader',"

religion, VW on, VII, B.6; LVIII, B.46; LIX, i, B.91

Renan, Ernest, Saint Paul, VII, i, B.1, 12

reviewing, VW on, XXXIX, i; XLIX, B.34. See also criticism; journalism

Reynolds, Mrs. Fred, The Making of Michael, XXXV, B.25

Reynolds, Joshua, Discourses on Painting and the Fine Arts, XVI, i, A.1-3; XXVI, i, B.31

Rhys, Ernest, ed., Modern English Essays, XLIX, i, B.13

Richards, Grant, Memories of a Misspent Youth, LVIII, B.50

Richards, I. A., Principles of Literary Criticism, XVIII, i, B.7

Richardson, Dorothy, XXXI, B.2

Richardson, Samuel: MacCarthy on, LVIII, B.21, 31 VW on, XLIX, B.20

Richmond, Bruce, editor of $T L S, \mathrm{~V}, \mathrm{i}$; XLII, i

Rishton, Maria Allen, XIII, i, B.21 


\section{[ INDEX ]}

Rita (Mrs. Desmond Humphreys), Recollections of a Literary Life, LX, B.48

Roberts, Harry, "The Sanctity of Human Life,'” LVIII, B.9

Robins, Elizabeth: A Dark Lantern, XXXV, B.15 Theatre and Friendship, LVIII, B.44

Robinson, Henry Crabb, Diary, Reminiscences and Correspondence, $\mathrm{XXX}, \mathrm{B} .2$; XXXVIII, B.19

Robson, William A., ed., The British Civil Service, VII, B.4

Rogers, Benjamin Bickley: ed., The Birds, XIX, B.35 ed., The Frogs, XXXIV, B.13, 14

Room of One's Own, A (VW), 9, 22 reviews of, XLVI, i; LVIII, B.24, 34 VW notes for, IX, i, B.8; XIII, i; XIV, i, B.9; XLVI, i; XLVII, B.37

Rossetti, Christina: Life of . . (Sandars), XXII, B.18, 19 Poetical Works, XXII, B.19 VW essay on, XXII, i

Rothenstein, Sir William: Men and Memories, LXI, B.7; LXII, i, B.2, 5

Roger Fry's letters to, LXIV, B.18

Rowan, Archibald Hamilton, Autobiography, IX, B.11

Royal Academy of Art, The, VW notes on exhibition, 18; XLIV, i, B.13

royalty:

VW essay on, XXVI, i

VW on, XXVI, i, B.30

Roydon, Maude, XXXVII, B.2

Ruskin, John, Praeterita, XIV, i, B.6

Russell, Bertrand:

ed., The Amberley Papers, VI, i, B.17

"Bertie on cruelty," VW entry, VII, B.12

Freedom and Organization, VII, B.12; XXXIII, B.3; LIX, B.52

Roger Fry's letters to, LXIV, B.10

The Scientific Outlook, LVIII, B.11, 13

Russell, Patricia, ed., The Amberley Papers, VI, B.17

Russian literature, VW on, I, B.4; XXIX, B.4; XLIX, B.28

Rutland, Countess of (Elizabeth Sidney), 5; XI, B.8

Rutter, Owen, Portrait of a Painter, Philip de László, XXXVI, B.5
Sackville-West, Vita, "Introduction" to Clifford's Diary, 9; XVI, B.14; XIX, B.3

Sainte-Beuve, C. A.: "Marivaux," XXV, B.1

"La Morgrave de Bareith," XXXV, B.29

St. John, Christopher, Ellen Terry and Bernard Shaw, LVIII, B.69

St. Paul's Cathedral: program for service, LX, B.11 VW on service at, LIX, i, B.91

Saintsbury, George:

A History of Elizabethan Literature, XIX, B.9

History of English Prosody, XXII, B.19

Saint-Simon, Duk de (Louis de Rouvroy), XXIX, i, B.6

Salmond, Monica, Bright Armour, VII, B.12; XXXIII, B.13; LIX, B.59

Sand, George, Histoire de ma vie, VII, B.12; XXVI, B.14; LX, i, B.20

Sandars, Mary F., The Life of Christina Rossetti, XXII, i, B.18, 19

Sargent, John Singer, LXIII, B. 12

satire, VW on, XXV, B.37; XXXVIII, B.20

Sayce, A. H., Reminiscences, XIX, i, B.46

"Sayings and Quotations," VW heading, 20; XXXVIII, B.19, 21, 22

Schick, J., ed., The Spanish Tragedy (Kyd), XIX, B.24; XXV, B.6

scholars, VW on, XLIX, B.24

Schreiner, Olive:

Letters, XLVII, B.12

The Story of an African Farm, XLVII, B.12

VW essay on, XLVII, $i$

science, LVIII, i, B.10, 11, 13, 14; LIX, B.23, 29; LX, B.27

Sclater, William Lutley, Sterne's Eliza, XLIX, i, B.12

Scott, J. M., Gino Watkins, VII, B.12; XXXIII, B.12; LIX, B.58

Scott, Sir Walter, 14

The Antiquary, XXVI, i, B.22; XLVII, i, A.1

Bewick on, XXIV, i, B.6

The Bride of Lammermoor, XXV, B.27 compared to Stevenson, XXV, B.28

“'Henry Fielding," XLVII, B.13

Ivanhoe, XXXII, i, B.18, 21

Letters on Demonology, XXXVII, B.5

Memoirs of Jonathan Swift, V, B.2 


\section{[ INDEX ]}

The Private Letter-Books, XIII, i, B.20 Redgauntlet, XLVII, B.17

VW on, XXXII, B.18; XLIX, B.32

Sévigné, Madame de:

compared to English prose writers, XXXVII, i

Lettres, XVI, i, B.1; XXXVII, i, B.12; LIV, i, B.2

sexes:

equality of, LVIII, B.37

psychology of, LIX, B.21

Shakespeare, William, 13

Antony and Cleopatra, XLVII, B.3

Coriolanus, XXVI, B.25e; XXXVII, B.7

"dark lady" of the sonnets, XXXVII, B. 16

Hamlet, XXIX, B.6; XXXVIII, B.18;

XLV, B.1

Julius Caesar, XXIII, B.4

King John, XXV, i, B.7; XLVII, i, B.25

King Lear, XXIX, B.7

A Life of . . (Lee), XXV, B.4, 10

list of works, XLVII, B.24

Macbeth, XXIX, i, B.9

Measure for Measure, 17; XXXVIII,

B.15, 16, 18

The Merry Wives of Windsor, XXVI, B.29

Othello, XXIX, B.8

Pericles, XXVI, B.25c

Poems, XXXVII, B.16

The Rape of Lucrece, XXV, B.10

Richard II, XXV, i, B.7; XLVII, i, B.27

Richard III, XLVII, B.29

Romeo and Juliet, XXIX, i, B.3; XLVII, i, B.23

Shakespeare (Raleigh), XIX, B.16

Shakespearean Tragedy (Bradley), XXIX, B.6

"Shakespeare, William"' (Lee), XLVII, B.24

The Taming of the Shrew, XXVI, B.25b

The Tempest, IV, i

Timon of Athens, XXVI, B.25f

Titus Andronicus, XXVI, B.25d

Troilus and Cressida, XXVI, B.25a; XLIX, B.23

Twelfth Night, I, i, A.1; XIX, B.15

Venus and Adonis, XXV, B.10

VW on, XXIX, B.3, 7-9; XLV, i; XLVII, B.3, 23; XLIX, B.30, 35

William Shakespeare (Chambers), XXXVII, B.13
Shaw, George Bernard:

"As I See It," LX, B.79

Ellen Terry and . . . , LVIII, i, B.69

Roger Fry's letter to, LXVI, B.3

Shelley, Percy Bysshe:

tr., The Banquet (Plato), XXXVIII, B.17

"A Defence of Poetry," XXX, B.5, 9

Preface to Alastor, XXX, B.2

Shelley (Peck), XXV, i, B.30

Sheridan, Richard Brinsley, XX, B.6

Shorter, Clement, IX, B.2

Sichel, Edith, Catherine de Medici and the

French Reformation, XXXV, B.10

Sichel, Walter, The Sands of Time, X, B.6

Sidney, Sir Philip:

in Ben Jonson's Conversations with William Drummond, XI, B.7

The Countess of Pembroke's Arcadia, VIII, i, B.2; XLVIII, i, B.3

Defence of Poesie, XXX, B.5; XLVII, B.5

Life of . . (Greville), XX, B.15

Sir Philip Sidney (Addleshaw), XX, B.14

Sir Philip Sidney (Wilson), XI, B.5

VW essay on, VIII, $\mathrm{i}$; XI, i; XX, i; XLVIII, $\mathrm{i}$

VW notes for essay, XII, i, B.4; XLVIII, B.3

Simon, Shena Lady, LX, B.15

Simpson, Percy, Ben Jonson, XI, B.6, 7

Sinclair, May, "The Novels of Dorothy

Richardson," 18-19; XXXI, i, B.2

Sinclair, Upton, Candid Reminiscences, LVIII, B.67

Smith, Florence M., Mary Astell, VII, B.12; X, B.7; XXVI, B.7

Smith, G. C. Moore, "Introduction" to $G a$ briel Harvey's Marginalia, XI, B.9

Smith, G. Gregory, Ben Jonson, XIX, B.31, 32,34

Smith, Logan Pearsall, The Life and Letters of Sir Henry Wotton, XI, B.11

Smith, Sydney, XVI, i, A.1-3

Smyth, Ethel, 4, 25

Female Pipings in Eden, LVIII, i, B.17

VW and, as "Miss Beale and Miss

Buss," LVIII, i

Socialist party, LX, B.22

"Some Elizabethans," VW notes for essay (The Common Reader: Second Series), 20; XI, i, B.10; XII, i, B.4 
"Some Elizabethans and Montaigne," VW notes for essay (The Common Reader), 20; XIX, i, B.22

"song-making instinct," $\mathrm{VW}$ on, 17

Sophocles:

The Ajax, XIX, B.49, 54; XXXIV, B.1012

The Antigone, 13; X, i, B.8; XIX, B.49, 50; XLV, i, B.1; XLVII, i, B.19, 22; LX, B.82; LXI, i, A.2

The Oedipus Coloneus, XIX, B.49, 51; XXX, i, B.10

Oidipus-Roi, XIX, 52

Philoktetes, XIX, B.44

The Tragedies, XIX, B.49

Les Trakhiniennes, XIX, B.53

VW on, XLIX, B.30

Spanish Civil War, LVI, i, B.6; LIX, B.44; LX, B.17, 33

"Speech Before the London/National Society for Women's Service," LVIII, i

Spence, Joseph, Anecdotes, Observations and Characters, II, B.6

Spenser, Edmund:

The Faerie Queene, XXXVII, i, B.14;

XLV, i, B.4, 6, 8, 10, 11

"as feminist," XLV, B.7, 8

Jonson on, XLV, B.9

"The Life of . . .' (Collier), XXV, B.18; XXXVII, i, B.9

The Shepheardes Calendar, XXV, B.18

VW essay on, XLV, $\mathrm{i}$

VW on, XLV, B.5, 11

Warton on, XLV, B.9

sports, see women, in sports

Squire, Sir John Collings:

Reflections and Memories, VII, B.12; XXXIII, B.15; LIX, B.61

review of A Room of One's Own (VW), LVIII, B.24

Stanley, Henrietta Maria, XXXVII, B.2

Stanley, Lady Augusta, Letters, LVIII, i, B.35

Stanley, Lady Maria Josepha Holroyd, VI, i, B.16-18; XXXVII, B.2

Stawell, Florence M., Goethe and Faust, LVIII, i, B.32

Steadman, F. Cecily, In the Days of Miss Beale, LVIII, i, B.49
Steele, Richard, "To Mr. Congreve," XL, B.6

Stendhal (Henri Beyle), V, i Journal, XVIII, i; XIX, i, B.1

The Life of Henri Brulard, XVIII, i, B.10

Le Rouge et le noir, 12, 13; XVIII, i, B.3, 4

VW essay on, XVIII, i; XIX, i

Stephen, Barbara:

Emily Davies and Girton College, XLVI, i; LVIII, B.35; LX, B.76

Life of Miss Emily Davies, IX, i, B.8

Stephen, Sir James, Essays in Ecclesiastical Biography, LIX, B.48

Stephen, Julian Thoby, XLIX, i, B.9

Stephen, Leslie, 6, 7, 8, 10, 12

“Addison, Joseph, D.D.," II, B.1

"'Defoe, Daniel,"' III, B.4

“De Quincey,'” XXV, B.39

"Hazlitt, William," XXII, B.5

"Horace Walpole," XLIV, B.8

"The Study of English Literature," 6

Swift, V, B.1

Sterne, Laurence, 14

Letters, XLVI, B.11, 13

The Life and Letters of . . . (Melville), XLIX, B.11

The Life and Times of . . (Cross), XLVI, B.12

A Sentimental Journey, XXV, B.9; XXIX, B.11; XLVI, B.12, 14

Sterne's Eliza (Wright and Sclater), XLIX, i, B.12

Tristram Shandy, XIV, i, B.16; XXV, B.37; XXIX, B.10; XLVI, A.2; compared to Ulysses, XXXI, B.3

VW essays on, XXIX, i; XLVI, i

VW on, XIV, B.16; XXXI, B.3

Stevenson, Robert Louis, 14 compared to Defoe and Scott, XXV, B.28 The Master of Ballantrae, XXV, B.28

Strachey, Sir Edward, "Introduction" to Le Morte D'Arthur, XVI, B.5

Strachey, (Joan) Pernel: letter to VW, LIX, B.10 VW heading, XLIV, B.6

Strachey, Philippa: “The Bazaar. Pippa," VW entry, VII, B.12 on the Contributory Pensions Bill, LX, i, B.26, 36 


\section{[ INDEX ]}

Strachey, Rachel (Ray), LX, B.12

Careers and Openings for Women, VII, B.4, 12; XXVI, B.8

The Cause, IX, i

suffrage, VII, B.10; LIX, B.61; LX, B.51, 56,77 . See also women, politics and; women's movement

Sullivan, J.W.N., But for the Grace of God, LVIII, B.5, 12

"Supplement to the Dictionary of the English Language," VW entry, LVI, i

Surtees, Robert Smith, XIX, i, B.8

Sutton, Denys, ed., Letters of Roger Fry, LXIII, B.4; LXIV, B.8

Swanwick, H. M., I Have Been Young, VII, B.10, 12; XXXVII, i, B.2

Swift, Jonathan:

"Cadenus and Vanessa," V, B.6

"Correspondence Between Swift and Miss Vanhomrigh," V, B.5

"Epistolary Correspondence," V, B.5

Gulliver's Travels, XXXVIII, i, B.20

Journal to Stella, V, i, B.3; XLVIII, i, B.7

Memoirs of . . (Scott), V, B.2

miscellaneous works, $\mathrm{V}, \mathrm{B} .8$

"Poems Addressed to Vanessa and Stella," V, B.4

Swift (Stephen), V, B.1

VW essay on, $\mathrm{V}, \mathrm{i}$

Swinburne, Charles Algenon, Love's Cross Currents, XXIX, B.2

Symonds, John Addington, Shakspere's Predecessors in the English Drama, 16; XXV, B. 15

Synge, John Millington, XXXIII, B.1; LIX, B.46

Synge, Mrs. Hamilton, A Supreme Moment, XXXV, B.44

Talfourd, Sergeant, "Some Thoughts Upon the late William Hazlitt," XXII, B.4

Teeling, William, "Nazi 'Blood and Race' Theory,"' LIX, B.75

Temple, Sir William:

The Letters of Dorothy Osborne to . . . XVI, i; XLVIII, B.6; LII, i, B.1 Memoirs of . . . (Courtenay), XLVIII, B.5
Tennyson, Lord Alfred, The Princess, LVIII, B.42, 52

Terry, Ellen, Ellen Terry and George Bernard Shaw, LVIII, i, B.69

Thackeray, William Makepeace, 10 on Arthur's Education Fund, LIX, B.56

"'On Being Found Out," LX, B.5

The History of Pendennis, VII, B.12;

XXXI, i, B.5; LIX, B.56, 69

Lewis Melville on, XXXV, B.5

on Oliver Goldsmith, LIII, B.7

VW on, XXXI, B.5; XXXV, B.6

Thirlmere, Rowland, Letters from Catalonia, XXXV, B.13

Thompson, Edward, review of The Dunciad, LVIII, B.71

Thompson, Sir J. J., Recollections and Reflections, LIX, B.70

Thomson, Ethel H., The Life and Letters of William Thomson, Archbishop of York, XXXI, i, B.6

Thomson, William, Archbishop of York, XXXI, i, B.6

Thorp, Margaret Ferrand, Charles Kingsley, LX, B.81, 83

"Thoughts on Peace in an Air Raid," VW notes for essay, XXI, i, B.4; XXXVI, i; XXXVII, i; XXXIX, i, B.3

Thrale, Mrs., see Piozzi, Hester Lynch

Three Guineas, 7, 10, 21, 22-24, 25

VW notes for book, VII, i, B.4-9, 12; XXXIX, i, B.3; LV, i, B.1, 5; LVI, i, B.1, 3, 4, 6; LVII, i, B.3, 4; LVIII, i, A.1-2, B.3, 45, 46, 48; LIX, i, A.1-2; LX, i, A.1-2

Tilley, A. A., "The Reformation in France," XXXV, B.11

Tinker, Chauncey Brewster, Young Boswell, XLIX, B.10

Todd, Margaret, The Life of Sophia JexBlake, VII, B.12, 13; XXVI, B.4; LX, B.57

Tolstoi, Leo: Anna Karenina, XIII, i; XXIX, i, B.4 Nicholson on, LVIII, B.20

VW on, XIII, i War and Peace, XIII, i, B.6

Townsend, Lewis W., Oliver Wendell Holmes, XXIX, i

Toynbee, T. Philip, LX, B.53 
Travers, Rosalind, The Two Arcadias, XXXV, B.43

Trevelyan, George Macaulay, History of England, XXXVII, i, B.6

Trevelyan, Janet P., The Life of Mrs. Humphrey Ward, XXV, i, B.5

Trevelyan, Robert C., Roger Fry's letters to, LXI, B.1; LXIV, B.6, 7

Trollope, Anthony:

Autobiography, XXV, B.26; XXVI, i, B.32

Barchester Towers, XXV, B.26

Hawthorne on, XXV, B.26; XXVI, B.32

The Small House at Allington, XLVI, B. 23

Turgenev, Ivan, 14

Fathers and Children, I, B.7

A House of Gentlefolk, I, B.6

A Lear of the Steppes and Other Stories, I, B.14; XLVI, B.19

Letters, I, B.2

On the Eve, I, B.5

Rudin, I, B.3-4

Smoke, I, B.8

Souvenirs sur . . . (Pavlousky), I, B.1

A Sportsman's Sketches, I, B.9

Torrents of Spring and Other Stories, I, B. 12

Tourgeniev (Maurois), I, B.3

Virgin Soil, I, B.11

VW essay on, I, i

VW on, I, B.4, 10, 12, 13, 14

Turner, E. M., Josephine Butler, XXVI, B.16

Turner, Ralph E., James Silk Buckingham, LV, B.11

Turning the Page, VW title for book, 4; XVI, i; XXXVII, i. See also “ 'Anon' and 'The Reader' ,'

"Two Women" (VW), cutting of essay, LVIII, B.35

Tyrrell, Robert Yelverton, ed., The Bacchae, XIX, B.47

uniforms, 23-24

for army, XL, B.8, 63

for postal workers, XL, B.9

See also dress

universities:

more money for, LIX, B. 24 scholarships awarded, LX, B.85, 86

women and, LVIII, B.64

See also Cambridge University; Oxford University

Upson, Arthur, The City, XXXV, B.41

Vachell, Horace Annesley:

Distant Fields, LX, B.2

The Face of Clay, XXXV, B.53

Valentine, LVIII, B.58

Van Doran, Irita, of the New York Herald Tribune, IX, i

Verney, Frances Partenope and Margaret M., eds., Memoirs of the Verney Family, XIX, B. 43

Virgil, The Fourth Georgic, XXXIV, B.9

"Vision of England, The," VW heading, LVI, B.5

Voltaire (François Marie Arouet), Candide, XXXVIII, i, B.21

Walker, Kenneth, The Intruder, LIX, B.71

Walkley, A. B., XLII, i

Walpole, Horace:

Berry on, XLIV, B.9

Correspondence, XVI, i

on Gibbon, VI, B.13

Horace Walpole (Dobson), XLIV, B.11

Horace Walpole (Ketton-Cremer), XVI, i

"Horace Walpole"' (Stephen), XLIV, B.8

Letters (ed. Cunningham), XLIV, B.9

Letters to the Rev. William Cole, XVI, i

Supplement to the Letters (ed. Toynbee), XLIV, i, B.7, 10, 12

VW essays on, XLIV, i; XLV, i, A.1

war:

church on, LIX, B.78, 79; LX, B.28

cost of (Pankhurst), LVIII, V.65

ideal of army and, LX, B.1

Memories of Four Years of (Salmond), LIX, B.59

men and, XXXIII, B.10, 18; XXXVI, i,

B. 2, 8; LVI, B.7; LVIII, B.25, 58;

LIX, B.11, 64

Shaw on, LX, B.79

VW on, XXI, i, B.4; XXXVI, i;

XXXVII, i, B.2; XXXIX, i, B.3; LVI, i, B.1, 4, 6; LVIII, B.45 
women and, LVIII, B.35; LIX, B.8; LX, B. $10,30,43,84$

writers and, LIX, B.37; LX, B.37

Ward, Mrs. Humphrey:

Fenwick's Career, XXXV, B.54

The Life of . . (Trevelyan), XXV, B.5

Warren, Herbert, LX, B.3

Warton, Thomas, Observations on the Faerie Queene, XLV, B.9

Waterford, Louisa, Marchioness of, XVIII, i, B.5

Watkins, Gino, VII, B.12; XXXIII, B.12; LIX, B.58

Watson, Foster, Richard Hakluyt, XLVII, i, B.15

Watson, Gilbert, The Voice of the South, $\mathrm{XXXV}, \mathrm{B} .26,36$

Waves, The (VW), 7

Webbe, William, A Discourse of English Poetrie, XII, B.3

Webster, John, 15

compared to Molière, XIX, B.21

The Duchess of Malfi, XIX, B.18

The White Devil, XIX, B.20; XXV, B.2; LX, B.49

Weeton, Ellen, Journal of a Governess, VII, B.12; XXXIII, B.4; LIX, B.53

Wellesley, Lady Dorothy, Matrix, XIV, B.9

Wells, G. P., The Science of Life, LVIII, i, B. 10

Wells, H. G.:

Experiment in Autobiography, VII, i, B.3, 11, 12; LVI, B.3

The Science of Life, LVIII, i, B.10

Wharton, Edith, The House of Mirth, 8; XXXV, B.24, 36

Whateley, Monica, letter to VW, LX, B.45

Whibley, Charles, "Introduction"' to Robinson Crusoe, IV, B.1

White, Gilbert:

Observations on Various Parts of Nature, XXIV, B.5

VW essay on, XXIV, i

"White, Gilbert" (Newton), XXIV, B.4

The Works in Natural History, XXIV, B.3

White, Joseph Blanco, Life, XLIX, B.36

Whitman, Walt, Leaves of Grass, VII, B.12

"Why Art To-day Follows Politics," VW draft for essay, XXXIX, i, B.2
Wild, Sir Ernest, VII, B.12; XXXIII, B.20; LIX, B.66

Wilde, Oscar, LV, B.9

Wilhelmina, Morgravine of Baireuth, XXXV, B.29-31

Wilkinson, Tate:

Memoirs, XVIII, i, B.8

The Wandering Patentee, XVIII, B.6

Williams, Basil, Roger Fry's letters to, LXIV, B.13

Williams, Blanche Colton, George Eliot, LV, B. 10

Williamson, George C., Lady Anne Clifford, XVI, B.15; XXXVII, i, B.18; XLVIII, i, B. 2

Wilson, Harriet, Memoirs, XX, B.7

Wilson, Mona, Sir Philip Sidney, XI, B.5

Wilson, Woodrow, "States Rights (18501860)," XXXV, B.2

Winstanley, Denys A., Unreformed Cambridge, LV, B.12

Winstanley, Lilian, Hamlet and the Scottish Succession, XXXVIII, B.18

Witches of Warboys, The, XXXVII, B.5

Wodehouse, Dr. Helen, "How I was Educated," LVIII, B.51

Wollstonecraft, Mary: compared to Dorothy Wordsworth, XX, B.9

Letters to Imlay, IX, B. 12

Letters Written during a Short Residence in Sweden, Norway, and Denmark, IX, B.11, 15

Memoirs of . . . (Godwin), IX, B.10, 11 The Posthumous Works, IX, B.11

$A$ Vindication of the Rights of Women, IX, B. 14

VW essay on, $\mathrm{X}, \mathrm{i}$

VW notes for essay, IX, i, B.9, 13

women:

as accountants, LVIII, B.26

as air pilots, LIX, B.9; LX, B.43, 44

allowances, XXXIII, B.5; XXXVII, B.2; LIX, B.55

anonymity of, LVIII, B.72

artists, XXXIII, B.16, 21; LIX, B.12, 62, 67

Bagehot on, LVIII, B.8

in business, LVIII, B.33 
women (cont.)

at Cambridge University, LVIII, 61; LIX,

B.10, 16; LX, B.39

chivalry and, LX, B.48

in the church, XXVI, B.3, 6; LVIII,

B.68; LX, B.66, 68; LXI, B.8

cigarette smoking, LVIII, B.18, 50

in the Civil Service, VII, B.4; LVIII,

B.22, 28, 63

clerical unemployment and, LIX, B.20

as companions, LVIII, B.5, 12

crime and, LVIII, B.38

cruelty of, LVIII, B.30

as cultural inheritors, VW on, 5-10

dependence of, LIX, B.19; LX, B.18

D. H. Lawrence on, LVIII, B.47, 73

disinterestedness of, LV, B.6; LIX, B.88

duties of (Gisborne), VII, B.16

eating, XXXIII, B.6; LVIII, B.16

education of, 4, 5, 8, 9, 10; III, B.8, 9;

VII, B.5-6; XXVI, B.11; XXVII, B.2;

XXXIII, B.4, 16, 21, 22; LV, B.14;

LVIII, B.3, 8, 40, 42, 49, 51, 56, 64;

LIX, B.12, 53; LX, B.19, 23, 24, 60,

83. See also Astell, Mary; Beale, Doro-

thea; Clough, Anne Jemima; Davies,

Emily

Einstein on, LVIII, B.17

eloquence of, LVIII, B.56

employment for, XXVI, B.8; LX, B.12

equal pay for, LIX, B.45

family life and, LVIII, B.2

Fry on, LXII, B.1m

Gore on, XXXIII, B.14; LIX, B.13

as homemakers, $\mathrm{LX}, \mathrm{B} .77$

housework of, LX, B.34

imitation of men, LIX, B.19

influence of, VII, B.7

influence on French aesthetics, XXXVIII, B.1

influence on French society, XXXVIII,

B.1; LV, B.9

intellect compared with men, LVIII, B.19;

LX, B.47

Joad on, XXXIII, B.6; LVI, B.3; LVIII,

B.4; LIX, B.22, 96

Judge MacCardie on, 23; LVIII, B.19

Judge McCleary on, LVIII, B.37

Labour Exchange and, LVIII, B.22

lack of privacy, IX, B.8 as ladies, LVIII, B.69

legal status of, 8; XXVII, B.2; LVIII, B.37; LIX, B.17; LX, B.77

librarians, LVIII, B.23

in medicine, XXXVII, B.1; LVIII, B.70; LX, B.24, 60. See also Jex-Blake, Sophia

men's dislike of, LX, B.55

men's economic support of, LX, B.18

metaphysical purpose and, XIV, B.9

as motor learner drivers, LX, B.16

under Nazi regime, LIX, B.31, 81; LX, B.45, 64

objections to work by, LVIII, B.22, 23, 33; LIX, B.14, 20

at Oxford, LVIII, B.1, 54; LX, B.19

oysters popular with, LX, B. 25

as patrons, 5, 9; XLVIII, i; LVIII, B.39 pensions for, LIX, B.40; LX, B.26, 36

physical education for, LVIII, B.49

politics and, XXXIII, B.19; LIX, B.5, 54, 65,96 ; LX, B.26, 36, 42, 45, 51, 58,

77. See also suffrage; women's movement

in professions, VW on, 3; $\mathrm{LV}, \mathrm{i}, \mathrm{B} .1$;

LVII, B.3; LVIII, B.46

psychology of, XXVI, B.6; LIX, B.21

recruits for army, LX, B.59

refusing to have children, $\mathrm{LX}, \mathrm{B} .30$

rights of (Wollstonecraft), IX, B.14

Saint Paul on, LIX, B.92, 93

sexuality of, XXIII, i, B.2

in sports, LIX, B.42; LX, B.32, 40

status of, LX, B.77

Thackeray on, LX, B.5

in theater, LVIII, B.44

veterinarians, $\mathrm{LX}, \mathrm{B} .35$

in Victorian period (Bott and Clephane),

$\mathrm{X}$, B.4; LVIII, B.62

war and, LVIII, B.30; LIX, B.8; LX,

B.10, 30, 43, 84. See also war, VW on

as weaker sex, LVIII, B.27

Wells on, VII, B.3, 11; LVI, B.3

work in slums, LX, B.81

Wright on, XXXIII, B.9; LVIII, B.27

as writers, XIII, i; XIV, i, B.9; XXXVIII, B.1, 23; XLVI, i, B.17; XLVII, i;

LVIII, B.39

See also childbirth; VW's indexes, LVIII, A.1-2; LIX, A.1-2; LX, A.1-2 
Women's Co-operative Guild, XII, i, B.5-6

Women's movement, VII, B.3, 11; XXI, B.4; LIX, B.13. See also suffrage

Wood, Thomas, True Thomas, LX, B.4

Woodforde, James, The Diary of a Country Parson, XV, i, B.3; XIX, B.2; XLVIII, i, B.12

Woolf, Leonard, letter about Spain, LIX, B.44

Woolf, Virginia:

article about (J. B.), LX, B.54

earnings for articles, IX, B.5; XLVI, B. 24 on importance of audience to literature, 8 , 10-11, 16-18, 25

influence of Leslie Stephen on, 6-7, 10 as inheritor of literary tradition, 4-6, 7 on interconnection of social and literary conventions, 9-10

letter about Spain, LIX, B.44

list of names, XLVII, B.20

list of phrases and people (1940), XXI, i, B.1

list of works, LVII, B.1

on literature as common mind, 3, 5, 25

on literature and history, 6, 7-10

love of reading, 3-4, 11, 26

new gold pen, $X X, i$

as patron of Newnham College, LIX, $i$

as reader of her culture, 22-24

reading lists, XXVI, i; XXIX, B.1, 19; XXX, B.5

reads works by and about women, 8-10 shopping list, III, B.6

supports London/National Society for

Women's Service, LIX, i

as teacher, 7, 12; XXVII, $\mathrm{i}$

tests powers of her pen, XIII, B.13

theory and practice of reading, 3, 6-7, 10 -

18,25

unidentified entries: "Austen Chamberlain," XVIII, B.1; "Cameron," XVIII, B.1; "'The Editor much regrets," XXV, B.3i; "The golden June rising from dirt ... ," XXIV, B.17; "life of Ld. M.T.," LIX, B.49; Lord Darling, XVIII, B.1; "Mirsky/Dotty/Quennell/ Leave back plain," XIV, B.22 use of reading notes in writing, 18-24 Virginia Woolf (Bell), LVII, i, B.1; LX, B.54 on "voice" in literature, 10-11, 17

Wordsworth, Dorothy:

compared to Mary Wollstonecraft, XX, B.9

De Quincey on, XX, B.10

Dorothy Wordsworth (Lee), XX, B.10

Journals, XX, B.9, 11

VW essay on, $\mathrm{XX}, \mathrm{i}$

VW on, $\mathrm{XX}, \mathrm{i}$

William Wordsworth on, XXXVIII, i, B.24-25

Wordsworth, William:

Blake on, XXXVIII, B.19

on Dorothy Wordsworth, XXXVIII, B.2425

Guide to the Lakes, XXXV, B.56

"The Orchard," XXXVIII, B. 24

"Preface to Lyrical Ballads," XXX, B.1, 5

The Prelude, IX, B.9; XXXVIII, B.24; XIVII, B.33

"'Tintern Abbey,"' XXXVIII, B.24

William Wordsworth (Harper), XXXVIII, B.25

Wotton, Sir Henry, The Life and Letters of ..., XI, B.11

Wright, Arnold, Sterne's Eliza, XLIX, i, B.12

Wright, Elizabeth Mary, The Life of Joseph Wright, VII, B.12; X, i, B.1; XXIII, i, A.2; XXXIII, B.9; LVIII, i, B.27, 66

Wright, Joseph, VII, B.12; X, i, B.1; XXIII, i, A.2; XXXIII, B.9; LVIII, i, B.27, 66

Wright, Thomas: ed., Correspondence (Cowper), IX, B.1 The Life of Daniel Defoe, III, B.1, 5, 9 The Life of William Cowper, IX, i, B.4

Wright, W. Aldis, "Preface" to Bacon's Essays, XXXVII, B.15

writing:

"Art of . . ." (VW heading), 20; XXXVIII, B.9-10

"Professional . .." (VW heading), LIX, B.89

VW on, XXI, B.1; XLIX, B.31

Wycherley, William, The Plain Dealer, XLVII, B.18

Wyndham, George, "Introduction" to The Poems of Shakespeare, XXXVII, B.16 
[ INDEX ]

Years, The:

Dante and, 18; LI, i

VW draft for, XLV, B.7

VW heading, LXIII, B.2

Yeats, William Butler:

Autobiographies, XXV, i, B.34
The Death of Synge, VII, B.12; XXXIII, B.1; LIX, B.46

Estrangement, LIX, B.46

Zimmern, Alfred E., The Greek Commonwealth, XXV, i, B.22 


\section{TITLE INDEX TO VIRGINIA WOOLF'S PUBLISHED WORKS}

The Title Index lists those of Virginia Woolf's published essays and books that are associated with the entries in the sixty-seven volumes of reading notes. It provides the user with a guide to all of the volumes that contain material pertinent to a particular essay or book, whether this material is in the introduction to the volume or in the entries themselves. The references are to volume numbers only.

"Addison,", II

After His Kind (Henderson), VW review of, XXXV

“Anon,"' XVI, XXI, XXXVII, XLVIII

“Antiquary, The," XXVI, XLVII

“Appreciations,", XLVII

"Archbishop Thomson,", XXXI

“Art of Biography, The, , XLV

“Augustine Birrell,", XIII, XX

Author's Progress, The (Lorimer), VW review of, XXXV

Barham of Beltana (Norris), VW review of, XXXV

“'Beau Brummell,', IX, XX

"Belle of the Fifties, A," XXXV

"Bentley," XXV, XLIX

Blanche Esmead (Maitland), VW review of, XXXV

"Bluest of the Blue, The," XXXV

Brown House and Cordelia, The (Booth), VW review of, XXXV

By Beach and Bogland: Some Irish Stories (Barlow), VW review of, XXXV

"Byron and Mr. Briggs," XLIX

“'Captain's Death Bed, The," X

“Coleridge as Critic,' XXX

"Common Reader, The'” XXXVIII
Common Reader, The, II; III; XIX; XXV;

XXX; XXXI; XXXVIII; XLI; XLVII;

XLIX

“Addison," II

"Archbishop Thomson," XXXI

"'Bentley," XXV, XLIX

"The Common Reader," XXXVIII

"Defoe," III

"The Elizabethan Lumber Room," XIX, XXXVIII

"George Eliot," XLI

"How it Strikes a Contemporary," XIX

"Jane Austen," XLIX

"'Joseph Conrad," XLVII

"'The Modern Essay,"' XLIX

"Modern Fiction," XXXI

"Notes on an Elizabethan Play," XIX, XXV, XXXVIII, XLVII

"On Not Knowing Greek," XIX, XXV, XLVII, XLIX

"The Pastons and Chaucer,"' XXXVIII, XLVII, XLIX

Common Reader, The: Second Series, IV, V, VIII, IX, XI, XII, XIII, XV, XIX, XX, XXII, XLII, XLVI, XLVIII, L, LII

"Beau Brummell," IX, XX

“" 'The Countess of Pembroke's Arcadia,', 'VIII, XI, XII, XX, XLVIII

“Cowper and Lady Austen," IX 
Common Reader, The (cont.)

"De Quincey's Autobiography," XV, XLVIII

“Donne After Three Centuries," VIII, XI, XX, XLVIII, LVIII

"Dorothy Osborne's 'Letters,' '” XLVI, XLVIII, LII

"Dorothy Wordsworth," XX

"Dr. Burney's Evening Party," XIII, XLVI

"Geraldine and Jane," XIII

“" 'I am Christina Rossetti,, " XXII

"Jack Mytton," L

James Woodforde, XV, XIX, XLVIII

"Lord Chesterfield's Letters to his Son," XIV, XLVI, XLVIII

"Mary Wollstonecraft," IX

"The Novels of George Meredith," XXVI, XLVI

"The Novels of Thomas Hardy," XX, XXVI, XLII

“" 'Robinson Crusoe,', ' IV, XLVIII

“'The 'Sentimental Journey,', X XVI

"The Strange Elizabethans," XI, XII, XLVIII

"'Swift's 'Journal to Stella,', , V, XLVIII

"'William Hazlitt,"' XX, XXII

"Compromise, The," XXV

Compromise, The (Gerard), VW review of, $\mathrm{XXXV}$

Coniston (Churchill), VW review of, XXXV

"Congreve," XVIII

"Congreve's Comedies: Speed, Stillness and Meaning," XL

"Cosmos, The," XXV

"Countess of Pembroke's Arcadia, The," VIII, XI, XII, XX, XLVIII

"Cowper and Lady Austen," IX

"Crabbe," X

Dark Lantern, A (Robins), VW review of, XXXV

“David Copperfield," V

Debtor, The (Freeman), VW review of, XXXV

"Defoe," III

“" 'Delta,' " XXXV

“De Quincey's Autobiography," XV, XIVIII
"Description of the Desert, A," XXXV

Devil's Due, The (Burgin), VW review of, XXXV

"Donne After Three Centuries," VIII, XI, XX, XLVIII, LVIII

“Dorothy Osborne's Letters," XLVI, XLVIII, LII

"'Dorothy Wordsworth," XX

"Dr. Burney's Evening Party," IX, XIII, XIVI

"Eliza and Sterne," XLIX

"Elizabethan Lumber Room, The," XIX, XXXVIII

"Emerson's Journals," XXIX

"English Aristocrat, An,” XIV, XLVI, XLVIII

"Essay in Criticism, An," XXV

Face of Clay, The (Vachell), VW review of, XXXV

"Faery Queene, The," XLV

"Fanny Burney's Half-Sister," XIII

"Fantasy upon a Gentleman who Converted his Impression of a Private House into Cash," LVII, LX

Flood Tide, $A$ (Debenham), VW review of, XXXV

Flush: A Biography, XXXII, XLVIII, LVIII

Fortunes of Farthings, The (Dawson), VW review of, XXXV

"Gas at Abbotsford,"' XXIV

"George Eliot," XLI

"Geraldine and Jane," XIII

"Half of Thomas Hardy," XIV

"Henry James' Ghost Stories," XXVI, XXXVIII

"Herman Melville," XLIV

"Historian and 'The Gibbon,' The," VI

"Horace Walpole," XLIV

House of Mirth, The (Wharton), VW review of, XXXV

House of Shadows, The (Farrer), VW review of, XXXV

"How it Strikes a Contemporary," XIX

"'How Should One Read a Book?" XVIII 
"Humane Art, The," XVI

“' 'I am Christina Rossetti,, , XXII

"Impassioned Prose," XV, XXV

"Introductory Letter," in Life as We Have Known It, XII

"Is Fiction an Art?" XXV

"Jack Mytton," L

Jacob's Room, XLIX

"James Woodforde," XV, XIX, XLVIII

"Jane Austen," XLIX

"Jane Austen Practising," XLIX

" "Jones and Wilkinson," XVIII

"Joseph Addison," II

"Joseph Conrad," XLVII

"Journeys in Spain," XXXV

"Leaning Tower, The," XVI, XXI, LVI

Letter Killeth, The (Inchbold), VW review of, XXXV

"Letters of Henry James, The," XLIII

"Lewis Carroll," XXXIX

Life as We Have Known It (Llewelyn Davies), VW introductory letter to, XII

"Life Itself," XV, XIX, XLVIII

"Life of John Mytton, The," L

"Literary Geography," XXXV

Lone Marie (Norris), VW review of, XXXV

"Lord Chesterfield's Letters to His Son," XIV, XLVI, XLVIII

“"Madame de Sévigné," XVI, XXXVII, LIV

"Madeleine," XLI

Making of Michael, The (Reynolds), VW review of, XXXV

"Man at the Gate, The," XXIV

"Mary Wollstonecraft," IX

"Memories," XLVI

"Memories of a Working Women's Guild," XII

"Modern Essays," XLIX

"Modern Fiction," XXXI

"Modern Novels," XXXI

Moments of Being, XXI

"Mr. Benson's Memories," XIX

"Mr. Conrad: A Conversation," XXV

"Mr. Henry James's Latest Novel,"' XXXV

Mrs. Dalloway, XLVII

"Mrs. Dalloway in Bond Street," XLIX
Mrs. Grundy's Crucifix (Brown), VW review of, XXXV

“Mrs. Thrale," XVI

Nancy Stair (Lane), VW review of, XXXV

"New Biography, The," XIV

"Nineteenth-Century Critic, A," XXXV

"Not One of Us," XXV

"Notes on an Elizabethan Play," XIX, XXV, XXXVIII, XLVII

"Novels of Defoe, The," III

"Novels of E. M. Forster, The," XV

"Novels of George Meredith, The," XXVI, XLVI

"Novels of Thomas Hardy, The," XX, XXVI, XLII

“Novels of Turgenev, The," I

“'Oliver Goldsmith," XXIII, LIII, LXVII

"'Oliver Wendell Holmes," XXIX

"Olive Schreiner," XLVII

“'On Not Knowing Greek,” XIX, XXV, XLVII, XLIX

“'On Re-reading Novels," XXVI, XLIX

Pargiters, The, X, XXIII, LV, LVIII, LIX

"Pastons and Chaucer, The," XXXVIII, XLVII, XLIX

"Phases of Fiction," IX, XIII, XIV, XVIII, XXV, XLVI

Player Under Three Reigns, A (Forbes-Robertson), VW review of, XLVII

"Poetic Drama, The," XXXV

“'Poets' Letters,"' XXXV

"Private Papers of Henry Ryecroft, The, by George Gissing," XXXV

"Professions for Women," XII, LVIII

"Reader, The," XVI, XXXVII, XLVIII

"'Reading," XIX, XXXVIII

"Reflections at Sheffield Place," VI

"Restoration Comedy," XLVII

Reviewing, XXXIX

"Rev. William Cole, The: A Letter," VIII

Richard Hakluyt (Watson), VW review of, XLVII

Robert Smith Surtees (Surtees \& Cuming), VW review of, XIX

“Robinson Crusoe," IV, XLVIII 
Roger Fry: A Biography, XVI, XXVI, XXXVI, XXXIX, LIV, LVII, LXI-LXVI

Room of One's Own, A, IX, XIII, XIV, XLVI, XLVII, LVIII

Rose of Lone Farm (Hayden), VW review of, XXXV

"Royal Academy, The," XLIV

"Royalty," XXVI

"Royalty," review of The Story of my Life (Marie, Queen of Roumania), XXVI

“'Ruskin Looks Back on Life, 'Praeterita' ... ," XIV

"'Sara Coleridge," XXIV

Scholar's Daughter, The (Harraden), VW review of, XXXV

“'Sentimental Journey, A,"' XLVI

"Sir Thomas Browne," XXV

"Sister of Frederick the Great, The," XXXV

"Sketch of the Past, A," XXI

Smoke Rings and Roundelays (Partington), VW review of, XLVII

"Soul of an Archbishop, The," XXXI

"Speech Before the London/National Society for Women's Service," XII, LVIII

"'Stendhal,"' XVIII, XIX

"Sterne," XXIX

"'Sterne's Ghost," XVIII

"Strange Elizabethans, The," XI, XII, XLVIII

Supreme Moment, A (Synge), VW review of, XXXV
"Sweetness-Long Drawn Out," XXXV

“Swift's Journal to Stella," V, XLVIII

"Their Passing Hour," XXXV

“'Thomas Hardy's Novels," XX, XXVI, XLII

"Thoughts on Peace in an Air Raid," XXI, XXXVI, XXXVII, XXXIX

Three Guineas, VII, X, XXVI, XXXIII, XXXVI, XXXVII, XXXIX, LV-LX, LXI

Tower of Siloam, The (Graham), VW review of, XXXV

"Trafficks and Discoveries," review of English Seamen in the Sixteenth Century (Froude) and The Hakluyts' Voyages, Travels and Discoveries, XXXVIII

"Trafficks and Discoveries," review of English Voyages of the Sixteenth Century (Raleigh), XXXV

“" 'Twelfth Night' at the Old Vic," I

"Two Antiquaries: Walpole and Cole," XVI

" "Two Irish Novels,"' XXXV

"Two Women," XLVI, LVIII

“White's Selborne," XXIV

"Why Art To-day Follows Politics," XXXIX

"Wm. Hazlitt the Man," XX, XXII

"Women and Fiction," IX, XIV

"Wordsworth and the Lakes," XXXV

Years, The, XLV, LI

\section{Library of Congress Cataloging in Publication Data}

Silver, Brenda R., 1942-

Virginia Woolf's reading notebooks.

Includes bibliographical references and index.

1. Woolf, Virginia, 1882-1941-Books and reading.

I. Woolf, Virginia, 1882-1941. II. Title.

PR6045.072Z8764 823'.912 81-47156

ISBN 0-691-06179-3 AACR2 ISBN 0-691-01347-0 (pbk.)

Brenda R. Silver is Associate Professor of English at Dartmouth College.

DOI: $10.1349 /$ ddlp.3522 